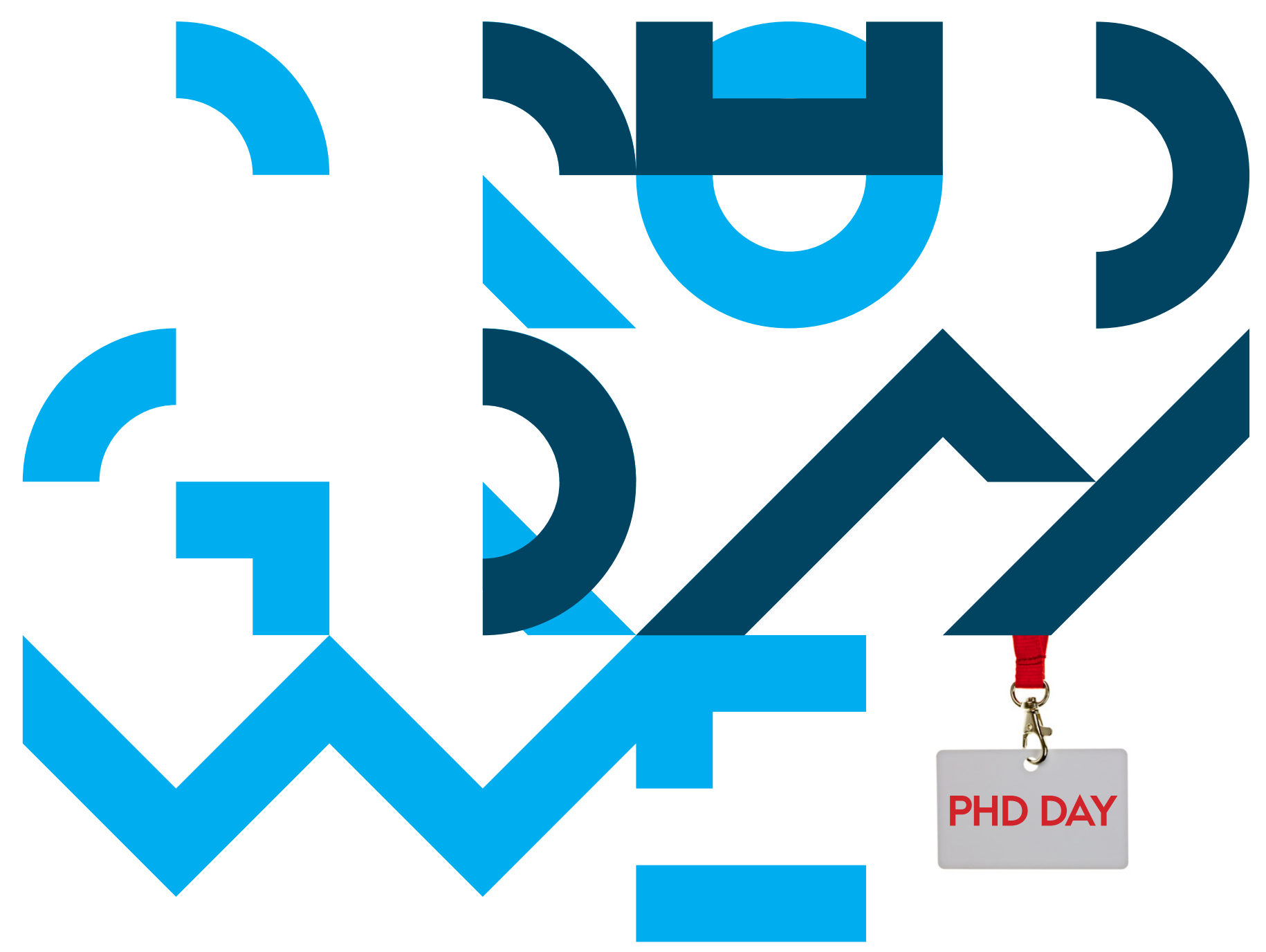

PROGRAMME \& ABSTRACTS 11 JANUAR 2013

$1 \cup$ ANRHUS 


\section{PHD DAY

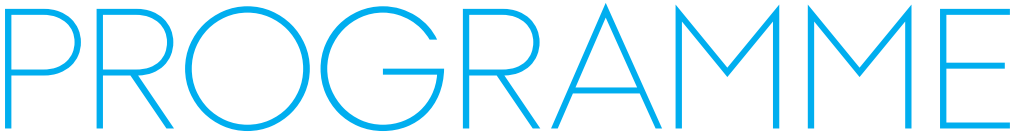

\subsection{Welcome}

By Allan Flyvbjerg, Dean, Faculty of Health

The Lakeside Lecture Theatres, Aarhus University

8.20 Welcome

By Kristina Laut, Chairman of the PhD Association

8.25 On today's programme

Helle Pratorius, Chairman of the Organizing Committee

8.30 Fogh Nielsen Prize Competition

Chaired by Søren Moestrup, Chairman of the Fogh Nielsen board, and

Kristina Laut, Chairman of the PhD Association

9.15 Coffee break

9.30 'Future talent - future challenge'

Georg Metz, author and journalist on today's theme

Moderated by Lise Wogensen Bach, Vice Dean, Head of Graduate School, Faculty of Health

10.00 Panel debate based on the theme of the day and speak by Georg Metz

Participants are:

- Margrethe Vestager,

Minister for Economic Affairs and the Interior

- Janet Metcalfe

Chair and Head of Vitae

- Svend Hylleberg,

Dean, School of Business and Social Sciences

- Jørgen Frøkicer,

Professor, deputy chairman the Danish Council for Independent Research, Medical sciences

- Martin Skøtt,

PhD student, Department of Biomedicine

Moderated by Lise Wogensen Bach,

Vice Dean, Head of Graduate School, Faculty of Health 


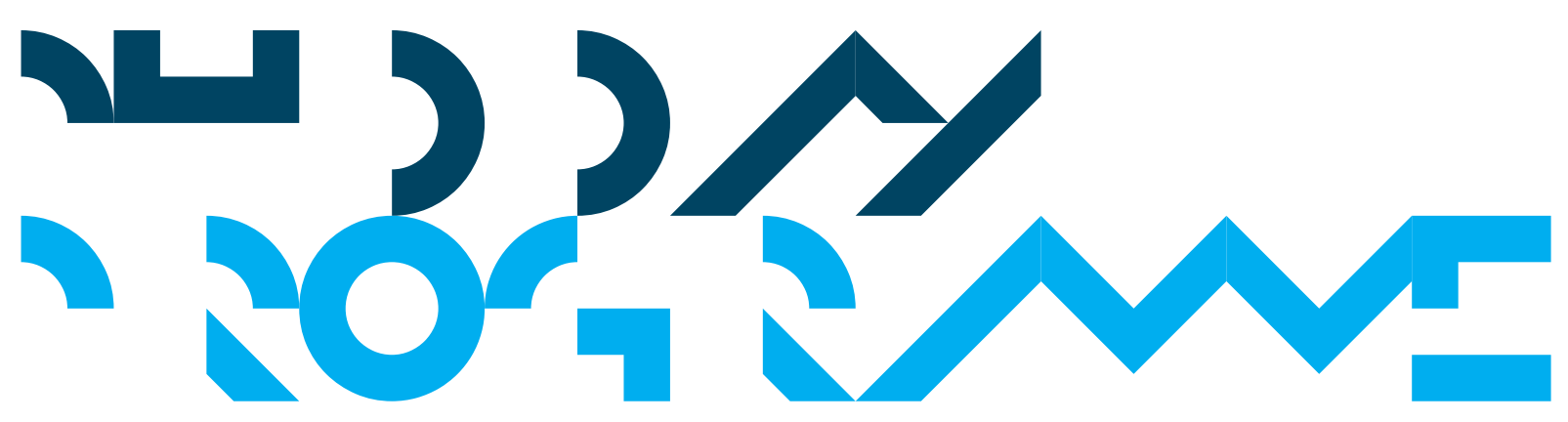

11.15 Oral presentations

12.45 Lunch/poster view

13.15 Poster presentations

14.30 Coffee break

14.45 Hanstedgaard Fund Prize and Misses Anna and Dagny Hjerrild scholarship for the elimination of animal testing in scientific research Chaired by Allan Flyvbjerg, Dean, Faculty of Health

15.00 Skou Lecture

By Professor Timothy Lash,

Wake Forest School of Medicine

Chaired by Allan Flyvbjerg, Dean, Faculty of Health

15.45 Poster and oral awards

16.15 Closing remarks

By Lise Wogensen Bach, Vice Dean, Head of Graduate School

18.30 Dinner and presentation of prizes at Turbinehallen, Aarhus

Festive speech

Morten Charles, MD, PhD

22.00 Band and dance

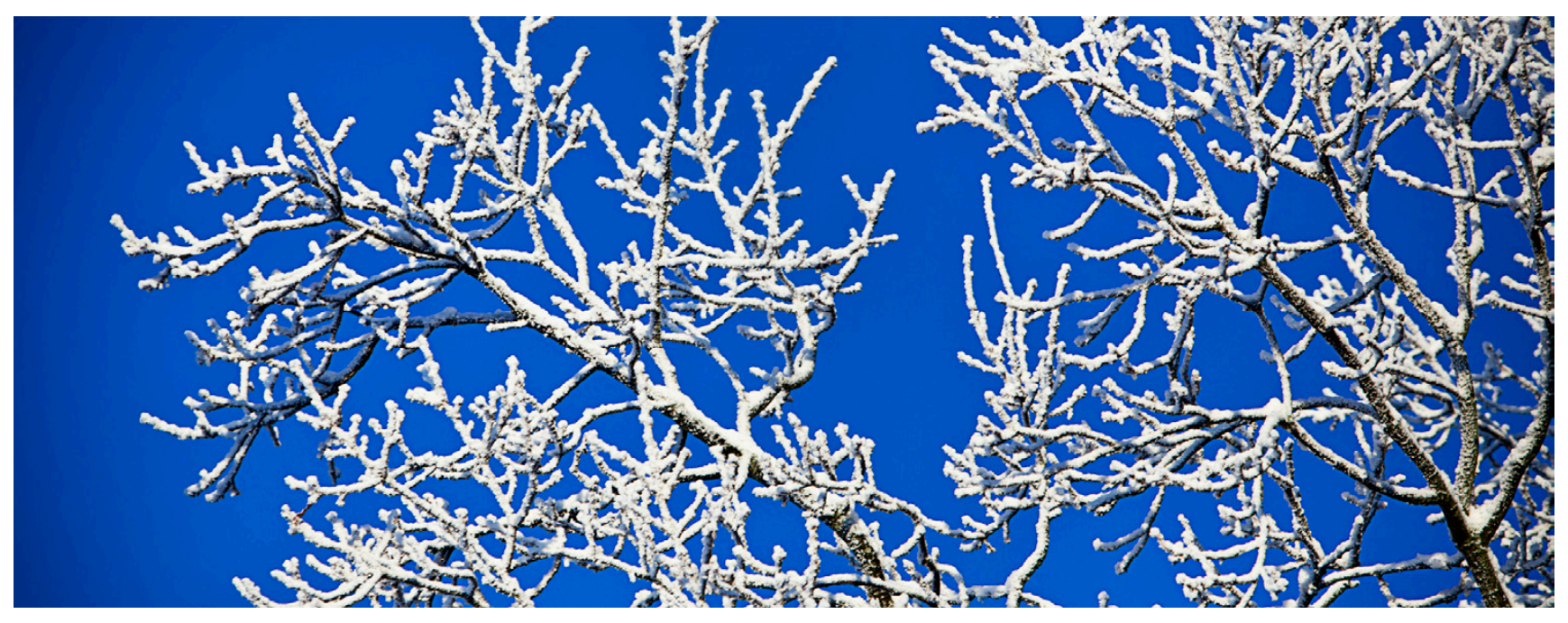




\section{Aarhus University \\ Graduate School of Health}

\section{PHD DAY \\ $11^{\text {th }}$ JANUARY 2013}




\section{Contents and Information}

Welcome 6

$\begin{array}{ll}\text { Talent and more ... } & 7\end{array}$

The Skou Lecture $\quad 8$

Aarhus Graduate School of Health 9

The PhD Association $\quad 10$

$\begin{array}{ll}\text { Partner Contributions } & 11\end{array}$

Session Chairmen $\quad 19$

Session Overview 20

$\begin{array}{ll}\text { Abstracts } & 41\end{array}$

$\begin{array}{ll}\text { Index of authors } & 267\end{array}$

$\begin{array}{ll}\text { Map } & 271\end{array}$

Practical information:

- Lunch will be held in the foyer at the Lakeside Lecture Theatre.

- Posters will be shown in the Lakeside Lecture Theatre and the Bartholin Building.

- Posters should be hung up between 16.30 and 20.00 on January $10^{\text {th }}$ or between 7.30 and 8.00 on January $11^{\text {th }}$. All posters must be taken down immediately after the closing of the conference.

- Oral presenters for sessions 01-05 must meet in the auditorium concerned between 7.30 and 8.00 on January $11^{\text {th }}$ to save their presentation onto the auditorium hard disk.

Organizing committee:

- Helle Prcetorius, Professor, DrMedSc, Dept. of Biomedicine, Chairman

- Kristina Laut, PhD student, Dept. of Public Health

- Line Raaby Olsen, PhD student, Dept. Clinical Medicine

- Shivani Joshi, PhD student, Dept. of Clinical Medicine

- Tine Gregersen, PhD student, Dept. of Clinical Medicine

- Martin Skøtt, PhD student, Dept. of Biomedicine

- Claus Gravholt, Professor, DrMedSc, Dept. of Clinical Medicine

- Niels Jessen, Ass. Professor, Dept. of Clinical Medicine

- Martin Roelsgaard, Ass. Professor, Dept. of Biomedicine

- Lene Birkegaard Pedersen, PhD Administration

- Trine Ji Holmgaard Jensen, PhD Administration

- Emil Toft Brøndum, PhD Administration

- Filippo Peder D'Andrea, PhD Administration 


\section{Future talent - future challenge}

The organising committee, on behalf of the PhD-Association, welcome all students, faculty members and distinguished guests to the PhD Day 2013.

This year's programme is quite exciting. The Skou lecture is held by Professor Timothy Lash and the panel debate will focus on the theme of the day, 'Future talent - future challenge'. We hope the debate will draw attention to the challenges of defining, scoping out and nurturing tomorrow's talents and what we may anticipate to be the future challenges.

The choice of this year's honouree Skou Lecturer follows naturally the line of great speakers at the PhD Day. Professor Lash has an outstanding academic career within epidemiology, and has received several awards for excellence in teaching and research on the aetiology and treatment of breast cancer. We are happy that Professor Lash has accepted the invitation and look forward to his lecture.

For this year's panel debate we dare to say, that the line-up is no less than exceptional. Georg Metz, author and journalist, has a long-standing record of lifting the public debate while staying focused on all aspects of a given issue, including those most critical. This is truly a rare talent and therefore we can think of no one better to set the stage for the debate on 'Future talent - future challenge' than Georg Metz. The panel consist of Minister for Economic and Interior Affairs Margrethe Vestager, Chair and Head of Vitae Dr. Janet Metcalfe from the U.K., Professor Jørgen Frøkiœr member of the Danish Research Council as well as Dean Svend Hylleberg from the School of Business and Social Sciences. This should guarantee a lively debate on the highest level.

This year's abstract book gives an insight into what the future holds and the PhD Day is brimming with excellent research presented by dedicated and talented PhD students from the Graduate School of Health, Aarhus University. The PhD students at Health are deeply engaged in the challenges of the future through their continuous research. Fuelled by commitment, curiosity and creativity, today's student will become the future talents who dare take on the future challenges.

A warm thanks goes out to all those who have taken the time to participate and helped make this PhD Day a leading event.

Professor Helle Prœetorius

Chairman of the Organizing Committee

Health, Aarhus University

Professor Allan Flyvbjerg

Dean

Health, Aarhus University
Professor MSO Lise Wogensen Bach

Vice-dean and Head of Graduate School

Health, Aarhus University

Kristina Laut

Chairman of the $\mathrm{PhD}$ association

Health, Aarhus University 


\title{
Talent and more ...
}

This year's invited speaker on the theme "Future talent - future challenge" is Georg Metz. For many years Georg Metz has helped shape the public opinion within a variety of fields as author, journalist, writer and editor. The following is an introduction to this year's theme.

\begin{abstract}
"When looking up the word talent at Google, the search engine hits insist that the concept of 'talent' covers acquired skills in a certain area of expertise: football, art - or brain research. In this sense, the definition - somewhat surprisingly seen from a traditional etymological perspective - seems to match the modern world's notion on human achievements: if you try hard enough, if you make an effort, if you face the challenges head-on, if you stand the test, then the audience, the media - and the grant-awarding authorities - will praise and reward you. Visibility, will-power and success are now synonymous with talented quality. We are all experts, a former Danish Prime Minister claimed; we shape our own happiness and determine the amount of applause that we receive when our acquired talent is recognized. Posing on the music conductor podium on national TV is seen as an expression of talent;
\end{abstract} a talent for taking up challenges. The core performance is directing a symphony orchestra. From an objective perspective, this would require considerable natural abilities, many years of education and extensive experience, but all this must step back for the great achievement of conquering yourself and wanting to do this. Publish or perish. Without getting carried away by symbolic over-interpretations and pure panic, we may say that the recent years' research scandals, where the number of laboratory rats did not quite correspond to the claimed findings, certainly demonstrate a grotesque, but natural consequence of performance ambition rather than scientific honesty. You could claim that this controversy calls for new literary works on the notion of talent gone wild. Although the consequences rarely correspond to the scale of the most remarkable cases, these nevertheless tend to leave traces and trigger more research spin in the media, which is increasingly met with

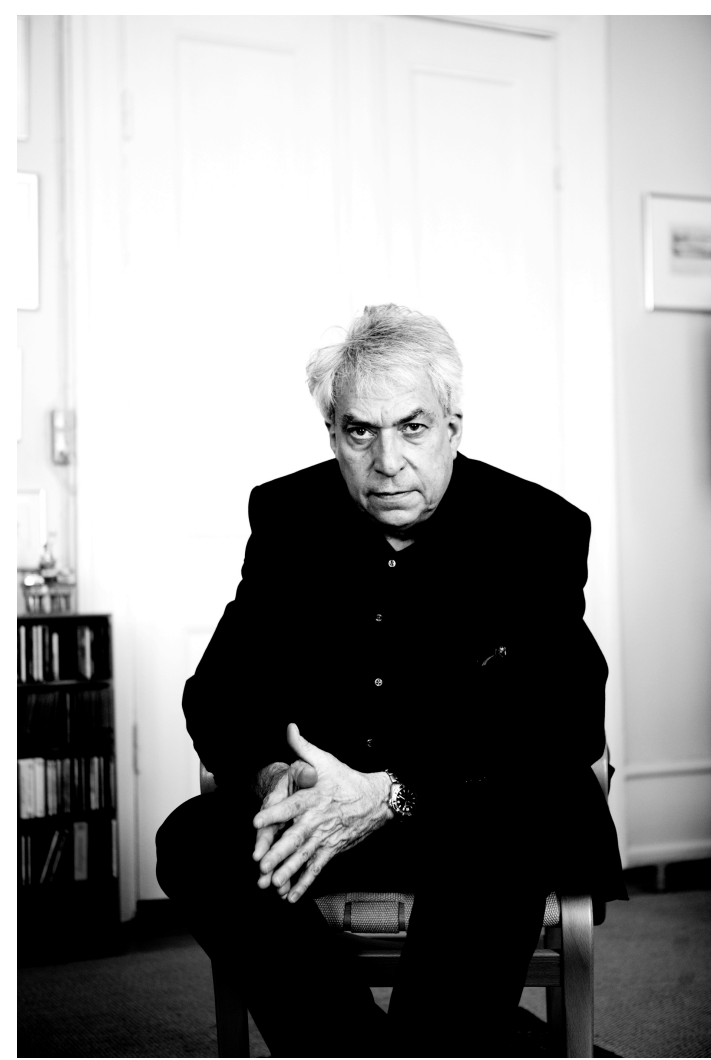
criticism."

Georg Metz 


\section{The Skou Lecture}

Timothy Lash holds academic appointments as Professor in the Department of Epidemiology \& Prevention, Division of Public Health Sciences, Wake Forest School of Medicine and as Professor of Cancer Epidemiology in the Department of Clinical Epidemiology, Aarhus University School of Public Health. He has co-authored two textbooks that focus on the methods of conducting epidemiologic research and analysing epidemiologic datasets. He has participated in the $\mathrm{PhD}$ dissertation of more than twenty students, including many at Aarhus University. Two of his students were awarded the Society for Epidemiologic Research's Abraham Lilienfeld Student Prize for most outstanding dissertation research in epidemiology. His research focuses on breast cancer causes, outcomes, and survivorship. His lecture will present several of these research topics, and lessons learned about the scientific process and its interactions with society.

Timothy Lash received a Bachelor of Science degree in Life Sciences from the Massachusetts Institute of Technology in 1987, a Masters of Public Health in Epidemiology from the Boston University School of Medicine in 1992, and a Doctorate of Science in Epidemiology from the Boston University School of Public Health in 1999. He has been a member of the faculties of the Boston University School of Public Health, Aarhus University, and Wake Forest School of Medicine, and has served on the editorial board of several epidemiology journals. He worked for ten years as a consultant in environmental health sciences before completing his graduate education.

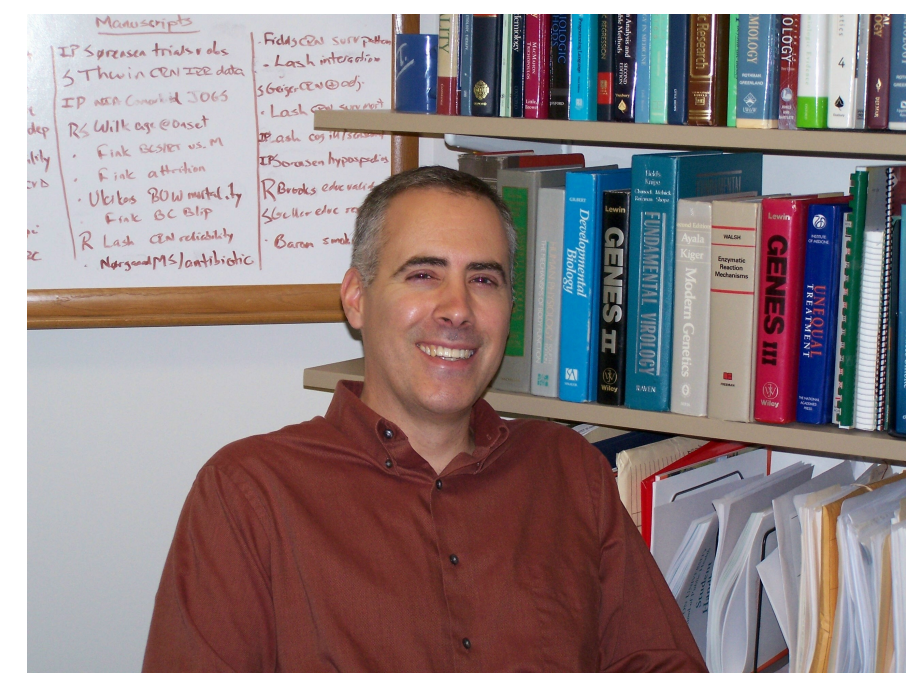

Timothy L Lash DSc, MPH

Professor

Wake Forest School of Medicine
Email: tlash@wakehealth.edu

Professor of Cancer Epidemiology Aarhus University 


\section{Graduate School of Health}

Aarhus University, Health is one of the four main academic areas at Aarhus University and comprises a number of pre-clinical departments within biomedicine and public health, odontology, forensic medicine and clinical medicine. The latter being a collaboration between AU Health and the health care region of central Denmark and located at the Aarhus University Hospital. The Graduate School of Health was established in 1996, and was based on a tradition of providing quality postgraduate courses started in the 1970s. The Graduate School of Health is headed by the Vice Dean of Talent Development in close collaboration with the PhD committee and the graduate programme leaders. The school has about $670 \mathrm{PhD}$ students shared between the 11 graduate programmes and 100 research year students.

Research training at both pre- and postgraduate level at Health falls under the Graduate School of Health - a multidisciplinary graduate school with long-standing traditions for recruiting students from the entire health science area. The graduate school aims to give the individual students broad knowledge of scientific theories, methodologies and tools required for health science research, and to develop their ability to independently address scientific issues.

Across departmental boundaries 11 graduate programmes help ensure that all PhD students at the faculty are part of a relevant and challenging environment: 'Membrane Transporters and Receptors', 'Molecular Metabolism and Endocrinology', 'Public Health', 'Inflammation and Infection', 'Cardiovascular', 'Laboratory Medicine', 'Neuroscience', 'Oncology', 'Translational Molecular Medicine', 'Odontology, Orthopaedics and Rheumatology', and 'Clinical Medicine'. A unified approach at graduate school level ensures a consistent level of quality of the PhD education, while thematic and crossdisciplinary graduate programmes guarantees the availability of cross-disciplinary resources.

The graduate school offers three-year PhD programmes as well as four-year and five-year integrated $\mathrm{MD} / \mathrm{PhD}$ programmes. In addition, the school offers $\mathrm{PhD}$ programmes for combination with clinical work or a specialist training position. The research year is another offer to undergraduate medical students, who wish to take a year off to complete a research project under supervision. Four times a year a general call for grant applications is announced. Depending on external funding the general call is supplemented by specialized calls.

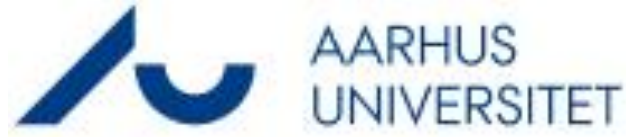




\section{Phoassociation.dk}

\section{All PhD students at HEALTH are members}

including you!

We work on improving your PhD education at HEALTH.

Main activities include

- Collaboration with the Graduate School of Health to

$>$ improve PhD courses

$>$ facilitate studying abroad

$>$ influence the structure of our PhD education

- Organizing "after-work meetings"

$>3$ meetings each term with interesting speakers

- Co-organizer of the PhD day.

"Like" us on facebook - search for "The PhD Association"

The PhD association has a board of $11 \mathrm{PhD}$ students. If you are interested in joining our work or just have good ideas please contact us at kontakt@phdforeningen.dk

We look forward to seeing you! 


\section{Det Sundhedsvidenskabelige Bibliotek - Library of Health Sciences AU Library}

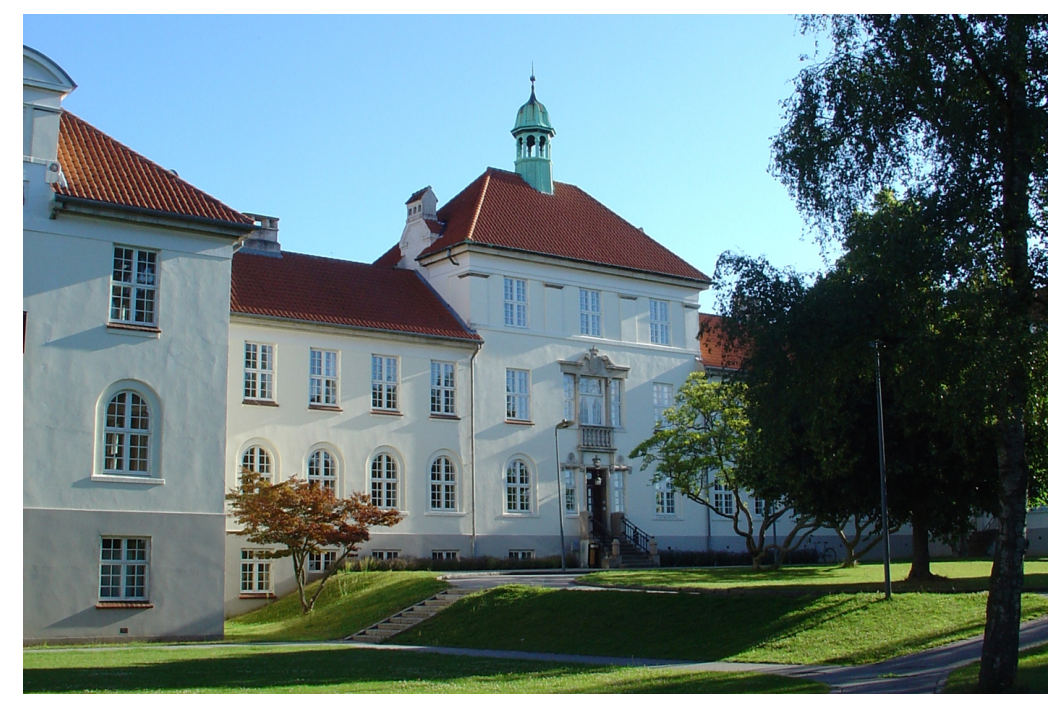

bibliotek.au.dk

The library provides help and guidance on information and literature search

- Access to relevant literature

- Individual support and help for literature search designed for your specific project

- Regular PhD courses 'Literature Search in Medical Databases'

Just contact us...

Library of Health Sciences, AU Library

Victor Albeck Building, Vennelyst Boulevard 4, Aarhus C

Phone: 89462362

Email: svb@statsbiblioteket.dk 


\section{Research Support Office - So You can Focus on Research}

(Forskningsstøtteenheden)

The Research Support Office at Aarhus University and Aarhus University Hospital is your point of entry to the world of fundraising. The Research Support Office is divided into Pre-Award, Post Award, and Strategy.

The Pre-Award Health-Team provides support to all researchers within the health sciences. Knowing that different researchers have different requirements, The Research Support Office offers the assistance you need - for free!

For instance we offer:

- To help tailor your application to specific calls

- To provide input on non-scientific parts of your application

- To provide structure and clarity

- Workshops on how to write a good application

- www.ResearchFunding.Net - an extensive database of national and international funding opportunities.

In order for us to provide you with the best possible service, it is imperative you contact us early in the application process.

\section{Health Team - Contact Information}

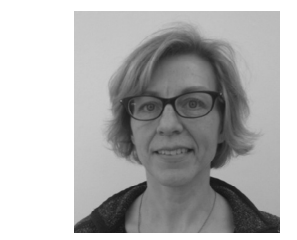

Anne Birgitte Lindgren, annelind@rm.dk

78469962

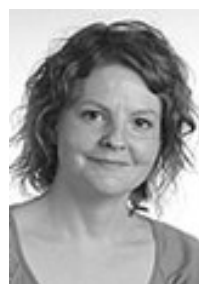

Inge Andresen ingeandr@rm.dk 78461571

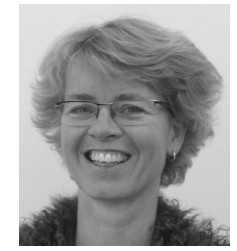

Birgit Christensen, birgichr@rm.dk 78464591

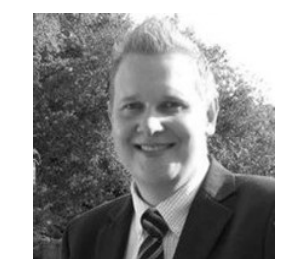

Morten Hollænder Beeck mortbeec@rm.dk 20374763

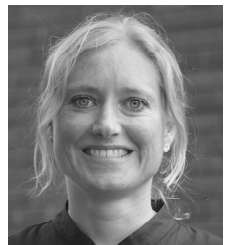

Marianne Jensby Nielsen marjenni@rm.dk 20374759

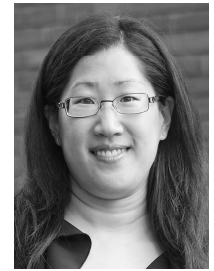

Rikke Nan Valdemarsen rikkvald@rm.dk 31434458

www.au.dk/fse

\section{Research Support Office}

Aarhus University \& Aarhus University Hospital

Peter Sabroes Gade 12, Building 14A, 8000 Aarhus C 


\section{PhD - and then what?}

Do you wish to continue research after finishing your $\mathrm{PhD}$ ?

\section{Think about joining the Danish Society for Postdoctoral Health Research}

The Society was founded in 2012 by Health Professionals who found it challenging to combine clinical work and research. The purpose of the Society is to promote, improve, and develop opportunities to do health research after being awarded a PhD- or DrMedSc-degree.

We focus on integrating clinical work with research.

\section{Mission statement}

The Danish Society for Postdoctoral Health Research works to provide:

- the opportunity to network with other postdoctoral research fellows

- education and training including

Symposia, workshops, after-work-meetings and access to postdoctoral courses

- access to IT infrastructure: email service, server for data back-up, software licenses and IT- support in general

- a liaison between postdoctoral researchers and the university

- a collective voice for issues that are relevant and of interest to postdoctoral researchers towards institutions e.g. the Danish Health and Medicines Authority, Danish Regions, the Danish Agency for Science, Technology and Innovation, different Unions, and the Hospital Board of Directors .

- social events

Everyone with a PhD or DrMedSc in Health Sciences can join the Society.

For more information visit us at our stand. 

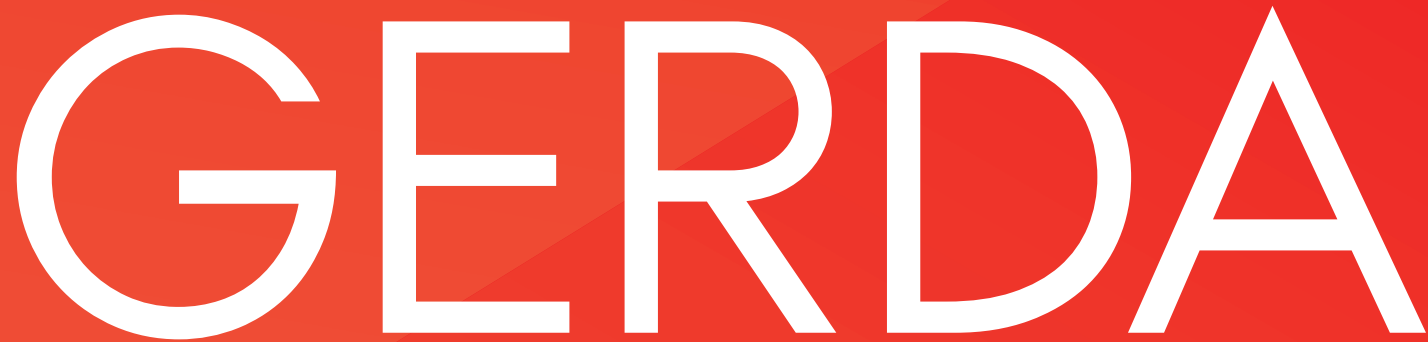

AU ALUMNI COMMUNITY NAMED AFTER THE FIRST ALUM
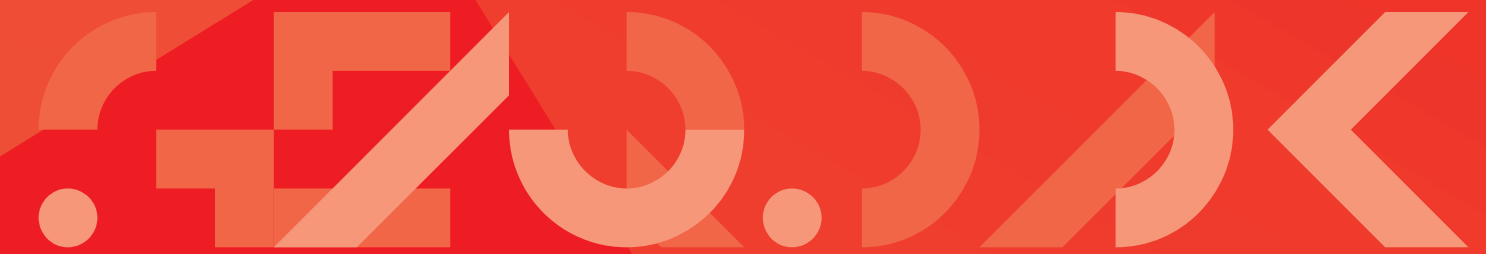

\section{GERDA WHO?}

Gerda, our online community for alumni, is named in honor of the first alumn from AU who graduated in 1935.

Today, the alumni community is a central meeting point for alumni, students, faculty and staff, which sets the perfect scene for discovering old and new connections, staying up to date on events and other networking offers.

It's free to be a member - all you have to do is activate your profile at gerda.au.dk. 


\section{International Academic Staff Services (IAS) at International Centre}

In close collaboration with AU Human Resources, the International Academic Staff Services (IAS) helps foreign researchers (including PhD students) and their families overcome the practical challenges tied to their life in Denmark. As part of this, the unit operates a service desk and an extensive web-portal (www.ias.au.dk) for international and Danish PhD students admitted to AU.

The service desk, "International Staff and Student Service", is open Monday Friday $10 \mathrm{~h} 00-14 \mathrm{~h} 00$ and it is located at the International Centre, HøeghGuldbergs Gade 4 (the Dale T. Mortensen Building).

The IAS assists international staff and PhDs through social and cultural events, counseling about practicalities for AU researchers planning a period abroad, counseling about issues of relevance for the family, including job for spouse, international schools and kindergarten etc.

IAS furthermore assists international staff and PhD students through guidance with paperwork and practical challenges during their stay in Denmark, including health insurance, extension of residence and work permits etc.

Four times a year the IAS invites newly arrived PhD students and researchers to a half-day Orientation Day. Orientation Day gives an introduction to important practical matters related to working and living in Denmark as well as introduction to the research environment at AU. For further information, see www.ias.au.dk/oday.

Lastly, IAS organizes social activities for staff and their families through the University International Club (UIC) and in cooperation with the PhD House Activity Group. For further information, see www.au.dk/uic .

\section{The PhD-House and the PhD House Activity Group}

The PhD House is located in the Dale T. Mortensen Building (Høegh-Guldbergs Gade 4). The PhD-House offers a combination of administrative services, lecture rooms for PhD courses on transversal skills and a café for young researchers at Aarhus University. Furthermore, the PhD associations have the possibility to use the PhD House's facilities to host events.

The PhD House is thus a focal point for national and international PhD students, where they can meet both professionally and socially.

The PhD House contains:

- Dales Café, which offers quality coffee, sandwiches and a wide selection of beers

- Conference facilities for PhD courses

- IC Dormitory for international PhD students

- Office facility for AU PhD associations

- A service desk for PhD students, the International Staff and Student Service

- AU housing department at the International Centre dealing with housing matters for international PhD students
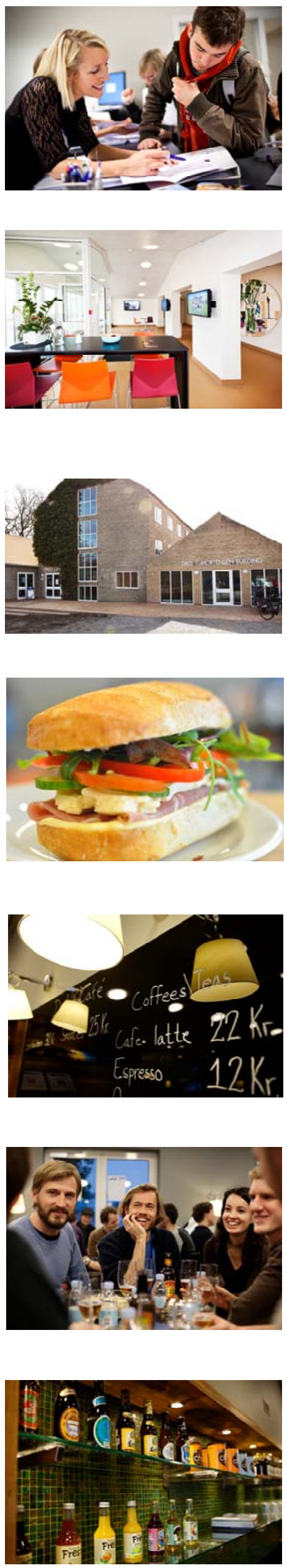


\section{Get a free Career Health Check}

\section{It's your Future - It's your Talent - It's your Challenge!}

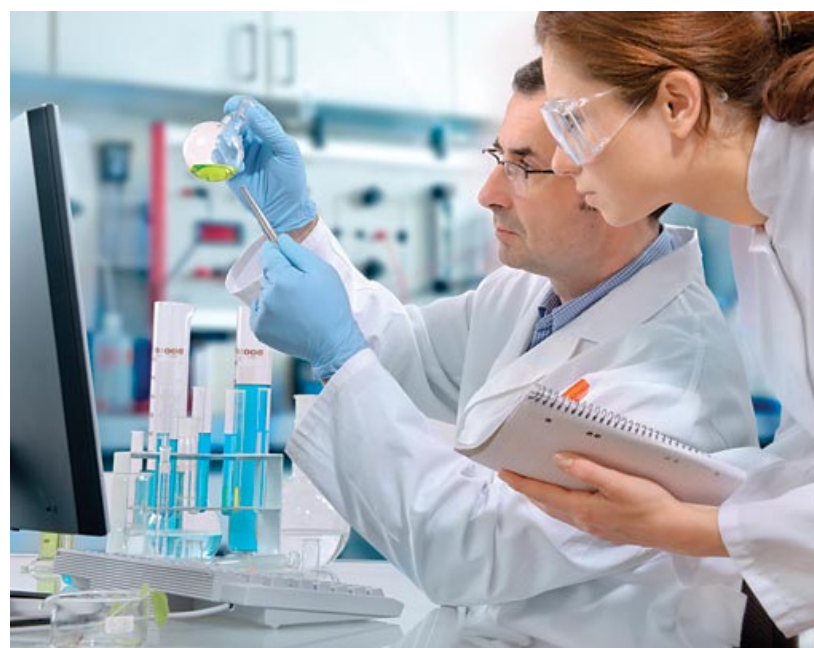

Do you know which career path to choose when finishing your PhD? Are you aware of your many opportunities? Which specific competences are companies interested in as regards $\mathrm{PhD}$ students from HEALTH?

If these are some of the questions you ask yourself without knowing the answer, we may be able to guide you.

We are a newly established unit with the main purpose of offering career services to PhD students at HEALTH.

We offer:

- Information on career opportunities

- Individual feedback on applications and CVs

- Individual coaching sessions

- Specific career events and services (to be announced online in 2013)

- AU Job \& Project Bank

- A growing knowledge of relevant companies and their interest in you.

Do not hesitate to contact us and get a head start on your career.

We very much look forward to meeting you.

Best regards,

AU Career, Health

Jeanette Bach

Career Consultant - HEALTH

Ph.: 87153598

Mobile: 29454952

Email: Jeanette.bach@sun.au.dk
Vibeke Broe

PhD Career Consultant

Mobile: 29426029

Email: Vibr@adm.au.dk

www.career.au.dk www.careercentre.au.dk 


\title{
Student counsellor for PhD students
}

\author{
Surviving you dissertation
}

From time to time it is more than a book title.

In the knowledge that studying for a PhD can be an overwhelming challenge, then Health has established a student counsellor for PhD students. What would you answer if I asked:

Is it difficult to plan your daily work?

Are things not working?

Is it hard to collaborate with your supervisor?

Do you find your situation as a PhD student difficult or unsatisfactory?

I am always an interested listener. As PhD student counsellor I am a professional interlocutor. Conversations with me are confidential and anonymity is promised. It is not an alternative to the professional research supervision. By means of conversations, the counsellor can help students become aware of what they perceive as difficult and why. This is done in close collaboration with the Secretary of The Graduate School of Health if the process related issues have administrative elements. The intention is to help PhD students gain clarity, come to terms with their situation. It is also to help them to see other opportunities, if they experience personal problems or other difficulties related to the process of working and studying as a PhD student. The counsellor can also assist students to make competent decisions.

You are always welcome to contact the PhD student counsellor!

Sometimes sooner is better than latter - no problem is too small for a talk.

Personal contact: Sanne Angel

phdstudievejleder@sun.au.dk

Phone: 87167889 


\section{It's your Future - It's your Talent - It's your Challenge!}

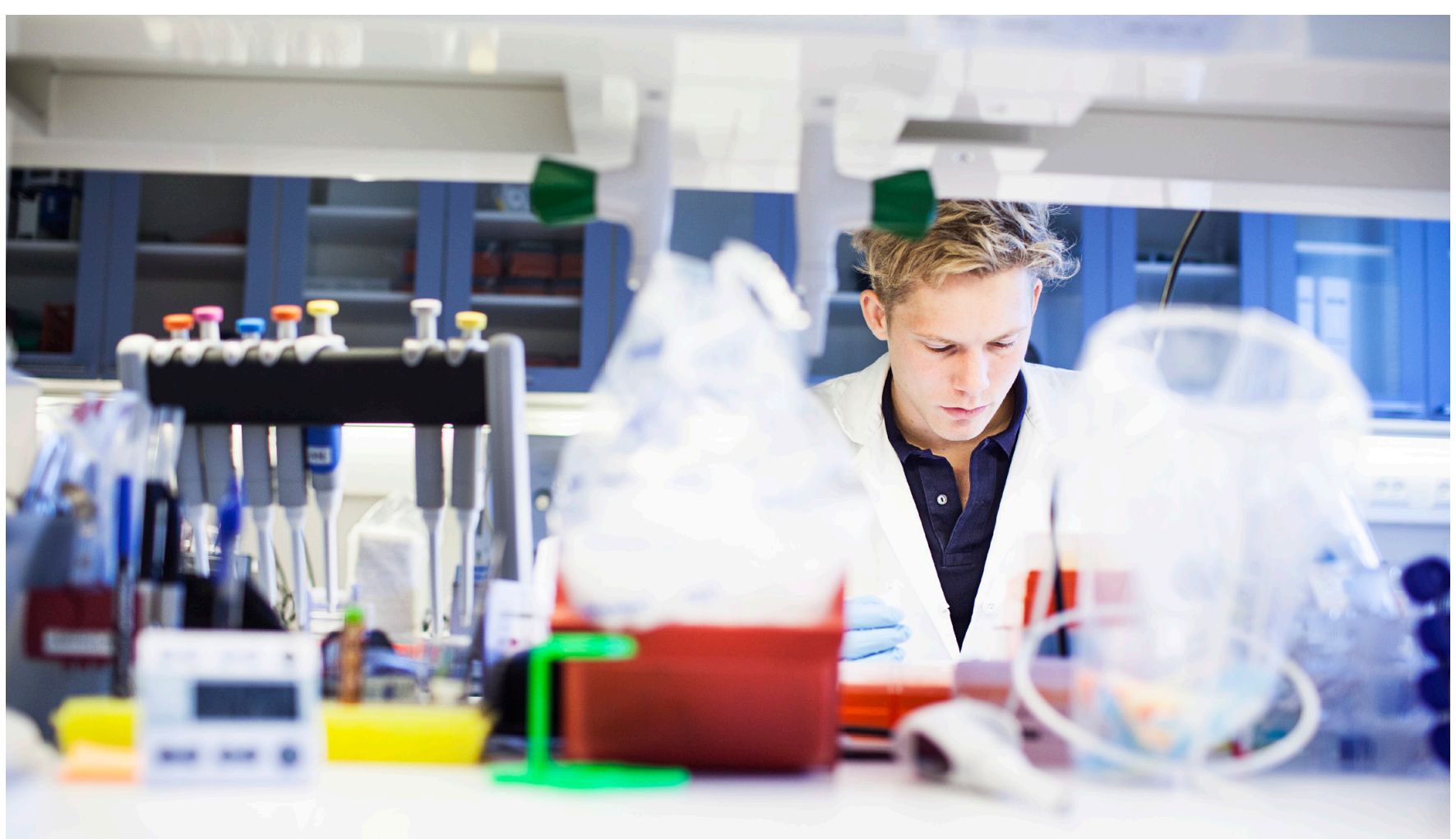

\section{REMEMBER TO VISIT THE CAREER TENT AT PHD DAY 2013}

For the first time at the PhD Day, you will have the opportunity to speak with companies about your future career oportunities, and talk about career-related subjects with AU representatives.

\section{WHERE: You will find the career tent \\ just next to the Lakeside Lecture Theatres \\ WHEN: It will be open from 12 TO 15, which means you will have plenty of time to go and have a chat.}

Do not miss this opportunity to visit the Career Tent, where AU representatives, as well as a selective range of companies, specifically interested in PhD students from

HEALTH, will be ready to welcome you!
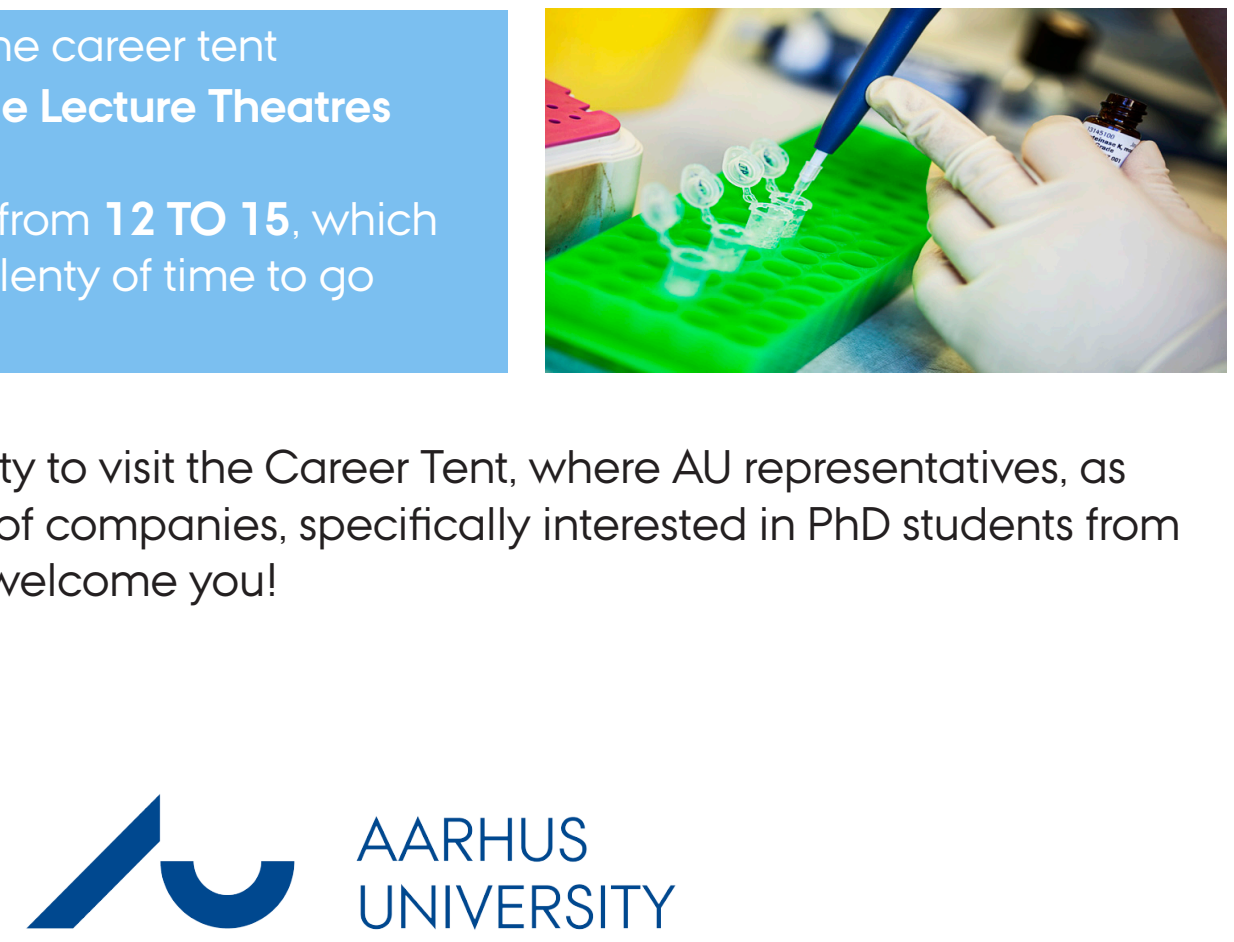

AARHUS

UNIVERSITY 


\section{Session Chairmen}

01

$\mathrm{O} 2$

$\mathrm{O} 3$

04

O5

$\mathrm{P} 1$

P2

P3

P4

P5

P6

P7

P8

P9

P10

P1 1

$\mathrm{P} 12$

$\mathrm{P} 13$

P14

P15

P16

P17

P18

P19

$\mathrm{P} 20$

P2 1

P22

$\mathrm{P} 23$

P24

$\mathrm{P} 25$

P26

$\mathrm{P} 27$

P28

P29

P30

P31

P32

P33

P34

P35

P36

P37

P38

P39

P40
Mette Madsen, Rikke Holm Jensen \& Sys Hasslund Svensson Michael Mulvany, Efe Levent Aras \& Zhanna Tairova

Erling Bjerregaard Pedersen, Trine Grantzau \& Kresten Krarup Keller William J Gaynor, Michael René Skjelbo Nielsen \& Ditte Olsen

Kim Overvad, Jurgita Janukonyté \& Anne Skakkebœk Jensen

Carsten Stengaard \& Dirk Troitzsch

Jens Rolighed \& Shallu Sharma

Jens Leipziger \& Louise Tram Henriksen

Jørn Olsen \& Frank Holden Mose

Jan Blaakœr \& Lau Brix

Mette Bjerre, Steffen Bank \& Mariane Høgsbjerg Schleimann

Tove Christensen, René Østgård \& Srikanth Chiliveru

Ebba Nexø, Louise Brøndt Hartlev \& Babak Jalilian

Marc de Leval, Asger Andersen \& Jonas Agerlund Povlsen

Michael Rahbek Schmidt, Carsten Stengaard \& Vibeke Secher Nielsen

Troels Fogh Pedersen \& Christian Daugaard Peters

Bjørn Richelsen, Christoffer Laustsen \& Mark Reinhard

Robert Fenton \& Karina Bech Cullberg

Marianne Nordsmark, Julie Damgaard Sandahl \& Lotte Sander

Marie Stampe Ostenfeld \& Johanne Lade Keller

Jan Alsner, Esben Schjødt Worm \& Eduardo Vazquez Garza

Lau Brix \& Jesper Kallehauge

Christer Swan Andreassen

Maiken Stilling \& Emilia Horjales

Helle Damkier, Pauline de Bruijn \& Sascha Eichendorff

Bent Deleuran \& Jacob Mørup Schlütter

Mads F. Kjølby \& Trine Dalsgaard

Karin Birkenkamp-Demtröder \& Nanna Cornelius

Per Höllsberg \& Martin Mørck Mortensen

Lise Lotte Hansen \& Xue Lin

Raben Rosenberg, Line Granild Bie Mertz \& Páll Karlsson

Jakob Blicher \& Zita Dósa

Karin Lykke-Hartmann \& Nicolai Ladegaard

Rikke Nørregaard \& Maria Tørring

Søren A. Ladefoged \& Peter Niekerk

Mariane Schleimann \& Niklas Telinius

Daniela Grimm

Kamille Smidt Rasmussen

Annette de Thurah \& Julie Glavind

Vivi Schlünssen \& Gry Kjœrsdam Telleus

Kirsten Lomborg \& Charlotte Olesen

Marianne Vamosi \& Palle Larsen

Anette Werner \& Malene Krogsgaard Bording

Else Marie Damsgaard \& Kirsten Hansen

Lone Sunde \& René Ernst Nielsen 


\section{Session Overview \\ Fogh-Nielsen Prize Competition.}

Eva Holm Greibe. PIECES FOR THE VITAMIN B 12 JIGSAW PUZZLE

Kirstine Kjœr Kirkegaard. TIME-LAPSE MONITORING AS A TOOL FOR ASSESMENT OF HUMAN EMBRYOS

Mohit Kothari. COMPARISON OF TRAINING-INDUCED CORTICAL PLASTICITY BETWEEN

THREE TONGUE TRAINING PARADIGMS

\section{Oral session 1 GP1, GP7 \& GP11.}

Chairmen: Mette Madsen, Rikke Holm Jensen (PhD student) \& Sys Hasslund Svensson (PhD student)

$001.01 \quad K r i s t i a n$ Stødkilde-Jørgensen. ZOOMING IN ON HAPTOGLOBIN PHENOTYPES

O01.02 Trine Nielsen. DIRECTING HER4 MRNA EXPRESSION TO CYT2 BY ANTISENSE OLIGONUCLEOTIDE DECREASES GROWTH OF BREAST CANCER CELLS IN VITRO AND IN VIVO

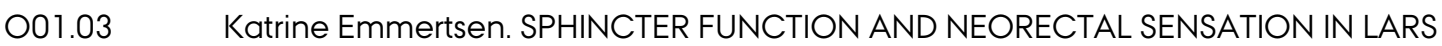
PATIENTS

O01.04 Charlotte Hartig Andreasen. DOES PREVIOUS PERIACETABULAR OSTEOTOMY COMPROMISE OPTIMAL CUP POSITIONING AND CLINICAL OUTCOME OF TOTAL HIP REPLACEMENT?

O01.05 Jan Rölfing. ERYTHROPOIETIN DIRECTLY STIMULATES OSTEOGENESIS

001.06 Lena Lindtoft Rosenbck. CHARACTERIZATION OF A NOVEL PHOSPHORYLATION SITE IN THE SODIUM CHLORIDE COTRANSPORTER, NCC

\section{Oral session 2 GP3 \& GP1 2.}

Chairmen: Michael Mulvany, Efe Levent Aras (PhD student) \& Zhanna Tairova (PhD student)

002.01 Zara Ann Stokholm. OCCUPATIONAL NOISE EXPOSURE AND THE RISK OF STROKE

O02.02 Karen Kjœr Larsen. MYOCARDIAL INFARCTION AND RISK OF SUICIDE

002.03 Sanne Lemcke. EARLY REGULATION AND TEMPER IN SMALL CHILDREN LATER DIAGNOSED WITH AUTISM SPECTRUM DISORDER. A FOLLOW-UP STUDY IN THE DANISH NATIONAL BIRTH COHORT

002.04 Lene Søndergård Larsen. A COMPANIONSHIP BETWEEN STRANGERS - THE HOSPITAL ENVIRONMENT AS A CHALLENGE TO PATIENT-PATIENT INTERACTION IN ONCOLOGY WARDS

O02.05 Mette Julsgaard Nielsen. ADHERENCE TO MEDICAL TREATMENT AMONG PREGNANT WOMEN WITH ULCERATIVE COLITIS (UC)

O02.06 Henrik Gammelager. FIVE-YEAR RISK OF END-STAGE RENAL DISEASE AFTER SURVIVING DIALYSIS-REQUIRING ACUTE KIDNEY INJURY AMONG INTENSIVE CARE PATIENTS: A NATIONWIDE COHORT STUDY

\section{Oral session 3 GP5 \& GP9.}

Chairmen: Erling Bjerregaard Pedersen, Trine Grantzau (PhD student) \& Kresten Krarup Keller (PhD student)

003.01 Anders Gade Kjœrgaard. ENDOTHELIAL ACTIVATION IS GREATER IN SEPTIC THAN IN NON-SEPTIC ICU PATIENTS

O03.02 Caroline Winther Tørring. THE B 1-CELL SUBPOPULATION IS DIMINISHED IN RELAPSINGREMITTING MULTIPLE SCLEROSIS PATIENTS

O03.03 Julie Prahl. PLASMA CONCENTRATIONS OF FIRST-LINE ANTITUBERCULOSIS DRUGS IN A RANDOM SAMPLE OF TUBERCULOSIS PATIENTS IN DENMARK 
O03.04 Jens Reumert Laurberg. THE MOLECULAR SIGNATURE OF METASTATIC BLADDER CANCER

O03.05 Christina Gade Jespersen. ANDROGEN DEPRIVATION THERAPY AND RISK OF MYOCARDIAL INFARCTION AND STROKE, 2002 TO 2012: A NATIONWIDE DANISH POPULATION-BASED COHORT STUDY

003.06 Hanna Rahbek Mortensen. RISK FACTORS FOR SWALLOWING DYSFUNCTION AFTER RADIOTHERAPY IN THE DAHANCA 6 \& 7 RANDOMIZED TRIAL

\section{Oral session 4 GP6 \& GP8.}

Chairmen: William J Gaynor, Michael René Skjelbo Nielsen (PhD student) \& Ditte Olsen (PhD student)

$004.01 \quad$ Rikke Esberg Kirkfeldt. PNEUMOTHORAX IN CARDIAC PACING: A POPULATION-BASED COHORT STUDY OF 28,860 DANISH PATIENTS

$004.02 \quad$ Line Gebauer Josefsen. NEURAL CORRELATES OF EMOTION RECOGNITION IN MUSIC IN ADULTS WITH AUTISM SPECTRUM DISORDER

$004.03 \quad$ Bent Roni Ranghøj Nielsen. THE EFFECT OF SHORT-TERM CHANGES IN CIRCULATING FREE FATTY ACIDS ON MYOCARDIAL AND SKELETAL MUSCLE LIPID CONTENT: A RANDOMIZED TRIAL IN HEART FAILURE PATIENTS WITH TYPE 2 DIABETES

004.04 Thomas Andersen Rix. FISH, MARINE N-3 POLYUNSATURATED FATTY ACIDS AND THE DEVELOPMENT OF ATRIAL FIBRILLATION

O04.05 Mads Jensen. INTENTIONAL CAPTURE

004.06 Per Qvist. A NOVEL BRDI KNOCKOUT MOUSE MODEL FOR SCHIZOPHRENIA EXHIBITS COGNITIVE DEFICITS, PPI DISRUPTION AND INCREASED DRUG-INDUCED LOCOMOTOR HYPERACTIVITY

\section{Oral session 5 GP2 \& GP10.}

Chairmen: Kim Overvad, Jurgita Janukonyté (PhD student) \& Anne Skakkebœk Jensen (PhD student)

O05.01 Lea Johanne Brader. A HEALTHY NORDIC DIET IMPROVES AMBULATORY BLOOD PRESSURE IN SUBJECTS WITH METABOLIC SYNDROME: A SYSDIET SUB-STUDY

005.02 Merete Hartvigsen. BREAD-BASED DIETS CONTAINING ISOLATED ARABINOXYLAN OR RYE WHOLE GRAIN WITH OR WITHOUT KERNELS HAVE SIMILAR BENEFICIAL EFFECTS ON GLUCOSE AND LIPID METABOLISM AND CHANGES IN GENE EXPRESSIONS IN INSULIN SENSITIVE TISSUES IN ZDF RATS

005.03 Jesper Sand Sørensen. BIOACTIVE IGF-I AND IGFBP- 1 IN DANISH CHILDREN AND ADOLESCENTS 3-5 YEARS AFTER ONSET OF TYPE 1 DIABETES. EFFECT OF RESIDUAL BETACELL FUNCTION

O05.04 Steffen Jensen. DETECTION OF CIRCULATING MIRNAS IN COLORECTAL CANCER

O05.05 Rasmus Otkjœr Bak. POTENT MICRORNA SUPPRESSION BY RNA POL II-TRANSCRIBED TOUGH DECOY INHIBITORS

005.06 Anne Sørensen. CHANGES IN HUMAN PLACENTAL OXYGENATION DURING MATERNAL HYPEROXIA AS ESTIMATED BY BOLD MRI 


\section{Poster session 1 GP12: Clinical Medicine.}

Chairmen: Carsten Stengaard \& Dirk Troitzsch (PhD student)

P01.01 Maria Charlotte Steffensen. HEART VALVE DISEASE AMONG PATIENTS WITH HYPERPROLACTINAEMIA: A NATIONWIDE POPULATION-BASED COHORT STUDY

P01.02 Jacob Gamst. MORTALITY AMONG INTENSIVE CARE PATIENTS WITH PRE-EXISTING ATRIAL FIBRILLATION: A DANISH COHORT STUDY

P01.03 Michael Dalager-Pedersen. MYOCARDIAL INFARCTION AND STROKE AFTER INCIDENT COMMUNITY-ACQUIRED BACTEREMIA: A 19-YEAR COHORT STUDY

P01.04 Christina Mørup Jørgensen. INCREASED OXYGEN SATURATION IN RETINAL VESSELS OF PATIENTS WITH DIABETIC RETINOPATHY REQUIRING TREATMENT

P01.05 Nicoline Valentina Krogstrup. EARLY CHANGES IN PLASMA CREATININE PREDICT ONEYEAR GRAFT FUNCTION FOLLOWING KIDNEY TRANSPLANTATION

P01.06 Morten Schmidt. BODY MASS INDEX IN YOUNG ADULTHOOD AND RISK OF TYPE 2 DIABETES, CARDIOVASCULAR DISEASE AND DEATH BEFORE 55 YEARS OF AGE: A DANISH POPULATION-BASED COHORT STUDY

P01.07 Kristian Krogh. REALISM IN RESUSCITATION TRAINING: DOES TIME MATTER?

\section{Poster session 2 GP12: Clinical Medicine.}

Chairmen: Jens Rolighed \& Shallu Sharma (PhD student)

P02.01 Thomas Deleuran. MORTALITY AND RISK OF COMPLICATIONS OF CIRRHOSIS PATIENTS UNDERGOING HIP AND KNEE ARTHROPLASTY

P02.02 Mette Holland-Fischer. RHEUMATOID ARTHRITIS AND MORTALITY OF HOSPITALIZED PNEUMONIA; A POPULATION-BASED COHORT STUDY

P02.03 Anne Birgitte Simonsen. ALLERGIC CONTACT DERMATITIS IN DANISH CHILDREN

P02.04 Troels Johansen. A THEORETICAL FRAMEWORK FOR UNDERSTANDING BLOOD GAS LEVELS IN ASTHMA

P02.05 Leif Rognås. PREHOSPITAL ADVANCED AIRWAY MANAGEMENT

P02.06 Ane Birgitte Telén Andersen. PARENTAL INFLAMMATORY BOWEL DISEASE AND RISK OF ASTHMA IN OFFSPRING - A NATIONWIDE DANISH COHORT STUDY

P02.07 Zhanyuan Kang. TNF- $\alpha$ AND IL-17A-INDUCED S100A7 EXPRESSION IS REGULATED BY A P38 MAPK AND ERK1/2 DEPENDENT MECHANISM IN CULTURED HUMAN KERATINOCYTES

\section{Poster session 3 GP1 2: Clinical Medicine.}

Chairmen: Jens Leipziger \& Louise Tram Henriksen (PhD student)

P03.01 Christian Lottrup. ASSESSMENT WITH THE FUNCTIONAL LUMINAL IMAGING PROBE (FLIP) DISTINGUISHES OESOPHAGO-GASTRIC JUNCTION DISTENSIBILITY IN BARRETT'S OESOPHAGUS PATIENTS WITH HIATAL HERNIAS FROM HEALTHY CONTROLS - A PILOT STUDY

P03.02 Susanne Haas. FECAL INCONTINENCE AND SACRAL NERVE STIMULATION. IS CEREBRAL NEURO MODULATION A CAUSE OF EFFECT?

P03.03 Charlotte K. Lautrup. INCIDENCE OF COLORECTAL CANCER IN FIRST DEGREE RELATIVES TO COLORECTAL CANCER PATIENTS. A DANISH COHORT STUDY

P03.04 Palle Bager. FREQUENCY OF IRON SUBSTITUTION AND ANAEMIA AT DISCHARGE FROM A DANISH UPPER GI BLEEDING CENTRE

P03.05 Jonathan Montomoli. THIRTY-DAY MORTALITY IN PATIENTS UNDERGOING SURGERY BECAUSE OF DIVERTICULITIS: A DANISH NATIONWIDE COHORT STUDY

P03.06 Anne-Mette Haase. GASTROINTESTINAL CONTRACTION PATTERNS AND SEGMENTAL TRANSIT TIMES EVALUATED WITH AMBULATORY CAPSULE TRACKING 
P03.07 Eva Bjerre Ostenfeld. PREADMISSION USE OF SYSTEMIC GLUCOCORTICOIDS AND 30DAY MORTALITY AFTER COLORECTAL CANCER SURGERY

P03.08 Jesper Padkcr Petersen. THE UGT1A 1*28 ALLEL'S ASSOCIATION TO CRITICAL JAUNDICE

\section{Poster session 4 GP12: Clinical Medicine.}

Chairmen: Jørn Olsen \& Frank Holden Mose (PhD student)

P04.01 Kristoffer Koch. IMPACT OF SOCIOECONOMIC POSITION ON RISK OF COMMUNITYACQUIRED BACTEREMIA: A POPULATION-BASED CASE-CONTROL STUDY

P04.02 Betina Hansen. THE VALIDITY OF THE REGISTRATION OF ACUTE MEDICAL HOSPITAL ADMISSIONS IN THE DANISH NATIONAL REGISTRY OF PATIENTS

P04.03 Mikkel Andreas Strømgaard Andersen. CRITERIA-BASED EMERGENCY MEDICAL DISPATCH - A NOVELTY IN DENMARK

P04.04 Anne Fia Grann. COMORBIDITY AND SURVIVAL OF DANISH MELANOMA PATIENTS

P04.05 Trine Eilenberg. TREATMENT OF PATIENTS WITH HEALTH ANXIETY. A RANDOMIZED CONTROLLED TRIAL OF ACT (ACCEPTANCE AND COMMITMENT THERAPY) GROUP TREATMENT COMPARED TO A WAITING LIST

P04.06 Dorthe Krogsgaard Bonnerup. PROSPECTIVE VALIDATION OF AN ALGORITHM (MERIS) THAT CAN STRATIFY PATIENTS ACCORDING TO RISK OF MEDICATION ERRORS: A PILOT STUDY

P04.07 Malene Schou Nielsson. PREVALENCE OF BACTEREMIA IN THE INTENSIVE CARE UNIT: A DANISH CROSS-SECTIONAL STUDY

P04.08 Eva Sœdder. RISK FACTORS FOR MEDICATION ERRORS

\section{Poster session 5 GP12: Clinical Medicine.}

Chairmen: Jan Blaakœr \& Lau Brix (PhD student)

P05.01 Rikke Kade. ULTRASOUND GUIDED INSERTION OF CENTRAL UMBILICAL CATHETERS IN NEWBORN INFANTS: A NEW STANDARD IN THE CLINICAL PRACTISE?

P05.02 Anne Gulbech Ording. IMPACT OF BIOLOGIC INTERACTION BETWEEN BREAST CANCER AND COMORBIDITY ON ALL-CAUSE MORTALITY

P05.03 Cathrine Bach. MEASUREMENT OF FETAL DNA IN PLASMA OF PREGNANT WOMEN

P05.04 Lene Hee Christensen. NEW METHOD TO EVALUATE THE BIOMECHANICAL PROPERTIES OF THE UTERINE CERVIX

P05.05 Marie Krarup Schrøder. IS THERE A GENDER DIFFERENCE IN THE PATHOGENESIS OF CHILDHOOD NOCTURNAL ENURESIS?

P05.06 Cathrine Ladegaard Wildenschild Nielsen. HISTORY OF PRETERM DELIVERY AND TIME TO PREGNANCY (TTP)

P05.07 Niels Bjerregård Matthiesen. PATTERNS OF PRENATAL CEREBRAL GROWTH AMONG INFANTS WITH CONGENITAL HEART DISEASE

P05.08 Anne Nakano Jensen. AGE AND SEX-RELATED DIFFERENCES IN PROCESSES OF CARE AND MORTALITY AMONG PATIENTS WITH INCIDENT HEART FAILURE IN DENMARK, 2003-2010

\section{Poster session 6 GP5: Inflammation and Infection.}

Chairmen: Mette Bjerre, Steffen Bank (PhD student) \& Mariane Høgsbjerg Schleimann (PhD student)

P06.01 Christian Bo Poulsen. A NEW MODEL FOR FLOW-MEDIATED ACCELERATION OF CORONARY ATHEROSCLEROSIS

P06.02 Kanja Krogh. DEVELOPMENT OF A PROCESS TO THE PURIFICATION OF MANNANBINDING LECTION (MBL) AND TEST OF MBL IN A GLUCOE BIOSENSOR FOR CONTINOUS BLOOD GLUCOSE MONOTORING 
P06.03 Annette Søndergaard. MOLECULAR ORGANIZATION OF SMALL PLASMIDS BEARING $\mathrm{BLA}_{\text {TEM-1 }}$ AND CONFERRING RESISTANCE TO BETA-LACTAMS IN HAEMOPHILUS INFLUENZAE

P06.04 Søren Brandsborg. RESTORATIVE PROCTOCOLECTOMY (RPC) IN PATIENTS WITH ULCERATIVE COLITIS (UC): A CROSS-SECTIONAL DANISH POPULATION STUDY ON FUNCTION AND QUALITY OF LIFE

P06.05 Winnie Ridderberg. MULTILOCUS SEQUENCE ANALYSIS OF ISOLATES OF ACHROMOBACTER FROM PATIENTS WITH CYSTIC FIBROSIS REVEALS INFECTING SPECIES OTHER THAN ACHROMOBACTER XYLOSOXIDANS

P06.06 Randi Heidemann Gottfredsen. CHARACTERIZATION OF THE R213G VARIANT OF EXTRACELLULAR SUPEROXIDE DISMUTASE

P06.07 Line Raaby OIsen. MIRNA NORMALIZATION CANDIDATES FOR QPCR IN LESIONAL AND NON-LESIONAL PSORIATIC SKIN

\section{Poster session 7 GP5: Inflammation and Infection.}

Chairmen: Tove Christensen, René Østgård (PhD student) \& Srikanth Chiliveru (PhD student)

P07.01 Thomas Aagaard Rasmussen. THE HISTONE DEACETYLASE (HDAC) INHIBITOR PANOBINOSTAT (LBH589) INDUCES HIV- 1 EXPRESSION AT THERAPEUTIC CONCENTRATIONS AND WITH HIGHER POTENCY THAN OTHER HDAC INHIBITORS IN CLINICAL USE

P07.02 Marie Beck Iversen. IDENTIFICATION OF AN EARLY CXCR3-DEPENDENT ANTIVIRAL MECHANISM IN THE FEMALE GENITAL TRACT WORKING PRIOR TO THE ACTION OF INTERFERONS

P07.03 Torben Hansen. COMBINATION OF ZOLEDRONIC ACID AND TARGETED THERAPY IS ACTIVE BUT MAY INDUCE OSTEONECROSIS OF THE JAW IN PATIENTS WITH METASTATIC RENAL CELL CARCINOMA

P07.04 Johannes Martin Schmid. INCREASED ALLERGEN-SPECIFIC IGG4 LEVELS ARE LINKED TO SUPPRESSED IGE TITERS WHEN ANALYZED BY MULTIPLEX MOLECULAR ALLERGEN CHIP BUT NOT BY FLUOROENZYME IMMUNOASSAY

P07.05 Kathrine Hansen. IFI16 IS AN EARLY SENSOR OF LISTERIA MONOCYTOGENES DNA IN THE CYTOSOL STIMULATING IFNB EXPRESSION

P07.06 Troels Rønn Kjœr. STRUCTURAL CHARACTERIZATION OF MANNAN-BINDING LECTIN AND ITS ASSOCIATED PROTEINS

P07.07 Tue Wenzel Kragstrup. PLASMA LEVELS OF SOLUBLE CD1 8 ARE NEGATIVELY ASSOCIATED TO DISEASE ACTIVITY IN SPONDYLOARTHRITIS

\section{Poster session 8 GP5: Inflammation and Infection.}

Chairmen: Ebba Nexø, Louise Brøndt Hartlev (PhD student) \& Babak Jalilian (PhD student)

P08.01 Morten Leif Munding Stilund. SOLUBLE CD163 AS A DIAGNOSTIC MARKER IN MULTIPLE SCLEROSIS

P08.02 Lise Tornvig Erikstrup. CLOSTRIDIUM DIFFICILE INFECTION IN A MOUSE MODEL

P08.03 Nis Pedersen Jørgensen. IN VIVO MEASUREMENT OF BACTERIAL LOAD IN A MODEL OF STAPHYLOCOCCUS AUREUS IMPLANT ASSOCIATED OSTEOMYELITIS CAUSED BY THE FORMATION OF A BACTERIAL BIOFILM

P08.04 Stinne Ravn Greisen. INCREASED LEVELS OF SOLUBLE PROGRAMMED CELL DEATH 1 (SPD-1) AND ITS SOLUBLE LIGAND (SPD-L1) IN EARLY RHEUMATOID ARTHRITIS ARE ASSOCIATED WITH DISEASE ACTIVITY AND PROGRESSION

P08.05 Maria Rusan. PREVALENCE OF HUMAN PAPILLOMAVIRUS IN TONSILLAR DISEASES IN DENMARK

P08.06 Tue Kruse Rasmussen. T CELLS FROM SLE PATIENTS SHOW INCREASED REACTIVITY TO IL-2 1 AS MEASURED BY PHOSPHORYLATION OF STAT3 

PROPIONIBACTERIUM ACNES ISOLATED FROM HEALTHY AND ACNE AFFECTED HUMAN SKIN

\section{Poster session 9 GP6: Cardiovascular.}

Chairmen: Marc de Leval, Asger Andersen (PhD student) \& Jonas Agerlund Povlsen (PhD student)

P09.01 Torbjørn Halle Brøgger. PLACENTAL VASCULAR RESPONSES ARE DEPENDENT ON SURROUNDING TISSUE

P09.02 Johan Heiberg. REDUCED EXERCISE CAPACITY IN PATIENTS OPERATED FOR VENTRICULAR SEPTAL DEFECT

P09.03 Camilla Nyboe. CLOSURE OF ATRIAL SEPTAL DEFECT IN THE ADULT

P09.04 Janni Majgaard Jensen. EFFECT OF ISOTONIC AND HYPERTONIC SODIUM CHLORIDE AND GLUCOSE ON EXCRETION OF URINARY AQUAPORIN2 IN HEALTHY SUBJECTS

P09.05 Sisse Anette Thomassen. CAN NEAR-INFRARED SPECTROSCOPY DETECT CRITICAL PERFUSION IN MUSCLE TISSUE DURING CARDIOPULMONARY BYPASS IN AN ANIMAL MODEL?

P09.06 Anders Jorsal. CARDIAC EFFECTS OF GLP-1 TREATMENT IN PATIENTS WITH CHRONIC HEART FAILURE

P09.07 Dinah Sherzad Khatir. REPRODUCIBILITY OF RENAL ARTERY FLOW AND BLOOD OXYGEN LEVEL DEPENDENT MEASUREMENTS USING MAGNETIC RESONANCE IMAGING IN PATIENTS WITH CHRONIC KIDNEY DISEASE AND HEALTHY CONTROLS

\section{Poster session 10 GP6: Cardiovascular.}

Chairmen: Michael Rahbek Schmidt, Carsten Stengaard (PhD student) \& Vibeke Secher Nielsen (PhD student)

P10.01 Jacob Johnsen. ROLE OF O-LINKED N-ACETYLGLUCOSAMINE (O-GLCNAC) AND AFFERENT NEURAL PATHWAYS IN REMOTE ISCHEMIC PRECONDITIONING (RIPC)

P10.02 Troels Fogh Pedersen. THE EFFECT OF PRECONDITIONING FOR PREVENTION OF PERIOPERATIVE MYOCARDIAL ISCHEMIA IN ABDOMINAL AORTIC ANEURYSMS

P10.03 Sarah Holmboe. INOTROPIC EFFECTS OF ILOPROST IN THE HYPERTROPHIC AND FAILING RIGHT HEART

P10.04 Simon Winther. OSTEOPROTEGERIN AS A PROGNOSTIC MARKER OF MORTALITY IN HEMODIALYSIS PATIENTS WITH CARDIOVASCULAR DISEASE

P10.05 Steven Brantlov. BIOELECTRICAL IMPEDANCE SPECTROSCOPY FOR CLINICAL ASSESSMENT OF BODY COMPOSITION IN HEALTHY AND SICK CHILDREN

P10.06

Eva Amalie Nielsen. SURGICAL TREATMENT OF PULMONARY STENOSIS - 50 YEARS OF FOLLOW-UP

\section{Poster session 11 GP6: Cardiovascular.}

Chairmen: Troels Fogh Pedersen \& Christian Daugaard Peters (PhD student)

P11.01 Anne Sophie Pinholt Kancir. EFFECT OF HYDROXYETHYL STARCH ON RENAL HANDLING OF SODIUM AND WATER, VASOACTIVE HORMONES, BIOMARKERS AND CIRCULATION IN PATIENTS UNDERGOING HIP REPLACEMENT.

P11.02 Nicolaj Christopher Hansson. MULTIDETECTOR COMPUTED TOMOGRAPHY VERSUS TRANSESOPHAGEAL ECHOCARDIOGRAPHY FOR ANNULAR SIZING IN TRANSCATHETER AORTIC VALVE REPLACEMENT

P11.03 Susanne Bendesgaard Pedersen. GEOGRAPHICAL VARIATION IN THE USE OF IMPLANTABLE CARDIOVERTER-DEFIBRILLATOR (ICD) TREATMENT AMONG PATIENTS WITH PRIOR MYOCARDIAL INFARCTION IN DENMARK

P11.04 Jannik Bertelsen. RANDOMIZED CLINICAL PILOT TRIAL COMPARING EFFICACY AND SAFETY OF CARDIAC REHABILITATION: IN HOSPITAL VS OUT OF HOSPITAL 
P11.05 Anne Dorte Blankholm. MAGNETIC RESONANCE ANGIOGRAPHY OF THE PELVIC VESSELS IN CANDIDATES FOR KIDNEY TRANSPLANTATION WITHOUT USE OF CONTRAST AGENTS

\section{Poster session 12 GP2: Molecular Metabolism and Endocrinology.}

Chairmen: Bjørn Richelsen, Christoffer Laustsen (PhD student) \& Mark Reinhard (PhD student)

P12.01 Sine Knorr Sørensen. ENVIROMENTAL VERSUS GENETIC AND EPIGENETIC INFLUENCES ON GROWTH, METABOLISM AND COGNITIVE FUNCTION IN OFFSPRING OF MOTHERS WITH TYPE 1 DIABETES

P12.02 Mette Bohl Larsen. DAIRY LIPIDS, PROTEINS AND THE METABOLIC SYNDROME - "DAIRY HEALTH"

P12.03 Anne Grethe Schioldan. THE METABOLIC EFFECTS OF RESISTANT STARCH AND ARABINOXYLANS IN SUBJECTS WITH METABOLIC SYNDROME

P12.04 Søren Møller Madsen. MUSCLE TISSUE OXYGENATION

P12.05 Karen Krogh Fjeldborg. THE MACROPHAGE SPECIFIC SERUM MARKER SOLUBLE CD163 IS INCREASED IN OBESITY AND PARTIALLY NORMALIZED AFTER DIETARY INTERVENTION

P12.06 Nilani Ramshanker. GLUCOCORTICOID-INDUCED INHIBITION OF IGF-I ACTIVTY: EXPLORATION OF UNDERLYING MECHANISMS

P12.07 Marie Juul Ørnstrup. EFFECTS OF RESVERATROL ON PROLIFERATION AND DIFFERENTIATION OF HUMAN BONE MARROW-DERIVED OSTEOBLASTS

\section{Poster session 13 GP2: Molecular Metabolism and Endocrinology.}

Chairmen: Robert Fenton \& Karina Bech Cullberg (PhD student)

P13.01 Jeppe Skov. GLUCAGON-LIKE PEPTIDE-1 (GLP-1): EFFECT ON KIDNEY HEMODYNAMICS AND RENIN-ANGIOTENSIN-ALDOSTERONE SYSTEM IN HEALTHY MEN

P13.02 Poul Vestergaard Nielsen. GROWTH HORMONE SIGNALING IN MUSCLE AND FAT: A COMPARATIVE STUDY OF SIGNAL MECHANISMS IN MUSCLE AND FAT, BETWEEN YOUNG AND OLD OF BOTH SEXES

P13.03 Marianne Kjœr Poulsen. EFFECTS OF RESVERATROL ON LIVER FAT CONTENT AND FAT METABOLISM IN OBESE MEN WITH NON-ALCOHOLIC FATTY LIVER DISEASE

P13.04 Thomas Nordstrøm Kjœr. INVESTIGATIONS OF THE ANTI-INFLAMMATORY EFFECTS OF RESVERATROL STUDIED IN VIVO AND IN VITRO

P13.05 Ann Mosegaard Bak. THE INFLUENCE OF BODY COMPOSITION ON GROWTH HORMONE SIGNALLING, ENERGY METABOLISM AND INSULIN SENSITIVITY AFTER 72 HOURS OF FASTING

P13.06 Julie Støy. BASAL METABOLIC PHENOTYPE CHARACTERIZATION OF CARRIERS OF A VARIANT IN THE GENE X

\section{Poster session 14 GP9: Oncology.}

Chairmen: Marianne Nordsmark, Julie Damgaard Sandahl (PhD student) \& Lotte Sander (PhD student)

P14.01 Katherina Farr. LUNG TOXICITY AND SURVIVAL IN RADICAL RADIOTHERAPY OF STAGE III NON-SMALL-CELL LUNG CANCER

P14.02 Christina Daugaard Lyngholm. LONG-TERM FOLLOW-UP OF LATE MORBIDITY, COSMETIC OUTCOME AND BODY IMAGE AFTER BREAST CONSERVING THERAPY. A STUDY FROM THE DANISH BREAST CANCER COOPERATIVE GROUP (DBCG)

P14.03 Martin Bjerregård Pedersen. DIGITAL PATHOLOGY FOR THE ASSESSMENT OF TISSUE MICROARRAYS IN PERIPHERAL T-CELL LYMPHOMAS

P14.04 Ninna Aggerholm Pedersen. THE INFLUENCE OF HYPOXIA ON SARCOMA PATIENT RESISTANCE TO CHEMOTHERAPY AND IRRADIATION THERAPY 
P14.05 Steffen Falgreen Larsen. COMMONLY USED SUMMARY STATISTICS IN CELL LINE BASED DRUG DOSE RESPONSE STUDIES ARE INFLUENCED BY DRUG EXPOSURE TIME

P14.06 Marie Louise Bønnelykke-Behrndtz. CHARACTERISATION OF INNATE IMMUNE CELL SUBTYPES IN ULCERATED MELANOMA

P14.07 Anja Pagh. THE VALUE OF ROUTINE FOLLOW-UP AFTER TREATMENT FOR HEAD AND NECK CANCER. A NATIONAL DAHANCA STUDY

P14.08 Helene Myrtue Nielsen. THE CELL SPECIFIC METHYLOME PROFILE PAVES THE WAY FOR CANDIDATE BIOMARKERS OF DIAGNOSTIC AND PREDICTIVE VALUE FOR PATIENTS WITH PHILADELPHIA CHROMOSOME NEGATIVE MYELOPROLIFERATIVE NEOPLAMS

\section{Poster session 15 GP9: Oncology.}

Chairmen: Marie Stampe Ostenfeld \& Johanne Lade Keller (PhD student)

P15.01 Lene Sofie Granfeldt Østgård. DO RESULTS FROM CLINICAL TRIALS IN ACUTE MYELOID LEUKAEMIA REFLECT CLINICAL REALITY? A DANISH NATIONAL COHORT STUDY OF 813 PATIENTS

P15.02 Kristine Raaby Jakobsen. CHARACTERISATION OF CANCER STEM CELLS IN NSCLC CELL LINES

P15.03 Sara Correia Marques. FUNCTIONAL ANALYSIS OF MICRORNA-DEPENDENT CHEMOSENSITIVITY IN B-CELL CANCERS BY LENTIVIRAL TRANSDUCTION IN HUMAN CANCER B-CELL LINES

P15.04 Katja Maretty Nielsen. THE POPULATION-BASED AARHUS SARCOMA REGISTRY: VALIDITY, COMPLETENESS AND INCIDENCE OF BONE AND SOFT TISSUE SARCOMAS IN WESTERN DENMARK

P15.05 Mohamed Ahmed Hassan. ACCELERATED RADIOTHERAPY WITH OR WITHOUT NIMORAZOLE IN A RANDOMIZED MULTICENTER TRIAL

P15.06 Anne Bodilsen. DOES MARGIN SIZE MATTER IN BREAST CONSERVING SURGERY? A RETROSEPCTIVE COHORT STUDY

P15.07 Lotte Andreasen. THE SEARCH FOR GENETIC MARKERS TO PREDICT THE CANCER-LIKE DISEASE, PTD, WHICH MIGHT DEVELOP AFTER AN ABNORMAL HUMAN PREGNANCY

P15.08 Mette Winther. ANALYSIS OF THE CLINICAL IMPACT OF A NOVEL CHEMOTHERAPY AND IRRADIATION SENSITIVITY PREDICTOR IN GASTROESOPHAGEAL CANCER

\section{Poster session 16 GP9: Oncology.}

Chairmen: Jan Alsner, Esben Schjødt Worm (PhD student) \& Eduardo Vazquez Garza (PhD student)

P16.01 Martin Skovmos Nielsen. RESPIRATORY GATED IGRT USING FIDUCIAL MARKER. TREATMENT PLANNING AND IMAGE GUIDANCE ACCURACY

P16.02 Trine Majken Gade Bonnesen. ADULT LIFE AFTER CHILDHOOD CANCER IN SCANDINAVIA (ALICCS) - LATE RENAL AND GASTROINTESTINAL EFFECTS AND THEIR PREVENTION IN CHILDHOOD CANCER SURVIVORS

P16.03 Søren Ravn. MORPHOLOGICAL MRI VERSUS DIFFUSION TENSOR IMAGING BASED ASSESSMENT OF WHICH BRAIN TUMOUR PATIENTS ARE IN NEED OF PRESURGICAL LANGUAGE FUNCTIONAL MRI

P16.04 Thomas Lyhne Ravkilde. TIME-RESOLVED EVOLVEMENT OF TARGET DOSE DISTRIBUTION DURING IMAT WITH AND WITHOUT DYNAMIC MLC TRACKING

P16.05 Sandy Mohamed Ismail Mohamed. MODELS FOR BRACHYTHERAPY DOSE DEESCALATION IN LOW RISK LOCALLY ADVANCED CERVICAL CANCER PATIENTS

P16.06 Søren Haack. BO-CORRECTION AND K-MEANS CLUSTERING FOR ACCURATE AND AUTOMATIC IDENTIFICATION OF REGIONS WITH REDUCED APPARENT DIFFUSION COEFFICIENT (ADC) IN ADVANCED CERVICAL CANCER AT THE TIME OF BRACHYTHERAPY 
P16.07 Lotte Bonde Bertelsen. RADIOACTIVE LABELLING AND HOMING OF ENDOTHELIAL PROGENITOR CELLS

Poster session 17 GP9: Oncology, GP1 1: Tooth, Bone and Joint Diseases.

Chairmen: Lau Brix \& Jesper Kallehauge (PhD student)

P17.01 Sepp De Raedt. FULLY AUTOMATED MEASUREMENT OF RADIOLOGICAL ANGLES IN HIP DYSPLASIA USING CT IMAGES

P17.02 David Christoffer Hansen. COMBINED PROTON AND X-RAY TOMOGRAPHY

P17.03 Jill Rachel Mains. DYNAMIC CONTRAST-ENHANCED IMAGING AS A POTENTIAL BIOMARKER IN METASTATIC RENAL CELL CARCINOMA: PRELIMINARY ANALYSIS FROM THE DARENCA- 1 STUDY

P17.04 Rubens Spin-Neto. CONE BEAM CT IMAGE ARTIFACTS RELATED TO HEAD MOTION SIMULATED BY A ROBOT SKULL: VISUAL CHARACTERISTICS AND IMPACT ON IMAGE QUALITY

P17.05 Lise Thorsen. DOSE COVERAGE OF INTERNAL MAMMARY LYMPH NODES IN BREAST CANCER RADIOTHERAPY: MISSION ACCOMPLISHED?

P17.06 Joan Fledelius. FDG-PET/CT FOR RESPONSE EVALUATION IN LOCALLY ADVANCED NSCLC PATIENTS; A PILOT STUDY

P17.07 Jesper Thygesen. THE INFLUENCE OF ITERATIVE RECONSTRUCTION ON FUNCTIONAL PARAMETERS IN DYNAMIC CONTRAST-ENHANCED CT-IMAGING (DCE-CT)

P17.08 Anne Vestergaard. COMPARISON OF ADAPTIVE PLAN SELECTION VS. PLAN-OF-THEDAY IN RADIOTHERAPY FOR BLADDER CANCER

\section{Poster session 18 GP1 1: Tooth, Bone and Joint Diseases.}

Chairmen: Christer Swan Andreassen \& Jan Rölfing (PhD Student)

P18.01 Mikkel Tøttrup. IN VITRO VALIDATION OF MICRODIALYSIS FOR THE MEASUREMENT OF CEFUROXIME CONCENTRATION

P18.02 Maj Høygaard Nicolaisen. ORAL HEALTH IMPACT AFTER REPLACEMENT OF A MISSING POSTERIOR TOOTH WITH A FIXED DENTAL PROSTHESIS: A CLINICAL TRIAL

P18.03 Thøger Persson Krogh. COMPARATIVE EFFECTIVENESS OF INJECTION THERAPIES IN LATERAL EPICONDYLITIS: A SYSTEMATIC REVIEW AND NETWORK META-ANALYSIS OF RANDOMIZED CONTROLLED TRIALS

P18.04 Kristian Andersen. EFFECT OF MANDIBULAR DISTRACTION OSTEOGENESIS ON TMJ WITH EXPERIMENTAL ARTHRITIS

P18.05 Daniel Belstrøm. BACTERIAL PROFILE OF SALIVA IN ORAL HEALTH

P18.06 Akiko Shimada. EFFECTS OF SYSTEMIC GLUTAMATE ON CRANIOFACIAL PAIN

P18.07 Morten Christian Bay Grauballe. DIABETES AND PERIODONTITIS: THE ROLE OF TNFALPHA AND RAGE IN A RAT MODEL

P18.08 Abhishek Kumar. PERIODONTAL MECHANORECEPTORS AND THEIR ROLE IN FINE MOTOR CONTROL OF THE JAW

\section{Poster session 19 GP11: Tooth, Bone and Joint Diseases.}

Chairmen: Maiken Stilling \& Emilia Horjales (PhD student)

P19.01 Anette Liljensøe. DOES BODY COMPOSITION HAVE ANY EFFECT ON THA-SCHEDULED PATIENTS' ASSESSMENT OF THEIR OWN HIP PROBLEMS? A PREOPERATIVE CROSSSECTIONAL STUDY

P19.02 Michael Skovdal Rathleff. HIGH PREVALENCE OF DAILY PAIN AND MULTI-SITE PAIN - A CROSS-SECTIONAL STUDY AMONG 3000 ADOLESCENTS 
P19.03 Lone Ramer Nygaard Mikkelsen. THE INFLUENCE OF ASSISTIVE DEVICES AND MOVEMENT RESTRICTIONS DURING REHABILITATION AFTER FAST-TRACK TOTAL HIP REPLACEMENT (THR)

P19.04 Merete Gregersen. A LIBERAL BLOOD TRANSFUSION STRATEGY AFTER HIP FRACTURE SURGERY DOES NOT INCREASE THE RISK OF INFECTION IN FRAIL ELDERLY PATIENTS

P19.05 Lene Rahr Wagner. INCREASED RISK OF REVISION SURGERY AFTER ANTERIORMEDIAL COMPARED WITH TRANSTIBIAL TECHNIQUE FOR FEMORAL DRILLHOLE PLACEMENT DURING ANTERIOR CRUCIALTE LIGAMENT RECONSTRUCTION. RESULTS FROM THE DANISH KNEE LIGAMENT RECONSTRUCTION REGISTRY (DKRR)

P19.06 Manoj Ramachandran. COMPARISON OF OUTCOMES AND COMPLICATIONS OF HIP ARTHROSCOPY FOR MIXED HIP DISORDERS IN ADOLESCENTS VERSUS ADULTS: A PROSPECTIVE COHORT STUDY

P19.07 Jannie Dahl Hald. HEALTH-RELATED QUALITY OF LIFE IN ADULTS WITH OSTEOGENESIS IMPERFECTA IS IMPAIRED BY PREVALENCE OF MULTIPLE FRACTURES

P19.08 Kresten Rickers. EXPERIMENTAL REGENERATIVE REPAIR OF ANNULUS FIBROSUS USING SCAFFOLDS AND MESENCHYMAL STEM CELLS IN A PORCINE HERNIATION MODEL

\section{Poster session 20 GP1: Membrane, Transporters and Receptors.}

Chairmen: Helle Damkier, Pauline de Bruijn (PhD student) \& Sascha Eichendorff (PhD student)

P20.01 Henriette Lajgaard Christensen. DOES NA:HCO 3 COTRANSPORTER E2 REGULATE CEREBROSPINAL FLUID PH AND RESPIRATORY RATE?

P20.02 Nina Jensen. PHYSIOLOGICAL AND PATHOLOGICAL FUNCTION OF THE TYPE II SODIUM-DEPENDENT PHOSPHATE TRANSPORTERS WITH FOCUS ON THEIR ROLE IN CALCIFICATION

P20.03 Mie Rostved Rasmussen. THE PSEUDOXANTHOMA ELASTICUM ENIGMA; A SEARCH FOR THE ABCC6 SUBSTRATE

P20.04 Steen Fagerberg. P2X RECEPTOR-DEPENDENT ERYTHROCYTE DAMAGE BY ALPHAHEMOLYSIN FROM ESCHERICHIA COLI TRIGGERS PHAGOCYTOSIS BY THP- 1 CELLS

P20.05 Anders Riisager Sørensen. SIGNAL TRANSMISSION FROM MUSCLE ACTIVITY TO CLC-1 CHLORIDE CHANNEL FUNCTION

P20.06 Casper Kornbech Larsen. COLONIC K+ SECRETION IN KCNMB2 KNOCKOUT MICE

P20.07 Tine Kjœrgaard. TRAFFICKING OF LRP1 AND LRP2 IN HUMAN PLACENTA

P20.08 Søren Brandt Poulsen. INACTIVATION OF THE EPITHELIAL SODIUM CHANNEL (ENAC) IN THE ALDOSTERONE-SENSITIVE CONNECTING TUBULE

\section{Poster session 21 GP7: Laboratory Medicine.}

Chairmen: Bent Deleuran \& Jacob Mørup Schlütter (PhD student)

P21.01 Omar Abuyaman. STUDIES ON THE SOLUBLE RECEPTOR FOR VITAMIN B ${ }_{12}$ UPTAKE (SCD320) DURING PREGNANCY

P21.02 Helen Nordahl Madsen. THE IMPACT OF ANTI-MULLERIAN HORMONE (AMH) ON THE EPIDERMAL GROWTH FACTOR (EGF) SYSTEM IN PREANTRAL FOLLICLES

P21.03 Alice Østergaard. STRUCTURAL AND CONFORMATIONAL CHARACTERIZATION OF INACTIVE FORMS OF ANTITHROMBIN (AT)

P21.04 Anette Tarp Hansen. INCREASED RISK OF THROMBOSIS IN PREGNANCY AFTER IN VITRO FERTILIZATION: A DANISH NATIONAL COHORT STUDY

P21.05 Tina Rask Elmholdt. GADOLINIUM DEPOSIT IN SKIN BIOPSIES FROM RENAL IMPAIRED PATIENTS WITH AND WITHOUT NEPHROGENIC SYSTEMIC FIBROSIS

P21.06 Johan Frederik Berg Arendt. ELEVATED PLASMA VITAMIN B12 LEVELS AS A MARKER FOR OCCULT CANCER 


\section{Poster session 22 GP10: Translational Molecular Medicine.}

Chairmen: Mads F. Kjølby \& Trine Dalsgaard (PhD student)

P22.01 Zahra Nochi. THE ROLE OF ALPHA-LIPOIC ACID IN MEDIUM-CHAIN ACYL-COA DEHYDROGENASE DEFICIENCY

P22.02 Navid Sahebekhtiari. MITOCHONDRIAL DYSFUNCTION AND MITOCHONDRIAL ACETYLATION IN FAO DEFECTS

P22.03 Veerle Paternoster. CONDITIONAL INACTIVATION OF THE SCHIZOPHRENIA AND BIPOLAR DISORDER ASSOCIATED GENE IN THE CENTRAL NERVOUS SYSTEM OF MICE

P22.04 Morten Torvund-Jensen. STRUCTURAL CHARACTERIZATION OF THE INTERACTION BETWEEN HAPTOGLOBIN-HEMOGLOBIN AND MACROPHAGE RECEPTOR CD 163

P22.05 Xiao Ma. IDENTIFICATION OF POSSIBLE DRIVING FACTORS OF ENDOTHELIAL CELL TUBE FORMATION DURING CULTIVATION ON THE RANDOM POSITIONING MACHINE

P22.06 Dennis Kjølhede Jeppesen. QUANTITATIVE PROTEOMICS OF FRACTIONATED MEMBRANE AND LUMEN EXOSOME PROTEINS FROM ISOGENIC METASTATIC AND NON-METASTATIC BLADDER CANCER CELLS

P22.07 Halldór Bjarki Einarsson. IMMUNOGENICITY OF POLYCAPROLACTONE

P22.08 Maja Ludvigsen. DIFFERENT PROTEIN EXPRESSION PATTERNS MAY INDICATE DIFFERENT DISEASE MECHANISMS IN OLDER AND YOUNGER HL PATIENTS

\section{Poster session 23 GP10: Translational Molecular Medicine.}

Chairmen: Karin Birkenkamp-Demtröder \& Nanna Cornelius (PhD student)

P23.01 Emil Hagen Ernst. COMPARATIVE STUDIES ON GLOBAL GENE ANALYSIS OF OOCYTES AND GRANULOSA CELLS FROM DIFFERENT STAGES IN EARLY HUMAN FOLLICULOGENESIS

P23.02 Jonas Jensen. INCREASED BONE FORMATION IN A PORCINE CRITICAL SIZE DEFECT WHEN USING HYALURONIC ACID AND TCP COATED POLYCAPROLACTONE SCAFFOLDS SEEDED WITH AUTOLOGOUS DENTAL PULP STEM CELLS

P23.03 Anto Praveen Rajkumar Rajamani. BRDI GENE KNOCK-OUT MOUSE MODEL EXHIBITS REVERSIBLE DEPRESSIVE PHENOTYPE AND COGNITIVE DEFICITS

P23.04 Gitte Brinch Andersen. ELUCIDATION OF THE PATHOGENESIS OF OSTEOSARCOMAS (OS) THROUGH HIGH-THROUGHPUT FUNCTIONAL EPIGENOMICS

P23.05 Helle Kristensen. EPIGENETIC SILENCING AND BIOMARKER POTENTIAL OF MIR-224, MIR-452 AND THEIR HOST GENE GABRE IN PROSTATE CANCER

P23.06 Lea Hougaard Pedersen. POTENTIAL BENIFICIAL EFFECTS OF MEPO-PLASMID ON TGFß 1-INDUCED GLOMERULARSCLEROSIS

P23.07 Anne Louise Askou. INTEGRATION-DEFICIENT LENTIVIRAL VECTORS AS GENE DELIVERY VEHICLES FOR TREATMENT OF AMD

P23.08 Inge Gram Carlsen. REGULATION OF PHOSPHORYLATED HEAT SHOCK PROTEIN 27 IN RESPONSE TO ACUTE URETERAL OBSTRUCTION

\section{Poster session 24 GP10: Translational Molecular Medicine.}

Chairmen: Per Höllsberg \& Martin Mørck Mortensen (PhD student)

P24.01 Aida Solhøj Hansen. SIGNIFICANCE OF CD46 ISOFORMS FOR ENTRY OF HUMAN HERPESVIRUS 6B

P24.02 Henrik Lauridsen. LEARNING FROM NATURE: MYOCARDIAL REGENERATION FOLLOWING INFARCTION

P24.03

Lise Lindahl. SUBSEQUENT CANCERS, MORTALITY AND CAUSES OF DEATH IN PATIENTS WITH MYCOSIS FUNGOIDES AND PARAPSORIASIS: A DANISH NATIONWIDE POPULATION-BASED COHORT STUDY 
P24.04 Michal Switnicki. DEVELOPMENT OF INTEGRATIVE DATA ANALYSIS TOOLS TO IDENTIFY CLINICALLY RELEVANT MOLECULAR CHANGES IN PROSTATE CANCER: A SYSTEMS BIOLOGY APPROACH

P24.05 Line Nilsson. COX-2 INHIBITION EXACERBATES SODI DOWREGULATION AND THE PROGRESSION OF RENAL OXIDATIVE STRESS IN RESPONSE TO UUO

P24.06 Mia Benedicte Lykke Roest Laursen. METABOLIC FINGERPRINT OF REMOTE PRECONDITIONING

P24.07 Shivani Joshi. HIGH-RESOLUTION MELTING ANALYSIS FOR STUDY OF GENE VARIATIONS IN NEPHROTIC SYNDROME

P24.08 Mia Møller. GENETIC AND EPIGENETIC HETEROGENEITY OF PROSTATE CANCER

\section{Poster session 25 GP10: Translational Molecular Medicine.}

Chairmen: Lise Lotte Hansen \& Xue Lin (PhD student)

P25.01 Siri Hundtofte Strand. GENOMEWIDE PROFILING OF THE PROSTATE CANCER METHYLOME FOR DETECTION OF NEW PROSTATE CANCER BIOMARKERS

P25.02 Yujia Cai. POTENT DNA TRANSPOSITION BY PROTEIN TRANSDUCTION OF THE PIGGYBAC TRANSPOSASE FROM LENTIVIRAL GAG PRECURSORS

P25.03 Trine Salomon Andreasen. INVESTIGATING SMALL METABOLITES: DEVELOPMENT OF UPLC-MS/MS METHOD FOR ANALYSIS OF AMINO ACIDS AND ACYLCARNITINES

P25.04 Kang Ran. ANNULUS FIBROSUS TISSUE ENGINEERING BY SEEDING STEM CELLS INTO ELECTROSPUN NANOFIBROUS SCAFFOLDS

P25.05 Lene Hjelle Tauris. LINKAGE STUDY ON A LARGE FAMILY WITH NOCTURNAL ENURESIS AND ESTABLISHMENT OF A WEB-BASED NOCTURNAL ENURESIS BIOBANK

P25.06 Kasper Hansen. A NOVEL MR, CT, PET COMPATIBLE PRESSURE CHAMBER FOR STUDIES IN HYPERBARIC PHYSIOLOGY

P25.07 Paula Fernandez Fernandez Guerra. NEW PROTOCOL FOR MITOCHONDRIAL AND CELLULAR ASSESSMENT OF HUMAN DERMAL FIBROBLASTS

\section{Poster session 26 GP8: Neuroscience.}

Chairmen: Raben Rosenberg, Line Granild Bie Mertz (PhD student) \& Páll Karlsson (PhD student)

P26.01 Gitte Bundgaard Christiansen. SORCS3 IS A KEY PLAYER IN LONG-TERM DEPRESSION (LTD) IN THE HIPPOCAMPUS

P26.02 Søren Dinesen Østergaard. THE ASSOCIATION BETWEEN PSYCHOTIC MANIA, PSYCHOTIC DEPRESSION AND MIXED AFFECTIVE EPISODES AMONG 14,530 PATIENTS WITH BIPOLAR DISORDER

P26.03 Janne Mortensen. EARLY POST-STROKE USE OF SELECTIVE SEROTONIN REUPTAKE INHIBITORS AND CLINICAL OUTCOME AMONG PATIENTS WITH ISCHEMIC STROKE: A REGIONAL PROPENSITY-SCORE MATCHED FOLLOW-UP STUDY

P26.04 Anna Tietze. IMAGING OF WHITE MATTER INFILTRATION END HETEROGENEOUS HISTOPATHOLOGY IN CEREBRAL GLIOMAS: DO [ $\left.{ }^{11} \mathrm{C}\right]$-METHIONINE POSITRON EMISSION TOMOGRAPHY AND PERFUSION-WEIGHTED MAGNETIC RESONANCE IMAGING YIELD SIMILAR RESULTS?

P26.05 Lene Duez. EPILEPTIC FOCUS FOUND BY MAGNETOENCEPHALOGRAPHY IN THE EPILEPSY SURGERY EVALUATION

P26.06 Christina Sølvsten. NEURONAL EPIGENETIC ALTERATIONS INDUCED BY PHYSICAL EXERCISE.

P26.07 Maryam Ardalan. CHARACTERIZATION OF MINICOLUMNS IN HUMAN CEREBRAL CORTEX

P26.08 Anne Virring Sørensen. REPORTED SLEEP PROBLEMS AND DAILY FUNCTIONING IN CHILDREN WITH ADHD AND IN CONTROLS 


\section{Poster session 27 GP8: Neuroscience.}

Chairmen: Jakob Blicher \& Zita Dósa (PhD student)

P27.01 Lise Ventzel. PAIN AND NEUROPATHY AFTER CHEMOTHERAPY: A PROSPECTIVE STUDY

P27.02 Anita Eskildsen. PROGNOSIS OF COGNITIVE IMPAIRMENTS IN PATIENTS WITH WORKRELATED STRESS

P27.03 Christina Fischer. CHRONIC INFUSION WITH LIPOPOLYSACCHARIDE DOES NOT ALTER BEHAVIOURAL OR METABOLIC PARAMETERS IN RATS

P27.04 Nicole Jeanette S. Springer. SENSORY FUNCTION AND NERVE FIBRE DENSITY IN THORACOTOMY PATIENTS

P27.05 Marie Louise Schmitz. QUALITY OF LIFE ACCORDING TO STROKE ETIOLOGY IN PATIENTS RECEIVING THROMBOLYTIC THERAPY

P27.06 Karen Lund. THE ROLE OF SUGGESTIBILITY AND ABSORPTION FOR A PLACEBO EFFECT IN HEALTHY VOLUNTEERS

P27.07 Mikkel Mylius Rasmussen. DEFECATION IN SUPRACONAL SPINAL CORD INJURY

P27.08 Freja Cecilia Brandt Bertelsen. AN ANIMAL MODEL FOR THE FETAL VALPROATE SYNDROME - WITH RELEVANCE TO AUTISM

\section{Poster session 28 GP8: Neuroscience.}

Chairmen: Karin Lykke-Hartmann \& Nicolai Ladegaard (PhD student)

P28.01 Lisbeth Lund Jensen. APP STAINING IN SUDDEN INFANT AND EARLY CHILDHOOD DEATH

P28.02 Arnela Mehmedbasic. THE INFLUENCE OF SORLA ON APP PROCESSING IN RETINA

P28.03 Justyna Zareba. ALPHA-SYNUCLEIN INDUCED NEURODEGENERATION IN PARKINSON'S DISEASE: INTER- AND INTRA-NEURONAL PROGRESSION

P28.04 Noomi Gregersen. ARE TMEM GENES POTENTIAL CANDIDATE GENES FOR PANIC DISORDER?

P28.05 Simon Mølgaard Jensen. STRUCTURAL AND FUNCTIONAL ASPECTS OF SORTILIN INTERACTION WITH GABAERGIC INTERNEURONS

P28.06 Anne Højland. CHARACTERIZING MEMORY AND LEARNING ABILITIES OF SORLA KNOCK-OUT MICE

P28.07 Simple Futarmal Kothari. NEUROSENSORY ASSESSMENT IN PATIENTS WITH TOTAL TEMPOROMANDIBULAR JOINT PROSTHESES

P28.08 Henriette Bjerregaard. IBOGAINE ANALOGS IN THE HUMAN SEROTONIN TRANSPORTER

\section{Poster session 29 Research Year.}

Chairmen: Rikke Nørregaard \& Maria Tørring (PhD student)

P29.01 Anders Raouf El-Galaly. DORZOLAMIDE-INDUCED RELAXATION OF PORCINE RETINAL ARTERIOLES IN VITRO DEPENDS ON NO RELEASED FROM THE PERIVASCULAR RETINA

P29.02 Safa Talib AI Therwani. THE EFFECTS OF VASOPRESSIN ANTAGONISM ON RENAL SODIUM AND WATER HANDLING AND THE CIRCULATION DURING INHIBITION OF THE NITRIC OXIDE SYSTEM IN HEALTHY SUBJECTS

P29.03 Sheyanth Mohanakumar. IMPORTANCE OF CHLORIDE FOR THORACIC DUCT CONTRACTILITY AND SPONTANEOUS CONTRACTIONS

P29.04 Nichlas Riise Jespersen. ISCHEMIC PRECONDITIONING AND INHIBITION OF THE MALATE-ASPARTATE SHUTTLE PRESERVES MITOCHONDRIAL RESPIRATION AND DECREASES ROS PRODUCTION IN THE ISOLATED RAT HEART

P29.05 Eva Futtrup Sørensen. PTLD AFTER KIDNEY TRANSPLANTATION IN WESTERN DENMARK AND EBV STATUS 
P29.06 Britt Borg. BEWARE THE SLEEPING BLADDER IN MONOSYMPTOMATIC NOCTURNAL ENURESIS

P29.07 Anne Yoon Krogh Grøndal Hansen. DUAL INVERSION RECOVERY MAGNETIC RESONANCE IMAGING FOR MORE ACCURATE MYOCARDIAL INFARCT SIZE DETERMINATION: A HISTOLOGICAL VALIDATION STUDY

P29.08 Tine Jepsen Nielsen. PATIENT-REPORTED HEALTH STATUS AND RISK OF NEW CARDIOVASCULAR EVENTS IN PATIENTS WITH FIRST-TIME MYOCARDIAL INFARCTION

P29.09 Mette Ji Riis-Vestergaard. SPONTANEOUS RELAXATION OF PORCINE RETINAL ARTERIOLES IN VITRO IS CAUSED BYADENOSINE

\section{Poster session 30 Research Year.}

Chairmen: Søren A. Ladefoged \& Peter Niekerk (PhD student)

P30.01 Louise Rottbøll Poulsen. EXPLORING VALRUBICIN'S POTENTIAL ROLE IN TREATING ACNE

P30.02 Jannie Sørensen. HEREDITARY HYPERHOMOCYSTEINEMIA - AN UNDERESTIMATED DISEASE?

P30.03 Sebastian Ranzi Kotze. LOW-GRADE INFLAMMATION AND HAEMOGLOBIN LEVELS IN DANISH BLOOD DONORS

P30.04 Nikolaj Gehr. IMMUNOREGULATORY MECHANISMS IN B CELLS FROM MS PATIENTS

P30.05 Julie Kristine Laustsen. OX40 AND OX40L IN REHUMATOID ARTHRITIS

P30.06 Solbritt Birla Grønbœk. THE ASSOCIATION BETWEEN A DECREASED GLUT4 AMOUNT IN ADIPOSE TISSUE AND THE DEVELOPMENT OF INSULIN RESISTANCE AND TYPE 2 DIABETES

P30.07 Mette Hansen Viuff. PRENATAL DIAGNOSIS OG SEX CHROMOSOME ABNORMALITIES

P30.08 Lars Markvardsen. RANDOMIZED, DOUBLE-BLIND, PLACEBO-CONTROLLED TRIAL OF THE EFFECT OF SUBCUTANEOUS IMMUNOGLOBULIN ON MUSCULAR PERFORMANCE IN CHRONIC INFLAMMATORY DEMYELINATING POLYNEUROPATHY

\section{Poster session 31 Research Year.}

Chairmen: Mariane Schleimann \& Niklas Telinius (PhD student)

P31.01 Lotte Vinther Christensen. MICROBIOLOGICAL SPECTRUM AND SUSCEPTIBILITY PATTERNS OF BACTERIA CAUSING BLOODSTREAM INFECTION IN PAEDIATRIC ONCOLOGY PATIENTS

P31.02 Søren Hoberg. CHARACTERIZATION OF FUNCTIONAL MOTIFS WITHIN THE HERPESVIRAL DR6 PROTEIN

P31.03 Dea Jensen. INHIBITION OF DEATH SIGNALS BY A NOVEL VIRAL PROTEIN

P31.04 Ann Marlene Gram Christensen. PROCALCITONIN-GUIDED DETECTION OF STREPTOCOCCAL ACUTE TONSILLITIS

P31.05 Sine Kirstine Kratholm. IL-21 IS IMPORTANT IN INNATE IMMUNE PROTECTION AGAINST VIRUS INFECTIONS

P31.06 Bo Hønge. HEPATITIS B IN A WEST AFRICAN HIV COHORT WITH HIGH HIV-2 PREVALENCE

P31.07 Dea Kejlberg Jensen. INHIBITION OF CELL DEATH BY A NOVEL VIRAL PROTEIN

\section{Poster session 32 Research Year.}

Chairmen: Daniela Grimm \& Lene Stødkilde-Jørgensen (PhD Student)

P32.01 Mia-Maiken Kallestrup Jørgensen. NEUROTROPHIC FACTORS IN CEREBROSPINAL FLUID IN PATIENTS WITH DIABETIC POLYNEUROPATHY 
P32.02 Hanne Rheder Ellegaard. A PROSPECTIVE STUDY OF ULTRASOUND OF THE ULNAR NERVE AT AND BELOW THE ELBOW IN PATIENTS WITH COMPRESSION NEUROPATHIES - CORRELATION WITH THE ELECTROPHYSIOLOGICAL MEASUREMENTS

P32.03 Karl Ole Köhler. PATTERNS AND DETERMINANTS OF NON-STEROIDAL ANTIINFLAMMATORY DRUG (NSAID) USE AMONG 174,845 USERS OF ANTIDEPRESSIVE AGENTS IN DENMARK

P32.04 Jenny-Ann Phan. NORADRENERGIC PROTECTION OF DOPAMINERGIC TRANSMISSION IN PARKINSON'S DISEASE

P32.05 Ina Skyt Østergaard. PERCEPTUAL DISTORTION OF THE FACE EVOKED BY EXPERIMENTAL PAIN AND LOCAL ANAESTHESIA IN HEALTHY VOLUNTEERS

P32.06 Bochra Zareini. COGNITIVE COMPLEXITY AND DISORDERS OF CONSCIOUSNESS

\section{Poster session 33 Research Year.}

Chairmen: Kamille Smidt Rasmussen \& Niels Secher (PhD Student)

P33.01 Marlene Skovgaard Sørensen. OUTCOME OF PNEUMOCOCCAL LOWER RESPIRATORY TRACT INFECTION WITHOUT PULMONARY INFILTRATE OR BACTEREMIA - A POPULATION-BASED COHORT STUDY

P33.02 Bjørn Borsøe Christensen.AUTOLOGOUS CARTILAGE CHIPS FOR OSTEOCHONDRAL REGENERATION

P33.03 Christina Kjœrgaard Rasmussen. SIMPLE LEARNING OF 2- AND 3-DIMENSIONAL TRANSVAGINAL ULTRASOUND IN DIAGNOSING ADENOMYOSIS

P33.04 Iben Bach Pedersen. CHANGES IN CORNEAL BIOMECHANICAL PROPERTIES AFTER LASER REFRACTIVE SURGERY: A RETROSPECTIVE STUDY

P33.05 Malene Tanderup Kristensen. CROSS-BORDER REPRODUCTIVE CARE - SURROGACY AND GLOBALIZATION

P33.06 Lars Ølgaard Bloch. IMAGING OF VESSEL WALL EDEMA USING 3D T2-WEIGHTED MRI

P33.07 Karen Lise Dahl Andersen. ASSESSMENT OF HEPATITIS B VIRUS AND HEPATITIS C VIRUS SEROLOGY PREVALENCE AMONG HIV PATIENTS: A CROSS-SECTIONAL STUDY

P33.08 Sashia Pernille Bak-Nielsen. THE RIGIDITY OF CORNEAS BEFORE AND AFTER CORNEAL CROSS-LINKING - AS MEASURED BY THE CORVIS ST

P33.09 Helga Haahr-Lillevang. THE PREDICTIVE VALUE OF THE ISHIHARA TEST FOR THE RESULT OF THE OPTEC 9OOLANTERN TEST

\section{Poster session 34 GP3: Public Health.}

Chairmen: Annette de Thurah \& Julie Glavind (PhD student)

P34.01 Xiao Qin Liu. BEREAVEMENT DURING PREGNANCY AND THE RISK OF PRE-ECLAMPSIA

P34.02 Stina Lou. HIGH-RISK FOR DOWN'S SYNDROME: PRACTISING NON-DIRECTIVE INFORMATION AND INFORMED CHOICE

P34.03 Therese Koops Grønborg. INTERPREGNANCY INTERVAL AND AUTISM SPECTRUM DISORDERS: A DANISH POPULATION-BASED COHORT STUDY

P34.04 Helene Kirkegaard. HOW IS PREGNANCY-RELATED WEIGHT CHANGES AND BREASTFEEDING RELATED TO LONG-TERM MATERNAL WEIGHT AND WAIST-TOHEIGHT RATIO? A PATH ANALYSIS

P34.05 Ann Dyreborg Larsen. PSYCHOSOCIAL JOB STRAIN AND RISK OF ADVERSE BIRTH OUTCOME

P34.06 Heidi Cueto. FOLIC ACID OR MULTIVITAMIN SUPPLEMENT USE AND MENSTRUAL CYCLE PATTERNS: AN INTERNET-BASED CROSS-SECTIONAL STUDY 


\section{Poster session 35 GP3: Public Health.}

Chairmen: Vivi Schlünssen, Vibeke Høgh (PhD Student) \& Gry Kjœrsdam Telleus (PhD student)

P35.01 Lena Hohwü. PRENATAL STRESS FOLLOWING MATERNAL BEREAVEMENT DURING PREGNANCY AND OVERWEIGHT IN YOUNG ADULTHOOD: A COHORT STUDY IN 110,782 DANISH CONSCRIPTS

P35.02 Katja Glejsted Ingstrup. BEREAVEMENT IN THE ANTENATAL PERIOD AND ORAL CLEFT IN THE OFFSPRING

P35.03 Ingeborg Hedegaard Kristensen. RELATIONS BETWEEN INFANT AND VOUNERABLE FIRST TIME'S MOTHERS - DOES VIDEO GUIDANCE WITH THE MARTE MEO METHOD PROMOTE THE PROCESS? INTERVENTION STUDY IN A COMMUNITY SETTING

P35.04 Bjørn Bay. FERTILITY TREATMENT AND RISK OF CHILDHOOD AND ADOLESCENT MENTAL DISORDERS: A REGISTER-BASED COHORT STUDY

P35.05 Natalie Momen. PROGRAMMING EFFECTS OF EARLY LIFE EXPOSURES ON CHILDHOOD CANCER: A POPULATION BASED COHORT STUDY IN 7.1 MILLION CHILDREN IN DENMARK, SWEDEN AND FINLAND

P35.06 Philip Finn Rising Nielsen. CHILDHOOD INFECTION AND SCHIZOPHRENIA IN ADOLESCENCE AND EARLY ADULTHOOD

P35.07 Pia Løvschal-Nielsen. THE SOCIAL BECOMING OF A CHILD WITH CANCER

P35.08 Birgit Bjerre Høyer. MOTOR DEVELOPMENT FOLLOWING IN UTERO EXPOSURE TO P,P'DDE AND CB-153: A FOLLOW-UP STUDY OF CHILDREN AGED 5-9 YEARS IN GREENLAND, UKRAINE AND POLAND.

\section{Poster session 36 GP3: Public Health.}

Chairmen: Kirsten Lomborg \& Charlotte Olesen (PhD student)

P36.01 Trine Allerslev Horsbøl. HAEMATOLOGICAL CANCER AND RETURN TO WORK: A REGISTER-BASED COHORT STUDY

P36.02 Charlotte Handberg. MALE CANCER SURVIVORS PARTICIPATION IN MUNICIPAL CANCER REHABILITATION - A QUALITATIVE STUDY OF THE MALE AND THE HEALTH PROFESSIONAL PERSPECTIVE

P36.03 Lotte Dahl Kristensen. LIFE AFTER CANCER: CHANGING THE PARADIGM OF FOLLOWUP FOR LOW-STAGE GYNECOLOGICAL CANCER PATIENTS

P36.04 Louise Mahncke. EFFECT OF DIRECT REFERRAL FOR FAST CT SCAN IN EARLY LUNG CANCER DETECTION IN GENERAL PRACTICE. A CLINICAL CLUSTER-RANDOMISED TRIAL.

P36.05 Christina Maar Andersen. DOES ATTACHMENT STYLE AFFECT PATIENT AND DOCTOR DELAY IN CANCER INVESTIGATION?

P36.06 Mads Lind Ingeman. THE NON-ORGAN-SPECIFIC CANCER FAST TRACK

P36.07 Peter Hjertholm. VARIATION IN PROSTATE SPECIFIC ANTIGEN (PSA) TEST ORDERING AMONG DANISH GENERAL PRACTITIONERS AND THE INCIDENCE AND PROGNOSIS OF PROSTATE CANCER

P36.08

Henry Jensen. REDUCED DELAY IN DIAGNOSIS OF CANCER AFTER IMPLEMENTATION OF 'FAST TRACK'

\section{Poster session 37 GP3: Public Health.}

Chairmen: Marianne Vamosi \& Palle Larsen (PhD student)

P37.01 Annesofie Lunde Jensen. OSTEOPOROSIS GROUP EDUCATION: A WAY TO HEALTH MAINTENANCE

P37.02 Lone Flarup. REASONS FOR ENCOUNTER AT THE DANISH OUT OF HOURS SERVICE: A POPULATION-BASED 1-YEAR CROSS-SECTIONAL STUDY 
P37.03 Kasper Grosen. PREDICTION OF POSTOPERATIVE PAIN FOLLOWING CHEST WALL SURGERY

P37.04 Connie Timmermann. EXPERIENCING LIFE-THREATENING ILLNESS IN THE HOSPITAL ENVIRONMENT - A QUALITATIVE INQUIRY

P37.05 Ethel Mary Brinda Alexander. NATURE AND DETERMINANTS OF OUT-OF-POCKET HEALTH EXPENDITURE AMONG OLDER PEOPLE IN A RURAL INDIAN COMMUNITY

P37.06 Line Flytkjœr Jensen. THE ASSOCIATION BETWEEN DISTANCE TO SCREENING UNIT AND PARTICIPATION

P37.07 Maria Theresa Wimberley Böttger. PHARMACO-EPIDEMIOLOGIC STUDY OF PREDICTORS FOR CLOZAPINE TREATMENT IN PATIENTS WITH TREATMENT RESISTANT SCHIZOPHRENIA

P37.08 Camilla Hoffmann Merrild. THE EMBODIMENT OF SOCIAL INEQUALITY: A COMPARATIVE ANTHROPOLOGICAL STUDY OF HEALTH SEEKING PRACTICES IN TWO DIFFERENT SOCIAL GROUPS

\section{Poster session 38 GP3: Public Health.}

Chairmen: Anette Werner \& Malene Krogsgaard Bording (PhD student)

P38.01 Noora Ronkainen. RUNNING IN BEIJING - AN EXISTENTIAL INVESTIGATION OF CHALLENGED RUNNER IDENTITIES

P38.02 Priscila Corraini. RELIABILITY OF CLINICAL PERIODONTAL MEASUREMENTS

P38.03 Anne Mette Lund Würtz. SUBSTITUTIONS OF RED MEAT, POULTRY AND FISH, AND RISK OF ISCHEMIC HEART DISEASE

P38.04 Gitte Susanne Rasmussen. STRUCTURED PATIENT EDUCATION TO YOUNG PEOPLE WITH PSORIASIS: ANALYZING FOCUS GROUP DISCUSSIONS

P38.05 Nanna Rolving Rasmussen. DOES A PREOPERATIVE COGNITIVE INTERVENTION IMPROVE RETURN TO WORK AND DAILY LIFE IN PATIENTS UNDERGOING LUMBAR SPINAL FUSION SURGERY?

P38.06 Trine Nøhr Winding. PERSONAL PREDICTORS OF EDUCATIONAL ATTAINMENT AFTER COMPULSORY SCHOOL: INFLUENCE OF MEASURES OF VULNERABILITY, HEALTH AND SCHOOL PERFORMANCE

P38.07 Mette Kjœrgaard Nielsen. DEPRESSION AND ANXIETY IN FAMILY CAREGIVERS OF TERMINALLY ILL PATIENTS. WHO IS AT RISK?

P38.08 Else-Marie Dalsgaard. SOCIOECONOMIC POSITION, CARDIOVASCULAR RISK FACTORS AND MEETING TREATMENT TARGETS AMONG PEOPLE WITH TYPE 2 DIABETES IDENTIFIED BY SCREENING

Poster session 39 GP3: Public Health.

Chairmen: Else Marie Damsgaard \& Kirsten Hansen (PhD student)

P39.01 Marianne Johansson Jørgensen. CONCURRENT PARTNERS - A PREDICTOR FOR CHLAMYDIA

P39.02 Jette Pedersen. DOES THE PRESENCE OF A CLINICAL DIETICIAN IMPROVE GERIATRIC PATIENTS' ENERGY INTAKE AND PREVENT WEIGHT LOSS?

P39.03 Allan Riis. INTRODUCTION OF NEW LOW BACK PAIN GUIDELINES IN GENERAL PRACTICE

P39.04 Charlotte Green. RELIABLE AND VALID ASSESSMENT OF COMPETENCE IN OPEN INGUINAL HERNIA REPAIR

P39.05 Camilla Plambeck Hansen. ADIPOSE TISSUE TRANS-FATTY ACIDS AND CHANGES IN BODY WEIGHT AND WAIST CIRCUMFERRENCE

P39.06 Else Toft Würtz. OCCUPATIONAL COPD. PREVALENCE AND GENETIC RISK FACTORS IN A POPULATION-BASED STUDY OF 45- TO 84-YEAR-OLD DANES 
P39.07 Rasmus Østergaard Nielsen. RUNNING-RELATED INJURIES AMONG NOVICE RUNNERS: A ONE-YEAR PROSPECTIVE FOLLOW-UP STUDY

\section{Poster session 40 GP3: Public Health.}

Chairmen: Lone Sunde \& René Ernst Nielsen (PhD student)

P40.01 Pia Viuf Ørby. DIURNAL VARIATION IN POLLUTANTS AND POLLEN LEVELS BASED ON THREE URBAN POLLEN STATIONS IN AARHUS, DENMARK DURING THE TIME PERIOD 2009-2011.

P40.02 Merete Møller. SHOULDER INJURIES AND RISK FACTORS IN DANISH YOUTH HANDBALL A 1-YEAR PROSPECTIVE COHORT STUDY

P40.03 Lotte Maxild Mortensen. POLYUNSATURATED FATTY ACIDS; INTERACTIONS, GENETIC PATHWAYS AND RISK OF ATRIAL FIBRILLATION

P40.04 Therese JuUl. INTERNATIONAL VALIDATION OF THE LOW ANTERIOR RESECTION SYNDROME SCORE

P40.05 Michael Smcrup Brandt. VESTIBULAR DYSFUNCTION IN 745 ELDERLY CITIZENS

P40.06 Mette Damborg Hansen. SUBSTITUTIONS OF FOODS IN RELATION TO RISK OF ISCHEMIC HEART DISEASE

P40.07 Thomas Winther Frederiksen. OCCUPATIONAL NOISE EXPOSURE AND INDIVIDUAL RISK FACTORS FOR HEARING LOSS AND TINNITUS

P40.08 Ditte Lammers Vernal. A SYSTEMATIC REVIEW OF THE LONG-TERM OUTCOME OF EARLY ONSET SCHIZOPHRENIA

\section{Presented abstracts.}

A.01 Kristina Grønborg Laut. VARIATION IN TREATMENT ACCESS TO PRIMARY ANGIOPLASTY IN SELECTED EUROPEAN COUNTRIES

A.02 Charlotte Hyldgaard. COMORBIDITY AND PROGNOSIS IN IDIOPATHIC PULMONARY FIBROSIS

A.03 Stine Elleberg Petersen. EVALUATION OF FUNCTIONAL AND STRUCTURAL ANORECTAL CHANGES FOLLOWING RADIOTHERAPY FOR PROSTATE CANCER

A.04 Juan Manuel Shiguetomi Medina. THERMAL EPIPHYSIODESIS MADE WITH RADIOFREQUENCY ABLATION: AN ALTERNATIVE TREATMENT FOR LEG LENGTH DISCREPANCY

A.05 Pernille Endrup Jacobsen. DEVELOPMENTAL ENAMEL DEFECTS IN CHILDREN PRENATALLY EXPOSED TO ANTI-EPILEPTIC DRUGS

A.06 Michael Eriksen Benros. NATIONWIDE STUDIES ON AUTOIMMUNITY, INFECTIONS AND CANCER AS RISK FACTORS FOR PSYCHIATRIC DISORDERS

A.07 Jan Danz. PERIODONTAL EFFECTS OF ORTHODONTIC EXPANSION

A.08 Finn Sørensen. CARTILAGE ENGINEERING BY EQUINE MESENCHYMAL STROMAL CELLS - HYALURONAN GEL CONSTRUCTS IN VITRO

A.09 Anders Sommer Knudsen. EMPIRIC VERSUS IMAGING-GUIDED LEFT VENTRICULAR LEAD PLACEMENT IN CARDIAC RESYNCHRONIZATION THERAPY: DESIGN OF THE IMAGING CRT STUDY

A.10 Ingrid Nilsson. A SAFE START OF LIFE: DEVELOPMENT AND EVALUATION OF A PROGRAMME SUPPORTING ESTABLISHMENT OF BREASTFEEDING FOR PARENTS DURING SHORT-TIME HOSPITALIZATION POST PARTUM 


\section{PhD Student Chairmen Abstracts.}

CH.01 Rikke Holm Jensen. MUTATIONAL STUDIES IDENTIFY A PUTATIVE TRANSPORT PATHWAY FOR THE $3^{\text {RD }} \mathrm{NA}^{+}$ION

CH.02 Sys Hasslund Svensson. RAAV-GDF5 GENE DELIVERY IMPROVES JOINT FLEXION IN A MURINE MODEL OF FLEXOR TENDON REPAIR

CH.03 Efe Levent Aras. COST-EFFECTIVENESS OF SURGICAL AND CONSERVATIVE TREATMENT OF SPINAL FRACTURES

CH.04 Zhanna Tairova. DISRUPTION OF RETINOID AND CYP SYSTEMS AND EMBRYO DEVELOPMENT IN MARINE ORGANISMS: A POTENTIAL MODEL FOR HUMANS

CH.05 Kresten Krarup Keller. BONE FORMATION AND RESORPTION ARE BOTH INCREASED IN AUTOIMMUNE ARTHRITIS

CH.06 Trine Grantzau. LUNG CANCER AMONG WOMEN TREATED FOR EARLY BREAST CANCER WITH POSTOPERATIVE IRRADIATION: FOCUS ON RADIATION DOSE AND TREATMENT TECHNIQUES

CH.07 Michael René Skjelbo Nielsen. A HIGH ADIPOSE TISSUE ARACHIDONIC ACID CONTENT IS ASSOCIATED WITH A HIGHER RISK OF MYOCARDIAL INFARCTION: A DANISH CASE COHORT STUDY

CH.08 Ditte Olsen. SORLA REGULATES GDNF ACTIVITY THROUGH SORTING OF GDNF AND ITS RECEPTORS GFRA 1 AND RET

CH.09 Jurgita Janukonyté. DIURNAL VARIATION IN THE PHARMACOKINETICS OF GROWTH HORMONE ADMINISTERED AS A CONTINUOUS SUBCUTANEOUS INFUSION IN GHDEFICIENT SUBJECTS

CH.10 Anne Skakkebck Jensen. NEUROANATOMICAL CORRELATES OF KLINEFELTER SYNDROME STUDIED IN RELATION TO THE NEUROPSYCHOLOGICAL PROFILE

CH.11 Dirk Troitzsch. PERIOPERATIVE MONITORING OF MYOCARDIAL TISSUE OXYGENATION AND POSTISCHEMIC CARDIAC PERFORMANCE IN PEDIATRIC CARDIAC SURGERY

CH.12 Shallu Sharma. LONG-TERM HEALTH CARE UTILIZATION AND OUTCOME AFTER ADULT SCOLIOSIS SURGERY

CH.13 Louise Tram Henriksen. CLINICAL ASPECTS OF ASPARAGINASE-ASSOCIATED ALLERGY IN THE TREATMENT OF CHILDHOOD ACUTE LYMPHOBLASTIC LEUKAEMIA IN THE NORDIC AND BALTIC COUNTRIES

CH.14 Frank Holden Mose. INCREASED NO ACTIVITY DURING STATIN TREATMENT IN PATIENTS WITH NON-DIABETIC NEPHROPATHY

CH.15 Lau Brix. INTERACTIVE MR IMAGING AND RECONSTRUCTION OF MOVING ANATOMICAL STRUCTURES

CH.16 Steffen Bank. CAN GENETIC MARKERS PREDICT THE RESPONSE OF TNF INHIBITOR THERAPY?

CH.17 Mariane Høgsbjerg Schleimann. THE HERPESVIRAL PROTEIN DR6 SUPPRESSES CELL PROLIFERATION

CH.18 Srikanth Chiliveru. CYTOSOLIC DNA RECOGNITION IN KERATINOCYTES - A POTENTIAL IMPLICATION FOR EARLY PSORIASIS PLAQUE FORMATION

CH.19 René Østgård. BOWEL INFLAMMATION IN SPONDYLOARTHRITIS IS DETECTABLE BY CALPROTECTIN AND AMELIORATED BY TREATMENT WITH ADALIMUMAB

CH.20 Louise Brøndt Hartlev. DESIGN-BASED STEREOLOGY FOR ESTIMATION OF ABSOLUTE VOLUME AND SURFACE AREA OF THE HYALINE AND CALCIFIED CARTILAGE COMPARTMENTS OF HUMAN FEMORAL HEADS

CH.21 Babak Jalilian. GLATIRAMER ACETATE IN TREATMENT OF MULTIPLE SCLEROSIS: A TOOLBOX OF RANDOM CO-POLYMERS FOR TARGETING INFLAMMATORY MECHANISMS OF BOTH THE INNATE AND ADAPTIVE IMMUNE SYSTEM? 
CH.22 Asger Andersen. RIGHT VENTRICULAR HYPERTROPHY AND FAILURE ABOLISH CARDIOPROTECTION BY ISCHEMIC PRECONDITIONING

CH.23 Jonas Agerlund Povisen. TEMPORAL CHARACTERIZATION OF CARDIAC ISCHEMIAREPERFUSION INJURY

CH.24 Vibeke Secher Nielsen. FUNCTIONAL ROLE OF CA ${ }^{2+}$-ACTIVATED CL ${ }^{-} \mathrm{CHANNEL}^{-}$ CANDIDATES IN VASCULAR SMOOTH MUSCLE CELLS

CH.25 Carsten Stengaard. DIAGNOSTIC AND PROGNOSTIC POTENTIAL OF PREHOSPITAL HIGHLY SENSITIVE TROPONIN T MEASUREMENT FOR TRIAGE OF PATIENTS WITH SUSPECTED ACUTE MYOCARDIAL INFARCTION

CH.26 Christian Daugaard Peters. A RANDOMIZED TRIAL OF THE ANGIOTENSIN II RECEPTOR BLOCKER IRBESARTAN IN CHRONIC RENAL FAILURE (SAFIR-STUDY): CARDIOVASCULAR EFFECTS IN NEWLY STARTED HAEMODIALYSIS PATIENTS

CH.27 Christoffer Laustsen. $300 \mathrm{~T} \mathrm{IN} \mathrm{VIVO} \mathrm{MRI} \mathrm{H} \mathrm{H}_{2} \mathrm{O}-\mathrm{THE}$ NEW SUPER CONTRAST AGENT Mark Reinhard. POSTPRANDIAL MINERAL METABOLISM IN HEMODIALYSIS PATIENTS Karina Bech Cullberg. RESVERATROL INHIBITS THE HYPOXIC EFFECTS IN ADIPOSE TISSUE, ADIPOCYTES AND MACROPHAGES

Julie Damgaard Sandahl. TRANSLOCATION T(6;9)(P22;Q34) IN PEDIATRIC AML: A RETROSPECTIVE INTERNATIONAL STUDY

Lotte Sander. MRI DELINEATION MAY REDUCE URINARY TOXICITY IN PROSTATE RADIOTHERAPY

Johanne Lade Keller. THE IMMUNOHISTOCHEMICAL EXPRESSION OF TUMOR SUPPRESSOR P16 IS AN INDEPENDENT PROGNOSTIC MARKER IN CUTANEOUS MELANOMA

Esben Schjødt Worm. 3D TIME-RESOLVED MOTION MONITORING DURING RADIOTHERAPY

Eduardo Vazquez Garza. NK-SUBTYPE CELL PROLIFERATION AND UPREGULATION OF CD56 SURFACE MARKER IN MONONUCLEAR CELLS FROM HEALTHY DONORS STIMULATED WITH HUMAN CYTOMEGALOVIRUS

CH.36 Emilia Horjales. INFLUENCE OF EMOTIONALLY-LOADED VISUAL STIMULI ON EXPERIMENTAL JAW-MUSCLE PAIN AND ITS RELATION WITH THE TRI-ALLELIC POLYMORPHISM ON THE SEROTONIN TRANSPORTER GENE

CH.37 Pauline de Bruijn. BASOLATERAL P2X RECEPTORS TRIGGER A MARKED ALKALINIZATION OF MOUSE THICK ASCENDING LIMB

CH.38 Sascha Eichendorff. CD163-TARGETED LIPOSOMES WITH PH-SENSITIVE PEGSHIELDING FOR ENHANCED INTRACELLULAR DELIVERY OF BIOACTIVE SUBSTANCES

CH.39 Jacob Mørup Schlütter. THE NUMBER OF FETAL CELLS IN MATERNAL BLOOD DOESN'T CHANGE AFTER ULTRASOUND SCANNING

CH.40 Trine Dalsgaard. DEVELOPMENT OF GENE THERAPY OF PKU

CH.41 Nanna Cornelius. SECONDARY COQ10 DEFICIENCY IN RIBOFLAVIN RESPONSIVE MULTIPLE ACYL-COA DEHYDROGENATION DEFICIENCY (RR-MADD) PATIENTS; A RHODOBACTOR AND HUMAN CELL STUDY

CH.42 Martin Mørck Mortensen. MIRNA AND WHOLE GENOME PROFILING OF PROSTATE CANCER SAMPLES IDENTIFY 5 NOVEL MIRNAS ASSOCIATED WITH DISEASE OUTCOME

CH.43 Xue Lin. INTEGRATIVE ANALYSES OF GENE EXPRESSION AND DNA METHYLATION PROFILES IN A BREAST CANCER CELL LINE MODEL OF TAMOXIFEN-RESISTANCE INDICATE A CRUCIAL ROLE OF CELLS WITH STEM-LIKE PROPERTIES

CH.44 Páll Karlsson. EPIDERMAL NERVE FIBER LENGTH IN HEALTHY SUBJECTS AND IN 
PATIENTS WITH NEUROPATHY

CH.45 Line Granild Bie Mertz. ANGELMAN SYNDROME: GENOTYPE COMPARED WITH PHENOTYPE

CH.46 Zita Dósa. REDUCED HIPPOCAMPAL GABAERGIC ACTIVITY IN A LOW BIRTH WEIGHT RAT MODEL OF DEPRESSION

CH.47 Nicolai Ladegaard. SOCIAL COGNITION IN MAJOR DEPRESSIVE DISORDER

CH.48 Maria Tøring. NO EFFECT OF LACTATE ON THE DIAMETER OF PORCINE RETINAL ARTERIOLES WITH DIFFERENT DIAMETER IN VITRO

CH.49 Peter Niekerk. ELUCIDATION OF STEM CELL BIOLOGY IN CHRONIC MYELOID LEUKAEMIA

CH.50 Niklas Telinius. CALCIUM DYNAMICS IMPORTANT FOR GENERATING CONTRACTIONS IN THE HUMAN THORACIC DUCT

CH.51 Julie Glavind. TIMING OF ELECTIVE CAESAREAN SECTION AND NEONATAL MORBIDITY: A RANDOMISED CONTROLLED TRIAL

CH.52 Gry Kjœrsdam Telleus. CHILDREN AND ADOLESCENTS WITH ANOREXIA NERVOSA

CH.53 Charlotte Olesen. GENERIC SUBSTITUTION APPEARS TO INCREASE ADHERENCE IN ELDERLY PATIENTS WITH POLYPHARMACY

CH.54 Palle Larsen. EFFECTIVENESS OF FLUID RESTRICTION IN THE NONPHARMACOLOGICAL REHABILITATION IN HEART FAILURE PATIENTS: A PROTOCOL FOR A REVIEW OF CURRENT LITERATURE

CH.55 Malene Krogsgaard Bording. CLINICAL DECISION-MAKING IN OUTPATIENT MENTAL HEALTH CARE

CH.56 Kirsten Hansen. "WHEN A PARENT SUFFERS FROM DEPRESSION" - INTERVIEW INVESTIGATION AMONG DANISH FAMILIES

CH.57 René Ernst Nielsen. INCREASING MORTALITY GAP FOR PATIENTS DIAGNOSED WITH SCHIZOPHRENIA: A NATIONWIDE STUDY OVER THREE DECADES

CH.58 Jan Rölfing. VOLUNTEER CHAIRMAN EXTRAORDINAIRE

CH.59 Lene Stødkilde-Jørgensen. VOLUNTEER CHAIRMAN EXTRAORDINAIRE

CH.60 Niels Secher. VOLUNTEER CHAIRMAN EXTRAORDINAIRE

CH.61 Vibeke Høgh. VOLUNTEER CHAIRMAN EXTRAORDINAIRE 


\section{Abstracts}

Eva Holm

Greibe

Kirstine Kjœr Kirkegaard
PIECES FOR THE VITAMIN B 12 JIGSAW PUZZLE

\section{E. Greibe}

Department of Clinical Biochemistry, Aarhus University Hospital

The general concept is that 3 vitamin B12-binders are involved in B12uptake and transportation. IF ensures intestinal uptake, TC promotes cellular internalization, and $\mathrm{HC}$ floats around with active or inactive $\mathrm{B} 12$. We challenged this concept by showing zebrafish to express just one B12binder with features common to all above-mentioned binders(1). To further explore this, we turned to the much larger rainbow trout, again finding only one B12-binder. Benefitting from our discovery of high concentration in roe fluid, we purified the protein and determined its primary structure. We showed the protein to be resistant to proteolysis, which again challenged the bioavailability of B12 in seafood(2).

During pregnancy, the unborn child relies on the mother for B12. We showed changes in the B12-binders suggesting that B12 is transported from mother to fetus mainly in early pregnancy(3). After birth, the child depends on B12 bound to $\mathrm{HC}$ in mother's milk. Our lab recently developed a method that for the first time allowed a reliable determination of milk-B12. We showed milk-B12 to mirror B12 status in both mother and child, and that B 12 supplied at 4 month is insufficient for ensuring an optimal B1 2 status in the baby (manus in prep).

In conclusion, our study shows the 3 human B12-binders to originate from a common and proteolytic resistant ancestor that may decrease the bioavailability of seafood-B 12. During lactation, the amount of B12 delivered at 4 month is insufficient to ensure B1 2 status of the child. In our future studies, we will explore the nature of B12-binders in food stuff to gain further knowledge on B12-binders and bioavailability of B12. Our focus will be cow's milk.

TIME-LAPSE MONITORING AS A TOOL FOR ASSESMENT OF HUMAN EMBRYOS

K. Kirkegaard ${ }^{7,2}$, J. Hindkjœer ${ }^{2}$, H.J. Ingerslev ${ }^{1,2}$

${ }^{1}$ Department of Clinical Medicine, Aarhus University, ${ }^{2}$ The Fertility Clinic, Aarhus University Hospital

Time-lapse analysis allows for a detailed analysis of embryo development and may provide new markers of viability and thereby potentially improve embryo selection after in vitro fertilization (IVF) (Kirkegaard et al. 2012a). Concerns have been given to the safety of time-lapse. We evaluated the development of human embryos in a randomized clinical trial, concluding that the time-lapse incubator supports embryo development similarly to a conventional incubator (Kirkegaard et al. 2012b). We then performed a series of time-lapse studies investigating the effect of different exposures related to IVF. Preimplantation genetic diagnosis requires DNA, which can be obtained by a biopsy of the embryo. We evaluated development after the biopsy and found an altered mechanism of hatching and a prolongation of the biopsied cell stage only, whereas the duration of subsequent cleavages was normal (Kirkegaard et al. 2012c). Our findings are the first to describe how biopsy affects only the stage where biopsy is performed. Investigating the influence of oxygen tension ( $5 \%$ vs. $20 \%$ ), we found a significant delay in completion of the $3^{\text {rd }}$ cell cycle and reduced developmental rates at several embryonic stages after culture in $20 \%$ (paper submitted). Our findings are the first to support the existence of a stage-dependent response to oxygen in human embryos. Furthermore, we describe two distinct mechanisms of hatching related to fertilization method (ICSI/IVF) and suggest that timing of hatching is associated with fertilization 
Mohit Kothari

method (paper in preparation). Finally, putative markers of pregnancy potential have been investigated in a prospective cohort study, but results remain to be analyzed.

COMPARISON OF TRAINING-INDUCED CORTICAL PLASTICITY BETWEEN THREE TONGUE TRAINING PARADIGMS

M. Kothari ', P. Svensson ', 2 , J. Jensen ${ }^{3}$, A. Kjœersgaard ${ }^{3}$, J.F. Nielsen ${ }^{3}$, L. BaadHansen $^{7}$

'Section of Clinical Oral Physiology, Department of Dentistry, Aarhus University, Aarhus, Denmark, ${ }^{2}$ MIND Lab, Center for Functionally Integrative Neuroscience, Aarhus University Hospital, Aarhus, Denmark, ${ }^{3}$ Research Unit, Hammel Neurocentre, Hammel, Denmark

Rehabilitation of tongue function in dysphagia patients lacks scientific evidence. Previously, our group has shown that force level and task complexity influence tongue motor learning (Kothari et al., 2012). The aim of this ongoing study is to compare training-induced cortical plasticity between 3 tongue training paradigms: 1. Simple tongue protrusion (STP), 2. Playing computer game using Tongue Drive System (TDS), 3. The present dysphagia training protocol: Facio-Oral Tract Therapy (FOTT). Also, we compared subject-based reports of the tasks.

48 subjects will be included in this study. So far, 16 healthy subjects were randomized into 3 groups with 1 hr of STP, TDS, or FOTT. Corticomotor excitability was assessed as tongue motor evoked potentials (MEPs) evoked by transcranial magnetic stimulation (TMS) before, immediately after and 1 hr after tongue training. Subject-based reports of fun, pain, fatigue and level of motivation were evaluated on a 0-10 numerical rating scale (NRS) after every session.

ANOVA of preliminary data showed that there was no significant effect of group $(P=0.384)$ or time $(P=0.277)$, but the amplitude of the MEPs increased significantly with stimulus intensity $(P<0.001)$. There was a tendency towards a significant interaction between intensity and time $(P=0.068)$ with increased MEPs after training at high stimulus intensities. FOTT induced more pain $(P=0.008)$ compared to TDS with no significant difference for fun, fatigue or motivation ( $P>0.113$ ) between groups. No significant differences between groups could be detected in the preliminary analysis. However, the tongue MEPs increased after training with higher intensities of TMS indicating cortical plasticity.

O01.01 Kristian StødkildeJørgensen

ZOOMING IN ON HAPTOGLOBIN PHENOTYPES

\section{K. Stødkilde-Jørgensen, C. Brix Folsted Andersen, S. Kragh Moestrup}

\section{Department of Biomedicine, Aarhus University}

Haptoglobin is an acute-phase protein found in the circulation. During intravascular hemolysis, haptoglobin rapidly forms a complex with released hemoglobin resulting in a haptoglobin-hemoglobin complex that is recognized and endocytosed by macrophages. This ensures clearance of hemoglobin, thus avoiding any oxidative damage caused by its prosthetic heme group.

Human haptoglobin is encoded by two different haptoglobin alleles, resulting in either dimeric haptoglobin or higher-order multimers. Despite being a well-studied protein, the structure of haptoglobin was for long enigmatic. Recently, the structure of the dimeric form of porcine haptoglobin in complex with hemoglobin was published. The structure reveals why the haptoglobin-hemoglobin interaction is one of the strongest non-covalent bindings known in biology. Additionally, the structure provides an explanation for the architecture that allows for higher-order multimers of haptoglobin. 
O01.02 Trine Nielsen DIRECTING HER4 MRNA EXPRESSION TO CYT2 BY ANTISENSE OLIGONUCLEOTIDE DECREASES GROWTH OF BREAST CANCER CELLS IN VITRO AND IN VIVO

T.Ø. Nielsen', S. Sørensen 2', F. Dagnces-Hansen ${ }^{3}$, J. Kjems², B. Sørensen'

'Department of Clinical Biochemistry, Aarhus University Hospital,

${ }^{2}$ Department of Molecular Biology and Genetics, Aarhus University,

${ }^{3}$ Department of Biomedicine, Aarhus University

The tyrosine kinase receptor HER 4 is a member of the epidermal growth factor receptor (EGFR) family. It plays diverse roles in cancer development and cancer progression and can both exert oncogenic and tumorsuppressive activities. Alternatively, spliced isoforms of HER4 are critical to the different signalling possibilities of HER4. We demonstrate that a spliceswitching oligonucleotide (SSO) can direct the alternative splicing of HER4 from the CYT1 to the CYT2 isoform in HER4-expressing MCF7 breast cancer cells. This was accompanied by a decreased growth of the MCF7 cells ( $p<$ 0.0001 ). In addition, the SSO treatment induced apoptosis in the cells as well as a decreased activity of Akt. We confirmed the SSO-dependent switching of the HER4 isoform CYT1 to CYT2 expression in a xenografted mouse tumor model driven by subcutaneously injected MCF7 cells. We hence demonstrated the feasibility of SSO-directed splice-switching activity in vivo. Furthermore, the SSO treatment efficiently decreased the growth of the xenografted tumor $(p=0.0014)$. These results may pave the way for the development of a new anticancer drug for HER4-deregulated cancers in humans.

001.03 Katrine Emmertsen

\section{SPHINCTER FUNCTION AND NEORECTAL SENSATION IN LARS PATIENTS}

\section{K.J. Emmertsen, S. Bregendahl, P. Christensen, S. Laurberg}

Colorectal Surgery Research Department P, Aarhus University Hospital

Introduction: Low anterior resection for rectal cancer often results in severe bowel dysfunction (Low Anterior Resection Syndrome (LARS)) with incontinence, urgency, clustering and frequent bowel movements. The pathophysiology of LARS remains poorly understood, but seems multifactorial. The aim of this study was to investigate sphincter function and neorectal sensation in LARS patients.

Methods: 51 patients were included and divided into groups of no/major LARS (12/39 patients) according to the LARS score. Of these, 19 patients had received neoadjuvant radiotherapy and 23 had a rectal neoreservoir (side-to-end anastomosis or colonic J-pouch). We performed anal manometry and investigated neorectal sensation.

Results: A trend was seen towards lower sphincter pressures in patients with major LARS compared to no LARS, both for resting ( $41.9 \mathrm{vs} .60 .9 \mathrm{cmH} 2 \mathrm{O}$, $\mathrm{P}=0.09$ ) and squeeze pressures (93.1 vs. $113.8 \mathrm{cmH} 2 \mathrm{O}, \mathrm{P}=0.08$ ). Likewise, for resting pressures in irradiated compared to non-irradiated patients (39.7 vs. $50.6 \mathrm{cmH} 2 \mathrm{O}, \mathrm{P}=0.06$ ). For squeeze pressure, no difference was found in irradiated vs. non-irradiated patients ( 101.9 vs. $95.7 \mathrm{cmH} 2 \mathrm{O}, \mathrm{P}=0.81$ ). Rectal sensation showed a trend towards smaller maximal rectal capacity in patients with major LARS compared with no LARS ( 143 vs. $212 \mathrm{~mL}, P=0.08$ ).

Conclusion: Sphincter function and neorectal volume seem to be important factors in the pathophysiology of LARS, but further larger studies are needed. 
001.04 Charlotte Hartig Andreasen
DOES PREVIOUS PERIACETABULAR OSTEOTOMY COMPROMISE OPTIMAL CUP POSITIONING AND CLINICAL OUTCOME OF TOTAL HIP REPLACEMENT?

C. Hartig-Andreasen ${ }^{7}$, M. Stilling ${ }^{7}$, K. Søballe ${ }^{7}$, T.M. Thillemann ${ }^{2}$, A. Troelsen ${ }^{3}$

'Department of Orthopedic Research, Aarhus University, ${ }^{2}$ Department of Orthopedic Surgery, Aarhus University, ${ }^{3}$ Department of Orthopedic Surgery, Hvidovre Hospital

Background: Although periacetabular osteotomy (PAO) is a success, some dysplastic hips develop osteoarthritis following PAO. Typically these hips suffer from severe dysplasia before PAO. The conversion of PAO to THR may therefore be associated with technical challenges that could compromise good cup positioning and clinical outcome.

Aim/purpose: To evaluate radiographic, clinical and patient-reported outcome of THR in hips with previous PAO.

Materials and methods: 38 hips (34 pt.) treated with THR after previous PAO were included in the study. The mean age at THA was 40.5 years. The follow-up included AP pelvic and lateral hip radiographs that were analyzed for acetabular cup position, 2D linear wear (Polywear), heterotopic calcification, osteolysis or loosing. A clinical hip examination was performed, and Harris Hip score (HHS), SF36 and WOMAC questionnaires were collected. Any complications/revisions were noted.

Findings/results: 16 patients had remaining dysplasia $\left(\mathrm{CE}<25<\right.$ sup $>0</$ sup $>$, range $\left.-5^{\circ}-24^{\circ}\right)$ after PAO. At a mean follow-up of 6.4 years (4.2-10.1) after THR, the cup abduction angle was $43^{\circ}$ (range $28^{\circ}-65^{\circ}$; $n=1>60^{\circ}$ ), cup anteversion was $22^{\circ}$ (range $7^{\circ}-43^{\circ} ; n=2>40^{\circ}$ ) and polyethylene wear rate (MoM and CoC excluded) was $0.15 \mathrm{~mm} /$ year (range 0.05-0.27). There were no component revisions or dislocations. Patients reported VAS satisfaction of 10 ( 10 being the best), a total WOMAC score of 78 ( 100 the best), and a HHS of 89 ( 100 the best), all median values. Leg-length after THR was confined within $1 \mathrm{~cm}$ in 33 hips and within $2 \mathrm{~cm}$ in 5 hips.

Conclusion: In general THR after previous PAO can be performed with optimal cup position, high patient satisfaction, good patient-reported outcome and few complications.

O01.05 Jan Rölfing ERYTHROPOIETIN DIRECTLY STIMULATES OSTEOGENESIS

\section{J.D. Rölfing, C.E. Bünger}

Orthopaedic Research Lab, Aarhus University Hospital

Introduction: Erythropoietin (EPO) is an erythropoiesis-stimulating agent. Beyond this well-known role EPO has shown to increase bone formation in several animal studies. However, its way of osteogenic action is yet unknown. Both direct and indirect mechanisms have been proposed. In the present study the hypothesis was a direct stimulation of proliferation and osteogenic differentiation of mesenchymal stem cells (MSC). Methods: 13500 cells/cm2 human MSC were seeded into 96-well plates using osteogenic medium. After 24 hours adhesion period the medium was replaced and different concentrations of EPO were added. Proliferation was assessed with cell proliferation kit (XTT) and osteogenic differentiation with alkaline phosphatase assay (ALP) at 2 and 7 days after treatment. Results: EPO significantly increased XTT levels at 2 days $(p<0.007)$ and ALP concentrations at 2 and 7 days ( $p<0.05$ and $p<0.01$ respectively). EPO enhanced proliferation rate and osteogenic differentiation in a dosedependent manner. Discussion: This study shows that EPO directly stimulates proliferation and osteogenic differentiation of primary hMSC in an osteogenic environment. In an earlier study we have shown, that EPO also increases bone formation and angiogenesis. Therefore, there is growing 

$\begin{array}{cl}001.06 & \text { Lena Lindtoft } \\ \text { Rosenbcek }\end{array}$

O02.01 Zara Ann Stokholm evidence supporting the theory that EPO exhibits both a direct and indirect way of osteogenic action. EPO may be a promising growth factor in the field of orthopedics and its efficacy as an osteogenic agent will be extensively investigated.

CHARACTERIZATION OF A NOVEL PHOSPHORYLATION SITE IN THE SODIUM CHLORIDE COTRANSPORTER, NCC

L.L. Rosenbaek, ${ }^{1,2}$, M. Assentoft ${ }^{3}$, N.B. Pedersen ${ }^{7}$, N. MacAulay ${ }^{3}$, R.A. Fenton ${ }^{1,2}$

${ }^{1}$ Department of Biomedicine, Aarhus University, ${ }^{2}$ Center for Interactions of Proteins in Epithelial Transport (InterPrET), Aarhus University, ${ }^{3}$ Department of Cellular and Molecular Medicine, University of Copenhagen

The function of the sodium chloride cotransporter, NCC, can be modulated by protein phosphorylation. We have characterized the role and physiological regulation of a novel phosphorylation site in NCC at S124. Novel phospho-specific antibodies targeting pS124-NCC demonstrated a band of $160 \mathrm{kDa}$ in the kidney cortex, but not medulla, which was preabsorbed by a corresponding phosphorylated peptide. Confocal microscopy with kidney tubule segment-specific markers localized pS124NCC to all DCT cells. Electron microscopy demonstrated pS124-NCC to colocalize with total NCC in the apical plasma membrane of DCT cells and intracellular vesicles. Acute treatment of Munich-Wistar rats or vasopressin deficient Brattleboro rats with the vasopressin type-2 receptor specific agonist dDAVP significantly increased pS124-NCC abundance, with no changes in total NCC plasma membrane abundance. pS124-NCC levels also increased in abundance in rats after stimulation of the RAAS by dietary low sodium intake. In contrast to other NCC phosphorylation sites, the kinases SPAK and OSR 1 were not able to phosphorylate NCC at S124. Protein kinase arrays identified multiple kinases that were able to bind to the region surrounding S124. Four of these kinases (IRAK2, CDK6/Cyclin D1, NLK, and mTOR/FRAP) showed weak, but significant, phosphorylation activity. In oocytes, $36 \mathrm{Cl}$ uptake studies and biochemical analysis showed decreased activity of plasma membrane-associated NCC when replacing S1 24 with Ala(A) or Asp(D). In novel tetracycline inducible MDCKII-NCC cell lines, S124A and S124D mutants were able to traffic to the plasma membrane similarly to wildtype NCC.

\section{OCCUPATIONAL NOISE EXPOSURE AND THE RISK OF STROKE}

\section{Z.A. Stokholm' ', J.P. Bonde ${ }^{2}$, K.L. Christensen ${ }^{3}$, A.M. Hansen ${ }^{4}$, H.A. Kolstad ${ }^{7}$ \\ 'Danish Ramazzini Centre, Department of Occupational Medicine, Aarhus University Hospital, ${ }^{2}$ Department of Occupational and Environmental Medicine, Copenhagen University, Bispebjerg Hospital, ${ }^{3}$ Department of Internal Medicine and Cardiology A, Aarhus University Hospital, ${ }^{4} \mathrm{National}$ Research Centre for the Working Environment, Copenhagen}

Aims: Traffic noise about $60 \mathrm{~dB}(\mathrm{~A})$ has recently been associated with an increased risk of stroke. We aimed at investigating this relation for 80-86 $\mathrm{dB}(\mathrm{A})$ occupational noise.

Methods and results: We followed 116,601 blue-collar industrial workers from 625 companies within 10 different industrial trades and 47,685 whitecollar workers of 100 financial companies by Danish registries linkage from 2001 to 2007. Full-shift noise exposure levels were estimated from random subsets of workers at start and end of follow-up. We identified cases of stroke $(n=976)$ from the Danish National Hospital Register. After adjustment for age, gender, socioeconomic status, calendar year, employment status and duration of employment, the regression model showed increased rate ratios for the industrial blue-collar workers compared with white-collar financial workers (adjusted rate ratio $[R R]=1.30,95 \%$ confidence interval 
$[\mathrm{Cl}]=1.07-1.58)$

Conclusion: Our study did not support an association between occupational noise exposure and stroke at noise exposure levels ranging between 80 and $86 \mathrm{~dB}(\mathrm{~A})$.

O02.02 Karen Kjœr MYOCARDIAL INFARCTION AND RISK OF SUICIDE

Larsen

K.K. Larsen ${ }^{7}$, E. Agerbo ${ }^{2}$, B. Christensen' ${ }^{7}$, J. Søndergaard ${ }^{3}$, M. Vestergaard ${ }^{7}$

'Department of Public Health, Aarhus University, ${ }^{2}$ Centre for Register-based Research, Aarhus University, ${ }^{3}$ Institute of Public Health, University of Southern Denmark

Background:

Myocardial infarction (MI) is associated with an increased risk of anxiety, depression, low quality of life and all-cause mortality. Whether $\mathrm{Ml}$ is associated with an increased risk of suicide is unknown. We examined the association between Ml and suicide.

Methods and results:

We conducted a population-based case-control study by retrieving data from five nationwide longitudinal registers in Denmark. As cases, we selected all persons between 40-89 years who died by suicide from 1981 to 2006. As controls, we randomly selected up to 10 persons per case matched by sex, day of birth and calendar time. We identified 19,857 persons who committed suicide and 190,058 controls. MI was associated with a marked increased risk of suicide. The risk of suicide was highest during the first month after discharge for $\mathrm{Ml}$ for patients with no history of psychiatric illness (adjusted rate ratio, 3.25 ; $95 \%$ confidence interval, 1.61 to 6.56 ) and for patients with a history of psychiatric illness (adjusted rate ratio, 64.14; 95\% confidence interval, 13.40 to 307.01 ) as compared with those with no history of $\mathrm{Ml}$ or psychiatric illness. However, the risk remained high for at least five years after $\mathrm{MI}$. The rate ratio of suicide after $\mathrm{Ml}$ tended to decrease with age at first $\mathrm{MI}(\mathrm{p}<0.001$ for trend).

Conclusion:

$\mathrm{MI}$ is followed by an increased risk of suicide for persons with and without psychiatric illnesses. Our results suggest the importance of screening patients with $\mathrm{Ml}$ for depression and suicidal ideation.

O02.03 Sanne Lemcke EARLY REGULATION AND TEMPER IN SMALL CHILDREN LATER DIAGNOSED WITH AUTISM SPECTRUM DISORDER. A FOLLOW-UP STUDY IN THE DANISH NATIONAL BIRTH COHORT

\section{S. Lemcke' , E.T. Parner ${ }^{2}$, M. Bjerrum², P.H. Thomsen ', M.B. Lauritsen ${ }^{3}$ \\ ${ }^{1}$ Regional Centre for Child and Adolescent Psychiatry Risskov, Aarhus University Hospital, ${ }^{2}$ Department of Public Health, Aarhus University, ${ }^{3}$ Research Unit of Child and Adolescent Psychiatry Aalborg, Aarhus University Hospital}

Introduction and objectives: The aim is to study whether prospectively collected information from mothers regarding deviations in their child's development and behaviour during the first two years of life can predict the risk of autism spectrum disorder (ASD) later in life.

Methods: In the Danish National Birth Cohort (DNBC) mothers were interviewed about their child's development and behaviour when the child was 6 and 18 months of age, respectively. Children later diagnosed with ASD in the cohort are identified through the Danish National Patient Register. Analyses of interview material will provide information about signs of ASD before the age of two years.

Results: The study is ongoing. The study cohort consisted in August 2011 of 
002.04 Lene Søndergård Larsen
O02.05 Mette Julsgaard Nielsen
76,322 children; of which 973 children were diagnosed with ASD. At the age of 6 months, a different pattern of breastfeeding and crying in children later diagnosed with ASD was reported by mothers compared to the whole cohort. At 18 months of age, associations to later ASD diagnosis were found if the mother described the child's temper as being cautious and less active, and to lesser extent if she described differences in the sleep pattern.

Conclusion: The results indicate that mothers' information about deviations in early regulation is associated with the child's risk of being diagnosed later with ASD.

A COMPANIONSHIP BETWEEN STRANGERS - THE HOSPITAL ENVIRONMENT AS A CHALLENGE TO PATIENT-PATIENT INTERACTION IN ONCOLOGY WARDS

L.S. Larsen ${ }^{1,2}$, B.H. Larsen', R. Birkelund ${ }^{2}$

${ }^{1}$ Centre of Nursing Research, Viborg, ${ }^{2}$ Department of Publich Health (Nursing Sciences), Health, Aarhus University

Aim: To identify and discuss the impact of the hospital environment on interaction between cancer patients.

Background: In recent years, researchers have focused on identifying and describing features of the hospital environment which promote healing, recovery and well-being. It has been discovered that architectural features affect hospitalized patients both positively and negatively. But the research has failed to include patients and fellow patients as part of the hospital environment.

Method: A qualitative approach with participant observation and qualitative interviews was used. From a total of 85 observed cancer patients, ten men and ten women were interviewed.

Findings: Patients had ambiguous views regarding their fellow patients and the hospital environment. The hospital environment imposed conditions that caused stress factors such as the loss of personal privacy and control; but it also offered the possibility of good company and support from fellow patients. Refuge from fellow patients was hard to achieve, and the fact that personal conversations might be overheard by fellow patients caused patients to withhold important information from healthcare professionals. Nevertheless, patients accepted the hospital environment uncritically, with resignation or with silent rebellion.

Conclusion: Hospitalized cancer patients accepted the hospital environment. In spite of the stress imposed by this environment, the lack of refuge possibilities and the withholding of information in multiple-bed rooms, 18 out of 20 patients preferred multiple-bed rooms with the company of fellow patients. Further investigation of the correlation in this field is needed.

ADHERENCE TO MEDICAL TREATMENT AMONG PREGNANT WOMEN WITH ULCERATIVE COLITIS (UC)

M. Julsgaard', M. Nørgaard', C.L. Hvas', A. Grosen', S. Hasseriis', L.A. Christensen

'Department of Medicine V (Gastroenterology \& Hepatology), Aarhus University Hospital, ${ }^{2}$ Department of Clinical Epidemiology, Aarhus University Hospital

Introduction: Adherence to medical treatment of UC is important for maintenance of remission. Predictors and prevalence rates of nonadherence to medical treatment among pregnant UC patients have not previously been investigated.

Methods: Women with UC in North-Western Denmark, who had given birth 
in 2000-2005. Diagnoses and birth outcome were confirmed by populationbased medical databases. Predictors for and extent of non-adherence (less than $80 \%$ intake of daily prescribed medicine dose) were investigated by questionnaires. We assessed the validity of self-reported data for use of medication by comparing these to data from the regional prescription database.

Results: Of 115 women with UC, 93 (81\%) fulfilled the questionnaire. 63 $(68 \%)$ stated to be in medical treatment. Adherence to medical treatment was $60 \%$. Women receiving counselling were less likely to be non-adherent (POR 0.20, $\mathrm{P}=0.04,95 \% \mathrm{Cl} .04-.94$ ). Quiescence in UC was a reason for nonadherence among $67 \%$ of those who were non-adherent prior to pregnancy and $59 \%$ during pregnancy. Prior to pregnancy, $23 \%$ stated fear of negative effect on fertility/foetus as a reason for being non-adherent, and the number increased to $50 \%$ during pregnancy. An increase in flare during $(40 \%)$ compared with prior to pregnancy ( $14 \%$ ) was found $(p<0.05)$. The vast majority stated adherence to medical treatment, and all but one were listed in the prescription database. All women were non-smokers.

Conclusion: Adherence to medical treatment was high. Quiescence and fear of negative effect on fertility/foetus were predictors of non-adherence. Counselling increased adherence. Pregnancy in itself seemed to increase flare risk during pregnancy.

002.06 Henrik FIVE-YEAR RISK OF END-STAGE RENAL DISEASE AFTER SURVIVING Gammelager DIALYSIS-REQUIRING ACUTE KIDNEY INJURY AMONG INTENSIVE CARE PATIENTS: A NATIONWIDE COHORT STUDY

H. Gammelager', C.F. Christiansen', M.B. Johansen', E. Tønnesen², B. Jespersen ${ }^{3}$, H.T. Sørensen ${ }^{7}$

'Department of Clinical Epidemiology, Aarhus University Hospital, Aarhus, Denmark, ${ }^{2}$ Department of Anesthesiology and Intensive Care Medicine, Aarhus University Hospital, Aarhus, Denmark, ${ }^{3}$ Department of Nephrology, Aarhus University Hospital, Aarhus, Denmark

Introduction: Dialysis-requiring acute kidney injury (AKI) is common among intensive care unit (ICU) patients. However, follow-up data on risk of endstage renal disease (ESRD) among these patients remain sparse. We assessed the 5-year risk of ESRD among ICU patients with dialysis-requiring AKI who survived to hospital discharge compared with other ICU patients.

Methods: We used population-based medical registries to identify all adult patients admitted to an ICU in Denmark from 2005 through 2010, who survived until hospital discharge. Dialysis-requiring AKI patients were identified as patients in need of acute dialysis upon or after ICU admission. Subsequent ESRD was defined as a need for chronic dialysis for more than three months or a kidney transplant. We computed cumulative ESRD risk and estimated hazard ratios (HR) using a Cox model adjusted for potential confounders.

Results: We identified 96,020 ICU patients who survived to hospital discharge. Of these, 2,894 (3.0\%) had an episode of dialysis-requiring AKI following ICU admission. The subsequent risk of ESRD up to 180 days after hospital discharge for these patients was $9.7 \%$, compared with $0.1 \%$ for other ICU patients. This corresponds to an adjusted HR of 99.7 (95\% confidence interval [Cl], 75.2-132.2). Among patients who survived 180 days after hospital discharge without developing ESRD $(n=88,010)$, the 181day to 5 -year ESRD risk was $3.8 \%$ for patients with dialysis-requiring $\mathrm{AKI}$, compared with $0.4 \%$ for other ICU patients, corresponding to an adjusted HR of 5.7 (95\% Cl, 4.2-7.7).

Conclusions: Dialysis-requiring AKI among ICU patients is an important risk factor for ESRD up to five years after hospital discharge. 
${ }^{1}$ Aarhus University Hospital, Research Laboratory for Biochemical Pathology, Aarhus C., Denmark, ${ }^{2}$ Aarhus University Hospital, Department of Anaesthesiology and Intensive Care, Aarhus C., Denmark,

${ }^{3}$ Regionshospitalet Randers, Department of Anaesthesiology and Intensive Care, Randers, Denmark, ${ }^{4}$ Aarhus University Hospital, Department of Medicine V (Hepatology and Gastroenterology), Aarhus C., Denmark Introduction: Endothelial activation is a pivotal event in the development and escalation of sepsis into severe sepsis and septic shock. A central part of endothelial activation is the up-regulation of cellular adhesion molecules (CAMs) including E-selectin, ICAM-1, VCAM-1 and PECAM-1. These CAMs are also found in a soluble form (sCAMs). In this study, we examined the levels and the relationship between sCAMs and already available clinical scores and routine blood samples in two groups of ICU patients.

Methods: 30 ICU patients were included in the study; 15 patients with severe sepsis or septic shock and 15 severely ill non-septic patients. Severely ill was defined as an APACHE II score above 13 at ICU admission. 15 healthy volunteers matched on age and gender served as a control group. Clinical scores were calculated at bedside and levels of soluble E-selectin, ICAM-1, VCAM- 1 and PECAM- 1 were measured using flow cytometry.

Results: We found increased levels of $s E$-selectin ( $p<0.001$ ), sICAM- 1 $(p<0.001)$ and sPECAM- $1(p=0.004)$ in the septic group compared to the non-septic group, whereas levels of SVCAM-1 did not differ between groups. sICAM- 1 correlated with APACHEII $(p=0.001)$, SOFA $(p=0.02)$ and CRP $(p=0.005)$, but not with leukocyte count. We found no such correlations to these clinical scores and routine blood samples regarding $s E-$ selectin, SVCAM- 1 and SPECAM-1.

Conclusions: We found increased levels of sE-selectin, sICAM-1 and sVCAM-1 in the septic group compared to the non-septic group and controls. Furthermore, we found ICAM- 1 to be associated with SOFA, APACHEll and CRP.

003.02 Caroline THE B1-CELL SUBPOPULATION IS DIMINISHED IN RELAPSING-REMITTING Winther Tørring MULTIPLE SCLEROSIS PATIENTS

\author{
C.W. Tørring ${ }^{1,2}$, T. Petersen ${ }^{1}$, P. Höllsberg ${ }^{2}$ \\ 'Department of Neurology, Aarhus University Hospital, ${ }^{2}$ Department of \\ Biomedicine, Aarhus University
}

The therapeutic benefit of B-cell depletion in multiple sclerosis (MS) suggests that $B$ cells are involved in the pathogenesis of this disease. Recently, two subtypes of human B cells (CD1 1b-and CD $11 b+B 1$ cells) have been identified by multiple surface markers, distinct transcriptomic profiles and different functionality. The frequency of $C D 11 \mathrm{~b}+\mathrm{B} 1$ cells is markedly elevated in lupus patients (SLE), and our aim is to examine whether this is the case in MS.

By polychromtic flow cytometry, we examined the frequency of CD20+CD27+CD43+CD $11 b+$ cells and CD20+CD27+CD43+CD $11 b-$ cells in blood mononuclear cells from newly diagnosed, untreated relapsingremitting $M S$ patients $(\mathrm{N}=26)$ and an age and gender matched control group $(\mathrm{N}=26)$.
Surprisingly, our data demonstrate that the phenotype of B 1 cells seems two overlap the phenotype of either T cells (CD $11 \mathrm{~b}$ - B 1 cells) or monocytes (CD1 1b+ B1 cells). Using FACS, we sorted the subsets for confocal microscopy to identify the cells. This indicated that most of the CD1 1b+B 1 
cells were doublets of CD3 $+T$ cells and CD20+ B cells, but importantly a small fraction of cells were positive for both CD3 and CD20. Using a gating strategy excluding CD3+ cells, we found a significantly decreased frequency of the total population of B1 cells in patients and controls (mean $1.2 \%$ vs. $1.7 \%$ of total CD20+B-cells). In contrast to SLE, we found no significant difference in the two subtypes of B1 cells in MS compared with controls. We are examining different surface markers on the two subsets to describe their differences. Furthermore, we are investigating the T-cellinteracting B1-cells, whose abundance and activity may be important in MS.

(

PLASMA CONCENTRATIONS OF FIRST-LINE ANTITUBERCULOSIS DRUGS IN A RANDOM SAMPLE OF TUBERCULOSIS PATIENTS IN DENMARK

J.B. Prahl', N. Frimodt-Møller ${ }^{2}$, A.B. Andersen ${ }^{3}$

'International Reference Laboratory of Mycobacteriology, Statens Serum Institut, Copenhagen., '2 Dept. of Clinical Microbiology, Hvidovre Hospital, Copenhagen., ${ }^{3}$ Department of Infectious Diseases, Odense University Hospital, Odense.

Background: Low plasma concentrations of first-line tuberculosis (TB) drugs (isoniazid (INH), rifampicin (RIF), ethambutol (EMB) and pyrazinamide (PZA)) have frequently been observed, but the clinical significance remains to be determined.

Objectives: To assess the prevalence of, investigate possible risk factors for and consequences of low plasma concentrations in TB patients in Denmark.

Methods: 2-hour blood samples were collected from 32 patients with active TB and 3 patients receiving prophylactic treatment. Plasma concentrations were determined using HPLC Tandem Mass Spectrometry. Target ranges were obtained from the literature. Clinical charts were reviewed for baseline characteristics and clinical status at 2, 4 and 6 months after initiation of treatment.

Results: Plasma concentrations below lower normal limit of RIF were observed in $19 / 33$ (58\%), of INH in $25 / 35$ (71\%), of EMB in $13 / 28$ (46\%), of PZA in $3 / 29$ (10\%) and of both INH and RIF in 15/33 (45\%). Plasma concentrations of INH were correlated inversely with CRP both at baseline $(p=0.007)$ and at time of sampling $(p<0.001)$ and positively with treatment time ( $p=0.014$, when adjusted for CRP at baseline). Plasma concentrations of RIF decreased with increasing age $(p=0.006)$. During 1 year follow-up, treatment failure occurred in 5 patients ( 3 patients died, 2 had relapse). Treatment failure was observed more frequently in patients with below median values of RIF $(p=0.044)$, of INH $(p=0.041)$ and of both drugs $(\mathrm{p}=0.005)$.

Conclusions: Plasma concentrations of RIF and INH below lower normal limit are frequently observed in TB patients in Denmark. Low values of RIF and $\mathrm{INH}$ are associated with an increased risk of treatment failure. $\begin{array}{ll}003.04 & \begin{array}{l}\text { Jens Reumert } \\ \text { Laurberg }\end{array}\end{array}$

THE MOLECULAR SIGNATURE OF METASTATIC BLADDER CANCER

J.R. Laurberg', J.B. Jensen ${ }^{2}$, B.P. Ulhøi', S. Højer ${ }^{3}$, M. Borre ${ }^{2}$, T. Ørntoft ${ }^{7}$, L. Dyrskjøt ${ }^{7}$

${ }^{1}$ Department of Molecular Medicine, Aarhus University Hospital, ${ }^{2}$ Department of Urology, Aarhus University Hospital, ${ }^{3}$ Institute of Pathology, Aarhus University Hospital

Background: Metastasis is the principal event leading to death in individuals with cancer, and several attempts have been made to define a molecular signature to predict metastasis in bladder cancer. However, to this date, none have investigated the actual gene-expression in metastasis in bladder cancer, to see if the proposed genes leading to metastasis are expressed in the metastasis. 
Materials and methods: We compared the gene-expression profiles of 10 primary bladder tumors to 12 matched lymph node metastasis and used 8 primary tumors without metastasis as controls. mRNA expression was measured using Affymetrix U133 +2 GeneChips. MicroRNA expression was measured using TaqMan ${ }$ MicroRNA Assays from Applied Biosystems.

We used mRNA data from a previously published study with 69 primary bladder tumors (Riester $M$ et al.) to identify potential markers for metastasis. Gene Set Enrichment Analysis (GSEA) was used to test previously published gene signatures. Immunohistochemistry on a Tissue Micro Array with was used to test if differences in mRNA were equal to changes at protein level.

Results: 12 genes were significantly up-regulated at least two fold in primary tumors with metastasis compared to non-metastatic tumors in both patient cohorts. DNA double-strand repair profiles was significantly enriched in tumors without metastasis. Two previously reported gene sets identified from comparison of metastases and primary tumors were significantly enriched in the primary tumors. 29 microRNAs, including Mir 143 and 145, were down regulated in the lymph nodes compared to the primary tumors, and only one was up-regulated. Pathway analysis confirmed these findings at mRNA target levels

003.05 Christina Gade ANDROGEN DEPRIVATION THERAPY AND RISK OF MYOCARDIAL Jespersen INFARCTION AND STROKE, 2002 TO 2012: A NATIONWIDE DANISH POPULATION-BASED COHORT STUDY

\section{C.G. Jespersen', M. Nørgaard², M. Borre}

'Department of Urology, Aarhus University Hospital, Brendstrupgaardsvej 100, 8200 Aarhus N, Denmark, ${ }^{2}$ Department of Clinical Epidemiology, Aarhus University Hospital, Olof Palmes Allé 43-45, 8200 Aarhus N, Denmark

Objectives: To investigate the association between androgen deprivation therapy (ADT) and development of myocardial infarction and stroke in all Danish men with prostate cancer from 2002 to 2010.

Material and methods: We conducted a national cohort study of all patients with incident prostate cancer registered in the Danish Cancer Registry from 1 January 2002 through 2010. We identified patients diagnosed with myocardial infarction or stroke after date of initiation of medical endocrine therapy (gonadotropin-releasing hormone agonists/anti-androgens) or bilateral orchiectomy through the Danish National Patient Registry. Hazard ratios of myocardial infarction and stroke comparing ADT users with nonusers were estimated using Cox regression analysis while adjusting for age, prostate cancer stage, comorbidity and calendar period.

Results: Of 31,571 prostate cancer patients, 9,204 (29\%) received medical endocrine therapy and 2,060 (7\%) were orchiedectomized. In patients treated with medical endocrine therapy, the adjusted hazard ratio of myocardial infarction was 1.28 (95\% Cl 1.12-1.47) and of stroke 1.22 (95\% Cl 1.07-1.38) compared with nonusers of androgen deprivation therapy. The adjusted hazard ratio of myocardial infarction and stroke after orchiectomy was 0.95 (95\% Cl 0.74-1.23) and 1.03 (95\% Cl 0.83-1.29), respectively.

Conclusion: In this nationwide cohort study of more than 30,000 prostate cancer patients, we found that endocrine hormonal therapy was associated with a significantly increased risk of both myocardial infarction and stroke. In contrast, we did not find this association after orchiectomy.

003.06 Hanna Rahbek RISK FACTORS FOR SWALLOWING DYSFUNCTION AFTER RADIOTHERAPY Mortensen IN THE DAHANCA 6 \& 7 RANDOMIZED TRIAL

H.R. Mortensen ', K. Jensen', J. Overgaard'², L. Specht ${ }^{3}$, M. Overgaard', J. Johansen $^{4}$, J.F. Evensen ${ }^{5}$, E. Andersen', L.J. Andersen', H.S. Hansen', C. Grau' ${ }^{1}$ Department of Oncology, Aarhus University Hospital, ${ }^{2}$ Experimental Clinical 
Oncology, Aarhus Universityhospital, ${ }^{3}$ Copenhagen University Hospital,

${ }^{4}$ Odense University Hospital, ${ }^{5}$ Rikshospitalet Oslo, ${ }^{6} \mathrm{Herlev}$ Hospital, ${ }^{7}$ Aalborg Hospital

Background: Dysphagia is a common and debilitating side-effect in head and neck radiotherapy (RT). The aim was to establish a multivariate predictive model for acute and late dysphagia after RT, based on information from a large prospective trial.

Materials and methods: The DAHANCA 6\&7 randomized phase-III study included 1,476 patients with squamous cell carcinoma of the head and neck eligible for primary RT alone. Patients were randomized between 5 or 6 weekly fractions of conventional RT and received 66-68 Gy in 33-34 fractions. If non-glottic cancer Nimorazole was administered, patients were seen weekly during treatment and at regular intervals until 5 years after treatment. Prospective morbidity recordings were available from 1,468 patients.

Results: Acute dysphagia according to DAHANCA grades 1, 2, 3 and 4 occurred in $83 \%, 71 \%, 43 \%$ and $23 \%$, respectively. Severe dysphagia, defined as "taking liquid food only" or worse, occurred in $47 \%$ and $38 \%$ of patients receiving accelerated or conventional radiotherapy, respectively, $(p=0.001)$. At 1, 2, 3, 4 and 5 years, the prevalence of chronic dysphagia greater than grade 0 was $46 \%, 32 \%, 29 \%, 24 \%, 23 \%$, respectively, with no difference between 5 and 6 fractions.

In a multivariate analysis, the following were significant independent factors for severe acute dysphagia: T3-T4 tumors, N-positive, non-glottic cancer, age $>62$ years, baseline dysphagia $>1$ and accelerated radiotherapy. The following factors were prognostic factors for late dysphagia: non-glottic cancer and baseline dysphagia $>1$.

Conclusion: Predictive models were established to characterize patients at risk of developing acute or late dysphagia in the DAHANCA 6\&7 trial.

004.01 Rikke Esberg PNEUMOTHORAX IN CARDIAC PACING: A POPULATION-BASED COHORT Kirkfeldt STUDY OF 28,860 DANISH PATIENTS

R.E. Kirkfeldt ${ }^{1,4}$, J.B. Johansen ${ }^{2,4}$, E.A. Nøhr ${ }^{3}$, M. Møller ${ }^{2,4}$, P. Arnsbo ${ }^{4}$, J.C. Nielsen

'Department of Cardiology, Aarhus University Hospital, ${ }^{2}$ Department of Cardiology, Odense University Hospital, ${ }^{3}$ Section of Epidemiology, Department of Public Health, Aarhus University, ${ }^{4}$ The Danish Pacemaker Register

Purpose: To identify patient- and procedure-related risk factors for pneumothorax treated with a chest tube after pacemaker (PM) implantation.

Methods: A population-based cohort study was performed based on data from the Danish Pacemaker Register (DPR), which includes all Danish patients who received their first permanent PM from 1997 to 2008. Multiple logistic regression was used to estimate adjusted odds ratios (aOR) with $95 \%$ confidence intervals for the association between risk factors and pneumothorax treated with a chest tube.

Results: The study population consisted of 28,860 patients: male patients, $\mathrm{n}=15,785$ ( $55 \%$ ); median age 77 years $\left(25^{\text {th }}\right.$ and $75^{\text {th }}$ percentile: $\left.69-84\right)$. A total of 190 patients $(0.7 \%)$ were treated for pneumothorax. The risk of pneumothorax was higher in women (aOR $1.9(1.4-2.6)$ ), and in patients with age $>80$ years (aOR 1.4 (1.0-1.9)), a prior history of chronic obstructive pulmonary disease (COPD) (aOR 3.9 (1.6-9.5)), implantation of a dual chamber pacemaker (aOR 1.5 (1.0-2.2)), venous access with subclavian vein puncture (aOR 7.8 (4.9-12.5)), venous access with both subclavian vein puncture and cephalic vein cut down (aOR 5.7 (3.0-10.8)) and implantation 
in a non-university centre (aOR 2.1 (1.6-2.9)).

Conclusions: The risk of pneumothorax requiring a chest tube after device implantation is low. The venous access route seems to be the most important risk factor for pneumothorax. The cephalic vein cut down technique should be applied whenever possible, especially if the patient has a prior history of COPD, is older or is female. It should be considered to use venography or ultrasound to visualize the veins before device implantation in selected patients.

004.02 Line Gebauer Josefsen
004.03 Bent Roni Ranghøj Nielsen
NEURAL CORRELATES OF EMOTION RECOGNITION IN MUSIC IN ADULTS WITH AUTISM SPECTRUM DISORDER

\section{Gebauer}

Center of Functionally Integrative Neuroscience, Aarhus University

Background: Music is a potent source for eliciting emotions, but not everybody experience emotions in the same way. Social and emotional difficulties are core characteristics of autism spectrum disorders (ASD). Difficulties in recognizing emotions from faces and speech are widely studied in ASD, and impairments are associated with differential brain responses. However, whether these difficulties and differential brain responses generalize to music is less clear.

Aim: The objective of the present study was to investigate the neural correlates of emotion recognition in music in high-functioning adults with ASD. Besides, we intend to investigate how potential differences are related to autistic traits.

Method: 19 adults with $\mathrm{ASD}(2$ \% , mean age $=26.2, \mathrm{SD}=5.6$, mean $\mathrm{IQ}=108$, 14.56 ) and 21 typically developing adults ( 2 , mean age $=24.9, S D=4.6$, mean $I Q=115, S D=12.53$ ) were scanned using functionally magnetic resonance imaging ( $\mathrm{fMRI}$ ), while listening to happy, sad and neutral musical excerpts.

Results: Our results demonstrated that the ASD group rated happy music as less happy than did the TD group and showed increased brain activity in response to happy music in posterior cingulate (PCC) and medial prefrontal cortex (mPFC).

Discussion: PCC and mPFC are associated with memory functions, suggesting that these areas support a compensatory mechanism for recognizing emotions in music in people with ASD. Thus, we hypothesize that the ASD group rely on learned strategies based on previously heard melodies to a greater extent than do typically developed controls.

THE EFFECT OF SHORT-TERM CHANGES IN CIRCULATING FREE FATTY ACIDS ON MYOCARDIAL AND SKELETAL MUSCLE LIPID CONTENT: A RANDOMIZED TRIAL IN HEART FAILURE PATIENTS WITH TYPE 2 DIABETES

R. Nielsen ', H. Nørrelund ${ }^{2}$, U. Kampmann ${ }^{3}$, W. Kim ${ }^{7,4}$, S. Ringgård ${ }^{4}$, M. Schäer ${ }^{5}$, N. Møller ${ }^{3}$, H.E. Bøtker ${ }^{7}, H$. Wiggers'

${ }^{1}$ Dept. of Cardiology, Aarhus University Hospital, Aarhus, Denmark, ${ }^{2}$ Dept. of Medicine, Viborg Hospital, Viborg, Denmark, ${ }^{3}$ Dept. of Endocrinology and Metabolism, Arhus University Hospital, Aarhus, Denmark, ${ }^{4}$ The MR-center, Aarhus University Hospital, Aarhus, Denmark, ${ }^{5}$ Russell H. Morgan Department of Radiology and Radiological Science, Philips Healthcare, The Johns Hopkins University School of Medicine, Baltimore, Maryland, USA.

Background: Myocardial lipid content (MYLC) and left ventricular ejection fraction (EF) are inversely correlated in heart failure patients with type 2 diabetes (HF-T2D). Measuring MYLC, as opposed to skeletal muscle lipid content (SMLC), is technically more complicated and time-consuming.

Purpose: To investigate the correlation between changes in MYLC and SMLC 
in HF-T2D patients.

Methods: Fifteen HF-T2D patients $(E F<45 \%)$ underwent 8 hours of high- and low-circulating free fatty acids (FFA) in a randomized cross-over designed trial. MR proton spectroscopy (MRS) was used to measure MYLC and SMLC expressed as percentage of water content.

Results: Circulating FFA levels differed between study arms $(0.05$ (mean) \pm 0.01 (SEM) $\mathrm{mmol} / \mathrm{L}$ (low FFA) vs. $1.07 \pm 0.07 \mathrm{mmol} / \mathrm{L}$ (high FFA); $\mathrm{p}<0.001)$. Thirteen patients completed SMLC measurements and ten patients completed MYLC measurements in both study arms. MYLC was significantly higher during the high FFA arm $(0.78 \pm 0.23 \%$ vs $1.16 \pm 0.19 \%$; $p<0.01)$, whereas SMLC $(0.80 \pm 0.09 \%$ vs $0.84 \pm 0.10 \%, p=0.12)$ did not differ between study arms. No association was found between MYLC and SMLC in either study arm ( $p=0.93$ (low FFA); $p=0.63$ (high FFA)). SMLC and the level of insulin resistance (HOMA-IR) correlated positively in both study arms $\left(r^{2}=0.39, p=0.02\right.$, (low FFA); 0.30, $p=0.041$, (high FFA)), whereas no association was found between MYLC and HOMA-IR.

Conclusion: In HF-T2D patients, MYLC and SMLC respond differently to shortterm changes in circulating FFA, suggesting different regulatory mechanisms of lipid content in heart and skeletal muscle. Our findings show that SMLC cannot be used to assess content of and changes in MYLC.

004.04 Thomas FISH, MARINE N-3 POLYUNSATURATED FATTY ACIDS AND THE Andersen Rix DEVELOPMENT OF ATRIAL FIBRILLATION
T.A. Rix ', A.M. Joensen' ', S. Lundbye-Christensen', S. Riahi ${ }^{7}$, K. Overvad ${ }^{1,2}$, E.B. Schmidt
'Department of Cardiology, Center for Cardiovascular Research, Aalborg Hospital, Aarhus University Hospital, ${ }^{2}$ Section for Epidemiology, Department of Public Health, Aarhus University

Some studies have reported a beneficial effect of fish intake with respect to the development of atrial fibrillation, but reports from different studies are inconsistent. The cohort Diet, Cancer and Health included 57,055 Danish citizens aged 50 to 64 years enrolled between 1993 and 1997. Baseline data included information on health, medication, lifestyle, a semiquantitative food frequency questionnaire including 20 questions regarding intake of fish and food products containing fish as well as measurements of anthropometry, blood pressure and blood samples. During follow-up, a total of 3,425 incident cases of atrial fibrillation were recorded in the National Patient Registry. The validity of the diagnosis of atrial fibrillation is high with a positive predictive value of $92.6 \%$ in this cohort. Data were analyzed in a sex-stratified Cox multivariate regression model with age as time axis and modelling risk as a restricted cubic spline of $n-3$ PUFA consumption. Preliminary results show a lower risk of $A F$ in persons with a median consumption of marine n-3 PUFA, and final results will be reported.

004.05 Mads Jensen INTENTIONAL CAPTURE

M. Jensen ${ }^{1,2}$, E. Vagnoni ${ }^{4}$, M. Overgaard ${ }^{2}$, P. Haggard ${ }^{3}$

${ }^{1}$ Center of Functionally Integrative Neuroscience, Aarhus University,

${ }^{2}$ Cognitive Neuroscience Research Unit, Aarhus University, ${ }^{3}$ Institute of Cognitive Neuroscience, UCL, ${ }^{4}$ Department of Psychological Sciences, Birkbeck, University of London

Two types of questions can be raised about the knowledge that we have about our own actions: (1) what information is accessible and (2) what information is retained of our own action? Or: Does it affect what I know about my own actions whether those actions were intended, or is all I need somatic information caused by a bodily movement?

To investigate this question, we used a forced two-choice paradigm to 
make participants press a key with either their left or right index finger. Simulatenously with the voluntary actions we used Transcranial Magnetic Stimulation (TMS) to induce involuntary movements in either the finger that they moved or in the finger which they did not move. We then asked the participants to recall either which finger they moved or which finger was moved by the TMS.

We found that in incongruent trials (i.e. the participant moved one finger and TMS was applied to the other) participants were better at remembering their own intentional actions compared to involuntary movements. Further, we found that when asked to report which finger was moved by the TMS the participants reported the finger they intentionally moved, but not the other way around.

We argue that the best explanation of the results is what we denote intentional capture. That is, when participants are asked to report their action, the answer is shaped by their intentions of what they intended to do rather then what happened to their body, so when asked to report the involuntary movement, participants report the voluntary action, but when asked to report the voluntary action participants report the voluntary action.

A NOVEL BRDI KNOCKOUT MOUSE MODEL FOR SCHIZOPHRENIA EXHIBITS COGNITIVE DEFICITS, PPI DISRUPTION AND INCREASED DRUG-INDUCED LOCOMOTOR HYPERACTIVITY

P. Qvist ${ }^{7,2,3,4}$, A. Rajkumar, 2, 4, J.H. Christensen, ${ }^{7,4}$, M. Nyegaard, ${ }^{7}$, K. Fejgin ${ }^{3}$, O. Mors ${ }^{2,4}$, M. Didriksen ${ }^{3,4}$, A.D. Børglum ${ }^{7,2,4}$

${ }^{1}$ Department of Biomedicine, Aarhus University, ${ }^{2}$ Centre for Psychiatric Research, Aarhus University Hospital, Risskov, ${ }^{3} \mathrm{H}$. Lundbeck A/S, Synaptic Transmission 2, Valby, ${ }^{4}$ The Lundbeck Foundation Initiative for Integrative Psychiatric Research, iPSYCH

We have repeatedly shown association of the gene, BRD1, to both schizophrenia and bipolar disorder. We have created a mouse strain heterozygous for a constitutively inactivated allele of the gene (R mice). In the present study, we wished to perform a phenotypic characterization of this $\mathrm{R}$ mouse and establish the involvement of Brd 1 in behavioural traits which are comparable to the endo-phenotypes displayed by schizophrenic patients.

$\mathrm{R}$ mice were phenotyped in a series of behavioural models related to schizophrenia symptomatology. The behaviour was explored at baseline and after psychostimulant challenge.

Behaviours reflecting positive symptomatology of schizophrenia were explored by prepulse inhibition (PPI), a translational measure of preattentive information processing, and by psychostimulant-induced locomotor hyperactivity. To assess aspects of negative symptoms, social behaviour was explored. The memory and learning component of cognition were examined in a comprehensive battery of maze-based tests supported by tests of fear conditioning and social memory. Finally, executive cognitive functioning was tested in attentional set shifting.

In our study, we see that Brd1 plays a role in several behaviours comparable to schizophrenia endophenotypes. Although these deficits are most evident in tests for cognitive function and memory tasks requiring retention of learned information, Brd 1 also seems to be involved in mechanisms relating to both psychosis and social deficits. The next immediate step will be to elucidate the molecular and cellular pathways that underlie the observed phenotypes through mRNA expression analysis, magnetic brain imaging and assays for neuronal connectivity. 
O05.01 Lea Johanne Brader

O05.02 Merete Hartvigsen
A HEALTHY NORDIC DIET IMPROVES AMBULATORY BLOOD PRESSURE IN SUBJECTS WITH METABOLIC SYNDROME: A SYSDIET SUB-STUDY

\section{Brader', M. Uusitupa' , L.O. Dragsted ${ }^{3}$, K. Hermansen ${ }^{7}$}

'Department of Medicine and Endocrinology MEA, Aarhus University Hospital, Denmark, ${ }^{2}$ Institute of Public Health and Clinical Nutrition, University of Eastern Finland, Kuopio University Hospital, Kuopio, Finland, ${ }^{3}$ Department of Human Nutrition, Faculty of Science, University of Copenhagen, Denmark

Background: Lowering of blood pressure (BP) in subjects with metabolic syndrome (MetS) is important in the prevention of cardiovascular disease. A healthy Nordic diet may have a favourable impact on BP.

Objective: To compare the influence on blood pressure of a healthy Nordic diet with an isocaloric habitual Nordic diet in subjects with features of MetS.

Design: A randomized, controlled, dietary study was conducted. In a subgroup of 37 subjects, ambulatory BP was monitored and 24-h urine was collected before and after 12 wks intervention. A healthy Nordic diet embraced whole grain products, berries, fruits, vegetables, rapeseed oil, fish, nuts, low-fat dairy products and avoiding sugar-sweetened products. A habitual Nordic diet formed the control diet.

Results: The systolic BP, diastolic BP and mean arterial pressure (MAP) were lowered by the healthy Nordic diet (by $-3.4 \%, p=0.021 ;-4.8 \%, p=0.001$ and $4.2 \%, p=0.002$, respectively) and were unchanged by the control diet $(-0.2 \%$, $\mathrm{p}=0.837 ; 1.0 \%, \mathrm{P}=0.396$ and $0.5 \%, \mathrm{p}=0.639$, respectively). At $12 \mathrm{wks}$, these changes were different between diets for diastolic $(p=0.001)$ and MAP $(p=0.006)$, but not for systolic BP $(p=0.122)$. Heart rate tended to be lower on healthy Nordic diet ( $p=0.057)$. Urinary sodium excretion, $\mathrm{K}^{+}$excretion and sodium $/ \mathrm{K}^{+}$ratio were unaffected by diets and consequently not associated with the healthy Nordic diet-induced BP lowering.

Conclusions: A healthy Nordic diet decreased diastolic ambulatory BP and MAP in weight-stable subjects with features of MetS compared with a habitual Nordic diet. A healthy Nordic diet may possess potential in the prevention of cardiovascular disease.

BREAD-BASED DIETS CONTAINING ISOLATED ARABINOXYLAN OR RYE WHOLE GRAIN WITH OR WITHOUT KERNELS HAVE SIMILAR BENEFICIAL EFFECTS ON GLUCOSE AND LIPID METABOLISM AND CHANGES IN GENE EXPRESSIONS IN INSULIN SENSITIVE TISSUES IN ZDF RATS

\author{
M.L. Hartvigsen', P.B. Jeppesen', H.N. Lcerke ${ }^{2}$, E.N. Njabe', K.E. Bach \\ Knudsen ${ }^{2}$, K. Hermansen ${ }^{7}$ \\ 'Department of Medicine and Endocrinology, MEA, Aarhus University \\ Hospital, ${ }^{2}$ Department of Animal Science, Aarhus University
}

Background and aim: The mechanisms underlying beneficial preventive effects of whole grains on the development of type 2 diabetes (T2D) and cardiovascular diseases are not yet clarified. The aim of our study was to compare the effects of bread-based diets on glucose and lipid metabolism and gene changes in Zucker Diabetic Fatty (ZDF) rats. The diets consisted of rye breads with kernels (RK), rye whole meal bread with milled kernels (RMK), wheat bread with beta-glucan (BG) or arabinoxylan (AX) and white wheat bread (WB) as control.

Methods: Using a parallel design, male ZDF rats ( $n=12$ per group) were fed diets containing chopped bread of AX, BG, RK, RMK and WB. Diets were given ad libitum for 7 weeks. Blood samples were analyzed and gene expressions were determined in muscle, fat and liver tissues.

Results: AX, RK and RMK improved glycemic control, total cholesterol and changed expressions in adipose tissue of GAPDH, adipoR 1, AMPK, LPL, FAS, SREBP-1c, SREBP-2, JNK-1 and in hepatic tissue of PCG-1a. BG had similar 
O05.03 Jesper Sand Sørensen effects as WB.

Conclusions: In the present study, BG was found to be neutral regarding glucose metabolism. This indicates that physiochemical properties of fibres play a key role for the beneficial effects. The results suggest that wheat bread with $A X$ has similar beneficial metabolic effects as RK and RMK in preventing T2D and hypercholesterolemia in ZDF rats.

BIOACTIVE IGF-I AND IGFBP- 1 IN DANISH CHILDREN AND ADOLESCENTS 35 YEARS AFTER ONSET OF TYPE 1 DIABETES. EFFECT OF RESIDUAL BETACELL FUNCTION

\section{J.S. Sørensen}

Department of Pediatrics, Aarhus University Hospital

Background and Objective: Patients with type 1 diabetes (TID) show abnormalities in the GH-IGF-I axis. Portal insulin stimulates hepatic IGF-I generation and adults with TID and a residual betacell function (RBCF) have higher levels of IGF-I than patients without RBCF. Therefore, we compared bioactive IGF-I, total IGF-I and IGFBP-1 in RBCF positive and negative TID children/adolescents and in healthy controls.

Methods: 336 children/adolescents ( 167 females) with a median age of 13.6 yrs(range 4.8--18.9) and TID for 3--5 yrs, and 70 ( 40 female) healthy controls with a median age of 12.1 yrs(7.4--16.9) were investigated. Bioactive IGF-I was determined by cell-based IGF-I KIRA assay, IGF-I and IGFBP-1 by immunoassay. A positive RBCF was defined as a mealstimulated C-peptide $>100$ pM.

Results: Patients had lower $(p<0.001)$ bioactive IGF-I (Mean \pm SD) $(1.56 \pm 0.96$ vs. $2.36 \pm 1.02 \mu \mathrm{g} / \mathrm{I})$ and total IGF-I $(251 \pm 108$ vs. $302 \pm 137 \mu \mathrm{g} / \mathrm{I})$, whereas IGFBP- 1 was higher $(342 \pm 251$ vs. $200 \pm 91 \mu \mathrm{g} / \mathrm{l} ; \mathrm{p}<0.001)$. RBCF+ patients had higher bioactive IGF-I and total IGF-I, but lower IGFBP-1 as compared to $R B C F \div$ patients. In regards to pubertal status, prepubertal RBCF+ children had higher bioactive IGF-I and total IGF-I but lower IGFBP-1 as compared to prepubertal $\mathrm{RBCF} \div$ children. Similar differences were not observed in pubertal children.

Conclusion: Using a highly specific IGF-I bioassay we show that children with TID had lower bioactive and total IGF-I, and higher IGFBP-1 as compared to healthy children. A positive RBCF stimulated the IGF-system in prepubertal, but not pubertal children. We hypothesize that during puberty, the GH surge overrides the stimulatory effect of insulin on the hepatic IGF-I generation.

\section{Steffen Jensen DETECTION OF CIRCULATING MIRNAS IN COLORECTAL CANCER}

\section{S.G. Jensen, D.K. Jeppesen, H.J. Nielsen, T.F. Ørntoft, M.S. Ostenfeld, C.L. Andersen}

Department of Molecular Medicine, Aarhus University Hospital, Skejby, DK8200 Aarhus N, Denmark.

INTRODUCTION: Detection of colorectal cancer (CRC) at early stage is speculated to increase the overall survival of patients. A potential diagnostic approach for this could be the detection of miRNAs circulating in blood, either freely, protein bound, or contained in micro-vesicles (exosomes).

AIM: To investigate the potential of miRNAs and feasibility of exosome isolation in plasma as novel biomarkers for early detection of CRC.

METHODS: The study was initiated by evaluation of methods for isolation of tumor exosomes and for profiling miRNAs with low abundance. Dynabeads were used to isolate exosomes expressing EpCAM. Transmission electron microscopy (TEM) and Western Blotting was used to verify successful isolation of exosomes and the presence of EPCAM. QRT-PCR was 
conducted to profile the miRNA expression.

RESULTS: Bradford protein assay and TEM revealed successful isolation of CRC-derived exosomes. Western blotting demonstrated expression of EpCAM on exosomes and verified successful isolation of exosomes using dynabeads. Using serial dilutions of isolated exosomes spiked into PBS or plasma, a high linearity in miRNA signal vs. input material was observed using EpCAM beads, but not negative lgG control beads. Furthermore, miRNA fold changes observed between cancer and control plasma samples were improved when quantification on $\mathrm{EpCAM}^{+}$-exosomes rather than on free circulating miRNAs.

CONCLUSIONS: Certain miRNAs isolated from plasma exosomes showed potential to distinguish cancer and controls.

O05.05 Rasmus Otkjœr POTENT MICRORNA SUPPRESSION BY RNA POL II-TRANSCRIBED TOUGH Bak DECOY INHIBITORS

\section{R.O. Bak, A.K. Hollensen, M.N. Primo, C.D. Sørensen, J.G. Mikkelsen}

Department of Biomedicine, Aarhus University

miRNAs have emerged as important regulators of gene expression and play a role in almost any cellular process and as potential triggers of disease. Suppression of miRNA activity by synthetic inhibitors may suffer from the need for repeated administration and poor delivery in hard-to-transfect cell types. As an alternative to synthetic agents, we here investigated DNAencoded miRNA inhibitors delivered by plasmid transfection or by lentiviral transduction. In a luciferase-based assay, we compared the potency of seven types of miRNA inhibitors transcribed as short RNAs from an RNA Pol III promoter. We found superior activity of two decoy-type inhibitors; a 'Bulged Sponge' with eight miRNA binding sites and a hairpin-shaped 'Tough Decoy' containing two miRNA binding sites. We demonstrate for the first time that Tough Decoy inhibitors retain their miRNA suppression capacity when embedded in the 3' UTR of longer mRNA transcripts expressed from an RNA Pol II promoter. This approach allows easy temporal and spatial regulation of miRNA activity using inducible and tissue-specific Pol II promoters. We also demonstrate the feasibility of simultaneously inhibiting two different miRNAs using a single Tough Decoy transcript carrying two different miRNA binding sites. Extending this approach, we inhibited six different miRNAs from a single vector encoding a Pol II transcript containing three consecutive Tough Decoys, each with two different miRNA binding sites. These novel RNA Pol II-transcribed Tough Decoy inhibitors may be employed for spatiotemporal regulation of miRNA activity as well as for therapeutic targeting of one or more aberrantly expressed miRNAs.

005.06 Anne Sørensen CHANGES IN HUMAN PLACENTAL OXYGENATION DURING MATERNAL HYPEROXIA AS ESTIMATED BY BOLD MRI
A. Sørensen ${ }^{7}$, D.A. Peters ${ }^{2}$, E.T. Fründ ${ }^{3}$, G. Lingman ${ }^{4}$, O.B. Christiansen ${ }^{7}, N$. Uldbjerg $^{5}$
'Department of Obstetrics and Gynecology, Aalborg Hospital, Aarhus University Hospital, ${ }^{2}$ Department of Clinical Engineering, Aarhus University Hospital, ${ }^{3}$ Department of Radiology, Aalborg Hospital, Aarhus University Hospital, ${ }^{4}$ Department of Obstetrics and Gynecology, Lund University Hospital, ${ }^{5}$ Department of Obstetrics and Gynecology, Skejby Hospital, Aarhus University Hospital

Objectives: The purpose of this study was to investigate changes in human placental oxygenation during maternal hyperoxia by using the non-invasive blood oxygen level dependent (BOLD) magnetic resonance imaging (MRI) technique.

Methods: Eight healthy pregnant women in gestational week 28 to 36 were 
included in the study. By using a facial mask, maternal hyperoxia was induced for 5 minutes. The BOLD MRI scan was performed using a 1.5 Tesla system with the following parameters: repetition time $=8000 \mathrm{~ms}$, echotime $=50 \mathrm{~ms}$ and flip angle $=90$.

Results: In the BOLD image, the normoxic placenta appeared heterogeneous with darker areas located to the fetal side and brighter areas to the maternal side. During hyperoxia, the placenta became brighter and the structure more homogeneous. The BOLD signal of the total placenta $\left(\triangle B O L D_{\text {Total }}\right)$ increased by $15.2 \pm 3.2 \%$ (mean $\left.\pm S D\right),(p<0.0001)$. The increase was predominantly seen in the dark areas in the fetal part of the placenta $\left(\triangle \mathrm{BOLD} \mathrm{Dark}_{\mathrm{D}}\right) 32.1 \pm 9.3 \%$ when compared to the bright areas in the maternal part $\left(\triangle B O L D_{\text {Bright }}\right) 5.4 \pm 3.5 \%$

Conclusion: During hyperoxia, the total placental oxygenation increased significantly. The increase was predominantly seen in the darker areas. This finding and the anatomic location of the dark placental areas suggest that the darker areas represent the fetal circulation of the placenta. To our knowledge, this is the first study that successfully visualizes changes in placental oxygenation by using the BOLD MRI technique. The perspective of this method could be a test of placental function. In pregnancies complicated by placental insufficiency, $\triangle B O L D_{\text {Total }}$ might be reduced. Further research is needed.

P01.01 Maria Charlotte HEART VALVE DISEASE AMONG PATIENTS WITH HYPERPROLACTINAEMIA: A Steffensen NATIONWIDE POPULATION-BASED COHORT STUDY

\section{Steffensen}

Medical Department, MEA, Aarhus University Hospital

Background: Increased risk of heart valve disease during treatment with certain dopamine agonists, such as cabergoline, has been observed in patients with Parkinson's disease. The same compound is used to treat hyperprolactinemia, but it is unknown whether this also associates with heart valve disease.

Objectives: To assess the incidence of diagnosed heart valve disease and cardiac valve surgery among patients with hyperprolactinemia, compared to a general population cohort in Denmark.

Design: A nationwide population-based cohort study

Methods: We identified 2381 hyperprolactinemia patients with a first-time diagnosis recorded from 1994 through 2010 in the registry, with no previous hospital diagnosis of heart valve disease. Each patient was compared to 10 age- and gender-matched comparison cohort members from the general population. Sub-analysis was made in a cohort of 2387 hyperprolactinemia patients with no previous cardiac valve surgery and 23,870 comparison cohort members.

Results: Nineteen (0.80\%) hyperprolactinemic patients were diagnosed with heart valve disease, compared to $75(0.31 \%)$ persons in the comparison cohort. Seven of the 10 patients treated with cabergoline and diagnosed with heart valve disease were asymptomatic and diagnosed on the basis of an echocardiography performed as a safety measure. However, only two patients $(0.08 \%)$ with hyperprolactinemia underwent surgery, compared to $28(0.12 \%)$ persons in the general population cohort.

Conclusions: Data from the present register-based study do not support that hyperprolactinaemia or its treatment is associated with an increased risk of clinically significant heart valve disease. 
J. Gamst, 2, 3, 4, C.F. Christiansen', M.B. Johansen', L.H. Rasmussen 2, ${ }^{4}$, B.S. Rasmussen ${ }^{3}$, R.W. Thomsen ${ }^{7}$

${ }^{1}$ Department of Clinical Epidemiology, Aarhus University Hospital,

${ }^{2}$ Department of Cardiology, Aalborg Hospital, Aarhus University Hospital,

${ }^{3}$ Department of Anaesthesia, Aalborg Hospital, Aarhus University Hospital,

${ }^{4}$ Aalborg AF Study Group

Introduction: It is unknown whether pre-existing AF may influence the prognosis of patients admitted to an intensive care unit (ICU).

Objectives: To examine mortality within 30 days following ICU admission among patients with and without a history of AF.

Methods: All patients admitted to ICUs in Northern Denmark (population $\approx$ 1.8 million) in the period 2005 - 2007 were identified through the Danish National Patient Registry. Likewise, we identified patients with a hospital diagnosis of AF within 5 years prior to admission. The Kaplan-Meier method was used to estimate 30 -day mortality risk. Cox regression analyses were used to compute hazard ratio (HR) for 30-day mortality. The HR estimate was adjusted for sex, age and three levels of comorbidity defined from the Charlson Comorbidity Index.

Results: Among the 28,172 ICU patients included, 8.1\% had previously been diagnosed with AF. Patients with AF had a 30 -day mortality of $25.1 \%$ compared to $14.9 \%$ in patients without AF. HR adjusted for gender, age and comorbidity was 1.04 (95\% Cl: $0.95-1.14)$. Among patients with a history of myocardial infarction, an adjusted HR of 1.33 (95\%Cl: $1.02-1.75)$ was observed when comparing patients with and without AF.

Conclusions: ICU patients with pre-existing AF have a substantially higher mortality risk than ICU patients without previous AF. However, the increased mortality seems mostly to be related to higher age and more comorbidity rather than to AF itself. In patients with previous myocardial infarction, patients with AF had a markedly increased mortality risk compared to patients without AF.

P01.03 Michael

DalagerPedersen MYOCARDIAL INFARCTION AND STROKE AFTER INCIDENT COMMUNITYACQUIRED BACTEREMIA: A 19-YEAR COHORT STUDY

M. Dalager-Pedersen ${ }^{1,3}$, M. Søgaard ${ }^{2,3}$, H.C. Schønheyder ${ }^{2}$, H. Nielsen ${ }^{7}$, R.W. Thomsen $^{3}$

'Department of Infectious Diseases, Aalborg Hospital, Aarhus University Hospital, ${ }^{2}$ Department of Clinical Microbiology, Aalborg Hospital, Aarhus University Hospital, ${ }^{3}$ Department of Clinical Epidemiology, Aarhus University Hospital

Background: Various infectious diseases have been associated with development of acute myocardial infarction (AMI) and ischemic stroke. Still, the risk and underlying mechanisms are not well understood.

Objectives: To evaluate the risk for AMI and stroke up to one year after community-acquired bacteremia (CAB), and secondly to identify clinicomicrobiological risk factors for AMI/stroke.

Methods: We conducted a population-based cohort study in Northern Denmark, 1992-2010, which included 4,384 adult internal medical ward patients who had first-time positive blood cultures drawn on admission. For each CAB patient, we selected 10 population comparisons matched for sex, age and date of admission. Data on bacteremia, biochemistry, medication, comorbidity and all events of AMI and stroke hospitalized in the region were extracted from health-care databases. We used Cox regression analysis to estimate adjusted hazard ratios (HRs) and $95 \%$ confidence intervals $(\mathrm{Cl})$ for 
the composite outcome AMI/stroke within 0-30 and 31-365 days after admission.

Results: The adjusted HR for AMI/stroke was 20.2 within 30 days of $\mathrm{CAB}(\mathrm{Cl}$ 15.0-27.2) and 1.4 ( $\mathrm{Cl} 1.1-1.8) 31-365$ days after admission. Gram-positive infections were associated with a higher risk increase (0-30 days HR=28.5, $\mathrm{Cl}$ 17.1-47.7) than Gram-negative infections (0-30 days HR=16.1, Cl 10.724.1), partly due to a very high risk among patients with Staphylococcus aureus infection ( 0 -30 days $\mathrm{HR}=91.5, \mathrm{Cl} 20.6-405.6)$. For late AMI/stroke, endocarditis was a notable risk factor (31-365 days $\mathrm{HR}=3.6, \mathrm{Cl} 1.6-8.1$ ).

Conclusion: CAB, especially with agents like $S$. aureus, is associated with a highly increased short-term risk of $A M I$ and stroke.

P01.04 Christina Mørup INCREASED OXYGEN SATURATION IN RETINAL VESSELS OF PATIENTS WITH Jørgensen DIABETIC RETINOPATHY REQUIRING TREATMENT

C.M. Jørgensen', S. Hardarson ${ }^{2}$, T. Bek ${ }^{7}$

'Department of Ophthalmology, Aarhus University Hospital, ${ }^{2}$ Department of Ophthalmology, University of Iceland

Diabetic retinopathy is characterized by hyperperfusion in the macular area resulting in diabetic maculopathy, and hypoperfusion in the retinal periphery resulting in retinal ischemia that stimulates neovascularization. The purpose of the study was to study the consequences of perfusion changes on retinal metabolism by assessing retinal oxygenation in patients with these complication types.

184 consecutive patients with diabetes mellitus, referred for specialist evaluation, were subjected to a routine clinical examination, including oximetry (Oxymap T1, vs. 2.2.1). The relative oxygen saturation in an arteriole and its adjoining venule were compared between 32 patients who were diagnosed with proliferative diabetic retinopathy, 45 patients who were diagnosed with diabetic retinopathy requiring treatment, 98 patients who were diagnosed with retinopathy not requiring treatment, 9 patients who were diagnosed with diabetes mellitus without diabetic retinopathy and 37 healthy persons.

Oxygen saturation was independent of patient age and diabetes duration. Patients with proliferative diabetic retinopathy had significantly higher oxygen saturation than patients with retinopathy not requiring treatment in retinal arterioles $(p=0.03)$, whereas patients with diabetic maculopathy had a significantly higher oxygen saturation than patients with retinopathy not requiring treatment in retinal venules $(p=0.01)$

Increased oxygen saturation in patients with diabetic retinopathy may be the result of disturbances in retinal metabolism or retinal blood flow. An elucidation of the background for these changes may contribute to a further understanding of the pathophysiology of diabetic retinopathy.

P01.05 Nicoline Valentina Krogstrup
EARLY CHANGES IN PLASMA CREATININE PREDICT ONE-YEAR GRAFT FUNCTION FOLLOWING KIDNEY TRANSPLANTATION

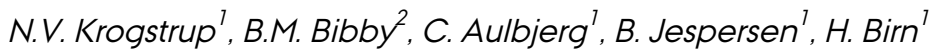

${ }^{1}$ Department of Renal Medicine, Aarhus University Hospital, ${ }^{2}$ Department of Public Health (Biostatistics), Aarhus University

Background: Much research focuses on optimising long-term kidney graft function. Delayed graft function requiring post-transplant dialysis is associated with poorer long-term graft survival. However, little is known about the long-term effects of non-dialysis requiring early graft dysfunction. This study evaluates the association between early kidney graft function, as reflected by the rate of changes in $\mathrm{p}$-creatinine within the first seven days post-transplant, with one year graft function. 
Methods: A single-centre, retrospective analysis of 84 consecutive, dialysis independent kidney transplants followed for one year at Aarhus University Hospital. P-creatinine was registered for seven days post-transplant and after one year along with relevant patient characteristics. A multiple linear regression model was used to analyze the association between early changes in $\mathrm{p}$-creatinine and $\mathrm{p}$-creatinine after one year.

Results: In most patients, the early change in p-ceatinine could be modelled by an exponential function. The rate constant, reflecting the rate of decrease in $\mathrm{p}$-creatinine, correlated negatively with $\mathrm{p}$-creatinine at one year when corrected for age, cold ischemia time and donor type $(p=0.04$, $\mathrm{n}=62)$. The correlation was influenced by recipient age $(p=0.05)$, but not by cold ischemia time $(p=0.65)$ or type of donor (living vs deceased, $p=0.51)$.

Conclusion: Early changes in p-creatinine are associated with one-year kidney graft function indicating 1) that non-dialysis dependent differences in early graft function may be important for long-term outcome and 2) that this may be used as surrogate marker in studies aimed at advancing longterm outcome by improvement of early graft function.

P01.06 Morten Schmidt BODY MASS INDEX IN YOUNG ADULTHOOD AND RISK OF TYPE 2 DIABETES, CARDIOVASCULAR DISEASE AND DEATH BEFORE 55 YEARS OF AGE: A DANISH POPULATION-BASED COHORT STUDY

M. Schmidt ${ }^{7,2,3}$, S. Johannesdottir, ${ }^{7,2}$, S. Lemeshow ${ }^{2}$, T. Lash ${ }^{7}$, H.E. Bøtker ${ }^{3}$, H.T. Sørensen"

${ }^{1}$ Department of Clinical Epidemiology, Aarhus University Hospital, ${ }^{2}$ The Ohio State University College of Public Health, Columbus, Ohio, ${ }^{3}$ Department of Cardiology, Aarhus University Hospital

Background: Adult body mass index (BMI) has consistently been related to mortality, but little is known about the impact of young adulthood BMI on premature type 2 diabetes, cardiovascular disease or death. We examined this association.

Methods: We used the Northern Denmark conscription database to access $\mathrm{BMI}$ of all male conscripts from the 1955 birth cohort $(n=6502)$. Using population-based registries, we followed all draftees from their $22 \mathrm{nd}$ birthday until an outcome, emigration, or their 55-year birthday, whichever came first. Using regression analyses, we calculated risk differences (RDs) and hazard ratios (HRs) with $95 \%$ confidence intervals (Cls) associating BMI groups and outcomes, adjusting for cognitive test score and years of education.

Results: Two-thirds of all obese persons encountered at least one outcome before their 55-year birthday. Compared with persons of normal weight, the corresponding RD was $28 \%$ (95\% Cl: 19 to 38$)$ and the $\mathrm{HR}$ was $3.00(95 \% \mathrm{Cl}$ : 2.25 to 4.01). Obesity was associated with an event rate that was increased more than 7-fold for type 2 diabetes, 4-fold for venous thromboembolism, and 2-fold for myocardial infarction, hypertension and death. Data for stroke were inconclusive due to wide Cls.

Conclusions: Two-thirds of all men with young adulthood obesity died prematurely or were diagnosed with type 2 diabetes, myocardial infarction, stroke, venous thromboembolism or hypertension before reaching 55 years of age. Obesity was thus associated with a 3 -fold increased event rate compared with normal weight, corresponding to an absolute risk increase of almost $30 \%$. 


\section{K. Krogh, C.B. Høyer, B. Eika}

Centre for Medical Education, Aarhus University

Aim: This study explores the impact of realism in time during resuscitation training in simulation-based education (SBE).

Background: It is observed that young doctors are not able to keep track of time and tend to rush CPR during resuscitation in real-life resuscitation attempts as well as in simulation. One factor for this neglect of time could be the impairment of time control during simulation-based training. Instructors often compress time, in the sense that the 120 seconds CPR between heart rhythm controls/defibrillation is compressed to 30-60 seconds during training. To explore the impact of realism in time during SBE, it is questioned how novices' resuscitation performance is affected by real time compared to compressed time during SBE.

Method: Fifty-one (of 52) $4^{\text {th }}$ year medical students completed the one-day course and post test. All novices with no prior training in advanced resuscitation. During the course, the intervention group used $120 \mathrm{sec}$ and the control group used compressed " $120 \mathrm{sec}$ " of CPR (30-45 sec) between rhythm controls/defibrillation. Participants were assessed using a validated test in a post-test only design.

Results: The time intervals between rhythm controls/defibrillation show a near normal distribution for the intervention group around 120 seconds, whereas the time intervals for the control group are widely spread with large variance in time, primarily less than 120 seconds. Using Stata/IC 11.2 , the Mann Whitney test reveals a statistically significant $p$-value $<0.001$ between the two groups.

Conclusion: Realism in time during SBE significantly affects the performance of novices' ability to conduct resuscitation in a simulated environment.

MORTALITY AND RISK OF COMPLICATIONS OF CIRRHOSIS PATIENTS UNDERGOING HIP AND KNEE ARTHROPLASTY

\section{T. Deleuran ${ }^{\text {l, }}$, H. Vilstrup ', S. Overgaard ${ }^{3}$, P. Jepsen ${ }^{1,2}$}

'Department of Medicine V (Hepatology and Gastroenterology), Aarhus University Hospital, ${ }^{2}$ Department of Clinical Epidemiology, Aarhus University Hospital., ${ }^{3}$ Departments of Orthopaedics, Odense University Hospital.

Cirrhosis is associated with severe morbidity and high mortality; the median survival after diagnosis is 5 years. In Denmark, the prevalence of cirrhosis is $10,000-15,000$ and the most prevalent etiology is alcohol. The clinical course of cirrhosis is characterized by impaired ability to tolerate infections and other stressful events. Cirrhosis patients that undergo abdominal surgery carry an increased mortality risk. The risk of mortality and complications in the context of extra-abdominal surgery is less well described.

Aim: To describe the risk of mortality and complications among patients with cirrhosis who undergo hip and knee arthroplasty and compare this to the risk for those without cirrhosis. To identify predictors for complications within the cohort of the patients with cirrhosis who undergo hip or knee arthroplasty.

Methods: By performing a historical registry-based cohort study based on linkage of the Danish National Patient Registry (NPR), the Danish Hip Arthroplasty Registry and the Danish Knee Arthroplasty Registry, we will compare cumulative risk of mortality and complications among patients with and without cirrhosis, and use Cox regression analysis to adjust for confounding by e.g. age and gender. We will use logistic regression to find predictors of mortality and complications within the cohort of patients with 
cirrhosis that undergo hip or knee artrhoplasty.

Results: We have access to preliminary data of 411 patients with cirrhosis who underwent hip or knee arthroplasty from January 1995 to the December 2011 . Within the first 90 days after surgery, 19 patients died.

Conclusion: We cannot make conclusions on the basis of the preliminary results.

P02.02 Mette Holland- RHEUMATOID ARTHRITIS AND MORTALITY OF HOSPITALIZED PNEUMONIA; A Fischer
M. Holland-Fischer ${ }^{1,2}$, A. Riis ${ }^{2}$, M. Nørgaard ${ }^{2}$, H.T. Sørensen ${ }^{2}$, R.W. Thomsen ${ }^{2}$
${ }^{1}$ Department of Rheumatology, Aalborg Hospital, Aarhus University Hospital,
${ }^{2}$ Department of Clinical Epidemiology, Aarhus University Hospital, Aarhus,
Denmark
Background: Studies have shown that rheumatoid arthritis is associated with reduced lifespan and increased risk of infections. However, little is known about whether rheumatoid arthritis is associated with an increased mortality following pneumonia.

Methods: We conducted this population-based cohort study of adults with a first-time hospitalization for pneumonia between 1997 and 2004 in Northern Denmark. Information on rheumatoid arthritis, comorbidity and drug use was obtained from medical databases. We used Cox regression to estimate the adjusted mortality rate ratio (MRR) within 30 days following hospitalization among patients with and without rheumatoid arthritis, controlling for sex, age, comorbidity level, previous alcoholism-related disorders and preadmission use of antibiotics or immunosuppressants.

Results: In total, 666 (2.2\%) of 29,900 hospitalized pneumonia patients had rheumatoid arthritis. Pneumonia patients with rheumatoid arthritis were slightly older and more likely to have a history of cardiovascular comorbidity or immunomodulatory drug use than other pneumonia patients. The 30-day mortality among patients with rheumatoid arthritis was slightly higher than that among other patients: $17.4 \%$ vs. $15.4 \%$ after 30 days, resulting in a crude 30-day MRR of 1.14 (95\% Cl 0.95-1.37) and an adjusted 30-day MRR of 1.08 (95\% Cl 0.90-1.31).

Conclusion: Rheumatoid arthritis was not associated with a substantially increased mortality following hospitalization for pneumonia. Our future studies will explore how rheumatoid arthritis disease severity and immunomodulatory therapy may affect pneumonia outcome.

P02.03 Anne Birgitte Simonsen

\section{ALLERGIC CONTACT DERMATITIS IN DANISH CHILDREN}

\author{
A.B. Simonsen ${ }^{7,4}$, M. Deleuran ', C.G. Mortz' , J.D. Johansen ${ }^{3}$, M. Sommerlund \\ ${ }^{1}$ Department of Dermatology, Aarhus University Hospital, ${ }^{2}$ Department of \\ Dermatology, Odense University Hospital, ${ }^{3}$ National Allergy Research \\ Centre, Copenhagen University Hospital, ${ }^{4}$ Department of Clinical Medicine, \\ Aarhus University
}

Background: Allergic contact dermatitis $(A C D)$ in children was previously considered a rare occurrence. However, the growing number of case reports and cross-sectional studies through the past three decades indicate that $A C D$ is in fact a highly relevant diagnosis in children. Contact allergy and $A C D$ among Danish children referred for patch testing has never previously been studied.

Objectives: To describe the demographic characteristics of the study population of Danish children referred for patch testing, to examine the frequency and relevance of positive patch tests and to determine the most common allergens.

Methods: Evaluation of data from The Danish National Contact Allergy 
Database on 2647 children referred for patch testing in Danish dermatology clinics during 2003-2011.

Results: 1748 girls and 899 boys were suspected of having ACD. Fortyseven percent $(n=1231)$ of the 2647 children had at least one positive patch test reaction. The associated relevance was $73.6 \%(n=906)$. The top five allergens yielding relevant reactions were nickel sulphate $(18.7 \%, n=491)$, fragrance mix II (9.1\%, $n=170)$, fragrance mix I (7.2\%, $n=190)$, paraphenylenediamine $(4.3 \%, n=111)$ and cobalt chloride $(4.0 \%, n=106)$.

Conclusions: Our results are in accordance with international data. We previously published a review of international studies on ACD in children and found reported sensitization rates of $26.6-95.6 \%$ in selected groups of children. $A C D$ is a relevant diagnosis in children and should always be considered when encountering children with suspected ACD or recalcitrant eczema.

P02.04 Troels Johansen

P02.05 Leif Rognås
A THEORETICAL FRAMEWORK FOR UNDERSTANDING BLOOD GAS LEVELS IN ASTHMA

\section{T. Johansen}

Lung Medicine Research Unit, Aarhus University Hospital

Acute asthma is associated with hypoxemia, though measured $\mathrm{CO}_{2}$ levels range between gross hypocapnia, normocapnia or in severe cases hypercapnia. Venous admixture due to ventilation/perfusion (V/Q) inequalities plays a significant role in causing hypoxemia in all levels of attack severity, with hypoventilation and resultant hypercapnia playing an increasing role in the most severe attacks as fatigue of the respiratory muscles develops.

Clinical blood gas levels in acute asthma have been often been reported in the literature, but an adequate and consistent explanation of the patterns in $\mathrm{CO}_{2}$ and $\mathrm{O}_{2}$ has not been attained.

The present theoretical work builds on data from the literature. The aim is to formulate a new approach to explaining and visualizing blood gases levels in general and asthma in particular by incorporating both the effects of $V / Q$ mismatch and changes in minute ventilation and pulmonary blood flow.

This method demonstrates how the range of blood gas levels in acute asthma (from hypo-capnic slight hypoxemia to hyper-capnic gross hypoxemia) can be understood and visualized on the basis of the difference in the capacitance of the blood for oxygen and $\mathrm{CO}_{2}$, respectively.

PREHOSPITAL ADVANCED AIRWAY MANAGEMENT

L. Rognås ${ }^{\text {1, 2, 3, } 4, \text { T.M. Hansen }}{ }^{3}$, H. Kirkegaard', E. Tønnesen ${ }^{5}$

${ }^{1}$ Norwegian Air Ambulance Foundation, ${ }^{2}$ Mobile Emergency Care Unit, Department of Anaesthesiology, Viborg Regional Hospital, ${ }^{3}$ Mobile Emergency Care Unit, Department of Anaesthesiology, Aarhus University Hospital, ${ }^{4}$ Research Center for Emergency Medicine, Aarhus University Hospital, ${ }^{5}$ Department of Anaesthesiology, Aarhus University Hospital

Background: Prehospital advanced airway management (PHAAM) is a potentially lifesaving intervention. When performed on the wrong patients or in a suboptimal way, PHAAM may worsen patient outcome, even to the point of being lethal. Recent publications indicate a potential for quality improvement in PHAAM. The risks and complications related to PHAAM in general, and prehospital endotracheal intubation (PHETI) in particular, are significant. The quality of PHAAM in Denmark and the effect of implementing a standard operating procedure (SOP) in a physician-staffed emergency medical system (EMS) are unknown.

Aims: 1) to estimate the rate of PHAAM-related complications, difficult PHETI 
and impossible PHETI in our services

2) to gain detailed knowledge of the patient population, the indications for performing PHAAM and the use of airway back-up devices in our services

3) to gain detailed knowledge of patient population, rate of complications and mortality in the group of patients where EMS physicians considered performing PHAAM, but chose not to, and to identify the physicians' reasons for not performing PHAAM in these cases

4) to investigate if end-tidal $\mathrm{CO}_{2}$ collected as part of PHAAM can be used to guide decision-making during prehospital cardio-pulmonary resuscitation

5 ) to evaluate the effect of introducing a SOP for controlled ventilation.

Methods: We have prospectively collected data from approximately 1000 consecutive patients treated by the physician-staffed EMS and the Helicopter Emergency Medical Service in the Central Denmark Region during a 21 -month period in 2011 and 2012. We implemented the SOP in February 2012.

Results: Data are currently being analyzed.

P02.06 Ane Birgitte PARENTAL INFLAMMATORY BOWEL DISEASE AND RISK OF ASTHMA IN Telén Andersen OFFSPRING - A NATIONWIDE DANISH COHORT STUDY

\section{A.B.T. Andersen, V. Ehrenstein, R. Erichsen, T. Frøslev, H.T. Sørensen}

Department of Clinical Epidemiology, Aarhus University Hospital

Purpose: Inflammatory bowel disease (IBD) and asthma are immunemediated diseases that may be related. We thus aimed to investigate if parental IBD is associated with asthma in offspring.

Methods: We conducted a cohort study of children born in Denmark in 1979-2009, with follow-up throughout 2010. Data were obtained from Danish medical registries. IBD and asthma were identified using hospital diagnoses and/or redeemed prescriptions. Absolute risk of asthma was estimated using the Kaplan-Meier method and incidence rate ratios were estimated using Cox proportional-hazards regression, while adjusting for known relevant risk factors for asthma.

Results: The cohort consisted of 1,845,281 children of whom 14,952 had either maternal or paternal IBD. Among children without parental IBD, the risk of asthma was $2.3 \%$ after 2 years, $3.7 \%$ after 5 years, $5.1 \%$ after 10 years and $6.0 \%$ after 15 years of follow-up. Corresponding estimates in children with parental IBD were $3.1 \%, 4.6 \%, 6.0 \%$ and $6.9 \%$. The adjusted incidence rate ratio (aIRR) for asthma in children with parental IBD was 0.99 (95\% confidence interval [Cl] 0.93-1.06) compared with children without parental IBD. For children with parental Crohn's disease, the alRR was $1.11(95 \% \mathrm{Cl}$ : 1.00-1.24), and for children with parental ulcerative colitis the alRR was 0.93 (95\% $\mathrm{Cl}$ 0.85-1.01) compared to children without parental IBD. We found corresponding results when restricting the analyses to children aged 5 years or older and in sensitivity analyses including anti-asthma medication.

Conclusion: We found no substantial increased risk of asthma in children with parental IBD.

P02.07 Zhanyuan TNF- $\alpha$ AND IL-17A-INDUCED S100A7 EXPRESSION IS REGULATED BY A P38 Kang MAPK AND ERK1/2 DEPENDENT MECHANISM IN CULTURED HUMAN KERATINOCYTES

\section{Z.Y. Kang, M. Mose, L. Iversen, C. Johansen}

Department of Dermatology, Aarhus University Hospital

S100A7 (also known as psoriasin) is an antimicrobial protein, known to be overexpressed in lesional psoriatic skin. The mechanism regulating its expression, however, is poorly understood. The p38 mitogen-activated 
P03.01 Christian Lottrup

protein kinase (MAPK) and extracellular signal regulated kinase (ERK1/2) signalling pathways have previously been demonstrated to be activated in lesional psoriatic skin. The purpose of this study was to investigate the role of p38 MAPK and ERK $1 / 2$ in the expression and regulation of S100A7 in cultured human kerationcytes. We demonstrated that stimulation of human keratinocytes with TNF-a and IL-17A in combination resulted in an increased mRNA and protein level of S100A7, which was significantly higher than the observed increase in S100A7 induced by the individual cytokines. To analyze the signalling pathways involved in the regulation of S100A7, we preincubated keratinocytes with a p38 MAPK, an ERK 1/2 or a c-Jun $\mathrm{NH}_{2}$-terminal kinase (JNK) inhibitor before stimulation with TNF-a and IL-17A. By quantitative PCR, we demonstrated that the mRNA expression of S100A7 was significantly reduced by a p38 MAPK $(p=0.031)$ and an ERK $1 / 2$ inhibitor $(p=0.046)$, whereas preincubation with a JNK inhibitor had no effect on the mRNA expression of S100A7. Similar results were found at the protein level of S100A7, as demonstrated by western blotting. In conclusion, our results demonstrate that the P38 MAPK and ERK $1 / 2$ signalling pathways are involved in the TNF- $a$ and IL-17A-induced regulation of S100A7.

ASSESSMENT WITH THE FUNCTIONAL LUMINAL IMAGING PROBE (FLIP) DISTINGUISHES OESOPHAGO-GASTRIC JUNCTION DISTENSIBILITY IN BARRETT'S OESOPHAGUS PATIENTS WITH HIATAL HERNIAS FROM HEALTHY CONTROLS - A PILOT STUDY

C. Lottrup ', J. Liu' 2, P. Ejstrud ', M. Ostapiuk ', B.P. McMahon 4, A.M. Drewes

'Mech-Sense, Department of Gastroenterology, Aalborg Hospital,

${ }^{2}$ Department of Gastroenterology, China-Japan Friendship Hospital, Beijing, China, ${ }^{3}$ Advanced Endoscopy Unit, Department of Surgery, Aalborg Hospital, ${ }^{4}$ Department of Medical Physics and Clinical Engineering, Adelaide and Meath Hospital Dublin, Tallaght, Ireland

Background: Patients with gastro-oesophageal reflux disease have previously been shown to have increased distensibilty of the oesophagogastric junction (OGJ). The Functional Luminal Imaging Probe (FLIP) is a novel method to assess the distensibility as it relates to competency of sphincters in the gastrointestinal tract. The aim of this study was to use FLIP to assess the distensibility of two hernia separated sphincter components; namely the true lower oesophageal sphincter (LOS) as well as the diaphragmatic crural component.

Material and methods:A pilot study compared ten Barrett's oesophagus patients with hiatal hernia to eight healthy controls. A FLIP probe capable of measuring cross-sectional area during inflation with saline was placed straddling the oesophago-gastric junction. In patients, the LOS, the DH and the hiatal hernia cavity were located and measured separately.

Results: At $50 \mathrm{~mL}$ distension, the true LOS was significantly more distensible $(p=0.005)$ and the balloon prsssure was significantly lower $(p=0.04)$ in hernia patients. The hernia patients had a diaphragmatic sphincter component significantly more distensible $(p=0.002)$ and with a significantly lower pressure $(p=0.002)$ than their true LOS. At low distension volumes, the geometric profile of a hiatal hernia could be assessed visually with both sphincter regions visible at each end of the hernia.

Conclusions: FLIP is a practicable method to assess the distensibility of the OGJ also in the presence of a hiatal hernia. FLIP assessment may be used to better understand the function and competency of the OGJ and the roles that the different parts of the junction play. 

NEURO MODULATION A CAUSE OF EFFECT?

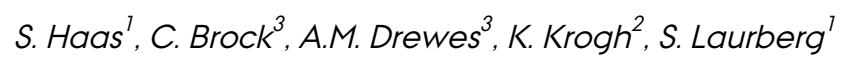

${ }^{1}$ Surgical Department P, Aarhus University Hospital, ${ }^{2}$ Department of Gastroenterology V, Aarhus University Hospital, ${ }^{3}$ Mech-Sense, Department of Gastroenterology, Aalborg University Hospital

Background: Fecal incontinence (FI) is a devastating disorder with great impact on quality of life. Depending on the cause and severity of Fl, treatment ranges from conservative to injectable bulking agents, sphincter reconstruction, sacral nerve stimulation (SNS) or stoma.

SNS improves $\mathrm{Fl}$ in up to $80 \%$ of patients with preceding positive percutaneous nerve evaluation (PNE), but the mode of action is still uncertain. Recent studies suggest that SNS affects the cerebral processing of rectal/anal stimuli through the afferent nerves from these segments.

Hypothesis: Cerebral processing of rectum/anal stimuli is different when comparing healthy volunteers and idiopathic FI (IFI) patients. Further, this processing varies depending of the kind of Fl (passive/urge) and is altered in patients with successful SNS treatment.

Methods: 20 healthy volunteers are compared to $20 \mathrm{IFI}$ patients. $20 \mathrm{IFI}$ patients undergoing SNS will be examined before PNE, after PNE and, if positive, 1 year after permanent electrode implantation: A 64-channel EEG cap is mounted and continuous electroencephalograms are recorded while subjects receive rectal/anal stimuli in form of rapid balloon distensions. The EEGs provide evoked potentials, which are processed though multichannel matching pursuit, inverse modelling and subject's MRI cerebrum. This yields a functional image with a high resolution in time that allows us to study ongoing processes in the cerebrum.

Perspectives: We hope to gain more understanding of the pathology behind IFI and about the mode(s) of action of sacral nerve stimulation. Cerebral responses may predict treatment outcome and thus improve the selection of possible SNS candidates.

P03.03 Charlotte K.

INCIDENCE OF COLORECTAL CANCER IN FIRST DEGREE RELATIVES TO Lautrup COLORECTAL CANCER PATIENTS. A DANISH COHORT STUDY

C.K. Lautrup ${ }^{1,2}$, E. Mikkelsen ${ }^{2}$, T.L. Lash ${ }^{2,3}$, N. Katballe $^{4}$, L. Sunde ${ }^{7}$

${ }^{1}$ Department of Clinical Genetics, Aarhus University Hospital, ${ }^{2}$ Department of Clincial Epidemiology, Aarhus University Hospital, ${ }^{3}$ Department of Epidemiology and Prevention, Wake Forest School of Medicine, North Carolina, USA, ${ }^{4}$ Department of Cardiothoracic and Vascular Surgery, Aarhus University Hospital

Background: First degree relatives (FDRs) to colorectal cancer (CRC) patients are reported to have a 2-3 times increased risk of CRC, increasing to a 4 -fold risk if more than one FDR is affected. However, previous studies have not excluded high-risk families with a known genetic predisposition of CRC when estimating the relative risk.

Aim: To evaluate the risk of CRC among FDRs to patients with the disease after exclusion of high-risk families.

Methods: A cohort study including 1200 patients diagnosed with CRC in 1995-98 and their FDRs. At the time of diagnosis, the 1200 patients reported the number of FDRs in their families and the occurrence of CRC among these. We identified FDRs with name and CPR number by using church books, municipality countings and population registry cards combined with the Danish Civil Registration System. Data regarding CRC diagnosis will be 
obtained from the Danish Cancer Registry and the Danish National Patient Registry. The families are categorized in risk groups (high, moderate and low) based on the CRC occurrence in the family prior to the patient's diagnosis and high-risk families are excluded. Living FDRs will be followed regarding the frequency of $\mathrm{CRC}$ from time of diagnosis in their relative to 31 December 2010 and compared to a matched reference cohort.

Results: Preliminary results show that 3747 living FDRs from 1050 families can be included in the study. 24 high-risk families have been identified. Approximately 200 families can be included in the moderate risk group. We will present descriptive data of the cohort and estimate the risk of CRC in the risk groups compared to the reference cohort by use of incidence rate ratios.

\section{A DANISH UPPER GI BLEEDING CENTRE \\ P. Bager, J.F. Dahlerup \\ Department of Medicine V (Hepatology and Gastroenterology), Aarhus University Hospital \\ Background: Acute upper gastrointestinal bleeding is common and anaemia at discharge is common as well. Follow-up studies of patients after discharge are limited. Furthermore, guidelines for follow-up and treatment of post-discharge anaemia are not published. \\ Method: We performed a local retrospective evaluation of 169 patients admitted for acute upper gastrointestinal bleeding. \\ Results: The retrospective evaluation found that more than $80 \%$ of the patients admitted for acute upper gastrointestinal bleeding were discharged with apparent anaemia, and oral iron supplementation was recommended for $16 \%$ of the discharged anaemic patients. Our study revealed no standardized follow-up protocols for anaemic patients. \\ Conclusion: The follow-up praxis for patients with anaemia was inconsistent. Based on our research, well-designed studies are needed to determine the most effective post-discharge treatment for patients still anaemic at discharge after endoscopic treatment of acute nonvariceal upper gastrointestinal bleeding. \\ P03.05 Jonathan THIRTY-DAY MORTALITY IN PATIENTS UNDERGOING SURGERY BECAUSE OF Montomoli DIVERTICULITIS: A DANISH NATIONWIDE COHORT STUDY}

FREQUENCY OF IRON SUBSTITUTION AND ANAEMIA AT DISCHARGE FROM

\section{J. Montomoli, E. Erichsen, T. Nilsson, H.T. Sørensen}

Department of Clinical Epidemiology, Aarhus University Hospital

Background: Among benign disorders of the colon, diverticular disease is the most frequent indication for colorectal surgery. The prevalence of liver disease is increasing worldwide. However, knowledge on postoperative mortality after surgery for diverticular disease in patients with liver disease is limited.

Methods: Using Danish medical databases, we conducted a nationwide cohort study of all patients undergoing first-time surgery for diverticular disease from 1978 through 2009. Patients with any previous diagnosis of liver disease were categorized in two cohorts: those with non-cirrhotic liver disease and those with liver cirrhosis. We used a Cox regression model to compare 30-day mortality in diverticular disease patients with non-cirrhotic liver disease or liver cirrhosis to a reference cohort of patients without liver disease. Hazard ratios were used as measures of the relative risk (RR) of death, adjusting for gender, age, timing and type of surgery, comorbidities, and alcoholism.

Results: A total of 12,025 patients undergoing diverticular disease surgery 
P03.06 Anne-Mette Haase

P03.07 Eva Bjerre Ostenfeld were included in the study. Of these, 181 (1.5\%) had non-cirrhotic liver disease, and $68(0.6 \%)$ had cirrhosis. Thirty-day mortality was $10.0 \%$ in patients with non-cirrhotic liver disease and $16.2 \%$ among patients with liver cirrhosis, compared to $9.2 \%$ in patients without liver disease. After adjustment, this corresponded to RRs of 1.25 (95\% Cl: $0.78-2.01)$ for patients with non-cirrhotic liver disease, and 2.15 (95\% Cl: 1.16-3.98) for patients with liver cirrhosis.

Conclusions: Pre-existing liver cirrhosis was associated with a markedly increased 30-day mortality following diverticular disease surgery.

GASTROINTESTINAL CONTRACTION PATTERNS AND SEGMENTAL TRANSIT TIMES EVALUATED WITH AMBULATORY CAPSULE TRACKING

A.M. Haase', T. Gregersen' , L. Fynne', V. Schlageter ${ }^{2}$, M. Demierre ${ }^{2}$, P. Kucera ${ }^{2}$, M. Scott ${ }^{3}$, S. Laurberg ${ }^{7}$, K. Krogh ${ }^{7}$

'Departement of Medicine $\vee$ (Hepatology and Gastroenterology), Aarhus University Hospital, ${ }^{2}$ Motilis, Lausanne, Switzerland, ${ }^{3}$ Royal London Hospital and Barts \& London University, UK

Objective: To test the possibility of ambulatory assessment of gastrointestinal movement patterns and segmental transit times by tracking of ingested electronic capsules.

Methods: Motilis-3D-transit is a novel ambulatory system, whereby one or more electronic capsules (diameter $8 \mathrm{~mm}$ ) emitting magnetic fields are tracked by external sensors carried in a belt. In an ongoing study, sixteen healthy subjects ingested an electronic capsule in the morning and evening on day 1 and again in the morning on day 2 . The three capsules were tracked simultaneously while located in various parts of the gastrointestinal tract. The subjects were allowed to keep up most aspects of daily life including travelling by public transport.

Results: In the ambulatory setting, simultaneous location and tracking of three capsules located in various segments of the gastrointestinal tract was possible. Continuous recordings were obtained from ingestion until exit of the capsules for up to 60 hours. Characteristic basic contraction frequencies of 3 per minute in the stomach, 8-11 per minute in the small intestine and 36 per minute in the colon were clearly visible. Gastric emptying, duodenal passage, small intestinal transit, ileo-cecal passage and segmental colorectal transit times were determined. Distance covered during colonic mass movement was identified.

Conclusion: Ambulatory and continuous tracking of three electronic capsules throughout the gastrointestinal tract was realized by using Motilis3D-transit. This approach allows minimally invasive estimation of gastrointestinal contraction patterns, gastric emptying, small intestinal transit and segmental colonic transit times.

PREADMISSION USE OF SYSTEMIC GLUCOCORTICOIDS AND 30-DAY MORTALITY AFTER COLORECTAL CANCER SURGERY

\section{E.B. Ostenfeld ${ }^{7}$, R. Erichsen ${ }^{\text {, O O. Thorlacius-Ussing }}{ }^{2}$, A.H. Riis ${ }^{\text {, H.T. Sørensen }}{ }^{7}$}

'Department of Clinical Epidemiology, Aarhus University Hospital, Aarhus, Denmark, ${ }^{2}$ Department of Gastrointestinal Surgery, Aarhus University Hospital, Aalborg, Denmark

Background: Surgical treatment of colorectal cancer (CRC) is crucial for cure as well as palliation, but carries serious risks for the patient. Use of systemic glucocorticoids can lead to numerous side effects, some of which may affect mortality after CRC surgery. Examples are hyperglycemia, electrolyte and fluid disturbances, hypertension, atherosclerosis, arrhythmias, thrombosis, peptic ulcer, delayed wound healing and infections, which all increase the risk of post-surgical adverse outcomes. 
Aim: To examine 30-day mortality after CRC surgery among users of systemic glucocorticoids compared to non-users.

Methods: We will perform a nationwide cohort study including patients who underwent surgical treatment for a CRC diagnosis between 2001 through 2011 and who are recorded in the Danish Colorectal Cancer Group Database. Patients will be followed from the date of CRC surgery until death, emigration or 30 days postoperative, whichever comes first, and we will use the Kaplan-Meier method to conduct survival curves. Cox proportional-hazard regression will be applied to estimate 30-day mortality rate ratios among systemic glucocorticoid users compared to non-users, adjusting for covariates. In sub-analyses, we will stratify across tumor site (colon or rectum), urgency of surgery (planned or acute) and comorbidity according to the American Society of Anaesthesiologists (ASA) score (I, II or $>$ III).

Perspectives: This large-scale population-based cohort study will provide important knowledge about the impact of glucocorticoids on CRC postsurgical mortality. An association between the two will have major clinical implications for improving CRC pre-surgical risk assessment and treatment strategies.

P03.08 Jesper Padkœr THE UGT1A1 *28 ALLEL'S ASSOCIATION TO CRITICAL JAUNDICE

Petersen

J.P. Petersen ${ }^{7,2}$, T.B. Henriksen" ${ }^{2}$, M.V. Hollegaard ${ }^{3}$, O. Thorlacius-Ussing ${ }^{4}$, F. Ebbesen ${ }^{7}$

${ }^{1}$ Pediatric Department, Aalborg University Hospital, ${ }^{2}$ Pediatric Department, Aarhus University Hospital, Skejby, ${ }^{3}$ Section of Neonatal Screening and Hormones, Statens Serum Institut, ${ }^{4}$ Department of Surgery, Aalborg University Hospital

Objective: The majority of all newborns develop neonatal jaundice. This is mainly a benign occurrence, but a small group proceeds to develop critical jaundice (serum bilirubin $>420 \mu \mathrm{mol} / \mathrm{L}$ ), which is a major risk factor in the development of kernikterus. Neonatal jaundice is the result of an imbalance between bilirubin production and elimination. Hepatic UGT1A1 is the rate limiting enzyme in bilirubin catabolism. The genetic polymorphism UGT1A $1 * 28$ causes down regulation of UGT1A1 activity, and UGT1A1 *28 allel homozygote's have marked reduced UGT1A1 activity. Allel frequency varies with ethnicity and is in Denmark approximately $30 \%$. Our objective is to clarify the contribution of the UGT1A ${ }^{*} 28$ allel in development of critical jaundice.

Methods: We will compare UGT1A $1 * 28$ allel status between all Danish newborns from 2000 to 2007 with critical jaundice and a control population. Our study utilizes the Danish Critical Jaundice Database (DCJD) at the Aalborg Pediatric Research Unit and the Danish Newborn Screening Biobank(DNSB). DCJD encompasses all newborn children with critical hyperbilirubinaemia born in the current century in Denmark after 35 gestational weeks (GA). For the present study, infants of Caucasian descent born from 2000 to 2007 were considered $(n=257)$. A control group $(n=514)$ was drawn from public registers. At DNSB, dried blood spots of cases and controls are identified and from a sample a whole genome DNA amplification is done. From DNA, individual UGT1A1*28 allel status is determined. Association between genotype and risk of critical hyperbilirubinaemia will be described on the basis of conditional logistic regression analysis with control for relevant confounders.

P04.01 Kristoffer Koch IMPACT OF SOCIOECONOMIC POSITION ON RISK OF COMMUNITYACQUIRED BACTEREMIA: A POPULATION-BASED CASE-CONTROL STUDY

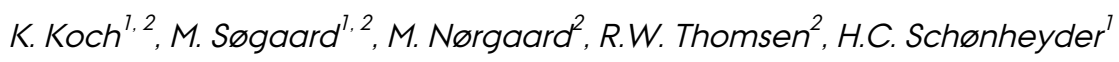

'Department of Clinical Microbiology, Aalborg Hospital, Aarhus University 
Hospital, ${ }^{2}$ Department of Clinical Epidemiology, Aarhus University Hospital

Objectives: To examine the association between socioeconomic position (SEP) and the risk of community-acquired bacteremia.

Methods: We conducted this population-based case-control study in two Danish regions (North Denmark Region and Capital Region). Through a bacteremia research database, we identified all patients of working age (30-65 years) hospitalized with first-time community-acquired bacteremia during the period 2000-2008. For each bacteremia case, we selected 10 controls from the general population by sex, age and region of residence. We obtained detailed individual-level information on SEP through linkage with public registries and examined three measures of SEP: educational attainment, personal income and employment status. We used conditional logistic regression to compute odds ratios as estimates of incidence rate ratios for hospitalization with bacteremia. We adjusted for non-Danish origin, marital status, pre-existing chronic diseases and conditions related to alcohol and drug abuse.

Results: The study included 5,492 cases with community-acquired bacteremia and 54,920 population controls. Persons of lower SEP had a higher risk of hospitalization with bacteremia than those of high SEP. This association was observed for all examined SEP indicators (adjusted odds ratio for short vs. long education, 1.52 [Cl, 1.39-1.66]; low-income vs. highincome tertile, 1.61 [Cl, 1.48-1.76]; early retirement pension vs. employed, $2.38[\mathrm{Cl}, 2.17-2.61])$.

Conclusions: We found a notable inverse relation between socioeconomic position and risk of community-acquired bacteremia.

P04.02 Betina Hansen THE VALIDITY OF THE REGISTRATION OF ACUTE MEDICAL HOSPITAL ADMISSIONS IN THE DANISH NATIONAL REGISTRY OF PATIENTS

\section{B. Vest-Hansen, A.H. Riis, C.F. Christiansen}

Department of Clinical Epidemiology, Aarhus University Hospital

Background: The Danish National Registry of Patients (DNPR) encompasses comprehensive information on hospital admissions in Denmark since 1977. A code indicating admission type, acute or non-acute, was added to the DNPR in 1987. In general, administrative data and diagnoses in the DNPR are considered of high validity.

Objective: To examine the validity of registration of acute admission type among medical patients in the DNPR using medical record review as the reference standard.

Methods: We used the DNPR to identify a random sample of 175 medical hospital admissions in the North Denmark Region during 2009. The medical records of the patients were retrieved and evaluated. According to the triage process described in the medical record, the admissions were assigned to be either acute or non-acute, respectively. We computed positive predictive value (PPV), sensitivity and specificity including 95\% confidence intervals $(\mathrm{Cl})$ using the medical record review as reference standard.

Results: The final analysis included 158 medical hospital admissions after excluding 14 emergency room patients and three patients with missing information. A total of 127 were registered with an acute admission type and 31 with a non-acute admission type. The overall PPV of the acute admissions was $97.6 \%$ (95\% Cl 93.3\%; 99.5\%). Sensitivity was $97.6 \%(95 \% \mathrm{Cl}$ 93.3\%; 99.5\%) and specificity was $90.3 \%$ (95\% Cl 74.2\%; $98.0 \%$ ).

Conclusion: We found that registration of acute admission type among medical patients in the DNPR has high validity. 
P04.03 Mikkel Andreas CRITERIA-BASED EMERGENCY MEDICAL DISPATCH - A NOVELTY IN Strømgaard DENMARK

Andersen

M.S. Andersen

Prehospital Research Unit, Central Region Denmark \& Department of Clinical Epidemiology, Aarhus University Hospital

Purpose: A nationwide radical change has been implemented in the prehospital organization in Denmark. Assessment and prioritization of 112 callers with medical problems have previously been conducted mainly by the police. However, 112 calls concerning illness and injury are now redirected to one of five emergency medical dispatch (EMD) centres, staffed with nurses, paramedics and doctors. The EMD staff uses a criteria-based protocol (The Danish Index) to divide callers into five levels of acuity (A-E); level A being patients with potential life-threatening symptoms. We present the first data on level of acuity, admission and mortality rate after implementation of EMD in Denmark.

Methods: A follow-up study conducted in three large regions, representing $75 \%$ of the Danish population (5.6 million). During six months, all 112 callers in contact with an EMD centre were included. Information on vital status and hospital contacts was obtained through individual-level record linkage with population-based national registries.

Results: In total, we identified 100,508 contacts of which 88,840 had information on acuity level registered. $39.1 \%$ was assessed as level A, $35.2 \%$ as $B, 1.6 \%$ as $C, 0.2 \%$ as $D$ and $23.9 \%$ as $E$ receiving advice only or a taxi. Mortality rate on the same date as the 112 call varied from $4.4 \%$ (group A) to $0.0 \%$ (group D). 30 -day mortality rate varied from $8.6 \%$ (group A) to $0.9 \%$ (group D). Hospital admission rate varied from $65.3 \%$ (group A) to $30.0 \%$ (group D).

Conclusion: The implementation of a new EMD organization in Denmark has implications for a large group of patients with considerable variation in need of hospitalization and short-term mortality risk.

P04.04 Anne Fia COMORBIDITY AND SURVIVAL OF DANISH MELANOMA PATIENTS

Grann

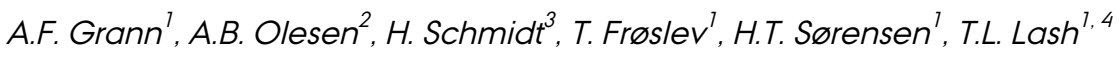
'Department of Clinical Epidemiology, Aarhus University Hospital,
${ }^{2}$ Department of Dermatology, Aarhus University Hospital, ${ }^{3}$ Department of Oncology, Aarhus University Hospital, ${ }^{4}$ Department of Epidemiology \& Prevention, Wake Forest School of Medicine, North Carolina

Background: During the last decades, the incidence of cutaneous melanoma has been rising in fair-skinned populations. In 2010, 1789 people in Denmark were diagnosed with melanoma. Patients aged 65 years or older constitute more than half of melanoma patients. The elderly have more chronic diseases and use more drugs than younger persons. These comorbidities may have an influence on cancer risk and prognosis.

Objective: To compare mortality rates in a cohort of melanoma patients with a comparison cohort from the background population. To evaluate the interaction between melanoma and comorbid diseases.

Methods: We performed a population-based cohort study of melanoma patients diagnosed between 1987 and 2010. Ten patients were matched to every melanoma patient on age, sex, calendar year and comorbidities. We calculated interaction contrasts based on 1 - and 5-year cumulative mortality.

Results: The study population included 23,476 patients diagnosed with melanoma of which $19 \%$ had 1 or more hospital-registered comorbidity. We examined rates of 1 - and 5-year mortality among melanoma patients and compared them with rates of the comparison cohort. Within the first year 
after melanoma diagnosis, $5.6 \%$ of melanoma patients and $2.2 \%$ of persons in the matched cohort died (mortality rate ratio $=2.90,95 \% \mathrm{Cl}=2.74,3.14$ ). In the following period, $1-5$ years, MRR was $2.33,95 \% \mathrm{Cl}=2.24,2.42$. Within the first year after diagnosis, the interaction contrast increased with higher level of comorbidity.

Conclusion: High level of comorbidity at time of melanoma diagnosis was associated with increased mortality. This effect was most pronounced during the first year after melanoma diagnosis.

P04.05 Trine Eilenberg TREATMENT OF PATIENTS WITH HEALTH ANXIETY. A RANDOMIZED CONTROLLED TRIAL OF ACT (ACCEPTANCE AND COMMITMENT THERAPY) GROUP TREATMENT COMPARED TO A WAITING LIST

\section{T. Eilenberg ${ }^{7}$, L. Frostholm ${ }^{7}$, E. Oernboel', W. Rief ${ }^{2}$, P. Fink ${ }^{7}$}

${ }^{1}$ The Research Clinic for Functional Disorders and Psychosomatics, Aarhus University Hospital, Aarhus, Denmark, ${ }^{2}$ Department of Clinical Psychology and Psychotherapy, University of Marburg, Marburg, Germany

Background: Health anxiety is a prevalent somatoform disorder, but rarely diagnosed or treated. Severe health anxiety might be persistent and associated with high societal costs.

The essential features of health anxiety are exaggerated rumination with intrusive worries about harbouring a serious illness. Treatment of health anxiety is sparsely investigated. The study tests the effect of Acceptance and Commitment Therapy (ACT) in groups in patients with severe health anxiety in a randomized controlled design. Methods: A 126 consecutive referred patients to The Research Clinic for Functional Disorders, Aarhus University Hospital, with severe health anxiety were block-randomised to either a) ACT treatment in groups or b) 9-months waiting list. Primary outcome measurement is health anxiety symptoms measured by Whiteley7 Index and secondary measurements are psychosocial functioning,emotional distress and health care utilization (patient registers). Patients are followed-up by questionnaires for 6 months. The trial is registered in a database for clinical trials: ClinicalTrials.gov Identifier no: NCTO1 158430.

Results: The uncontrolled pilot study $(\mathrm{N}=34)$ shows significant reductions at 6 months: a $49 \%$ reduction in health anxiety (Whiteley-7 Index), a $47 \%$ decrease in emotional distress (SCL-8) and $40 \%$ decrease in somatic symptoms (SCL-90-R). Furthermore, $87 \%$ of patients found that the treatment had improved their quality of life.

Perspective: The development of evidence-based treatment may lead to better quality of life for the patients and reduction in health care costs.

P04.06 Dorthe Krogsgaard Bonnerup PROSPECTIVE VALIDATION OF AN ALGORITHM (MERIS) THAT CAN STRATIFY PATIENTS ACCORDING TO RISK OF MEDICATION ERRORS: A PILOT STUDY

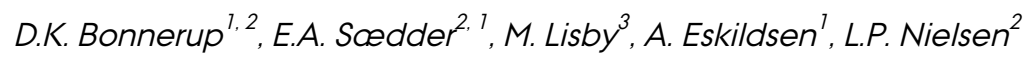

${ }^{1}$ The Hospital Pharmacy, Aarhus University Hospital, ${ }^{2}$ Department of Clinical Pharmacology, ${ }^{3}$ Center of Emergency Medicine Research

Background: Medication errors play an important role in patient safety. It is known that the risk of experiencing medication errors correlates to both patient-related factors, e.g. comorbidity and age, as well as drug-related factors, e.g. number of drugs and their potential toxicity. An algorithm (MERIS) has been developed in order to stratify patients according to their risk of experiencing medication errors.

Aim: The primary aim is to prospectively validate an algorithm (MERIS) that can stratify patients according to their risk of experiencing medication errors. The secondary aim is to pilot-test methods and interventions that were 
hypothesized to decrease the number of medication errors.

Methods: he study is a pilot study. One hundred patients will be included at the emergency department at Aarhus University Hospital. Acutely admitted patients $>17$ years treated with at least one drug will be included. Patients who are dying or suicidal will be excluded. The patients' individual risk of medication errors will be calculated and patients in high risk will undergo a medication review. After discharge, the included patients' records will be examined for potential and actual medication errors. Finally, the algorithms specificity, sensitivity and predictive values will be calculated.

Results: reliminary results will be shown at the PhD day in January 2013.

Perspectives: ased on the validated algorithm, it is possible to identify the patients who are at highest risk of experiencing medication errors. The algorithm will be tested in a randomized controlled trial to examine whether a differentiated medication review based on the algorithm can reduce the number of medication errors.

P04.07 Malene Schou PREVALENCE OF BACTEREMIA IN THE INTENSIVE CARE UNIT: A DANISH Nielsson CROSS-SECTIONAL STUDY

M.S. Nielsson', C.F. Christiansen', M.B. Johansen', S. Ellermann-Eriksen ${ }^{2}$, H.C. Schønheyder ${ }^{3}$, B.S. Rasmussen ${ }^{4}$, E. Tønnesen ${ }^{5}$, M. Nørgaard ${ }^{7}$

'Department of Clinical Epidemiology, Aarhus University Hospital,

${ }^{2}$ Department of Clinical Microbiology, Aarhus University Hospital,

${ }^{3}$ Department of Clinical Microbiology, Aalborg Hospital, Aarhus University Hospital, ${ }^{4}$ Department of Anaesthesia and Intensive Care Medicine, Aalborg Hospital, Aarhus University Hospital, ${ }^{5}$ Department of Anaesthesia and Intensive Care Medicine, Aarhus University Hospital

Infectious diseases, including bacteremia, are a frequent cause of admission to the ICU and a severe potential complication during ICU stay. Limited data exist on how age is related to prevalence of bacteremia among ICU patients. The aim of this study is to determine the prevalence of bacteremia among a cohort of Danish ICU patients in relation to age by linking data from population-based medical and administrative registries. Furthermore, we aim to describe the clinical manifestations associated with bacteremia among elderly ICU patients compared with younger age groups, and finally, to compare type of bacteremia (Gram-positive, Gram-negative, or polymicrobial/yeasts) between age groups.

Information on all first-time admissions to an ICU located in the North and Central Denmark region during 2005-2011 will be obtained from the Danish National Patient Registry (DNPR). The North Jutland County Bacteraemia Database and the Laboratory Information System (MADS) will be used to identify ICU patients with bacteremia among patients living in the North Denmark region and the Central Denmark region, respectively. In addition, data obtained from different population-based registries will be used to characterize and compare bacteremia with non-bacteremia ICU patients in terms of organ-specific dysfunction, comorbidity and immune status. We plan to estimate the prevalence of bacteremia among elderly ICU patients compared with younger age groups and to estimate prevalence proportion ratios (PPRs) using logistic regression to adjust for potential confounders.

P04.08 Eva Sœdder RISK FACTORS FOR MEDICATION ERRORS
E.A. Saedder ', D.K. Bonnerup ${ }^{2}$, M. Lisby ${ }^{3}$, L.P. Nielsen' ${ }^{7}$ B. Brock ${ }^{4}$
${ }^{1}$ Department of Clinical Pharmacology, Aarhus University Hospital, ${ }^{2} \mathrm{Hospital}$ Pharmacy, Aarhus University Hospital, ${ }^{3}$ Center of Emergency and Medical Research, Aarhus University Hospital, ${ }^{4}$ Department of Biochemistry and Department of Biomedicine, Aarhus University Hospital
Background: The risk of medication errors is related to patient age, 
comorbidities, individual drugs and polypharmacy. A literature search was performed to determine the importance of patient-related risk factors.

Methods: Literature search in Bibliotek.dk, Embase, Psychinfo, Pubmed, SweMed and The Cochrane Library. Search terms were risk factors, medication errors, adverse effects, drug toxicity, adverse drug reaction, drug therapy and errors in different combinations.

Result: The search yielded 3302 hits. Articles examining medication errors or adverse effects causing hospitalization, prolonged hospitalization, lifesaving treatment, permanent injury or death and the connection to risk factors were chosen. Studies in children, developing countries and studies not using statistical methods were excluded, leaving 193 articles. After selecting studies focusing on factual harm, 48 different studies remained. The most frequent risk factors examined were the number of drugs, patient age, co morbidity, length of hospitalization, gender and renal insufficiency. When considering potential risk factors, 29/42 studies found a relation to the number of drugs, 17/41 studies found a relation to patient age, 14/27 to comorbidity, $5 / 11$ to length of hospitalization, $7 / 24$ to gender and finally $6 / 12$ to renal insufficiency.

Discussion: Number of drugs seems the only risk factor related to medication errors. Patient populations as well as collection and assessment methods are very different, which may explain this finding. Also, application of statistical methods on a very inhomogeneous population could be problematic. Therefore conclusions should be drawn very carefully.

P05.01 Rikke Kaae ULTRASOUND GUIDED INSERTION OF CENTRAL UMBILICAL CATHETERS IN NEWBORN INFANTS: A NEW STANDARD IN THE CLINICAL PRACTISE?

R. Kaae ', B. Eika' ${ }^{2}$, E. Sloth ${ }^{3,3}$, T.B. Henriksen ${ }^{7}$

${ }^{1}$ Department of Pediatrics, Aarhus University Hospital, ${ }^{2}$ MEDU, Aarhus University, ${ }^{3}$ Department of Anaesthesiology, Aarhus University Hospital

Objectives: Umbilical line placement is a routine procedure to secure central venous access during the first hours of life for many infants admitted to the neonatal intensive care unit. By convention, the correct location of a central umbilical catheter (CUC) is checked by an Anterior-posterior chest X-ray. This method is time consuming, exposes the newborn infant to radiation and involves manipulation of a sick infant. In clinical practice, evaluation of the placement of CUC hampers observation, nursing and treatment during the critical transition period after birth. The optimal CUC position may be evaluated by using bedside ultrasound by the neonatologist on call. Ultrasound has been shown to readily identify CUC tip position when performed by experienced ultrasounds specialists. General experience using ultrasound for CUC placement is currently limited. It is also unknown how much training is necessary for an optimal evaluation of CUC placement in a team of neonatologists. The two methods, $X$-ray and ultrasound, have yet to be compared in the daily clinical practice.

Design:

A prospective experiment in which 150 newborns requiring a central umbilical catheter (CUC) will be randomized to evaluation of catheter placement by ultrasound carried out by neonatologist on call versus AP Xray. Primary outcome will be time spent with the procedure.

A learning study assessing the ultrasonographic skills of 40 neonatologists, previously inexperienced with ultrasound scanning, after 2, 4 and 6 hours of training, respectively, and comparing these skills with the skills of experienced ultrasounds specialists. 
P05.02 Anne Gulbech IMPACT OF BIOLOGIC INTERACTION BETWEEN BREAST CANCER AND Ording COMORBIDITY ON ALL-CAUSE MORTALITY

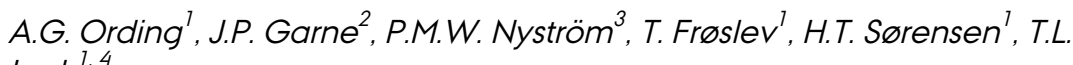
Lash $^{1,4}$

${ }^{1}$ Department of Clinical Epidemiology, Aarhus University Hospital, Denmark,

${ }^{2}$ Breast Clinic, Aalborg Hospital, Aarhus University Hospital, Denmark,

${ }^{3}$ Department of Oncology, Uppsala University Hospital, Sweden,

${ }^{4}$ Department of Epidemiology \& Prevention, Wake Forest School of Medicine, Winston-Salem, North Carolina, USA

Background: It is largely unknown whether there is a biologic interaction between comorbidities and breast cancer that impacts mortality, beyond that expected by the individual effects of breast cancer and comorbidity.

Methods: To ascertain mortality rates, we conducted a nationwide matched cohort study of all breast cancer patients aged between 45 and 85 years who were diagnosed between 1995 and 2008 and a cohort of women without breast cancer matched to the breast cancer patients on diseases included in the Charlson Comorbidity Index ( $\mathrm{CCl}$ ). Breast cancer patients were identified in the Danish Cancer Registry and the matched cohort in the Civil Registration System. Diagnoses included in the $\mathrm{CCl}$ were collected from the National Registry of Patients. We computed mortality rates for the two cohorts within one and five years of follow-up and calculated the interaction contrast (IC), which measures the excess or deficit mortality rate above or below that expected, given the baseline mortality rate, the effect of breast cancer on the mortality rate and the effect of comorbidity.

Results: In the first year of follow-up, the ICs were 17/1000 person-years (PY) $(95 \% \mathrm{Cl}: 10,28)$ for a CCl score of $1,12 / 1000$ PY $(95 \% \mathrm{Cl}: 5.8,20)$ for $\mathrm{CCl}$ scores of $2-3$, and $29 / 1000 \mathrm{PY}(95 \% \mathrm{Cl}: 20$, 42) for a CCl score $\geq 4$. These represented $17 \%, 9 \%$ and $10 \%$ of total mortality rates, respectively, among the breast cancer patients with comorbid diseases. In the >1-5 year survivor cohort, the ICs were near null.

Conclusion: The study showed a biologic interaction between $\mathrm{CCl}$ score at diagnosis and mortality in breast cancer patients, particularly within one year after breast cancer diagnosis.

P05.03 Cathrine Bach MEASUREMENT OF FETAL DNA IN PLASMA OF PREGNANT WOMEN C. Bach ${ }^{1,2}$, N. Uldbejrg ${ }^{2,3}$, S. Sommer', S. Koelvraa ${ }^{4}$

${ }^{1}$ Department of Obstetrics and Gynecology, Horsens Regional Hospital, ${ }^{2}$ Institute of Clinical Medicine, Aarhus University, ${ }^{3}$ Department of Obstetrics and Gynecology, Aarhus University Hospital, Skejby, ${ }^{4}$ Department af Genetics, Vejle Sygehus

Objectives: Blood plasma of pregnant women contains circulating fetal cells as well as cell free fetal DNA (ff DNA). The concentration of ffDNA is significantly higher than the number of fetal cells. The level of ffDNA increases during pregnancy and the levels of ffDNA tend to elevate in a number of conditions with placental pathology e.g. preeclampsia and placenta previa.

Over the last years, several studies have been published on association between ffDNA and obstetrics complications. However, these studies primarily rely on pregnant women carrying male fetuses. It is a major limitation that the analysis includes only half of the pregnant women, i.e. the half carrying a male fetus, and this is the reason why it has not been used as a non-invasive prenatal diagnostic test. Therefore, there is great interest in the development of a gender-independent marker. Differences in the methylation profiles of ffDNA and maternal DNA offer opportunities for the development of such a gender-independent marker. 
Aim:

1. To develop a method to measure fetal DNA in maternal blood, independent of fetus gender.

2. To investigate the association between the level of fetal DNA in the maternal blood and the function of placenta.

Method: Based on the chemical differences in DNA from the fetus and mother, we will search for a gender-independent marker for the ffDNA. Afterwards, this marker will be used in the second part of the study. The study is based on blood-test from pregnant women. The women are recruited from Horsens Regional Hospital when they are at the hospital for a routine ultrasound. The blood-tests is analysed by PCR technique.

Status: The project is ongoing.

P05.04 Lene Hee NEW METHOD TO EVALUATE THE BIOMECHANICAL PROPERTIES OF THE Christensen UTERINE CERVIX

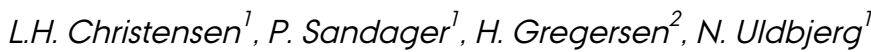

'Department of Obstetrics and Gynecology Y, Aarhus University Hospital ${ }^{2} \mathrm{SDC}$, Beijing and the Giome Institute

Objective: The objective of the present project was to evaluate if a new method, the Endolumenal Functional Lumen Imaging Probe (EndoFlip) could be used to estimate the distensibility in the uterine cervix in vivo.

Design: Experimental study.

Setting: Department of Obstetrics and Gynaecology, Aarhus University Hospital, Denmark.

Population: Early pregnant women admitted for abortion before 12 weeks of gestation and term pregnant women admitted for elective caesarean section.

Methods: The EndoFlip is a catheter which can measure 16 diameters simultaneously and a corresponding pressure inside a saline-filled bag. The patients were sedated and the catheter was placed in the uterine cervix with the patients in lithotomy position. Two series of bag distensions were performed with $50 \mathrm{ml}$ saline in each filling.

Results: For the early pregnant women, the cervix was not distensible in middle part and there seemed to be a difference between the two ends of the cervical channel. For term pregnant women, the cervix was soft in the middle part and there was little difference between the two ends of the cervix.

Conclusion: It is possible to measure the diameter along the cervical channel and a corresponding pressure inside a saline-filled bag.

P05.05 Marie Krarup IS THERE A GENDER DIFFERENCE IN THE PATHOGENESIS OF CHILDHOOD Schrøder NOCTURNAL ENURESIS?

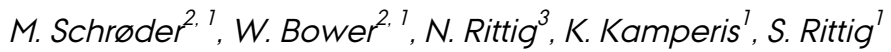

${ }^{1}$ Department of Pediatrics, Aarhus University Hospital, ${ }^{2}$ Department of Clinical Medicine, Aarhus University, ${ }^{3}$ Department of Endocrinology, Aarhus University Hospital

Introduction: A gender difference in antidiuretic function has been proposed in adults possibly due to greater renal V2receptor density in women. The study investigates gender difference in polyuria causing monosymptomatic nocturnal enuresis (MNE) in children.

Methods: Data derived from 940 children from our secondary/tertiary 
P05.06 Cathrine Ladegaard Wildenschild Nielsen
P05.07 Niels

Bjerregård Matthiesen referral center. Data were based on 2 week home recordings of enuretic episodes, nocturnal urine output, and 4 days of FV-charts. Patients with daytime incontinence, constipation and incomplete home recordings were excluded, 401 MNE patients (260 boys, 141 girls, 5-15 years, mean 8,49 $\pm 1,9$ ) were analyzed. The primary outcome was gender differences in nocturnal polyuria(NP) (nocturnal urine volume (NUV) of $130 \%$ of expected MVV). Secondary outcomes were gender differences in MVV compared to expected MVV and average NUV. T-statistics and $\mathrm{chi}^{2}$ were used.

Results: No gender difference was seen in the occurrence of NP ( $20 \%$ girls vs. $26 \%$ boys, $p=0.45$ ). No gender difference was found in average (girls $285 \mathrm{ml} \pm 111 \mathrm{vs}$. boys $292 \mathrm{ml} \pm 88, \mathrm{p}=0.53$ ) or max. (girls $402 \mathrm{ml} \pm 149 \mathrm{vs}$. boys $423 \pm 133, p=0.16)$ NUV on wet nights. MVV compared to expected MVV for age was greater in girls $(0.85 \pm 0.37$ vs. $0.76 \pm 0.26 p=0.005)$.

Conclusions: Gender differences seem of little importance in childhood NP. The gender difference found in MVV is interesting and indicates a more pronounced bladder reservoir dysfunction in boys yielding higher MNE prevalence. Although no gender difference was found in the occurrence of NP, it would be interesting to investigate if the gender differences in AVP sensitivity, suggested in adults, are present in a healthy pediatric population.

HISTORY OF PRETERM DELIVERY AND TIME TO PREGNANCY (TTP)

C. Wildenschild ', A.H. Riis' , V. Ehrenstein' ', E. Hatch' ${ }^{2}$, L.A. Wise ${ }^{2,3}$, K.J. Rothman, ${ }^{2,4}$ H.T. Sørensen', E.M. Mikkelsen ${ }^{7}$

'Department of Clinical Epidemiology, Aarhus University Hospital,

${ }^{2}$ Department of Epidemiology, Boston University School of Public Health,

${ }^{3}$ Slone Epidemiology Center, Boston University, ${ }^{4}$ RTI Health Solutions,

Research Triangle Park

Background: An estimated 6-15\% of pregnancies end in a preterm birth, thus affecting a considerable proportion of women. A familial component of preterm birth has been suggested, as women who were themselves born premature are more likely to deliver their child prematurely. However, research on the fecundability of women with a history of preterm birth or the potential influence of familial patterns of preterm birth on fecundability is largely absent.

Aim: The primary aim of our study is to examine the association between having a history of preterm birth and fecundability. As a secondary aim, we will investigate the potential influence of a familial history of preterm birth on fecundability.

Materials and methods: We will use data from a prospective cohort study of around 6,000 Danish pregnancy planners conducted during 2007-201 1 ("Snart-Gravid.dk"). Eligible women were 18-40 years old, in a relationship with a male partner, and not receiving fertility treatment. Participants provided data on history of preterm birth and TTP, as well as their Civil Personal Registration (CPR) number, enabling linkage with the Danish Medical Birth Registry and retrieval of registry-based data on previous preterm birth. Using the CPR number, we will also obtain data on preterm births among participants' mothers and sisters. We will calculate fecundability ratios with $95 \%$ confidence intervals for women with a history of preterm birth relative to women without, using proportional probabilities regression models.

Results: We will present preliminary results by January 2013.

PATTERNS OF PRENATAL CEREBRAL GROWTH AMONG INFANTS WITH CONGENITAL HEART DISEASE

N.B. Matthiesen ', P. Agergaard', V. Hjortdal', J.R. Østergaard'

${ }^{1}$ Department of Pediatrics, Aarhus University Hospital, ${ }^{2}$ Cardiothoracic 
Research Department T, Aarhus University Hospital

Background: Microcephaly is more common in children with congenital heart disease (CHD), and the relation to neurological deficits has been demonstrated. However, confounders such as genetic syndromes and low placental weight were not sufficiently accounted for in existing studies. Additionally, the focus has been on complex CHDs, and the impact of more common CHDs has yet to be evaluated.

Methods: A register-based study was performed comprising a validated cohort of 2,947 Danish children born 2000-2008 with CHD. Genetic, newborn and maternal parameters were identified in national registries, and each child was randomly matched to three nonsyndromic children without CHD according to gender and gestational age. By means of linear and logistic regression analysis, newborn head circumference will be adjusted to genetic, newborn and maternal parameters.

Results: High numbers of diagnostic subgroups are represented: e.g. transposition of the great arteries $(n=189)$, tetralogy of fallot $(n=210)$, coarctation of the aorta $(n=207)$, atrioventricular septal defect $(n=184), V S D$ $(n=904)$ and ASD $(n=535)$. Trisomy $21(n=180)$ and $22 q 11.2$ -

deletion/duplication $(n=46)$ and other genetic abnormalities have been determined. Main outcome measure is newborn head circumference, nonadjusted and adjusted to newborn, maternal and genetic parameters comparing diagnostic subgroups of $\mathrm{CHD}$ to healthy controls. Analyses are undergoing.

Conclusion: The strength of this study, more than tripling the numbers of the largest study in the field, lies within the possibility to adjust head circumference to confounders such as genetic abnormalities and placental weight through data from unique national registries.

P05.08 Anne Nakano AGE AND SEX-RELATED DIFFERENCES IN PROCESSES OF CARE AND Jensen MORTALITY AMONG PATIENTS WITH INCIDENT HEART FAILURE IN DENMARK, 2003-2010

\author{
A. Nakano', S.P. Johnsen', M.L. Svendsen', K. Egstrup ${ }^{2}$ \\ 'Department of Clinical Epidemiology, Aarhus University Hospital, \\ ${ }^{2}$ Svendborg Hospital
}

Aim: To examine age- and sex-related differences in processes of care and 1-year mortality.

Methods: In this nationwide cohort study, we included patients from the Danish National Heart Failure Registry 2003-2010, $n=23,361$. The registry monitors guideline recommended processes of care: echocardiography, New York Heart Association (NYHA) classification, angiotensin converting enzyme (ACE) inhibitors /angiotensin II receptor (ATII) blocker, physical training and patient education. Age- $(\leq 65,>65-80,>80$; reference males $\leq 65$ ) and sex-related differences in 1-year mortality; adjusted for patient characteristics and processes of care.

Results: Higher age was associated with lower quality of care.

Relative Risk (RR) for receiving specific processes of care for patients $>80$ years varied from (RR 0.71; $95 \%$ Confidence Interval $(\mathrm{Cl}) 0.68-0.74$ ) to (RR

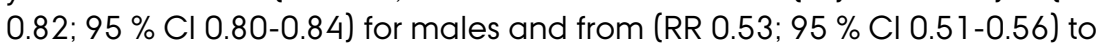
(RR 0.70; $95 \% \mathrm{Cl} 0.62-0.72$ ) for females compared with men $\leq 65$ years. Higher age was associated with higher 1-year mortality also after adjustment for patient characteristics. Further adjustment for processes of care lowered the hazard ratios, although the difference did not reach statistical significance; Hazard Ratio (HR) for both sexes $>80$ years, males from(HR 7.17; $95 \% \mathrm{Cl} 6.29-8.17)$ to(HR 4.31; $95 \% \mathrm{Cl} 3.22-5.77)$ and for females from ( $\mathrm{HR} 4.85 ; 95 \% \mathrm{Cl} 3.79-6.22$ ) to ( $\mathrm{HR} 4.52 ; 95 \% \mathrm{Cl} 3.29-6.19$ ). 
P06.01 Christian Bo Poulsen
P06.02 Kanja Krogh
Conclusion: Elderly Danish patients with HF received less intensive care than younger patients, irrespective of sex. Differences in care may contribute to age-related differences in mortality. No systematic sex-related differences in care and mortality were identified.

\section{A NEW MODEL FOR FLOW-MEDIATED ACCELERATION OF CORONARY} ATHEROSCLEROSIS

C.B. Poulsen' , N. Pareek', R. Krams' ${ }^{2}$, R. Pedrigi ${ }^{2}$, R. de Silva' ${ }^{2}$, A.K. Grøndal', E.H. Christiansen ', N.R. Holm ${ }^{7}$, E. Falk ${ }^{7}$

'Department of Cardiology and Institute of Clinical Medicine, Aarhus University Hospital, ${ }^{2}$ Imperial College London

Background: In the Western world atherosclerosis(AS) is a leading cause of morbidity and mortality. During the past 40 years, it has been clear that low shear stress in the arterial wall plays an important role in the initiation and acceleration of AS. Studies have been conducted in rodents by applying a constrictive cast on the outside of the arteries, but no large-scale animal model and no endovascular approach exist.

Aim: To develop focal AS by inserting a stenotic stent designed to generate low shear stress in the coronary arteries of hypercholesterolemic pigs. We then determine wall and shear stress patterns in close proximity to the stent by computational fluid dynamics(CFD), finite element analysis (FEA) of the vessel wall, and, in the long-term, combining the two techniques to construct a fluid structure interaction(FSI) analysis.

Materials and methods: We used 4 transgene PCSK9 pigs. In September 2012, one month after high fat diet was initiated, the stenotic stent was inserted into the left anterior descending artery or left circumflex artery. Before and after implantation, we performed coronary angiography, intravascular ultrasound, optical coherence tomography and flow measurements. This will be repeated at weeks 9 and 17 to assess AS. After the last imaging (week 17), the pigs will be sacrificed and the heart and aorta removed. The coronary arteries will then be used for histological evaluation, the data from which will be correlated to the results from the mechanical models.

Perspectives: We envision that a reliable porcine, endovascular model for flow mediated AS will be of importance in understanding how biomechanics influences the development of focal AS.

DEVELOPMENT OF A PROCESS TO THE PURIFICATION OF MANNANBINDING LECTION (MBL) AND TEST OF MBL IN A GLUCOE BIOSENSOR FOR CONTINOUS BLOOD GLUCOSE MONOTORING

\section{K. Krogh}

Institute of Biomedicin, Århus University

Medtronic has developed a device for Continuous Glucose Monitoring (CGM) that uses an optical principle for the detection of glucose in interstitial fluid. The technology is based on Fluorescence Resonance Energy Transfer (FRET), where Mannan-Binding Lectin (MBL) is stained with a donor chromophore and dextran, which binds to the MBL, is stained with an acceptor chromophore. In FRET the fluorescence emission spectrum of the donor chromophore overlaps the absorption spectrum of the acceptor chromophore. This means that when the two chromophores are in close proximity, the fluorescent signal emitted by the donor chromophore is quenched to a degree that reflexes the distance between the two FRET components.

When the sensor is inserted in to the skin glucose competes with dextran for the binding to $\mathrm{MBL}$, increasingly mounts of glucose will reduce the quenching of the donor chromophore, as the dextran is displaced from MBL. 


\title{
P06.03 Annette
} Søndergaard

Thus, the intensity of the fluorescent signal emitted from the donor chromophore is correlated with the concentration of glucose in the interstitial fluid.

The MBL used in this technology has so far been obtained from plasma. This $M B L$ is of a suboptimal grade and in a less than ideal formulation. Therefore better purification procedures are needed to generate $M B L$ preparations of good quality.

MOLECULAR ORGANIZATION OF SMALL PLASMIDS BEARING BLA TEM-1 $_{\text {TND }}$ AND CONFERRING RESISTANCE TO BETA-LACTAMS IN HAEMOPHILUS INFLUENZAE

A. Søndergaard ${ }^{7}$, A. San Millan ${ }^{2}$, A. Santos-Lopez ', S.M. Nielsen ${ }^{7}$, B. Gonzalez-Zorn", N. Nørskov-Lauritsen'

${ }^{1}$ Department of Clinical Microbiology, Aarhus University Hospital,

${ }^{2}$ Departamento de Sanidad Animal, Facultad de Veterinaria, and VISAVET, Universidad Complutense de Madrid, Spain

Objective: Molecular characterization of small bla $\mathrm{TEM}-1_{\mathrm{T}}$ bearing plasmids in Haemophilus influenzae.

Background: Haemophilus influenzae is the major human pathogen of the genus Haemophilus and a significant cause of respiratory tract infections, acute otitis media, pneumonia and purulent meningitis. The prevalent resistance mechanism in $\mathrm{H}$. influenzae is the production of narrow-spectrum $\beta$-lactamases, which hydrolyze the penicillin class of $\beta$-lactams. TEM- 1 is the dominant $\beta$-lactamase in $\mathrm{H}$. influenzae and can be located on small plasmids.

Results: 470 clinical isolates of $\mathrm{H}$. influenzae were tested for production of $\beta$ lactamase. Of the 98 strains positive for $\beta$-lactamase production, 17 strains proved to carry the gene bla $\mathrm{TEM}-1_{1}$ on a small plasmid. The small bla $\mathrm{T}_{\mathrm{TEM}-1}$ bearing plasmids were characterized by PCR and complete sequencing. Three distinct plasmids with sizes from 4,304 to 5,646 nucleotides were characterized: pA1606, pA 1209 and pPN223. In addition to TEM-1 and a replication enzyme of the Rep 3 superfamily, both pA 1606 and pA 1209 carried an open reading frame (ORF) similar to a plasmid recombination enzyme gene described in Gram-positive bacteria. Additionally, pA 1606 carried a Tn3 resolvase gene. All three plasmid types transformed the susceptible strain Rd into the ampicillin-resistant phenotype.

Conclusion: Clinical isolates of $\mathrm{H}$. influenzae may harbour at least three different types of small bla TEM-1 $_{1}$ bearing plasmids. The presence of the same plasmid type in genetically distinct strains indicates that horizontal transfer of these plasmids occurs in nature.

P06.04 Søren RESTORATIVE PROCTOCOLECTOMY (RPC) IN PATIENTS WITH ULCERATIVE Brandsborg COLITIS (UC): A CROSS-SECTIONAL DANISH POPULATION STUDY ON FUNCTION AND QUALITY OF LIFE

\author{
S. Brandsborg' , A. Tøttrup' ', J. Nicholls' ${ }^{2}$ S. Laurberg ${ }^{7}$ \\ ${ }^{1}$ Colorectal Surgical Unit, Aarhus University Hospital, Denmark, ${ }^{2}$ Imperial \\ College, London, United Kingdom
}

Aim: To evaluate function and quality of life (QoL) in all Danish RPC patients because of UC.

Method: 1757 RPC patients were identified between 1980 and 2010. 58 had died at the time of the study. 130 had pouches excised and 64 a diverting stoma. 276 had research protection, leaving 1229 patients receiving questionnaires on pouch function and generic/condition-specific QoL. 1057 (86\%) responded. Patients were divided into gender and 3 groups according to the interval from RPC as follows: 0-10, 11-20 and 21-30 
P06.05 Winnie Ridderberg
P06.06 Randi

Heidemann

Gottfredsen years.

Results: There were no differences between the 3 groups regarding daily and nocturnal defecation frequency, use of antibiotics, anti-diarrhoeal medication, feeling of incomplete emptying or minor incontinence. The incidence of major incontinence and pad use were higher in patients operated $21-30$ years ago $(p=0.01, p=0.009)$. Urgency was more frequent in patients operated $0-10$ years ago $(p=0.009)$. Median number of bowel movements $/ 24$ hours was 7 for females and 6 for males $(P<0.001) .56 \%$ of women and $44 \%$ of men experienced urgency $(p=0.0021)$. Pad usage was more frequent among females than males, $62 \%$ versus $38 \%(p<0.001)<b r />$ Men had significantly higher QoL scores than women.

Conclusion: Women have significantly more bowel movements, urgency and pad use associated with reduced QoL. In general, however, RPC conferred good function and a high degree of satisfaction with the operation.

MULTILOCUS SEQUENCE ANALYSIS OF ISOLATES OF ACHROMOBACTER FROM PATIENTS WITH CYSTIC FIBROSIS REVEALS INFECTING SPECIES OTHER THAN ACHROMOBACTER XYLOSOXIDANS

\section{W. Ridderberg ${ }^{2,1}$, M. Wang ${ }^{2}$, N. Nørskov-Lauritsen ${ }^{2}$}

${ }^{1}$ Department of Clinical Medicine, Aarhus University, ${ }^{2}$ Department of Clinical Microbiology, Aarhus University Hospital

A multilocus sequence analysis (MLSA) scheme was developed for characterization of strains and species from the genus Achromobacter, which are increasingly recovered from patients with cystic fibrosis (CF). Five conserved housekeeping genes were selected for the MLSA, which was applied to a diverse collection of 77 Achromobacter strains originating from Europe, Asia and South America, and including type strains of the seven recognized Achromobacter species, six environmental strains, eight non-CF clinical strains and $56 \mathrm{CF}$ clinical strains. The discriminatory power of MLSA, based on 2,098 nucleotides (nt), was much superior to a 16S rRNA gene comparison based on 1,309 $\mathrm{nt}$. Congruence was observed between singlegene trees and a concatenated gene tree. MLSA differentiated all seven current Achromobacter species and also demonstrated the presence of at least four novel potential species within the genus. CF isolates were predominantly Achromobacter xylosoxidans (64\%), an undescribed Achromobacter species (18\%) and Achromobacter ruhlandii (7\%). A clone of Achromobacter, which has spread among patients from Danish CF centres in Aarhus and Copenhagen, was identified as Achromobacter ruhlandii. MLSA facilitates the specific identification of isolates of Achromobacter necessary for describing their role in clinical infections.

\section{CHARACTERIZATION OF THE R213G VARIANT OF EXTRACELLULAR} SUPEROXIDE DISMUTASE

\author{
R.H. Gottfredsen', U.G. Larsen', R.P. Bowler', D.A. Goldstrohm², S.V. Petersen' \\ ${ }^{1}$ Department of Biomedicine, Aarhus University, ${ }^{2}$ Department of Medicine, \\ National Jewish Health, Denver, CO, USA
}

Oxidative stress may evolve from an increased load of reactive oxygen species (ROS) or from a decrease in antioxidant capacity. Since ROS have the capacity to irreversibly disrupt the function of biomolecules,

development of oxidative stress has been associated with a large number of diseases.

The protein extracellular superoxide dismutase (EC-SOD) is the only scavenger of the superoxide radical generated in the extracellular space, and has been shown to play an important role in cardiovascular and pulmonary diseases. 
P06.07 Line Raaby Olsen

P07.01 Thomas Aagaard Rasmussen

Two-three percent of the Danish population carries a variant of the protein characterized by an amino acid substitution in the C-terminal region of the protein (R213G). As this substitution affects the proteins' ability to immobilize on cell surfaces and bind ligands in the extracellular space, individuals carrying this variant, have an increased concentration of the protein in circulation. A large study has associated R213G heterozygosity with increased risk of ischemic heart disease.

The aim of this study is to characterize the differences between the wildtype (wt) and R213G EC-SOD with emphasis on protein synthesis in cells exposed to stress. For this purpose we have established cell lines expressing wt and R213G EC-SOD. Furthermore, we use primary bone marrow-derived macrophages established from wt, R213G homozygous and heterozygous mice. Cells were exposed to stress and several parameters were monitored including cellular distribution, protein secretion, and cell surface association. Our analyses provide new insights into cellular control of antioxidant capacity of the extracellular space and clarify the impact of the R213G substitution on EC-SOD biology.

MIRNA NORMALIZATION CANDIDATES FOR QPCR IN LESIONAL AND NONLESIONAL PSORIATIC SKIN

\section{Raaby, A. Langkilde, C. Johansen, L. Iversen}

Department of Dermatology, Aarhus University Hospital

Background: MicroRNA (miRNA) is an upcoming research area, and quantitative reverse transcriptase in real-time (qPCR) is an important tool in the investigation. The small non-coding RNA candidates used for normalization in psoriatic skin biopsies have never been sufficiently validated.

Objectives To identify a reliable normalization candidate for miRNA analysis with qPCR in lesional versus non-lesional psoriatic skin.

Methods 5 miRNA candidates previously used for normalization in psoriatic skin were identified through search in the literature. 5 new candidates were uncovered using the NormFinder algorithm on miRNA microArray data $(n=6)$. The candidates were validated with paired psoriatic biopsies $(n=10)$ with qPCR. The stability of the miRNAs was determined with NormFinder and geNorm.

Results: The two algorithms ranked the candidates similarly with an excellent correlation $\left(r^{2}=0.98\right)$. miR-26a (geNorm M-value $(\mathrm{gMv})=0.566$ and NormFinder stability value $(\mathrm{NFsv})=0.285)$ and $\mathrm{miR}-23 \mathrm{~b}(\mathrm{gMv}=0.566$ and $N F s v=0.295$ ) had the best stability, whereas the most commonly used candidate, RNU48, had less favourable stability ( $\mathrm{gMv}=0.803$ and $\mathrm{NFsV}=0.532$ ).

Conclusions: This is the first study to validate the reliability of miRNA candidates for normalization by qPCR. From this study, we conclude that $\mathrm{miR}-26 \mathrm{a}$ and $\mathrm{miR}-23 \mathrm{~b}$ are the best candidates and better candidates than those previously used. miR-26a and/or miR-23b should therefore be used for miRNA normalization in future studies when comparing biopsies of lesional and non-lesional psoriatic skin.

THE HISTONE DEACETYLASE (HDAC) INHIBITOR PANOBINOSTAT (LBH589) INDUCES HIV-1 EXPRESSION AT THERAPEUTIC CONCENTRATIONS AND WITH HIGHER POTENCY THAN OTHER HDAC INHIBITORS IN CLINICAL USE

T.A. Rasmussen', O.S. Søgaard', C.R. Brinkmann', F. Wightmann ${ }^{2,5}$, S. Lewin ${ }^{2}$ 4, 5 , J. Melchjorsen ', C. Dinarello ${ }^{3}$, L. Østergaard', M. Tolstrup ${ }^{7}$

${ }^{1}$ Department of Infectious Diseases, Aarhus University Hospital, ${ }^{2}$ Department of Medicine, Monash University, Melbourne, Australia, ${ }^{3}$ Department of Medicine, University of Colorado Denver, USA, ${ }^{4}$ Infectious Disease Unit, 
Alfred Hospital, Melbourne Australia, ${ }^{5}$ Centre for Virology, Burnet Institute, Melbourne Australia

Objective: We aimed to compare the potential for inducing HIV production and the effect on T-cell activation of potent HDAC inhibitors (HDACi) undergoing clinical investigation.

Methods: The latently infected cell lines $\mathrm{ACH} 2$ and $\mathrm{U} 1$ were treated with the HDACi panobinostat, givinostat, belinostat, vorinostat and valproic acid. Viral induction was estimated by p 24 production. Peripheral blood mononuclear cells from uninfected donors were treated with the HDACi and the expression of activation markers was measured by flow cytometry. Finally, the ability of givinostat, belinostat and panobinostat to reactivate latent HIV1 in primary T-cells was investigated by using a latent primary CD4+ T cell infection model.

Results: The HDACi displayed significant potency differences in stimulating HIV- 1 expression with panobinostat > givinostat $\approx$ belinostat $>$ vorinostat $>$ valproic acid. Panobinostat was significantly more potent than all other HDACi and induced virus production even in the very low concentration range 8-31 nM. Expression of the early activation marker CD69 increased moderately in all HDAC inhibitor-treated T-cells compared to untreated cells. Finally, proof was obtained that panobinostat, givinostat and belinostat induce virus production in latently infected primary cells at therapeutic concentrations with panobinostat being the most potent stimulator.

Conclusion: At therapeutic concentrations, panobinostat stimulates HIV-1 expression in latently infected cells with greater potency than other HDAC inhibitors under clinical investigation. These findings warrant further investigation, and panobinostat is now being advanced into clinical testing against latent HIV infection.

P07.02 Marie Beck IDENTIFICATION OF AN EARLY CXCR3-DEPENDENT ANTIVIRAL MECHANISM Iversen IN THE FEMALE GENITAL TRACT WORKING PRIOR TO THE ACTION OF INTERFERONS

\author{
M.B. Iversen', S.K. Kratholm', A.R. Thomsen', C. Holm', S.R. Paludan' \\ ${ }^{1}$ Department of Biomedicine, Aarhus University, ${ }^{2}$ Department of International \\ Health, Immunology and Microbiology, University of Copenhagen
}

Purpose:Recognition of pathogens and subsequent immune response is an important defence against infections. This process is mediated by pattern recognition receptors (PRRs), which recognize conserved pathogenassociated molecular patterns. Vaginal HSV-2 infection of mice results in a release of cytokines, initiating and directing the subsequent immune response. The aim of this project is to describe and characterize early innate immune response at mucosal surfaces elicited by vaginal HSV-2 infection.

Material and methods: Mice are infected vaginally with HSV-2. The mice were examined daily and scored for disease development. Viral load and cytokine concentrations were determined in vaginal washes. The presence, recruitment and activation state of immune effector cells were examined by flow and IHC. PRRs expression in the vagina is investigated by qPCR.

Results: The expression kinetics of several cytokines in response to HSV-2 infection was investigated and CXCL9 and 10 were the only ones induced already within $24 \mathrm{~h}$ p.i. This was in contrast to the IFNs, which were not induced until day 2 p.i. The CXCL9/10 receptor KO mice (CXCR3-/- mice) had elevated virus titers on day 1 p.i. and showed pronounced signs of disease compared to WT mice. Furthermore, there seemed to be a dysregulated recruitment of effector cells in CXCR3-/- mice in response to HSV-2 infection.

Conclusion: Our data indicate the existence of a CXCR3 receptor 
dependent antiviral mechanism working prior to the induction of interferons. Epithelial cells of the vagina recognize HSV-2 and subsequently release CXCL9 and 10. The PRR expression studies indicate that DAI may be a candidate for HSV-2 sensing in the vagina. BUT MAY INDUCE OSTEONECROSIS OF THE JAW IN PATIENTS WITH METASTATIC RENAL CELL CARCINOMA

\author{
T. Smidt-Hansen', T. Folkmar', K. Fode ', M. Agerbaek' , F. Donskov' \\ ${ }^{1}$ Department of Oncology, Aarhus University Hospital, ${ }^{2}$ Department of Oral \\ and Maxillofacial Surgery, Aarhus University Hospital
}

Background: The efficacy and safety of zoledronic acid (ZA) combined with targeted therapy (TT) is unclear.

Methods: We performed a retrospective study in patients with metastatic renal cell carcinoma ( $\mathrm{mRCC}$ ) treated with ZA and TT.

Results: Twenty-one patients received ZA and TT to prevent skeletal-related events (SRE) with no pre-therapy oral and maxillofacial (OMF) examination (cohort A). Six patients (29\%) developed osteonecrosis of the jaw (ONJ) and this was only observed in patients receiving sunitinib and ZA. Sixteen patients received TT and ZA for hypercalcaemia with no pre-therapy OMF examination (cohort B). In these patients no ONJ was observed. Nine patients received ZA and TT with a pre-therapy OMF examination (cohort C). One patient ( $11 \%$ ) developed ONJ during sunitinib and ZA treatment. The mean skeletal morbidity rate was 0.8 for patients in cohort $A$ and 1.2 in cohort $C$. In the combined cohort $A$ and $C(N=30), 47 \%$ had developed SREs, $7 \%$ pathological fracture, $7 \%$ medullary compression and $37 \%$ progression of bone metastases. Patients who developed ONJ had a significantly improved median survival of 31.6 months compared with median survival of 14.5 months in patients with no ONJ $(p=0.039)$.

Conclusion: The combination of ZA with TTs resulted in high, clinical meaningful activity. Osteonecrosis of the jaw may be exacerbated by concomitant ZA and sunitinib. Regular OMF examinations before and during treatment are utterly required.

P07.04 Johannes INCREASED ALLERGEN-SPECIFIC IGG4 LEVELS ARE LINKED TO SUPPRESSED Martin Schmid IGE TITERS WHEN ANALYZED BY MULTIPLEX MOLECULAR ALLERGEN CHIP BUT NOT BY FLUOROENZYME IMMUNOASSAY

\author{
J.M. Schmid' , P.A. Wuertzen' ${ }^{2}$, R. Dahl', H.J. Hoffmann' \\ ${ }^{1}$ Dept. of Respiratory Medicine, Aarhus University Hospital, ${ }^{2}$ Dept. of \\ Experimental Immunology, ALK-abelló, Hoersholm DK
}

Background: Induction of a specific lgG4 response suppressing the lgEmediated symptoms is a key element in the protective effect of allergy specific immunotherapy (ASIT). IgE measurement by fluoroenzyme immunoassay (FEIA) is a standard procedure for allergy diagnosis. It is supplemented by a chip-based single allergen array, which may have different dynamics.

Materials and methods: 24 subjects suffering from allergic rhinitis were randomized to receive standard subcutaneous ASIT $(n=18)$ or to an open control group $(n=6)$. Allergen specific lgE and lgG4 were measured at baseline and when reaching maintenance dose by using both FEIA and the multiplex molecular allergen chip (MMAC) assay. Data are presented as mean with $95 \% \mathrm{Cl}$.

Results: ASIT increased allergen specific lgG4 levels, measured both by MMAC (from 0.3 to 5.0 ISAC specific units (ISU) ( $\triangle: 2.7-6.7$ ISU; $p=0.0001$ ) and FEIA (from 0.1 to $5.2 \mathrm{mg} / \mathrm{l}, \Delta: 2.3-7.9 \mathrm{mg} / \mathrm{ml} ; \mathrm{p}=0.0006$ ). Specific lgE increased from 23.0 to $48.8 \mathrm{kU} / \mathrm{I}$ when measured by FEIA $(\Delta:$ : 4.4-47.2; 
$\mathrm{p}=0.01)$ while it decreased from 21.4 to 2.5 ISU ( $\Delta:-10.0 ;-27.8 ; p=0.0002)$ when measured by MMAC. No significant changes occurred in the control group.

Conclusion: FEIA measurements indicate that lgG4 and IgE increase during ASIT updosing. In contrast, when IgE was measured by a MMAC assay, a decrease in lgE seems to indicate successful ASIT. This may be owing to an inhibition of lgE-binding in vitro in the MMAC assay, possibly reflecting functional lgE inhibition in vivo. The chip-based measurements may thus be useful in monitoring the clinical effect of ASIT.

IFI 16 IS AN EARLY SENSOR OF LISTERIA MONOCYTOGENES DNA IN THE CYTOSOL STIMULATING IFNB EXPRESSION

\section{K. Hansen', S.B. Jensen', T.A. Decker ${ }^{2}$, K.A. Horan', S.R. Paludan'}

${ }^{1}$ Department of Biomedicine, Aarhus University, Denmark, ${ }^{2}$ Max F. Perutz Laboratories, Department of Microbiology, Immunobiology and Genetics, University of Vienna, Vienna, Austria

Objective: Infection with Listeria monocytogenes (L. monocytogenes) induces a potent innate immune response. Induction of the immune response is dependent on bacterial secretion of listeriolysin O (LLO), which mediates the escape of $L$. monocytogenes to the cytosol after entry by phagocytosis. IFI1 6 is a predominantly nuclear protein, which distributes to the cytosol upon viral infection and UV irradiation. Recent studies show that IFI 16 directly interacts with cytosolic DNA to induce IFNb. We investigated the role of IFI 16 in the sensing of cytosolic L. monocytogenes DNA during infection.

Materials and methods: THP1, a non-adherent monocyte-like cell line differentiated into macrophage-like cells, was used for all studies. Shorthairpin-RNA was used for knock-down of the intracellular DNA sensor IFI16. Co-localization between bacterial DNA and IFI 16 was investigated by confocal microscopy.

Results: In THP-1 cells, L. monocytogenes induced a potent IFN-b expression. This induction was dependent on bacterial escape into the cytoplasm. Short-hairpin-RNA knock-down of the intracellular DNA sensor IFI1 6 strongly reduced $\mathrm{L}$. monocytogenes-induced IFN-b expression, indicating a role of IFI16 in the sensing of L. monocytogenes. Transfection with $L$. monocytogenes homogenates induced IFN-b expression in differentiated THP1 cells, and this was sensitive to DNase treatment of the homogenates. We observed that L. monocytogenes DNA was present in the cytoplasm during infection and this co-localized with IFII6 and the adaptor molecule STING.

Conclusion: Based on these results, we conclude that IFII 6 is a sensor of $\mathrm{L}$. monocytogenes DNA in the macrophages stimulating IFN-b expression.

\section{STRUCTURAL CHARACTERIZATION OF MANNAN-BINDING LECTIN AND ITS} ASSOCIATED PROTEINS

\author{
T.R. Kjœer', G.R. Andersen ${ }^{2}$, S. Thiel ${ }^{7}$ \\ ${ }^{1}$ Department of Biomedicine, ${ }^{2}$ Department of Molecular Biology and \\ Genetics
}

The ability of pattern-recognition molecules (PRMs) to bind foreign markers, so-called pathogen-associated molecular patterns (PAMPs), is central to the innate immune defence. The complement system is an important defence mechanism within the innate immune system and consists of soluble and membrane bound proteins in extracellular fluids capable of reacting towards specific molecular patterns associated with, e.g., pathogens and necrotic cells.

The oligomeric mannan-binding lectin (MBL) is the most studied PRMs of the 
complement system. Upon recognition and binding to a suitable pattern, a conformation change in MBL ensures activation of associated serine proteases, such as MASP-2. MASP-2, the most important serine protease of the lectin pathway, is able to cleave complement factors $\mathrm{C} 2$ and $\mathrm{C} 4$ and initiate the downstream activation of the complement cascade.

This project centres on a characterization of the lectin pathway complement activating complex; MBL:MASP-2. We strive towards a better biophysical characterization of MBL together with its interaction partners and ultimately hope to present a structural model of the interaction.

We plan to separate MBL into distinct oligomers, produce and purify MASP2 and a MBL associated protein and characterize their interaction with MBL via surface plasmon resonance, isothermal titration calorimetry, small-angle $X$-ray scattering and crystallization.

By describing the interaction of these complexes at an atomic level, we believe we can provide the best possible foundation for selectively inhibiting specific parts of the complement system. This may be of large clinical relevance in a number of inflammatory conditions.

P07.07 Tue Wenze

PLASMA LEVELS OF SOLUBLE CD18 ARE NEGATIVELY ASSOCIATED TO Kragstrup DISEASE ACTIVITY IN SPONDYLOARTHRITIS

T.W. Kragstrup ${ }^{7}$, M. Hvid ${ }^{7,2}$, R. Østgård ${ }^{7,3}$, B. Schiøttz-Christensen ${ }^{4}$, A.G. Jurik ${ }^{5}$, T. Vorup-Jensen', B. Deleuran ${ }^{7,2,6}$

${ }^{1}$ Department of Biomedicine, Aarhus University, ${ }^{2}$ Department of Clinical Medicine, Aarhus University, ${ }^{3}$ Department of Internal Medicine, Silkeborg Hospital, ${ }^{4}$ Aarhus Rheumatology Clinic, Private practice, ${ }^{5}$ Department of Radiology, Aarhus University Hospital, ${ }^{6}$ Department of Rheumatology, Aarhus University Hospital

Background: Lack of valid measures of disease activity and prognosis is a key challenge in spondyloarthritis (SpA). Leukocyte migration from the blood into the joints plays a key role in active SpA and the beta-2 integrin CD18 is important for this process. The soluble form of CD18 (sCD18) has been found to be shed from leukocytes in inflammation and to be present in the blood.(1)

Objectives: To examine if SCD18 is a novel marker of disease activity in SpA.

Methods: The level of sCD 18 in plasma from a study population encompassing $84 \mathrm{SpA}$ patients and a control group of normal healthy volunteers (NHV) was analyzed by a time resolved immunoflourometric assay (TRIFMA) and correlated to markers of disease activity.

Results: The plasma level of SCD 18 was decreased in SpA patients compared to NHV. In HLA-B27 positive SpA patients, the level of sCD 18 was negatively correlated to self-assessment scores (BASDAl and morning stiffness), clinical findings (physicians global assessment, thoracic chest expansion and BASMI) and test results (CRP and sacroiliac joint MRI). Interestingly, CRP did not show any significant relation to clinical findings or MRI activity in this study population.

Conclusion: SCD 18 is associated with markers of disease activity in HLA-B27 positive SpA patients. Thus SCD 18 could be a novel disease activity marker in SpA.

References: 1. Gjelstrup LC, Boesen T, Kragstrup TW, Jorgensen A, Klein NJ, Thiel S, Deleuran B, Vorup-Jensen T. Shedding of large functionally active CD 1 1/CD 18 Integrin complexes from leukocyte membranes during synovial inflammation distinguishes three types of arthritis through differential epitope exposure. J Immunol. 2010;185(7):4154-68. 
P08.01 Morten Leif Munding Stilund

P08.02
SOLUBLE CD163 AS A DIAGNOSTIC MARKER IN MULTIPLE SCLEROSIS M. Stilund ', H.J. Møller ${ }^{3}$, T. Christensen ${ }^{2}$, A. Reuschlein ${ }^{3}$, P.V. Rasmussen ${ }^{7}, T$. Petersen $^{7}$

'Department of Neurology, Aarhus University Hospital, Denmark., ${ }^{2}$ Department of Biomedicine -Medical Microbiology and Immunology, Aarhus University, Denmark, ${ }^{3}$ Department of Clinical Biochemistry, Aarhus University Hospital, Denmark

Background: CD163 is a macrophage specific protein, which in its soluble form ( $\mathrm{SCD}$ 163) has been shown to be up-regulated in serum from patients with multiple sclerosis (MS).

Hypothesis and aim: We wanted to investigate if sCD163 was measurable in cerebrospinal fluid (CSF) and whether it may serve as a novel diagnostic marker for MS.

Methods: Paired samples of CSF and serum were drawn from 165 patients suspected for MS or other neurological disease at the Department of Neurology at Aarhus University Hospital. For each patient, an MRI scan was performed and the revised diagnostic criteria for MS used. Based on the diagnosis, patients were divided into groups: clinically definite MS ( $n=82)$, clinically isolated syndrome $(n=34)$, a control group $(n=25)$ with neurological symptoms yet had a normal MRI, normal CSF and a normal neurological clinical examination, and a group $(n=24)$ with one unspecified paraclinical finding and a normal neurological clinical examination. After diagnosis, CSF and serum levels of sCD163 were determined by ELISA.

Results: Soluble CD163 was detectable in all CSF samples. We found significantly higher median levels in patients with MS compared to the control group $(0.098 \mathrm{mg} / \mathrm{ml}$ versus $0.071 \mathrm{mg} / \mathrm{ml}, \mathrm{p}<0.003)$. We also found indications for local production of sCD163 in the CNS.

Conclusion: Soluble CD163 is measurable in CSF, and the levels are increased in MS and may contribute to the diagnosis and differentiation between subgroups in the MS population.

Lise Tornvig CLOSTRIDIUM DIFFICILE INFECTION IN A MOUSE MODEL

Erikstrup

\section{L.T. Erikstrup ', B. Kristensen ${ }^{2}$, K.E. Olsen ${ }^{2}$, K. Fuursted ${ }^{2}$ \\ ${ }^{1}$ Department of Clinical Microbiology, Aarhus University Hospital, ${ }^{2}$ Statens Serum Institut}

Background: $\mathrm{C}$. difficile is the major cause of nosocomial infectious diarrhoea. Previous antimicrobial treatment is the predominant risk factor for acquisition of $C$. difficile and $C$. difficile infection.

Objective: To investigate the effect of broad-spectrum antimicrobials on colonization, sporulation and toxin production of $\mathrm{C}$. difficile in a mouse model.

Methods: In order to establish C. difficile infection in C57BL/6 mice, their normal enteric flora must be disrupted. This is done by pretreating the mice with an antimicrobial mixture containing kanamycin, gentamycin, colistin, metronidazole and vancomycin for 3 days. Following a 2-day period without antimicrobials, the mice receive a dose of clindamycin on day -1 . On day 0 , mice are challenged with $\mathrm{C}$. difficile $10^{7} \mathrm{CFU}$. The mice are divided into different groups receiving different broad-spectrum antimicrobials for approximately 5 days after their $\mathrm{C}$. difficile challenge. Mice are followed for 2-3 weeks and monitored daily with weight and a clinical score. Stool samples are collected and examined for bacterial load and toxin amount. At the end of the observational period, the mice are sacrificed. Histopathological analysis of colonic tissue will be performed to evaluate mucosal damage and inflammation. 
P08.03 Nis Pedersen Jørgensen
Results: Studies are currently being carried out. Pilot studies have been performed to determine the inoculum of $C$. difficile. Power calculations based on mean relative weight loss have been performed in order to evaluate the sample size for further studies.

Perspective: If successful, this model will improve our understanding of the role of antimicrobials in the pathogenesis and establishment of $\mathrm{C}$. difficile infection.

IN VIVO MEASUREMENT OF BACTERIAL LOAD IN A MODEL OF STAPHYLOCOCCUS AUREUS IMPLANT ASSOCIATED OSTEOMYELITIS CAUSED BY THE FORMATION OF A BACTERIAL BIOFILM

N. Jørgensen ${ }^{1,2}$, E. Petersen ${ }^{2}$, R.L. Meyer ${ }^{3}$, K. Fuursted ${ }^{4}$

'Department of Clinical Microbiology, Aarhus University Hospital,

${ }^{2}$ Department of Infectious Diseases Q, Aarhus University Hospital, ${ }^{3}$ Interdisciplinary Nanoscience Center, Aarhus University, ${ }^{4}$ Statens Serum Institut

Background: Staphylococci are the most common pathogen causing infections on orthopedic implants, with S. aureus accounting for nearly $35 \%$ of all implant associated osteomyelitis. Implant associated osteomyelitis is often characterized by the formation of bacterial biofilms, greatly increasing antibiotic resistance. Treatment options are hindered by the lack of an animal model.

Methods: 2 strains of bioluminescent S. aureus, Xen29 (Methicillin susceptible) and Xen31 (Methicilin resistant) were used to infect female C57Bl/6 mice.

The implant-associated OM was established by a transcortical implantation of a stainless steel pin through the tibia. Prior to surgery, the pins were incubated in PBS containing 25\% murine serum for 24 hours. Afterwards, the pins were removed and placed in a $\mathrm{MH}$ bouillon containing $3.5 \% \mathrm{NaCl}$ and $10^{6} \mathrm{cfu} / \mathrm{mL}$ and incubated for additional 24 hours.

3 groups were generated, 1 Xen29, 1 Xen 31 and 1 control. Each group consisted of 5 animals. At specific timepoints, bacterial load was measured by detecting photon-emission from metabolic active bacteria using an IVIS $®$ imaging system. Assessment of biofilm formation on the implant was done by epifluorescent microscopy.

Results: Final analyses of bioluminescent measurements are currently being carried out, but preliminary results suggest that this is a precise method for non-invasive determination of bacterial load.

Perspective: If successful, this model will allow for in vivo measurement of bacterial load in animal models, thus providing more precise studies on the effect on antimicrobial treatments.

P08.04 Stinne Ravn INCREASED LEVELS OF SOLUBLE PROGRAMMED CELL DEATH 1 (SPD-1) Greisen AND ITS SOLUBLE LIGAND (SPD-L1) IN EARLY RHEUMATOID ARTHRITIS ARE ASSOCIATED WITH DISEASE ACTIVITY AND PROGRESSION

S.R. Greisen', T.K. Rasmussen ", K. Stengaard-Pedersen ${ }^{2}$, M.L. Hetland ${ }^{3}$, K. Hørslev-Petersen ${ }^{4}$, M. Hvid' ${ }^{7}$, B. Deleuran'

${ }^{1}$ Department of Biomedicine, Aarhus University, ${ }^{2}$ Department of Rheumatology Aarhus University Hospital, ${ }^{3}$ Department of Rheumatology, Hvidovre and Glostrup Hospitals, ${ }^{4}$ King Christian X Hospital for Rheumatic Disease, University of Southern Denmark

Introduction: Programmed death 1 (PD-1) and its ligand (PD-L1) are immunoregulatory molecules functioning by downregulating immune responses. $\mathrm{PD}-1$ is present on follicular $T$ cells $\left(T_{F H}\right)$, which are important in the formation of memory plasma cells. PD-1 and PD-L1 exist in bioactive 
soluble forms(SPD- 1 and SPD-L1).

Methods: In plasma samples from early Rheumatoid Arthritis (RA) patients, we measured plasma levels of SPD-L1 and SPD- 1 at baseline and 9 months after treatment initiation. We examined for correlations with disease activity in 28 joints (DAS28), IgM-rheumatic factor (IgM-RF), anti-cyclic citrullinated peptide (anti-CCP), C-reactive protein (CRP), IL-21 and total Sharp score (TSS). In a sample set $(n=30)$ of chronic RA patients ( $>8$ years of disease), we measured SPD- 1 and SPD-L 1 in plasma and synovial fluid and in plasma of healthy volunteers $(H V)(n=20)$.

Results: Plasma levels of SPD- 1 in early and chronic RA were increased compared to HV. Plasma levels of SPD-L 1 in early RA were reduced following 9 months treatment. In early RA, the change in SPD- 1 was associated with DAS28 and inversely with TSS. Plasma levels of SPD- 1 and sPD-L1 correlated with IgM-RF and IL-21. Further, sPD-1 correlated with level of anti-CCP antibodies.

Conclusion: The significantly elevated plasma levels of both SPD-1 and SPD$\mathrm{L} 1$ in early RA patients point to strong activation of antigen presenting cells and $T$ cells in the initial phases of the disease. The observed association to disease parameters as well as IgM-RF, anti-CCP antibodies and IL-21 further supports PD- 1 pathway involvement in the activation of $\mathrm{T}-, \mathrm{B}$ and $\mathrm{T}_{\mathrm{FH}}$ cells in the central mechanism and mediators of disease progression in RA.

P08.05 Maria Rusan PREVALENCE OF HUMAN PAPILLOMAVIRUS IN TONSILLAR DISEASES IN DENMARK

M. Rusan ", 2, 3 , T.E. Klug' ', J.J. Henriksen', J. Bonde ${ }^{4}$, K. Fuursted ${ }^{2}$, T. Ovesen ${ }^{7}$

${ }^{1}$ Dept. of Otorhinolaryngology, Aarhus University Hospital, ${ }^{2}$ Dept. of Clinical Microbiology, Aarhus University Hospital, ${ }^{3}$ Department of Clinical Medicine, Aarhus University, Aarhus, Denmark, ${ }^{4}$ Dept. Pathology\& Clinical Research Center, Hvidovre Hospital, Hvidovre, Denmark

Background: Denmark has a high incidence of HPV-associated tonsillar carcinoma. The epidemiology and natural history of tonsillar infections with HPV in Denmark are not characterized.

Aim: To determine the prevalence and types of HPV in tumor-free tonsils in a Danish population.

Methods: We examined both palatine tonsils from patients, aged 8 to 30 , undergoing acute bilateral tonsillectomy for peritonsillar abscess (PTA) $(n=25)$ or elective bilateral tonsillectomy $(n=55)$ for chronic tonsillar diseases. HPV was detected by a nested PCR approach and typed by sequencing, as well as with the CLART HPV 2 Clinical Array.

Results: Seven patients (8.8\%) were positive for HPV by nested PCR. One of these was also positive using the CLART HPV 2 Clinical Array. Contralateral tonsils were all negative. Five of the seven patients had PTA, thus the prevalence in the PTA group was $20 \%(5 / 25)$. The prevalence in the elective group was $3.6 \%(2 / 55)$. HPV prevalence between the two groups was significantly different (Fisher's exact test, $p=0.03$ ).

Conclusions: The prevalence of HPV in patients with chronic tonsillar diseases is similar to that reported by prior studies. However, the prevalence in the PTA group is considerably higher (20\%), suggesting a possible link between HPV infection and PTA pathogenesis. Concordance between contralateral tonsils was zero. Past studies likely underestimate the prevalence of tonsillar HPV infections as they do not consider both palatine tonsils. Nested PCR detected HPV in $8.8 \%$ of samples compared to $1.3 \%$ by CLART HPV 2 Clinical Array. Although labour-intensive, this method may provide a more accurate reflection of HPV prevalence in tonsillar tissue. 

MEASURED BY PHOSPHORYLATION OF STAT3

T.K. Rasmussen ', A. Thyssen ', A. Voss' ${ }^{2}$, M. Hvid ${ }^{3}$, B. Deleuran ${ }^{1,4}$

${ }^{1}$ Department of Biomedicine, Aarhus University, ${ }^{2}$ Department of Rheumatology, Odense University Hospital, ${ }^{3}$ Institute for Clinical Medicine, Aarhus University, ${ }^{4}$ Department of Rheumatology, Aarhus University Hospital

Background: Interleukin 21 (IL-21) is produced by CD4+ T cells and signals through phosphorylation of STAT3. IL-21 has been suggested to be important in systemic lupus erythematosus (SLE), as it is crucial for B cell proliferation and antibody production.

Objectives: To investigate the plasma levels and production of IL-2 1 in SLE patients and further to investigate if T cells from SLE patients show altered STAT3 reactivity when stimulated with IL-21.

Methods: Plasma samples from SLE patients $(n=48)$ and healthy volunteers $(\mathrm{HV})(\mathrm{n}=32)$ were collected. For cellular studies, peripheral blood mononuclear cells (PBMC) were isolated from SLE patients $(n=14)$ and HV $(n=14)$.

IL-2 1 reactivity was measured by flow cytometry, using hrlL-21 stimulated PBMC and staining for phosphorylated STAT3 (pSTAT3) in a time-dependent assay. Production of IL-21 was measured by flow cytometry in PBMC. Plasma levels of IL-21 were measured using ELISA.

Results: IL-2 1 plasma levels were not increased in SLE patients, and we did not observe a correlation to SLEDAl or to the individual components of SLEDAI. However, CD4+ T cells, but not B and NK cells, from SLE patients showed significantly increased resting levels of PSTAT3 and increased phosphorylation of STAT3 when stimulated with IL-21. Furthermore, the percentages of both CD4+ T cells capable of producing IL-21 were increased.

Conclusions: In SLE patients, we observed normal serum levels of IL-21, an increased capacity to produce IL-21 and augmented STAT3 phosphorylation in T cells when stimulated with IL-21. This suggests that SLE has an increased IL-21 turnover, supporting its role in the pathogenesis of SLE. AFFECTED HUMAN SKIN

\section{G.J.M. Christensen, H.B. Lomholt, H. Brüggemann, M. Kilian}

Department of Biomedicine, Aarhus University

Introduction: The aim of this study was to map antagonistic interactions between two predominant members of the skin microbiota, S. epidermidis and $P$. acnes and to determine the potential contribution and significance of bacterial interferences in the pathogenesis of acne vulgaris.

Methods: Ninety-six staphylococcal test strains isolated from healthy and acne-affected skin were examined for inhibitory activity against representatives of 59 individual evolutionary lineages of $P$. acnes isolated from acne, healthy skin and systemic infections. The antagonistic effect of $P$. acnes against $\mathrm{S}$. epidermidis was also examined. The screenings were carried out as simultaneous antagonism assays.

Results and discussion: Bacterial antagonism among predominant members of the skin microbiota was a common finding in these in vitro screening experiments. Among 96 staphylococcal strains tested, all displayed antagonistic activity against at least one of the 59 P. acnes indicator strains. A subgroup of genetically closely related $P$. acnes strains 
isolated from patients with severe acne was significantly less susceptible to the staphylococcal BLIS than other strains. In addition, a sub-group of $P$. acnes was able to strongly inhibit S. epidermidis indicator strains, and genome sequencing of these $P$. acnes strains revealed the presence of a genomic island harbouring a gene cluster for thiopeptide biosynthesis. Our data suggest that bacterial interactions on the skin may play a role in jeopardizing normal balances in the skin microbiota, potentially leading to acne.

P09.01 Torbjørn Halle Brøgger TISSUE

\author{
T. Broegger ${ }^{1,2}$, A. Forman', C. Aalkjcer ${ }^{2}$ \\ ${ }^{1}$ Gynecology and obstetrics - Skejby sygehus, ${ }^{2}$ Biomedicine, Aarhus \\ university
}

Background: The placenta is the base for the exchange of nutrients, oxygen and waste products for the fetus.

The placental vessels hold a crucial role in regulation the blood flow, and a compromised placental function leads to serious complications such as fetal death or growth retardation.

An in-depth understanding of the mechanism regulating blood flow and perfusion is necessary if we are to come up with new ideas for intervention and treatment.

Materials and methods: From fresh born placentas, stem villi arteries were carefully dissected. The artery branches were divided. The surrounding tissue was removed from one end and was left untouched in the other end.

Then, using wire myography, they were investigated in terms of contractility and sensitivity to physiological relevant human-like agonists.

Results: Sensitivity to $\mathrm{PGF}_{2 \mathrm{a}}$, Tx-analog, 5-HT and endothelin-1 was significantly lower in arteries with intact surrounding tissue compared to arteries stripped of the tissue.The maximal force development was also significantly lower in arteries with surrounding tissue when they were depolarized high extracellular $\left[\mathrm{K}^{+}\right]$or stimulated with $\mathrm{PGF}_{2 \mathrm{a}}$ or endotheline1.

Conclusion: The perivascular tissue significantly alters stem villi arteries' sensitivity and force development in a suppressive way.

This implicates a new aspect of blood flow regulation in the placenta. SEPTAL DEFECT

J. Heiberg ${ }^{7}$, S. Laustsen ${ }^{2}$, M. Krintel Petersen ${ }^{2}$, V.E. Hjortdal'

'Dept. of Cardiothoracic \& Vascular Surgery, Aarhus University Hospital, Denmark, ${ }^{2}$ Dep. of Physio \& Ergotherapy, Aarhus University Hospital, Denmark

Background: Ventricular septal defects (VSDs) are generally closed very simply, and postsurgical the patients are considered healthy with normal physical capacity. The aim of this study is to investigate whether this is actually true.

Methods: We tested cardiopulmonary exercise capacity in 21 patients and 11 healthy control subjects on an ergometer cycle. Pulmonary ventilation and gas exchange were simultaneously measured. Each test was performed as a maximal incremental test. During the test session, respiratory gas exchange was measured along with heart rate, blood pressure, and EKG. Endpoints were: maximal oxygen uptake, maximal workload, and anaerobic ventilatory threshold. 
Preliminary results: VSD patients had a median age at surgery of 2.6 years (1.5-4.1 years) and 21.1 years (19.8-23.2 years) at the time of examination. Compared to controls, they had a markedly, impaired maximal oxygen uptake, median $38.0 \mathrm{ml} \mathrm{O}^{2} \mathrm{~kg}^{-1} \mathrm{~min}^{-1}\left(31.6-40.8 \mathrm{ml} \mathrm{O}^{2} \mathrm{~kg}^{-1} \mathrm{~min}^{-1}\right)$ vs. $45.8 \mathrm{ml}$ $\mathrm{O}^{2} \mathrm{~kg}^{-1} \mathrm{~min}^{-1}\left(41.1-49.9 \mathrm{ml} \mathrm{O}^{2} \mathrm{~kg}^{-1} \mathrm{~min}^{-1}\right)$ in control subjects, $\mathrm{p}<0.01$.

Furthermore, absolute and relative anaerobic thresholds were reduced in VSD patients, median $22.1 \mathrm{ml} \mathrm{O}^{2} \mathrm{~kg}^{-1} \mathrm{~min}^{-1}\left(17.5-25.9 \mathrm{ml} \mathrm{O}^{2} \mathrm{~kg}^{-1} \mathrm{~min}^{-1}\right)$ and $60.0 \%$ (54.0-72.7\%), respectively, vs. $33.5 \mathrm{ml} \mathrm{O}^{2} \mathrm{~kg}^{-1} \mathrm{~min}^{-1}\left(25.1-41.6 \mathrm{ml} \mathrm{O}^{2}\right.$ $\mathrm{kg}^{-1} \mathrm{~min}^{-1}$ ) and $76.1 \%(64.0-86.4 \%$ ), respectively, $\mathrm{p}<0.05$ for both parameters Lastly, maximal workload was significantly reduced, median $3.2 \mathrm{~W} \mathrm{~kg}^{-1}$ (2.7$\left.3.6 \mathrm{~W} \mathrm{~kg}^{-1}\right)$ vs. $4.1 \mathrm{~W} \mathrm{~kg}^{-1}\left(3.2-4.3 \mathrm{~W} \mathrm{~kg}^{-1}\right)$ in control subjects, $\mathrm{p}<0.01 .<\mathrm{br} />$ Conclusion: Patients with a surgically closed VSD had a markedly reduced exercise capacity compared to healthy controls; findings include effortindependent measurements.

P09.03 Camilla Nyboe CLOSURE OF ATRIAL SEPTAL DEFECT IN THE ADULT

C. Nyboe' , M. Fenger-Grøn², J.E. Nielsen-Kudsk ${ }^{3}$, V.E. Hjortdal ${ }^{7}$

${ }^{1}$ Department of Cardiothoracic Surgery, Aarhus University Hospital,

${ }^{2}$ Research Unit for General Practice, Aarhus University, ${ }^{3}$ Department of Cadiology, Aarhus Universityhospital

Introduction: Treatment of atrial septal defect (ASD) in adults is still controversial and with older age the likelihood of treatment is decreased. The aim of this study was to investigate the effect of ASD closure in adults in our institution in a retrospective review.

Methods: Patients ( $\mathrm{N}=207$ ) had an isolated ASD closed at Aarhus University Hospital from 1990 to 2008. Eleven were lost to follow-up and thus 196 were included in the study. Hospital records were reviewed and symptoms and echocardiographic findings preoperative and at 3 months follow-up registered. Patients were divided into; Group I ( $N=117)$ : less than 50 years old and group II $(\mathrm{N}=79)$ : more than 50 years. Results within and between the 2 groups were compared.

Results: One patient died during follow-up. Complications occurred in $18 \%$ in group I and $22 \%$ in group II. There was an absolute risk reduction of $62 \%$ and $52 \%$, respectively, in RV dilatation after operation. Atrial fibrillation (AF) was noticed in $6 \%$ of the young and $47 \%$ of the elderly with a reduction after treatment to $26 \%$ in group II (ARR $20 \%, p<0.0001$ ). Subjective symptoms occurred in $75 \%$ in group I and $99 \%$ in group II with a postoperative reduction to $43 \%$ and $67 \%$, respectively. In group I $70 \%$ felt improvement of symptoms, while it was $86 \%$ in group II.

Conclusions: Symptoms and RV dilatation is more pronounced in the elderly and reversibility is higher in the young patients. However, the elderly benefit substantially from ASD closure. Improvement of symptoms was reported by $86 \%$. In $50 \%$ RV dilatation was reduced after 3 months and almost half of the patients with AF recovered from it. ASD closure after the fifth decade is therefore recommendable.

P09.04 Janni Majgaard EFFECT OF ISOTONIC AND HYPERTONIC SODIUM CHLORIDE AND Jensen GLUCOSE ON EXCRETION OF URINARY AQUAPORIN2 IN HEALTHY SUBJECTS

\section{J.M. Jensen, F.H. Mose, J.N. Bech, E.B. Pedersen}

Department of Medical Research Holstebro Hospital and Aarhus University Introduction and aims: Urinary excretion of aquaporin2 (u-AQP2) is currently used to evaluate the water transport in AQP2 water channels in the nephron. The aim of this study was to measure $u-A Q P 2$ after isotonic saline, hypertonic saline and glucose infusion in healthy subjects.

Methods: We studied the effect of isotonic saline $0.9 \%(23 \mathrm{ml} / \mathrm{kg})$, 
P09.05 Sisse Anette Thomassen hypertonic saline $3.0 \%(7 \mathrm{ml} / \mathrm{kg})$ and isotonic glucose $5 \%(23 \mathrm{ml} / \mathrm{kg})$ at the end of three periods each of a 5-day duration with wash-out periods of two weeks between interventions, in a randomized, placebo-controlled, crossover study. The study comprised 23 healthy subjects, who consumed a standardized diet for 4 days before each examination day. GFR was measured as ${ }^{51} \mathrm{Cr}$-EDTA renal clearance. We measured free water clearance $(\mathrm{CH} 2 \mathrm{O})$, fractional excretion of sodium ( $\left.\mathrm{FE}_{\mathrm{Na}}\right)$, plasma concentrations of renin (PRC), aldosterone ( $\mathrm{p}$-Aldo) and $\mathrm{u}-\mathrm{AQP} 2$ at baseline and after infusion.

Results: After isotonic saline infusion, $\mathrm{U}-\mathrm{AQP} 2$ and $\mathrm{CH} 2 \mathrm{O}$ were unchanged, whereas $\mathrm{FE}_{\mathrm{Na}}$ increased (167\%). After hypertonic saline infusion, there was an increase in $\mathrm{u}-\mathrm{AQP} 2(344 \%)$ and $\mathrm{FE}_{\mathrm{Na}}(144 \%)$, whereas $\mathrm{CH} 2 \mathrm{O}$ decreased $(-186 \%)$. After isotonic glucose infusion, there was a decrease in u-AQP2 ($64 \%)$ and $\mathrm{FE}_{\mathrm{Na}}(-31 \%)$ whereas $\mathrm{CH} 2 \mathrm{O}$ increased (230\%). GFR increased slightly and to the same extent during all three infusions. PRC and p-Aldo decreased after isotonic and hypertonic saline infusion, but not after glucose infusion.

Conclusions: The study documented that u-AQP2 reflects changes in water channel activity in the kidney tubule during different types of volume expansion in healthy subjects and underlines the value of $u-A Q P 2$ to estimate water transport.

CAN NEAR-INFRARED SPECTROSCOPY DETECT CRITICAL PERFUSION IN MUSCLE TISSUE DURING CARDIOPULMONARY BYPASS IN AN ANIMAL MODEL?

S.A. Thomassen ', B. Kjcergaard', P. Sørensen ${ }^{3}$, A. Larsson 4', J.J. Andreasen ${ }^{2}$, B.S. Rasmussen ${ }^{\prime}$

'Cardiovascular Research, Department of Anaesthesia and Intensive Care, Aalborg University Hospital, ${ }^{2}$ Cardiovascular Research, Department of Cardiothoracic Surgery, Aalborg University Hospital, ${ }^{3}$ Department of Neurosurgery, Aalborg University Hospital, ${ }^{4}$ Department of Anaesthesiology and Intensive Care, Uppsala University, Sweden

Introduction: Higher co-morbidity, age and weight of the patients scheduled for today's cardiac surgery question the calculation of blood flow during cardiopulmonary bypass (CPB). The purpose of this animal study was to investigate if near infrared spectroscopy (NIRS) of regional muscle tissue can be used as an early detector of inadequate blood flow during CPB.

Method: Twelve $80 \mathrm{~kg}$ pigs were anaesthetized and normothermic CPB was established with a blood flow of $2.5 \mathrm{~L} / \mathrm{min} / \mathrm{m}^{2}$ for one hour. Thereafter, the pigs were randomized to a blood flow of either $2.0 \mathrm{~L} / \mathrm{min} / \mathrm{m}^{2}$ (Group I) or $1.5 \mathrm{~L} / \mathrm{min} / \mathrm{m}^{2}$ (Group II) for another hour and finally one hour with blood flow of $2.5 \mathrm{~L} / \mathrm{min} / \mathrm{m}^{2}$. Regional tissue oxygen saturation $\left(\mathrm{tSO}_{2}\right)$ was measured by placing a NIRS electrode on the skin above a large lower limb muscle. Perfusate from microdialysis of the large muscle, intestinal mucosa and brain was collected every 20 minutes. Systemic oxygen consumption was estimated by measurement of mixed venous saturation, base excess and lactate.

Results: PreCPB StO 2 values for group I and group II were $64(\mathrm{Cl} ; 62,66)$ and $74.6(\mathrm{Cl} ; 67.5,81.7)$. $\mathrm{StO}_{2}$ was unchanged in group I $(P=0.13)$, but decreased to very low values in group $\|(P=0.02)$ during the period of low blood flow. The minimum $\mathrm{tSO}_{2}$ values during blood flow $2.0 \mathrm{~L} / \mathrm{min} / \mathrm{m}^{2}$ and $1.5 \mathrm{~L} / \mathrm{min} / \mathrm{m}^{2}$ were 49 and 38, respectively. Analysis of microdialysis is still ongoing.

Discussion: NIRS on regional muscle tissue seems to be able to detect low and critical values of blood flow during CPB. However, the results have to be confirmed by the analysis of the microdialysis before a conclusion can be made. 

HEART FAILURE

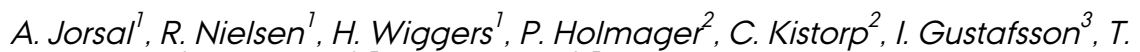
Boesgaard $^{4}$, L. Tarnow ${ }^{4,5}$, A. Flyvbjerg $^{6,5}$

'Department of Cardiology, Aarhus University Hospital, ${ }^{2}$ Department of Endocrinology and Internal Medicine, Center of Endocrinology and Metabolism, Herlev University Hospital, ${ }^{3}$ Department of Cardiology, Herlev University Hospital, ${ }^{4}$ Steno Diabetes Center, ${ }^{5}$ Health, Aarhus University, ${ }^{6}$ Department of Endocrinology and Internal Medicine, Aarhus University Hospital

Background: Glucagon-like peptide 1 (GLP-1) is a naturally existing hormone, which is a part of the incretine system. A beneficial effect of GLP-1 on cardiac function has recently been suggested in small, non-randomised clinical studies, demonstrating improved left ventricular ejection fraction (LVEF) in both diabetic and non-diabetic patients with chronic heart failure (CHF). Liraglutide (Victoza ${ }^{\circledR}$ ) is a GLP-1-analogue developed for the treatment of type 2 diabetes (T2D). However, the impact of Liraglutide on cardiac function has not previously been investigated in chronic heart failure patients.

Hypothesis: Liraglutide improves left ventricular systolic and diastolic function in CHF patients with and without T2D.

Design and methods: An investigator initiated, multi-centre, randomised, double-blind, parallel, placebo controlled intervention trial.

A total of $240 \mathrm{CHF}$ patients with LVEF < 45\% (intended $50 \%$ with T2D) will be randomised to either subcutaneous injection of Liraglutide $1.8 \mathrm{mg}$ once daily or matching placebo for 24 weeks. The effect of Liraglutide on left ventricular systolic and diastolic function will be evaluated by advanced echocardiography using 2D, 3D, and tissue Doppler imaging.

Perspectives: Potentially Liraglutide can improve heart function substantially, thus changing the prognosis of CHF patients worldwide.

P09.07 Dinah Sherzad REPRODUCIBILITY OF RENAL ARTERY FLOW AND BLOOD OXYGEN LEVEL Khatir DEPENDENT MEASUREMENTS USING MAGNETIC RESONANCE IMAGING IN PATIENTS WITH CHRONIC KIDNEY DISEASE AND HEALTHY CONTROLS

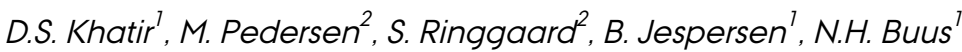

${ }^{1}$ Department of Renal Medicine, Aarhus University Hospital, Skejby Sygehus, ${ }^{2}$ MR Research Center, Aarhus University Hospital, Skejby

Background: Reduction in renal artery blood flow (RBF) and tissue oxygenation may contribute to development of chronic kidney disease (CKD). Magnetic resonance imaging (MRI) using gadolinium-based contrast agents can determine renal tissue perfusion, but is associated with adverse reactions in patients with CKD. RBF and renal tissue deoxyhemoglobin status can be measured without the use of contrast agents.

Methods: RBF and oxygenation in both kidneys were determined on two separate occasions with 1-2 weeks interval in 11 CKD patients and 9 healthy volunteers. All investigations were performed in a 1.5 Tesla Siemens Avanto MRI system. RBF was measured by phase-contrast sequence and calculated as the product of the cumulative vessel blood velocity and the diagonal vessel area using Siemens software. Blood Oxygen Level Dependent (BOLD) MRI was used as an estimate of intrarenal oxygenation. A mixed model was used to assess variation.

Results: Both scan procedures were successful in 10 patients (20 kidneys) and 8 controls ( 16 kidneys). Averaged RBF ( $\mathrm{ml} / \mathrm{min}$ ) for patients were 
$170 \pm 130$ and $186 \pm 137$ and for controls $356 \pm 119$ and $361 \pm 107$ for first and second scans, respectively. The intra class coefficient (ICC) was 0.78 for patients and 0.94 for controls. BOLD renal cortex ICC was 0.67 for patients and 0.60 for controls. Renal medulla ICC was lower than for the cortex for patients, 0.30 , but not for controls, 0.63 . No significant differences were found between groups.

Conclusion: MRI-based determinations of RBF and tissue oxygenation are highly reproducible in both CKD patients and healthy controls.

P10.01 Jacob Johnsen ROLE OF O-LINKED N-ACETYLGLUCOSAMINE (O-GLCNAC) AND AFFERENT NEURAL PATHWAYS IN REMOTE ISCHEMIC PRECONDITIONING (RIPC)

\section{J. Johnsen, S.B. Kristiansen, N.B. Strøttrup, H.E. Bøtker}

Cardiology Research B, Aarhus University Hospital

Background: Having demonstrated that rIPC reduces myocardial injury in patients with $A M I$, our ongoing studies focus on the mechanisms underlying the effects of rIPC. Diabetic patients have impaired clinical outcome after an AMI, which may be due to reduced cardioprotective capacity. Key metabolic proteins in cardiomyocytes are dynamically modified by $\mathrm{O}$ GlcNAc. O-GlcNAc is a metabolic sensor, linking glucose metabolism to cellular function including cardioprotection. O-GlcNAc signalling is altered in diabetes. Experimental studies suggest involvement of neural pathways in the communication between the remote preconditioned tissue and the heart. Diabetic neuropathy is a common complication in diabetes which may contribute to an impaired clinical outcome following AMI in diabetic patients. The effector(s) of rIPC is dialyzable and transferrable from human subjects to mice.

Aim: To study extracellular and intracellular effectors of rIPC with emphasis on the role of O-GICNAc and afferent neural pathways.

Methods: The effects of rIPC are examined in an isolated mouse heart model using dialysate from human blood.

For examination of the involvement of an afferent neural pathway blood samples are drawn from patients undergoing neural blockage of an upper extremity and ipsilateral or contralateral rIPC.

For examination of the involvement of O-GIcNAc and diabetes, blood samples are drawn prior to and following rIPC in diabetic and non-diabetic human subjects, and the dialysate is used to perfuse diabetic and nondiabetic mice hearts with or without inhibitors of O-GlcNAc signalling in addition to perfusion of hearts from a non-diabetic, conditional O-GICNAc knock-out mouse strain.

P10.02 Troels Fogh THE EFFECT OF PRECONDITIONING FOR PREVENTION OF PERIOPERATIVE Pedersen MYOCARDIAL ISCHEMIA IN ABDOMINAL AORTIC ANEURYSMS

\section{T.F. Pedersen, N. Eldrup, W. Paaske \\ Dept. T of Heart-Lung-Vascularsurgery, Aarhus University Hospital}

The purpose is primarily to investigate whether peripheral preconditioning induced by brief, intermittent constriction of the blood supply to one arm can reduce the incidence of perioperative myocardial ischemia in patients operated electively for infrarenal aortic aneurysm. Secondary, the impact of peripheral preconditioning on the perioperative inflammatory response is investigated.

The study is conducted as a prospective, randomized, single-blinded study including 200 patients with abdominal aortic aneurysm hospitalized for elective surgery. Patients are recruited from the departments of vascular surgery at Aalborg Sygehus and at Aarhus University Hospital, Skejby.

Patients are randomized to either 1) preconditioning of one arm starting at 
the beginning of the operation and the usual surgery or 2) no preconditioning and usual surgery. The preconditioning is performed in practice by a conventional blood pressure cuff attached to an arm and inflated for $4 \times 5$ minutes with a 5 -minute break in between. The handling of the blood pressure cuff is performed by anaesthesia staff and is blinded to the operators. Patients will, as a result of usual clinical practice, be monitored during surgery for signs of cardiac ischemia and an ECG will be taken daily. In addition, blood samples consisting of troponin T, CKMB, LDH, hemoglobin, creatinine, urea, sodium, potassium, leukocyte counts and CRP will be collected after the surgery and the following five days. At all blood samplings, a sample $(9 \mathrm{ml}$ ) will be centrifuged and plasma stored for analysis of inflammatory markers. Events in the first 30 postoperative days will be registered.

P10.03 Sarah Holmboe INOTROPIC EFFECTS OF ILOPROST IN THE HYPERTROPHIC AND FAILING RIGHT HEART

S. Holmboe', A. Andersen', M.D. Vildbrad', J.M. Nielsen', S. Ringgaard', J.E. Nielsen-Kudsk ${ }^{7}$

'Department of Cardiology - Research, Department of Clinical Medicine, Aarhus University Hospital, ${ }^{2}$ The MR Centre, Aarhus University Hospital

Aim: To investigate if iloprost has a direct inotropic effect in the pressure overloaded hypertrophic and failing right ventricle (RV).

Methods: Rats were subjected to pulmonary trunk banding (PTB) $(n=8)$ or SHAM operation $(n=8)$. After development of RV hypertrophy and failure, measurements were made at baseline and after iv administration of placebo, iloprost 10ng/kg/min (Ilol0) and iloprost 100ng/kg/min (llo100) Cardiac output, blood pressure and RV function were evaluated by MRI, echocardiography and invasive pressure measurements.

Results: Animals subjected to PTB developed significant RV hypertrophy and failure. RV weight/tibia length ratio was elevated, and tricuspid annular plane systolic excursion was markedly decreased compared to SHAM animals. lloprost caused a decrease in mean arterial blood pressure (MAP). In both groups of animals, infusion of llo100 induced an increase in stroke volume (placebo vs llo100, \pm SEM: PTB $0.19 \pm 0.008$ vs $0.21 \pm 0.01 \mathrm{~mL}, \mathrm{p}<0.01$, SHAM $0.25 \pm 0.01$ vs $0.28 \pm 0.01 \mathrm{~mL}, \mathrm{p}<0.05$ ) as well as in $\mathrm{dP} / \mathrm{dtmax}$ (placebo vs llo 100, \pm SEM: PTB $4730 \pm 451$ vs $5338 \pm 605 \mathrm{mmHg} / \mathrm{sec}, \mathrm{p}<0.05$, SHAM $2218 \pm 218$ vs $2521 \pm 386 \mathrm{mmHg} / \mathrm{sec}, \mathrm{p}<0.05)$. Additionally, an elevation in cardiac output (placebo vs llo100, \pm SEM: $63.0 \pm 5$ vs $71.4 \pm 5 \mathrm{~mL} / \mathrm{min}$, $\mathrm{p}<0.001$ ) and RV systolic pressure (placebo vs llo 100, \pm SEM: PTB $110 \pm 6$ vs $121 \pm 6 \mathrm{mmHg}, \mathrm{P}<0.01$ ) was observed in the PTB group. Infusion of nitroprusside, titrated to cause the same level of decrease in MAP as iloprost, did not increase any of the measured parameters.

Conclusion: Our results suggest that iloprost has inotropic properties, directly improving ventricular function in the hypertrophic and failing as well as in the healthy right heart.

P10.04 Simon Winther OSTEOPROTEGERIN AS A PROGNOSTIC MARKER OF MORTALITY IN HEMODIALYSIS PATIENTS WITH CARDIOVASCULAR DISEASE

\section{S. Winther}

Department of Cardiology, Aarhus University Hospital, Aarhus, Denmark

Background: Patients with end-stage renal disease treated with hemodialysis (HD) have an increased mortality, mainly caused by cardiovascular disease (CVD). Osteoprotegerin (OPG) is a glycoprotein involved in the regulation of the vascular calcification process. Previous studies have demonstrated that elevated OPG in plasma is related both to severity of vascular calcification and mortality. The aim of this study was to investigate if OPG was a prognostic marker of mortality in patients with end- 
stage renal disease and previously documented CVD.

Methods: We prospectively followed 206 HD patients with documented CVD. CVD was defined as previously documented myocardial infarction, angina pectoris, angiographically documented coronary arteriosclerosis, stroke, transient ischemic attack or peripheral vascular disease. Plasma levels of OPG were measured at baseline and the patients were followed for 2 years or until reaching the primary endpoint, all-cause mortality.

Results: All-cause mortality during follow-up was 44\% (90/206) and median follow-up to the primary endpoint was 314 days. Levels of OPG were divided into tertiles. High OPG levels were associated with increased mortality, using the first tertile as reference, with a HR of $1.83(\mathrm{Cl} 1.05-3.20)$ for the second tertile and a HR of 1.72 ( $\mathrm{Cl} 0.95-3.09)$ for the third tertile. In the survival analysis, this was not statistically significant with an adjusted $p$ value of 0.08 and an adjusted $p$-value for a trend of 0.07

Conclusions: In contrast to previous studies, we were not able to demonstrate that high levels of OPG in a cohort of HD patients with documented CVD were associated with an increased mortality.

P10.05 Steven Brantlov BIOELECTRICAL IMPEDANCE SPECTROSCOPY FOR CLINICAL ASSESSMENT OF BODY COMPOSITION IN HEALTHY AND SICK CHILDREN

S. Brantlov' ${ }^{7}$ L. Jødal', A. Lange ${ }^{3}$, R.F. Andersen ${ }^{3}$, S. Rittig ${ }^{3}$

'Dept. of Clinical Engineering, Aarhus University Hospital, ${ }^{2}$ Dept. of Nuclear Medicine, Aalborg Hospital, ${ }^{3}$ Dept. of Pediatrics, Aarhus University Hospital

Background: Assessment of body composition (BC) is crucial when evaluating nutritional and fluid status in children, as well as effect of treatment.

Reference methods are e.g. isotopic dilution (D2O, $2 \mathrm{H} 2 \mathrm{O}$, bromide, etc.) and DEXA scanning (Dual Energy X-ray Absorptiometry). These techniques are invasive, expensive, time-consuming and require highly trained personnel and are therefore not suitable for routine paediatric examination.

In this context, non-invasive bioelectrical impedance spectroscopy (BIS) is the most advanced method on the market, which is both user friendly, gentle to the patient and inexpensive.

The method is accurate and precise when used on healthy adults. However, to be considered valid in healthy and sick children, it is necessary with an in-depth understanding of accuracy, precision and biological variation.

Purpose: To evaluate and validate the BIS method in healthy children, in children undergoing cardiac surgery and in children with acute nephrotic syndrome (NS). The healthy children will be used as reference material.

Materials and methods: A 4-electrode BIS device will be used, which measures tissue impedance at different frequencies. Total body water (TBW), intracellular (ICW) and extracellular water (ECW) measured with the $\mathrm{BIS}$ device will be validated against the reference methods, D2O and bromide.

Perspectives: The clinical potential of the BIS method is great compared with invasive methods. The method can provide the clinician with rapid information about changes in $\mathrm{BC}$ in sick children and may thus offer the clinician a promising tool to optimize patient treatment during cardiac surgery in children, in particular children with acute NS. 

UP

\section{E.A. Nielsen, V.E. Hjortdal \\ Cardiothoracic Research Department T, Aarhus University Hospital}

Background: The natural history of the surgically relieved pulmonary artery stenosis is only scantly described since balloon valvuloplasty has replaced surgery. We hypothesize that the incidence of morbidity and mortality increase with increasing time and that more than $30 \%$ have been reoperated due to pulmonary regurgitation before the age of 40 years.

Materials and methods: A retrospective follow-up study of the population treated surgically for pulmonary stenosis at Aarhus University Hospital between 1 January 1957 and 31 December 2000.

Results: Of 87 patients, 6 were excluded due to missing information. The age at primary surgery was less than 15 years in more than $70 \%(n=58)$ of the study population of 81 patients. Valvular stenosis was the most common pathology, $84 \%(n=68)$, the remaining had an infundibular stenosis. Three patients died (age 0, 40 years and one unknown), resulting in a mortality of $2.4 \%$. The mean age for all patients at follow-up was 32 years (range 4-79 years). At a maximum follow-up of 54 years and a mean follow-up of 25 years, $18(24 \%)$ required at least one reintervention. Pulmonary valve replacement due to pulmonary regurgitation was the most common reintervention (60\%). Out of 19 patients older than 40 years and 15 patients between 30 and 40 years of age $47 \%$ and $28 \%$, respectively, have had a reoperation.

Conclusion: With a mean long-term follow-up of 25 years (max. 54 years), reintervention was necessary in $24 \%$ and almost half of the patients reaching the age of 40 years had a reoperation. This retrospective study shows that there is a call for prolonged follow-up and reintervention in patients operated for simple pulmonary stenosis.

P11.01 Anne Sophie EFFECT OF HYDROXYETHYL STARCH ON RENAL HANDLING OF SODIUM Pinholt Kancir AND WATER, VASOACTIVE HORMONES, BIOMARKERS AND CIRCULATION IN PATIENTS UNDERGOING HIP REPLACEMENT.

\section{A.S. Kancir ${ }^{7}$, N.P. Ekeløf', E.B. Pedersen ${ }^{7}$}

${ }^{1}$ Department of medical research, Holstebro Hospital, ${ }^{2}$ Department of anesthesiology, Holstebro Hospital

Background: Hydroxyethyl starch (HES) is widely used in hospitals to maintain circulation in critically ill patients. In recent years studies have raised suspicion that HES is nephrotoxic. So far acute kidney injury has been diagnosed based on creatinine measurements, but new technology allows for earlier diagnosis using measurements of biomarkers in urine. The purpose of this project is to investigate HES's potential toxicity and effects on the circulation and kidneys using measurements of biomarkers specific for toxicity and for the sodium/water balance in the urine and by measurements of vasoactive hormones in the blood after administration of HES 130/0.4

Design: The study is a randomised, double blinded, placebo-controlled study with 40 patients undergoing hip replacement. Patients are randomized to receive either Voluven (HES 130/0.4) or sodiumchloride 9 $\mathrm{mg} / \mathrm{ml}$ i.v during surgery. The patients will receive $7.5 \mathrm{ml} / \mathrm{kg}$ projectfluid the first hour and $5 \mathrm{ml} / \mathrm{kg}$ in subsequent hours.

Methods: ELISA will be used to measure the biomarkers specific for nephrotoxic damage, while radioimmunoassay will be used to measure the biomarkers specific sodium/water balance and Theis effekt on the kidney. Vasoactive hormones will be measured in the blood to assess the effect on 
P11.02 Nicolaj Christopher Hansson the circulation, and radioimmunoassay will be used to analyze the samples. Blood pressure, pulse and endtidal CO 2 will be recorded continuously throughout the operation

Perspectives: Results are expected to contribute new knowledge about HES's effect on the kidneys and circulation and may have implications for future clinical practice concerning fluid therapy in surgery

MULTIDETECTOR COMPUTED TOMOGRAPHY VERSUS TRANSESOPHAGEAL ECHOCARDIOGRAPHY FOR ANNULAR SIZING IN TRANSCATHETER AORTIC VALVE REPLACEMENT

N.C. Hansson' , L. Thuesen', V.E. Hjortdal', J. Leipsic' ${ }^{3}$, H.R. Andersen' ', S.H. Poulsen', J.G. Webb ${ }^{3}$, E.H. Christiansen', L.E. Rasmussen' ${ }^{2}$, L.R. Krusell', K. Terp $^{2}$, K.E. Klaaborg', M. Tang' ${ }^{2}$, J.F. Lassen', H.E. Bøtker ', B.L. Nørgaard ${ }^{7}$

'Department of Cardiology, Aarhus University Hospital, Skejby, ${ }^{2}$ Department of Cardiothoracic Surgery, Aarhus University Hospital, Skejby, ${ }^{3}$ Department of Medical Imaging and Division of Cardiology, St. Pauls Hospital, University of British Columbia, Vancouver, British Columbia, Canada

Background: Paravalvular aortic regurgitation (PAR) remains a major limitation in transcatheter aortic valve replacement (TAVR).

Objectives: The influence of aortic annular assessment with either multidetector computed tomography (MDCT) or conventional transesophageal echocardiography (TEE) on the incidence of postprocedural PAR was evaluated.

Methods and Results: In a observational study design, outcomes following TAVR with a balloon expandable THV were compared in two cohorts identified according to whether THV size selection was based on TEE (study group 1, $\mathrm{n}=80$ ) or MDCT (study group 2, $\mathrm{n}=58$ ).

Results :The two study groups were comparable with regard to baseline clinical, risk score and echocardiographic characteristics. The incidence of moderate/severe PAR was lower in study group 2 than in group 1, 8.6\% versus $28.8 \%(p<0.01)$. Using receiver operating curves analysis, the difference between the THV nominal diameter and MDCT annular diameter was predictive of moderate/severe PAR (AUC 0.84; 95\% Cl: 0.72-0.92). Neither age, gender, body mass index, annular eccentricity index, aortic valve calcification nor the difference between the THV diameter and the TEE annular diameter predicted post-procedural PAR. Increased THV oversizing relative to the MDCT mean annular diameter was associated with reduced severity of PAR. No difference in per-procedural complications between two study groups was observed.

Conclusion: MDCT-based annular sizing in TAVR significantly reduces postprocedural PAR, and THV oversizing appears pivotal in this aspect. Further delineation of the optimal degree of THV oversizing is needed.

P11.03 Susanne Bendesgaard Pedersen
GEOGRAPHICAL VARIATION IN THE USE OF IMPLANTABLE CARDIOVERTERDEFIBRILLATOR (ICD) TREATMENT AMONG PATIENTS WITH PRIOR MYOCARDIAL INFARCTION IN DENMARK

S.B. Pedersen', S.P. Hjortshøj', S.H. Poulsen' ', H.E. Bøtker ', H.T. Sørensen ${ }^{3}$, R.E. Kirkfeldt ${ }^{7}$ J.C. Nielsen ${ }^{7}$

'Department of Cardiology, Aarhus University Hospital, Aarhus, ${ }^{2}$ Department of Cardiology, Aarhus University Hospital, Aalborg, ${ }^{3}$ Department of Clinical Epidemiology, Aarhus University Hospital, Aarhus

Introduction: Patients with prior myocardial infarction (MI) and heart failure are at high risk of sudden cardiac death due to arrhythmias. Implantable cardioverter-defibrillator (ICD) treatment is offered to patients with MI and an ejection fraction $\leq 35 \%$. Previous studies have shown significant variation in ICD implantation rates (ICD-IRs) both between Western countries and 
regionally within Western countries. The ICD-IR is lower in Denmark (DK) than in other Western countries, but whether significant geographical variation in ICD-IRs exists within DK has never been examined.

Objectives: To examine whether there is a significant geographical variation in ICD-IRs within DK in patients with $\mathrm{MI}$ and if so whether the variation correlates with the distance from a patient's home to the nearest ICD treatment center and to which extent geographical differences in comorbidity of ICD treated patients contribute.

Materials and methods: The study is a nationwide cohort study using Danish medical registries. Patients with $\mathrm{MI}$ who received first-time ICD treatment in Denmark from 2007 through 2012 will be identified by linkage of the Danish National Registry of Patients to the Danish Pacemaker and ICD Registry. Addresses and Charlson comorbidity indexes of study participants will be found using the Danish Civil Registration System and the Danish National Registry of Patients.

Perspectives: This study is the first to examine geographical variation in ICDIRs in DK. If ICD treatment is found less applied in some parts of DK, measures can be taken to ensure proper use of ICD treatment in these areas, thereby possibly reducing sudden cardiac death in DK.

P11.04 Jannik Bertelsen

P11.05 Anne Dorte Blankholm
RANDOMIZED CLINICAL PILOT TRIAL COMPARING EFFICACY AND SAFETY OF CARDIAC REHABILITATION: IN HOSPITAL VS OUT OF HOSPITAL

J. Bertelsen', H.L. Kanstrup ', J. Refsgaard', B. Christensen ${ }^{3}$, K.L. Christensen ${ }^{7}$

${ }^{1}$ Department of Cardiology B, ${ }^{2}$ Department of Medicine, Viborg Hospital, ${ }^{3}$ Department of Public Health

Introduction: In Denmark, phase II Cardiac Rehabilitation (CR) after Acute Coronary Syndrome (ACS) has until now been conducted in-hospital due to safety issues as this treatment was considered to require presence of cardiac specialists. The latest Danish municipality reform from 2007 aims to shift the responsibility of health, prevention and rehabilitation from the hospitals to the local communities. Our aim is to establish a shared care model for phase II CR involving the municipalities and general practitioners to a greater extent and test the feasibility of this model compared to hospital-based CR.

Material and methods: The study is a randomized controlled clinical multicenter pilot trial to investigate the effect of hospital-based CR compared to Shared Care CR following hospital admission due to Acute Coronary Syndrome. The diagnosis was in all cases verified by the presence of stenotic or thrombotic lesions in Coronary Angiography. 208 participants are to be included and randomized before discharge from the hospital. Primary endpoint is adherence to the multidisciplinary and individually tailored CR-programme involving patient education, dietary guidance, smoking cessation, exercise training, psychosocial support and clinical assessment. Changes in modifiable risk factors are measured. The study was registered at clinicalTrials.gov, identifier NTC 01522001.

Conclusion: Hopefully, the study will help clarify whether phase II CR after ACS can be conducted safely outside the hospitals and whether it is feasible.

Funding: The trial is supported by the Central Denmark Region and forms part of a research programme for chronic care in patients with cardiovascular disease.

MAGNETIC RESONANCE ANGIOGRAPHY OF THE PELVIC VESSELS IN CANDIDATES FOR KIDNEY TRANSPLANTATION WITHOUT USE OF CONTRAST AGENTS

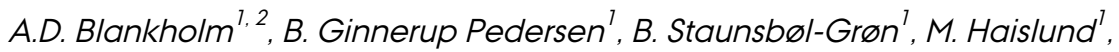




\section{S. Laustsen ${ }^{3}$, S. Ringgaard ${ }^{2}$}

'Department of Diagnostic Imaging, MR.centre, Aarhus University Hospital, ${ }^{2}$ Department of Clinical Medicine, MR Research Centre, Aarhus University, ${ }^{3}$ Department of Cardiothoracic - and Vascular Surgery

Contrast agents based on gadolinium can cause Nephrogenic Systemic Fibrosis and contrast agents based on iodine can cause nephropathy in patients at risk.

We aimed to find a robust non-contrast magnetic resonance angiography method, providing a sufficient image quality, for evaluation of the pelvic vessels before kidney transplantation.

Fifty-four patients were scanned before kidney transplantation with the following MRA sequences: 2D Time of flight (TOF), 3D TOF, 3D Phase Contrast (PC), 3D balanced SSFP (BTFE) and a 2D Spin Echo with subtraction (TRANCE). The MRA sequences were evaluated with respect to contrast ratio, diagnostic quality and artefacts. The PC scored best with respect to contrast ratio and was significantly better than the 2D TOF $(p<0.001)$. No significant difference was found in diagnostic performance between the 2D TOF and the PC ( $p>0.2)$, whereas the 2D TOF was significantly better than the 3D TOF, B-TFE and TRANCE sequences $(p<0.001$ in all cases). The smallest amount of artefacts was seen on the PC sequence (mean 1.17; Sd 0.37), $(0.001<\mathrm{p}<0.005)$ and the 2D TOF was rated second best (mean 2.38; sd 0.55). The PC and 2D TOF scored best and second best on all evaluated parameters and were significantly better compared with the other sequences.

Example of scan times for a heart rate of $60 \mathrm{bpm}$ with similar coverage: $2 D$ TOF:5:63min, 3D TOF:5:21 min, 3D PC: 7:30min, 3D BTFE: 5:10min and TRANCE: 6:04. In conclusion, MRA without use of contrast agents can be used as a preoperative examination for assessment of vessel status in candidates for kidney transplantation. A combination of a 2D TOF and a 3D $P C$ is recommended and can be performed within a reasonable scan time. GROWTH, METABOLISM AND COGNITIVE FUNCTION IN OFFSPRING OF MOTHERS WITH TYPE 1 DIABETES

S. Knorr' ${ }^{7}$ D.M. Jensen ${ }^{2}$, T.F. Ørntoft ${ }^{3}$, C.H. Gravholt, ${ }^{1,3}$

'Department of Endocrinology and Internal Medicine, Aarhus University Hospital, ${ }^{2}$ Department of Endocrinology, Odense University Hospital, ${ }^{3}$ Department of Molecular Medicine, Aarhus University Hospital

Background: Health results from a combination of genetic susceptibility and environmental influences. While genotype is determined at conception, phenotype is modulated and influenced by environmental and epigenetic factors throughout life.

During 1993-99, all pregnancies in women with pregestational type 1 diabetes (T1DM) were reported to a national registry in the Danish Diabetes Association. This registry contains detailed information of maternal demography, pregnancy outcome and diabetes status in a cohort of 900 women and their offspring.

Aim: To use this cohort to determine potential influence of a hyperglycaemic intrauterine environment and the genetic and epigenetic influences on health, growth and metabolism in childhood and adolescence - the metabolic memory at birth.

Methods: The present study consists of three related sub-studies. The participants are offspring of T1DM patients reported to the national registry and controls from the background population matched in age, gender and socioeconomic status. 
P12.02 Mette Bohl Larsen
P12.03 Anne Grethe Schioldan
Study 1: A clinical examination to determine the following endpoints: diabetes/pre-diabetes, pubertal development, overweight, cognitive function, body composition, blood pressure, dyslipidaemia, insulin levels, markers of autoimmunity (GAD-antibodies) and PCOS.

Study 2: A register-based study that examines the effect of intrauterine hyperglycaemia on congenital malformations, morbidity, mortality and socioeconomic status.

Study 3: A sub-group of index children and controls $(n=100)$ will be studied using DNA and RNA methodology enabling profiling of methylation status (DNA) of 450,000 CpG islands and the possible effect on expression (RNA) and phenotypic outcome.

DAIRY LIPIDS, PROTEINS AND THE METABOLIC SYNDROME - "DAIRY HEALTH"

\section{Bohl, S. Gregersen, K. Hermansen}

Department of Endocrinology, MEA, AUH, THG

Background: Obesity increases the incidence of metabolic syndrome (MeS). Food quality is considered important for this development. Dairy products comprise varying nutritional components. They contain a large amount of saturated fat, which traditionally is linked to risk of CVD. However, milk fat contains large amounts of short- and medium-chain saturated fatty acids (SMC-SFA), which may have beneficial effects. In addition, milk protein (particular whey) has shown beneficial effects on glucose disposal and inflammation. But intervention studies are lacking.

Hypothesis: Whey protein and SMC-SFA both improve insulin sensitivity, postprandial lipid metabolism, blood pressure and inflammatory stress in humans with MeS or abdominal obesity and possess preventive effects on the risk of developing CVD and T2DM. We hypothesize that they act synergistic.

Design: A randomized double-blinded, controlled parallel 12-week dietintervention trial stratified by MeS and abdominal obesity. Milk fat is made into butter with different contents of SMC-SFA as a result of two different cattle feeding strategies. Each participant will daily consume $63 \mathrm{~g}$ milk fat and $60 \mathrm{~g}$ protein (whey/casein). We recruit 64 subjects and randomize into 4 diets.

Trial participants attend 8 visits during 12 weeks. Visit 1 (screening blood samples, OGTT, anthropometry), visit 2 (meal test with 2 indirect calorimetry, 2 fat biopsies, blood sampling), visit 3 (dexa-scan, diurnal blood pressure), visit 4-6 (anthropometry), visit 7 (as visit 2), visit 8 (as visit 1+3).

Perspective: Results will contribute with new knowledge of potential synergistic effects of dairy products and may be used in future diet recommendations.

THE METABOLIC EFFECTS OF RESISTANT STARCH AND ARABINOXYLANS IN SUBJECTS WITH METABOLIC SYNDROME

\section{A.G. Schioldan, S. Gregersen, K.E.B. Knudsen, K. Hermansen}

Department of Endocrinology MEA, Aarhus University Hospital, THG

Background: Lifestyle-related diseases are among the most common causes of premature death. The Metabolic Syndrome (MeS) is a cluster of risk markers for type 2 diabetes (T2D) and CVD. The risk markers are dyslipidemia, elevated fasting glucose, abdominal adiposity and hypertension. Previous studies on resistant starch (RS) and arabinoxylans (AX) have shown beneficial effects on parameters characterizing MeS. The effects of a diet rich in both RS and AX have not been tested before.

Objective: To compare the effects of a diet rich in both RS and AX with a 
low fibre diet assessed by measurements of parameters characterizing MeS.

Design: A controlled, randomized cross-over study is conducted in 20 subjects with MeS. The subjects will undergo $2 \times$ four weeks dietary interventions. The fibre rich diet is characterized by a high content of $A X$ ( $35 \mathrm{~g} /$ day) and RS ( $20 \mathrm{~g} /$ day) and is compared with a low fibre diet ( $20 \mathrm{~g}$ DF/day). Weight stability is intended during the interventions.

The primary endpoint is postprandial triglyceride response to a standardized mixed meal. Secondary endpoints are insulin sensitivity (Matsuda Index, HOMA), fructosamin, incretin responses, diurnal blood pressure, inflammatory markers (hs-CRP, IL-6, adiponectin), energy expenditure (indirect calorimetry), liver fat content (MR spectroscopy) and gene expression in subcutaneus adipose tissue.

Perspectives: The epidemic growth of T2D raises an urgent need to find effective, non-pharmacologic methods to prevent MeS and T2D. This project will provide new insight into the synergistic potential of combining $A X$ and $\mathrm{RS}$ as dietary fibres in the prevention of Type 2 Diabetes and CVD. P12.04 Søren Møller
Madsen

P12.05 Karen Krogh Fjeldborg
MUSCLE TISSUE OXYGENATION

\section{S.M. Madsen}

Institut for Klinisk Medicin, Center for Funktionel Integrativ Neurovidenskab Muscle tissue oxygenation:

Our knowledge about the regulation of skeletal muscle perfusion is predominantly based on Krogh's work from 1910-20's. In cooperation with Erlang, Krogh assumed that each capillary is the only supplier to a cylindrical muscle tissue area, which surrounds the capillary. Subsequently, this was demonstrated in vivo in different animals. Here, Krogh demonstrated the capillaries' ability to open (so-called capillary recruitment), which occurred concurrently with an augmenting metabolic demand in a view to increasing the muscles' total capillary surface area, finally maximizing the diffusion of relevant substances (e.g. oxygen and glucose). However, the model has proven problematic, as for instance it does not take the complexity of oxygen exchange within the microvasculature into consideration.

The relation between tissue perfusion (measured in $\mathrm{mL}$ blood per $100 \mathrm{~mL}$ tissue per minute) and the availability of oxygen in tissue is traditionally derived from the flow-diffusion equation, developed by Bohr, Kety, Crone and Renkin. The equation, referred to as the Bohr-Kety-Crone-Renkin (BKCR) equation, describes the extraction properties of a single capillary for a given blood flow. When applied to tissue, the equation's predictions are therefore only accurate when muscle blood flow is homogenously distributed among tissue capillaries, and the number of perfused capillaries is independent of flow. In fact, PET and intravital microscopy studies demonstrate that muscle capillary transit times are highly heterogeneous during rest, and that optimal extraction of solutes at high flow rates depends on parallel homogenization of capillary transit times.

THE MACROPHAGE SPECIFIC SERUM MARKER SOLUBLE CD163 IS INCREASED IN OBESITY AND PARTIALLY NORMALIZED AFTER DIETARY INTERVENTION

\section{K. Fjeldborg}

Department of Endocrinology, MEA, Aarhus University Hospital

Introduction: Soluble CD163 (sCD163) is a new macrophage specific serum marker elevated in inflammatory conditions. Recently, it was found to be elevated in obesity and to be a strong predictor of the development of type 2 diabetes. We investigated whether dietary intervention and moderate exercise was related to changes in SCD163 and how SCD163 is associated 
to insulin resistance in obesity.

Design: Ninety-six obese subjects were enrolled in the study of which 62 followed a very low energy diet (VLED) programme for 8 weeks followed by 3-4 weeks of weight stabilization and 34 subjects followed a moderate exercise programme for 12 weeks. 36 lean subjects were included in a control group.

Results: SCD163 was significantly higher in obese subjects $(2.27 \pm 1.04$ $\mathrm{mg} / \mathrm{L})$ compared with lean $(1.62 \pm 0.41 \mathrm{mg} / \mathrm{L}, \mathrm{p}<0.001)$. Weight loss $(11 \%)$ induced by VLED resulted in an $11 \%$ reduction and partial normalization of $\mathrm{sCD} 163$ to $1.98 \pm 0.9 \mathrm{mg} / \mathrm{L}(\mathrm{p}<0.001)$. Exercise for 12 weeks had no effect on weight or circulating SCD 163. At baseline, SCD163 was significantly correlated with BMI, waist circumference, HOMA-IR (all $p<0.001$ ) and the leptin-to-adiponectin ratio, LAR ( $p<0.05)$. In a multivariate linear regression analysis, SCD 163, adiponectin and hs-CRP remained independently and significantly associated to HOMA-IR (all $p<0.05$ ). After further adjustment for waist circumference, only SCD 163 was associated with HOMA-IR $(\beta=0.19$, $\mathrm{p}<0.05) .<\mathrm{br} />$ Conclusion: We showed that sCD 163 is increased in obesity and may be partially normalized by dietary intervention, but not by moderate exercise. Furthermore, we confirm that sCD 163 is a good marker for obesity-related insulin resistance.

P12.06 Nilani Ramshanker

\section{GLUCOCORTICOID-INDUCED INHIBITION OF IGF-I ACTIVTY: EXPLORATION OF UNDERLYING MECHANISMS}

N. Ramshanker', M.H. Vendelbo', U. Espelund', N. Møller ', ${ }^{7}$, B. Honore ${ }^{3}$, J.O. Jørgensen ${ }^{1,2}$, N. Jessen ${ }^{4}$, J. Frystyk ${ }^{1,2}$

'Medical Research Laboratory, Department of Clinical Medicine, Faculty of Health, Aarhus University, DK-8000 Aarhus, ${ }^{2}$ Departments of Endocrinology and Internal Medicine, Aarhus University Hospital, DK-8000 Aarhus, ${ }^{3}$ Department of Biomedicine, Faculty of Health, Aarhus University, DK-8000 Aarhus, ${ }^{4}$ Research Laboratory for Biochemical Pathology, Institute of Clinical Medicine, Faculty of Health and Sciences, Aarhus University, DK-8000

Background: Long-term treatment with glucocorticoid (GC) induces a general state of catabolism and increases insulin resistance. The underlying mechanisms are insufficiently characterized. However, GC-induced changes in the biological activity of insulin-like growth factor I (IGF-I) appear to be of outmost importance. Conversely, stimulation of endogenous IGF-I by growth hormone ( $\mathrm{GH}$ ) therapy diminishes the catabolic effects of chronic GC treatment. By use of an advanced, in-house developed IGF-I specific bioassay, we have been able to demonstrate that the ability of GC to inhibit IGF-I action lies within the initial event in the IGF-I signalling cascade; i.e. GC inhibits IGF-I mediated IGF-I receptor phosphorylation.

Aim: To further investigate 1) whether GC induces IGF-I inhibiting substances in serum or interstitial fluid that block the ability of IGF-I to phosphorylate its receptor in vitro, 2) whether GC inhibits intracellular IGF-I signalling in vitro and in vivo and 3) the mechanisms by which $\mathrm{GH}$ counteracts the CG-mediated inhibition of IGF-I action.

Study design and methods: Randomized, double-blinded, placebocontrolled, cross-over study with 20 healthy subjects. 10 subjects will receive $371 / 2 \mathrm{mg}$ of prednisolone for 5 days, then washout for 4 weeks, and finally placebo for 5 days. The remaining 10 subjects will be investigated in the opposite order. Overnight fasting serum and whole blood will be collected on days 1, 3 and 5. On half of the subjects, muscle and adipose tissue biopsies will be collected on day 5 before and after an IV bolus injection of $\mathrm{GH}(0.5 \mathrm{mg})$. Suction blister technique before and after a hyperinsulinemic euglycemic clamp will be performed on the remaining half of the subjects. 
${ }^{1}$ Depart. of Endocrinology and Internal Medicine MEA, Aarhus University Hospital, ${ }^{2}$ Depart. of Internal Medicine, Regional Hospital Randers, ${ }^{3}$ Depart. of Internal Medicine M, Regional Hospital Silkeborg

Background: Resveratrol (RSV) reduces OVX-induced and immobilizationinduced bone loss in rodents. In studies of HMSC-TERT cells, ST2 cells, and HBMSCs from one fetus, RSV stimulates osteoblastic proliferation and differentiation dose-dependently. The aim of this study was to investigate whether RSV affects the proliferation and differentiation of bone marrowderived osteoblasts from adult human donors.

Methods: HBMSCs were derived from the bone marrow of 13 donors. Serum-free cell cultures from each donor were then stimulated with different doses of RSV $\left(10^{-8} \mathrm{M}-10^{-5} \mathrm{M}\right)$ and compared with unstimulated control cultures. We measured thymidine incorporation, methylene blue, alkaline phosphatase, procollagen type 1 (P1NP), and osteoprotegerin (OPG).

Results: RSV did not affect cell number (methylene blue, $P=0.80$ ). Thymidine incorporation differed significantly between the unstimulated control cultures and the cultures stimulated with RSV $(P<0.001)$. Post hoc Bonferroni correction revealed that only $1 \mu \mathrm{M}$ RSV reduced thymidine incorporation $(P=0.02)$. Alkaline phosphatase activity also differed significantly between the cultures $(P=0.002)$, with a significant reduction in the cultures stimulated

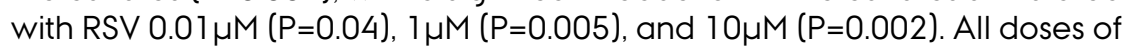
RSV increased both OPG and PINP, but not significantly $(P=0.85$ and $\mathrm{P}=0.28$, respectively)

Conclusion: In this study of HBMSCs RSV had no effects on cell number, but $1 \mu M$ RSV did inhibit proliferation in terms of thymidine incorporation. Effects on differentiation were ambiguous. Alkaline phosphatase activity was reduced, while PINP and OPG tended to increase with increasing doses of RSV, but not significantly.

GLUCAGON-LIKE PEPTIDE-1 (GLP-1): EFFECT ON KIDNEY HEMODYNAMICS AND RENIN-ANGIOTENSIN-ALDOSTERONE SYSTEM IN HEALTHY MEN

J. Skov ${ }^{7,2}$, A. Dejgaard', J. Frøkicer ${ }^{3}$, J.J. Holst ${ }^{4}$, T. Jonassen ${ }^{4}$, S. Rittig ${ }^{5}$, J.S. Christiansen $^{7}$

'Department of Enodocrinology and Diabetes, MEA, Aarhus University Hospital, ${ }^{2}$ Novo Nordisk A/S, ${ }^{3}$ Department of Clinical Medicine - Biomedical Radio Isotope Techniques, Aarhus University Hospital, ${ }^{4}$ Institute of Biomedicine, University of Copenhagen, ${ }^{5}$ The Department of Paediatrics, Aarhus University Hosptital

Glucagon-like peptide-1 (GLP-1) is an incretin hormone with multiple actions besides control of glucose homeostasis. GLP- 1 is known to cause natriuresis in men, but the effects on basic renal physiology in humans are still to be thoroughly described. Rodent studies have shown that GLP- 1 based treatment protects against diabetic nephropathy.

This study aimed to demonstrate the effects of GLP-1 on kidney haemodynamics, electrolyte handling and the renin-angiotensinaldosterone system.

Twelve healthy young men were examined in a randomised, controlled, double-blinded, single-day, cross-over trial to evaluate the effects of two hours of GLP-1 infusion. Glomerular filtration rate (GFR) and renal plasma flow (RPF) were assessed with ${ }^{51} \mathrm{Cr}$-EDTA and ${ }^{123}$ I-hippuran, respectively, using steady-state infusion technique with urinary sampling. 
GLP- 1 had no significant impact on GFR $[+1.9 \%, 95 \% \mathrm{CI}(-0.8 ; 4.6 \%)]$ nor RPF $[+2.4 \%, 95 \% \mathrm{Cl}(-3.6 ; 8.8 \%)$. Fractional excretion of lithium increased by $9 \%(p=0.013)$ and sodium clearance increased by $40 \%(p=0.007)$. Angiotensin II decreased by $19 \%(p=0.003)$, while renin, aldosterone and the urinary excretion of angiotensinogen showed no significant changes.

The results indicate that, although GLP- 1 markedly reduces proximal tubule sodium reabsorption, the acute effects on GFR and RPF are very limited in healthy men. The finding of GLP- 1's ability to reduce angiotensin II concentration is novel and we hypothesise that GLP-1, at least in part, functions through down-regulation of the renin-angiotensin system.

GROWTH HORMONE SIGNALING IN MUSCLE AND FAT: A COMPARATIVE STUDY OF SIGNAL MECHANISMS IN MUSCLE AND FAT, BETWEEN YOUNG AND OLD OF BOTH SEXES

\section{P.F. Vestergaard, J.O. Jørgensen}

Department of endocrinology and internal medicine, Aarhus University Hospital NBG

Introduction: Growth Hormone (GH) is the primary anabolic hormone during calorie restriction. $\mathrm{GH}$ is secreted in short bursts during night, and secreted at the onset of physical activity. GH facilitates hepatic IGF-I and IGF-II production, lipolysis whole body protein synthesis, and collagen synthesis.

During aging $\mathrm{GH}$ production decrees, which is associated with several physiological changes. Such as, reduced Lean body mass, increased fat mass and reduced strength. Several clinical trials have shown that $\mathrm{GH}$ supplementation can increase lean body mass. It is speculated that the mechanism behind this could be explained with changes in $\mathrm{GH}$ effects on muscle signaling. Furthermore, it is well known that females have a reduced hepatic IGF-I stimulated GH response compared to men. It could be speculated that this phenomenon, reduced $\mathrm{GH}$ sensitivity, is present in fat and muscle cells as well. Neither of the assumptions above has been investigated.

Objective: The purpose of this study was to investigate the $\mathrm{GH}$ facilitated response in muscle and fat between sexes and different ages.

Methods: 20 persons was include in this controlled randomized blinded intervention study, the persons was divided in 4 groups- 1) young Males $<30$ years, 2) young females $<30$ years, 3 ) elderly males $>60$ years, 4) elderly females $>60$ years. The intervention consisted of 2 days, one day the participants was given a bolus of $\mathrm{GH}$, the other day the participants was given a bolus of saline.

Results: Will be available autumn 2012

P13.03 Marianne Kjœr EFFECTS OF RESVERATROL ON LIVER FAT CONTENT AND FAT METABOLISM Poulsen IN OBESE MEN WITH NON-ALCOHOLIC FATTY LIVER DISEASE

\section{M.K. Poulsen, S. Nielsen}

Department of Endocrinology and Internal Medicine, Aarhus University Hospital

Introduction: Obesity causes marked health problems worldwide. The condition is linked with non-alcoholic fatty liver disease (NAFLD) and steatohepatitis (NASH); two potentially fatal diseases. In animals with NAFLD, Resveratrol (Rsv) imitates the beneficial effects of calorie restriction. The need of prevention and intervention strategies are required in humans.

Obejectives: To examine whether Rsv has the same beneficial effects in humans as described in animals. The hypotheses are that Rsv reduces VLDLTG secretion, reduces liver fat content and improves insulin sensitivity.

Methods: The study is a double-blind placebo-controlled trial of sixteen 
obese men with NAFLD treated with either Rsv or placebo for six months. A control group consists of eight obese men without NAFLD. The participants are examined at start with MR scan and whole-body scan to determine body composition; with MR spectroscopy to determine liver fat content and a metablic study day using different radioactive tracers and indirect calorimetry to determine FFA turnover, VLDL-TG turnover and insulin sensitivity. All examinations are repeated after six months of intervention, thereby determining possible long-term effects of Rsv on fat and glucose metabolism.

Results: The study is still ongoing, but scheduled to end in 2014. So far, only twelve participants are included; about half in the intervention group and half in the control group. No data have yet been analyzed.

P13.04 Thomas INVESTIGATIONS OF THE ANTI-INFLAMMATORY EFFECTS OF RESVERATROL Nordstrøm Kjœr STUDIED IN VIVO AND IN VITRO

\section{T. Nordstrøm Kjœer}

Department of Endocrinology MEA, Aarhus University Hospital

Background: Low-grade inflammation due to macrophage infiltration and hypoxia in adipose tissue is thought to be the link between obesity and metabolic syndrome (MS). Resveratrol (RSV), a natural anti-inflammatory compound, reduces inflammation and normalizes both insulin sensitivity and lifespan of diet-induced obese rodents. RSV also inhibits proliferation of vascular smooth muscle cells, which plays a role in developing cardiovascular disease.

Sirt 1 enzymes, which are thought to mediate the RSV effects in rodents, are present in human fatty tissue (HFT). In vitro, RSV reduces secretion of the macrophage-attracting MCP1 in HFT and reduces inflammation. Hypoxiainduced inflammation in HFT is completely reverted when exposed to RSV.

Aim: To investigate the anti-inflammatory effects of RSV in vivo and in vitro to clarify its potential in preventing or treating MS.

Method: In vivo study: 72 men with MS are treated with RSV 500 mg $\times 2$ or $75 \mathrm{mg} \times 2$ daily or placebo for 4 months. Before and after treatment, biopsies from skeletal muscle and adipose tissues are obtained. MR and DEXA scans are used to quantify body fat amount and body composition. Every other month blood tests are performed to follow inflammation, lipid profile, liver function, insulin sensitivity, RSV and RSV metabolites.

In vitro studies: Collaborators are studying cell cultures of 3T3 adipocyte, skeletal muscle and THP macrophage cell lines to find relevant RSVtargeting proteins. After identification of relevant proteins, further cell studies will be conducted.

Results: In vivo study: 69 men have been screened. 40 were eligible and included. To date, 19 have completed the four months of treatment and 5 have dropped out.

P13.05 Ann THE INFLUENCE OF BODY COMPOSITION ON GROWTH HORMONE Mosegaard Bak SIGNALLING, ENERGY METABOLISM AND INSULIN SENSITIVITY AFTER 72 HOURS OF FASTING

A.M. Bak, N. Jessen, J.O.L. Jørgensen, J. Rungby, N. Møller

Department of Medical Endocrinology, MEA, Aarhus University Hospital

Obesity is an increasing health problem in the modern world. Obese subjects have high levels of free fatty acids (FFAs) in their blood, and FFAs are protein sparing, but also cause increased insulin resistance. Prolonged fasting is equally associated with reduced sensitivity to insulin. Obesity leads to low growth hormone $(\mathrm{GH})$ levels, whereas fasting is accompanied by high $\mathrm{GH}$ and FFA levels. It is likely that obese individuals are more capable 
of fasting than lean individuals due to increased activation of $\mathrm{GH}$ signalling and subsequent protein sparing.

In lean and obese subjects, we aim to compare substrate metabolism and signalling pathways in fat and muscle tissue after stimulation with growth hormone and during fasting.

Material and methods: 8 lean (BMI 19-23) and 8 obese (BMI 32-40) healthy young men are examined on 4 occasions: (i) after an overnight fast of $12 \mathrm{~h}$ (ii) after $72 \mathrm{~h}$ of fasting (iii) after an overnight fast of $12 \mathrm{~h}$ with a bolus injection of $\mathrm{GH}(0,005 \mathrm{mg} / \mathrm{kg})$ at the beginning of the study day (iv) after 72 $\mathrm{h}$ of fasting with inhibition of lipolysis (T. acipimox $250 \mathrm{mg}$ ) during the last 12 hours of the fasting period.

The test subjects will go through a 6-hour study period which includes a 2hour hyperinsulinemic euglucemic clamp ( $30 \mathrm{mU} / \mathrm{m}^{2} / \mathrm{min}$ ). Biopsies from muscle and adipose tissue will be obtained and analyzed with molecular biology methods. Substrate metabolism will be assessed with tracer techniques and relevant hormones and metabolites will be measured.

BASAL METABOLIC PHENOTYPE CHARACTERIZATION OF CARRIERS OF A VARIANT IN THE GENE X

J. Støy', U. Kampmann Opstrup ', A. Hørlyck², H. Stødkilde-Jørgensen ${ }^{3}, C$. Christensen", I. Brands/und ${ }^{5}$, J. Rungby', A. Mengel, L. Buus', T. Hansen ${ }^{6}$, O. Borbye Pedersen ${ }^{6}$, N. Møller ${ }^{\text {T. }} 7$

'Department of Internal Medicine and Endocrinology, MEA, Aarhus University Hospital, 'Department of Radiology, Aarhus University Hospital, Skejby, ${ }^{3}$ MR center, Aarhus University Hospital, Skejby, , Department of Medicine, Vejle Sygehus, ${ }^{5}$ Department of Clinical Biochemistry, Vejle Sygehus, ${ }^{6}$ Marie Krogh Center for Metabolic Research, University of Copenhagen, ${ }^{7}$ M-Research Laboratories, Aarhus University Hospital

Recently, a variant in the gene $X$ was identified by exome sequencing of 2,000 Danes and subsequent association studies in 33,885 cases and controls with metabolic disorders. The aim of the present study is to carry out a metabolic phenotype characterization of carriers of the variant in the gene $X$.

Hypotheses: The disease-associated allele in the gene $X$ is associated with: 1. Insulin resistance, 2. Reduced beta cell function, 3 . Accumulation of fat in skeletal muscle and liver and increased whole-body fat content, 4. Osteopenia, 5. Hypertension, 6. Atherosclerosis and 7. Changes in the lipoprotein profile.

Materials and methods: 40 healthy males matched by genotype, age and $\mathrm{BMI}$ are invited for the following study protocol:

Day 1: DXA scan for evaluation of BMD in the hip, lumbar spine and forearm and for total fat mass and lean body mass. Evaluation of endogenous glucose production and free-fatty acid turnover by use of a glucose and palmitate tracer, muscle and adipose tissue biopsy, biochemical profiling and indirect calorimetry. Estimation of first- and second-phase insulin secretion in response to iv. administration of $25 \mathrm{~g}$ glucose. Assessment of insulin sensitivity by use of the hyperinsulinemic euglycemic clamp. Indirect calorimetry, blood sampling, and muscle and adipose tissue biopsy will be repeated during the clamp. The forearm technique will be used to assess a$\checkmark$ differences of metabolites across the forearm. A 24-hour ambulatory blood pressure measurement will be obtained.

Day 2: MR spectroscopy of the liver and anterior tibial muscle to assess fat content, and ultrasonography of the common carotid artery to assess carotis intima-media thickness. 
P14.01 Katherina Farr LUNG TOXICITY AND SURVIVAL IN RADICAL RADIOTHERAPY OF STAGE III NON-SMALL-CELL LUNG CANCER

\section{K.P. Farr, A.A. Khalil, M.M. Knap, C. Grau}

Department of Clinical Oncology, Aarhus University Hospital, Denmark

Background: The aim of the study was to investigate clinical and dosimetric factors contributing to the development of radiation pneumonitis (RP) and its influence on patient survival.

Materials and methods: 150 consecutive patients receiving radiotherapy for non-small-cell lung cancer (NSCLC) from 2007 to 2010 were analysed. RP was graded by CTC-AE version 3.0. The clinical and dosimetric parameters related to RP were analysed.

Results: Preliminary data from the first 103 patients, with median follow-up of 16 months, showed that mild RP was observed in 21 patients and moderate to severe RP was observed in 16 patients, including one death due to RP. CT changes were observed in 76 patients, in 59 patients they were confined to high dose target, while 17 patients had out-of-target changes. Median time to the onset of symptoms was 4.5 months ( $\mathrm{Cl} 95 \%$ 4.2-4.9). All the severe RP incidents occurred in the first 6 months. The median OS of this group was 12 months, which was significantly lower than for patients with mild RP (21 months, $p=0.004)$. Among dosimetric factors, mean lung dose was significantly associated with the incidence of severe $\operatorname{RP}(p=0.03)$. Clinical factors, such as weight loss, comorbidity and lung dysfunction did not show any significant association, but the trend was towards severe RP. A statistical analysis of the entire cohort of 150 patients is underway.

Conclusion: Severe RP is a significant sideeffect of radiotherapy and is in some cases potentially lethal. The incidence of severe RP in our study is similar to the published data. The mortality rate of patients with severe RP is extremely high. Further studies on methods to reduce the lung toxicity are needed.

P14.02 Christina Daugaard Lyngholm
LONG-TERM FOLLOW-UP OF LATE MORBIDITY, COSMETIC OUTCOME AND BODY IMAGE AFTER BREAST CONSERVING THERAPY. A STUDY FROM THE DANISH BREAST CANCER COOPERATIVE GROUP (DBCG)

\section{C.D. Lyngholm, P.M. Christiansen, T.E. Damsgaard, J. Overgaard}

Department of Experimental Clinical Oncology, Breast and Endocrine Surgery Unit, Department P, and Department of Plastic Surgery, Aarhus University Hospital

Background: The Danish Breast Cancer Cooperative Group (DBCG) introduced BCT as a standard treatment in Denmark in 1990. The aim of this study was to investigate late morbidity and cosmetic outcome after BCT and to associate these with patient, tumor and treatment characteristics.

Material and methods: A total of 214 patients treated with BCT from 1989 to 2002 participated in a follow-up visit comprising an interview, clinical examination, photos of the breast region and completion of a questionnaire.

Results: Median follow-up time was 12 years (range 7 to 20). Moderate to severe fibrosis was found in $23 \%$ of patients and was associated with chemotherapy (OR: $2.6, \mathrm{Cl}[1.1 ; 5.9], \mathrm{p}=0.02$ ) and large breast size (OR: 3.2 , $\mathrm{Cl}[1.6 ; 6.4], \mathrm{p}=0.001)$. Patients with a satisfactory cosmetic outcome, when assessed by a clinician, were characterized by small tumors (OR 3.2, CI [1.5; 6.8], $\mathrm{p}=0.003$ ) and small- to medium-sized breasts (OR 2.0, $\mathrm{Cl}[1.1 ; 3.5]$, $\mathrm{p}=0.002$ ). Fifty percent of patients scored good or excellent when assessed by a clinician compared to $88 \%$ when reported by the patients themselves. Patients satisfied with their own cosmetic outcome were the younger 
P14.03 Martin Bjerregård Pedersen

P14.04 Ninna Aggerholm Pedersen patients ( $<50$ years; OR $3.2, \mathrm{Cl}[1.1 ; 8.6] \mathrm{p}=0.03$ ) with no postoperative complications (OR 3.3, $\mathrm{Cl}$ [1.2; 9.2], $\mathrm{p}=0.02$ ).

Conclusion: The majority of patients were satisfied with their cosmetic outcome after BCT, whereas only half of the patients were found to have a good or excellent cosmetic outcome when assessed by the clinician. The level of moderate to severe fibrosis was acceptable compared to both national and international studies with similar patient compositions.

DIGITAL PATHOLOGY FOR THE ASSESSMENT OF TISSUE MICROARRAYS IN PERIPHERAL T-CELL LYMPHOMAS

M.B. Pedersen' , R. Riber-Hansen ${ }^{2}$, P.S. Nielsen ${ }^{2}$, K. Bendix ${ }^{2}$, S.J. Hamilton-

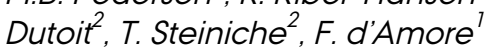

'Department of Hematology Aarhus University Hospital, ${ }^{2}$ Institute of Pathology, Aarhus University Hospital

Tissue microarray (TMA) is a well established histopathological technique for high-throughput analysis of protein expression. We report on the use of virtual TMAs to validate the adequacy of proposed TMA construction protocols for use in peripheral T-cell lymphomas (PTCL) and to determine the number of cores needed to represent whole slide (WS) results. In addition, we applied digitalized image analysis (DIA) to compare automated quantification of immunohistochemical staining (IHS) with traditional manual quantification.

IH stained WS were digitalized and a virtual TMA with six $1 \mathrm{~mm}$-diameter cores per case was designed to analyze 30 PTCL cases. We compared agreement scoring IHS for CD2, CD30 and Ki67 in WS versus TMA cores by using different quantification approaches i.e. 1) DIA and 2) manual stereological counting. In addition, we assessed the number of TMA cores required to reflect the results derived from WS

The number of digitally simulated TMA cores required to represent matched WS was found to be 3 or 4 , depending on the biomarker under study. Agreement, evaluated by Bland-Altman and correlation plots using 4 TMA cores, was good between both manually and digitally quantified WS and corresponding results comparing DIA WS with DIA TMA cores.

We show that use of a digitally simulated virtual TMA is a cost-effective and tissue-saving way to validate the effectiveness of planned TMA studies. This approach is applicable in determining the number of TMA cores needed to adequately represent the tumor heterogeneity found in PTCL. Furthermore, quantification by DIA matches manual counting for assessment of biomarker expression and is a useful analysis tool for TMA-based studies.

THE INFLUENCE OF HYPOXIA ON SARCOMA PATIENT RESISTANCE TO CHEMOTHERAPY AND IRRADIATION THERAPY

N. Aggerholm Pedersen ${ }^{1,2}$, A. Safwat ${ }^{2}$, J. Alsner ${ }^{7}$, O. Steen Nielsen ${ }^{3}$

${ }^{1}$ Department of Experimental Clinical Oncology, Aarhus University Hospital, ${ }^{2}$ Department of Oncology, Aarhus University Hospital, ${ }^{3}$ Faculty of Health, Aarhus University

Background: About 300 new cases of sarcomas are identified each year in DK. For some of these patients, the prognosis is poor; in part because of poor response to chemotherapy and radiotherapy. Our department has previously shown that hypoxia inside the tumours is an indicator of poor prognosis of sarcomas. In head and neck cancer, a hypoxia-induced gene profile (HIGP) has been identified. The aim of the present study is to investigate in human sarcomas whether hypoxia can be identified by the presence of a HIGP and to evaluate the impact of this profile on overall survival and response to treatment. 
Material and methods:

Study I: An already validated HIGP of head and neck cancer will be explored in biopsies from STS patients (cohort 1; 30 patients) by using qPCR and microarrays. The HIGP obtained from these result will be correlated to oxygen tension measurement (from the tumour) performed on each patient.

Study II: A cohort of 60 STS patients (cohort 2) selected from the sarcoma database are matched to cohort 1 according to patient characteristic and tumour histology. The presence of the HIGP will be correlated to the OS.

Study III: Validation of the HIGP is done in an independent data set. A cohort of 600 patients selected from the sarcoma database according to tumour histology and treatment modality (cohort 3) is tested for HIGP and correlated to response to chemotherapy and OS.

Conclusion and perspectives: The HIGP found in head and neck cancer may be a universal classifier for other cancer types. If a HIGP correlates with overall survival or is predictive in regard to response to treatment in STS, this could be the target for development of new treatment modalities.

P14.05 Steffen Falgreen COMMONLY USED SUMMARY STATISTICS IN CELL LINE BASED DRUG DOSE Larsen RESPONSE STUDIES ARE INFLUENCED BY DRUG EXPOSURE TIME

\section{S. Falgreen, M. Bach, H.E. Johnsen, K. Dybkœr, M. Bøgsted}

Department of Haematology, Aarhus University Hospital

One of the primary methods for discovering and evaluating new anticancer drugs is dose response experiments conducted on human cancer cell line panels. Conventionally used summary statistics for such experiments are systematically biased by drug exposure time, so that fast proliferating cell lines appear overly sensitive. This bias is often disregarded in large cell lines screens, which may lead to suboptimal drug evaluations.

In the present PhD study, I have established a differential equation modelling growth of cell lines affected by an anticancer drug and used it to develop a method capable of adjusting dose response data for the influence of drug exposure time.

A doxorubicin dose response screen of 16 diffuse large B-cell lymphoma and 12 multiple myeloma cell lines is used to illustrate the bias correction. The correlation between doubling time and drug resistance was decreased by $0.21(95 \% \mathrm{Cl} 0.07,0.35)$ between the original and adjusted models.

By use of the seminal growth inhibition screen $\mathrm{NCl} 60$, we show that it possible to adjust existing dose response data to account for differences in doubling time between cell lines. This is done for 1700 compounds, resulting in an average decrease of $0.145(95 \% \mathrm{Cl} 0.141 ; 0.2)$ in the correlation between doubling time and drug resistance.

In conclusion, bias corrected drug evaluations have the potential to renew previous resistance predictions and drug identification studies as well as improve future drug evaluation studies.

P14.06 Marie Louise CHARACTERISATION OF INNATE IMMUNE CELL SUBTYPES IN ULCERATED Bønnelykke- MELANOMA

Behrndtz

M.L. Bønnelykke-Behrndtz, T. Engberg Damsgaard, H.J. Møller, T. Steiniche, H. Schmidt

Aarhus University Hospital

Ulceration is one of the strongest known prognostic markers for poor survival in primary melanoma. It is therefore surprising that adjuvant interferon-alpha seems to improve the overall survival of patients with ulcerated melanomas in subgroup analyses.

Little is known about why melanomas ulcerate and how interferon works in 
these patients. We hypothesize that ulcerated melanomas form a subgroup displaying increased proliferation, hypoxia and angiogenesis and that infiltration of innate immune cells is pivotal in creating this pro-tumoural microenvironment. However, innate immune cells may apparently be reversed and have an anti-tumoral impact on the microenvironment in response to interferon-alpha.

In the present study, ulceration and epidermal involvement are evaluated in a group of 200 patients with ulcerated melanoma and a matched group of 200 patients with non-ulcerated tumours. The study endpoints are recurrence free and overall survival.

We use immunohistochemistry to analyze general tumour proliferation (Ki67), tumour hypoxia (HIF-1) and angiogenesis (VEGF). The location and density of subtypes of the innate immune system, including tumourassociated neutrophils (CD66b), tumour-associated macrophages (Cd163, Tie-2) and dendritic cells (CD123 and DC-LAMP), are linked to matrixdegradative factors (MMP9, NE), proliferative (NE) and pro-angiogenic factors (MMP, Ang-2).

We expect our findings to bring important prognostic information and contribute to a better understanding of the tumour biology of ulcerated melanoma.

P14.07 Anja Pagh THE VALUE OF ROUTINE FOLLOW-UP AFTER TREATMENT FOR HEAD AND NECK CANCER. A NATIONAL DAHANCA STUDY

[.A. [Pagh', T. Vedtofte', C.D. Lynggaard ${ }^{3}$, N. Rubek ${ }^{4}$, M. Lonka', J. Johansen ${ }^{6}$, E. Andersen ${ }^{2}$, C.A. Kristensen ${ }^{3}$, C.V. Buchwald ${ }^{4}$, M. Andersen', C. Godballe', J. Overgaard', C. Grau ${ }^{8}$

${ }^{1}$ Department of experimental clinical oncology (EKO), ${ }^{2}$ Department of oncology, Herlev, ${ }^{3}$ Department of oncology, Rigshospitalet, ${ }^{4}$ Department of ORL, H\&N Surgery, Rigshospitalet, ${ }^{5}$ Department of Ear, Nose and Throat, Aalborg, ${ }^{6}$ Department of oncology, Odense, ${ }^{7}$ Department of Ear, Nose An throat, Odense, ${ }^{8}$ Department of oncology, Århus, ${ }^{9}$ Dept.of oncology, Aalborg

Background: The post treatment surveillance is well integrated in the oncologic care tradition, based on the risk of developing recurrent disease or new primary tumors in treated patients. Furthermore, follow-up (FU) serves as an opportunity to monitor treatment effects and to provide clinical care of side effects. In this study, we measured the activity and effectiveness of routine FU and assessed the value of FU from the perspectives of both physicians and the patients.

Patients and methods: During a period of six weeks a prospective cross section cohort of 624 patients attending regular FU were enrolled. All patients had received intended curative treatment for head and neck cancer (HNC) and were all followed according to DAHANCA guidelines.

Results: The majority (91\%) of the 619 visits was planned, and $75 \%$ of all visits included either tumor or treatment related problems. Suspicion of recurrent disease led to further diagnostic work-up in 80 (13\%) visits. A total of 29 recurrences were found, and of these 7 (25\%) were asymptomatic. Treatment-related normal-tissue problems were addressed in $72 \%$ of all visits, and among these $18 \%$ required intervention. Although the majority of problems occurred within a few years after treatment, $39 \%$ of patients seen after 3 years also had problems. A total of $97 \%$ of patients expressed satisfaction with the planned FU.

Conclusion: Only few relapses are found in asymptomatic patients at routine FU, with only one silent recurrence detected per 99 FU visits. However, HNC survivors have a substantial need for management of sequelae and rehabilitation. In this context, a centralized routine FU may still be worthwhile. 
P14.08 Helene Myrtue THE CELL SPECIFIC METHYLOME PROFILE PAVES THE WAY FOR CANDIDATE Nielsen BIOMARKERS OF DIAGNOSTIC AND PREDICTIVE VALUE FOR PATIENTS WITH PHILADELPHIA CHROMOSOME NEGATIVE MYELOPROLIFERATIVE NEOPLAMS

\author{
H.M. Nielsen ", 2 , C.L. Andersen' , L.L. Hansen ${ }^{2}$, H.C. Hasselbalch ${ }^{3}$, K. Grønbcek ${ }^{7}$ \\ ${ }^{1}$ Department of Hematology, Rigshospitalet, ${ }^{2}$ Department of Biomedicine, \\ Aarhus University, ${ }^{3}$ Department of Oncology and Hematology, Roskilde \\ hospital
}

Philadelphia chromosome negative myeloproliferative neoplasms may depict a biologic continuum starting from essential thrombocytosis (ET) to polycytemia vera (PV) and may end with the advanced myelofibrotic (MF) stage, where the majority of patients suffer from bone marrow fibrosis, extramedullary hematopoiesis and hypermetabolic syndrome; or the condition may transform into acute myeloid leukaemia. We hypothesized that MF patients would benefit from the FDA approved Vorinostat treatment and that specific DNA methylation changes can be used as biomarkers for predicting response to treatment. In addition, we hypothesize that methylation of driver genes of MF patients may be identified. $63 \mathrm{ET} / \mathrm{PV}$ patients and $15 \mathrm{MF}$ patients are enrolled in this phase II clinical study, where they have been given Vorinostat for six months. Blood samples have been taken continuously. DNA was extracted from specific cell types including CD34+ stem cells $(n=6)$, granulocytes $(n=15)$ and mononuclear cells $(n=15)$. The genome-wide DNA methylation profile before treatment will be established using the Infinium 450K Methylation BeadChip (Illumina) platform. The most differential methylated genes found in MF patients will subsequently be analyzed in ET and PV. As we compare the DNA methylation profiles between the specific cell types, we will be able to evaluate whether peripheral blood granulocytes and mature mononuclear cells carry similar changes as their malignant progenitors. In addition, our study may identify genes driving the malignant clone. Importantly, we will most likely be able to uncover DNA methylation biomarkers of predictive value with this unique set-up.

P15.01 Lene Sofie

DO RESULTS FROM CLINICAL TRIALS IN ACUTE MYELOID LEUKAEMIA

Granfeldt

Østgård REFLECT CLINICAL REALITY? A DANISH NATIONAL COHORT STUDY OF 813 PATIENTS

\title{
L.S. Ostgård' , M. Nørgaard", H. Sengeløv ${ }^{3}$, J. Nørgaard ${ }^{7}$ \\ ${ }^{1}$ Department of Hematology, Aarhus University Hospital, ${ }^{2}$ Department of Clinical Epidemiology, Aarhus University Hospital, ${ }^{3}$ Department of Hematology, Rigshospitalet
}

Previous studies have documented the underrepresentation of elderly and minorities in clinical trials of leukaemia. If characteristics of patients included in clinical protocols differ markedly from the characteristics of the majority of patients treated off-protocol, the external validity of clinical trials may be threatened.

The Danish National Acute Leukaemia Database (ALDB) includes detailed data on a large well-defined non-selected population (coverage $>95 \%$ of AML pts diagnosed since 2000). In Denmark, AML patients have been included in 3 different European multicenter protocols. We analyzed a cohort of $2624 \mathrm{AML}$ patients. We compared patients treated with curative intent according to the protocols $(n=391)$ with patients treated with curative intent off-protocol $(n=422)$ with regard to characteristics, possible prognostic factors and survival. For comparable groups, we divided patients into 2 age groups.

Performance status score (WHO), LDH-level, presence of secondary AML and performance of alloHCT were all unevenly distributed. We also found a superior survival in on-protocol patients under 60 years. After controlling for 
possible prognostic factors, protocol participation still seemed to be associated with longer $O S$ in patients under 60 years $(\mathrm{HR} 0.66,95 \% \mathrm{Cl} 0.48$ $0.99, p=0.02$ ), but not in patients 60 years or older (HR $1.17,95 \% \mathrm{Cl} 0.87$ 1.57).

Intensively treated patients included in AML trials in Denmark had a more favourable profile than patients treated with standard regimens. Populationbased studies may thus play an important role in examining some aspects of prognosis in AML. In this context, the Danish ALDB has proven to be a valuable data source.

P15.02 Kristine Raaby Jakobsen

\section{CHARACTERISATION OF CANCER STEM CELLS IN NSCLC CELL LINES \\ K. Raaby ${ }^{7,2}$, A.L. Nielsen', B.S. Sørensen ${ }^{2}$ \\ 'Department of Biomedicine, ${ }^{2}$ Department of Clinical Biochemistry, Aarhus University Hospital}

Lung cancer has a very poor prognosis, and relapse from chemotherapeutic treatment is often seen. It has been proposed that the high incidence of relapse is due to a chemotherapeutic resistant population of tumour cells that is either present before the initiation of treatment or develops during the treatment. These cells are called Cancer Stem Cells (CSCs) or Tumor Initiating Cells (TICs). Experiments have shown that it is possible to provoke the generation of chemotherapy-resistant cells with stem cell-like features, when certain Non-Small Cell Lung Cancer (NSCLC) derived cell-lines are grown in serum depleted medium supplemented with growth factors and treated with chemotherapy.

There is a lack of consensus on how to distinguish CSCs from other cells within a cancer cell population. Our aim is to generate a population of CSCs expressing the stem cell markers CD133, CD326, Nestin, Nanog, ALDH and Oct4 from the lung adenocarcinoma cell lines A549 and HCC827. The cells will be sorted for the expression of the membrane proteins CD133 and CD326, and the population expressing both markers will be used for subsequent expression and epigenetic analyses including studies of DNAmethylation and histone modifications.

Aberrant expression of the EGF system has shown importance in the development of lung cancer, and we are interested in changes seen in this system during the dedifferentiation into the CSC form. The goal is to find epigenetic changes in genes encoding receptors and ligands from the EGF system that correspond to the development of therapy resistance and hereby find epigenetic markers of therapy resistant cells that can be applied as a diagnostic marker.

P15.03 Sara Correia FUNCTIONAL ANALYSIS OF MICRORNA-DEPENDENT CHEMOSENSITIVITY IN Marques B-CELL CANCERS BY LENTIVIRAL TRANSDUCTION IN HUMAN CANCER BCELL LINES

S.C. Marques', J.G. Mikkelsen' , H.E. Johnsen ', M. Bøgsted ', K. Dybkaer ${ }^{7}$

${ }^{1}$ Department of Haematology, Aalborg Hospital Science and Innovation Center, Aalborg Hospital, Aarhus University Hospital, ${ }^{2}$ Department of Biomedicine, Aarhus University

Approximately 1,000 Danes are annually diagnosed with B-cell-derived bone marrow or lymph node malignancies and receive chemotherapy attempting to eliminate the tumour and cure patients. At present, treatment strategies are based on diagnostic entities, currently determined by age and performance status rather than tumour biology. The overall survival rate remains dismal, mainly due to treatment resistance. Individualized treatment guidance is required to improve treatment outcome by identifying patients who are unlikely to do well with conventional treatments and may benefit 
from novel agents. MicroRNAs, small non-coding RNA molecules, are involved in a large number of biological processes like proliferation, differentiation and apoptosis, and alterations in their expression have been shown to contribute to the development and resistance of solid tumours and haematological malignancies. The hypothesis of this project is that a range of deregulated microRNAs are involved in the development of drug resistance. The project aims are to use global microRNA expression profiling, drug screens and restricted regression techniques to generate chemosensitivity/-resistance signatures for doxorubicin by using related bioinformatic approaches, as previously used for mRNA-based prediction of melphalan sensitivity in myeloma patients, and to manipulate the microRNA expression in B cells with an optimized lentiviral vector system. We expect to be able to experimentally validate the predicted importance of each specific microRNA on chemosensitivity and therefore to establish significant predictive correlations between chemotherapy response and microRNA expression.

P15.04 Katja Maretty THE POPULATION-BASED AARHUS SARCOMA REGISTRY: VALIDITY, Nielsen COMPLETENESS AND INCIDENCE OF BONE AND SOFT TISSUE SARCOMAS IN WESTERN DENMARK

K. Maretty-Nielsen ${ }^{1}$, N. Aggerholm-Pedersen ${ }^{1,2}$, J. Keller ${ }^{3}$, A. Safwat ${ }^{2}$, S. Bcerentzen ${ }^{4}$, A.B. Pedersen ${ }^{5}$

${ }^{1}$ Department of Experimental Clinical Oncology, Aarhus University Hospital, ${ }^{2}$ Department of Oncology, Aarhus University Hospital, ${ }^{3}$ Department of Orthopedic Surgery E5, Aarhus University Hospital, ${ }^{4}$ Department of Pathology, Aarhus University Hospital, ${ }^{5}$ Department of Clinical Epidemiology, Aarhus University Hospital

Aim: The aim of the present study was to validate the data in Aarhus Sarcoma Registry (ASR) and examine the incidence of sarcomas in western Denmark by using validated, population-based registry data.

Methods: This study was based on bone and soft tissue sarcoma patients treated at the Sarcoma Centre of Aarhus University Hospital from 1 January 1979 to 31 December 2008. All medical files (golden standard) were reviewed using a standardized form. The Danish Cancer Registry (DCR) was used as reference to assess completeness of patient registration in ASR. The crude and $\mathrm{WHO}$ age-standardized incidence as well as age-, gender- and annual-specific incidences were estimated.

Results: The validation process added 385 to the 1442 patients that were registered in ASR ( $26.7 \%$ increase). Before validation, an average of $70.5 \%$ of data among the variables was correct. The average completeness of the registered variables was $83.7 \%$ before validation and improved to $99.3 \%$ after validation. The 1827 patients in ASR after validation include $85.3 \%$ of the patients registered in DCR. The overall WHO age-standardized incidence for sarcoma in the trunk and extremities in western Denmark in the period 1979-2008 was 2.2 per 100,000, being 0.8 for bone sarcomas and 1.4 for soft tissue sarcomas.

Conclusion: The validation process significantly improved the completeness of variables and the quality of data in ASR. With a completeness of $85.3 \%$, ASR is now a population-based, validated and valuable tool for epidemiological research and quality-improvement in sarcomas. It is our recommendation that documented validation of registries should be a prerequisite for publishing studies from them.

P15.05 Mohamed ACCELERATED RADIOTHERAPY WITH OR WITHOUT NIMORAZOLE IN A Ahmed Hassan RANDOMIZED MULTICENTER TRIAL

\author{
M.A. Hassan', J. Alsner', T. Shouman ${ }^{2}$, C. Grau', J. Overgaard ${ }^{7}$ \\ 'Department of Experimental Clinical Oncology, Aarhus University Hospital,
}


Denmark., ${ }^{2}$ National Cancer Institute, Cairo University, Egypt

Objective: The study aims to introduce a new way of improving the effect of radiotherapy in HNSCC and identify those patients who are most likely to benefit from the modification of hypoxia during the radiotherapy treatment.

Background: Significant improvement in loco-regional control and diseasespecific survival by radiotherapy for patients with head and neck cancer could be achieved by reducing the overall treatment time and modification of hypoxia by Nimorazole. So, it is expected that the optimal treatment option is reducing the overall treatment time with concomitant use of Nimorazole. A recent study could identify a hypoxia profile consisting of 15 genes that may be able to distinguish hypoxic tumors from non-hypoxic tumors in vivo. Quality assurance is an integrated part of any study, particularly if it is an international study involved in multicentres in different countries.

Material and methods: A stratified, randomized phase III trial (sponsored by the International Agency of Atomic Energy) of patients with HNSCC randomized to accelerated radiotherapy \pm Nimorazole. The QA procedures are applied to ensure consistency and validity of the data. Biological materials are collected from the participating centres for RNA extraction and quantitative PCR analysis will be done as well as immunohistochemistry for HBV associated $\mathrm{p} 16$ expression.

Results: The trial started on 1 March 2012. 38 patients were recruited from 4 centres (Islamabad, Cairo, Karachi and Peshawar) until September 2012. The data collection is conducted through electronic forms on the trial website. The treatment documentation of the first recruited patients in each centre has been sent for quality assurance review.

P15.06 Anne Bodilsen DOES MARGIN SIZE MATTER IN BREAST CONSERVING SURGERY? A RETROSEPCTIVE COHORT STUDY

\section{A. Bodilsen, P. Christiansen}

Surgical Research Unit, Department P, Aarhus University Hospital

Introduction: Breast conserving surgery is the treatment of choice for about $70 \%$ of Danish women with invasive breast cancer. In this context, it is important to preserve the breast without increasing risk of recurrence. Margin width may be of importance in this matter. Previous research has mainly focused on correlation between margin width and local recurrence. Other endpoints have been less intensely studied. Due to a limited number of patients in former studies, an indebt analysis of factors which in correlation with margin width increase risk of recurrence has not been performed either. In addition, risk or benefits of re-excision in case of insufficient margin is widely unknown.

Aim: To study effect of margin width on recurrence and mortality and to identify high-risk groups based on tumour variables and patients characteristics. Furthermore, we intend to explore prevalence and effect of re-excision.

Method: Included are all women treated for invasive breast cancer in Denmark during 1996-2009. Data is collected from the National Health Registry, Pathology Database and Danish Breast Cancer Cooperation Group.

Results: 17,096 women are identified and included in the cohort. Preliminary results found $2.5 \%$ with local recurrence, $0.8 \%$ with regional recurrence and $4.0 \%$ with distant metastasis. $3.5 \%$ had died. Further analysis will be initiated in the near future.

Perspective: The aim is to evaluate the prognostic significance of margin width as well as contribute to a better understanding of factors influencing 
outcome after surgical treatment for invasive breast cancer.

P15.07 Lotte Andreasen
THE SEARCH FOR GENETIC MARKERS TO PREDICT THE CANCER-LIKE DISEASE, PTD, WHICH MIGHT DEVELOP AFTER AN ABNORMAL HUMAN PREGNANCY

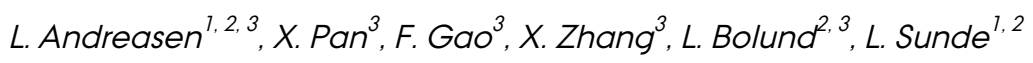

${ }^{1}$ Department of Clinical Genetics, Aarhus University Hospital, Skejby Sygehus, Denmark., Department of Biomedicine, Aarhus University, Aarhus, Denmark., 'B Beijing Genomics Institute/HuaDa-Shenzhen, Shenzhen, China.

Introduction: Hydatidiform mole (HM) is an abnormal human pregnancy characterized by nonexistent, or abnormal, embryonic development and hydropic enlargement of the placenta.

After a HM pregnancy, there is a risk of developing a cancer-like disease "persistent trophoblastic disease" (PTD). If untreated, the condition is lethal. However, most affected individuals are cured by cancer chemotherapy. About $10 \%$ of HMs lead to PTD, and after a mole pregnancy the women are encouraged to follow a control programme for 6-12 months. During that time, the women are strongly advised not to initiate a new pregnancy. The etiology of HM and PTD, is virtually unknown.

Purpose: We aim to investigate the methylation pattern in $\mathrm{HMs}$ that give rise to PTD. The methylation pattern of the human genome is one of the cell's mechanisms to regulate gene expression and is important in cancer development. We hope to identify prognostic markers that can predict which women will develop PTD and will need chemotherapy after a HM pregnancy. We also hope our results will add to the knowledge about carcinogenesis in general.

Method: The employed technology, reduced representation bisulfite sequencing (RRBS), is based on next generation sequencing and identifies the methylation patterns in high resolution. We are comparing HM samples that developed into PTD with HM samples not resulting in PTD. The analysis is carried out at BGI, China.

Results: We are currently analysing the generated data.

Discussion: We hope to be able to distinguish the HMs developing into cancer from the non-invasive HMs.

P15.08 Mette Winther ANALYSIS OF THE CLINICAL IMPACT OF A NOVEL CHEMOTHERAPY AND IRRADIATION SENSITIVITY PREDICTOR IN GASTROESOPHAGEAL CANCER

\section{Winther, M. Nordsmark, J. Alsner}

Dept. of Experimental Clinical Oncology and Dept. of Oncology, Aarhus University Hospital.

Background: Patients with gastroesophageal cancer (GEC) have a very poor prognosis with an overall survival rate at $25-40 \%$. Large variability still persists among patients in response to standard treatments. In order to improve treatment regiments and prognosis for these patients, new individual and predictive strategies such as microarray profiling are needed.

Aim: The aim is to determine and validate predictive miRNAs for GEC treatment response.

Methods: In retrospectively collected diagnostic and pre-treatment tumor biopsies (formalin-fixed paraffin-embedded specimens) from 98 patients with GEC, miRNA gene expression will be studied in order to predict sensitivity to different chemotherapeutic agents. Patients have received regimens of concomitant chemotherapy and irradiation with or without 
surgery or perioperative chemotherapy in the time period 1994-2011.

Medical Prognosis Institute, DK, has developed a novel bioinformatics approach in which they have identified different predictive miRNA biomarkers that contribute to an index of sensitivity. Gene expression profiling is performed using Affymetrix miRNA GeneChips for FFPE specimens. A regularity-approved DNA Chip Platform (Affymetrix DX2), Agilent's Bioanalyzer and Nano-Drop are available for the analysis.

The primary endpoint is pathological response and the secondary endpoint is overall survival.

Results: Data analysis is ongoing.

Conclusion: Results obtained using new microarray-based technologies in order to predict treatment response in patients with GEC will be presented. The perspective is to contribute to the development of individual anticancer therapies by the use of microarray profiling.

P16.01 Martin Skovmos RESPIRATORY GATED IGRT USING FIDUCIAL MARKER. TREATMENT Nielsen $\quad$ PLANNING AND IMAGE GUIDANCE ACCURACY

M.S. Nielsen, J. Carl

Department of Medical Physics, Oncology, Aalborg Hospital, Aarhus University

Purpose:

Image Guided Radiotherapy (IGRT) with fiducial markers can be used to limit treatment margin and possibly limit toxicity after radiotherapy. Fiducials like gold marker seeds (GM) and NiTi stents can be inserted into an organ in motion and used for respiratory gated Image Guided Radiotherapy (gated IGRT). This study will describe the uncertainty in fiducials definition (GM and NiTi stents) on treatment planning using 4DCT and gated IGRT.

Method:

A commercially available BrainLAB gating phantom has been modified to be used with GM seeds and NiTi stents. A software script is developed to automatically find fiducial markers on 4DCT scans. Precision in marker detection is evaluated as residual between centre of mass detected on $4 D C T$ relative to actual physical fiducial position. Detection accuracy is evaluated for fiducials with orientation at 0,45 and 90 degrees relative to the superior-inferior respiratory movement at a slice thickness of $1.25 \mathrm{~mm}$ and $2.50 \mathrm{~mm}$.

Precision using gated IGRT is verified by fast stereoscopic X-ray images at BrainLAB ExacTrac V5.5.2. X-ray images are acquired at different amplitudes equivalent phantom velocity in the range $0-15 \mathrm{~mm} / \mathrm{sec}$.

Results:

Prediction errors for fiducials in 4DCT are in the range 1-5 $\mathrm{mm}$ for phantom velocity up to $15 \mathrm{~mm} / \mathrm{sec}$. Residuals between physical positions and detected centre off mass correlate to phantom velocity at phase bin acquisition. No correlation is found among fiducial prediction errors and orientations relative to superior-inferior axis and CT slice thickness.

Gated IGRT using ExacTrac software can be verified within $1.3 \mathrm{~mm}$, which results in total prediction errors for fiducials of up to $5 \mathrm{~mm}$.

P16.02 Trine Majken ADULT LIFE AFTER CHILDHOOD CANCER IN SCANDINAVIA (ALICCS) - LATE Gade RENAL AND GASTROINTESTINAL EFFECTS AND THEIR PREVENTION IN Bonnesen CHILDHOOD CANCER SURVIVORS

T.G. Bonnesen', J.F. Winther', J.H. Olsen², H. Hasle'

${ }^{1}$ Department of Pediatrics, Aarhus University Hospital, Skejby, ${ }^{2}$ Danish 
Cancer Society, Institute of Cancer Epidemiology, Copenhagen

Introduction: With the remarkable improvement in survival of childhood cancer, morbidities and late complications related to the cancer and its treatment become more apparent. The aim is to investigate possible late renal and gastrointestinal complications in a large population-based setting, using the unique resources of nationwide health registries in the Nordic countries.

Methods: The cohort will include approximately 55,000 children diagnosed with cancer before age 20 from beginning of cancer registrations in the 1940s and through 2008. A population comparison cohort (1:5), reflecting morbidity in the background population, will be randomly selected from the Central Population Registries matched by gender, age and country. Study subjects will be followed up for selected outcomes in the National Patient, Prescription and Medical Birth Registries and the Cause of Death Registries in the Nordic countries. Information on treatment exposure will be retrieved from medical records and dose-response analyses will be performed. Cox proportional hazard models will be used to estimate the relative risks of the selected late effects in cancer survivors in comparison with population cohort members.

Results: In the coming years, a variety of outcomes of renal and gastrointestinal diseases will be investigated. Characteristics of the cohort and the first preliminary results will be presented at the meeting.

Conclusion: The ultimate goals are to ameliorate treatment protocols, limit late effects and improve long-term follow-up for survivors of childhood cancer.

P16.03 Søren Ravn MORPHOLOGICAL MRI VERSUS DIFFUSION TENSOR IMAGING BASED ASSESSMENT OF WHICH BRAIN TUMOUR PATIENTS ARE IN NEED OF PRESURGICAL LANGUAGE FUNCTIONAL MRI

S. Ravn', M. Holmberg ${ }^{3}$, P. Sørensen 4', J. Frøkjcer' , J. Carl'

'Department of Radiology, Aalborg Hospital/ Aarhus University Hospital, ${ }^{2}$ Department of Medical Physics, Oncology, Aalborg Hospital/ Aarhus University Hospital, ${ }^{3}$ Department of Oncology, Aalborg Hospital/ Aarhus University Hospital, ${ }^{4}$ Department of Neurosurgery, Aalborg Hospital/ Aarhus University Hospital

Introduction: Knowledge of functional areas in the brain is essential to avoid damage during surgery. Eloquent cortical language areas can be visualized by pre-surgical language functional MRI (PLfMRI). The decision to perform PLfMRI is in general based on patient symptoms and proximity of tumour localisation to eloquent language areas based on morphological MRI [ad modem Stippich C et al. 2007]. Diffusion Tensor Imaging (DTI) is an advanced MRI technique which makes it possible to visualize white matter tracts in the brain, e.g. the arcuate fasciculus (AF).

Purpose: To perform virtual dissection of the AF in brain tumour patients by using DTI in order to study if the relationship between the tumour and the AF differs significantly between the patients who were allocated to PLfMRI a.m. Stippich and those who were not.

Materials and methods: Retrospective study of 20 patients with low-grade brain tumours who were allocated to PLfMRI ad modem Stippich. Group: A10 -PLfMRI. Group B: 10 patients +PLfMRI . All patients had completed a DTI scan. Data were analyzed using logistic regression. Estimates of Odds Ratio (OR) are given together with $95 \%$ confidence intervals.

Results: None of the patients experienced any language deficits prior to surgery. No difference in distance between AF and the tumour was seen between the two groups $(O R=0.87(0.27 ; 2.86) p=0.83)$. Adjusting for three possible outliers still did not indicate any difference between the to groups 
$(\mathrm{OR}=1.63(0.33 ; 8.08) \mathrm{p}=0.55)$

Conclusion: The results indicate that the judgement of the tumour localisation compared to eloquent language areas based on morphological MRi are insufficient.

P16.04 Thomas Lyhne TIME-RESOLVED EVOLVEMENT OF TARGET DOSE DISTRIBUTION DURING Ravkilde IMAT WITH AND WITHOUT DYNAMIC MLC TRACKING

T. Ravkilde ${ }^{7,2}$, P.J. Keall ${ }^{3}$, C. Grau', M. Høyer ', P.R. Poulsen ${ }^{1,2}$

'Department of Oncology, Aarhus University Hospital, Denmark., ${ }^{2}$ Department of Clinical Medicine, Aarhus University, Denmark., ${ }^{3}$ Sydney Medical School, University of Sydney, Australia.

Purpose: In radiotherapy of cancer, dynamic multi-leaf collimator (DMLC) tracking has been shown to substantially mitigate the impact of target motion on the accumulated dose during intensity modulated arc therapy (IMAT). However, the questions of when and why dose quality is compromised during beam delivery remain unanswered. The aim of this study was to investigate the ability of DMLC tracking to maintain the dose distribution throughout beam delivery using time-resolved dose distribution measurements.

Materials an methods: A phantom measuring dose with two orthogonal diode arrays at $72 \mathrm{~Hz}$ was moved about during beam delivery. Motions reproduced four representative lung tumor trajectories. For each trajectory, the same highly modulated IMAT lung plan was delivered with and without DMLC tracking on a linear accelerator. The real-time 3D target position signal for tracking was provided by an electromagnetic transponder during beam delivery. Off-line, the measured dose distributions were downsampled to $50 \mathrm{~Hz}$ to reduce noise and compared with a static reference dose distribution using a time-resolved $3 \% / 3 \mathrm{~mm} Y$-test.

Results: The static reference dose distribution was measured four times with $100 \%$ reproducibility in the accumulated dose. For experiments with motion, the accumulated doses dropped from a mean $y$-test failure rate of $20.5 \%$ without tracking to $0.05 \%$ with tracking.

Conclusions: The tracking substantially mitigated motion-induced errors in the dose delivery. The time-resolved measurements allow pinpointing of transient errors in dose delivery as well as monitoring of erroneous dose evolvement in key target positions.

P16.05 Sandy MODELS FOR BRACHYTHERAPY DOSE DE-ESCALATION IN LOW RISK Mohamed Ismail Mohamed LOCALLY ADVANCED CERVICAL CANCER PATIENTS

\section{S. Mohamed}

\section{Oncology Department, Aarhus University Hospital}

Purpose: Explore the possibilities of dose de-escalation for low risk tumours in locally advanced cervical cancer.

Materials and method: Low risk were tumours $<=5 \mathrm{~cm}$ width on MRI \& -ve lymphnodes. Patient had EBRT \& BT with tandem ring applicator \pm interstitial needles. Vaginal points were appointed at the level of the ring at the mucosal surface $\& 5 \mathrm{~mm}$ depth. DVH parameters were compared for 3 plans: 1.Optimised plan (as delivered), 2. Low dose plan, which is down-scaled and normalized to $85 G$ y to D90 HR CTV, 3. Reduced vaginal loading plan, where a vaginal mucosa dose constraint of $140 \%$ of 17.5 Gy was applied, which is $120 \mathrm{~Gy}$ in total EQD2. EBRT \& BT doses were added and normalized to a 2 Gy fraction size (EQD2) using the linear quadratic model ( $a / \beta=3$ Gy for OARs, $\alpha / \beta=10$ Gy for tumour, $T 1 / 2=1.5 \mathrm{~h}$ ).

Results: Out of 60 consecutive patients of locally advanced cervical cancer, 12 were included for this analysis as low-risk patients. Plan "1" delivered 
P16.06 Søren Haack BO-CORRECTION AND K-MEANS CLUSTERING FOR ACCURATE AND AUTOMATIC IDENTIFICATION OF REGIONS WITH REDUCED APPARENT DIFFUSION COEFFICIENT (ADC) IN ADVANCED CERVICAL CANCER AT THE TIME OF BRACHYTHERAPY
S. Haack', E.M. Pedersen ${ }^{2}$, M.S. Vinding ${ }^{3}$, J.F. Kallehauge ${ }^{4}$, J.C. Lindegaard ${ }^{5}$, K. Tanderup ${ }^{5}$, S.N. Jespersen ${ }^{6}$
'Department of Clinical Engineering, ${ }^{2}$ Department of Radiology, Aarhus University Hospital, ${ }^{3}$ inSpin, iNANO, Aarhus University, ${ }^{4}$ Department of Medical Physics, Aarhus University Hospital, ${ }^{5}$ Department of Oncology, Aarhus University Hospital, ${ }^{6} \mathrm{CFIN} /$ Mindlab, Aarhus University

Diffusion Weighted MRI (DW-MRI) has shown great potential in diagnostic cancer imaging and may have value for monitoring tumor response during radiotherapy (RT). Patients with locally advanced cervical cancer are treated with brachytherapy (BT) using an intracavitary applicator with steep dose gradients, making accurate delineation essential. Including DW-MRI in dose-planning of BT could improve target delineation and dose delivery to tumor. An important obstacle to be overcome is the pronounced sensitivity of EPI based DW-MRI to BO inhomogeneity, leading to geometrical distortions. This study evaluates the use of k-means clustering for automatic user-independent delineation of regions of reduced apparent diffusion coefficient (ADC) and the value of B0 correction of DW-MRI for reduction of geometrical distortions during dose planning of BT. DW-MRI was collected from ten MRI examinations of eight patients. To ensure non-biased detection of tumor tissue on DW-images, ROls were created using user-independent k-means clustering. The percentage of DWI ROI inside the GTV (clinical tumor volume) was $67.1 \pm 10.6 \%$ (non-corrected) and $73.1 \pm 12 \%$ (BOcorrected), respectively. The BO correction thus increased the overlap of DWI $\mathrm{ROI}$ and GTV volumes (Students paired t-test $\mathrm{p}=0.011$ ) with a mean improvement of $6.0 \pm 5.9 \%$. The Jaccard similarity index was also improved (Students paired t-test $\mathrm{p}=0.018$ ) from $0.47 \pm 0.11$ (non-corrected) to $0.52 \pm 0.13$ (corrected). The difference in tandem centre marked on T2W and DW images was $2.5 \pm 1.2 \mathrm{~mm}$ (non-corrected) and $1.3 \pm 0.9 \mathrm{~mm}$ (BO corrected), showing a better spatial match for the BO-corrected DW images (Students paired t-test $\mathrm{p}=0.039$ ).

P16.07 Lotte Bonde Bertelsen
RADIOACTIVE LABELLING AND HOMING OF ENDOTHELIAL PROGENITOR CELLS

L.B. Bertelsen ', M.R. Horsman ${ }^{2}$, L. Falborg ${ }^{3}$, H. Stødkilde-Jørgensen ${ }^{7}$

'MR-Research Centre, Aarhus University Hospital, Skejby, Aarhus, Denmark, ${ }^{2}$ Dept. Of Experimental Clinical Oncology, Aarhus University Hospital-NBG, Aarhus, Denmark, ${ }^{3}$ Dept. Of Nuclear Medicine, Aarhus University HospitalNBG, Aarhus, Denmark

Background and aim: Endothelial Progenitor Cells (EPC) are believed to be crucial in the process of forming new blood vessels in tissue suffering from ischemia. To elucidate the degree of EPC homing in tumor tissues, 
radioactive labelled cells were injected in a mouse model, carrying an implanted tumor, and traced in the mouse.

Materials and methods: EPCs were isolated from human umbilical cord blood using anti-CD34 magnetic beads and incubated with ${ }^{111}$ Indiumtropolon equal to $0.37 \mathrm{MBq}$ per $3 \times 10^{6}$ cells. After radioactive labelling, the EPCs were administered i.v. into CDF 1 mice carrying a $\mathrm{C} 3 \mathrm{H}$ mammary carcinoma implanted on their right rear foot. Following euthanasia at various time points after cell administration, the mice were dissected and the ${ }^{111}$ indium activity in the individual organs was quantified by gamma counting.

Results and discussion: Indium activity was primarily found in the lung, liver, spleen, kidneys and tumor. The high activity in the kidneys could indicate a substantial loss of indium from the cells. Our results show that cell retention of indium decreased over time, and that injected free indium does have a distribution pattern much like the one seen with injected indium labelled EPCs. As seen from the literature, a few percent of the injected activity was located to the tumor area. However, it can still be discussed whether this ${ }^{11}$ indium activity originated from homing of living EPCs or rather, to a certain degree, corresponded to free ${ }^{111}$ indium chloride.

P17.01 Sepp De Raedt FULLY AUTOMATED MEASUREMENT OF RADIOLOGICAL ANGLES IN HIP DYSPLASIA USING CT IMAGES

S. de Raedt', M. de Bruijne ${ }^{2,3}$, I. Mechlenburg' ${ }^{7}$, M. Stilling ', L. Rømer ${ }^{4}$, K. Søballe

'Orthopedic Research Group, Aarhus University, ${ }^{2}$ Department of Computer Science, University of Copenhagen, ${ }^{3}$ Biomedical Imaging Group Rotterdam, Erasmus MC, ${ }^{4}$ Department of Radiology, Aarhus University Hospital

Developmental hip dysplasia is a debilitating condition that is commonly diagnosed by manual measurements. The aim of this study was to develop a fully automated measurement method using CT images.

Using the automatically segmented hip, the centre point of the femoral head was determined by fitting a sphere to the surface of the femoral head. The local axis was determined and corrected for the tilt of the pelvis. Starting from the centre point, the necessary reference points were identified by automatically rotating a line until the edge of the acetabulum was reached in the respective directions. Using the reference points, the CE angle (CE), acetabular-anteversion (AcAV) angle, posterior sector (PS) angle and anterior sector (AS) angle were calculated. The method was validated against manual measurements as performed in daily practice on 52 hips. We report mean average difference with $95 \%$ limits of agreement, and concordance correlation coefficient (CCC) between the two methods.

The mean CE angle was $21.2^{\circ}$ (Avg. diff. $0.0 \pm 5.4$, CCC: 0.93 ). The mean AcAV angle was $19.8^{\circ}$ (Avg. diff. $-0.9 \pm 3.6$, CCC: 0.95 ). The mean PS angle was $86.5^{\circ}$ (Avg. diff. $1.8 \pm 6.2$, CCC: 0.87). The mean AS angle was $49.0^{\circ}$ (Avg. diff. $0.8 \pm 5.6, \mathrm{CCC}: 0.95$ ). Three patients ( 6 hips) were excluded from analysis due to outlying measurements ( $>2 \mathrm{SD}$ ) due to osteophytes.

The new automated method achieves acceptable accuracy as validated against manual measurements. In the future, the method will be improved to correct for osteophytes and can be further developed to pre-operatively determine the optimal rotation of the acetabulum before periacetabular osteotomy.

P17.02 David COMBINED PROTON AND X-RAY TOMOGRAPHY

Christoffer Hansen D.C. Hansen

Experimental Clinical Oncology 
P17.03 Jill Rachel Mains
Introduction: Particle radiation therapy has the ability to greatly improve the outcome for many types of cancers in comparison to traditional X-ray therapy, but is limited in dose accuracy by the conversion of conventional $\mathrm{X}$-ray CT images into electron densities. Proton tomography has previously been proposed as a way to overcome these problems. We have developed a new method for combining proton tomography with traditional cone beam X-ray tomography to overcome the shortcomings of both imaging modalities. For proton tomography, this mainly regards the finite range which limits the angles that can be shot through in some scenarios.

Methods: A Catphan 500 resolution phantom was scanned using an X-ray cone beam CT scan. A digital replica of the phantom was created in the Monte Carlo framework Geant4. This was used to simulate a fan beam proton tomography scan of the phantom, registering entrance and exit positions and angles, as well as energy loss. The proton image was reconstructed using a linear least squares approach. The X-ray cone beam data were incorporated into the reconstruction as a weighted Tikhonov regularisation term, a technique successfully used in MRI reconstruction.

Results: The image reconstruction using spline based proton paths yielded a spatial resolution of less than $1.0 \mathrm{~mm}$. Adding cone beam based regularisation greatly reduced background artefacts and improved the numerical stability of the reconstruction.

Conclusions: Adding cone beam information to proton tomography without explicit conversion from Hounsefield units to electron densities proved to be an efficient way of improving proton tomography image quality.

DYNAMIC CONTRAST-ENHANCED IMAGING AS A POTENTIAL BIOMARKER IN METASTATIC RENAL CELL CARCINOMA: PRELIMINARY ANALYSIS FROM THE DARENCA- 1 STUDY

J.R. Mains ', F. Donskov' ${ }^{2}$, F. Rasmussen ${ }^{7}$

'Department of Radiology, Aarhus University Hospital, ${ }^{2}$ Department of Oncology, Aarhus University Hospital

BACKGROUND: Functional imaging information as a supplement to conventional imaging based on RECIST in metastatic cancer patient is lacking. The DARENCA- 1 study is a randomized phase II study of IL-2/IFN-a with and without bevacizumab in the treatment of metastatic renal cell carcinoma (mRCC) and includes dynamic contrast-enhanced (DCE) imaging as an integrated part of the study.

OBJECTIVES:To evaluate the first 17 patients by performing a preliminary analysis of DCE-CT compared to best response and progression-free survival based on RECIST 1.1 and overall survival.

METHODS: Each patient is scanned using DCE-CT before starting treatment, after 5 weeks, after 12 weeks and every 3 months thereafter or until treatment completion, progression, death or intolerable toxicity. Each patient also undergoes routine CT scans every 3 months, evaluated using RECIST 1.1. Patients with at least 2 years follow up are included in this analysis, and their DCE-CT scans are analyzed slice by slice. For each scan, a median value is found for tumor perfusion $(\mathrm{ml} / \mathrm{min} / 100 \mathrm{ml})$, peak enhancement (HU), time to peak (s), and blood volume $(\mathrm{ml} / 100 \mathrm{~g})$. These values are then analyzed with respect to the chosen endpoints. As the phase II study is ongoing, these preliminary analyses are performed without regard to treatment.

RESULTS AND CONCLUSIONS: 17 patients have at least two years follow up. In four of these, the DCE-CT scans are of suboptimal technical quality due to movement, for which the available analysis program cannot compensate. Possible trends found among the remaining 13 patients as well as lessons learned in this preliminary analysis will be presented. 
P17.04 Rubens SpinNeto

P17.05 Lise Thorsen
CONE BEAM CT IMAGE ARTIFACTS RELATED TO HEAD MOTION SIMULATED BY A ROBOT SKULL: VISUAL CHARACTERISTICS AND IMPACT ON IMAGE QUALITY

R. Spin-Neto', J. Mudrak', L.H. Matzen', J. Christensen', E. Gotfredsen', A. Wenzel $^{l}$

${ }^{1}$ Department of Dentistry, Aarhus University, ${ }^{2}$ Private practice, Ludwigsau, Germany

Background: Motion artifacts can be present in Cone Beam CT images. The impact of those artifacts on image quality and their visual characteristics has not yet been described. This study assesses simulated head motion image artifacts and their impact on CBCT image quality.

Methods: A fully dentate human skull incorporated in a robot simulated predetermined patient movements. Ten head motion patterns were tested (no motion was used as reference). Three CBCT units were used (KaVo,

Planmeca and Scanora 3D). Axial images were qualitatively assessed at three levels: mental, infraorbital, and supraorbital foramen (MF, IF, SF), and artifacts characterized as stripe-like, double contours, unsharpness or ringlike. A 100-mm visual analogue scale (VAS) was used to quantitatively assess image quality (IQ). Cross-sectional images of the lower third molar (TM) and MF bilaterally were also evaluated by VAS. Four examiners blinded to unit and motion assessed the images.

Results: For all units and motion patterns, stripe-like artifacts were the most common. The four observers agreed on the presence of at least one artifact type in $90 \%$. Axial images showed lower overall IQ after motion (VAS $=72.4 \pm 24.0 \mathrm{~mm}$ ) compared to reference images (VAS=97.3 $\pm 2.6 \mathrm{~mm}$ ). The most severe artifacts were seen at the MF level. For cross-sectional images, IQ was lowest after tremor. Mean IQ range was 74-89 and 57-90 for isolated and combined movements, respectively.

Conclusions: Head motion of any type resulted in artifacts in CBCT images. The impact on image quality depended on the region and level in the skull. Further studies will focus in the clinical relevance of these findings.

\section{DOSE COVERAGE OF INTERNAL MAMMARY LYMPH NODES IN BREAST} CANCER RADIOTHERAPY: MISSION ACCOMPLISHED?

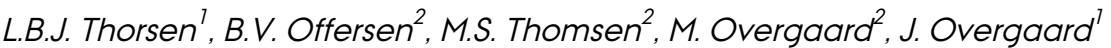 \\ 'Department of Experimental Clinical Oncology, Aarhus University Hospital, ${ }^{2}$ Department of Clinical Oncology, Aarhus University Hospital}

Background: In 2003, the Danish Breast Cancer Cooperative Group (DBCG) decided to continue to apply adjuvant radiotherapy (RT) to the internal mammary lymph nodes (IMNs) in patients with right-sided breast cancer $(B C)$, while refraining from treatment of the IMNs in patients with left-sided $\mathrm{BC}$ due to risk of radiation induced heart disease. We investigated whether conventional non-CT-based external beam $\mathrm{RT}$ regimens fulfilled this purpose.

Materials and methods: Therapy CT scans from 40 patients who received post-mastectomy (PM) or post-lumpectomy (PL) RT of the left or right breast were selected, 10 in each group. DBCG RT regimens were electron+photon fields $(E+P)$ for $P M$ patients and wide tangents (WT) or electron+tangents $(E+T)$ for PL patients. Field planning was conducted in the Eclipse ${ }^{T M} R T$ treatment planning system. Subsequently, IMN clinical target volumes (CTVs) were delineated. The percentage of the CTV receiving $90 \%$ of the intended dose (IMN90) was registered.

Results: Right-sided PM RT provided a mean IMN90 of $86.9 \%$ (95\%Cl: $83.0-$ 90.7). Left-sided PM RT provided a mean IMN90 of $8.0 \%$ (95\%Cl: -3.5- 19.5). Right-sided PL RT with WT provided a mean IMN90 of $73.4 \%(95 \% \mathrm{Cl}: 56.8$ - 
89.9), and right-sided PL RT with E+T provided a mean IMN90 of $89.2 \%$ (95\%Cl: 84.4-94.1). Left-sided PL RT provided a mean IMN90 of $16.0 \%$ (95\%Cl: 0.7-31.4). Right-sided IMNs consistently received larger doses than left-sided IMNs $(p<0.0001)$.<br />Conclusions: In full agreement with the intention of the DBCG, patients with right-sided $B C$ had excellent dose coverage of the IMNs, while those with left-sided BC had modest dose coverage. This warrants further studies of the effect of adjuvant IMN radiotherapy. PATIENTS; A PILOT STUDY

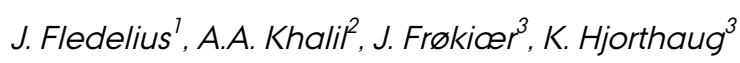

${ }^{1}$ Department of Nuclear Medicine, Herning hospital, ${ }^{2}$ Department of Oncology, Aarhus University Hospital, ${ }^{3}$ Department of Nuclear Medicine and PET Center, Aarhus University Hospital

Introduction: Lung cancer patients with locally advanced NSCLC can potentially be cured with chemo-radiotherapy. Being able to predict who could benefit from this intensive treatment strategy can help us improve the outcome and avoid unbeneficial treatments. 18F-FDG-PET/CT is routinely used for staging of NSCLC patients and for evaluation of response in various other cancer types. Recently, PERCIST 1.0 was proposed as a criterion for evaluating response by FDG-PET/CT.

The purpose of this study was to investigate whether PET/CT will add valuable prognostic information to help tailor patient treatment accordingly.

Methods: 21 consecutive patients diagnosed with locally advanced NSCLC, who had both a baseline PET/CT scan and an evaluation PET/CT scan performed after 1-4 cycles of chemotherapy prior to curative intended radiation therapy, were included in the study from September 2009 until March 2011 . The PET/CT scans were analyzed by an experienced evaluator semi-quantitatively. (Patient outcome was not known to the evaluator at the time of evaluation.) The change in SUL peak at the evaluation scan was calculated according to the PERCIST 1.0 and compared to progression free survival (PFS).

Results: The percentual change in SUL peak and the resulting response categories for progressive metabolic disease (PD), stable metabolic disease (SMD) and partial metabolic disease (PMR) correlate well with PFS.

Conclusion: Response by PERCIST 1.0 evaluated early in the course of curatively intended chemo-radiotherapy can be used to predict PFS, and progression at the early evaluation prior to radiotherapy predicts a poor outcome and may in the future be considered a valid indicator for change of therapeutic strategy.

P17.07 Jesper THE INFLUENCE OF ITERATIVE RECONSTRUCTION ON FUNCTIONAL Thygesen PARAMETERS IN DYNAMIC CONTRAST-ENHANCED CT-IMAGING (DCE-CT) J. Thygesen', M. Pedersen ${ }^{2}$, F. Rasmussen ${ }^{3}$

${ }^{1}$ Dept. of Clinical Engineering, AUH, ${ }^{2}$ Department of Clinical Medicine, AUH, ${ }^{3}$ Dept. of Radiology NBG, AUH

Background: DCE-CT is a promising diagnostic procedure in the evaluation of stroke, in lesion characterization and in the follow-up in cancer therapy. One of the challenges is the amount of radiation that the patient is exposed to. Iterative reconstruction in CT-imaging allows reduction of applied radiation dose or improvement of image quality. Both issues are important in DCE-CT.

Objectives:To investigate the effect of different levels of iterative reconstruction compared to the original filtered back projection (FBP) data on parameters such as relative blood flow ( $\mathrm{rBF}$ ), relative blood volume (rBV), 
P17.08 Anne Vestergaard

time-to-peak (TTP) and peak enhancement (PE).

Methods: Parametric maps were calculated by the slope method, both from the original dataset and from the datasets of the different levels of iterative reconstruction. The quantitative figures of DCE-CT functional parameters were measured by propagated ROI settings in cancer lesions in different anatomical locations. A comparison of the figures and the quality of the parametric displays were made.

Results and conclusions: The iterative reconstruction has no significant effect on the functional parameters measured in cancer lesions in different anatomical locations. The parametric displays have less noise the higher the level of iterative reconstruction. These results point to a potential reduction of the radiation dose received by the patients when DCE-CT is performed.

COMPARISON OF ADAPTIVE PLAN SELECTION VS. PLAN-OF-THE-DAY IN RADIOTHERAPY FOR BLADDER CANCER

A. Vestergaard', J. Søndergaard', L.P. Muren", 2 , U.V. Elstrøm' ', M. Høyer', J.B. Petersen

'Department of Medical Physics, Aarhus University Hospital, ${ }^{2}$ Department of Oncology, Aarhus University Hospital

Purpose: Patients with urinary bladder cancer are obvious candidates for image-guided adaptive radiotherapy due to the large variability in bladder shape and size during a treatment course. In this study we have compared conventional radiotherapy (RT) with two adaptive strategies, 1) daily plan selection- (PS), and 2) 'plan-of-the-day' strategy (PoD).

Methods: Seven patients with bladder cancer treated with $60 \mathrm{~Gy}$ in 30 fractions to the bladder volume with daily CBCT scans (a total of 210 CBCTs) were used for simulation of a daily adaptive PS strategy, where the most suitable plan from a library consisting of three IMRT-plans, corresponding to a small, medium and large target volume were selected for each treatment fraction (Vestergaard et al: Acta Oncol 2010). For PoD strategy, an IMRT-plan was re-optimized for each fraction based on bladder contours propagated using deformable image registration. Dose distributions for the two adaptive strategies as well as the conventional treatment were accumulated using the pre-release Dynamic Adaptive Radiation Therapy software (DART ${ }^{T M}$, VMS).

Results: Both adaptive strategies provided considerable sparing of normal tissue. The mean reduction of the volume receiving more than $45 \mathrm{~Gy}$ was $20 \%$ (range $0-39 \%$ ) and $58 \%$ (range $48-66 \%$ ) for the PS and the PoD strategy, respectively.

Conclusion:This study demonstrated considerable normal tissue sparing of both adaptive strategies, yet with superior results from PoD strategy, where the volume receiving high doses is on average more than halved. While "Plan-of-the-Day" is not yet clinical feasible plan selection, was implemented in October 2012 at AUH in a clinical trial.

P18.01 Mikkel Tøttrup IN VITRO VALIDATION OF MICRODIALYSIS FOR THE MEASUREMENT OF CEFUROXIME CONCENTRATION

M. Tøttrup ${ }^{1,2}$, H.B. Sørensen ${ }^{3}$, T.F. Hardlei ${ }^{4}$, K. Fuursted $^{5}$, K. Søballe $^{7}$

${ }^{1}$ Department of Orthopaedic Surgery, Aarhus University Hospital,

${ }^{2}$ Department of Orthopaedic Surgery, Horsens Hospital, ${ }^{3}$ Institute of Clinical Medicine Aarhus University, ${ }^{4}$ Department of Clinical Biochemistry, Aarhus University Hospital, ${ }^{5}$ Statens Serum Institut

Background: Microdialysis is a well known pharmacokinetic tool. It has been used for a variety of applications and in almost all tissues. In order to validate microdialysis for the in vivo measurement of cefuroxime we have conducted a series of preliminary in vitro experiments. The results of these 
experiments are presented in the following.

Methods: PBS buffered $\mathrm{NaCl}$ was used as test medium, while Ringers acetate was used as perfusate. As a result $\mathrm{pH}$ was kept constant. The catheters and precision pumps used were CMA 63 and CMA 107 respectively. Flowrate was set to be $2 \mu \mathrm{l} / \mathrm{min}$. Dialysates were collected with 20 minutes intervals. Relative recovery by gain and by loss was determined when varying drug concentration ( $1-1000 \mu \mathrm{g} / \mathrm{mL}$ ) and temperature (20 $41^{\circ} \mathrm{C}$ ). Concentrations of cefuroxime were determined using LC-MS/MS.

Results: The transportation of cefuroxime across the semipermeable membrane was bidirectional and independent of the concentration gradient. Relative recovery was found to be approximately $40 \%$, increasing slightly with increasing temperature.

Conclusions: Microdialysis seems to be a feasible method for in vitro measurement of cefuroxime. This suggests that reliable tissue measurements should be obtainable by implanting microdialysis catheters in various locations. A flowrate of $2 \mu \mathrm{l} / \mathrm{min}$ resulted in satisfying relative recoveries of approximately $40 \%$.

P18.02 Maj Høygaard ORAL HEALTH IMPACT AFTER REPLACEMENT OF A MISSING POSTERIOR Nicolaisen TOOTH WITH A FIXED DENTAL PROSTHESIS: A CLINICAL TRIAL

\section{M.H. Nicolaisen, G. Barahmi, L. Schropp, F. Isidor}

Department of Dentistry, Aarhus University

Introduction and aim: Missing one or more teeth is associated with compromised oral function and social stigmatization. The aim of this study was to examine if changes occur in oral health-related quality of life by replacing a missing posterior tooth with a fixed dental prosthesis (a dental bridge).

Methods: Thirty four patients ( 13 men, 21 women) aged 32-66 years with one missing posterior tooth received a 3 -unit fixed dental prosthesis. Control group: 20 healthy fully dentate individuals with normal occlusion and subjectively and objectively clinically sound teeth. The oral health-related quality of life was evaluated with the Oral Health Impact Profile (OHIP- 14) form. This questionnaire consists of 14 questions and is designed to measure self-reported oral functional limitation, discomfort and disability. Low OHIP scores indicate better oral comfort. The patient group was assessed before treatment and 2 weeks, 3 months and 1 year after treatment. The control group completed the OHIP questionnaire once.

Results: Before treatment, the patients reported (median 9.5) a statistically significant higher $(p<0.001)$ OHIP score, i.e. lower self-reported oral health compared to the control group (median 3.0). Three and 12 months after treatment, the patients' OHIP scores were reduced (median 3.0 and 3.5, respectively) to the level of the control group. This reduction in the OHIP scores, i.e. increase in self-reported oral health, was statistically significant ( $p$ $<0.001$ ).

Conclusions: Missing a posterior tooth has an impact on physical, emotional and social functioning. Replacement of a missing posterior tooth improves the self-reported oral health significantly.

P18.03 Thøger Persson COMPARATIVE EFFECTIVENESS OF INJECTION THERAPIES IN LATERAL Krogh EPICONDYLITIS: A SYSTEMATIC REVIEW AND NETWORK META-ANALYSIS OF RANDOMIZED CONTROLLED TRIALS

T. Krogh' ${ }^{7}$ E.M. Bartels', T. Ellingsen ${ }^{7}$, K. Stengaard-Pedersen ${ }^{3}$, R. Buchbinder ${ }^{4}$, U. Fredberg ${ }^{7}$, H. Bliddal', R. Christensen ${ }^{2}$

${ }^{1}$ Diagnostic Center, Regional Hospital Silkeborg, ${ }^{2}$ The Parker Institute, Frederiksberg Hospital, ${ }^{3}$ Dep. of Rheumatology, Aarhus University Hospital, 
${ }^{4}$ Monash Department of Clinical Epidemiology, Cabrini Hospital

Background: Injection therapy with glucocorticoids has been used since the 1950 s as a treatment strategy for lateral epicondylitis (tennis elbow). Lately several other injection therapies have become available.

Objectives: Using a systematic review and network meta-analysis, our objective was to assess the comparative effectiveness of different injection therapies used for pain reduction.

Methods: Structured literature searches. Selected studies were randomized controlled trials comparing different injection therapies and/or placebo injections for lateral epicondylitis. Risk of bias was assessed. The outcome measures were change in pain intensity and adverse events. Network (random effects) meta-analysis was applied. Standardized mean differences (SMDs) were used as the effect size.

Results: Seventeen trials ( 1381 patients) allocating individuals to injection with glucocorticoid, botulinum toxin, platelet-rich plasma, autologous blood, hyaluronic acid, prolotherapy, polidocanol, glycosaminoglycan polysulfate, and/or placebo, fulfilled the inclusion criteria. As an example, pooled results showed that glucocorticoid injection (investigated in 12 treatment arms with 310 patients) was no more effective than placebo with respect to improvement in pain (SMD -0.04 [95\% Cl -0.45 to 0.35], $\mathrm{P}=0.81$ ).

Conclusions: Our study found that most trials that have assessed the value of injection therapy for lateral epicondylitis are at high risk of bias and that their results therefore need to be interpreted with caution. Further high quality trials are needed in this area.

P18.04 Kristian Andersen
EFFECT OF MANDIBULAR DISTRACTION OSTEOGENESIS ON TMJ WITH EXPERIMENTAL ARTHRITIS

\section{K. Andersen}

Department of Oral and Maxillofacial Surgery and Oral Pathology, School of Dentistry, Aarhus University

Juvenile idiopathic arthritis (JIA) is a chronic disease characterised by unknown etiology, a duration of more than six weeks, and onset before the age of 16 years. Diagnostic imaging has shown morphological changes of the mandibular condyle in $62-87 \%$ of the patients. Traditional osteotomies, distraction osteogenesis (DO) or autogenous grafts may be necessary to normalize form and function of the mandible. Studies involving animals without JIA have indicated reversible changes of the temporomandibular joint (TMJ) after DO, but studies assessing the effect of DO on JIA-affected TMJ are lacking. Experimental arthritis of the TMJ can be induced by ovalbumin, why mandibular DO in rabbits with ovalbumin-induced arthritis of the TMJ is an appropriate model to gain knowledge about the effect of DO on JIA-affected TMJ. The study involves $32 \mathrm{New}$ Zealand White Rabbits randomized in four groups: 1) Arthritis and DO, 2) Arthritis and no DO, 3) No arthritis and DO, and 4) No arthritis and no DO. After ramus osteotomy, DO is initiated after a latency period of five days involving $0.5 \mathrm{~mm}$ twice daily for seven days. The animals are euthanized after six weeks of consolidation. The assessment involves analysis of vertical, sagittal, and transversal mandibular growth based on CT-scans. The histologic and stereologic evaluation involves unbiased estimates of total bone volume, total cartilage volume, joint surface characteristics, and total number of plasma cells. The assessment also involves micro-CT scanning. In summary, the background of the study is to evaluate the effect of mandibular DO on the TMJ with unilateral experimental arthritis. 
D. Belstrøm ${ }^{7,2}$, N.E. Fiehn ${ }^{3}$, K. Poulsen ${ }^{7}$, J. Reinholdt ${ }^{7}$, N. Kirkby ${ }^{4}$, C.H. Nielsen ${ }^{2}$, V. Klepac-Ceraj ${ }^{5}$, B.J. Paster ${ }^{6}$, P. Holmstrup ${ }^{7}$

'Department of Biomedicine, Faculty of Health, Aarhus University, Aarhus, Denmark, ${ }^{2}$ Institute for Inflammation Research, Department of Infectious Diseases and Rheumatology, Copenhagen University Hospital Rigshospitalet, Copenhagen, Denmark, ' Department of International Health, Immunology \& Microbiology, University of Copenhagen, Copenhagen, Denmark, 'Department of Medical Microbiology, Rigshospitalet, Copenhagen University Hospital, Copenhagen, Denmark, ${ }^{5}$ The Forsyth Institute, Department of Microbial Ecology and Pathogenesis, Cambridge, MA USA, 'Department of Oral Medicine, Infection \& Immunity, Harvard School of Dental Medicine, Boston, MA USA, ${ }^{7}$ Sections of Periodontology, Schools of Dentistry, Faculties of Health Sciences. Universities of Copenhagen and Aarhus. Denmark

Aims: The oral microflora comprising more than 700 bacterial species is generally considered beneficial. However, at present it is unknown whether oral or systemic diseases are reflected in qualitative changes of the microflora detected in saliva. Molecular methods, including Human Oral Microbe Identification Microarray (HOMIM), have increased the possibilities of investigating bacteria of the oral cavity. Here, the objective was to determine the potential of using bacterial profiles of saliva as a diagnostic tool to assess risk of future oral and systemic disease.

Material and methods: Saliva samples were collected from 386 participants of the population-based KRAM-study. Clinical and radiographic examinations were performed and individuals with caries and/or periodontal disease were excluded. Saliva was analyzed for the presence of approx. 300 bacterial species using HOMIM. Sub-groups were established based on age and gender. Kruskal Wallis and Chi-square tests were used to determine statistical differences between groups.

Results: 297 bacterial species were identified from 162 samples. Veillonella atypica and Streptococcus species were present in more than $98 \%$ of the samples. Samples taken from women resulted in hybridizations with more probes than male samples, while the amount of positive hybridizations increased with age. However, none of the differences observed were statistically significant.

Conclusion: Saliva is an easily accessible medium, containing information about the oral bacterial community. Further similar studies of patients with caries and periodontal disease may reveal whether salivary bacterial profiles are related to oral and systemic diseases.

P18.06 Akiko Shimada EFFECTS OF SYSTEMIC GLUTAMATE ON CRANIOFACIAL PAIN

\section{A. Shimada, L. Baad-Hansen, P. Svensson \\ Section of Clinical Oral Physiology, Department of Dentistry, Aarhus University}

Background: The purpose of this randomized, double-blinded and placebocontrolled study is to determine if repeated high-doses of MSG (over 5 days) can alter muscle pain sensitivity and subjective reports of craniofacial pain in healthy individuals.

Materials an methods: Six healthy adult subjects without any chronic craniofacial pain participated in this pilot study. Pressure pain threshold (PPT) and pressure pain tolerance (PPTol) were measured on the masseter, trapezius and thenar. Blood pressure and heart rate were also measured, and subjects were asked to complete a food questionnaire. In addition, blood and saliva samples were collected. After baseline measurements, subjects received a single dose of $150 \mathrm{mg} / \mathrm{kg}$ MSG or placebo (sodium 
chloride) daily for 5 days in a random order. Within 5 days, they received MSG more than 2 times. PPT, PPTOL, blood pressure and heart rate were monitored every $15 \mathrm{~min}$ for $60 \mathrm{~min}$. Subjects were also asked to report any adverse effects. A blood sample was taken before and 30 min after the oral administration on Days 1 and 5 when a microdialysis probe was inserted into the right masseter muscle. After a stabilization period of 1 hour $(2 \times 30$ min samples), 10 consecutive 20 min dialysis samples were taken for analysis of glutamate concentration. After the microdialysis probe was removed, PPT and PPTOL were determined again.

Results: PPT on MAL and diastolic blood pressure in the baseline session at Day 5 were significantly decreased compared to baseline at Day 1 ( $P<$ 0.05).

Conclusion: This study indicated that repeated high-dose peroral administration of MSG can be associated with measurable decreases in jaw muscle pain sensitivity.

P18.07 Morten DIABETES AND PERIODONTITIS: THE ROLE OF TNF-ALPHA AND RAGE IN A Christian Bay RAT MODEL

Grauballe

M.C.B. Grauballe', J.A. Østergaard' ${ }^{2}$, A. Flyvbjerg ${ }^{3,2}$, S. Schou 4 , P. Holmstrup ${ }^{7}$

${ }^{1}$ Department of Dentistry (Periodontology), Aarhus University, ${ }^{2}$ The medical Research Laboratories, Aarhus University, ${ }^{3}$ Department of Endocrinology and Internal Medicine, Aarhus University Hospital, ${ }^{4}$ Department of Dentistry (Oral and Maxillofacial Surgery), Aarhus University

Background: There is strong evidence that diabetes is a risk factor for the development of periodontitis (MP). However, it is presently unknown how MP may affect the diabetic state.

In diabetic patients, there is a correlation between elevated levels of Receptor for Advanced Glycation End-products (RAGE) and the development of systemic diabetic complications. The amount of RAGEs can be influenced by inflammation, and elevated levels of TNF-a are found in patients with MP. TNF-a is also an important factor in glucose metabolism and hyperglycemia leads to the formation of Advanced Glycation Endproducts (AGE), which can activate RAGE, thereby triggering an inflammatory response. The present study aims at elucidating the interplay between diabetes and MP by blocking key signalling pathways in both diseases.

Methods: Diabetic Zucker rats and their lean littermates are divided into 6 treatment groups. Lean Zucker rats without MP plus placebo, Lean Zucker rats with MP plus placebo, diabetic Zucker rats plus placebo, diabetic Zucker rats with MP plus placebo, diabetic Zucker rats with MP plus antiTNF-a, diabetic Zucker rats with MP plus anti-RAGE. MP is ligature induced for 4 weeks. Anti-TNF-a treatment is provided with Etanercept ${ }^{\circledR} 0.3 \mathrm{mg} / \mathrm{kg} 3$ times a week. Anti-RAGE treatment consists of RAGE antibody $1 \mathrm{mg} / \mathrm{kg} 3$ times a week.

Results: The results are currently being evaluated. Diabetic state is evaluated with OGTT, weight and blood glucose continuously. Systemic markers of inflammation are evaluated in plasma, while local inflammation is evaluated in liver, kidneys, heart and gingival. MP is evaluated with alveolar bone loss; microbiological evaluation is performed through microbe identification array. 
P18.08 Abhishek Kumar

P19.01 Anette Liljensøe
PERIODONTAL MECHANORECEPTORS AND THEIR ROLE IN FINE MOTOR CONTROL OF THE JAW

\author{
A. Kumar' , P. Svensson' , L. Baad-Hansen' ', F. Isidor ${ }^{2}$ \\ ${ }^{1}$ Session of Clinical Oral Physiology, Department of Dentistry, Aarhus \\ University, ${ }^{2}$ Session of Prosthodontics, Department of Dentistry, Aarhus \\ University
}

Background: The periodontal mechanoreceptors encode information about spatial, temporal and the intensity of tooth load and are also involved in the regulation of jaw muscles during mastication. This sensory information is processed by the brain in a feed-back manner to regulate the levels and directions of the bite forces used during manipulative actions. Furthermore, this information provided by the periodontal receptor is also used in a predictive feed-forward manner to adjust and adapt the motor programmes employed to split food using large biting forces and crush food during chewing. Thus, patients with implant-supported prostheses lack information from periodontal receptors and show decreased control of intense, spatial aspects of mastication. Hence the following hypothesis is designed: 'Inputs from the periodontal afferent receptors of natural teeth will facilitate the optimization of jaw motor control, which will be reflected in smaller variability of bite force values and jaw muscle activity than in subjects with implant-supported prosthesis'.

Methodology: 20 participants with implant-supported prostheses corresponding to one of the central incisors are included along with 20 fully dentate participants. The participants perform the 'hold and split' task of the food morsel. The force applied by the teeth to 'hold' and 'split' the morsel will constantly be recorded along with the corresponding EMG activity of the jaw muscles.

Results and conclusion: The results will provide an insight into the complex structure of the jaw motor system and neural control of jaw muscles during fine motor tasks such as splitting food in subjects with natural dentitions and implant supported prostheses.

\section{DOES BODY COMPOSITION HAVE ANY EFFECT ON THA-SCHEDULED PATIENTS' ASSESSMENT OF THEIR OWN HIP PROBLEMS? A PREOPERATIVE CROSS-SECTIONAL STUDY}

\section{A. Liljensøe', J.O. Lauersen" ${ }^{2}$, K. Søballe' , I. Mechlenburg ${ }^{7}$ \\ ${ }^{1}$ Orthopaedic Research Unit, Aarhus University Hospital, ${ }^{2}$ Department of Orthopaedics, Hospital Southern Jutland}

Introduction: The most frequent indication for THA is osteoarthritis (OA). Obesity is a significant factor for the development of OA. However, the associations between obesity and outcomes following THA are ambiguous. The purpose of this preoperative cross-sectional study was to investigate the THA-scheduled patients' demographic characteristics and to examine whether there was a correlation between the patients' body composition and their own assessment of their hip problems.

Method: The study is part of a cohort study investigating whether there is a correlation between the patients' body composition and their own assessment of their hip problems and quality of life one year postoperatively. With Dual Energy X-ray Absorptiometry (DXA), body composition was measured on 102 patients before THA. In addition, patients answered the hip-specific questionnaire HOOS and the patient reported outcome, SF-36.

Results: The study population consists of $54 \%$ women and has a mean age of 70 years. $40 \%$ are unskilled workers; $15 \%$ are still in employment, $8 \%$ are disability pensioners and $77 \%$ are old age pensioners. The mean percentage of fat was $36(15-53) \%$ and mean muscle mass was $48(31-73)$ 
P19.02 Michael

Skovdal

Rathleff

P19.03 Lone Ramer Nygaard Mikkelsen $\mathrm{g} / \mathrm{cm}^{2}$. We found no statistically significant relationship between body composition and any of the five HOOS subscales: Pain, Symptom, Function in daily living, Function in sport and recreation, and hip-related Quality of life.

Discussion: In our preoperative cross-sectional study, we found no association between the patients' body composition and their own assessment of their hip problems.

HIGH PREVALENCE OF DAILY PAIN AND MULTI-SITE PAIN - A CROSSSECTIONAL STUDY AMONG 3000 ADOLESCENTS

\section{M.S. Rathleff}

\section{HEALTH, Aarhus University}

Objective: To investigate the prevalence of self-reported daily and multi-site pain among adolescents aged 12-19 and the associations of daily pain and multi-site pain with person characteristics such as gender, age, Body Mass Index (BMI), European Quality of Life 5-Dimensions (EQ-5D) and sports participation.

Methods: A population based cross-sectional study was conducted among 4007 adolescents aged 12 to 19. All adolescents were invited to answer an online questionnaire as part of their physical education lessons. The questionnaire contained a pain mannequin with 12 predefined regions. The adolescents were asked to mark regions of the body with current pain and report the frequency of pain (rarely, monthly, weekly, more than one time per week, almost daily pain). In addition, the questionnaire contained questions on person demographics, sports participation and EQ-5D.

Results: A total of 2953 adolescents answered the questionnaire correctly (response rate of $73.7 \%$ ). $61 \%$ of all adolescents reported current pain in at least one region of the body and $33.3 \%$ reported multi-site pain (defined as current pain in at least two body regions). $19.8 \%$ reported daily pain. Female gender, worse EQ-5D index score and participating in sports more than three times per week, were associated with increased odds of having daily pain.

Conclusion: In this population based cohort, nearly two out of three adolescents reported current pain and on average one of three reported pain in more than one body region. One out of five reported daily pain. The study highlights a serious problem that calls for investigations into improved understanding, prevention and treatment of adolescents with pain.

THE INFLUENCE OF ASSISTIVE DEVICES AND MOVEMENT RESTRICTIONS DURING REHABILITATION AFTER FAST-TRACK TOTAL HIP REPLACEMENT (THR)

\section{L.R. Mikkelsen', K. Søballe', M.K. Petersen', S. Mikkelsen' , I. Mechlenburg ${ }^{2}$}

'Department of orthopaedic surgery, Silkeborg Regional Hospital,

${ }^{2}$ Department of orthopaedic surgery, Aarhus University Hospital,

${ }^{3}$ Department of Physiotherapy and Occupational Therapy, Aarhus University Hospital, Skejby/ Department of Public Health, Aarhus University

Background and objectives:

Improvements in surgical techniques might have changed the rationale for movement restrictions. Studies suggest that when an anterolateral surgical procedure is used hip precautions are unnecessary in order to prevent hip dislocation. Furthermore, the use of assistive devices and movement restrictions seem to prolong rehabilitation. Possible harms and benefits when a posterior surgical approach is used, as in Denmark, remain unknown.

The aim of this trial was to evaluate the influence of assistive devices and movement restrictions on early functional status, anxiety and activities of 
daily living (ADL).

Methods:

A quasi-experimental design was used to compare the conventional procedure (control group) with a new less restricted regime (intervention group). Assessments were made before surgery, 3 and 6 weeks postoperatively by means of; HOOS (function, pain, quality of life), HADS (anxiety and depression) and ADL evaluated by physiotherapists.

Results:

Data on 420 THR patients have been collected and data entry is currently ongoing. At the PhD Day, it is expected that results of the data analysis can be presented.

P19.04 Merete Gregersen
P19.05 Lene Rahr Wagner
A LIBERAL BLOOD TRANSFUSION STRATEGY AFTER HIP FRACTURE SURGERY DOES NOT INCREASE THE RISK OF INFECTION IN FRAIL ELDERLY PATIENTS

\author{
M. Gregersen', L.C. Borris², E.M. Damsgaard' \\ 'Department of Geriatrics, Aarhus University Hospital, ${ }^{2}$ Department of \\ Orthopaedics, Aarhus University Hospital
}

Background: Postoperative anaemia is common in frail elderly hip fracture patients. Blood transfusion down-regulates immune responses. Numerous studies suggest that transfusions slightly increase the risk of infections. Our aim is to assess whether a liberal postoperative blood transfusion strategy increases the risk of infection.

Material and methods: 185 hip fracture patients with postoperative anaemia aged 65 or older admitted from nursing home or senior housing for surgery were enrolled. The patients were randomized to two different blood transfusion strategies; a liberal or a restrictive. In the liberal strategy, transfusions were given when the hemoglobin level was less than $7 \mathrm{mmol} / \mathrm{l}$ $(11.3 \mathrm{~g} / \mathrm{dll})$. In the restrictive strategy, transfusions were given at hemoglobin levels below $6 \mathrm{mmol} / \mathrm{l}(9.7 \mathrm{~g} / \mathrm{dll})$. During the first 30 postoperative days, Creactive proteins (CRP), and leucocytes were determined weekly, and time to first treatment-requiring infection indicated by a positive urine culture or suspected infection.

Results: The likelihood ratio test (LRT) of the repeated measurements of CRP showed no difference in the logarithm transformed CRP values $(p=0.85)$ in the two groups. LRT of the repeated measurements of leucocytes showed no difference in the logarithm transformed leucocytes $(p=0.55)$. In a Cox regression model, time to first infection after surgery was similar in the two groups (Hazard Ratio 0.81 [95\% confidence interval: 0.58; 1.14]).

Conclusion: A liberal strategy of blood transfusion does not increase the risk of infection after hip fracture in frail elderly patients compared to a restrictive transfusion strategy.

INCREASED RISK OF REVISION SURGERY AFTER ANTERIORMEDIAL COMPARED WITH TRANSTIBIAL TECHNIQUE FOR FEMORAL DRILLHOLE PLACEMENT DURING ANTERIOR CRUCIALTE LIGAMENT RECONSTRUCTION. RESULTS FROM THE DANISH KNEE LIGAMENT RECONSTRUCTION REGISTRY (DKRR)

L. Rahr-Wagner, ${ }^{\text {I, }, ~ T . ~ T h i l l e m a n n ~}{ }^{2}$, A. Pedersen ', M. Lind ${ }^{2}$

'Department of Clinical Epidemiology, Aarhus Unversity Hospital, ${ }^{2}$ Sports Devision, Department of Orthopedic, Aarhus University Hospital

The wish of anatomical anterior cruciate ligament reconstruction ( $A C L r$ ) has led to increasing use of the anteromedial (AM) portal for femoral drill hole placement. The AM technique is more challenging compared to the traditional transtibial (TT) technique due to lack of "easy to use" guides and 
necessity of hyperflexion during drilling. The DKRR has monitored the quality and development in ACLr since 2005 and has registered femoral drilling technique since 2007. The objective of this study is to report revision rates with the AM and TT approach in ACLr.

Methods: Our cohort included 8375 primary ACLr procedures from the DKRR from 2007 to 2010. The survival of the two different drilling techniques was determined using revision ACLr as primary endpoint. For statistical analysis, Kaplan-Meier and Cox regression analyses were used. Patient related outsome scores were used as secondary outcome.

Results: The use of AM approach in Denmark increased from 13\% in 2007 to $40 \%$ in 2010 . The revision rate after 3 years using AM femoral drilling and TT femoral drilling was $4.7 \%$ and $2.6 \%$, respectively. AM technique was associated with an increased risk of revision of 2.04 (Cl: 1.39-2.99). Patientrelated outcome scores pre- and post-operatively were identical for the two groups.

Conclusion: The introduction of AM technique for femoral drilling in ACLr has resulted in an increased risk of revision compared to TT technique. A slight increase in technical failures due to the introduction of a new and more complex technique may explain the presented findings. Ongoing monitoring of the results with the AM approach is therefore necessary and exemplifies the importance of a national registry.

P19.06 Manoj COMPARISON OF OUTCOMES AND COMPLICATIONS OF HIP Ramachandran ARTHROSCOPY FOR MIXED HIP DISORDERS IN ADOLESCENTS VERSUS ADULTS: A PROSPECTIVE COHORT STUDY

M. Ramachandran', ', P. Achan', M. Gottliebsen', B. Moller-Madsen'

${ }^{1}$ Department of Children's Orthopaedics, Aarhus University Hospital, ${ }^{2}$ Department of Paediatric Orthopaedics, Barts and The London Children's Hospital, London, England

Introduction: The current literature indicates that hip arthroscopy is safe in both adolescents and adults with good early outcomes. There are currently no studies that directly compare the outcomes of the procedure for mixed indications in these two groups.

Methods: The study design was a prospective cohort study of 52 supine hip arthroscopies in 50 patients ( 26 adolescent hips, mean age 14.2 years and 26 adult hips, mean age 33.5 years) at a tertiary referral hospital between 2008 and 2010. Patient demographics, indications for surgery, Modified Harris Hip Scores (MHHS) and complications were recorded.

Results: The preoperative MHHS improved from a mean of 58.5 to 91.0 $(p<0.01)$ in the adolescent group and from 64.3 to $87.4(p<0.01)$ in the adult group at a minimum of 1 year. There was no statistical significance difference in outcome. There were 2 cases of transient lateral femoral cutaneous nerve palsy ( 1 adolescent and 1 adult) that resolved spontaneously. There were 2 transient pudendal nerve palsies that resolved spontaneously in the adolescent group. The mean traction time was 54.0 minutes in the adolescent group versus 55.5 minutes in the adult group. No cases of proximal femoral physeal growth disturbance or osteonecrosis were seen at the most recent follow-up.

Conclusion: Hip arthroscopy leads to early good outcomes with low complication rates in both adolescent and adult patients. The incidence of pudendal nerve palsy in the adolescent group needs to be further investigated, particularly in the context of traction forces on the adolescent pelvis. Outcomes, scores and complications in further patients in this cohort are currently being reviewed. 
P19.07 Jannie Dahl HEALTH-RELATED QUALITY OF LIFE IN ADULTS WITH OSTEOGENESIS Hald IMPERFECTA IS IMPAIRED BY PREVALENCE OF MULTIPLE FRACTURES

J.D. Hald ', L. Folkestad ${ }^{2}$, T. Harsløf ${ }^{7}$, M. Schmidt ${ }^{3}$, H. Gjørup ${ }^{3,4}$, D. Haubek ${ }^{3}$, K. Brixen $^{2}$, B.L. Langdahl

'Department of Endocrinology and Metabolism, Aarhus University Hospital,

${ }^{2}$ Department of Endocrinology, Odense University Hospital, ${ }^{3}$ Department of Dentistry, Health, Aarhus University, ${ }^{4}$ Center for Oral Health in Rare Conditions, Aarhus University Hospital

Osteogenesis imperfecta $(\mathrm{OI})$ is a hereditary disease of the connective tissue. Common symptoms are fractures, dentinogenesis imperfecta (DI) and hypermobility. Our aim was to determine the impact of fractures, hypermobility and DI on health-related quality of life (HRQoL) through a cross-sectional study of 54 Danish adult Ol patients.

Dental and physical exams were performed and information about number of self-reported fractures was collected by interviews. HRQoL was examined by the SF-36 questionnaire consisting of 36 questions in 8 major domains; 4 physical domains: Physical Function (PF), Role Physical (RP), Body Pain (BP) and General Health (GH) and 4 mental domains: Vitality (VT), Social Function (SF), Role Emotional (RE) and Mental Health (MH). Scores are 0100, a higher score reflects a better self-reported HRQoL. The 8 domains above were compared between $\mathrm{OI}$ patients with and without $\mathrm{DI}$, hypermobility or with less/equal to or more than 10 reported fractures.

Patients with DI had an impaired PF score, $p=0.04$. Increasing number of fractures decreased the PF score $(p=0.016)$.

We investigated HRQoL in relation to 3 phenotypical features. The only SF36 domain affected by DI and a high number of fractures was PF. It is not surprising that increasing number of fractures that may cause deformities and limit functionality impairs the physical function score. The effect on PF seen with $\mathrm{DI}$ is most likely caused by the coexistence of multiple fractures and DI in severely affected patients. Surprisingly, the other three physical domains or mental health domains were not affected, despite severe and lifelong symptoms of $\mathrm{O}$. This may reflect the adaption to a congenital disease.

P19.08 Kresten Rickers EXPERIMENTAL REGENERATIVE REPAIR OF ANNULUS FIBROSUS USING SCAFFOLDS AND MESENCHYMAL STEM CELLS IN A PORCINE HERNIATION MODEL

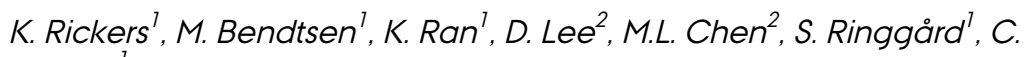
Bünger ${ }^{7}$

${ }^{1}$ Aarhus University Hospital, ${ }^{2}$ iNANO, Aarhus University

This study will investigate the possible use of 3 different scaffolds to help regenerate annulus fibrosus of the intervertebral disc (IVD). Degeneration of the IVD causes fissures and herniations in the annulus fibrosus. In order to treat the degenerated disc, the annulus fibrosus needs to heal these defects. In this study, a large defect in the annulus fibrosus is sealed with 3 different scaffolds. The study is carried out in a large porcine model. The defect is applied in the antero-lateral side of 4 lumbar and 3 cervical discs. Scaffolds are pressed into the defect and secured by sutures. After 3 months' observation, pigs are sacrificed, the spines harvested en bloc and frozen. Analyses include MRI, CT, histomorphology and immunohistochemistry. Mechanical properties of the different scaffolds as well as cell seeding efficiency will be characterized in vitro. Ex vivo testing of fixation stability when implanted into the IVD is planned to be performed in collaboration with VU medical center, Amsterdam and their biomechanical laboratory. This study can tell us more about the in vivo properties of the PIPA scaffold such as inflammatory response as well as nerve and vessel ingrowth. Future 
P20.01 Henriette Lajgaard Christensen

P20.02 Nina Jensen studies can take off from this study if the scaffold proves to be suited for repairing annulus defects.

DOES NA:HCO ${ }_{3}$ COTRANSPORTER E2 REGULATE CEREBROSPINAL FLUID PH AND RESPIRATORY RATE?

\section{H.L. Christensen, H.H. Damkier, J. Prcetorius}

Department of Biomedicine, Aarhus University

The aim of this project is to establish the role of the electrogenic sodium bicarbonate co-transporter $\mathrm{NBCe} 2$ in the regulation of cerebrospinal fluid (CSF) $\mathrm{pH}$, and thereby the respiratory rate and seizure susceptibility.

Despite the clear clinical importance, strikingly little is known about the molecular mechanisms behind CSF pH control. NBCe2 is a member of the solute carrier gene family (SLC4A) of bicarbonate transporters and has been found in the choroid plexus (CP), where it transports $\mathrm{Na}^{+}$and $\mathrm{HCO}_{3}^{-}$from the cells into the CSF. The localization, as well as the transport direction, makes the protein an obvious candidate for regulating CSF $\mathrm{pH}$. Thus, NBCe2 may be one molecular mechanism that protects CSF pH against rapid fluctuations in $\mathrm{pCO}_{2}$ or chronic acid load and secures a suitable respiratory drive.

To determine how NBCe2 is involved in CSF pH regulation, we have generated a novel CP-specific NBCe2 knockout mouse line. Molecular validation of the mouse line will be achieved through quantitative PCR, Western blotting and immuno-histochemistry. Measuring the $\mathrm{pH}$ regulation in isolated CP cells will validate functional NBCe2 knockout. I will compare the CSF $\mathrm{pH}$, pulmonary ventilation and seizure threshold upon acute changes in $\mathrm{PCO}_{2}$, and evaluate the effect of metabolic acid/base disturbance on the same parameters in wild type and NBCe2 knockout mice. Furthermore, the regulation of $\mathrm{NBCe} 2$ expression, membrane targeting and activity will be elucidated.

Hopefully, the results will lead to a better understanding of the mechanisms underlying CSF pH regulation - important knowledge that will be of great value in future research in respiratory control and epilepsy.

PHYSIOLOGICAL AND PATHOLOGICAL FUNCTION OF THE TYPE III SODIUMDEPENDENT PHOSPHATE TRANSPORTERS WITH FOCUS ON THEIR ROLE IN CALCIFICATION

\section{$N$. Jensen}

Department of Clinical Medicine, Section of Molecular Biology and Genetics, Aarhus University

The type III sodium-dependent phosphate symporters, PiT1 and PiT2, are known to be involved in calcification of the medial layer of arteries and calcifications in the brain (Farh's disease), respectively. Medial calcification is highly prevalent in patients with diabetes and chronic kidney disease and contributes to their increased risk of cardiovascular morbidity and mortality, and it is strongly associated with hyperphosphatemia (serum Pi levels > 1.45 $\mathrm{mM}$ ). Medial calcification takes place in close relationship to the vascular smooth muscle cells (VSMCs), which seem to undergo trans-differentiation to chondro-/osteoblast-like cells during the process of calcification both in vivo and in vitro. When VSMCs are grown under hyperphosphatemic conditions, they upregulate the expression of PiT 1, and it has been shown in vitro that knockdown of PiT1 decreases the calcification. Farh's disease is an inherited disease and it is strongly linked to mutations in PiT2 causing an impaired Pi uptake ability. An important regulator of calcification is the balance in the extracellular milieu between $\mathrm{Pi}$ and the calcification inhibitor pyrophosphate (PPi). PPi is transported out of cells by the membrane protein ANKH. PiT1 is known to interact with ANKH; it is unknown if PiT2 participates in this interaction. I hypothesize that hyperphosphatemia and the observed 
P20.03 Mie Rostved Rasmussen

P20.04 Steen Fagerberg mutations in PiT2 disrupt the Pi/PPi balance, leading to calcifications. The role of PiT1, PiT2 and ANKH in ectopic calcification will be studied in osteoblastic cells and human VSMCs. In addition, the effect of partially and complete PiT2 knockout will be studied in mice.

\section{THE PSEUDOXANTHOMA ELASTICUM ENIGMA; A SEARCH FOR THE ABCC6} SUBSTRATE

\section{M.R. Rasmussen, S.K. Moestrup}

Department of Biomedicine, Aarhus University

Pseudoxanthoma elasticum (PXE), caused by mutations in the ATP-binding cassette $(A B C)$ protein $A B C C 6$, is a serious genetic disorder with ectopic tissue mineralization affecting skin, eye and the cardiovascular system. Interestingly, ABCC6 protein is virtually absent in affected organs, whereas a high expression is seen in hepatocytes. This and further experimental evidence indicate that PXE is a metabolic liver disease where changes in the circulation affect the peripheral mineralization process. Owing to the well-characterized transport of organic substrates by related $A B C$ proteins, it has been proposed that PXE is caused by impaired export of an antimineralization small molecule compound. Alternatively, the ectopic mineralization in PXE could be due to hepatic accumulation of ABCC6 substrate(s) causing altered secretion of known anti-mineralization factors. At present, the identity of substances transported by ABCC6 remains unknown.

In the present study, a metabolomics-based screening approach will be used to identify ABCC6 substrates. Biological fluids like bile, plasma and urine from mice with viral-mediated knockdown of ABCC 6 in the liver will be analyzed and compared to fluids from wildtype mice by metabolomics using liquid-chromatography/mass spectrometry (LC/MS). In addition, biological samples from wildtype mice will be subjected to a transporter assay with $\mathrm{ABCC} 6$-expressing inside-out vesicles. The vesicular content will be analyzed by LC/MS.

With this study, it is our intention to disclose the physiological role of ABCC6. Hence, this may shed light on how impaired ABCC6 protein function in central organs causes alterations in peripheral tissues of PXE patients.

P2X RECEPTOR-DEPENDENT ERYTHROCYTE DAMAGE BY ALPHAHEMOLYSIN FROM ESCHERICHIA COLI TRIGGERS PHAGOCYTOSIS BY THP- 1 CELLS

\section{S.K. Fagerberg, M.G. Skals, J.G. Leipziger, H.A. Praetorius}

Department of Biomedicine (Physiology), Aarhus University

The pore-forming exotoxin a-hemolysin from E. coli causes a significant volume reduction of human erythrocytes that precedes the ultimate swelling and lysis. This shrinkage results from activation of $\mathrm{Ca}^{2+}$-sensitive $\mathrm{K}^{+}\left(\mathrm{K}_{\mathrm{Ca}} 3.1\right)$ and $\mathrm{Cl}^{-}$channels (TMEM16A) and reduced functions of both of these channels potentiate the HlyA-induced haemolysis. This means that $\mathrm{Ca}^{2+}$. dependent activation of $\mathrm{K}_{\mathrm{Ca}} 3.1$ and TMEM16A protects the cells against early haemolysis. Simultaneous to the HlyA-induced shrinkage, the erythrocytes show increased exposure of phosphatidyl-serine (PS) in the outer plasma membrane leaflet, which is known to be a keen trigger for phagocytosis.

We hypothesize that exposure to HlyA elicits removal of the damaged erythrocytes by phagocytic cells. Cultured THP- 1 cells as a model for erythrocytal phagocytosis were verified by a variety of methods including live cell imaging. We consistently found the HlyA to very potently trigger phagocytosis of erythrocytes by THP- 1 cells. The HlyA-induced phagocytosis was prevented by inhibition of $\mathrm{K}_{\mathrm{Ca}} 3.1$, which is known to reduce $\mathrm{PS}$ exposure in human erythrocytes exposed to both ionomycin and HlyA. 
Moreover, we show that the $\mathrm{P} 2 \mathrm{X}$ receptor inhibition, which prevents the cell damages caused by HlyA, also reduced the HlyA-induced PS exposure and phagocytosis. Based on these results, we propose that erythrocytes, damaged by HlyA-insertion, are effectively cleared from the blood stream. This mechanism will potentially reduce the risk of intravascular hemolysis.

P20.05 Anders Riisager SIGNAL TRANSMISSION FROM MUSCLE ACTIVITY TO CLC-1 CHLORIDE Sørensen CHANNEL FUNCTION

A. Riisager, T.H. Pedersen, O.B. Nielsen

Department of Biomedicine, Arhus University

Background and aim: In skeletal muscle, action potential (AP) firing elicits a Protein Kinase C (PKC) dependent down-regulation of CIC-1 chloride channel permeability, which is important for the maintenance of their excitability during work. The link between AP firing and PKC activation is unknown, but since PKC is sensitive to $\mathrm{Ca}^{2+}$, a role for the AP-induced $\mathrm{Ca}^{2+}$ transients has been suggested.

During work, the AP firing and the corresponding $\mathrm{Ca}^{2+}$ oscillations vary profoundly with the duration and intensity of the contractions. The importance of this variation for the regulation of the chloride channels is, however, unknown. The aim of this study was, therefore, to elucidate the relation between $\mathrm{Ca}^{2+}$ oscillations during AP stimulation of different intensities and durations and the acute regulation of chloride channels in muscle fibres.

Methods: APs were elicited in muscle fibres from rats, mice and humans by injecting currents via intracellular electrodes. Chloride channel permeability was estimated from resting membrane conductance determined using a two-electrode constant current technique. To determine intracellular $\mathrm{Ca}^{2+}$ oscillations, the $\mathrm{Ca}^{2+}$ indicator Mag-fluo-4 was injected into individual muscle fibres.

Results: Preliminary results suggest that the acute regulation of chloride channels depends most strongly on the intensity of AP stimulation rather than its duration, and that this dependency is related to a role for the stimulation-induced $\mathrm{Ca}^{2+}$ transients in the activation of PKC. The result furthers the understanding of the acute regulation of excitability in muscles in particular and of the pathways signalling AP activity to cellular processes in general.

P20.06 Casper Kornbech Larsen

\section{COLONIC K ${ }^{+}$SECRETION IN KCNMB2 KNOCKOUT MICE \\ C.K. Larsen}

Department of Biomedicine, Aarhus University

Colonic $\mathrm{K}^{+}$excretion occurs via the pump-leak mechanism, where $\mathrm{K}^{+}$is taken up from the basolateral side via the $\mathrm{Na}^{+} / \mathrm{K}^{+}$pump and the $\mathrm{NKCC} 1 \mathrm{co}-$ transporter and leaves the cells via apical $\mathrm{K}^{+}$channels. The BK channel has been identified as the relevant $\mathrm{K}^{+}$channel involved in $\mathrm{K}+$ secretion in the murine distal colon. The BK channel is composed of 4 a-subunits (encoded by the KCNMA 1 gene) and 4 modulatory $\beta$-subunits, of which there are 4 isoforms (encoded by the genes KCNMB 1-4). The channel is activated by membrane depolarization and increases in $\left[\mathrm{Ca}^{2+}\right]_{i}$. The sensitivity and kinetics depend on the associated $\beta$-subunits. In the murine colon, only the $\beta_{2}$-subunit (KCNMB2) is expressed. The $\beta_{2}$-subunit increases the sensitivity of the $\mathrm{BK}$ channel to $\left[\mathrm{Ca}^{2+}\right]_{\mathrm{i}}$, thus facilitating channel opening.

We purchased a novel global KCNMB2 knockout mouse to study intestinal $\mathrm{K}^{+}$secretion in the distal colon. Early data ( $\mathrm{n}=4 \mathrm{WT}$ and $\mathrm{KO}$ ) indicate that on a standard $\mathrm{K}^{+}$diet, $\mathrm{KCNMB}^{-1-}$ mice show intact colonic $\mathrm{K}^{+}$secretion. Interestingly, resting and $\mathrm{ATP}$-stimulated $\mathrm{K}^{+}$secretion was tentatively higher in $\mathrm{KCNMB2}^{-/-}$mice than in $\mathrm{KCNMB2}^{+/+}$mice. Colonic $\mathrm{K}^{+}$secretion on 
standard $\mathrm{K}^{+}$diet is small, but raising plasma aldosterone by feeding the mice a $5 \% \mathrm{KCl}$ diet for 4 days results in marked upregulation of colonic $\mathrm{K}^{+}$ secretion. Thus, the next step is to solidify these early data and repeat the measurements of resting and ATP-stimulated $\mathrm{K}^{+}$secretion in mice on a high $\mathrm{K}^{+}$diet. In summary, we speculate that the loss of the $\beta 2$-subunit may lead to a gain of function, i.e. an increase of colonic $\mathrm{K}^{+}$secretion.

P20.07 Tine Kjœrgaard TRAFFICKING OF LRP1 AND LRP2 IN HUMAN PLACENTA

\section{T. Kjcergaard, E.I. Christensen, M. Madsen}

Department of Biomedicine, Aarhus University

The low-density lipoprotein receptor-related protein 1 and 2 (LRP1 and LRP2) are known for their function in receptor-mediated endocytosis and interaction with a number of different ligands, e.g. lipoproteins, lipoprotein lipase and receptor-associated protein (RAP). In human tissues, LRP1 is mainly expressed in liver, placenta and nervous tissues and localize to both the apical and basolateral membrane. LRP2 is mainly expressed in polarized epithelial cells, e.g. of the kidney, and localize to the apical membrane.

It has been known for many years that LRP1 and LRP2 are both expressed in syncytiotrophoblasts of the human placenta. The syncytiotrophoblasts are cells in direct contact with the maternal bloodstream, and whether LRP 1 and LRP2 are involved in transplacental nutritional transportation processes during pregnancy is still unknown. Therefore, we have investigated the uptake of known LRP1 and LRP2 ligands in the trophoblast-like model cell lines JEG-3, JAR and BeWo, which are placental choriocarcinoma cell lines. For the ligands tested so far, LRP2 does not seem to have the same function as in the kidney. In contrast to the localization in other tissues, we find that LRP1 and LRP2 not only localize to the plasma membrane of syncytiotrophoblasts in term human placenta, but immunohistochemical staining also indicates massive intracellular vesicular localization.

To describe and characterize the intracellular localization (compartmentalization) and function of LRP1 and LRP2 in placenta, we are presently conducting trafficking studies of LRP1 and LRP2 in the placental cell lines mentioned above by using fluorescently tagged recombinant mini-receptors of LRP1 and LRP2.

P20.08 Søren Brandt INACTIVATION OF THE EPITHELIAL SODIUM CHANNEL (ENAC) IN THE Poulsen ALDOSTERONE-SENSITIVE CONNECTING TUBULE

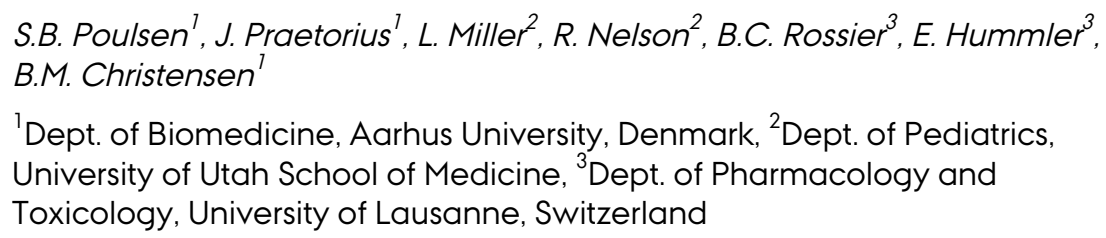

Renal ENaC-mediated $\mathrm{Na}^{+}$reabsorption is under tight control of aldosterone in the late distal convoluted tubule, the connecting tubule (CNT) and the collecting duct (CD). Inactivation of $\mathrm{aENaC}$ in the $\mathrm{CD}$ does not disturb $\mathrm{Na}^{+} / \mathrm{K}^{+}$balance in mice (Rubera et al, $\mathrm{JCl}$ 2003). However, deletion of $\mathrm{aENaC}$ in both the CD and CNT causes symptoms of PHA- 1 as evidenced by disturbances in $\mathrm{Na}^{+} / \mathrm{K}^{+}$balance both on a normal diet and on std. diets (Christensen et al, JASN, 2010). To further investigate the significance of $\mathrm{ENaC}$ for $\mathrm{Na}^{+} / \mathrm{K}^{+}$balance in the $\mathrm{CNT}$, we generated mice which should have a partial deletion of aENaC in the CNT. Mice with Cre-recombinase expressed under the control of the V-ATPase B 1 -subunit promoter (expresses Cre in part of the CNT cells, Miller et al, Kidney Int, 2009) were crossed with floxed Scnn la mice (Hummler et al, Genesis, 2002). When kept on a standard diet, the $\mathrm{KO}$ mice showed no significant difference in urinary $\mathrm{K}^{+}$and $\mathrm{Na}^{+}$excretion, urine output, or water intake (KO: $\mathrm{n}=10$; con: $\mathrm{n}=10$ ). 
P21.01 Omar

Abuyaman

Mice were subjected to a low $\mathrm{Na}^{+} /$high $\mathrm{K}^{+}$diet for $48 \mathrm{~h}$. After $24 \mathrm{~h}$, the $\mathrm{KO}$ mice showed a lower food $(p<0.05)$ and water intake $(p<0.05)$, and a tendency towards a lower urine output compared to the controls. By contrast, no significant differences were found after $48 \mathrm{~h}$. The plasma $\mathrm{K}^{+}$ level, however, was significantly higher in the $\mathrm{KO}$ after $48 \mathrm{~h}(\mathrm{p}<0.05, \mathrm{KO}$ : $\mathrm{n}=4$; con: $\mathrm{n}=5$ ). Furthermore, the relative weight loss was higher in the $\mathrm{KO}$ after $24 \mathrm{~h}(\mathrm{p}<0.05)$ and $48 \mathrm{~h}(\mathrm{p}<0.05)$. We show no change in kidney homeostasis in mice partly deficent for $\mathrm{aENaC}$ along the CNT when fed a std. diet. When the mice are challenged with a low $\mathrm{Na}^{+} /$high $\mathrm{K}^{+}$diet, the mice have increased $\mathrm{K}^{+}$levels in the plasma.

STUDIES ON THE SOLUBLE RECEPTOR FOR VITAMIN B ${ }_{12}$ UPTAKE (SCD320) DURING PREGNANCY

\author{
O. Abuyaman ', B.H. Andreasen ', E. Vittinghus' ${ }^{2}$, E. Nexø ${ }^{7}$ \\ 'Department of Clinical Biochemistry, Aarhus University Hospital,, \\ ${ }^{2}$ Department of Clinical Biochemistry, Randers County Hospital
}

Introduction: Cellular uptake of vitamin $\mathrm{B}_{12}\left(\mathrm{~B}_{12}\right)$ demands binding of the vitamin to transcobalamin (TC) and recognition of $\mathrm{TC}-\mathrm{B}_{12}$ by the receptor CD320, a receptor expressed in high quantities on human placenta. We have identified a soluble form of CD320 (sCD320) in plasma and here we present data on the occurrence of this receptor during pregnancy.

Methods: Twenty-seven pregnant women were examined at gestation weeks 13, 24 and 36 for serum sCD320, before and after 2 days intake of 3 $\times 9$ microgram $B_{12}$. In addition, paired serum and urine samples from ten pregnant women (gestational weeks 19-39) was analyzed.

Results: Mean \pm (SEM) of serum sCD320 increased from 28 (1.6) arb.u./L (gestation week 13) to 51 (3.4) arb.u./L (gestation week 36). The increase was followed by an increased secretion in the urine reaching levels of 116 ( 14.5) arb.u./L. Urinary sCD320 correlated with serum sCD320. Interestingly a small (mean: 2 arb.u.), but significant, increase in serum sCD320 was observed after administration of $\mathrm{B}_{12}$ over two days.

Conclusion: Serum sCD320 increase during pregnancy. This increase is judged to be caused by a higher release from cells rather than a decrease in kidney clearance. In addition sCD320 may be regulated by the intake of vitamin $B_{12}$.

P21.02 Helen Nordahl THE IMPACT OF ANTI-MULLERIAN HORMONE (AMH) ON THE EPIDERMAL Madsen GROWTH FACTOR (EGF) SYSTEM IN PREANTRAL FOLLICLES

H.N. Madsen ', H.J. Ingerslev', N. Tørring ${ }^{7}$

${ }^{1}$ Department of Clinical Biochemistry, Aarhus University Hospital, Skejby,

${ }^{2}$ The Fertility Clinic, Department of Obstetrics and Gynaecology, Aarhus University Hospital, Skejby

Background: Ovarian follicle maturation is a complex process that requires coordination between the hypothalamus, the anterior pituitary and different cell types within the follicle itself. Within the follicle, two growth factor systems, the anti-Müllerian Hormone (AMH) and the Epidermal Growth Factor (EGF), are known to regulate the growth and differentiation. AMH exerts an inhibitory effect on follicle recruitment and early folliculogenesis. Contrary to $\mathrm{AMH}$, the EGF system promotes folliculogenesis. The interaction and regulation of these two systems have not yet been elucidated.

Method: Cultures of preantral mouse follicles were treated with AMH for 6 , 12 and $24 \mathrm{hrs}$ in presence of the gonadotropins LH and FSH. Gene expression microarray analysis was conducted by employing the Affymetrix gene expression system (MG 430 2.0), and AMH-treated follicles were compared to untreated follicles. Differently expressed genes (DEGs) of the EGF-family receptors were determined based on a cut-off of 3-fold up- or 
Results: Gene-expression microarray analysis showed a transient upregulation of a subset of ligands of the EGF system including Betacellulin, Amphiregulin and Epiregulin. The ligands were upregualted at 6 to $12 \mathrm{hrs}$ followed by down-regulation at $24 \mathrm{hrs}$. Transforming growth factor alpha and the two receptors EGFr and ErbB3 were down-regulated at $12 \mathrm{hrs}$ to 24 hrs, respectively. Altogether, these preliminary results suggest that the role of $\mathrm{AMH}$ in early folliculogenesis involves the EGF system, but the interaction between EGF and $\mathrm{AMH}$ needs to be further clarified.

STRUCTURAL AND CONFORMATIONAL CHARACTERIZATION OF INACTIVE FORMS OF ANTITHROMBIN (AT)

\section{A. Østergaard' , M.B. Trelle ${ }^{2}$, J.K. Jensen ${ }^{3}$, S.R. Kristensen ${ }^{7}$, S. Pedersen ${ }^{7}$ \\ 'Department of Clinical Biochemistry, Aalborg Hospital, Aarhus University Hospital, ${ }^{2}$ Department of Biochemistry and Molecular Biology, University of Southern Denmark, ${ }^{3}$ Department of Molecular Biology and Genetics, Aarhus university}

AT is a member of the serpin super family and is considered the most im-por-tant endogenous anticoagulant. It inhibits several se-ri-ne proteases controlling coagulation activity and pre-ven-ting inappropriate clot formation. AT deficiency may therefore increase the risk of thrombosis. Mutations in the AT gene can result in conformational diseases, where native AT may change into an inactive latent form or other less active native forms forming dimer or polymers. This will reduce the activity of AT and thereby increase the risk of thrombosis. However, the mechanisms of these changes are only partially understood.

The aim of the project is to map the structural and conformational abnormalities of different inactive forms of AT by characterizing artificially produced dimer, trimer and latent AT, and of recombinant produced AT mutants known to be prone to make conformational changes, i.e. latent transition and polymerization.

Latent AT, dimer and polymers were produced by heating purified wt AT at high temperature. The polymeric forms were separated using chromatography. The AT forms were characterized by measuring activity, co-factor affinity, structure stability and pro-coagulant activity. Further structural analyses will be performed by Hydrogen-Exchange MS, small angle $X$-ray scattering and crystallography.

The polymeric forms have been successfully separated, and preliminary results show that the polymeric and latent forms have a severely reduced or no inhibitory activity compared with native AT. The results of this study will elucidate the complex process taking place in some patients with AT deficiency, and this may potentially help improve the therapy and prophylaxis.

P21.04 Anette Tarp INCREASED RISK OF THROMBOSIS IN PREGNANCY AFTER IN VITRO Hansen FERTILIZATION: A DANISH NATIONAL COHORT STUDY

\section{A.T. Hansen', U.S. Kesmodel', S. Juul ${ }^{2}$, A.M. Hvas ${ }^{7}$}

${ }^{1}$ Center of Hemophilia and Thrombosis, Department of Clinical Biochemistry, Aarhus University Hospital, Brendstrupgaardsvej 100, 8200 Aarhus N, Denmark., ${ }^{2}$ The Fertility Clinic, Department of Obstetrics and Gynecology, Aarhus University Hospital, 8200 Aarhus N, Denmark., 'Section of Epidemiology, Department of Public Health, Aarhus University, 8000 Aarhus C, Denmark

Background: In vitro fertilization (IVF) has been regarded a risk factor for thrombosis. In a recent national cohort study, we could not confirm the hypothesis that IVF treatment itself increases the risk of venous 
P21.05 Tina Rask Elmholdt thromboembolism if a pregnancy was not achieved. The aim of the present study was to investigate if the risk of venous thromboembolism is increased in pregnancies following IVF compared to other pregnancies.

Methods: A national register-based cohort study on 18,948 pregnancies conceived by IVF in Denmark from 1994 to 2005. Data from three national registers were linked. Medical records were reviewed to confirm the diagnoses of thrombosis. A recently published study on venous thromboembolism in pregnant and puerperal women in Denmark was used as a reference.

Findings: In total, 48 cases were identified; 36 ante partum and 12 post partum. Incidence rate ratios for first trimester venous thrombosis were 5.9 (95\% confidence interval $(\mathrm{Cl}) 2.7-12.8)$ for singleton pregnancies $(\mathrm{N}=12,728)$ and $7.9(95 \% \mathrm{Cl} 2.5-25.3)$ for multiple pregnancies $(\mathrm{N}=4,043)$ compared to the reference pregnancies, but increased risk was seen throughout pregnancy. Incidence rate ratios for post partum venous thrombosis were 1.2 (95\% Cl 0.5-2.8) for singleton pregnancies and 3.9 (95\% Cl 1.7-8.7) for multiple pregnancies compared to reference pregnancies.

Interpretation: We demonstrated a significantly increased risk of VTE in IVF pregnancies. The excess VTE risk was especially high during the first trimester and the first six weeks after delivery in both singleton and multiple pregnancies.

GADOLINIUM DEPOSIT IN SKIN BIOPSIES FROM RENAL IMPAIRED PATIENTS WITH AND WITHOUT NEPHROGENIC SYSTEMIC FIBROSIS

T.R. Elmholdt, ${ }^{1}$, A.B. Olesen ${ }^{2}$, M. Ramsing ${ }^{3}$, B. Newton ${ }^{4}$, I. Martinsen ${ }^{5}$, E. Hall, M. Pedersen

'Department of Clinical Medicine, Aarhus University, ${ }^{2}$ Department of Dermatology, Aarhus University Hospital, ${ }^{3}$ Department of Pathology, Aarhus University Hospital, ${ }^{4} G E$ Healthcare, Medical Diagnostics Discovery Research, Amersham, UK., ${ }^{5}$ GE Healthcare, Research and Development, Oslo, Norway, ${ }^{6}$ GE Global Research Niskayuna, NY USA, ${ }^{7}$ MR Research Centre Aarhus University

Purpose: In this study, we aim to investigate if renal impaired patients suffering from nephrogenic systemic fibrosis (NSF) compared to renal impaired patients without NSF differed in the amount of gadolinium (Gd) accumulated in the skin after exposure to: 1) assess if the level of Gd was associated to the severity of NSF, 2) identify the distribution, form and morphology of $\mathrm{Gd}$ and 3) measure if the procollagen III propeptide level was reflecting the degree of fibrosis activity.

Methods and materials: We performed a case-control study on renal impaired patients recruited from Aarhus University Hospital, all exposed to Gd; Group 1: renal impaired patients with NSF and Group 2: renal impaired patients without NSF. In Group 1, two biopsies were taken; one from lesional skin and one from non-lesional skin. In Group 2, one biopsy was taken from non-lesional skin. Biopsies were analysed using inductively coupled plasma sector field mass spectroscopy, scanning electron microscopy and transmission electron microscopy.

Results: 16 patients were included. 25 biopsies were performed. The average Gd concentration was highest in the lesional skin biopsies. High concentrations of $\mathrm{Gd}$ were also found in some of the non-lesional biopsies from Group 2. Gd was found in clusters with calcium and phosphate. The Gd was most frequently located in the deep dermis and subcutaneous fibrous septa. The level of procollagen III propeptide was, on average, twice as high in Group 1.

Conclusion: Renal impaired patients exposed to $\mathrm{Gd}$ do not necessarily develop NSF, even when Gd is accumulated in the skin years after 
exposure. We found that high levels of Gd were associated with an increased NSF severity.

P21.06 Johan Frederik ELEVATED PLASMA VITAMIN B12 LEVELS AS A MARKER FOR OCCULT Berg Arendt CANCER

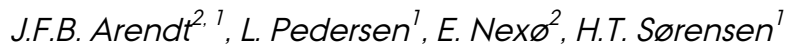 \\ ${ }^{1}$ Department of Clinical Epidemiology, ${ }^{2}$ Department of Clinical Biochemistry
}

Background: A substantial proportion of patients referred for B 12 measurement have elevated levels. Elevated plasma vitamin B 12 levels have been reported among cancer patients, but the risk for cancer among patients with newly diagnosed elevated B 12 level is poorly understood. We therefore examined the risk of subsequent cancer among Danish patients with incident high Cbl levels.

Methods: We included all patients with B12 levels of 200-600 (reference range), $601-800$ and $>800 \mathrm{pmol} / \mathrm{L}$ during 1998-2009 from the Laboratory Information Systems Database in Northern Denmark. To assess the cancer risk we compared the cancer rates among these patients with that of the general population during 1998-2010, computing standardized incidence ratios (SIRs). Data on the use of B12 supplements and cancer were obtained through the Aarhus University Prescription Database and the Danish Cancer Registry, respectively.

Results: We identified 354,175 patients with B 12 levels $>200 \mathrm{pmol} / \mathrm{L}$, and subsequent 23,618 cases of incident cancer. The median follow-up time was 3.5 years (interquartile range: 1.9-6.2). The first year SIR for non-B 12 supplemented patients 2.23 (95\% Cl: 2.18-2.28), and the SIR increased with higher B 12 levels. B 12 levels $>800$ pmol/L among non-supplemented patients were associated with the incidence of hematological cancers and cancers of the stomach, liver, pancreas, lung, kidney, urinary bladder, and prostate. No associations to high B 12 levels were found for colon, rectal, and breast cancer, malignant melanoma and cancers of the central nervous system.

Conclusion: High B 12 levels were associated with an increased cancer risk within the first year after the test.

P22.01 Zahra Nochi THE ROLE OF ALPHA-LIPOIC ACID IN MEDIUM-CHAIN ACYL-COA DEHYDROGENASE DEFICIENCY

\title{
Z. Nochi ${ }^{\text {I }, ~ R . I . ~ D u p o n t ~ B i r k l e r ~}{ }^{7}$, T.J. Corydon ${ }^{2}$, N. Gregersen ${ }^{7}$ \\ ${ }^{1}$ Research Unit for Molecular Medicine, Department of Clinical Medicine, Aarhus University Hospital and Faculty of Health, Aarhus University, ${ }^{2}$ Department of Human Genetics, Aarhus University
}

Mitochondrial fatty acid oxidation (FAO) defects have been acknowledged since the early 1970s, of which medium-chain acyl CoA dehydrogenase deficiency (MCADD) is the most frequent. The highly conserved fatty acid de novo synthesis pathway proceeds in a malonyl-CoA/acyl carrier protein (ACP)-dependent manner through a discrete set of enzymes. Generated octanoyl-ACP is a substrate for mitochondrial lipoic acid (LA) synthesis. LA is an essential cofactor of the pyruvate dehydrogenase (PD) complex and can also transiently and moderately increase reactive oxygen species (ROS) production, which serves as a signalling molecule. FAO is crucial in providing energy during periods when glucose is restricted or when energy needs are increased beyond the availability of glucose. In MCADD, the FAO is blocked, resulting in energy deficiency and accumulation of octanoylCoA, as well as clinical acute metabolic episodes or sudden death. It is noteworthy that $\mathrm{FAO}$ defects may have underlying ROS production; however, cells from MCAD patients are more resistant to oxidative stress than other FAO defects. The enzymatic defect results in an accumulation of octanoic acid (OA), the precursor of LA; therefore, we hypothesized that an 
P22.02 Navid MITOCHONDRIAL DYSFUNCTION AND MITOCHONDRIAL ACETYLATION IN Sahebekhtiari FAO DEFECTS

\section{N. Sahebekhtiari, P. Bross, J. Palmfeldt}

Research Unit for Molecular Medicine, Department of Clinical Medicine, Aarhus University Hospital and Aarhus University

Mitochondrial activity is essential for human health, and defects in mitochondrial functionality cause a wide range of disease including fatty acid oxidation (FAO) deficiencies. Mitochondrial activities in tissues are central for metabolism of lipids and fatty acids, and imbalance in this metabolism is involved in metabolic syndrome as well as inherited disorders of FAO. It is not clear whether oxidative stress is initiating or is a consequence of pathogenesis, but evidence supporting both is reported in the literature. While numerous mechanisms of injuries induced by oxidants and fatty acids have been identified, the impact on the overall content of mitochondrial proteins is still unclear. Altered expression of mitochondrial proteins and posttranslational modification (PTM) of these proteins is known to cause mitochondrial dysfunction. Recent proteomics surveys have revealed that lysine acetylation is a widespread PTM that is particularly abundant on mitochondrial proteins, suggesting that this posttranslational mechanism coordinates metabolism of carbon sources. This study will map the mitochondrial proteome as well as identify acetylated proteins under oxidative stress in order to delineate the relations between oxidative stress, fatty acid accumulation and acetylation. To find more details, we will elucidate the acetylation profile in unstressed and stressed cells from patients who suffer from FAO defects. Identification of the acetylated mitochondrial proteins will aid in further understanding the pathologic effector mechanisms of the disorders of FAO and might also provide information on therapeutic targets for mitochondrial oxidative stress related diseases.

P22.03 Veerle CONDITIONAL INACTIVATION OF THE SCHIZOPHRENIA AND BIPOLAR Paternoster DISORDER ASSOCIATED GENE IN THE CENTRAL NERVOUS SYSTEM OF MICE

V. Paternoster ${ }^{1,2}$, J.H. Christensen ${ }^{1,2}$, P. Qvist ${ }^{1,2}$, A. Hedemand ${ }^{1,2}$, M. Nyegaard $^{1,2}$, O. Mors ${ }^{2,3}$, A.D. Børglum, ${ }^{1,3}$

${ }^{1}$ Department of Biomedicine, Aarhus University, ${ }^{2}$ The Lundbeck Foundation Initiative for Integrative Psychiatric Research, iPSYCH, ${ }^{3}$ Centre for Psychiatric Research, Aarhus University Hospital

Accumulating evidence from genetic studies form strong evidence that the Bromodomain-containing 1 gene (BRDI) is involved in the pathogenesis of Schizophrenia (SZ) and Bipolar Disorder (BD). We aim at generating a mouse strain carrying a conditional inactivated allele of $\mathrm{Brd} 1 \mathrm{in}$ the central nervous system (CNS) neurons in order to establish the importance of Brd 1 in the adult brain and in behaviour.

C57BL/6 NTac mice carrying a targeted allele of Brd 1 with loxP sites flanking exon 3-5 were crossed with Nes-Cre mice carrying the Crerecombinase gene under control of the CNS-specific Nestin (Nes) promoter to obtain offspring carrying a deleted allele uniquely in the CNS. We confirm a reduction in full-length Brd 1 genomic DNA and Brd 1 transcripts in whole brain extracts from heterozygous (LC) and homozygous (FC) Brd1 knockout mice compared to wildtype animals (FW). In kidney, there is a slightly reduced amount of full-length Brdl gDNA and expression of Brdl mRNA, 
P22.04 Morten TorvundJensen

P22.05 Xiao Ma but not to the same level as in the CNS. The Nes-promoter was reported to be active to a lesser extent in kidney by the manufacturer of the Nes-Cre mouse. In liver and heart, no reduction was observed. No phenotyping results are available yet, though there is an indication of reduced growth in both $\mathrm{LC}$ and FC mice. Breeding of the mice (FW $x \mathrm{LC}$ ) to obtain FC offspring also revealed the offspring genotypes derivates from the Mendelian expectation, indicating partial embryonic loss of FC mice.

Our mouse strain carrying a conditional deleted allele of the Brdl gene will be an important tool to determine the importance of the $\mathrm{Brd} 1 \mathrm{gene}$ in the adult brain and in the pathogenesis of mental illnesses.

STRUCTURAL CHARACTERIZATION OF THE INTERACTION BETWEEN HAPTOGLOBIN-HEMOGLOBIN AND MACROPHAGE RECEPTOR CD163

\section{Torvund-Jensen}

Department of Biomedicine, Aarhus University

Release of hemoglobin ( $\mathrm{Hb}$ ) into the circulation during intravascular hemolysis is a potential hazard because $\mathrm{Hb}$ is a toxic compound outside red blood cells. The toxicity of $\mathrm{Hb}$ is mainly due to the reactivity of the heme group that is able to generate free radicals, which may eventually cause severe oxidative damage to tissues. In mammals, Hb released into the circulation is immediately bound by the plasma glycoprotein haptoglobin $(\mathrm{Hp})$ in one of the strongest non-covalent interactions observed in plasma. In the $\mathrm{HpHb}$ complex, $\mathrm{Hb}$ is protected from oxidative modification. Thus the function of $\mathrm{Hp}$ may be to protect the structural integrity of $\mathrm{Hb}$ by preventing oxidative modifications. The endocytic SRCR domain-containing macrophage receptor CD163 internalizes the $\mathrm{HpHb}$ complex in a $\mathrm{Ca}^{2+}$ dependent manner and degrades heme into non-toxic metabolites.

Detailed determination of the interfaces between CD 163 and $\mathrm{HpHb}$ could assist in development of cell-directed therapies targeting macrophage CD163, which is a highly attractive target candidate in many fatal diseases due to its restricted expression pattern and its ability to internalize ligands.

We recently determined the structure of porcine $\mathrm{HpHb}$ to $2.9 \AA$ resolution by protein X-ray crystallography. The main objective of my PhD studies will be to determine the structure of the receptor CD163 as well. $\mathrm{HpHb}$ is purified from blood, whereas CD163 is expressed using a mammalian expression system. Crystallization of CD 163 alone, as well as in complex with $\mathrm{HpHb}$, will be attempted. As CD163 is expected to adopt a rather flexible elongated fold, it may prove necessary to express only part of the extracellular segment to obtain crystallization.

IDENTIFICATION OF POSSIBLE DRIVING FACTORS OF ENDOTHELIAL CELL TUBE FORMATION DURING CULTIVATION ON THE RANDOM POSITIONING MACHINE

\section{Ma}

Department of Biomedicine, Aarhus University

When culturing human endothelial cells of the permanent line EA.hy926 on a microgravity-simulating random positioning machine (RPM), a tubular, three-dimensional (3D) growth pattern of free-floating aggregates can be observed beside the continuing proliferation of the adherent (AD) cells. Both $3 D$ aggregates and $A D$ cells' growth are most balanced on the RPM, and we separately harvested and analyzed them on day 5 and 7 and compared their proteomes and transcriptomes to those from control groups growing under normal static laboratory conditions for equal periods of time.

Differentially expressed proteins were identified using the free-flow isoelectric focusing method followed by mass spectrometry analysis. 149 differentially expressed genes were also detected as regulated proteins, 
P22.06 Dennis

Kjølhede Jeppesen and a validation of those transcripts involved in angiogenesis was independently performed using quantitative real-time PCR and Western Blot.

Compared to their respective $1 \mathrm{~g}$ control cells, 3D aggregates showed significantly elevated mRNA levels of ITGB 1, TGM2, TUBB6, CALD1, RDX, IL6, IL-8 and SPAG9 at day 5 and of IL-6, IL-8, ICAM- I, PAI-I and TUBB6 at day 7. In AD cells, we found IL-6, TLN 1, EZR, MSN, CALDI and TUBB6 mRNAs to be significantly upregulated on day 5 and PAI-1, PECAM- 1 and ITGB 1 on day 7. No significant changes were found for CAV1, ENG, ANXA2 and SPTAN 1. Only few genes were downregulated. In AD cells, it was GSN at day 5 and PECAM- 1 at day 7. No significant changes were found for CAV1, ENG, ANXA2 and SPTAN1.

Taken together, we conclude that transglutaminase 2, annexin A2, talin-1, ezrin, IL-6 and IL-8 may play a key role in the microgravity-dependent kind of tube formation.

QUANTITATIVE PROTEOMICS OF FRACTIONATED MEMBRANE AND LUMEN EXOSOME PROTEINS FROM ISOGENIC METASTATIC AND NON-METASTATIC BLADDER CANCER CELLS

D.K. Jeppesen', A. Nawrocki', K. Thorsen', S.G. Jensen' , B. Whitehead ${ }^{3}$, K. Howard', T.F. Ørntoft', M.R. Larsen', M.S. Ostenfeld ${ }^{7}$

'Department of Molecular Medicine, Aarhus University Hospital, Denmark, ${ }^{2}$ Department of Biochemistry, University of Southern Denmark, Denmark,

${ }^{3}$ The interdisciplinary Nanoscience Center (iNANO), Aarhus University, Denmark

Exosomes are small extracellular membrane vesicles present in biological fluids. They are secreted by various cell types and feature a rich array of membrane and luminal proteins. They are believed to be involved in biological processes such as cell-to-cell communication, tumorigenesis and cancer progression. Cancer and stromal cells release exosomes to both the cancer microenvironment and to circulation, where they may facilitate cancer progression and metastasis.

Here we present the first quantitative proteomic analysis of exosomes, fractionated by membrane or luminal localization, from isogenic bladder cancer cells with or without metastatic potential. Using the CLAD 1000 bioreactor system for increased yield, exosomes were isolated by ultracentrifugation in high yields from human bladder carcinoma cell line T24 without metastatic capacity and its two isogenic derivate cell lines SLT4 and FL3, which form metastases in the lungs and liver of mice. Using an iTRAQ proteomic approach, we have identified and quantified a number of exosomal membrane and luminal proteins that display significantly altered abundance in the metastatic exosomes compared to non-metastatic exosomes. A total of 60 and 61 proteins displayed differential abundance between SLT4 and FL3 vs. T24 exosomes, respectively.

Ingenuity pathway analysis of these proteins, revealed significant enrichment for proteins associated with cell-to-cell signalling and interaction, and cellular movement in exosomes with metastatic potential. Analysis of mRNA expression by Affymetrix GeneChip array revealed a significant correlation between differentially altered exosome proteins and cellular mRNA levels for FL3 exosomes.

P22.07 Halldór Bjarki IMMUNOGENICITY OF POLYCAPROLACTONE Einarsson H.B. Einarsson ${ }^{1,2}$, B. Jalilian ', H. Lysdahl', A. Baatrup ${ }^{2}$, A.B. Nielsen ${ }^{2}$, D.C.

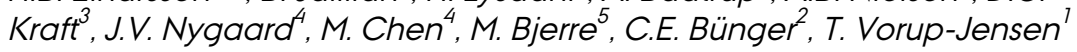

${ }^{1}$ Department of Biomedicine, Aarhus University, ${ }^{2}$ Orthopedic Research Laboratory, Aarhus University Hospital, ${ }^{3}$ School of Dentistry, Aarhus University, ${ }^{4}$ The Interdisciplinary Nanoscience Center, Aarhus University, 
${ }^{5}$ Department of Clinical Medicine, Aarhus University

Introduction: Exogenous antigens evoke immune response and are of nonself origin. In tissue engineering, polycaprolactone (PCL) is a template for cartilage and bone repairing. The aim of our study is to investigate the immunogenicity of PCL i.e. macrophage, osteoclast $(\mathrm{OC})$ and T cell response upon $\mathrm{PCL}$ exposure, complement activation, hence opsonization of $\mathrm{PCL}$ for phagocytosis, and $\beta_{2}$-integrin expression.

Materials \& methods: $\mathrm{PCL}$ plates were prepared by dissolving $50 \mathrm{KDa} \mathrm{PCL}$ granules at $100^{\circ} \mathrm{C}$, using borosilicate glass plate and mixed with $1 \mu \mathrm{m}$ microspheres at the ratio 1:5. Plates were characterized by scanning electron microscopy. Cells applied were monocytes and $\mathrm{T}$ cells at the ratio $1: 2$ and purity detected by flow cytometry. Genesis of $O C$ was triggered by $\mathrm{OC}$-inductive cytokines. Cell culturing was 7 days. Soluble (s) $\beta 2$-integrin expression and complement activation was measured by immunofluorimetic assay. We used Cell Tracker Green and Hoechst for viability; tartrate resistant acid phosphatase for phenotyping; and calcitonin receptor RT PCR for genotyping.

Results: Our data indicate cells of the monocyte-macrophage lineage to mediate degradation of PCL by formation of microscopically visible cavities. This phenomenon is enhanced in the presence of T cells. In addition, PCL induce soluble membrane attack complex activation and we observe phagocytosis of microspheres within PCL constructs. $s \beta_{2}$-integrin expression rises at $24 \mathrm{~h}$ suggesting increased activity of macrophages upon exposure to $\mathrm{PCL}$.

Conclusions: Apparently, cells of the monocyte-macrophage lineage are capable of degrading PCL. Such properties are important for successful use of PCL in tissue engineering.

P22.08 Maja Ludvigsen DIFFERENT PROTEIN EXPRESSION PATTERNS MAY INDICATE DIFFERENT DISEASE MECHANISMS IN OLDER AND YOUNGER HL PATIENTS

M. Ludvigen' ', P. Kamper' ${ }^{2}$, S.J. Hamilton-Dutroit ${ }^{3}$, K. Bendix ${ }^{3}$, F.A. d'Amore ${ }^{2}$, B. Honoré

'Department og Biomedicine, Aarhus University, ${ }^{2}$ Department of Haematology, Aarhus University Hospital, ${ }^{3}$ Institute of Pathology, Aarhus University Hospital

Introduction: In Western countries, the age distribution of Hodgkin lymphoma (HL) follows a characteristic bimodal curve showing the first peak at approx. 35 years and a second peak in late life, approx. 70 years. Whether this observation just originates as a function of age or rather relates to different underlying biological processes for $\mathrm{HL}$ is a much debated subject. Our aim is to provide hypothesis-generating data by using proteomic techniques comparing protein expression patterns in tumors from younger ( $\leq 60 \mathrm{yrs}$ ) and older ( $>60 \mathrm{yrs}$ ) HL patients in order to identify possible age-related differences.

Methods: Frozen tissue samples from HL patients with stage I or II were identified in the pathology archives and clinical data were obtained and examined. Tissues from 16 younger and 12 older patients were subjected to high-resolution 2-D gel electrophoresis. Individual protein spots were visualized with fluorescence staining and expression profiles in the two groups were compared by computer analysis. Proteins with a minimum of two fold differential expression were identified by LC-MS/MS and further studied by immunological methods.

Results: The protein expression profiles of the two analyzed clinical groups showed significant and distinct differences. Preliminary results suggest differential expression among proteins belonging to functional families such as cell cycle regulation and proto-oncogenes. 
P23.01 Emil Hagen

Ernst
Conclusion: Proteomic analysis found significant differences in the protein composition of $\mathrm{HL}$ tumor tissues from younger compared with older patients. Differential expression of a number of these proteins may provide further insights into the age-specific pathophysiology of $\mathrm{HL}$.

\section{COMPARATIVE STUDIES ON GLOBAL GENE ANALYSIS OF OOCYTES AND GRANULOSA CELLS FROM DIFFERENT STAGES IN EARLY HUMAN FOLLICULOGENESIS \\ E.H. Ernst ${ }^{7}$, P. Villesen ${ }^{2}$, C.Y. Andersen ${ }^{3}$, K. Lykke-Hartmann ${ }^{7}$ \\ ${ }^{1}$ Department of Biomedicine, Aarhus University, ${ }^{2}$ Bioinformatics Research Center (BiRC), Aarhus University, ${ }^{3}$ Laboratory of Reproductive Biology, Section 5712, The Julian Marie Centre for Women, Children and Reproduction, University Hospital of Copenhagen}

Oocytes become enclosed in primordial follicles during fetal life and remain dormant until activation followed by growth and meiotic resumption. Our knowledge about the molecular pathways involved in this activation is incomplete. Correct recruitment and early maturation of oocytes rely on finely tuned signalling pathways between the two components in follicles; the oocyte and the granulosa cells. Until now, only few of the pathways have been identified due to lack of appropriate methods for isolating these cells. The proposed research will carry out comprehensive transcriptome analysis of human immature follicles in order to identify the active genetic networks at play.

By laser capture micro-dissection, we have isolated pure pools of oocytes themselves and oocytes with granulosa cells from the primordial, primary, secondary and pre-antral stages of human folliculogenesis.

We will evaluate the global gene expression profiles by microarray analysis and confirm selected genes by qPCR.

Using mRNA expression as a message of molecular activity, we will provide a comprehensive dataset on activation and early maturation of human oocytes.

We expect to map the pathways activated for the oocyte and granulosa cells, respectively, in the different stages of folliculogenesis.

Activity in the cells forming the follicles throughout the different early stages of maturation will help us understand the process of correct gamete development in women.

The global gene expression profile of normal folliculogenesis can form a foundation for further studies regarding incorrect oocyte maturation causing infertility as seen in patients suffering from Polycystic Ovary Syndrome.

INCREASED BONE FORMATION IN A PORCINE CRITICAL SIZE DEFECT WHEN USING HYALURONIC ACID AND TCP COATED POLYCAPROLACTONE SCAFFOLDS SEEDED WITH AUTOLOGOUS DENTAL PULP STEM CELLS

J. Jensen ', C. Tvedesøe', D.C.E. Kraft', J.V. Nygaard', A.A. Kristiansen ${ }^{2}$, M. Chen $^{7,2}$, J. Baas ${ }^{7}$, C. Bünger ${ }^{7}$

${ }^{1}$ Orthopaedic Research Lab, Aarhus University Hospital, ${ }^{2}$ Interdisciplinary Nanoscience Center, Aarhus University, ${ }^{3}$ Section of Orthodontics, Department of Dentistry, Aarhus University

Introduction: Dental pulp tissue has been hypothesized as an alternative source of autologous adult mesenchymal stem cells for use in bone tissue engineering.

Methods: The scaffolds for cell seeding were comprised of the polymer polycaprolactone (PCL), bioplotted into at three-dimensional grid structure (bioplotted scaffold). Afterwards, a new scaffold was then created by 
infusing the bioplotted scaffold with hyaluronic acid + TCP and afterwards this was freeze-dried to create a micro-porous hydrophilic coating (HT scaffold). A total of 14 skeletally mature 1-year-old Danish landrace pigs were used with termination 5 weeks post surgery. One month prior to surgery, bone marrow from the proximal femur and one molar tooth was extracted from each individual pig. Mononuclear cells were isolated from each extraction source and differentiated into osteogenic lineage. A total of six $10 \mathrm{~mm}$ in depths and $15 \mathrm{~mm}$ in diameter non-penetrating holes were drilled in the calvaria. Three paired studies were chosen; 1) empty defect and HT scaffold, 2) HT scaffold and bioplotted scaffold and 3) HT scaffolds seeded with dental pulp stem cells (DPSCs) and HT scaffold seeded with bone mesenchymal stem cells. After termination, the specimens were $\mu C T$ scanned and bone volume to total volume (BV/TV) was determined.

Results: $\mu C T$ data showed significantly more bone formation in the defect containing the HT scaffold compared to the empty defect $(p=0.0203)$. HT scaffolds showed larger BV/TV compared to bioplotted only ( $p=0.0001)$. When comparing the HT scaffolds seeded with autologous stem cells, the defect containing scaffolds seeded with DPSCs had a significantly higher $\mathrm{BV} / \mathrm{TV}$ (0.009).

P23.03 Anto Praveen BRDI GENE KNOCK-OUT MOUSE MODEL EXHIBITS REVERSIBLE DEPRESSIVE Rajkumar Rajamani PHENOTYPE AND COGNITIVE DEFICITS

A.P. Rajkumar, 2, 3, P. Qvist, ${ }^{1,3}$, J.H. Christensen, ${ }^{\text {1, } 3}$, T. Fryland ${ }^{1,3}$, M. Nyegaard

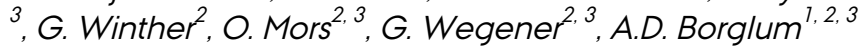

${ }^{7}$ Department of Biomedicine, Aarhus University, ${ }^{2}$ Center for Psychiatric Research, Aarhus University Hospital, ${ }^{3}$ The Lundbeck Foundation Initiative for Integrative Psychiatric Research, iPSYCH

Background: Schizophrenia and bipolar disorder associated Bromodomain containing 1 gene (BRD1) is implicated in the epigenetic regulation of neurons. Chronic stress and electroconvulsive seizures upregulate BRD1 expression in rat hippocampi. Hence, we investigated the affective behaviours and cognition of constitutive BRDI heterozygous gene knockout (BRD1-KO) mice.

Methods: We employed (i) Locomotion: open field, (ii) Depression: Forced swim test (FST) and Tail suspension test (TST), (iii) Anxiety: Bright open field, Light and dark box and Elevated plus maze, (iv) Cognition: Fear conditioning system (FCS) and 8-arm radial maze (8ARM). Each experiment involved 15 male and 15 female BRD1-KO mice with wild-type (WT) littermates as controls. We assessed depressive behaviours of another batch of female BRD1-KO mice with Imipramine and Fluoxetine ( $\mathrm{N}=329)$.

Results: BRD1-KO female mice exhibited more behavioural despair than WT controls during TST $(p=0.007)$ and FST $(p=0.002)$. Both Imipramine and Fluoxetine could reverse this depressive phenotype. Female and male BRD 1-KO mice had context-dependent learning deficits in FCS. BRD 1-KO male mice revealed working $(p=0.008)$ and visuo-spatial $(p=0.003)$ memory deficits in 8ARM. BRD1-KO mice did not differ on locomotion nor on their anxiety.

Conclusions: Replicated behavioural findings and their reversibility by antidepressant medications indicate the validity of female BRD 1-KO mice as a novel model for depression and the importance of BRD1 in the complex pathogenesis of depression. BRD1-KO mice models will help evaluating the neurodevelopmental abnormalities and epigenetic changes which are secondary to BRD1 deficiency.

P23.04 Gitte Brinch ELUCIDATION OF THE PATHOGENESIS OF OSTEOSARCOMAS (OS) Andersen THROUGH HIGH-THROUGHPUT FUNCTIONAL EPIGENOMICS

G.B. Andersen 
Department of Biomedicine, Aarhus University

Aims: The aim of this project is to identify new predictive and diagnostic biomarkers for patients diagnosed with osteosarcoma (OS) based upon epigenomic changes in the affected cancer cells.

Background: OS is the most common primary malignant bone tumor with a strong predilection for occurrence in children and young adults. The first indication of OS is pain, which is often misjudged with "growing pains," resulting in a late diagnosis. Consequently, some patients already have metastatic disease at diagnosis, while other patients do not respond to treatment with chemotherapy, resulting in a very poor prognosis and a longterm survival rate at only $20 \%$. OS is characterized by a complex array of cytogenetic abnormalities, and there is a huge necessity in understanding the biology of OS progression and metastasis in order to identify new biomarkers and new therapeutic approaches.

Material and methods: The OS methylome from patients with and without metastasis will be characterized and compared with non-malignant bone tissue. Significantly differentially methylated loci (> 25) will be validated in a larger cohort comprising $100 \mathrm{OS}$ and 50 metastases to establish the impact of each new biomarker.

We hypothesize that a solid understanding of tumorigenesis and progression of the disease can be obtained by establishing the epigeneticbased features of OS. Identification of highly specific biomarkers, detected by sensitive and robust methods, may possibly improve the outcome for OS patients.

P23.05 Helle EPIGENETIC SILENCING AND BIOMARKER POTENTIAL OF MIR-224, MIR-452

Kristensen AND THEIR HOST GENE GABRE IN PROSTATE CANCER

H. Kristensen ', C. Haldrup ', M.M. Mortensen ', M. Borre', S. Høyer ${ }^{3}$, P.J. Wild ${ }^{4}$, W.A. Schulz ${ }^{5}$, T.F. Ørntoft ${ }^{7}$, K.D. Sørensen ${ }^{7}$

'Department of Molecular Medicine, Aarhus University Hospital, Aarhus, Denmark, ${ }^{2}$ Department of Urology, Aarhus University Hospital, Aarhus, Denmark, ${ }^{3}$ Institute of Pathology, Aarhus University Hospital, Aarhus, Denmark, ${ }^{4}$ Institute of Surgical Pathology, Department of Pathology, University Hospital Zurich, Zurich, Switzerland, ${ }^{5}$ Department of Urology, Medical Faculty, Heinrich Heine University, Düsseldorf, Germany

Prostate cancer (PC) is the most frequently diagnosed cancer and the second leading cause of cancer death among men in the Western world. Currently used methods for PC diagnosis and prognosis are suboptimal, and new molecular biomarkers are urgently needed. This study investigates the expression and biomarker potential of miR-224, miR-452 and their host gene gamma-aminobutyric acid (GABA) A receptor family epsilon subunit (GABRE) in PC. We used transcriptional profiling and DNA methylation analyses of the GABRE promoter associated CpG island. Compared to benign prostate tissue, miR-224, miR-452 and GABRE transcript levels were significantly reduced in $P C$ tissue $(p<0.001)$. Bisulfite sequencing and quantitative methylation-specific $P C R$ revealed frequent promoter hypermethylation of GABRE in both PC cell lines and PC tissue samples. GABRE methylation accurately distinguished benign from $P C$ tissue samples $(p<0.001$ ) with $95.2 \%$ sensitivity and $94.2 \%$ specificity, thus potentially allowing the detection of PC through GABRE methylation analysis. In addition, by univariate and multivariate analyses, high GABRE methylation was significantly associated with early PSA recurrence after radical prostatectomy in three independent radical prostatectomy PC patient cohorts $(p=0.011, p=0.034$ and $p=0.022)$, and added significant independent value to established prognostic factors in two of the cohorts $(p=0.048$ and $p=0.032)$. Moreover, exogenous expression of miR-224 and miR-452 in PC cell lines was found to inhibit proliferation, migration and 
invasion. Presently, targets for the two miRNAs are being identified to elucidate the functional roles of miR-224 and miR-452 in PC.

P23.06 Lea Hougaard POTENTIAL BENIFICIAL EFFECTS OF MEPO-PLASMID ON TGF $\beta 1$-INDUCED Pedersen GLOMERULARSCLEROSIS

\author{
L. Pedersen', L. Wogensen', T.L. Dalsgaard', F. Dagnces-Hansen² \\ ${ }^{1}$ Research Laboratory of Biochemical Pathology, Aarhus University, \\ ${ }^{2}$ Department of Biomedicine, Aarhus University
}

Erythropoietin (EPO) is a $30.4 \mathrm{kDa}$ glucoprotein hormone produced primarily by the fetal liver and in the adult kidney. Peritubular fibroblasts in the kidneys register hypoxia if the haemoglobin levels are too low and respond by producing EPO. The circulating hormone binds to the EPO-receptor and exerts its haematopoietic effects by stimulating the proliferation and differentiation of erythrocytes with subsequent improved tissue oxygenation.

EPO receptors are furthermore expressed in non-haematopoitic tissue. Today, EPO is recognized as a cytokine with a much more pleiotropic potential. It is believed that EPO has organ-protective properties, but it remains to be elucidated whether these properties can restore the kidney function in patients with chronic kidney disease.

Our studies will be conducted by hydrodynamic gene transfer of a plasmid encoding murine EPO in a transgenic mouse model that overexpresses TGF$\beta 1$ locally in the kidneys. This model develops thickening of the glomerular basement membrane, deposition of the mesangial matrix and mild interstitial fibrosis. After a single hydrodynamic administration of plasmid DNA containing murine EPO gene under control of the ubiquitin promotor, sustained elevation in hemoglobin levels is observed for more than 70 days. This method makes it possible to study the long-term effect of EPO on renal damage.

With these studies, we will acquire knowledge of EPO's effect on the development of fibrosis in chronic kidney disease. We will also be able to demonstrate an alternative form of treatment - hydrodynamic gene therapy - for patients with anaemia.

P23.07 Anne Louise INTEGRATION-DEFICIENT LENTIVIRAL VECTORS AS GENE DELIVERY Askou VEHICLES FOR TREATMENT OF AMD

\title{
A.L. Askou, M.H. Holm-Nielsen, T.G. Jensen, L. Aagaard, J. Giehm Mikkelsen, T.J. Corydon
}

Department of Biomedicine, Aarhus University

VEGF plays an essential role in ocular angiogenic diseases including the late-stage form of AMD, which is the primary cause of vision loss in the Western world. Over-expression of VEGF leads to development of vasculature emanating from the choroid, invading the sub-retinal space through breaks in Bruch's membrane. Strategies leading to long-term suppression of inappropriate ocular angiogenesis are required.

We have evaluated the capacity of rAAV-encoded shRNAs or miRNAs to silence endogenous VEGF gene expression in mouse models. Levels of VEGF and sizes of the CNV were found to be significantly reduced following rAAV2/8-shRNA intramuscular and subretinal delivery, respectively. To further improve efficacy and biosafety, novel versatile vector constructs have been designed based on integration-deficient lentiviral vectors for elimination of adverse events caused by integration into the target cell genome. In these vectors, we combine RNA interference with overexpression of an anti-angiogenic inhibitor, PEDF. Furthermore, tissuespecific promoters together with miRNA target sites will be included to limit transgene expression to RPE cells. By use of this strategy, high efficiency of gene transfer and expression is possible in postmitotic tissue without a 
P23.08 Inge Gram Carlsen

P24.01 Aida Solhøj Hansen requirement for vector integration. Preliminary results show a silencing effect of lentivirally delivered anti-VEGF shRNAs both in vitro and in vivo. REGULATION OF PHOSPHORYLATED HEAT SHOCK PROTEIN 27 IN
RESPONSE TO ACUTE URETERAL OBSTRUCTION

\section{Carlsen, L. Nilsson, J. Frøkicer, R. Nørregaard}

Department of Clinical Medicine, Aarhus University Hospital, Skejby, Aarhus

Aim: In vivo, renal medullary interstitial cells (RMIC) and collecting duct principal cells ( $m k p C C D$ ) are subjected to inflammatory, oxidative and mechanical stress as a result of unilateral ureteral obstruction (UUO). Heat shock protein (HSP) HSP27 and HSP70 are induced by cellular stresses and play a role in cytoprotection. We examined the expression of HSP27, the phosphorylated state of HSP27 and HSP70 in vivo in rats subjected to acute UUO and in vitro in RMIC and mpkCCD exposed to inflammatory, oxidative or mechanical stress.

Methods: Rats were subjected to acute UUO for $6 \mathrm{~h}$ and $12 \mathrm{~h}$. To further examine the expression of HSP27, pHSP27 and HSP70 in response to inflammatory, oxidative and mechanical stress in vitro, we subjected RMIC and mpkCCD cell to IL-1 $\beta$, hydrogenperoxid $\left(\mathrm{H}_{2} \mathrm{O}_{2}\right)$ and stretch stimulation over time.

Results: The phosphorylated form of HSP27 (pHSP27) was increased in renal inner medulla (IM) after 6h and 12h UUO, while HSP27 and HSP70 expression was unchanged. Furthermore, expression of inflammatory (interleukin $1 \beta(\mathrm{IL}-1 \beta)$ and oxidative (hemeoxygenase 1 (HO-1)) marker was induced in response to $6 \mathrm{~h}$ and $12 \mathrm{~h}$ UUO. During in vitro studies, exposure to inflammatory, oxidative and mechanical stress changed both HSP27 and pHSP27 expression in RMIC, but not in mpkCCD, while HSP70 was not affected by any types of the stress conditions.

Conclusion: These data demonstrated that, in response to acute UUO, different forms of cellular stresses modulate HSP27 expression and phosphorylation in RMIC, and this may affect the ability of renal cells to intensify an effective cytoprotective response.

SIGNIFICANCE OF CD46 ISOFORMS FOR ENTRY OF HUMAN HERPESVIRUS 6B

\section{A.S. Hansen, M.H. Schleimann, P. Höllsberg}

Department of Biomedicine, Aarhus University

CD46 is a ubiquitously expressed glycoprotein on the surface of all nucleated human cells. Among other functions, CD46 acts as a cellular receptor for human herpesvirus $6 \mathrm{~B}(\mathrm{HHV}-6 \mathrm{~B})$, a virus that is causing the childhood disease examthem subitum and is associated with certain neuropathologies. Expression of recombinant full-length CD46 renders nonhuman otherwise resistant cells susceptible to HHV-6B-mediated membrane fusion and viral entry. Although HHV-6B may infect a broad range of cells either productively or nonproductively, it prefers to replicate in CD4+ T lymphocytes.

Alternative splicing produces multiple isoforms of CD46, and we hypothesize that the separate isoforms of CD46 may have different functions for HHV-6B infection and thereby play a role in the tropism of HHV6B.

To test this hypothesis, the coding cDNA sequences of the common CD46 isoforms were cloned into expression vectors containing a constitutive promoter. These vectors were transiently transfected into nonhuman cells lacking endogenous CD46 expression. In future work, cells expressing separate CD46 isoforms will be infected with HHV-6B, and viral entry will be determined by surface membrane expression of the viral glycoprotein 
P24.02 Henrik Lauridsen

gp60/110 (flow cytometry and confocal microscopy) and by the expression of the nuclear viral protein $7 \mathrm{C7}$ (confocal microscopy).

These analyses will establish if certain isoforms of CD46 are essential to HHV-6B entry. Since CD46 is expressed on more cell types than can be infected by $\mathrm{HHV}-6 \mathrm{~B}$, investigation of the significance of CD46 isoforms for viral entry may contribute to the understanding of $\mathrm{HHV}-6 \mathrm{~B}$ tropism and may suggest novel concepts of antiviral treatment.

\section{LEARNING FROM NATURE: MYOCARDIAL REGENERATION FOLLOWING} INFARCTION

\section{H. Lauridsen' ${ }^{7}$ A. Andersen ${ }^{2}$, C.B. Foldager ${ }^{3}$, J. Palmfeldt', M. Pedersen ${ }^{4}$}

${ }^{1} M R$ Research Centre, Department of Clinical Medicine, ${ }^{2}$ The Department of Cardiological Medicine B, Department of Clinical Medicine, ${ }^{3}$ The Department of Orthopaedics E, Department of Clinical Medicine, ${ }^{4}$ Research Unit for Molecular Medicine, Department of Clinical Medicine

Introduction: Regenerative potential in humans is limited. Like other mammals, we rely heavily on fibrosis and scar formation in response to injury. On the contrary, urodele amphibians (salamanders) such as the axolotl (Ambystoma mexicanum) are champions of tissue regeneration among vertebrates, mastering the ability to replace most tissues in addition to whole limbs, tail, jaw, etc., following damage or amputation. Myocardial restoration by cellular dedifferentiation, proliferation and redifferentiation following partial ventricular amputation is described in the axolotl. However, regeneration in the more relevant event of myocardial infarction remains undescribed as do the signalling cascades that initiate the process of cardiomyocyte dedifferentiation.

Materials and methods: Myocardial infarction is performed by cryoinjury, applying a $\mathrm{LN}_{2}$-cooled cryoprobe at the ventricular wall of anaesthetised axolotls. Myocardial restoration is monitored histologically using AFOG staining of myocardial sections. Functional restoration of cardiac output is monitored quantitatively using echocardiography and MRI. Proteomic profiles of cardiac tissue from regenerating vs. sham-operated animals are produced by LC-MS/MS and compared to reveal proteome differences at the outset of regeneration.

Results and discussion: The cryoinjury-induced myocardial regeneration model has been established and LC-MS/MS has proven useful for generating axolotl proteomes. Intentionally, the anatomical and functional process of myocardial regeneration following infarction in the axolotl will be revealed using our methods, and potentially it will be possible to identify signalling events at the protein level.

P24.03 Lise Lindahl SUBSEQUENT CANCERS, MORTALITY AND CAUSES OF DEATH IN PATIENTS WITH MYCOSIS FUNGOIDES AND PARAPSORIASIS: A DANISH NATIONWIDE POPULATION-BASED COHORT STUDY

\section{L.M. Lindahl', M. Fenger-Grøn² and L. Iversen'}

'Department of Dermatology, Aarhus University Hospital, Denmark; and 2Department of Clinical Epidemiology, Aarhus University Hospital and Research Unit for General Practice, Aarhus University, Denmark

Purpose: Data on risk of subsequent cancers, prognostic factors for mortality and causes of death are limited in patients with mycosis fungoides (MF) and non-existing in patients with parapsoriasis.

Materials and methods: We linked the Danish nationwide populationbased registries and identified our cohort of 386 patients with MF and 582 patients with parapsoriasis and assessed subsequent cancer risk, prognostic factors for mortality and causes of death compared to the general Danish population. 
Results: Incidence of subsequent cancers was significantly increased in patients with parapsoriasis, standardized incidence ratio (SIR) $2.0(95 \% \mathrm{Cl}$, 1.6 to 2.5 ), and a trend was observed in patients with MF, SIR 1.2 (95\% Cl, 0.9 to 1.5 ). Mortality was significantly increased in both patient groups with MF, SIR $2.0(95 \% \mathrm{Cl}, 1.8$ to 2.3$)$ and parapsoriasis, SIR $1.3(95 \% \mathrm{Cl}, 1.1$ to 1.5$)$. Excess mortality for MF was largest within the first 5 years of follow-up and causes of increased death included both malignant and non-malignant diseases.

Conclusion: In conclusion, our results demonstrate that parapsoriasis is a life-threatening disease with significantly increased risk of subsequent cancers and increased mortality, and not a benign disease as previously described. Furthermore, the largest excess mortality was found within the first 5 years of follow-up in patients with MF and this finding suggests that MF exists in two forms: 1) an aggressive form with fast progression and increased mortality and 2) a more indolent form with slow or no progression and a better prognosis.

DEVELOPMENT OF INTEGRATIVE DATA ANALYSIS TOOLS TO IDENTIFY CLINICALLY RELEVANT MOLECULAR CHANGES IN PROSTATE CANCER: A SYSTEMS BIOLOGY APPROACH

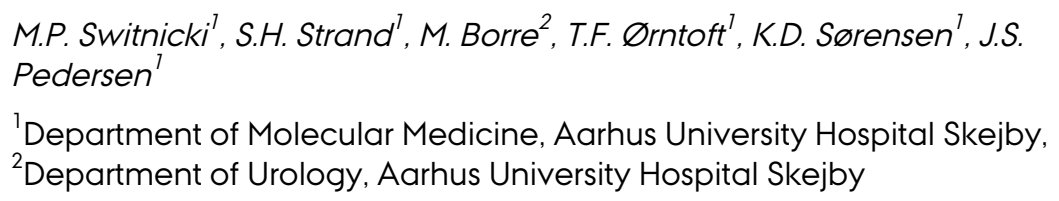

Prostate cancer (PC) is the most commonly diagnosed malignancy and the third leading cause of cancer-related death in males in the Western world. A major challenge in PC management is to identify whether a given PC is likely to progress rapidly and become life-threatening. This will be achieved by development of new bioinformatic approaches to integrative analysis of next generation sequencing data and microarray data.

We will use these methods on data from clinical prostate cancer tissue samples from a local PC biobank.

First we have analyzed DNA methylation using Illumina $450 \mathrm{~K}$ methylation arrays, which interrogate $>450.000$ CpG sites preferentially located in CpG islands and gene promoters.

We have found that methylation patterns can clearly differentiate PC from normal tissue. Detailed analyses of differential methylation have revealed the underlying complexity of the phenomena. Not only are high degrees of differential methylation (preferentially hypermethylation) observed in PC, but also a loss of the natural variability is seen in controls for a number of regions.

The highest degree of differential methylation is observed for 3'UTRs of genes and in $\mathrm{CpG}$ loci located in the distal flanking regions of $\mathrm{CpG}$-dense islands, called shelves.

A proportion of interrogated regions also show considerable variance between individual samples, which provides a potential for creation of signatures differentiating indolent and aggressive forms of PC.

The methylation results will next be augmented with a PC RNA-seq experiment. Other genomic types are planned for further inclusion in the analysis like reduced representation bisulfite sequencing data or histone marks, ChIP-seq. 
COX-2 INHIBITION EXACERBATES SODI DOWREGULATION AND THE PROGRESSION OF RENAL OXIDATIVE STRESS IN RESPONSE TO UUO

L. Nilsson ${ }^{1,2}$, J. Frøkicer ${ }^{1,2}$, R. Nørregaard ${ }^{1,2}$

${ }^{1}$ The Water and Salt Research Center, Aarhus University, ${ }^{2}$ Institute of Clinical Medicine, Aarhus University

Renal damage and oxidative stress resulting from unilateral ureteral obstruction (UUO) may be aggravated by reactive oxygen species (ROS). Deleterious effects of ROS are attenuated by antioxidant enzymes. We investigated the role of COX-2 in the progression of renal oxidative stress induced by UUO in mice.

Mice were subjected to UUO and treated with the selective COX-2 inhibitor parecoxib for 7 days. Using immunoblot analysis, we examined the regulation of antioxidant enzymes, catalase, superoxide dismutase 1 and 2 (SOD 1 and -2) in renal cortex and inner medulla. Immunohistochemistry was performed with oxidative stress markers.

COX-1 and -2 proteins were increased in response to UUO. SOD1 and -2 proteins were increased in IM in parecoxib treated sham operated mice. Parecoxib treated UUO mice had more reduced SODI protein level in IM and cortex than untreated UUO mice, whereas SOD2 and cortical catalase protein levels were unchanged.

COX-2 inhibition increased the renal SOD1 and -2, consistent with a stress response to increased ROS production. UUO reduced SOD 1 and catalase, and inhibited increased SOD1 and -2 seen with COX-2 inhibition.

In conclusion, suppression of renal antioxidant enzymes by UUO contributes to the progression of renal oxidative stress, a process exacerbated by COX2 inhibition.

P24.06 Mia Benedicte METABOLIC FINGERPRINT OF REMOTE PRECONDITIONING Lykke Roest Laursen

\section{Laursen, M. Johannsen}

Department of Forensic Medicine, Section for Toxicology and Drug Analysis, Aarhus University

Myocardial infarction is a major cause of morbidity and mortality, which raises a need for optimized treatment of ischemic-reperfusion injury. It is known that the size of an infarct in the heart can be limited by conditioning (pre, per and post heart failure). The most clinically suitable modality is remote perconditioning ( $\mathrm{rPerC}$ ) in which brief ischemia of a distant organ initiates protection in the target organ, even after the onset of the ischemic event. Furthermore, it has been shown that plasma isolated from human subjects undergoing $r$ PerC can induce protection in another subject or species, indicating the existence of circulating cardioprotective mediator(s). The plasma can even be dialyzed before use, and extensive studies indicate a molecular weight of the humoral mediator(s) between 3,500 and 10,000 Da in accordance with a small protein/peptide. A number of metabolic pathways have been shown to be effected by conditioning, but the exact nature of the mediator(s) is not yet known. In this project, it is hypothesized that cells grown in a medium supplemented with fractions of serum from subjects undergoing rPerC will adopt the "conditioned" phenotype. Untargeted metabolic profiling using LC-Q-TOF-MS will make a metabolic fingerprint of these "conditioned" cells obtainable, and a comparison with similar fingerprints of control cells and cells grown in a medium containing exogenous compounds, known to be cardioprotective, should subsequently lead to novel insight into the mechanism behind remote conditioning.

P24.07 Shivani Joshi HIGH-RESOLUTION MELTING ANALYSIS FOR STUDY OF GENE VARIATIONS IN NEPHROTIC SYNDROME 


\section{S. Joshi ${ }^{7}$, R. Andersen ${ }^{7}$, B. Jespersen ${ }^{2}$, M. Kjeldsen ${ }^{3}$, R. Olsen ${ }^{3}$, N. Gregersen ${ }^{3}$, S. Rittig ${ }^{7}$}

11) Pediatric Research Lab-A, Aarhus University Hospital, Department of Clinical Medicine, 8200, Aarhus N., ${ }^{2}$ 2) Department of Nephrology C, Aarhus University Hospital, Department of Clinical Medicine, 8200, Aarhus N., ${ }^{3} 3$ ) Research Unit for Molecular Medicine (MMF), Aarhus University Hospital, Department of Clinical Medicine, 8200, Aarhus N.

High-resolution melting analysis (HRMA) is a post-PCR analysis method to scan variations in nucleic acid sequences. It is based on detecting small differences in PCR melting (dissociation) curves. The procedure consists of a $\mathrm{PCR}$ in the presence of a DNA binding dye (LC green plus) followed by formation of heteroduplex and/or homoduplex molecules and a meltinganalysis step to detect variations, which are identified and confirmed by Sanger sequencing. HRMA is a simple, reliable and cost-effective method, which has been successfully applied to detect sequence variations. Nephrotic syndrome (NS) is characterized by severe proteinuria, hypoalbuminemia and edema. Variations in genes encoding glomerular proteins, namely NPHS 1, NPHS2 and INF2, have been identified in patients with Steroid resistant Nephrotic Syndrome (SRNS). As a consequence of poor response to steroid medication, these patients continue to have proteinuria and eventually they undergo dialysis or renal transplantation. If DNA analysis reveals pathogenic mutations, unwarranted attempts with steroids could be avoided. However, to the best of our knowledge, there are no such systematic genetic studies on Danish patients with SRNS. A good understanding of gene variations in patients with SRNS will have significant implications on diagnosis, counselling and overall clinical management. We aim to study the gene variation spectrum in Danish patients with SRNS, evaluate the usefulness of HRMA and establish a rapid gene variation scanning tool for SRNS genes. The development of HRMA for SRNS gene variation scanning and initial results will be discussed. Sørensen?

${ }^{1}$ Dept. of Molecular Medicine (MOMA), Aarhus University Hospital, ${ }^{2}$ Dept. of Molecular Biology and Genetics, Aarhus University, ${ }^{3}$ Dept. of Pathology, Aarhus University Hospital, ${ }^{4}$ Dept. of Clinical Medicine, Aarhus University Hospital, ${ }^{5}$ Dept. of Urology K, Aarhus University Hospital

Prostate cancer (PC) is the second leading cause of cancer deaths among Danish men and the most common cancer form with approximately 4000 diagnoses annually. Routine prognostic markers are unable to clearly differentiate indolent from aggressive PC hence more accurate biomarkers are needed. The primary aim of this project is to get a better understanding of PC evolution from early carcinogenesis to metastasis. This may allow identification of better biomarkers for PC diagnosis and prognosis, as well as discovery of novel potential therapeutic targets. Our hypothesis is that the marked heterogeneity found in primary PC tumours has attenuated PC biomarker development, and a deeper characterisation of this phenomenon is therefore sought. Until now, 12 PC patients ( $\mathrm{pN} 1$ ) with available cancer tissue specimens from both primary tumour and lymph node metastases have been identified. We will divide the prostate tissue samples into (histologically-guided) subpopulations, each of which will be analyzed in depth by Next Generation Sequencing and microarray-based genomewide molecular profiling at multiple molecular levels: genome, DNA methylome and transcriptome as well as combinations hereof. Metastases from the same patients will be analyzed in parallel. It is hypothesised that driver molecular alterations can be found by comparing alterations from each of the anatomical loci. Molecular changes associated with PC 
P25.01 Siri Hundtofte GENOMEWIDE PROFILING OF THE PROSTATE CANCER METHYLOME FOR Strand

development and/or metastasis will be determined via bioinformatic integration of data, and their biomarker potential will be investigated in large independent $\mathrm{PC}$ patient sets.

GENOMEWIDE PROFILING OF THE PROSTATE CANCER
DETECTION OF NEW PROSTATE CANCER BIOMARKERS

S.H. Strand ', M. Switnicki', P. Lamy', F.S. Pedersen' ${ }^{2}$, S. Høyer ${ }^{3}$, M. Borre ${ }^{4}$, J.S. Pedersen', T. Ørntoft', K.D. Sørensen ${ }^{\prime}$

'Dept. of Molecular Medicine, Aarhus University Hospital Skejby, Aarhus, Denmark, ${ }^{2}$ Dept. of Molecular Biology and Genetics, Aarhus University, Aarhus, Denmark, ${ }^{3}$ Institute of Pathology, Aarhus University Hospital, Aarhus, Denmark, ${ }^{4}$ Dept. of Urology, Aarhus University Hospital Skejby, Aarhus, Denmark

The currently available biomarkers for prostate cancer (PC) are unable to distinguish between the aggressive and indolent forms of PC, causing massive over-treatment. By using genomewide profiling of the epigenome in combination with expression profiling, we aim to identify new molecular biomarkers that should contribute to improved cancer treatment by increasing the specificity of PC diagnosis and prognosis.

In total, 21 tumor, 9 normal and 12 adjacent normal patient samples, 15 untreated cell lines and 4 cell lines treated with methylation inhibitor were run on the Illumina Infinium HumanMethylation450 BeadChip, which investigates the methylation at $>485,000 \mathrm{CpG}$ sites in the human genome at single base resolution. The data were analyzed using the Mann-Whitney rank-sum test, revealing the probes that were most significantly differentially methylated in tumor vs. normal samples. We selected 8 candidate methylation markers for validation. Gene-expression array analysis and investigation of publicly available datasets showed that at least three of these candidates were downregulated in PC compared to normal prostate tissue, consistent with gene silencing caused by promoter hypermethylation. Initial validation was carried out in PC cell lines by means of bisulphite sequencing and will be followed by methylation specific qRT-PCR (qMSP) in a small new patient/control cohort. The final validation will be carried out in a larger patient/control cohort with clinical information and long follow-up, whereby the diagnostic and prognostic biomarker potential of the candidate genes will be investigated.

P25.02 Yujia Cai POTENT DNA TRANSPOSITION BY PROTEIN TRANSDUCTION OF THE PIGGYBAC TRANSPOSASE FROM LENTIVIRAL GAG PRECURSORS

Y. Cai, R.O. Bak, N.H. Staunstrup, A.K. Hollensen, H. Christiansen, M.N. Primo, T. Corydon, J.G. Mikkelsen

Department of Biomedicine, Aarhus University

DNA transposon-based vectors have emerged as gene vehicles with therapeutic potential. So far, function of such vectors has relied on the delivery of the gene encoding the transposase, raising concerns related to persistent expression of the transposase and increased cytotoxicity. Here, we demonstrate high-efficiency transposition of piggyBac-derived transposon vectors facilitated by transposase protein packaged in VSV-G-pseudotyped lentiviral particles as part of the Gag protein. By inserting the transposase sequence upstream of Gag and downstream of an N-terminal heterologous myristoylation signal, we obtain robust packaging of the hyperactive piggyBac transposase, hyPBase, in virus particles, and we demonstrate that the transposase is released from the Gag-Pol polypeptide upon maturation of the lentiviral particles. Upon hyPBase protein transduction, potent VSV-G dependent DNA transposition is observed in target cells transfected with plasmid DNA harboring the piggyBac transposon, whereas a mutated version of the transposase is inactive. Notably, we observe that protein transduction of hyPBase results in higher levels of DNA transposition than 
P25.03 Trine Salomon

obtained in a conventional setting with hyPBase expression from transfected plasmid DNA. Finally, we show that hybrid, integrase-defective lentiviral vectors carrying (i) the hyPBase transposase protein and (ii) the transposon sequence facilitate potent transposition in a variety of cell types. Our data reveal new means of combining DNA transposition with lentiviral gene transfer and establish lentivirus-derived nanoparticles as a new tool for transposase protein delivery.

\section{Andreasen METHOD FOR ANALYSIS OF AMINO ACIDS AND ACYLCARNITINES \\ T. Salomón', R.I.D. Birkler', M. Johannsen' \\ 'Department of Forensic Medicine, Section for Toxicology and Drug Analysis, Aarhus University, ${ }^{2}$ Research Unit for Molecular Medicine, Aarhus University Hospital \\ Profiling low molecular weight compounds in biological systems can give insight into the dynamics of metabolic pathways under the influence of e.g. environmental or disease-related factors. Ultra high performance liquid chromatography coupled to electrospray tandem mass spectrometry (UPLC-ESI-MS/MS) is a highly sensitive tool for this purpose, and has broad substance coverage. In this study acylcarnitines and amino acids are emphasized.}

INVESTIGATING SMALL METABOLITES: DEVELOPMENT OF UPLC-MS/MS

Amino acids are central building blocks for proteins, but also serve nonprotein functions such as metabolic intermediates in energy turnover when other fuels are scarce. The amino acids included in the method have various physical and chemical properties, which are reflected in their behavior on the UPLC column (retention and chromatography) and in the mass spectrometer (ionization). A BEH Amide column was chosen, as it has the potential to retain and separate the polar metabolites and thereby increase sensitivity. Chromatography was generally good. Sensitivity range varied some, assumably due to varying ionization capability.

Acylcarnitines reflect the $\beta$-oxidation, i.e. fatty acid metabolism. These molecules consist of a charged carnitine residue covalently coupled to an apolar alkyl chain. The BEH Amide column proved to be very suitable; both retention and good peak separation was obtained. Furthermore, they showed excellent ionization in the mass spectrometer.

Yet remains to test and validate the method on biological samples. One application is analysis of microdialysates obtained from rat hearts (collaboration with the Department of Cardiology). The objective is to investigate the physiological adaptations to ischemic preconditioning.

P25.04 Kang Ran ANNULUS FIBROSUS TISSUE ENGINEERING BY SEEDING STEM CELLS INTO ELECTROSPUN NANOFIBROUS SCAFFOLDS

R. Kang ${ }^{7}$, M.L. Chen ${ }^{2}$, D. Le ${ }^{7}$, A. Baatrup ${ }^{7}$, H.S. Li $i^{7}$, C. Bunger ${ }^{7}$

${ }^{1}$ Orthopaedic Research Lab, Aarhus University, ${ }^{2}$ Interdisciplinary Nanoscience Center, Aarhus University

Background: Lower back pain is one of the most common debilitating pain conditions worldwide. Current treatments are largely palliative and do not aim to restore mechanical function. Thus, there is strong need for effective tissue engineering solutions. Regeneration of new tissue requires native tissue structure liking, biodegradable scaffolds. For annulus fibrosus, which contains about 20 lamellas with aligned collagen fibers, it is a big change to mimic the structure. Electrospining technique is a possible way to generate highly aligned arrays of polymeric nanofibers. The purpose of this study is to fabricate a 3D scaffold similar with annulus fibrosus extracellular matrix in architecture by electrospining method, and expect this scaffold will facilitate stem cells differentiation to form annulus fibrosus neo-tissue. 
P25.05 Lene Hjelle Tauris
Method: Polycaprolactone solution was ejected by electrospining to format aligned mesh of fibers. These meshes were tailored into strips with the inside fibers 30 degree to the axial of strip. Then by overlapping and connecting the strips to form a 3D structure, in which adjacent strips have opposite fiber direction. A $4 \mathrm{~mm}$ diameter disc were punched out from the 3D structure. Then human bone marrow stem cells were seeded in and culture in chemically defined medium with $10 \mathrm{ng} / \mathrm{ml} \mathrm{TGF- \beta 3.} \mathrm{At} \mathrm{1,} \mathrm{3,} \mathrm{and} 6$ weeks after cell seeding, samples were stained with DAPI, Alcian Blue, and Picrosirius Red. Additional samples were sectioned obliquely, stained with Picrosirius Red, and visualized via polarized light microscopy. Collagen 1, and aggrecan were measure by RT-PCR.

Result: The result have not come out yet.

LINKAGE STUDY ON A LARGE FAMILY WITH NOCTURNAL ENURESIS AND ESTABLISHMENT OF A WEB-BASED NOCTURNAL ENURESIS BIOBANK

L.H. Tauris' , J.H. Christensen' ${ }^{2}$, W. Bower' ${ }^{7}$ K. Kamperis ', A.D. Børglum ${ }^{2}$, H.L.

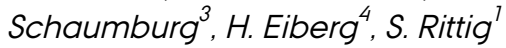

${ }^{1}$ Department of Pediatrics, Aarhus University Hospital, Skejby, ${ }^{2}$ Department of Biomedicine, Aarhus University, ${ }^{3}$ Department of Pediatrics, Regional Hospital, Randers, 'Institute of Medical Biochemistry and Medical Genetics, University of Copenhagen

Introduction: Nocturnal enuresis (NE) is a common disease in children. It is multifactorial in origin with strong genetic contribution. Linkage to several genomic regions has been reported in NE pedigrees. However, no specific gene variations have yet been identified as the cause of NE. The aim was to investigate the linkage between genetic markers and NE phenotype in a large family with autosomal dominant NE and to establish an international web-based NE biobank to identify variants and gene diversity possibly causing different NE phenotypes in children.

Methods: GW-SNP6-genotyping was performed on a 5-generation family having 14 NE affected individuals. After SNP-pruning and exclusion of markers that did not follow Mendelian inheritance, 79012 markers remained. These markers were subjected to an initial parametric linkage analysis using Merlin. Additionally, we are establishing an international enuresis biobank. Underpinning the biobank is a website, where patients can upload clinical data and bladder diaries. DNA from NE patients and their biological parents will be collected and stored in the biobank. Parents will appear as control groups.

Results: Positive LOD scores from the initial analysis were found on chromosomes 6q ( $Z=2.99$ (RS9400212, RS13198560)) and $14 \mathrm{q}(Z=2.35$ (RS878085)). The clinical phenotype was characterized by nocturnal polyuria, although presence of heterogeneity was seen. Affected subjects were desmopressin responders.

Conclusions: Data from our initial study of this family suggested linkage on chromosomes 6q and 14q. Establishment of a biobank will allow future association studies in nuclear families with NE to identify novel risk genes in NE.

P25.06 Kasper Hansen A NOVEL MR, CT, PET COMPATIBLE PRESSURE CHAMBER FOR STUDIES IN HYPERBARIC PHYSIOLOGY

K. Hansen ${ }^{2,1}$, M. Pedersen ${ }^{2,1}$

${ }^{1}$ Department of Clinical Medicine, Aarhus University, ${ }^{2}$ MR Research Centre, Aarhus University

Clinical motivation: Divers are inevitably subjected to changes in the respired gas partial pressures through their underwater activity. It is well known that decompression can lead to nucleation of inert gas bubbles in 
P25.07 Paula

Fernandez

Fernandez

Guerra tissues, blood and the lymphatic system, leading to decompression sickness (DCS), which can be disabling or life-threatening without immediate recompression treatment in a hyperbaric pressure chamber. However, many underlying physiological phenomena attributed to DCS are currently unknown. Computed tomography (CT) and magnetic resonance imaging (MRI) can visualise hard and soft tissue anatomy, respectively, and MRI can further be used to quantify oedema volumes, blood flow and tissue perfusion. In parallel, positron emission tomography (PET) can be used to detect metabolic and biological changes in tissues before morphological changes may appear.

Aim: First, to develop an experimental hyperbaric chamber compatible with MRI, CT and PET. Second, to investigate possible effects of pressurisation on imaging quality.

Method: The pressure chamber was constructed using non-magnetic material, allowing reproducible computer-controlled adjustments of gas pressures (50-1100 kPa) over time. Modality specific phantoms were scanned with all three modalities.

Results and conclusions: The system was demonstrated compatible with MRI, CT and PET with no artefacts in the acquired images. While most DCSrelated measurements are recorded after finishing the pressurisation protocol, we have demonstrated a system capable of performing noninvasive physiological measurements during pressurisation with promising applications in DCS medicine.

NEW PROTOCOL FOR MITOCHONDRIAL AND CELLULAR ASSESSMENT OF HUMAN DERMAL FIBROBLASTS

\section{P. Fernandez-Guerra ${ }^{7}$, P. Rodriguez-Pombo ${ }^{2}$, J. Palmfeldt ${ }^{7}$, P. Bross ${ }^{7}$}

${ }^{1}$ Research Unit for Molecular Medicine, Department of Clinical Medicine, Aarhus University and Aarhus University Hospital, Aarhus, Denmark, ${ }^{2}$ Centro de Diagnostico de Enfermedades Moleculares, Centro de Biologia Molecular "Severo Ochoa" CSIC-UAM, Departamento de Biologia Molecular, Universidad Autonoma de Madrid, Madrid, Spain

Human dermal fibroblasts (HDF) is an invaluable material in the characterization of different defects in patients with inherited diseases. Wide ranges of protocols have been described to study cellular function in HDF, but they have several drawbacks and limitations. We assessed a different methodology: image cytometry. This technique acquires fluorescent intensity data from labelled cell samples, as well as morphological information.

NucleoCounter ${ }^{\circledR} \mathrm{NC}-3000^{\mathrm{TM}}(\mathrm{NC}-3000)$ is an image cytometer with ability to handle large number of samples with a high degree of precision. It provides a low variation and consistency in repetitive analysis, making it an efficient device for monitoring cell processes. We established a protocol to analyze cellular parameters in HDF. These parameters include cell number and viability, thiol redox status and mitochondrial membrane potential; all three parameters are measured within the same sample. In order to detect effects in mitochondrial function and cellular physiology, normal human dermal fibroblasts (NHDF) were analyzed after treatment with hydrogen peroxide $\left(\mathrm{H}_{2} \mathrm{O}_{2}\right)$. NHDF were treated with $2 \mathrm{mM}$ and $4 \mathrm{mM} \mathrm{H}_{2} \mathrm{O}_{2}$ from 30 minutes to 2 hours.

Our results indicate that $\mathrm{H}_{2} \mathrm{O}_{2}$ exposure causes mitochondrial depolarization after 30 minutes, being the first parameter to change due to induced oxidative stress. Thiol redox status and viability start decreasing after 1 hour, presenting an exponential relation in a concentration-time dependent manner $\left(R^{2}=0.93\right)$. In conclusion, combined analyses of different cellular parameters performed in NHDF with $\mathrm{NC}-3000$ show this 
protocol to be an efficient tool for monitoring cellular function in HDF.

P26.01 Gitte

Bundgaard

SORCS3 IS A KEY PLAYER IN LONG-TERM DEPRESSION (LTD) IN THE

Christiansen HIPPOCAMPUS

G.B. Christiansen' , T. Breiderhoff ${ }^{2}$, A. Nykjaer ${ }^{3}$, K. Jensen $^{1,3,4}$, T. Willnow ${ }^{2}$, M.M. Holm ${ }^{7}$

'Synaptic Physiology Laboratory, Department of Biomedicine, Aarhus University, ${ }^{2}$ Max-Delbrueck-Centrum (MDC), Berlin, Germany, ${ }^{3}$ Lundbeck Foundation Research Center MIND, Department of Biomedicine, Aarhus University, ${ }^{4}$ Center for Psychiatric Research, Aarhus University Hospital

SorCS3 is a member of the VPS10P-domain receptor family also called the sortilins. Little is known about this receptor, but other family members have been shown to be key players in synaptic plasticity and different disorders in the CNS. The SorCS3 gene is strongly expressed in the CA1 of the hippocampus, and we have therefore performed electrophysiological analysis in this area on a SorCS3 deficient mouse model to investigate this receptor's role in synaptic plasticity.

Extracellular field recordings in the Schaffer collaterals-CA 1 synapses were performed on coronal slices from wild-type (WT) and knockout (KO) animals. Both NMDAR-dependent and mGluR-dependent long-term depression (LTD) analyses were performed on young mice (P17-P21), and long-term potentiation (LTP) and paired-pulse facilitation analyses were performed on mature mice (P30-P60). LTD and LTP are thought to be mediated mostly by plastic postsynaptic changes, while paired-pulse facilitation is mainly reflecting presynaptic mechanisms.

From the electrophysiological analysis, we found that both the NMDARdependent (WT: $83.8 \% \pm 3.0 \%$; KO: $99.6 \% \pm 4.3 \%$ ) and mGluR-dependent LTD (WT: $80.2 \% \pm 8.2 \%$; KO: $98.0 \% \pm 4.4 \%$ ) were absent in SorCS3 deficient mice. Furthermore, the late phase of LTP was reduced in SorCS3 deficient animals compared with WT littermates (WT: 150\% $\pm 12.5 \%$; KO: $123 \% \pm$ $8.9 \%)$, and no difference was found in the paired-pulse facilitation between $\mathrm{KO}$ and WT littermates.

Based on these results, we conclude that the SorCS3 receptor is likely to play a vital postsynaptic role in NMDAR-dependent and mGluR-dependent LTD, probably through interactions with key scaffolding proteins.

P26.02 Søren Dinesen THE ASSOCIATION BETWEEN PSYCHOTIC MANIA, PSYCHOTIC DEPRESSION Østergaard AND MIXED AFFECTIVE EPISODES AMONG 14,530 PATIENTS WITH BIPOLAR DISORDER

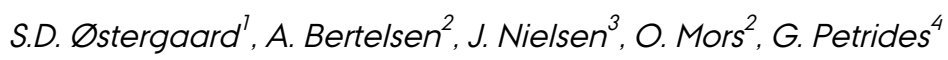

'Unit For Psychiatric Research, Aalborg Psychiatric Hospital, Aarhus University Hospital, Aalborg, ${ }^{2}$ Centre for Psychiatric Research, Aarhus University Hospital, Risskov, ${ }^{3}$ Centre for Schizophrenia, Aalborg Psychiatric Hospital, Aarhus University Hospital, Aalborg,, ${ }^{4}$ Zucker Hillside Hospital, Northshore-Long Island Jewish Health System, Glen Oaks, New York, USA

Background: Psychotic and mixed affective episodes are prevalent in the course of bipolar disorder. Despite many studies on the implications of psychotic mania (PM), psychotic depression (PD) and mixed affective episodes (MAE), relatively little is known about the relationship between the three subtypes. The present study aimed to investigate whether the occurrence of PM, PD and MAE were associated with one another.

Methods: This is a nationwide register-based, historical prospective cohort study. Data were obtained from the Danish Psychiatric Central Research Register. Subjects were defined as all individuals assigned with an ICD-10 diagnosis of bipolar disorder between 1 January 1994 and 31 December2010. Potential associations among psychotic and mixed 
affective episodes were tested by means of logistic regression.

Results: We identified 14,530 individuals with bipolar disorder with lifetime incidences of PM, PD and MAE of $19 \%, 15 \%$ and $17 \%$, respectively. We detected significant associations between PM \& MAE (Adjusted Odds Ratio $(A O R)=1.26, p=0.003), P D \& M A E(A O R=1.24, p=0.001)$, and $P M \& P D(A O R$ $=1.28, \mathrm{p}=0.005$ ).

Conclusions: According to this register-based study, PD, PM and MAE are all associated with one another. This knowledge should be taken into consideration by clinicians when monitoring patients with bipolar disorder and by nosologists when defining criteria and subtypes for bipolar disorder for the upcoming DSM-5 and ICD- 11 .

P26.03 Janne EARLY POST-STROKE USE OF SELECTIVE SEROTONIN REUPTAKE Mortensen INHIBITORS AND CLINICAL OUTCOME AMONG PATIENTS WITH ISCHEMIC STROKE: A REGIONAL PROPENSITY-SCORE MATCHED FOLLOW-UP STUDY J.K. Mortensen' , S.P. Johnsen" ${ }^{2}$, O. Mors ${ }^{3}$, G. Andersen'

'Department of Neurology, Aarhus University Hospital, Denmark, ${ }^{2}$ Department of Clinical Epidemiology, Aarhus University Hospital, Denmark, ${ }^{3}$ Centre for Psychiatric Research, Aarhus University Hospital, Denmark

Background: Post stroke depression (PSD) is common, affecting about $40 \%$ of stroke patients within the first year post stroke. Antidepressants, in particular serotonin reuptake-inhibitors (SSRIs), are widely used in treating PSD. SSRIs inhibit the reuptake of serotonin in presynaptic neurons and in platelets, thereby increasing the level of serotonin in the synaptic cleft and lowering the level of serotonin in platelets. The therapy is generally considered to be well tolerated and effective in treating PSD. However, it remains uncertain whether its potential antiplatelet effects have important clinical implications.

Aim: In a regional population-based propensity-score matched follow-up study, we aim to study new cardiovascular events (recurrent stroke and myocardial infarction), major bleeding and 30-day mortality in patients admitted with stroke and treated with SSRIs during their hospital stay.

Methods: The study will be based on individual level record linkage of data from Danish health care registries. Our cohort of stroke patients will be identified from the Danish Stroke Registry (DSR). SSRI users will be propensity-score matched to non-users in a 1:1 ratio, followed by Coxregression analysis to compute Hazard Ratios. Information on medication use will be extracted from the Danish Pharmaceutical Registry. To adjust for co-morbidity and risk factors, data from the National Patient Registry and the DSR will be used.

Results: Pending

P26.04 Anna Tietze IMAGING OF WHITE MATTER INFILTRATION END HETEROGENEOUS HISTOPATHOLOGY IN CEREBRAL GLIOMAS: DO [ ${ }^{1} \mathrm{C}$ ]-METHIONINE POSITRON EMISSION TOMOGRAPHY AND PERFUSION-WEIGHTED MAGNETIC RESONANCE IMAGING YIELD SIMILAR RESULTS?

A. Tietze ${ }^{\text {l, } 4}$, P. Borghammer', K. Mouridsen' ${ }^{7}$, S. Dyve ${ }^{3}$, L. Østergaard ${ }^{1,4}$

${ }^{1}$ Center of Functionally Integrative Neuroscience, Aarhus University, ${ }^{2}$ Dept. of Nuclear Medicine, Aarhus University Hospital, ${ }^{3}$ Dept. of Neurosurgery, Aarhus University Hospital, Denmark, ${ }^{4}$ Dept. of Neuroradiology, Aarhus University Hospital

Conventional Magnetic Resonance Imaging (MRI) is the cornerstone of cerebral glioma evaluation describing size, localization and morphological characteristics. However, the diffuse and infiltrative glioma growth remains undetected with this technique. As the treatment of gliomas is a subtle balance between the widest possible resection and preservation of brain 
function, exact tumour delineation is of crucial importance.

Various physiology-based MRI and Positron Emission Tomography (PET) techniques have been implemented with substantial improvement in diagnostics and tumour evaluation. $\left[{ }^{11} \mathrm{C}\right]$-methionine PET, an indirect marker for protein synthesis, has shown to detect tumour extent and heterogeneity at high sensitivity and specificity. Another more prevalent technique is perfusion-weighted MRI, thought to estimate tumour angiogenesis and capillary permeability, both a measure for malignancy. As $\left[{ }^{11} \mathrm{C}\right]$-methionine PET is an expensive and time-consuming technique, the objective of our study is to compare this method with perfusion-weighted MRI and conventional MRI. We present preliminary results in four patients with cerebral gliomas with respect to extent of white matter infiltration and tumour heterogeneity.

EPILEPTIC FOCUS FOUND BY MAGNETOENCEPHALOGRAPHY IN THE EPILEPSY SURGERY EVALUATION

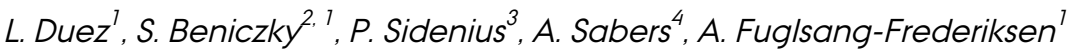

${ }^{1}$ Department of Neurophysiology, Aarhus University Hospital, ${ }^{2}$ Department of Neurophysiology, The Danish Epilepsy Centre in Dianalund, ${ }^{3}$ Department of Neurology, Aarhus University Hospital, ${ }^{4}$ Department of Neurology, Rigshospitalet

Background: Magnetoencephalography (MEG) is increasingly used in the non-invasive pre-surgical evaluation of patients with refractory focal epilepsy. MEG records the changes in magnetic fields generated by the activity of the neural networks in the brain ${ }^{1}$. EEG and MEG support each other in localizing the epileptic focus, because MEG mainly detects epileptic sources tangential to the scull and EEG mainly detects radial sources. The magnetic field recorded by MEG is not distorted by the scull and scalp ${ }^{2}$. Combination of MEG, EEG and cerebral MRI can estimate the location of the epileptic focus.

Method: The patient was a surgical candidate and the epileptic focus was unknown in spite of numerous tests to localize the epileptic focus. In addition to EEG these tests included MR, Positron emission tomography and Singlephoton emission computed tomography. 1 hour MEG in resting conditions and eyes closed was performed. MEG and MR data were analyzed using CURRY® Neuroimaging Suite.

Results: On data obtained by MEG, dipole localization (rotating/FIXED MUSIC) was performed on an average of 704 spikes regarded as the best defined of the total 2503 spikes found. This revealed a focus in the right postcentral gyrus/Brodmann area 43.

Conclusion: We report a case where the epileptic focus still was unknown in spite of numerous tests. MEG was able to identify epileptic activity and thereby an epileptic focus. This may be because MEG has a better spatial resolution than EEG. MEG should be considered in patients with refractory focal epilepsy.

\section{References:}

1. Stufflebeam et al. Hum Brain Mapp. 2009; 30(6):1813-1823.

2. De Tiege et al. J Neurol Neurosurg Psychiatry. 2012; 83(4):417-423. NEURONAL EPIGENETIC ALTERATIONS INDUCED BY PHYSICAL EXERCISE.

\section{C.A.E. Sølvsten, F. de Paoli, J.H. Christensen, A.L. Nielsen}

Institute of Biomedicine, Aarhus University

Human contains a large potential for genetic variability, which confers the ability to adapt their phenotype according to environmental demands. Epigenetic mechanisms affecting the chromatin structure and function 
P26.07 Maryam Ardalan

P26.08 Anne Virring Sørensen includes DNA methylation, histone modifications, and other types of chromatin remodelling activities. Epigenetics is deeply involved in phenotypic variation in health and disease and it is likely that understanding and manipulation of the epigenome holds enormous promise for preventing and treating common human illness. Epigenetics is also important to understand the role of the interaction between the genome and the environment in causing human diseases, and in modulating such interactions to improve human health.

Recently a link between environmental factors such as physical exercise and stress, and epigenetic modifications in the hippocampus has been shown. Exercise seems to improve cognitive responses to stress through enhancement of epigenetic mechanisms and gene expression in the hippocampus neurons.

One of the genes known to show altered expression due to exercise is Bdnf, the exact epigenetic mechanism behind the altered expression, however, has not been clarified. To determine in more details how exercise influences the epigenetic regulation, of Bdnf and other neurotropic factors, in hippocampus neurons, a commonly used rat model is being used. Two groups of rats will be examined, one where the rats has access to voluntary exercise in a running wheel and one where the rats are sedentary. After 2 weeks the rats are killed and epigenetic examinations, such as methylation assays and ChIP, will be performed.

CHARACTERIZATION OF MINICOLUMNS IN HUMAN CEREBRAL CORTEX

A. H. Rafati 1, 3, 2 , K.A. Dorph-Petersen 2, 3,4 ,F. Safavimanesh ${ }^{3,5}$, J. Gulddahl Rasmussen, ${ }^{3,5}$, J. Møller, ${ }^{3,5}$, J. Randel Nyengaard ${ }^{1,3}$

${ }^{1}$ Stereology and Electron Microscopy Laboratory, Aarhus University Hospital, ${ }^{2}$ Centre for Psychiatric Research, Psychiatric Hospital, Aarhus University, ${ }^{3}$ Centre for Stochastic Geometry and Advanced Bioimaging (CSGB), Aarhus University, ${ }^{4}$ Translational Neuroscience Program, Department of Psychiatry, University of Pittsburgh, ${ }^{5}$ Department of Mathematical Sciences, Aalborg University

The methods to detect or quantify the minicolumns in human cerebral cortex have long been subject to controversial discussions. Studies on minicolumns are basically based on two-dimensional image analysis of thin sections. The main drawback of such techniques is that they fail to reflect precisely the 3D structures organized radially in the cerebral cortex. In contrast to the 2D image techniques, current available modern quantitative light microscopy enables registration of 3D coordinates of cells. This yields data that help to test the hypotheses about existence of minicolumns. We aim to develop a robust 3D method for quantitative analysis of minicolumnar structure, e.g. number and size, based upon stereological sampling of the human cerebral cortex. In addition, we will search for changes in the minicolumnar pattern in specific brain areas (BA4 and BA46) of subjects with schizophrenia.

REPORTED SLEEP PROBLEMS AND DAILY FUNCTIONING IN CHILDREN WITH ADHD AND IN CONTROLS

\footnotetext{
A. Sørensen' , L. Møller', P. Jennum², P. Thomsen ${ }^{\prime}$

'Børne og Ungdomspsykiartrisk center, Risskov, AArhus university Hospital, ${ }^{2}$ Dansk Søvncenter, Glostrup

Background: Adhd (attention deficit/ hyperactive disorder) is a neurodevelopmental disorder with a prevalence of 2-5\%. Co-morbidity appears in up till $75 \%$ of children and $2 / 3$ of parents report significant sleep related problems. Daily function of children with ADHD is impaired compared to normal controls. Functional impairment is measured on family, school, peer and social factors, but whether the degree of functional
} 
P27.01 Lise Ventzel impairment and sleep related problems are correlated is not known. The aim of this study is to investigate how daily function and sleep are reported in children with ADHD compared to a matched control group and how the relation of impairment and sleep is correlated.

Method: A case control study. All consecutive patients age 6-14 years from the school department of Child Psychiatric Department, Risskov, are assessed with a rigorous diagnostic interview (Development and WellBeing Assessment) and validated questionnaires about sleep related problems (Children's Sleep Habits Questionnaire), daily functioning (Weiss Functional Impairment Rating Scale) and ADHD symptoms score (ADHD Rating Scale).

Results: Data collection is still ongoing so results are preliminary. We have results from 150 people in each group and there is at the moment statistical significant difference on all parameters between patients and controls. Baseline data and correlations will be presented in tables and graphs

PAIN AND NEUROPATHY AFTER CHEMOTHERAPY: A PROSPECTIVE STUDY

L. Ventzel', A.R. Jensen ${ }^{2}$, A.B. Jensen ${ }^{2}$, T.S. Jensen ${ }^{7}$, N.B. Finnerup ${ }^{7}$

'Danish Pain Research Center, Aarhus University Hospital, ${ }^{2}$ Department of Oncology, Aarhus University Hospital

Aim: Neurotoxicity is a dose-limiting side-effect of adjuvant chemotherapy, representing a significant problem since chemotherapy increases survival rates. Neurotoxic chemotherapeutics include docetaxel, used for high-risk breast cancer, and oxaliplatin, used for high-risk colorectal cancer. This study aims to estimate the incidence, severity, impact and characteristics of chemotherapy-induced neuropathy.

Methods: The study is a self-administered questionnaire study of 173 patients: 75 treated with oxaliplatin and 98 with docetaxel. Patients complete questionnaires at baseline, twice during and once at the end of treatment and 9 months after treatment. The questionnaires include the Pain Catastrophizing Scale, the Quality Of Life Questionnaire (EQ-5D), the Hospital Anxiety and Depression Scale, PainDetect and specific questions about chemotherapy-induced neuropathy.

Results: The most common symptoms of neuropathy in the docetaxel group were tingling (pins and needles) in the upper (46.2\%) and lower extremities $(47.7 \%)$ and throat discomfort (56.9\%). The most common symptoms in the oxaliplatin group were tingling (pins and needles) (92.5\%) and burning pain or discomfort with cold in the upper extremity (69.8\%) and jaw pain (69.8\%). In the docetaxel group, the self-reported health state (EQ-5D) decreased from $81.4(S D=13.9)$ at baseline to $58.8(S D=22.8)$ after the first chemotherapy. In the oxaliplatin group, it decreased from 81.1 (SD=18.7) to $69.2(S D=22.5)$.

Conclusion: This ongoing study shows that neuropathy, as well as pain, is a significant problem with important differences between the symptoms of oxaliplatin- and docetaxel-treated patients.

P27.02 Anita Eskildsen PROGNOSIS OF COGNITIVE IMPAIRMENTS IN PATIENTS WITH WORKRELATED STRESS
A. Eskildsen', L.P. Andersen' , A.D. Pedersen' , J.H. Andersen'
${ }^{1}$ Danish Ramazzini Center, Department of Occupational Medicine, Regional, ${ }^{2}$ Hammel Neurorehabilitation and Research Centre, Aarhus University Hospital
Patients on sick leave due to work-related stress* experience a mix of different physiological and psychological symptoms. Frequent main complaints are concentration problems and memory impairments. 
The aim of this study is to examine whether patients with work-related stress have more cognitive impairments than a matched control group without stress and to examine the changes in cognitive function at 1-year follow-up. Additionally, we want to examine if improved cognitive functioning is related to an improvement in sleep quality.

The study takes a prospective approach and follows a group of patients from shortly after onset of sick leave until expected recovery after 1 year. The patients are matched to healthy controls regarding age, gender and education. Both controls and patients are tested with a comprehensive standardized neuropsychological test battery at baseline and at 1 -year follow-up and are asked to fill out questionnaires regarding psychological and physiological symptoms including problems with sleep.

The present project can help elucidate how widespread cognitive impairments are in patients with work-related stress and whether these impairments are reversible. Additionally, if sleep problems are found to be a mediator of cognitive problems, more focus on sleep interventions in this group of patients would be appropriate.

*Work-related stress is here defined as a condition within the individual characterized by a persistent aversive tension which is considered related to a mismatch between the individual and the workplace.

CHRONIC INFUSION WITH LIPOPOLYSACCHARIDE DOES NOT ALTER BEHAVIOURAL OR METABOLIC PARAMETERS IN RATS

\section{Fischer ', B. Elfving ${ }^{\text {', S. Lund }}{ }^{2}$, G. Wegener ${ }^{\text {l, } 3}$}

${ }^{7}$ Centre for Psychiatric Research, Aarhus University Hospital - Risskov. Denmark, ${ }^{2}$ Medical Research Laboratory and Medical Department M (Endocrinology and Diabetes), Aarhus University Hospital, Denmark, ${ }^{3}$ Unit for Drug Research and Development, School of Pharmacy (Pharmacology), North-West University, Potchefstroom, South Africa

Chronic low-grade inflammation is a condition in which the immune system remains activated for a prolonged time. A chronic inflammatory state has been implicated in various disorders, such as type 2 diabetes mellitus (T2DM) and psychiatric disorders such as major depression. Several studies suggest a bi-directional relationship between T2DM and depression because of the co-occurrence of the two disorders. Since inflammation may be implicated in the pathophysiology of both depression and T2DM, it has been hypothesized that activated inflammatory pathways could mediate this association.

The aim of this study was to investigate effects of a systemic low-grade inflammation induced by lipopolysaccharide (LPS) on male SpragueDawley rats on depression-like behaviour and metabolic parameters. Chronic infusion $(2.5 \mu \mathrm{g} / \mathrm{h})$ of low doses of LPS $(75-300 \mu \mathrm{g} / \mathrm{kg} / \mathrm{day})$ for 28 days was performed by using intra-abdominal implanted osmotic minipumps (Alzet, 2ML4). After approximately 4 weeks, depression-like behaviour was assessed in the forced swim test (FST) and an oral glucose tolerance test was performed to evaluate glucose and insulin sensitivity. Furthermore, body weight and food and water intake was measured weekly.

Our results showed that LPS did not cause altered behaviour in the FST relative to vehicle treatment, indicative of no depression-like behaviour. Furthermore, no metabolic changes were observed in body weight and glucose and insulin values. However, LPS did cause an immediate physiological and behavioural reaction reflected as sickness behavior. Since we did not detect any long-term changes to induction with LPS, our results could suggest that endotoxin tolerance occurred. 
P27.04 Nicole Jeanette SENSORY FUNCTION AND NERVE FIBRE DENSITY IN THORACOTOMY S. Springer PATIENTS

\section{J.S. Springer, P.R. Karlsson, T.S. Jensen, L. Nikolajsen}

Danish Pain Research Center, Aarhus University Hospital, Aarhus, Denmark

Aim of investigation: Sensory loss as determined by quantitative sensory testing (QST) is usually associated with a similar reduction of nerve fibre density in punch skin biopsies. In this study, we look at patients with and without pain following thoracotomy and compare sensory function with nerve fibre density. Healthy individuals are used as controls.

Methods: Sixty individuals will be included: 20 thoracotomy patients with pain (VAS $\geq 3$ ), 20 thoracotomy patients without pain (VAS $\leq 1$ ) (age- and sex-matched), and 20 healthy individuals (age- and sex-matched). All individuals will be examined bilaterally on the thorax with QST, according to the protocol of the German Research Network on Neuropathic Pain (DFNS), with Laser Doppler imaging to measure the change in blood flow after capsaicin application and by skin biopsies. Questionnaires about quality of life, anxiety and depression, pain and pain sensitivity, chronic and neuropathic pain are included (HADS, PCS, Euro-Qol-5D, GCPS, PSQ, NPSI, PainDetect).

Results: The inclusion of patients and healthy volunteers is ongoing. Preliminary results suggest that patients without pain have an increased response to capsaicin, and patients with pain have a reduced response to capsaicin. QST suggests impaired thermal detection thresholds for patients without pain and impaired cold pain thresholds for patients with pain. Skin biopsies are currently being analysed.

Conclusion: The results will be presented at the PhD day. Among other results, we expect to find a relation between pain and nerve fibre density.

Acknowledgement: This study is part of the Innovative Medicine Initiative EUROPAIN, wWw.imi.europa.eu.

P27.05 Marie Louise QUALITY OF LIFE ACCORDING TO STROKE ETIOLOGY IN PATIENTS Schmitz RECEIVING THROMBOLYTIC THERAPY

M.L. Schmitz' S.P. Johnsen ${ }^{2}$, G. Andersen ${ }^{7}$

'Department of Neurology, Aarhus University Hospital, ${ }^{2}$ Department of Clinical Epidemiology, Aarhus University Hospital

Background: Ischemic stroke affects 12,000 Danish people annually. During the past decade, acute treatment with thrombolytic therapy has been increasingly used in this group of patients. The risk of post-stroke disability has therefore been markedly reduced. Despite a good functional outcome, poor quality of life $(\mathrm{QOL})$ is a relevant problem to some of the patients. No data exist on whether QOL differs in ischemic stroke patients according to stroke etiology.

Aim: To examine QOL in ischemic stroke patients at long-term follow-up after thrombolytic therapy and to analyze whether QOL differs according to stroke etiology. Moreover, to identify possible baseline predictors at hospital admission of QOL at long-term follow-up.

Methods: From April 2004 to December 2010, 545 consecutive patients underwent thrombolytic therapy in Aarhus due to acute ischemic stroke. Clinical data and acute MR scan of the brain were collected prospectively. We contacted 449 stroke survivors and 250 responded (56\%). QOL and functional outcome were assessed from October 2011 to October 2012 in a cross-sectional survey. QOL was assessed with the questionnaire "Stroke Specific Quality of Life" and functional outcome with the Modified Rankin Scale and the National Institutes of Health Stroke Scale. Stroke etiology was classified according to the Trial of ORG 10172 in Acute Stroke Treatment 
Criteria into the following groups: Large vessel disease, cardio embolic, small vessel disease, other etiology and unknown etiology.

Results: The study is in progress and will be completed in 2013.

THE ROLE OF SUGGESTIBILITY AND ABSORPTION FOR A PLACEBO EFFECT IN HEALTHY VOLUNTEERS

K. Lund ', L. Vase' ${ }^{2}$, G.L. Petersen ${ }^{2}$, T.S. Jensen ', N.B. Finnerup ${ }^{7}$

${ }^{1}$ Danish Pain Research Center, Aarhus University Hospital, ${ }^{2}$ Department of Psychology, Aarhus University

Background and aim: Suggestibility is one of the few personality traits that has been positively associated with a placebo effect (de Pascalis et al., 2002). However, this finding has not been replicated. The aim of the present study is to investigate to which extent suggestibility, the related phenomenon absorption and expectations predict the magnitude of the placebo effect.

Methods: Injection of hypertonic saline (HS) $5 \%$ in the masseter muscle is a reliable model of deep nociceptive pain that mimics clinical pain. Forty healthy volunteers ( 20 males $/ 20$ females) will receive injections with $\mathrm{HS}$ and injections with $\mathrm{HS}+$ lidocaine $(1 \%)$ in the masseter muscle. An open vs. hidden design will be used along with suggestions for pain relief. Pain is rated continuously and recorded on an electronic visual analogue scale (eVAS). Expectations are also rated on a visual analogue scale (VAS). At a separate visit, the participants will fill in the Tellegen Absorption Scale, and at the same visit the test Sensory Suggestibility Scale will be performed by a trained psychologist.

Results: At present 32, healthy volunteers ( 14 males/ 18 females) have been included in the study. The results from the study will be presented at the PhD day.

P27.07 Mikkel Mylius Rasmussen

\section{DEFECATION IN SUPRACONAL SPINAL CORD INJURY}

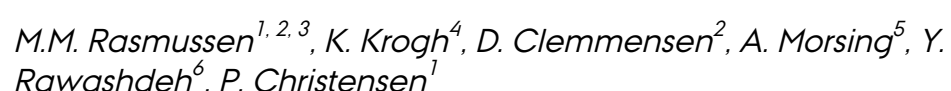

${ }^{1}$ Department of Surgery, Aarhus University Hospital, Denmark, ${ }^{2}$ Department of Neurosurgery, Aarhus University Hospital, Denmark, ${ }^{3}$ Department of Neurosurgery, Aalborg Hospital, Aarhus University Hospital, Denmark, ${ }^{4}$ Department of Hepato-gastroenterology, Aarhus University Hospital, Denmark, ${ }^{5}$ Department of Nuclear medicine and PET center, Aarhus University Hospital, Denmark, ${ }^{6}$ Department of Urology, Aarhus University Hospital, Denmark

Introduction: Bowel dysfunction in spinal cord injury (SCl) differs for supraconal (hypertonic effect) and conal/cauda equine (hypotonic effect) lesions. Conal/cauda equine lesions have been shown to induce defecation impairment with the colorectal scintigraphy. However, the defecation impairment in supraconal lesions has never been examined.

Material and Methods: Patients were recruited via file review in our Neurosurgical department. Out of 21 included, 6 were excluded (poor quality of the scintigraphy), leaving 15 (one female, 14 male, median age = 47 (22-74) years of age, SCl level C5-Th9) for further analysis. Patients were compared with a control group of healthy volunteers, $n=16$ (median age = 31 years of age (24-42)). All underwent a colorectal scintigraphy. SCl patients had symptomatology expressed using bowel function scores. Further a gastrointestinal transit time (GITT) investigation was performed.

Results: Defecation score for SCl patients $=36$ (0-149), stating that $36 \%$ of the rectosigmoid content was emptied during defecation. For the healthy volunteers $=84$ (3-290), $p=0.02$. Median GITT $=2.9$ days (1.5-5.8). The median neurogenic bowel dysfunction score $=10$ (3-23), median St. Marks 
P27.08 Freja Cecilia

Brandt

Bertelsen score $=4(0-10)$ and median Cleveland constipation score $=6$ (4-13). The variables; defecation score, GITT and symptom scores were related to each other. There seems to be a tendency towards low defecation score with increasing bowel function scores. No correlation was found to GITT for neither.

Conclusion: Supraconal and conal / cauda equina SCl have a uniform impaired bowel emptying. Results for supraconal lesions seems to relate to patient symptomatology.

AN ANIMAL MODEL FOR THE FETAL VALPROATE SYNDROME - WITH RELEVANCE TO AUTISM

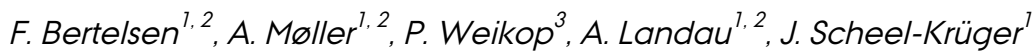

${ }^{1}$ Center of Functionally Integrative Neuroscience, Aarhus University, ${ }^{2} \mathrm{PET}$

Centre, Aarhus University Hospital, ${ }^{3}$ Laboratory of Neuropsychiatry, Psychiatric Centre Copenhagen

Background: In the human clinic, the fetal valproate syndrome is characterized by somatic malformations and cognitive dysfunctions, which may include the autistic spectrum disorders.

Aim: The aim of this study is to establish a novel animal model for autism induced by early prenatal administration of the antiepileptic drug valproate (VPA) to pregnant rats.

Material and methods: Eighteen pregnant rats were exposed to daily VPA or saline from the 12th day of pregnancy until birth. Neuropathological changes in the offspring were evaluated by stereology and presence of biomarkers in the prefrontal cortex, hippocampus and striatum, as well as by behavioural changes relevant to autism.

Results: We have found a significant increase in the number of neocortical cells in the VPA rats compared to controls. Serotonin levels in the striatum of the VPA rats were significantly reduced compared to controls. Furthermore, the play behaviour of VPA rats was reduced.

Perspectives: The combined approach of histology, biochemistry and behavioural studies is necessary in the characterization and development of a novel rodent model of autism. Translational studies using this model may result in a better understanding of the developmental changes occurring during pregnancy and leading to autism in the human condition. A valid animal model is the first step in the testing of new drug candidates of interest for the pharmacological treatment of autism. This is of particular importance since the deficits in social behaviour in autism are severely invalidating, and no pharmacological compounds are currently available for the improvement or treatment of the devastating core behavioural symptoms

P28.01 Lisbeth Lund Jensen

\section{APP STAINING IN SUDDEN INFANT AND EARLY CHILDHOOD DEATH}

\section{L.L. Jensen ${ }^{\text {l, }}$, R.W. Byard ', J. Banner}

'Department of Forensic Medicine, Aarhus University, Aarhus, Denmark, ${ }^{2}$ Discipline of Anatomy and Pathology, The University of Adelaide, South Australia, Australia

Even though the number of Sudden Infant Death Syndrome (SIDS) deaths declined rapidly after the putting infant to sleep on the back campaigns in the beginning of the nineties, SIDS is still one of the leading causes of infant death in the Western World. While much is known concerning the risk factors of SIDS, researchers have failed to identify the cause of the syndrome. One of the suggested sites for the underlying defect or predisposition is the central nervous system (CNS), and there is evidence that the SIDS infants have numerous discrete brain abnormalities. Several markers have been investigated but only limited data exists concerning $\beta$ - 
Amyloid Precursor Protein (APP) in SIDS. APP is produced in the neurons and it is transported by fast axonal transport. It is considered to be a fast and reliable marker of axonal damage in forensic cases. However, while some investigators have found APP in all their SIDS cases others have found none, and correlation to important risk factors such as sleeping conditions has not yet been investigated.

The aim of this PhD project was to determine the amount of APP in an Australian and Danish cohort of SIDS infants and whether APP was related to sleep-related variables.

The study included the 48 Australian and 78 Danish SIDS cases identified according to the San Diego criteria. A statistically significantly increased amount of APP in infants sleeping alone was found compared to the infants' bed-sharing with one or more adults. This association was found in both the Australian and the Danish cases emphasizing the validity of the findings, and suggesting that SIDS may be an entity with two subgroups.

P28.02 Arnela THE INFLUENCE OF SORLA ON APP PROCESSING IN RETINA

Mehmedbasic

\section{A. Mehmedbasic, O.M. Andersen}

Department of Biomedicine, Aarhus University

Alzheimer's disease (AD) is a progressive neurodegenerative disorder accounting for $60-80 \%$ of all dementia cases. It is estimated that over 24 million people are affected worldwide, and this number is expected to increase in the following decades.

Accumulation of extracellular Amyloid beta $(A \beta)$ plaques in the brain is one of the most prominent pathological hallmarks of $A D$. The $A \beta$ is a product of a sequential proteolytic processing of the amyloid precursor protein (APP); a process influenced by the cellular localization of the precursor. The sortilin related receptor with A-type repeats (sorLA) is an APP sorting receptor that retains APP in the perinuclear region of neurons in the brain and in culture, thereby decreasing the rate of APP processing and thus decreasing the amount of $A \beta$ generation. SorLA is genetically linked to late onset $A D$ (LOAD), and patients suffering from LOAD have decreased levels of the sorLA protein expression.

The brain, particularly the cortex and hippocampus, is the most common manifestation site of AD pathology, but increasing evidence shows that the eye, especially the retina, is also affected. SorLA's role and its influence on APP processing in retina have not yet been investigated. This PhD project aims to establish if sorLA has the same protective role in APP processing in retina and to assess sorLA's potential for early diagnosis of $A D$.

P28.03 Justyna Zareba ALPHA-SYNUCLEIN INDUCED NEURODEGENERATION IN PARKINSON'S DISEASE: INTER- AND INTRA-NEURONAL PROGRESSION

J. Zareba ${ }^{7,2}$, L. Carrascal', K. Boddum², C. Betzer ${ }^{3}$, P.H. Jensen ${ }^{3}$, K. Jensen $^{2,4}$, M. Romero-Ramos ${ }^{7}$

${ }^{1}$ CNS Disease Modeling Group, Department of Biomedicine, Aarhus University, Denmark, ${ }^{2}$ Synaptic Physiology Laboratory, Department of Biomedicine, Aarhus University, Denmark, ${ }^{3}$ Neurodegenerative Disease Laboratory, Department of Biomedicine, Aarhus University, Denmark, ${ }^{4}$ Center for Psychiatric Research, Aarhus University Hospital, Risskov, Denmark

Parkinson's disease (PD) is characterized by a progressive neurodegeneration in substantia nigra (SN), and presence of aggregated asynuclein (a-syn) throughout the CNS. a-syn plays a central role in PD and mutation or accumulation of the normal a-syn can lead to PD. The 'Braak hypothesis' of a-syn CNS pathology states that abnormally aggregated asyn is transmitted among neurons. In turn, this prion-like a-syn will further 
promote mishandling of intracellular a-syn.

Our hypothesis is that mishandling of a-syn in neurons leads to a prion-like progression and cellular changes in $\mathrm{Ca}^{2+}$ homeostasis that results ultimately into cell death. Our preliminary data suggest that oligomerized a-syn in neuronal cultures induces changes in cytosolic $\mathrm{Ca}^{2+}$ which could contribute to PD progression. This project aims to address 1) if aggregated a-syn can act as a somatic or axonal prion-like protein and 2) whether the modulation of $\mathrm{Ca}^{2+}$ homeostasis in a-syn overexpressing neurons can be used as a neuroprotective strategy in PD.

We use a rat PD model based on local overexpression in SN of a-syn using viral vectors encoding for human-a-syn or GFP as a control. To study the prion hypothesis we will further inject aggregated a-syn into SN or striatum and the neurodegeneration will be analyzed at behavioral and histological levels. To address a-syn-induced $\mathrm{Ca}^{2+}$ mishandling i) in vivo we will use the viral vector a-syn PD model and rats will be treated chronically with a $\mathrm{Ca}^{2+}$ channel blocker and neurodegeneration will be analyzed and ii) in vitro we will use cortical cell cultures from a a-syn transgenic mice to perform fura-2 imaging to get insight into a-syn-induced $\mathrm{Ca}^{2+}$ mishandling.

P28.04 Noomi Gregersen
ARE TMEM GENES POTENTIAL CANDIDATE GENES FOR PANIC DISORDER?

N.G. Gregersen ", 2, 3 , H.N. Buttenschøn", ${ }^{1}$, H.A. Dahl', A. Hedemand ${ }^{2,3}$, A.S. Kristensen ${ }^{7}$, D.P.D. Woldbye ${ }^{5}$, P. Koefoed ${ }^{5}$, S. Joensen ${ }^{6}$, T.A. Kruse , A. Erhardt $^{8}$, A.G. Wang, 9, , A.D. Børglum, ${ }^{2,3}$, O. Mors ${ }^{1,3}$

${ }^{1}$ Centre for Psychiatric Research, Aarhus University Hospital, Risskov, ${ }^{2}$ Dept. of Biomedicine, Aarhus University, ${ }^{3}$ The Lundbeck Foundation Initiative for Integrative Psychiatric Research, iPSYCH, ${ }^{4}$ Amplexa Genetics A/S, Odense, ${ }^{5}$ Laboratory of Neuropsychiatry, University of Copenhagen, ${ }^{6} \mathrm{Dept}$. of Psychiatry, National Hospital, Faroe Islands, ${ }^{7}$ Dept. of Clinical Genetics, University of Southern Denmark, ${ }^{8}$ Max Planck Institute of Psychiatry, Munich, Germany, ${ }^{9}$ Dept. of Psychiatry, HS Amager Hospital, Copenhagen University Hospital

A recent German genome wide association study (GWAS) ${ }^{1}$ showed a possible role of the TMEM132D gene in the aetiology of panic disorder (PD). Two TMEM genes (TMEM98 and TMEM132E) are located within a previously reported candidate region on chromosome $17^{2}$. The current study aimed to determine the possible role of TMEM genes in the aetiology of PD. We analysed 11 single nucleotide polymorphisms (SNPs) in TMEM98, 25 SNPs in TMEM132E and two SNPs in TMEM132D. The SNPs were analysed in three cohorts: a Faroese ( 36 cases and 162 controls), a Danish ( 243 cases and 649 controls), and the German GWAS cohort ( 236 cases and 222 controls).

The Faroese cohort: Two SNPs within TMEM132E showed association with PD (rs4795942, $p=0.035$; $r$ 1 2602358, $p=0.029$ ).

The Danish cohort: Three SNPs within TMEM132E showed association ( $r$ 887231, $p=0.004$; rs887230, $p=0.029$; rs4795942, $p=0.006$ ). One SNP within TMEM132D showed association ( $r$ 7309727, $p=0.02151$ ).

The German cohort: Two SNPs within TMEM132D showed association (rs7309727, $p=8.41 E-06 ; r s 11060369, p=0.002$ ).

It is likely that TMEM genes might contribute a moderate effect in the aetiology of PD. We observed nominal association between PD and SNPs located upstream and within TMEM132E. When analysing the Danish and Faroese cohorts in a combined sample rs887231 remained significantly associated after correcting for multiple comparisons. No association was seen between SNPs within TMEM98 and PD in any of the three cohorts. In the Danish cohort we were able to replicate the significant association between TMEM132D and PD seen in the German GWAS. 
1.Erhardt et al: Mol Psychiatry. 201 1; 16: 647-63

2.Gregersen et al: Eur J Hum Genet. 2012; 20: 84-90

P28.05 Simon STRUCTURAL AND FUNCTIONAL ASPECTS OF SORTILIN INTERACTION WITH Mølgaard Jensen GABAERGIC INTERNEURONS

\section{S. Jensen}

\section{Stereology \& Electron Microscopy Research Laboratory}

Hippocampal synaptic plasticity is considered the prime candidate for the cellular mechanism of learning. When an excitatory synapse is activated, brain-derived neurotropic factor (BDNF) is released to increase the efficiency of the synapse via binding to its receptor TrkB. Sortilin regulates the release of BDNF while SorCS2 transports TrkB to the surface. This makes sortilin and sorCS2 key elements in synaptic plasticity, and mutations in either of the receptors have shown to be prime candidates for development of some psychiatric diseases. However, little is known about the role of Sortilin and SorCS2 in the inhibitory system of the hippocampus.

The inhibitory system of the hippocampus consists of 21 subtypes of interneurons, defined by their electrophysiological pattern as well as their morphology and expression of molecular markers. These interneurons are crucial for proper function of the hippocampus as they, among other things, synchronize the firing pattern of excitatory neurons, something which is necessary for proper flow of information.

Initial studies have shown sortilin and sorcs2 to be expressed specifically in certain subtypes of interneurons within the hippocampus, indicating a specific role within these subtypes. To determine the function of the receptors in these interneurons, several different projects are being carried out. The results of these projects may in the future help us understand the development of some psychiatric diseases and hopefully point towards new treatment targets.

P28.06 Anne Højland CHARACTERIZING MEMORY AND LEARNING ABILITIES OF SORLA KNOCKOUT MICE

\section{A. Hoejland, S. Glerup, M.S. Nielsen}

The Lundbeck Foundation MIND center, Department of Biomedicine, University of Aarhus.

SorLa belongs to the vps $10 p$ domain receptor family. This receptor family is multifunctional and highly expressed in the nervous system, where they have been implicated in Alzheimer's disease and injury-related neuronal cell death. SorLa has been shown to be involved in regulating the level of lipoprotein lipase (LPL). As LPL in the brain is known to be important for learning and memory, the characterization of sorLa KO mice with regard to these parameters can indicate sorLa as an important factor in regulated release of LPL in hippocampal neurons.

Characterization of memory and learning abilities is accomplished by applying three different tests for cognition to both wild-type C57BL and sorLa knock-out mice (sorLa -/-). In this study Barnes Spatial Learning Maze, Passive Avoidance Task and Radial-8-arm Maze is used. The three tests vary in complexity and motivational factors and complement each other. Performance in these tests depends on spatial memory abilities and is very sensitive to variations in hippocampus. Thus the performance of the KOmice compared to wild-type mice indicates the effect of sorla on hippocampus, an effect that may very well be due to LPL-regulation by sorla in this area of the brain

Preliminary studies in Barnes Maze and Passive Aviodance test, show impaired learning as well as affected memory in the sorLa knock-out mice 
compared to wild type mice.

P28.07 Simple

Futarmal

Kothari

P28.08 Henriette Bjerregaard
NEUROSENSORY ASSESSMENT IN PATIENTS WITH TOTAL TEMPOROMANDIBULAR JOINT PROSTHESES

S.F. Kothri' , L. Baad-Hansen' , K. Andersen², P. Svensen ${ }^{1,3}$

${ }^{1}$ Section of Clinical Oral Physiology, Department of Dentistry, Aarhus University, ${ }^{2}$ Section of Oral Pathology and Maxillofacial Surgery, Department of Dentistry, Aarhus University, ${ }^{3}$ MIND LAB, Center for Functionally Intgrative Neuroscience, Aarhus University Hospital

Objectives: Quantitative sensory testing is a widely accepted tool to investigate somatosensory changes in pain patients. This study aimed to assess the somatosensory function in temporomandibular joint (TMJ) area and endogenous pain modulation in patients with TMJ prostheses and healthy controls.

Methods: Seven patients with TMJ prostheses and 20 healthy controls participated. Positive and negative somatosensory signs and symptoms were assessed using QST. Conditioned pain modulation (CPM) was assessed by comparing pressure pain thresholds (PPT) at baseline, during and after applying a conditioning cold stimulus at 2 intensities (painful and non-painful) at TMJ and thenar (control). The probability that an individual patient dataset was within the range of normal variability was calculated by Z-transform of QST data. Analysis of variance was performed on PPT values to test the effect of CPM in both the groups.

Results and conclusions: Five of the TMJ patients showed gain of sensory function for 6 parameters of QST- warm detection, thermal sensory limen, mechanical detection, mechanical pain, wind-up ratio and vibration detection and three of the patients showed loss of function for 4 parameters- heat pain, mechanical pain, vibration detection and PPT. There was a significant increase in PPT values during the application of painful cold stimulus at both sites in healthy subjects $(p<0.001)$, but not in the TMJ prostheses group $(p=0.476)$. This study showed that QST measures can assess somatosensory abnormalities in patients with total TMJ replacement. Noxious conditioning cold stimulus can evoke CPM-like effects in healthy subjects, but not in patients with TMJ reconstruction.

IBOGAINE ANALOGS IN THE HUMAN SEROTONIN TRANSPORTER H. Bjerregaard ', F. Nami ${ }^{2}$, H.H. Jensen ${ }^{2}$, O. Wiborg ${ }^{7}$, S. Sinning ${ }^{7}$

${ }^{1}$ Centre for Psychiatric Research, Aarhus University Hospital, Risskov, Aarhus University, ${ }^{2}$ Department of Chemistry, Aarhus University

The human serotonin transporter (hSERT) regulates serotonergic signalling in the brain by actively regulating the concentration of serotonin in the synaptic cleft. hSERT mediates reuptake of serotonin into the pre-synaptic neurons. hSERT is a molecular target for antidepressant drugs and psychostimulants that act by altering the serotonin concentration in the synapses.

Conformational changes of hSERT occur during substrate and ligand binding and during translocation of serotonin. During the transport cycle, hSERT shifts from an extracellular-facing conformation through an occluded state ending in a cytoplasmic-facing conformation.

A bound ligand induces a given conformation of hSERT and ibogaine, a hallucinogenic alkaloid, binds to hSERT and stabilizes an inward-facing conformation of hSERT. The interplay between ligand binding, substrate transport, and hSERT conformation is not fully understood.

We have analyzed binding characteristics of structural intermediates of serotonin and ibogaine by functional assays. The ibogaine analogues were characterized for their effect on inhibition of serotonin transport by hSERT 
and conformational changes in hSERT

We here map structural elements in the ibogaine/noribogaine structure responsible for inhibition of uptake and conformational changes in hSERT.

P29.01 Anders Raouf DORZOLAMIDE-INDUCED RELAXATION OF PORCINE RETINAL ARTERIOLES El-Galaly IN VITRO DEPENDS ON NO RELEASED FROM THE PERIVASCULAR RETINA

A. Galaly', M. Misfeldt ${ }^{7}$, S. Kringelholt ${ }^{7}$, C. Aalkjaer ${ }^{2}$, T. Bek ${ }^{7}$

${ }^{1}$ Department of Ophthalmology, Aarhus University Hospital, ${ }^{2}$ Department of Biomedicine, Aarhus University

Purpose: To study the involvement of nitric oxide (NO) in relaxation-induced by carbonic anhydrase inhibitors in porcine retinal arterioles in vitro.

Materials and methods: Porcine retinal arterioles with preserved perivascular tissue were mounted on a wire-myograph. After precontraction with the thomboxane analogue $U 46619$, the tone response after addition of the carbonic anhydrase inhibitor dorzolamide in increasing concentrations from $10^{-7}$ to $10^{-3} \mathrm{M}$ was tested, followed by removal of the perivascular retinal tissue and repetition of the concentration-response experiment. The experiments were repeated in the presence of the NO-synthase inhibitor LNAME or the guanylyl cyclase inhibitor ODQ.

Result: Dorzolamide induced a significant concentration-dependent relaxation of porcine retinal arterioles, both in the presence and absence of perivascular retinal tissue ( $p<0.0001$ for both comparisons). Both L-NAME and $O D Q$ significantly reduced dorzolamide-induced relaxation in the presence of perivascular retinal tissue ( $p<0.05$ for both comparisons).

Conclusion: The vasorelaxing effect of dorzolamide in porcine retinal arterioles depends on $\mathrm{NO}$ released from the perivascular retinal tissue.

P29.02 Safa Talib AI THE EFFECTS OF VASOPRESSIN ANTAGONISM ON RENAL SODIUM AND Therwani WATER HANDLING AND THE CIRCULATION DURING INHIBITION OF THE NITRIC OXIDE SYSTEM IN HEALTHY SUBJECTS

\section{S. Therwani, J. Majgaard Jensen, F.H. Mose, J. Bech, E.B. Pedersen}

Departments of Medical Research and Medicine, Holstebro Hospital and Aarhus University

Background: Tolvaptan is a selective V2 receptor (V2R) antagonist and is used in treatment of hyponatremia. Previous animal studies suggest that selective inhibition of $\mathrm{V} 2$ receptors increases free water clearance and sodium excretion. $V 2 \mathrm{R}$ antagonism increases plasma vasopressin (AVP). AVP may stimulate vascular $V 1$ receptors, which cause vasoconstriction. This may change central and periphery hemodynamics, including vasoactive hormones and secondary renal absorption of sodium and water. Nitric Oxide (NO) is a potent vasodilator. In the kidney NO promotes naturesis and diuresis. Whether $\mathrm{NO}$ is involved in the response of $\mathrm{V} 2 \mathrm{R}$ antagonism in the renal and vascular system is unclear.

Purpose: The purpose of this study is to examine the effect of V2R antagonism on NO inhibition in the renal and vascular system.

Method: 20 healthy subjects are enrolled in this randomized, cross-over, placebo-controlled, double-blinded trial with two examinations, placebo or $15 \mathrm{mg}$ tolvaptan. Four days prior to each examination, subjects are given a standardized diet. L-NMMA (a nitric oxide synthase inhibitor) is given and renal function (GFR, free water clearance), excretion of proteins from tubular water and sodium channels (U-AQP2 water and epithelial sodium channels), plasma concentration of vasoactive hormones (renin, ang.ll, aldosterone, AVP, ANP, BNP and endothelin-I), central hemodynamic and pulse wave velocity are measured before, during and after inhibition of nitric oxide synthesis. 
P29.03 Sheyanth IMPORTANCE OF CHLORIDE FOR THORACIC DUCT CONTRACTILITY AND Mohanakumar SPONTANEOUS CONTRACTIONS

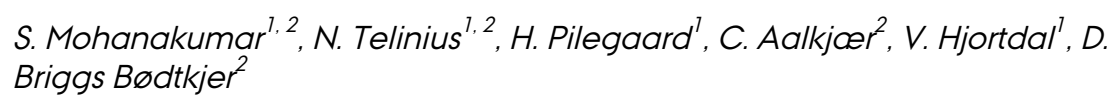

'Cardiothoracic Research Department T, Aarhus University Hospital,

${ }^{2}$ Department of Biomedicine, Aarhus University

Introduction: The lymphatic vasculature is a vast vascular network that regulates the tissue fluid balance. Excessive fluid is pumped away by the vessels as the smooth muscle cells in the vessel wall generate spontaneous contractions. Dysfunction of this delicate system causes oedema. The importance of chloride $\left(\mathrm{Cl}^{\prime}\right)$ for lymphatic vessel contractility has not been well investigated in animal models, and we have no knowledge of the importance of $\mathrm{Cl}^{-}$for the human thoracic duct.

Aim: To establish whether chloride plays a role in spontaneous and agonistinduced contractions in rat and human thoracic duct.

Material and methods: Thoracic ducts were harvested during oesophageal cancer surgery. Thoracic ducts from rats were free dissected and harvested immediately after sacrifice. Ring segments of the vessels were mounted in a wire myograph for isometric force measurements. Vessels generating phasic contractions were incubated a Physiological Saline Solution with $\mathrm{Cl}^{-}$ substituted with aspartate ( $\mathrm{Cl}^{-}$-free PSS) A cumulative concentration response curve to noradrenaline ( $1 \mathrm{nM}-10 \mu \mathrm{M}$, half logarithmic steps) were performed in normal PSS and $\mathrm{Cl}^{-}$-free PSS.

Results: Comparing the max contraction $(3 \mu \mathrm{M})$ of the human duct induced by noradrenaline showed a significant difference between vessel when incubated in PSS and $\mathrm{Cl}^{-}$free PSS $(p<0.005, n=7)$. The ducts showed almost no contractions in $\mathrm{Cl}^{-}$free PSS. Changing from PSS to $\mathrm{Cl}^{-}$-free PSS lead to full inhibition of phasic contractions in 6 out of 6 patients $(p<0.05)$ and 7 out of 7 rats $(p<0.05)$.

Conclusion: $\mathrm{Cl}^{-}$is essential for generation of spontaneous and agonist induced contractions in both human and rat thoracic ducts.

P29.04 Nichlas Riise ISCHEMIC PRECONDITIONING AND INHIBITION OF THE MALATE-

Jespersen ASPARTATE SHUTTLE PRESERVES MITOCHONDRIAL RESPIRATION AND DECREASES ROS PRODUCTION IN THE ISOLATED RAT HEART

N.R. Jespersen ', T. Yokota ${ }^{2}$, N.B. Støttrup ${ }^{7}$, F. Dela' ${ }^{2}$, H.E. Bøtker ${ }^{1}$

'Department of Cardiology, Aarhus University Hospital Skejby, ${ }^{2}$ Department of Biomedical Sciences, Panum Institute, Copenhagen

Introduction: Protection against ischemic reperfusion injury is dependent on preserved mitochondrial function and attenuation of reactive oxygen species. The malate-aspartate shuttle (MAS) may constitute a site for regulation of mitochondrial respiration and ROS production.

Hypothesis: We hypothesize that MAS activity modulates mitochondrial respiration and ROS production, in a similar manner as ischemic preconditioning (IPC), in the post-ischemic reperfused heart.

Methods: Isolated rat hearts were exposed to $30 \mathrm{~min}$ of global no-flow ischemia followed by $30 \mathrm{~min}$ of reperfusion. Hearts were randomised into: control ( $n=8), \operatorname{IPC}(n=8)$ and pre-ischemic aminooxyacetate (AOA) $(0.2 \mathrm{mM}$, $\mathrm{n}=8$ ) and perfused with a modified $\mathrm{KH}$-buffer containing $3 \%$ bovine serum albumin and either glucose $(11 \mathrm{mM})$ or glucose $(11 \mathrm{mM})+$ free fatty acids (palmitat: $0.4 \mathrm{mM}$ ). Following reperfusion, the left ventricle was rapidly 
cooled. Cardiac fibers were isolated and permeabilized for measurement of mitochondrial respiration and ROS production by high-resolution respirometry and fluorospectrometry.

Results: AOA and IPC significantly increased mitochondrial respiration compared to control. Mitochondrial ROS production normalized to $\mathrm{O}_{2}$ consumption was significantly attenuated in AOA and IPC vs control. Longchain fatty acids as additional substrate showed similar results as glucose perfused hearts.

Conclusion: Pre-ischemic MAS inhibition and IPC modulates mitochondrial respiration comparably during reperfusion independent of substrate availability. Pre-ischemic MAS inhibition decreases ROS production during reperfusion and may be an inherent part of the mechanism behind cardioprotection by IPC.

PTLD AFTER KIDNEY TRANSPLANTATION IN WESTERN DENMARK AND EBV STATUS

E.F. Sørensen' ', B. Jespersen' , S. Hamilton-Dutoit' ${ }^{2}$, F. d'Amore ${ }^{3}$, M. Vase ${ }^{3}$

${ }^{1}$ Department of Nephrology, Aarhus University Hospital, ${ }^{2}$ Institute of Pathology, Aarhus University Hospital, ${ }^{3}$ Department of Haematology, Aarhus University Hospital

Aim: The aim of the project is to make a full registration of Post-Transplant Lymphoproliferative Disorder (PTLD) cases occurring after kidney transplantation in West Denmark from 1990 to 2011 and in available PTLD tissues to look for the presence of EBV.

Background: PTLD are lymphoid or plasmacytic proliferations that develop as a result of immunosuppression after transplantation. It comprises a spectrum of lesions from infectious mononucleosis-like proliferations to progressive malign lymphoma, indistinguishable from lymphoma seen in immunocompetent individuals. PTLD can occur in all organs including the graft. In 1990-201 1, 2175 kidney transplantations were performed at Aarhus University Hospital, Skejby and Odense University Hospital. Approximately 50 cases are expected to be found in that period.

Methods: The PTLD cases will be identified by comparing the kidney transplantation register from Aarhus and Odense with a widely search in Patobank. The patients will be classified according to the WHO-

classification if any PTLD-like lesions are found in their tissue. In addition to a record of pathological data, the register will include clinical and paraclinical data. Formalin-fixed, paraffin-embedded biopsy specimens will be obtained from the archives of the participating departments of pathology. Tissue microarrays will be constructed and analyzed for EBV using immunohistochemistry and in situ hybridization.

Statistics: The presence of the factors included in the register will be compared with the presence of similar factors in control tissue from kidney transplanted patients without PTLD by using the Chi-square test and Coxregression model.

P29.06 Britt Borg BEWARE THE SLEEPING BLADDER IN MONOSYMPTOMATIC NOCTURNAL ENURESIS

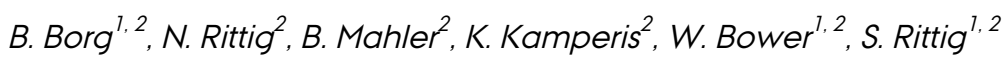

'Department of Clinical Medicine, Aarhus University, ${ }^{2}$ Centre of Child Incontinence, Pediatric department, Aarhus University Hospital

Introduction: Bladder reservoir function in children with nocturnal enuresis is assessed by maximal voided volumes (MVV) registered on frequencyvolume charts. Although a degree of association is evident, MVV does not always reflect nocturnal bladder reservoir function in MNE. We aimed to evaluate nocturnal bladder reservoir function during the night in children 
with apparently normal MVV.

Material and methods: Data from 557 children aged 5-15 treated for MNE in a tertiary referral centre were analyzed. Data from 135 children were excluded due to reduced MVV according to ICCS standardization and 156 due to lack of home recordings. The remaining 266 were divided into two groups based on whether MVV was above $(n=91)$ or below $(n=175)$ the average nocturnal urine production during wet nights (NUPw). First morning voids were not eligible as MVV

Results: $34 \%$ of the children with MNE and a normal bladder capacity had an average nocturnal urine production during wet nights below their MVV. one third of these had NUPw below $65 \%$ of MVV expected for age. These children did not differ significantly in terms of demographic characteristics, frequency of wet nights or treatment time needed to achieve dryness. Urine output during wet nights was lower in the group of children with MVV $>N U P w$ (diff: $96.45 \mathrm{~mL}, \mathrm{p}<0.05$ ).<br / > Conclusions: Children with MNE and apparently normal bladder reservoir function during daytime may experience wet nights with urine volumes well below their MVV and MVV expected for age. The fact indicates bladder reservoir function abnormalities during sleep that are not assessed by day recordings. Physicians treating children with MNE should consider combination treatment.

P29.07 Anne Yoon DUAL INVERSION RECOVERY MAGNETIC RESONANCE IMAGING FOR MORE Krogh Grøndal ACCURATE MYOCARDIAL INFARCT SIZE DETERMINATION: A Hansen HISTOLOGICAL VALIDATION STUDY

A.K. Grøndal', 2 , S.A. Peel', L.Ø. Bloch², E.S. Søvsø', S.F. Pedersen' ', J.L. Hønge', R. Botnar ${ }^{3}$, W.Y. Kim ${ }^{4}$, W.P. Paaske

${ }^{1}$ Department of Cardiothoracic and Vascular Surgery, ${ }^{2} \mathrm{MR}$ Research Centre, Aarhus University Hospital Skejby, ${ }^{3}$ Division of Imaging Sciences and Biomedical Engineering, King's College London, London, England, ${ }^{4}$ Dept. of Cardiology, Aarhus University Hospital Skejby

Background: Inversion-recovery (IR) magnetic resonance imaging (MR) is today's standard reference for myocardial infarction evaluation. However, Peel et al. found in 2012 that a dual IR prepulse outperformed conventional IR in infarct visualization, scar-to-blood contrast and expert consistency, but this novel technique has not been histologically validated.

Aim: This study sought to compare dual IR and conventional IR sequences with histological findings in an animal model of reperfused acute myocardial infarction.

Method: Ischaemia-reperfusion injury was induced in nine pigs by $40-$ minute balloon occlusion in LAD followed by reperfusion. One day postinjury, MR was performed using conventional IR and dual IR sequences at 1.5 T. After this, the pigs were euthanized. Their hearts were explanted, axially cut and incubated in a 2,3,5-triphenyltetrazolium chloride (TTC) solution. MR images were matched to the corresponding histopathology and the infarct sizes were compared.

Results: Nine pigs underwent balloon occlusion. Two were excluded due to ECG-triggering problems. Five out of the remaining seven pigs showed myocardial infarction after TTC staining. Both dual IR and conventional IR confirmed infarctions in all five pigs. Short-axis dual IR images show improved blood suppression compared with IR images and show good correlation with TTC images. In Bland-Altman analysis, scar size measurements made on dual IR images had better correlation with histology compared with the IR images.

Conclusion: In this experimental study, the dual IR prepulse resulted in more accurate myocardial infarct size determination compared with 
conventional IR sequence owing to better blood suppression.

Nielsen

PATIENT-REPORTED HEALTH STATUS AND RISK OF NEW CARDIOVASCULAR EVENTS IN PATIENTS WITH FIRST-TIME MYOCARDIAL INFARCTION

\section{T.J. Nielsen, K.K. Larsen, B. Christensen, M. Vestergaard}

Section for General Medical Practice, Department of Public Health, Aarhus University

Background: Myocardial infarction (MI) is a severe life event and affects several aspects of mental health negatively. Depression and anxiety increase the risk of adverse outcomes in patients with myocardial infarction (MI). Whether mental health status (MHS) is associated with adverse outcomes is unclear. We examined the association between MHS and new cardiovascular events or death in post-MI patients, taking into account depression, anxiety, cardiac disease severity, and potential behavioural mediators.

Materials and methods: We conducted a cohort study of patients with firsttime Ml between 1 January and 30 December 2009 and living in the Central Denmark Region, All patients were followed-up until 31 July 2012. MHS was assessed 3 months after the Ml using the Mental Component Summary (MCS) score of the Short-Form 12. The association between MCS score and subsequent cardiovascular events (Ml, heart failure, stroke/transient cerebral ischaemic attack) or death was examined using proportional hazard models, comparing the lower quartiles with the highest quartile ( $4^{\text {th }}$ quartile).

Results: Among a total of 1,288 eligible patients, 880 (68\%) completed a questionnaire. A total of 277 outcomes occurred during 1,940 person years of follow-up (median (SD) 2.6 (1.0) years). The risk of a new cardiovascular event or death increased with descending MCS score (hazard ratio $(\mathrm{HR})_{3 \mathrm{rd}}$ quartile, $1.40 ; 95 \% \mathrm{Cl}, 0.96-2.04, \mathrm{HR}_{2 \text { nd quartile, }} 1.60 ; 95 \% \mathrm{Cl}, 1.10-2.31, \mathrm{HR}_{1 \text { st quartile }}$, $2.40 ; 95 \% \mathrm{Cl}, 1.69-3.40)$. The association was attenuated when sequentially adjusted for depression and anxiety $\left(\mathrm{HR}_{1 \text { st quartile, }} 1.90 ; 95 \% \mathrm{Cl}, 1.26-2.88\right)$ and cardiac disease severity $\left(\mathrm{HR}_{1 \text { st quartile, }} 1.55 ; 95 \% \mathrm{Cl} 1.01-2.38\right)$, but remained statistically significant.

Conclusion: Poor MHS following $\mathrm{Ml}$ is associated with adverse prognosis, also after adjustments for depression and anxiety.

P29.09 Mette Ji RiisSPONTANEOUS RELAXATION OF PORCINE RETINAL ARTERIOLES IN VITRO Vestergaard IS CAUSED BYADENOSINE

M.J. Riis-Vestergaard' , M. Misfeldt' ${ }^{\prime}$ J. Leipziger' ${ }^{2}$, T. Bek $^{7}$

${ }^{1}$ Department of Ophthalmology, Aarhus University Hospital, ${ }^{2}$ Department of Biomedicine, Faculty of Health, Aarhus University

Background: Disturbances in the regulation of the retinal arteriolar tone are involved in the pathogenesis of vision-threatening diseases such as diabetic retinopathy, which may involve an effect of purines such as adenosine. Previous in vitro studies have shown a spontaneous relaxation of retinal arterioles with preserved perivascular retinal tissue over time. The purpose of the present study was to investigate whether adenosine contributes to this relaxing effect.

Methods: Porcine retinal arterioles with preserved perivascular retinal tissue were mounted in a wire myograph for isometric tone measurement. After pre-contraction, concentration-response experiments were performed with adenosine or none (time controls) and followed by removal of the perivascular tissue and repetition of the procedure. The experiments were repeated in the presence of the adenosine receptor antagonist 8-PSPT.

Results: In the presence of the perivascular retinal tissue, the arterioles showed spontaneous relaxation over time $(p<0.05)$, which disappeared 
after removal of the perivascular tissue. The addition of adenosine induced a concentration-dependent relaxation of retinal arterioles, independent of the presence of perivascular retinal tissue $(p<0.05)$. Both the spontaneous relaxation over time and the relaxation induced by adenosine could be significantly inhibited by 8 -PSPT ( $p<0.05$ for both comparisons).

Conclusion: Porcine retinal arterioles mounted in vitro are relaxed by adenosine released from perivascular retinal tissue. This should be considered in the interpretation of results from pharmacological studies of tone regulation of retinal arterioles.

P30.01 Louise Rottbøll EXPLORING VALRUBICIN'S POTENTIAL ROLE IN TREATING ACNE Poulsen

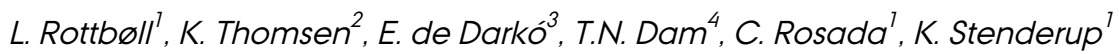

'Department of Dermatology, Aarhus University Hospital, Aarhus, Denmark, ${ }^{2}$ Department of Biomedicine, Aarhus University, Aarhus, Denmark, ${ }^{3}$ Valderm ApS, Lyngby, Denmark, ${ }^{4}$ Department of Dermatology, Roskilde Hospital, Roskilde, Denmark

Valrubicin is an anthracycline showing no toxicity upon skin contact compared to other anthracyclines. Currently, it is approved as Valstar ${ }^{\circledR}$ for the treatment of bladder cancer. In mouse models, we have demonstrated that topical application of valrubicin inhibits keratinocyte hyperproliferation in psoriatic skin, development of skin tumors and skin inflammation in contact dermatitis. In these skin diseases, hyperproliferation and inflammation are common traits. Acne vulgaris is the most common skin disorder. Development of the acne lesions includes hyperproliferation of the ductal keratinocytes and inflammation caused by P. acnes. Thus, topical valrubicin treatment may ameliorate acne.

The aim of the present study is to investigate valrubicin's potential to treat acne by investigating its anti-bacterial and anti-inflammatory effects in vitro and in vivo.

In vitro, the anti-bacterial effect of different valrubicin formulations was tested on P. acnes strains. Valrubicin was shown to lack anti-bacterial effect. However, the mRNA expression levels of the inflammatory cytokines IL $1 \beta$, IL8, and TNFa, which play important roles in acne, were significantly reduced in TPA stimulated HaCaT cells treated with valrubicin. Importantly, P. acnes was observed to induce these cytokines in HaCaT cells. In vivo, we employed the mouse model of P. acnes induced inflammation. Neither topical nor intra-dermal valrubicin treatment reduced the inflammation in our 15 days and 9 days studies, respectively.

In conclusion, valrubicin did not demonstrate an anti-bacterial effect, but showed anti-inflammatory effects in vitro and did not reduce $P$. acnes induced inflammation in vivo.

P30.02 Jannie Sørensen HEREDITARY HYPERHOMOCYSTEINEMIA - AN UNDERESTIMATED DISEASE? J. Sørensen', M. Gaustadnes' ${ }^{2}$, S.P. Stabler ${ }^{3}$, H.S. Mudd ${ }^{4}$, A.M. Hvas ${ }^{7}$

${ }^{1}$ Department of Clinical Biochemistry, Aarhus University Hospital, ${ }^{2}$ Department of Molecular Medicine, Aarhus University Hospital, ${ }^{3}$ Division of hematology, University of Colorado, USA, ${ }^{4}$ Laboratory of Molecular Biology, $\mathrm{NIH}$, Bethesda, USA

Background: Patients with severe hyperhomocysteinemia $(\mathrm{HHC})$ due to cystathionine B-synthase (CBS) deficiency are at high risk of developing retardation, ectopia lentis and thromboembolic events in early age. The prevalence of CBS deficiency is reported to be 1:58,000-1:1,000,000, depending on country. A study of the most common CBS mutation, c.833T>C, among 500 Danish newborns showed a surprisingly high prevalence at $1.4 \%$, corresponding to an incidence of predicted homozygosity at $1: 20,400$. 
Aims: To test the hypothesis that mutation prevalence in the CBS gene is underestimated in patients with severe HHC.To investigate the association between genotype and phenotype in patients with severe $\mathrm{HHC}$

Methods: Patients with plasma homocysteine (tHcy) $>50 \mathrm{mmol} / \mathrm{L}$ determined from 1998 to 2011 were identified in the laboratory database at the Department of Clinical Biochemistry, AUH. Blood tests and interviews on clinical symptoms were obtained. We measured P-cobalamins, P-folate, Pcreatinine, B-hemoglobin, B-erythrocyte mean cell volume. tHcy, cystathionine, cysteine, methionine, dimethylglycine, serine, glycine, methylcitrate and methylmalonate were determined by using a stable isotope dilution GC/MS. All patients were tested for $\mathrm{c} .833 \mathrm{~T}>\mathrm{C}$ mutation. For those with initial tHcy level $\geq 100 \mathrm{mmol} / \mathrm{L}$ and not homozygote for $\mathrm{C} .833 \mathrm{~T}>\mathrm{C}$, we performed a complete screening of the other 14 CBS exons using specific primers, direct sequencing or High Resolution Melting Analysis.

Results: From 1998 to 201 1, 644 patients had tHcy $>50$ mmol/L determined. Of these, $413(64 \%)$ patients were still alive, 178 patients agreed to participate and 32 of these were initially found to have a tHcy $>100$.

\section{LOW-GRADE INFLAMMATION AND HAEMOGLOBIN LEVELS IN DANISH BLOOD DONORS}

S.R. Kotze', C. Erikstrup ', O.B. Pedersen², K. Grau ${ }^{3}$, M.S. Petersen ', M. Christiansen', E. Sørensen $^{4}$, H. Ullum ${ }^{4}$

'Department of Clinical Immunlogy, Aarhus University Hospital, ${ }^{2}$ Department of Clinical Immunlogy, Nœstved Sygehus, ${ }^{3}$ Statens Serum Institut,

${ }^{4}$ Department of Clinical Immunlogy, Rigshospitalet

Background: Inflammation is associated with anaemia of chronic disease. However, possible associations between low-grade inflammation (slightly elevated inflammation) and anaemia have not been investigated. Creactive protein (CRP) is a general marker of inflammation and it is possible to accurately measure very low levels of CRP, so-called high-sensitivity CRP (hsCRP), and thus assess low-grade inflammation in healthy individuals.

Aims: To test whether hsCRP is associated with haemoglobin levels in healthy individuals.

Methods: The Danish Blood Donor Study (DBDS) is a large, populationbased study and biobank, currently with over 48,000 participating blood donors. Participating blood donors grant permission for routine blood samples to be used for research and fill out a questionnaire providing information such as anthropometric measurements, lifestyle factors and smoking habits. hsCRP levels were measured, and questionnaire data collected from 13,660 donors.

Results: Donors with elevated hsCRP ( $>3 \mathrm{mg} / \mathrm{l}$ ) comprised $16.1 \%$ of women and $6.5 \%$ of men. Multivariable logistic regression analysis adjusted for age, region, body mass index, exercise and frequency of donation during the year before inclusion, showed hsCRP>3 mg/I to be associated with a higher risk of having low haemoglobin levels (below the $10^{\text {th }}$ percentile) among current non-smoking women (odds ratio (OR): 1.64; $95 \%$ confidence interval (CI): 1.34-2.02), but not in non-smoking men (OR: 1.19; 95\% Cl: 0.85-1.66).

Conclusions: Our results indicate that low-grade inflammation does affect iron metabolism and thus, haemoglobin levels in blood donors.

P30.04 Nikolaj Gehr IMMUNOREGULATORY MECHANISMS IN B CELLS FROM MS PATIENTS N. Gehr' ${ }^{7}$ C.W. Tørring ${ }^{1,2,3}$, T. Petersen ${ }^{2}$, P. Höllsberg ${ }^{1,3}$

'Department of Biomedicine, Aarhus University, Aarhus, Denmark,

${ }^{2}$ Department of Neurology, Aarhus University Hospital, Aarhus, Denmark,

${ }^{3}$ Danish Neuroscience Center, Aarhus University Hospital, Aarhus, Denmark 
Background: Multiple sclerosis (MS) is a chronic inflammatory disease of the central nervous system. Treatment studies in MS patients with monoclonal antibodies against CD20 have shown beneficial effects. Ocrelizumab, a CD20 antibody, reduces the number of B cells with $99.8 \%$, and leads to significant reductions in "gadolinium-enhanced lesions" on MRI and in the number of clinical relapses. This indicates that B cells play a major role in the pathogenesis of MS. The notion that abnormalities in B-cell cytokines may contribute to pathologic states raises the intriguing corollary that B-cell cytokines could play important roles in the regulation of normal immune responses. Relatively little is known, however, about how B cell cytokines may contribute to human autoimmune disease.

Hypothesis: We hypothesize that B cells play a central role in the immunopathology of MS, not only as antibody producing cells, but also as antigen-presenting and cytokine-producing cells. We speculate that MS patients have an increased production of proinflammatory cytokines, but decreased production of suppressive cytokines.

Aim and methods: We will test our hypothesis by measuring B-cell cytokines with immunosuppressive and proinflammatory function in MS patients and controls. B cells from MS patients and matched controls are stimulated via their CD40 and B-cell receptors and the production of IL-6 (proinflammatory) versus IL-10, and the recently described IL-35 is examined by using ELISA tests.

Discussion: Examining the function of B cells in MS patients may provide a better understanding of the pathogenesis of the disease and may suggest novel targets of specific therapies.

P30.05 Julie Kristine OX40 AND OX40L IN REHUMATOID ARTHRITIS

Laustsen

\section{J.K. Laustsen}

Medical biomedicine

Background: OX40 and OX40L is mainly expressed by activated T cells and APCs, respectively, and exist in both soluble and membrane bound forms. The OX40 and OX40L interaction has been suggested to play a pivotal role in the development of autoimmune diseases, as it suppresses apoptosis in the $T$ cell, generates memory $T$ cells and induces proinflammatory cytokines. OX40 and OX40L exist

Objectives: To investigate the presence of OX40 and OX40L and their correlation with disease activity and progression in rheumatoid arthritis (RA).

Methods: A longitudinal sample set of newly diagnosed RA patients $(n=78)$ was provided by the OPERA biobank. For comparison plasma samples from healthy volunteers (HV) were collected $(n=38)$. By using ELISA, the plasma levels of soluble OX40 and OX40L were measured at 0 and 3 months, and investigated for correlation. Furthermore, the cellular expression of OX40 and OX40L was investigated by flow cytometry.

Results: The collection of data is still ongoing. The sOX40 level was not increased in RA patients at 0 months compared to HV. However, a correlation between sOX40 and swollen joints was observed. SOX40L was increased in RA patients at 0 months compared to $\mathrm{HV}$. The $\mathrm{SOX} 40$ and sOX4OL levels correlated $(p=0,0037)$

Conclusions (preliminary): We observed that the sOX40 and sOX40L levels correlated, and also we found increased levels of sOX4OL in RA patients. Further, sOX40 levels correlated with swollen joints. This supports that the OX40/OX40L ligation could play a role in RA. 

TISSUE AND THE DEVELOPMENT OF INSULIN RESISTANCE AND TYPE 2 DIABETES

\author{
S.B. Grønbcek' ', R. Pold' , B.C. Rolin ${ }^{2}$, T.B. Bödvarsdóttir ', S. Lund'
}

${ }^{1}$ Medical Research Laboratories, Department of Clinical Medicine, Aarhus University, ${ }^{2}$ Diabetes \& Obesity Pharmacology, Novo Nordisk A/S, Måløv

Background: T2D is characterized by insulin resistance in the peripheral tissues. The GLUT4-glucose transporter is the rate-limiting step in insulin stimulated glucose uptake. The GLUT4 amount in adipose tissue is markedly decreased in the insulin resistant state, while the total GLUT4 content in skeletal muscle is unchanged. Adipose specific GLUT4 knockout mice show a decreased insulin stimulated glucose uptake in their muscle tissue despite a normal amount of GLUT4. This suggests that adipose tissue plays a role in the development of insulin resistance in muscle tissue.

A new animal model, Psammomys obesus (Israeli sand rat), develops insulin resistance in muscle tissue when fed a high calorie diet. At the same time, GLUT4 disappears in adipose tissue. This animal model might therefore be used to elucidate the molecular mechanism behind the change in GLUT4 expression in adipose tissue and the development of peripheral insulin resistance. This may provide new and important knowledge about the pathogenesis of insulin resistance.

Materials and methods: Insulin resistance will be measured with the hyperinsulinemic-euglycemic clamp technique. Westernblotting and qPCR will be used for measurement of GLUT4 expression and different regulatory proteins.

Results: Preliminary results have confirmed that $\mathrm{P}$. obesus is insulin resistant in muscles, and this is associated with a decreased GLUT4 content in adipose tissue.

Conclusion: P. obesus might be a promising new animal model for examining the molecular mechanism behind the development of insulin resistance.

\footnotetext{
P30.07 Mette Hansen PRENATAL DIAGNOSIS OG SEX CHROMOSOME ABNORMALITIES Viuff

M.H. Viuff ${ }^{7}$, K. Stockholm ${ }^{\prime}$, B.B. Nielsen ${ }^{2}$, C.H. Gravholt ${ }^{1}$

'Department of Internal Medicine and Endocrinology, Aarhus University Hospital, ${ }^{2}$ Department of Gynecology and Obstetrics, Aarhus University Hospital

Background and objective: Sex Chromosome abnormalities (SCAs) involve numerical abnormalities of the $X$ or $Y$ chromosome. The most common are 47,XXY (Klinefelter syndrome) 45,X (Turner Syndrome), but SCAs consist of a wide range of numerical combinations. At birth, approximately $1 / 400$ newborns have SCAs, making it approximately twice as frequent as Down's syndrome (DS). Studies have also shown that the prevalence and incidence of SCAs is highly underestimated.In 2004-2006 a new screening procedure of pregnant women was implemented in Denmark. It's a combined risk assessment based on maternal age, nuchal translucency, serum free $\beta-h C G$ and pregnancy associated plasma protein. This method has shown to be a useful indicator of pregnancies with DS, but also a number of SCAs has been revealed using the screening. Our purpose is to investigate the prevalence and incidence of SCAs; furthermore we wish to identify other risk markers that can be used in the prediction of pregnancies with SCAs, to increase and improve our knowledge concerning prenatal diagnosis.
} 
P30.08 Lars Markvardsen
Methods: All post- and prenatal detected SCAs and DS karyotypes from Jan $1^{\text {st }} 2008$ to Dec. $31^{\text {st }} 2011$ are retrieved from the Danish Central Cytogenetic Register. The identities are used to access information regarding maternal age, ultrasonic findings and biomarker samples from the Foeto-database. Matched controls will be identified from the background population to analyze the significant predictors of a SCA pregnancy.

Hypothesis: It is possible to use the same predictors regarding SCAs that we use on DS today. Furthermore we can identify new ultrasonic and biochemical markers useful in improving prenatal diagnosis.

RANDOMIZED, DOUBLE-BLIND, PLACEBO-CONTROLLED TRIAL OF THE

EFFECT OF SUBCUTANEOUS IMMUNOGLOBULIN ON MUSCULAR PERFORMANCE IN CHRONIC INFLAMMATORY DEMYELINATING POLYNEUROPATHY

L.H. Markvardsen', J.C. Debost', T. Harbo', S. Sindrup ${ }^{2}$, H. Andersen' , I. Christiansen ${ }^{3}$, M. Otto ${ }^{4}$, N.K. Olsen ${ }^{5}$, L.L. Lassen ${ }^{6}$, J. Jakobsen ${ }^{7,3}$

'Department of Neurology, Aarhus University Hospital, ${ }^{2}$ Department of Neurology, Odense University Hospital, ${ }^{3}$ Department of Neurology, Rigshospitalet, ${ }^{4}$ Department of Neurophysiology, Aarhus University Hospital, ${ }^{5}$ Department of Neurology, Aalborg Hospital, ${ }^{6}$ Department of Neurology, Glostrup Hospital

Aims: We hypothesized that subcutaneous administration of immunoglobulins (SCIG) in chronic inflammatory demyelinating polyneuropathy (CIDP) is feasible, safe and superior to treatment with saline for the performance of muscle strength.

Design and patients: Patients (aged 18-80) with motor involvement in maintenance therapy with intravenous immunoglobulin (IVIG) full-filling the EFNS/PNS criteria for CIDP were randomized either to SCIG at a dose determined from their pre-study IVIG dose or to subcutaneous saline given twice or thrice weekly for 12 weeks at home.

Methods: At start and end of the trial as well as two weeks before $(-2,0,10$, $12 \mathrm{wks}$ ), isokinetic strength performance of four predetermined and weakened muscle groups was assessed. Also, data from a 40-meter walking test, the Overall Disability Sum Score (ODSS), 9-Hole Peg Test, Neurological Impairment Score (NIS), Medical Research Council (MRC) score and grip strength test, standardized electrophysiological recordings from three nerves and plasma lgG levels were obtained.

Results: SCIG treatment was well tolerated in all 15 patients for 12 weeks. Six patients complained of mild side-effects at the injection site. In the SCIG group, there was an increase in isokinetic muscle strength of $5.5+9.5 \%$ $(p<0.05)$ as compared to a decline of $14.4+20.3 \%(p<0.05)$ in the placebo group; the difference between the two groups being significant $(P<0.01)$. ODSS, NIS, MRC, grip strength and a 40-meter walking test improved following $\mathrm{SCIG}$ versus saline treatment.

Conclusion: Subcutaneous administration of immunoglobulins in CIDP is feasible, safe and effective and seems an attractive alternative to IVIG therapy.

P31.01 Lotte Vinther MICROBIOLOGICAL SPECTRUM AND SUSCEPTIBILITY PATTERNS OF Christensen BACTERIA CAUSING BLOODSTREAM INFECTION IN PAEDIATRIC ONCOLOGY PATIENTS

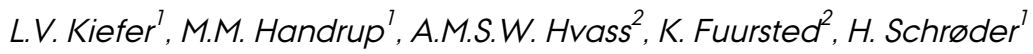

'Department of Paediatrics, Aarhus University Hospital Skejby, Denmark, ${ }^{2}$ Department of Medical Microbiology, Aarhus University Hospital Skejby, Denmark 
The treatment of most childhood cancers is very intensive. Due to the intensive chemotherapy, the children become very susceptible to infections. Bacteremia is an important cause of death among childhood cancer patients. The purpose of this study was to describe the epidemiology of bacteremia among children with cancer. We conducted a retrospective data collection of all patients registered at the paediatric department of haematology and oncology at Aarhus University Hospital from 2000 to 2012.

A total of 509 patients were registered with cancer. The study included 562 episodes of which 82 were polymicrobial and 20 fungemia.

Of the 660 microorganisms that were isolated, 317 (48\%) were grampositive bacteria, $323(49 \%)$ were gram-negative bacteria and $20(3 \%)$ were fungi. All patients had an indwelling central venous catheter (CVC) and a total of 198,299 CVC days were registered. The incidence rate (IR) of bacteremia was $2.8 / 1000$ CVC days; children with haematological malignancies had a higher rate ( $\mathrm{R}=3.5 / 1,000 \mathrm{CVC}$ days) compared with children with solid tumors ( $I R=1.9 / 1,000$ CVC-days) $(P<0.0001)$.

Susceptibility to empiric first-line antibiotic treatment (gentamycin + piperacillin-tazobactam) was $82 \%$ and $97 \%$ if only the most pathogenic bacteria were evaluated. The overall mortality was 18.5\% (95/509) and infection-related death occurred in 12 children.

Gentamycin and piperacillin-tazobactam, as first line therapy, give a sufficient antibacterial coverage in children with cancer. Continued surveillance of infections should guide future empiric antibiotic treatment.

CHARACTERIZATION OF FUNCTIONAL MOTIFS WITHIN THE HERPESVIRAL DR6 PROTEIN

\section{S. Hoberg, M.H. Schleimann, P. Höllsberg}

Department of Biomedicine, Aarhus University

Human herpesvirus-6B (HHV-6B) infects more than $95 \%$ of children in the Western world within the first three years of life. Primary infection is known as the childhood disease exanthem subitum. While this disease is harmless, $\mathrm{HHV}-6 \mathrm{~B}$ causes a latent infection and may later reactivate, in particular during conditions of immunosuppression. The human herpesvirus-6B encoded protein DR6 is known to be a trans-activator and localizes within the nucleus. We have previously shown that during human herpesvirus-6B infection DR6 is recruited to compartments, in which the virus is believed to replicate. Furthermore, we have shown that the protein is able to suppress cell proliferation when overexpressed alone.

Since DR6 is localized in close proximity to the DNA processivity factor $\mathrm{p} 41$, our hypothesis is that DR6 takes part in viral replication.

To further understand the mechanism of action of this protein, we are cloning several truncated versions of the DR6 full-length protein. The different truncated protein products are going to be overexpressed in the FIp In T-rex HEK system, which comprises an inducible tet-on system. Due to the tet-on mechanism, it is possible to control the expression and study the effects of the different proteins.

It is the aim of this project to define the region of DR6 necessary for its localization to the viral replication compartment. In addition, we want to determine which parts of DR6 are necessary for its cell suppressive function.

P31.03 Dea Jensen INHIBITION OF DEATH SIGNALS BY A NOVEL VIRAL PROTEIN

D.K. Jensen, E. Kofod-Olsen, M.H. Schleimann, P. Höllsberg

Department of Biomedicine, Aarhus University 
Regulation of cell death is important to maintain health by preventing survival of unwanted cells, such as cancer cells and infected cells. Many viruses have developed different mechanisms to escape the body's immune system, e.g. by inhibiting signalling through death receptors or the tumor suppressor protein $\mathrm{p} 53$.

The viral protein $\mathrm{U} 20$ is a single-pass membrane protein from human herpesvirus (HHV)-6B. We have previously demonstrated that it inhibits signalling through tumor necrosis factor receptor 1 (TNFR 1 ). In order to understand the mechanisms responsible for this inhibition, we aimed to determine whether the intracellular or the extracellular part of $\mathrm{U} 20$ alone could inhibit signalling through TNFR 1 .

By the use of lentiviral transduction, truncated U20 proteins were expressed in $\mathrm{HCT} 116$ cells. The ability of the extracellular and intracellular parts of U2O to rescue the infected cells from TNFa-induced apoptosis is going to be analyzed by Western blotting, flow cytometry and confocal microscopy.

Further knowledge on how HHV-6B inhibits death receptor signalling will provide a better understanding of viral immune evasion. Furthermore, U2O, or a part of the protein, might be useful as anti-TNF therapy for some chronic autoimmune disorders.

P31.04 Ann Marlene Gram Christensen

P31.05 Sine Kirstine Kratholm

\section{PROCALCITONIN-GUIDED DETECTION OF STREPTOCOCCAL ACUTE} TONSILLITIS

\author{
A.M.G. Christensen', M.K. Thomsen', T. Ovesen', T.E. Klug ${ }^{7}$ \\ 'Ear-Nose-Throat (ENT) Department, Aarhus University Hospital, \\ ${ }^{2}$ Department of Clinical Microbiology
}

Acute tonsillitis (AT) due to group A Streptococcous (GAS) is a prevalent condition in general practice (GP). In Denmark, the 4-point Centor Score (CS) and the Rapid Antigen Detection Test (RADT) are diagnostic standards in AT diagnose making. However, a diagnostic challenge in differentiating GAS and non-GAS infections remains as the sensitivity and specificity of RADT are influenced by several factors. Fusobacterium necrophorum (FN) may be an important, but largely underdetected cause of AT in young adults. Procalcitonin (PCT) is a relatively new infection marker, which has the advantage of more rapid and specific induction compared to $\mathrm{C}$ reactive protein (CRP). Our purpose was to investigate the usefulness of PCT as supplement to the RADT and the CS in the differential diagnose making between GAS and non-GAS AT. Secondly, we aimed to examine PCT as a diagnostic marker in AT due to $\mathrm{FN}$. This prospective case study was outbound from the ENT department, Aarhus University Hospital, and will be carried out in Skoedstrup GP. In total, 100 AT patients will be included from 27 August 2012. Inclusion criteria are: 1) age 15-40 years, 2) AT signs and presence of 2-4 CS, 3) no antibiotic treatment or other infections within the last month, 4) adequate tonsil swabs and 5) no suspicion of peritonsillar abscess. CS, RADT, throat swabs and blood samples (PCT, CRP, leukocyte count and absolute neutrophile count) will be obtained. PCT is able to supplement the CS and the RADT and thereby contribute to increased sensitivity and specificity in the differential diagnose making between AT due to GAS and other pathogens. Moreover, we hope to find an association between PCT levels and FN infection.

\section{IL-2 1 IS IMPORTANT IN INNATE IMMUNE PROTECTION AGAINST VIRUS} INFECTIONS S.K. Kratholm' ', M.B. Iversen' , L. Reinert' , A. Rankin', D. Young', S.R. Paludan',
C.K. Holm'

${ }^{1}$ Department of Biomedicine, Aarhus University, ${ }^{2}$ Immunology and Autoimmunity, Pfizer Inc. Cambridge, MA USA 
$\mathrm{IL}-21$ is a cytokine produced by NKT and CD4 ${ }^{+} \mathrm{T}$ cells and cytokine levels are increased in response to virus infections, where IL-21 has been shown to be essential in promoting adaptive immune responses. Cells from the innate immune system, such as NK cells and macrophages, are also important in immune protection against virus. These cells express IL-21R and respond to IL-21 with increased cytotoxicity and cytokine production. Currently, however, the role that IL-21 plays in regulating innate immune responses to virus infections is unknown. We used C57BL/6 WT and IL-21R KO mice and a murine vaginal HSV-2 infection model to show that IL-2 1 is indeed important in innate immune responses to virus. We found that expression of IL-2 1R was increased in the vaginal tissue early after infection, and this could be induced by poly(I:C) and IL-21. IL-21R KO mice exhibited increased vaginal viral titers on day 2 and 3 p.i. and subsequently developed significantly higher median disease scores and a lower survival rate compared to WT mice. In addition, WT mice infected with HSV-2 and pre-treated with $\mathrm{mlL}-21$ had decreased vaginal viral titers on day 2 p.i., significantly lower median disease scores and a higher survival rate compared to infected untreated WT controls. Collectively, our data demonstrate the novel finding that IL-21 plays a critical role in regulating innate immune responses against viral infections.

P31.06 Bo Hønge

HEPATITIS B IN A WEST AFRICAN HIV COHORT WITH HIGH HIV-2 PREVALENCE

B.L. Hønge ${ }^{7,2}$, S. Jespersen ${ }^{1,2}$, C. Medina ${ }^{3}$, D.S. Te ${ }^{3}$, Z. da Silva ${ }^{4}$, L. Østergaard' , C. Erikstrup 5 , H. Krarup 6

'Department of infectious disaeses Q, Aarhus University Hospital, Denmark, ${ }^{2}$ Bandim Health Project, Guinea-Bissau, ${ }^{3}$ National HIV Programme, Ministry of Health, Bissau, Guinea-Bissau, ${ }^{4}$ National Public Health Laboratory, Bissau, Guinea-Bissau, ${ }^{5}$ Department of Clinical Immunology, Aarhus University Hospital, Denmark, ${ }^{6}$ Department of Clinical Biochemistry, Aalborg University Hospital, Denmark

Introduction: After the introduction of antiretroviral therapy (ART) against $\mathrm{HIV}$, viral hepatitis has emerged as one of the biggest causes of death in patients co-infected with HIV and hepatitis. The West African country, Guinea-Bissau has the highest prevalence of HIV-2 in the world, and little is known about co-infection with HBV and HIV-2. In fact, no published information regarding hepatitis B infection in Guinea-Bissau is available.Methods: In this study we included all patients from an HIV cohort at the National Hospital Simão Mendes, Bissau. Since July 2007 patients have been tested for HBV with a rapid test, detecting the hepatitis B surface Antigen ( $\mathrm{HBsAg}$ ), and additional patient information has been entered into a database continuously.

Results: On 1 May 201 1, 2527 patients ( 1693 HIV-1, 461 HIV-2, 330 HIV-1/2, 42 HIV type unknown) had been included in the cohort. Of these 1227 (45.2\%) had been tested for HBsAg with 135 of those tested being positive ( $11.0 \%)$. The male/female ratio was significantly higher among $\mathrm{HBsAg}$ positive (0.66) than among HBsAg negative $((0.45)(p=0.03))$. HBsAg positive had a higher ALT than HBsAg negative, median $26 \mathrm{U} / \mathrm{I}$ (interquartile range 16-45) vs. $18 \mathrm{U} / \mathrm{I}$ (interquartile range 10-30), respectively $(\mathrm{p}<0.01) .<\mathrm{br}>\ln$ the survival analysis the mortality was not significantly higher among HBsAg positive. When adjusting for age, sex and HIV type, the hazard ratio (HR) was 1.80 (95\% Cl: 0.84-3.87). Loss to follow-up, an event associated with a very high mortality in these settings, was similar in the two groups (adjusted $\mathrm{HR}=1.04$ (95\% Cl: 0.73-1.50)).

Conclusions: In this West African HIV cohort we found a higher prevalence of hepatitis B in men and ALT levels was higher in the co-infected. Patients infected with hepatitis $B$ did not have a signifi cantly higher mortality in the study period. 
Regulation of cell death is important to maintain health by preventing survival of unwanted cells, such as cancer cells and infected cells. Many viruses have developed different mechanisms to escape the body's immune system, e.g. by inhibiting signalling through death receptors or the tumor suppressor protein p53.

The viral protein $\mathrm{U} 20$ is a single-pass membrane protein from human herpesvirus (HHV)-6B. We have previously demonstrated that it inhibits signalling through tumor necrosis factor receptor 1 (TNFR 1) In order to understand the mechanisms responsible for this inhibition, we aimed to determine whether the intracellular or the extracellular part of U20 alone could inhibit signalling through TNFR 1 .

By the use of lentiviral transduction, truncated $U 20$ proteins were expressed in HCT 116 cells. The ability of the extracellular and intracellular parts of U2O to rescue the infected cells from TNFa-induced apoptosis will be analyzed by Western blotting, flow cytometry and confocal microscopy.

Further knowledge on how HHV-6B inhibits death receptor signalling will provide a better understanding of viral immune evasion. Furthermore, U20, or part of this protein, might be useful as anti-TNF-therapy for some chronic autoimmune disorders.

P32.01 Mia-Maiken NEUROTROPHIC FACTORS IN CEREBROSPINAL FLUID IN PATIENTS WITH DIABETIC POLYNEUROPATHY

Jørgensen

$$
\text { M.K. Jørgensen ', J. Frystyk', H. TankisI }{ }^{3}, \text { H. Andersen }{ }^{7}
$$

${ }^{1}$ Department of Neurology, Aarhus University Hospital, ${ }^{2}$ Department of Clinical Medicine, Medical Research Laboratory, Aarhus University Hospital, ${ }^{3}$ Department of Clinical Neurophysiology, Aarhus University Hospital

Background: The pathogenetic factors underlying development of diabetic polyneuropathy (DP) remain unclear. Reduced neurotrophic stimulation has been proposed as a possible mechanism. The neurotrophic factors Insulinlike Growth Factor I and II (IGF I and II), Nerve Growth Factor (NGF) and Brain-derived Neurotrophic Factor (BDNF) are essential for development and regeneration of the nervous system . In earlier studies, reduced concentrations of IGF-I and II in blood and reduced concentrations of NGF and BDNF in muscle and skin biopsies have been found in patients with DP.

Aim: Our aims are to determine the concentration and biological activity of IGF-I and II, NGF and BDNF in cerebrospinal fluid and in serum in patients with/without DP as well as in healthy control subjects, and furthermore to relate the findings to peripheral nerve function .

Hypothesis: We hypothesize that DP develops due to reduced concentration and biological activity of neurotrophic factors. We expect the concentration of IGF-I and II, NGF and BDNF to be reduced in cerebrospinal fluid in patients with DP compared to diabetic patients without damage to the nervous system and healthy control subjects.

Methods: Diabetic patients with/without DP, patients suffering from polyneuropathy due to another etiology than diabetes and healthy control subjects will be included. Cerebrospinal fluid and serum will be analyzed to determine the concentration and biological activity of the neurotrophic factors IGF-I and II, NGF and BDNF. Peripheral nerve function will be evaluated by a clinical examination, isokinetic dynamometry and nerve conduction studies. 
P32.02 Hanne Rheder A PROSPECTIVE STUDY OF ULTRASOUND OF THE ULNAR NERVE AT AND Ellegaard BELOW THE ELBOW IN PATIENTS WITH COMPRESSION NEUROPATHIES CORRELATION WITH THE ELECTROPHYSIOLOGICAL MEASUREMENTS

\section{H.R. Ellegaard, E.Q. Montvillas, A. Hess, A. Fuglsang-Frederiksen}

Department of Clinical Neurophysiology

Background: Ulnar nerve entrapment (UNE) at elbow is the second most common peripheral nerve compression syndrome and occurs mostly due to mechanical forces. The use of electrodiagnostic techniques is helpful in establishing the diagnosis, but localization of the lesion can be difficult. Visualisation of the nerves by means of ultrasound may help reveal the site of compression and may shed light on the pathophysiology of the compression.

Aims: To clarify how reliable the ultrasound of the ulnar nerve at the elbow is in order to diagnose compression neuropathies, to elucidate some of the underlying mechanisms of UNE by investigating the ultrasound properties of the ulnar nerve in patients and their correlation with the electrophysiological findings and to establish the normative data for ultrasound measurements of the ulnar nerve.

Methods: The study will be a prospective, controlled, blinded study with a follow-up at 3 months. The reference values will be collected by a representative group of healthy controls. The ulnar nerve will be examined with the patient in the supine position and the arm beside the head with the elbow flexed. A generous amount of acoustic coupling gel is required with a high frequency linear array transducer and a small pressure to avoid deformation of the ulnar nerve. As reference, the patients and healthy controls will be examined electrophysiologically according to the department routine methods.

Perspectives: Ultrasound measurements of the ulnar nerve may be used to determine the presence and severity of the compression neuropathy of the ulnar nerve at the elbow and therefore may serve as a supplement to the electrophysiological examination. DRUG (NSAID) USE AMONG 174,845 USERS OF ANTIDEPRESSIVE AGENTS IN DENMARK O. Köhler', L. Petersen', O. Mors' ${ }^{\text {, C. Gasse }}{ }^{2}$
'Unit for Psychiatric Research, Department P, Aarhus University Hospital,
Risskov, ${ }^{2}$ National Centre for Register-based Research, Aarhus University

Background: It has been proposed that inflammation plays a role in the pathophysiology of depression. Both increased and decreased antidepressant treatment response of concomitant use of antidepressants and non-steroidal anti-inflammatory drugs (NSAID) have been reported. However, little is known about the prevalence of NSAID consumption among antidepressant users. The objective of the current study is therefore to identify and describe patterns and determinants of NSAID consumption among antidepressant users.

Methods: Population-based linkage study of medical and sociodemographic registries of all incident starters of antidepressants between 1997 and 2006 within a $25 \%$ sample of the Danish population. All results were adjusted for prior NSAID use, socio-demographic factors and somatic and psychiatric comorbidity.

Results: Among 174,845 incident antidepressant users, Selective Serotonin Reuptake Inhibitors (SSRI) (70.9\%) and Tri-Cyclic Antidepressants (TCA) (13.4\%) were most frequently prescribed. Of 74,416 patients on long-term antidepressant treatment, 29,522 (39.7\%) were using NSAIDs and 3.5\% were 
P32.04 Jenny-Ann Phan

P32.05 Ina Skyt Østergaard treated with two different NSAIDs concomitantly. NSAID consumption was found to be more than twice as high among SSRI and even four times higher among TCA users compared to the general population. Determinants for NSAID use were age, female gender, low education, TCA use and musculoskeletal disease. Previous hospitalizations with schizophrenia or depression lowered the risk for receiving NSAID.

Conclusions: We found a high prevalence of concomitant NSAID consumption in users of antidepressants. The next step will be to investigate the effect of NSAIDs on SSRI treatment response.

NORADRENERGIC PROTECTION OF DOPAMINERGIC TRANSMISSION IN PARKINSON'S DISEASE

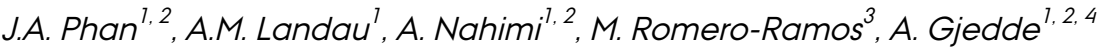

${ }^{1}$ Center of Functionally Integrative Neuroscience, Aarhus University Hospital, Aarhus University, Denmark, ${ }^{2}$ Department of Neuroscience and Pharmacology, University of Copenhagen, Denmark, ${ }^{3}$ Department of Biomedicine, Aarhus University, Denmark, ${ }^{4}$ Department of Radiology and Radiological Science, Division of Nuclear Medicine, Johns Hopkins Medical Institutions, Baltimore, MD.

The classical view of Parkinson's disease (PD) is complicated by recent evidence that the noradrenaline (NA) producing neurons in the locus coeruleus (LC) are affected in the earliest stages prior to the loss of dopaminergic neurons of substantia nigra (SN). The pathological hallmark of PD is the mishandling and aggregation of a-synuclein (ASYN), both in SN and LC, which is accompanied by the activated microglia and increased levels of pro-inflammatory cytokines. Remarkably, NA has been suggested to prevent inflammation by reducing synthesis and signalling of proinflammatory cytokines. Based on this evidence, we hypothesized that the initial loss of NA in PD may accelerate disease progression due to decreased capacity to counteract neuroinflammation. The goal of this study is to test the neuroprotective role of NA and to resolve whether lack of noradrenergic innervation exacerbates the ASYN induced nigral degeneration in PD.

Methods: PD will be induced in rats using viral vector-mediated overexpression of human ASYN. The severity of a selective ASYN overexpression either in the LC or SN will be evaluated and compared with a combined lesion to both areas by means of microPET imaging, behavioural analysis and immunohistochemistry.

Hypotheses: We hypothesize that a combined lesion to LC and SN will result in a greater dopaminergic cell death in $\mathrm{SN}$ and more severe motor deficits compared to an isolated lesion in either SN or LC.

Perspectives: This novel double-site ASYN overexpression model more closely resembles the pathologenesis found in human PD and may provide a basis for future research with a strong focus on the testing of neuroprotective therapeutics.

PERCEPTUAL DISTORTION OF THE FACE EVOKED BY EXPERIMENTAL PAIN AND LOCAL ANAESTHESIA IN HEALTHY VOLUNTEERS

L. Dagsdóttir ', I. Skyt ', 2, L. Baad-Hansen ', L. Vase ${ }^{2}$, E. Castrillon ', A. Roepstorff ${ }^{3}$, T.S. Jensen ${ }^{4}$, P. Svensson ${ }^{1,5}$

${ }^{1}$ Section of Clinical Oral Physiology, Department of Dentistry, Health, Aarhus University, ${ }^{2}$ Department of Psychology, Aarhus University, ${ }^{3}$ Interacting Mind Center, Aarhus University, ${ }^{4}$ Danish Pain Research Center, Aarhus University Hospital, ${ }^{5}$ MindLab, CFIN, Aarhus University Hospital

Background: Patients suffering from trigeminal neuropathic pain sometimes report that the painful area is "swollen" or "feels different". This is seen as a 
kind of perceptual distortion since there are no clinical signs of swelling. The neural mechanisms underlying these disturbances are poorly understood, but may originate from an overlap between cortical areas where perception of the face and pain in the face is represented.

Aim: To examine the possible effects of experimental pain or transient deafferentation due to local anaesthesia on the perceived magnitude of the face in the manipulated areas.

Methods: Hypertonic saline (HS) has previously been used to produce experimental pain. A total of $0.2 \mathrm{~mL} 5 \%$ hypertonic saline (HS) or $0.2 \mathrm{~mL}$ local anaesthetic (LA) was injected into six regions of the face. The pain intensity from the HS injections was evaluated on a 0-10 numerical rating scale. After the injections, participants were asked to draw the affected area and estimate any changes in the perceived size of the area $\mathrm{O}=$ no change, negative=decrease, positive=increase). The sensitivity of the areas was tested using quantitative sensory testing. The participants completed psychological questionnaires to measure the contribution of psychological factors.

Results: For most of the participants, both injection of HS and LA led to a significant increase in perceived size of the injected area $(p<.05)$ with the most pronounced increases observed in the buccal region and the least in the auriculotemporal region.

Conclusion: Experimental pain and local anaesthesia can cause transient perceptual distortions of the face.

Acknowledgments: The study was supported by an AU Ideas grant.

P32.06 Bochra Zareini COGNITIVE COMPLEXITY AND DISORDERS OF CONSCIOUSNESS

\section{B. Zareini, C. Koch-Jensen, B. Bergholt, B. Dahl, B. Johnsen, J. Nielsen, E. Weed, M. Petersen, M. Overgaard}

Cognitive Neuroscience Research Unit, CFIN, Department of neurosurgery, Department of Clinical Neurophysiology, Hammel Neurocenter, Aarhus University Hospital

In 2006 Adrian Owen chocked the world of neuroscientists with his activation study. The patient was a vegetative patient, and while being scanned she received 2 mental orders. Although diagnosed as a vegetative patient, she showed a significant fMRI response compared to a group of healthy participant.

This study and other EEG studies with P300 and N400 response in patients with $D O C$ raise the important question of residual consciousness and more importantly questioning the diagnosing procedures of patients with DOC.

The aim of this study is to investigate the relationship between the ability to have significant evoked response potentials (ERP's) and diagnosis in patients with DOC

We have constructed a 1 hour-long paradigm with different levels of sound and semantic comprehension, reflecting a hierarchy of different cognitive complexity. This paradigm will be presented to 3 different types of patients: coma-patients, vegetative and minimally conscious patients. The ability to evoke and the size of an ERP response will be compared with type of DOC to see if there are some kind of relationship between degree of consciousness disorder and the ability to evoke an ERP response.

P33.01 Marlene OUTCOME OF PNEUMOCOCCAL LOWER RESPIRATORY TRACT INFECTION Skovgaard Sørensen WITHOUT PULMONARY INFILTRATE OR BACTEREMIA - A POPULATIONBASED COHORT STUDY

M. Skovgaard', H.C. Schønheyder ${ }^{2}$, T. Benfield ${ }^{3}$, R.B. Nielsen ', J.D. Knudsen ${ }^{4}$, J. Bangsborg ${ }^{5}$, C. Østergaard , H.C. Slotved ${ }^{6}$, H.B. Konradsen 6 , L. 
Lambertsen $^{6}$, R.W. Thomsen ${ }^{7}$

'Department of Clinical Epidemiology, Aarhus University Hospital, ${ }^{2}$ Department of Clinical Microbiology, Aalborg Hospital, Aarhus University Hospital, ${ }^{3}$ Department of Infectious Diseases, Copenhagen University Hospital - Hvidovre, ${ }^{4}$ Department of Clinical Microbiology, Copenhagen University Hospital - Hvidovre, ${ }^{5}$ Department of Clinical Microbiology, Copenhagen University Hospital - Herlev, ${ }^{6}$ Statens Serum Institut, Denmark

Background: The prognostic impact of presence versus absence of a pulmonary infiltrate or bacteraemia in patients with confirmed pneumococcal lower respiratory tract infection (LRTI) remains unclear.

Methods: We conducted a population-based cohort study including 749 adults hospitalized in 2011 with LRTI symptoms and a pneumococcal isolate obtained from the LRT or blood. We compared risk factors, clinical characteristics and outcomes of pneumococcal LRTI among 228 patients with no pulmonary infiltrate or bacteraemia (nPnB), 256 with X-ray confirmed pneumonia (PnB) and 265 with pneumococcal bacteraemia (B).

Results: $\mathrm{nPnB}$ patients had more comorbidity than the other groups (Charlson index score $\geq 1$ : nPnB $80 \%$ vs PnB 69\% vs B 57\%), smoked more tobacco and had more respiratory symptoms. In contrast, $\mathrm{PnB}$ and particularly B patients had substantially higher $\mathrm{C}$-reactive protein (nPnB median 71 vs PnB 163 vs B 317 mg/L) and higher acute disease severity. All adverse outcomes increased successively from $\mathrm{nPnB}$ to $\mathrm{PnB}$ to $B$ patients: length of hospital stay ( 5 days vs 6 days vs 8 days); risk of intensive care admission ( $8 \%$ vs $21 \%$ vs $24 \%$ ); pulmonary complications ( $1 \%$ vs $4 \%$ vs $12 \%$ ); and 30 -day mortality ( $5 \%$ vs $11 \%$ vs $20 \%$ ). After confounder adjustment by Cox regression, the 30 -day RR of death was 2.06 ( $95 \% \mathrm{Cl} 0.90-4.75$ ) in $\mathrm{PnB}$ vs $\mathrm{nPnB}$ patients and $4.39(95 \% \mathrm{Cl} 1.98-9.71)$ in $\mathrm{B}$ vs $\mathrm{nPnB}$ patients.

Conclusion: Pneumococcal isolates are of clinical significance in LTRI patients' isolates, even without lung infiltrate or bacteraemia. Still, we observed an outcome gradient from patients with pneumococcal isolation compared to those with concomitant pneumonia and bacteraemia.

P33.02 Bjørn Borsøe Christensen
AUTOLOGOUS CARTILAGE CHIPS FOR OSTEOCHONDRAL REGENERATION

\section{B.B. Christensen, C.B. Foldager, C.E. Bünger, M. Lind}

Orthopaedic Research Laboratory, Aarhus University Hospital

Articular cartilage injuries have a very limited ability of spontaneous repair. The available treatment options are often expensive, require two separate surgeries and the repair tissue is fibrous and inferior to articular cartilage in regard to elasticity, strength and durability.

We propose the novel treatment autologous dual-tissue transplantation (ADTT). ADTT consists of autologous bone (AB) combined with autologous cartilage chips ( $c c$ ) embedded in fibrin. Furthermore, we propose the $c c$ matrix-induced autologous chondrocyte implantation sandwich (ccMAClsandwich) technique, in which ADTT is combined with the original $\mathrm{MACl}$ sandwich technique in order to avoid cell culturing and two procedures.

The aim of the PhD project is to develop and test the treatments mentioned above. We hypothesize that:

1) ADTT will improve the osteochondral repair compared to the use of $A B$ alone.

2) The ccMACl-sandwich technique will provide repair superior to that of the original $\mathrm{MACl}$-sandwich technique.

In study 1 and 2, 12 mini pigs will receive bilateral osteochondral knee defects and undergo one of the following treatments: 1) AB alone, 2) ADTT, 3 ) the $\mathrm{MACl}$-sandwich technique or 4) the ccMACl-sandwich technique. 
P33.03 Christina

Kjœrgaard

Rasmussen

P33.04 Iben Bach Pedersen
Observation period is 1 year. Evaluation will consist of MRI, histology and qRT-PCR. In study 3, 20 patients suffering from osteochondritis dissecans will be treated with the ADTT technique. The patients will be MRI scanned, KOOS scored and SF- 12 scored at 0,12 and 24 months.

The studies of this project may impact clinical practice within few years. The use of cartilage chips could improve clinical outcome and increase the number of treated patients due to the reduction in costs.

\section{SIMPLE LEARNING OF 2- AND 3-DIMENSIONAL TRANSVAGINAL ULTRASOUND IN DIAGNOSING ADENOMYOSIS \\ C.K. Rasmussen, M. Dueholm}

Department of Gynecology and Obstetrics, Aarhus University Hospital

Diagnosing adenomyosis with 2-Dimensional (2D) transvaginal ultrasound (TVU) is highly dependent on the observer. Using 3-Dimensional (3D) TVU, it is possible to visualize the junctional zone and to save 3D volumes. We evaluate the observer variation of 2 and 3D TVU between inexperienced and experienced observers for diagnosis of adenomyosis. The findings are controlled by the gold standard, pathology.

70 premenopausal women scheduled for either hysterectomy or transcervical resection of the endometrium (TCRE) for benign reasons were enrolled. Participating patients went through a preoperational 2 and 3D TVU examination performed by an experienced and an inexperienced observer, blinded to each other. 30 second $2 \mathrm{D}$ video sweeps and 3D volumes were saved for later evaluation. An inexperienced observer went through one month of structured learning how to control the high-end-scanner and visualize the uterus. Pattern recognition was practiced hereafter during realtime 2D examinations by focusing on different terms for diagnosis of adenomyosis. Imaging evaluation of saved 2D video sweep and 3D volumes were then evaluated using $4 \mathrm{D}$ view computer program. The process of learning was evaluated by the observer variation.

Preliminary results show that it may be possible to teach an inexperienced ultrasound observer how to diagnose adenomyosis. Kappa value of the first 35 patients enrolled was $0.328(0.162-0.388)$ and $0.519(0.404-0.678)$ for the last 35 patients when the end point was yes, no or maybe adenomyosis. When the end point was yes or no adenomyosis the kappa value went from $0.488(0.203-0.772)$ to $0.648(0.398-0.897)$. This shows that a substantial agreement can be achieved.

\section{CHANGES IN CORNEAL BIOMECHANICAL PROPERTIES AFTER LASER REFRACTIVE SURGERY: A RETROSPECTIVE STUDY}

\section{I.B. Pedersen, S. Bak-Nielsen, A. Ivarsen, J. Hjortdal \\ Department of Ophthalmology, Aarhus University Hospital}

Background: Laser refractive surgery involves removal of corneal tissue. After surgery, there is a risk of developing corneal protrusion and compromised visual acuity due to weakening of the tissue and biomechanical changes of the cornea. It is of great interest to find methods for clinical testing of the biomechanical properties of the cornea. With a new device, Corvis ST from Oculus, it is now possible to measure high-speed pictures of the deformation of cornea after an air puff.

Aim: With the raw traces of cornea during deformation, the project will focus on analyzing the change in corneal rigidity after laser refractive surgery, as well as the possible dependency of corneal thickness and corneal curvature.

Methods: Patients who underwent refractive surgery over 1 year ago will be called in for quality control examination and measured with the Corvis ST. 
The project will focus on 3 procedures used for correction of refractive errors:

- Laser-Assisted In Situ Keratomileusis, LASIK (30 patients)

- Small Incision Lenticule Extraction, ReLEx-Smile (30 patients)

- Femtosecond Lenticule Extraction, ReLEx-FLEx (30 patients)

Corneal rigidity parameters will be calculated in each group and compared statistically.

Perspectives: Identifying patients with particular low corneal rigidity is desirable. Surgery can be refrained and eventual development of corneal protrusion and compromised visual acuity can be avoided.

P33.05 Malene Tanderup Kristensen
Lars Ølgaard Bloch

\section{CROSS-BORDER REPRODUCTIVE CARE - SURROGACY AND} GLOBALIZATION

M. Tanderup-Kristensen ${ }^{7}$, S. Reddy', P. TulsI , B.B. Nielsen ${ }^{4}$

'Department of Clinical Medicine, Aarhus University, ${ }^{2}$ Centre of Social Medicine and Community health, Jawaharlal Nehru University, India, ${ }^{3}$ Dept. of Sociology, Delhi School of Economics, Delhi University, India, ${ }^{4}$ Dept of Obstetrics and Gynaecology, Aarhus University Hospital, Skejby

The differences in laws worldwide globalize fertility treatment and allow infertile people to seek treatment in countries like India, which have fewer restrictions and lower costs, but also have other medical ethics and standards.

The objective is to describe the cross-border reproductive care with a special focus on surrogacy. We wish to look at the opportunities available by using surrogacy as a method of having children and also the disadvantages of the same.

Data were collected in 16 Assisted Reproductive Technology clinics and 3 agencies in the National Capital Territory of Delhi, India. Doctors, surrogate mothers, agents and intended parents have been interviewed using semistructured open-ended interview guides. The study was conducted from December 2011 to November 2012.

Interventions like embryo transfer, foetal reduction, mode and time of delivery of the surrogate mother are decided by the doctors, agents, intended parents and, in few cases, the surrogate mother herself. Number of embryos transferred varies from clinic to clinic ranging from 1 to 7 , to keep a high success rate yet performing foetal reduction to keep multiple pregnancies low.

Globalization of fertility treatments increases the need of professionalism and regulation of clinics to safeguard the interest of the people who seek medical care abroad. It also increases the need for global responsibility to ensure the rights of the patients involved and to keep a check on the quality of the treatments worldwide.

IMAGING OF VESSEL WALL EDEMA USING 3D T2-WEIGHTED MRI

L.Ø. Bloch ${ }^{1,3}$, A.K. Grøndal' ${ }^{2}$, E.S.S. Hansen ${ }^{3}$, S.F. Pedersen ${ }^{2}$, J.L. Hønge ${ }^{2}$, W.P. Paaske ${ }^{2}$, W.Y. Kim ${ }^{1,3}$

'Department of Cardiology, Aarhus University Hospital, ${ }^{2}$ Department of Cardiothoracic \& Vascular Surgery T, Aarhus University Hospital, ${ }^{3} \mathrm{MR}$ Research Centre, Aarhus University Hospital

Background: Atherosclerosis remains a major health problem in the western world, and carotid atherosclerosis is an important contributor to embolic ischemic strokes, which may cause severe disability and death. Inflammation plays a pivotal role in all stages of atherosclerosis. It is both an initiating factor in the atherosclerotic process and a contributor to plaque destabilization and rupture. It remains a clinical challenge to identify 
rupture-prone atherosclerotic plaques. Inflammation, endothelial injury and angiogenesis are characteristic features of vulnerable plaques and may all be associated with vessel wall edema. In this regard, we hypothesize that edema may be used as a surrogate marker of disease activity in the atherosclerotic plaque. We aim to compare the ability of various MRI sequences to detect edema induced in porcine carotid arteries by acute balloon injury.

Methods. Edema will be induced unilaterally by balloon overstretch injury in the carotid artery of 12 pigs. Acutely post injury, the carotid arteries will be assessed using various MRI sequences. Among the sequences used are T2STIR, VISTA and DIXON. MR images will be compared and validated macroscopically be means of Evans Blue dye.

Results: We expect that the carotid edema will be present acutely and that the MRI sequences tested may improve the visualization of carotid edema as a marker of plaque activity.

Conclusion: If these MRI sequences can improve the visualization of carotid artery wall edema and characterize the atherosclerotic lesion, it may provide unique information in terms of plaque activity and risk stratification in individual patients.

P33.07 Karen Lise Dahl ASSESSMENT OF HEPATITIS B VIRUS AND HEPATITIS C VIRUS SEROLOGY Andersen PREVALENCE AMONG HIV PATIENTS: A CROSS-SECTIONAL STUDY

\section{K.L.D. Andersen, C.S. Larsen, P.D.C. Leutscher}

Department of Infectious Diseases, Aarhus University Hospital

Introduction: HIV patients are at increased risk of co-infection with hepatitis $B$ virus (HBV) and hepatitis $C$ virus ( $\mathrm{HCV}$ ) because of shared routes of transmission. Co-infection with HBV is seen among nearly $10 \%$ of European and American HIV patients and in a Danish HIV cohort $13 \%$ were found infected with HCV. Co-infection with chronic viral hepatitis is associated with increased mortality in HIV patients. For this reason, international guidelines recommend HBV vaccination of non-immune HIV patients, $\mathrm{HCV}$ screening and anti-HBV/HCV treatment if needed.

Objective: To assess HBV and HCV seroprevalence and HBV vaccination coverage rate among HIV patients.

Methods: In April 2012, a systematic HBV and HCV serology test surveillance programme was initiated as part of a cross-sectional study among HIV patients followed in a Danish out-patient clinic. In conjunction with the planned clinic visit schedule, patients were tested for HBsAg, anti-HBs and anti-HBc and anti-HCV (Architect ${ }^{\circledR}$, Abbott Diagnostics). If anti-HCV was positive, HCV RNA (Procleix ${ }^{\circledR}$, Norvatis) was measured. Based on these tests, patients were grouped as $\mathrm{HBV} / \mathrm{HCV}$ naïve or sero-positive due to history of infection or vaccination. Patient demographic data were analyzed according to $\mathrm{HBV} / \mathrm{HCV}$ immune status by use of Chi-Square $X^{2}$ test and Wilcoson's signed rank test.

P33.08 Sashia Pernille THE RIGIDITY OF CORNEAS BEFORE AND AFTER CORNEAL CROSS-LINKING Bak-Nielsen - AS MEASURED BY THE CORVIS ST

\section{S. Bak-Nielsen, I.B. Pedersen, A. Ivarsen, J. Hjortdal}

Department of Ophthalmology, Aarhus University Hospital

Background: Keratoconus is a bilateral corneal disease that develops during youth. At least 4,600 subjects are affected in Denmark. The disease causes thinning and protrusion of the cornea and compromises vision. In severe cases, corneal transplantation is the only treatment option. Corneal crosslinking $(\mathrm{CXL})$ is a newly introduced treatment, which may stop progression of the disease and thereby preserve visual acuity. The effect of CXL on the mechanical properties of the cornea has been documented in vitro, but in 
vivo studies have not been able to show an effect on the stiffness of the cornea. In this study, we aim to test a new device, Corvis ST, for clinical measuring of the cornea's biomechanical properties.

Methods: The project involves 4 studies:

- Reproducibility: 30 patients inter-session and inter-day

- Age-dependency: 30 patients aged 0-30 years and 30 patients aged 70 80.

- Discrimination between keratoconus and normal corneas: 30 keratoconus patients and 30 normal subjects.

- CXL: 30 keratoconus patients treated with CXL and 30 untreated keratoconus patients.

Perspectives: Earlier and more timed CXL treatments, resulting in a more cost-efficient and less invasive treatment.

P33.09 Helga Haahr- THE PREDICTIVE VALUE OF THE ISHIHARA TEST FOR THE RESULT OF THE Lillevang OPTEC 9OOLANTERN TEST

H. Haahr-Lillevang, T. Bek

Department of Ophthalmology, Aarhus University Hospital

Background: Defective colour vision (DCV) affects about $5 \%$ of the population, predominantly men. In some occupations, such as in aviation and railways, only a mild degree of DCV is allowed for safety reasons. Therefore, testing of the colour vision is a standard part of the medical examination for applicants to educations within these areas. In Denmark, this testing is performed using Ishihara's pseudoisochromatic test, and - if the applicant fails this test - this is followed by a lantern test performed at a specialized eye department. The purpose of the present study was to study whether a detailed analysis of the Ishihara test can reveal response patterns that predict whether the applicant will pass the lantern test.

Method: Colour vision examinations from 221 persons who had failed the Ishihara test and had been referred for a subsequent lantern test were used for the analysis. Special software was developed to test whether a wrong identification of specific combinations of Ishihara symbols could predict that the test person failed the lantern test with a sensitivity of 1.00 .

Results: Altogether 176,579 combinations of Ishihara symbols with a specificity of 1.00 were identified. Among these, the highest sensitivity of 0.34 was obtained with a wrong identification of symbols $3,18,20.1$ and 23.2.

Perspectives: Twenty-four percent of the persons who fail the Ishihara test can be predicted to also fail the lantern test. Referral of these patients to a specialized eye department can be saved.

P34.01 Xiao Qin Liu BEREAVEMENT DURING PREGNANCY AND THE RISK OF PRE-ECLAMPSIA

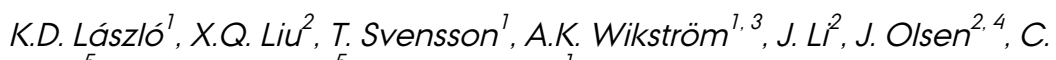
Obe $\digamma^{5}$, M. Vestergaard ${ }^{5}$, S. Cnattingius ${ }^{7}$

'1Clinical Epidemiology Unit, Department of Medicine, Karolinska University Hospital and Karolinska Institute, Stockholm, Sweden, ${ }^{2} 2$ Section for Epidemiology, Department of Public Health, Aarhus University, Denmark, 3 Department of Women's and Children's Health, Uppsala University, Uppsala, Sweden, ${ }^{4} 4$ Department of Epidemiology, School of Public Health, University of California, Los Angeles, California, USA, ${ }^{5}$ Research Unit and Section of General Practice, Department of Public Health, Aarhus University, Denmark

Background: Pre-eclampsia, a major cause of perinatal and maternal mortality, complicates approximately $3.2 \%$ pregnancies. Animal 
experiments have shown increased susceptibility to pre-eclampsia under stressful circumstances. Only a few studies have investigated the association between prenatal stress and pre-eclampsia, and the findings are controversial.

Objective: To study whether maternal bereavement during pregnancy is associated with an increased risk of pre-eclampsia.

Methods: This population-based cohort study used data from national registers in Denmark and Sweden. Singleton births in Denmark during 19782008 and in Sweden during 1973-2006 were included in our study. 124,525 births by women who lost a close relative (a child, partner/spouse, parent or sibling) during or up to 12 months before the pregnancy were included into the exposed group. The remaining 3,996,835 births were in the unexposed group. A logistic regression model was used to estimate the odds ratio (OR).

Results: Death of a close relative in the six months before or in the first trimester of pregnancy was associated with an increased risk of preeclampsia; the adjusted OR (95\% Cl) were 1.14 (1.06 - 1.23) and 1.14 (1.02 1.28), respectively. Exposure during this period was more closely related to early pre-eclampsia than with late pre-eclampsia. The strongest association was observed between the death of an older child and early pre-eclampsia (OR and $95 \% \mathrm{Cl}: 3.03(1.96-4.66)$ ).

Conclusions: Our finding suggests that stress may influence placental development. The public health implications of our findings are likely to be modest in populations with a low prevalence of severe stress exposures.

P34.02 Stina Lou HIGH-RISK FOR DOWN'S SYNDROME: PRACTISING NON-DIRECTIVE INFORMATION AND INFORMED CHOICE

\section{S.L. Fleron}

Department of Public Health, Aarhus University

Background: In Denmark, a first trimester risk assessment for Down's syndrome is available to all pregnant women. The national guidelines emphasise that this is not a screening programme. Instead, the purpose of the programme is to provide pregnant women with information and an opportunity of making a reproductive choice, based on informed consent. Non-directive information and individual choice are core ethical principles in most clinical practise. But how are these principles practised in situations where pregnant couples are in high risk of Down's syndrome?

Method: An exploratory qualitative approach was used. This included extensive, anthropological fieldwork at a prenatal ultrasound clinic and qualitative interviews with health professionals and pregnant couples.

Results and discussion: Results from the field studies show that the concepts of non-directive information and individual, informed choice are inadequate ways of describing and analysing the interaction between highrisk couples and health professionals. Using Annemarie Mol's concepts of 'logic of choice' and 'logic of care' as analytical framework, is it possible to identify two parallel and inter-mingling discourses in the interaction: One focused on the couple as autonomous choice-makers, the other focused on decision-making as a social process. Preliminary analysis suggests that allowing for both of these discourses gives a much more nuanced and complex picture of how high risk is communicated, understood and acted on by pregnant couples and health professionals.

P34.03 Therese Koops INTERPREGNANCY INTERVAL AND AUTISM SPECTRUM DISORDERS: A Grønborg DANISH POPULATION-BASED COHORT STUDY

T.K. Gronborg ${ }^{7}$, D.E. Schendel ${ }^{2}$, E.T. Parner ${ }^{7}$

${ }^{1}$ Section of Biostatistics, Department of Public Health, Aarhus University,

${ }^{2}$ National Center on Birth Defects and Developmental Disabilities, Centers 
for Disease Cintrol and Prevention, USA

Background: Autism spectrum disorders (ASDs) are neurodevelopmental disorders which are believed to have a strong genetic component, but recent studies have suggested that environmental factors also play a substantial part. Associations between adverse birth outcomes and the risk of ASD have been investigated in numerous studies, but the preconception factors shaping the fetal environment have received less attention. The interpregnancy interval is seen as a marker for nutrition in that a short interval is a proxy for lesser nutrition available for the subsequent child. A recent study has reported a 3 -fold increase in risk of ASD for children conceived shortly after the birth of the previous sibling.

Methods: We considered all children born in Denmark from 1 January 1980 through 31 December 2004. We calculated the interpregnancy interval between two births as the number of completed months elapsed between the date of the first birth and date of last menstrual period for the second birth. We estimated the relative risk of ASD comparing interpregnancy interval grouped in 12-month intervals.

Results: We found a moderate increase in risk of ASD for long interpregnancy intervals ( 1.6 (95\% Cl: 1.4-1.8)) comparing interpregnancy interval of 72 months or more with 24-35 months. We found no association between short interpregnancy intervals and risk of ASD.

Conclusions: We found no association supporting the hypothesis that short interpregnancy interval is a risk factor of developing ASD later in life. The moderate association between risk of ASD and long interpregnancy interval may be explained by other factors related to the family such as social factors.

P34.04 Helene HOW IS PREGNANCY-RELATED WEIGHT CHANGES AND BREASTFEEDING Kirkegaard RELATED TO LONG-TERM MATERNAL WEIGHT AND WAIST-TO-HEIGHT RATIO? A PATH ANALYSIS

\section{H. Kirkegaard ${ }^{7}$, H. Støvring ${ }^{3}$, T.I.A. Sørensen ${ }^{2}$, E.A. Nøhr}

${ }^{1}$ Section for Epidemiology, Department of Public Health, Aarhus University, ${ }^{2}$ Institute of Preventive Medicine, Copenhagen University Hospital, ${ }^{3}$ Section for Biostatistics, Department of Public Health, Aarhus University

Introduction: Pregnancy is a potential risk factor for excessive weight gain and may lead to long-term maternal weight gain. This study examined how breastfeeding and weight changes during pregnancy and early motherhood are related to weight and waist-to-height ratio $7 \mathrm{y}$ after birth. Also, we distinguish the direct effect from the one mediated through weight changes on the pathway.

Method: 23,701 women from the Danish National Birth Cohort with singleton births and no birth during follow-up were included. Information on anthropometric, breastfeeding, and covariates was obtained from interviews conducted at pregnancy wk 16, at mo 6 and 18 postpartum, and from a web-based-survey 7 y after birth. Using path analysis we assess the direct, indirect, and total effect of pre-pregnancy weight, gestational weight gain, postpartum weight changes, and duration of breastfeeding on longterm weight and waist-to-height ratio.

Results: The mean 7 y weight change was $2.1 \mathrm{~kg}$ and $23 \%$ gained $>5 \mathrm{~kg}$. The adjusted total effect of pregnancy-related weight changes and breastfeeding on both outcomes was significant. $87 \%$ of the effect of gestational weight gain on long-term weight was mediated through weight retention postpartum. Weight retention at $6 \mathrm{mo}$ and weight gain from 6 to 18 mo was highly associated with both outcomes. Duration of breastfeeding was inversely associated with both outcomes, however strongest for waistto-height ratio where $92 \%$ of the effect was direct and not mediated 
through postpartum weight loss.

Conclusions: These data suggest that breastfeeding has a beneficial effect on fat distribution. Weight changes in early motherhood are important for long-term weight gain.

P34.05 Ann Dyreborg PSYCHOSOCIAL JOB STRAIN AND RISK OF ADVERSE BIRTH OUTCOME Larsen
A.D. Larsen ${ }^{7,2}$, H. Hannert', M. Juhl ${ }^{3}$, C. Obel', A.M. Thulstrup ', J.P. Bonde ${ }^{5}$, K.S. Hougaard $^{2}$
'Department of Occupational Medicin, Aarhus University Hospital, ${ }^{2}$ National Research Centre for the Working Environment, Copenhagen, ${ }^{3}$ The Women and Children Research Unit, Juliane Marie Centret, Rigshospitalet, Copenhagen, Denmark, ${ }^{4}$ Department of Public Health, Aarhus University, ${ }^{5}$ Department of Occupational and Environmental Medicine, Copenhagen University Hospital Bispebjerg, Copenhagen

Background: A number of studies have examined the effects of prenatal stress on birth outcomes, but few with focus on psychosocial job strain. We aim to examine if working under high demands/low control during pregnancy is associated with risk of giving birth to a child born preterm or small/large for gestational age (SGA/LGA), and secondly if social support modifies this relationship.

Methods: Study population is 49,340 pregnancies from the Danish National Birth Cohort. Multinomial logistic regression estimates odds ratios. Covariates included: maternal age, BM, parity, exercise, smoking, alcohol and coffee consumption, manual work, maternal serious disease, parental height and gestational age at interview. In accordance with Good Epidemiological Practice, a protocol outlined the study design before analyses were initiated.

Results: Working in high strain jobs was associated with significantly lower odds of being born LGA (OR=0.806, $p=0.014 \mathrm{Cl}$ : [0.704-0.922]) when compared to low strain jobs. High social support seems to further lower the odds of having a LGA child (OR=0.754, $\mathrm{Cl}$ : [0.630-0.902]) - (adjusted values). Neither preterm, SGA nor the other social support categories were statistically significant.

Discussion: The study did not confirm previous findings on prenatal stress and risk of having a child born preterm or small for gestational age. Analyses did show a significant association between job strain and the risk of having a LGA child. A natural explanation could be a displacement of the entire weight curve toward the right - but this is not supported among the lower birth weights.

P34.06 Heidi Cueto FOLIC ACID OR MULTIVITAMIN SUPPLEMENT USE AND MENSTRUAL CYCLE PATTERNS: AN INTERNET-BASED CROSS-SECTIONAL STUDY

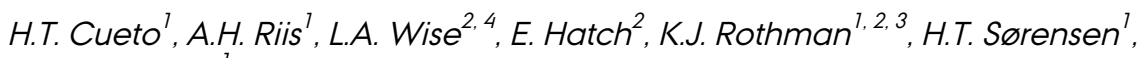
E.M. Mikkelsen ${ }^{\prime}$

'Department of Clinical Epidemiology, Aarhus University Hospital,

${ }^{2}$ Department of Epidemiology, Boston University School of Public Health, ${ }^{3}$ RTI Health Solutions, Research Triangle Park, North Carolina, ${ }^{4}$ Slone Epidemiology Center, Boston University

Introduction: Irregular cycles, long and short cycle length, and long duration of menses have been associated with reduced fecundability. Variability in cycle length is determined largely by variation in the follicular phase length. Increased folate levels may improve hormonal imbalance and increase oocyte maturation, but only few studies have examined the association between preconceptional folic acid (FA) or multivitamin (MV) use and menstrual patterns.

Objectives: We examined the association between FA or MV use and 
P35.01 Lena Hohwü

menstrual cycle regularity, cycle length, and duration and flow of menses.

Methods: We used self-reported baseline data on supplements, menstrual cycle characteristics and covariates from 5,383 women enrolled in the internet-based prospective cohort study "Snart-Gravid.dk". Using polytomous logistic regression, we estimated odds ratios (ORs) with 95\% confidence intervals $(\mathrm{Cl})$ for the association between FA or MV use and irregular cycles, short and long cycle length, and duration and flow of menses, respectively, with control for covariates. For the analyses on cycle length and menses characteristics, the sample was restricted to regular cyclers $(\mathrm{N}=4,039)$.

Results: Preliminary results showed that compared with non-users, FA or MV users had reduced odds of cycle length of

PRENATAL STRESS FOLLOWING MATERNAL BEREAVEMENT DURING PREGNANCY AND OVERWEIGHT IN YOUNG ADULTHOOD: A COHORT STUDY IN 1 10,782 DANISH CONSCRIPTS

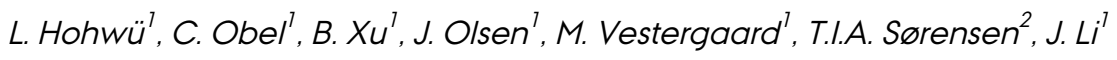

${ }^{1}$ Department of Public Health, Aarhus University, ${ }^{2}$ Institute of Preventive Medicine, Copenhagen University Hospital

Introduction: It has been suggested that prenatal stress contributes to the risk of obesity later in life. We examined whether prenatal stress related to maternal bereavement during pregnancy was associated with the risk of overweight in young adulthood.

Methods: We conducted a population-based cohort study of 110,782 Danish young male conscripts, who were born in 1983-1991 and presented for conscription in 2006-2009. By linkage of the conscription file ('session') and national registers, we identified 3139 conscripts who were exposed to prenatal stress, defined by being born to mothers who were bereaved by death of a close family member in the interval from one year before pregnancy until the delivery. Differences in means of obdy mass index (BMI) and relative risk (OR) of overweight and obesity between the exposed and the unexposed were estimated.

Results: The mean BMI were slightly higher in the exposed group $(24.1 \pm 4.2$ $\left.\mathrm{kg} / \mathrm{m}^{2}\right)$ than of those in the unexposed group $\left(23.9 \pm 4.1 \mathrm{~kg} / \mathrm{m}^{2}\right)$. The exposed conscripts had a $15 \%$ increased risk of being obese (adjusted OR $1.15,95 \% \mathrm{Cl} 1.02-1.30$ ). Children born to mothers who lost a child or spouse had a higher risk of obesity (OR $1.25,95 \% \mathrm{Cl} 0.93-1.68$ ) than unexposed children. Our data also suggest that exposure during early pregnancy seemed to carry a higher OR than exposure during other periods.

Conclusions: Our data support that severe stress during the prenatal period is associated with an increased risk of obesity in young adulthood.

P35.02 Katja Glejsted BEREAVEMENT IN THE ANTENATAL PERIOD AND ORAL CLEFT IN THE Ingstrup OFFSPRING

K.G. Ingstrup ' , H. Liang ${ }^{1,2}$, J. Olsen ', E.A. Nohr ${ }^{7}$, B.H. Bech ${ }^{7}$, C.S. Wu ${ }^{7}$, K. Christensen ${ }^{3}, \mathrm{~J} . \mathrm{Li}^{7}$

'Department of Public Health, Section for Epidemiology, Aarhus University, ${ }^{2}$, Department of Reproductive Epidemiology and Social Science, Shanghai Institute of Planned Parenthood Research, Shanghai,China, ${ }^{3}$ Department of Epidemiology, University of Southern Denmark, Denmark

Background: The aetiology of oral clefts is unknown but operates very early in prenatal life. The objective of the study was to investigate the associations between maternal bereavement (emotional stress) due to loss of a close relative from one year before pregnancy until the end of the first trimester and oral cleft in the offspring. We hypothesized sudden death of any relative and death of a child to have the highest impact. Methods: A 
P35.03 Ingeborg Hedegaard Kristensen population-based cohort study based on several Danish registers from 1978 to 2008. Our final study population consisted of 1771663 children of whom 35118 (2\%) were exposed. Results: In total, 3043 children were diagnosed with a cleft; 968 with cleft lip, 1206 with cleft lip and palate, and 869 with a cleft palate. Maternal bereavement due to the death of any close relative for any reasons, at any time point in the exposure window was associated with a significantly overall increased risk of oral cleft (OR $1.28,95 \% \mathrm{Cl}$ : $1.01 ; 1.61$ ). When mothers lost a relative due to a sudden death, the risk of oral clefts in the offspring was increased further (OR 1.76, 95\% Cl: 1.06; 2.94). Discussion: Our results are in agreement with previous animal and human studies. We only study live born children, but most children with isolated oral clefts survive. Since oral clefts are rare, we had a relatively small number of cases which results in reduced power to detect small differences. We did not have actual measurements of maternal stress hormones, but believe that bereavement due to death of a close relative produces a severe stress response in most people and thus documents a substantial exposure contrast. Also we did not have the opportunity to adjust for intake of folic acid and use of anti-depressant, however sub- analysis showed no difference in intake between exposed and unexposed mothers. Conclusion: Severe stress early in pregnancy may be added to the list of potential causes for oral clefts.

RELATIONS BETWEEN INFANT AND VOUNERABLE FIRST TIME'S MOTHERS DOES VIDEO GUIDANCE WITH THE MARTE MEO METHOD PROMOTE THE PROCESS? INTERVENTION STUDY IN A COMMUNITY SETTING

\section{I.H. Kristensen}

Section for Nursing, Department for Public Health, Aarhus University

Background: Infants develop their mentality, social and psychologically competences in relations with responsive mothers. Maternal responsiveness is defined as the mother's ability to recognise infants cues and act on those. At risk in developing relations are unsecure mothers, postpartum depressed mothers and mothers with preterm children.

Public health nurses have the opportunity to support the development of relations and some uses video-guidance with the Marte Meo method, but knowledge about the effect is lacking.

Study part 1:Method: To develop a screening tool to help nurses identify unsecure mothers, using Intervention Mapping: Need Assessment.

Study part 2: To develop a standardised preventive program. The intervention is done by public health nurses, in home visits to first time mothers in the period from the child 2 to 6 months aged in 2-5 home visits with video-guidance's. Excluded are families at sever risk who have been referred to treatment by psychiatric, psychological or social apartment.

Study part 3: To test the program.

Goal: To promote mothers parental self-efficacy, minimise mothers stress and mothers depressive mood.

To promote infants social competences. To promote mothers responsiveness and interaction with the infant.

Design: Quasi-experimental design.

The project is done in 5 municipals with 34 "interventions nurses" (having a 1 $1 / 2$ year educations as a Marte Meo therapist) and 80 "control nurses" who works as usually. The intervention group will include 150 families and they will be matched with 150 families from the control groups.

Selv reported quistionnaries to mothers and to public health nurses before and after the intervention period. 

MENTAL DISORDERS: A REGISTER-BASED COHORT STUDY

B. Bay ${ }^{1,2}$, E.L. Mortensen ${ }^{3}$, D. Hvidtjørn' ${ }^{4}$, U.S. Kesmodel ${ }^{2,1}$

${ }^{1}$ Department of Public Health, Section for Epidemiology, Aarhus University, Denmark, ${ }^{2}$ The Fertility Clinic, Dept. Of Obstetrics and Gynaecology, Institute of Clinical Medicine, Aarhus University, Denmark, ${ }^{3}$ Institute of Public Health, University of Copenhagen, Denmark, ${ }^{4}$ Epidemiology, Institute of Public Health, University of Southern Denmark

Background: Several follow-up studies have investigated potentially adverse effects of fertility treatment, mostly focusing on perinatal outcomes. In contrast, fewer and smaller studies have been conducted on the longterm development. Comparison of the previous studies is restricted by methodological shortcomings.

Methods: We compared the risk of mental disorders among 33,139 children conceived after fertility treatment and 555,828 children born after spontaneous conception (age group: 8-18 years). We assessed information on exposure to in vitro fertilization/intracytoplasmic sperm injection (IVF/ICSI) and ovulation induction (OI)/intrauterine insemination (IUI) and information on mental disorders from Danish health registers. We estimated the risk of mental disorders while adjusting for potential confounding variables. Further, we estimated the association between subtypes of procedures, hormonal treatment, gamete type and cause of infertility on the one hand and the risk of mental disorders on the other.

Results: The risk of mental disorder in children born after IVF/ICSI compared to spontaneously conceived children was not increased, except for a borderline significant increased risk of tic disorders (HR 1.4 (1.0-1.9)). In contrast, children born after OI/IUI had significantly increased risks of any mental disorder (HR 1.21 (1.11-1.31)), disorders of psychological development (HR $1.2(1.1-1.3)$ ) and behavioural, emotional or social disorders (HR $1.2(1.1-1.4)$ ).

Conclusion: We found an increased risk of mental disorders in children born after OI/IUI, while risk factors for children born after IVF/ICSI were found overall comparable to those of children conceived spontaneously.

P35.05 Natalie Momen PROGRAMMING EFFECTS OF EARLY LIFE EXPOSURES ON CHILDHOOD CANCER: A POPULATION BASED COHORT STUDY IN 7.1 MILLION CHILDREN IN DENMARK, SWEDEN AND FINLAND

N.C. Momen ', J. Olsen ${ }^{1,2}$, M. Gissler ${ }^{3,4}, \mathrm{~J}^{\prime} \mathrm{Li}^{7}$

'Section for Epidemiology, Department of Public Health, Aarhus University, Denmark, ${ }^{2}$ Department of Epidemiology, University of California, USA, ${ }^{3}$ National Institute for Welfare and Health, Finland, ${ }^{4}$ Nordic School of Public Health, Sweden

Childhood cancers are a leading cause of child deaths in affluent countries. Almost half are diagnosed before 5 years of age and the search for preventable risk factors should start in prenatal life.

This project aims to investigate effects of early life exposures on childhood cancer risk, using national registers of Denmark, Sweden and Finland. Potential causal exposures include psychological stress (bereavement in childhood), maternal smoking and use of medication in pregnancy. Research is lacking on the possible effects of stress, and results on smoking and medication are conflicting. Most research has relied on case-control studies, subject to the risk of recall bias; cohort studies have been relatively small and not adjusted for all relevant covariates.

Currently data are held on those born in Denmark (1968-2007) and Sweden (1973-2006), providing information on over 6 million children and almost 
10,000 childhood cancer cases. It is planned that Finnish data will be added. Linking civil, birth, prescription and cancer registries of the 3 countries will provide a cohort of 7.1 million children with data on the exposures, childhood cancers and many covariates; allowing analysis on cancer types, and on levels and timing of exposures (thought to modulate effects)

From birth, follow-up will continue until cancer diagnosis, death, emigration or 14 years of age. Hazard ratios will be estimated by Cox regression, adjusting for possible mediators and confounders such as birth characteristics and maternal factors. The study will be the first to examine the potential effects of early life factors on childhood cancer systematically in a large cohort with a complete follow-up.

\section{CHILDHOOD INFECTION AND SCHIZOPHRENIA IN ADOLESCENCE AND} EARLY ADULTHOOD

\section{P.R. Nielsen, M.E. Benros, P.B. Mortensen}

National Centre for Register-based Research, Aarhus University

Several studies have reported associations between maternal infections during pregnancy and the child's risk of schizophrenia. However, childhood infections have not been studied to the same extent and the results are far from conclusive.

Data from two population based registers, the Danish Psychiatric Central Register and the Danish National Hospital Register were used. We used a historical population-based cohort design and selected all individuals born in Denmark between 1981 and $2000(n=843$ 390). We identified all individuals with a first-time hospital contact with schizophrenia from 1991 through $2010(n=3409)$.

Our results indicate that individuals exposed to a hospital contact with infection during childhood are more likely to develop schizophrenia than individuals without a hospital contact with an infection with a relative risk of schizophrenia of 1.45 (1.35-1.55). The type of infection with the highest risk was bacterial infection, which was associated with an increased risk of schizophrenia 1.73 (1.55-1.92). The site of infection with the highest risk was hepatitis infections, which were associated with a relative risk of 4.05 (1.45 8.71).

In conclusion, the risk of schizophrenia was associated with childhood infections requiring hospitalization, and especially with bacterial infections. The association between childhood infection and schizophrenia may be due to inflammatory responses affecting the brain, or genetic and environmental risk factors aggregating in families.

P35.07 Pia Løvschal- THE SOCIAL BECOMING OF A CHILD WITH CANCER Nielsen P. Løvschal-Nielsen' ', L. Meinert', N. Clausen ${ }^{3}$, C.V. Nielsen ${ }^{4}$

'Institute of Public Health, Dept. of Social Medicine and Rehabilitation, ${ }^{2}$ Institute of Culture and Society, Dept. of Anthropology, ${ }^{3}$ Aarhus University Hospital, Skejby, ${ }^{4}$ Institute of Public Health, Dept. of Social Medicine and Rehabilitation

BACKGROUND: Children with cancer are facing a long period of uncertainty. It is accompanied by social segregation due to illness, therapy and risk of infections. This turns the image of culturally safe childood spaces into defiled spaces. Thus, illness and therapy are preventing the child from being an active child in may ways. Such an atypical childhood seems to leave little space for the child to navigate as child. However, little is known about children's strategies of action, how they are coping with uncertainty and disquiet about thte return to childhood spaces.

AIM: The aim of the study is to explore how children navigate in and out of 
P35.08 Birgit Bjerre Høyer the zones of uncertainty creating options for participation, despite being ill and socially segregated from their familiar environment. This knowledge is central to developing rehabilitation programs for children with cancer whose present and future participation are at risk.

PRELIMINARY FINDINGS: The case study is based on qualitative data generated during a one-year ethnographic fieldwork at the paediatric oncology isolation unit of $\mathrm{AUH}$ and in the home of a young girl. The case study shows how the endeavour for survival drew everybody's attention towards the girl's future, on her 'becoming' (an adult). When therapy ended, the girl's physical becoming seemed within reach. The ban was lifted; childhood spaces were defined as safe again. Despite her bodily weakness and the disquiet of her parent the girl chose friends and plays that demanded her physical participation and strength. Her strategy was aimed at recreating social certainty by being a bodily and social being in the present rather than a future becoming.

MOTOR DEVELOPMENT FOLLOWING IN UTERO EXPOSURE TO P,P'-DDE AND CB-153: A FOLLOW-UP STUDY OF CHILDREN AGED 5-9 YEARS IN GREENLAND, UKRAINE AND POLAND.

\section{B.B. HØYER ${ }^{1,2}$, C.H. Ramlau-Hansen ${ }^{3}$, H.S. Pedersen ${ }^{4}$, J.P. Bonde ${ }^{5}$, G. Toft}

'The Danish Ramazzini Centre, Department of Occupational Medicine, Aarhus University Hospital, Aarhus, Denmark., ${ }^{2}$ Department of Clinical Medicine, Aarhus University, Aarhus, Denmark, ${ }^{3}$ Department of Public Health, Section for Epidemiology, Aarhus University, Aarhus, Denmark., ${ }^{4}$ Centre for Arctic Environmental Medicine, Nuuk, Greenland., ${ }^{5}$ Department of Environmental and Occupational Medicine, Copenhagen University Hospital Bispebjerg, Copenhagen, Denmark.

Introduction and aim:

Polychlorinated biphenyls (PCBs) and the main metabolite of dichlorodiphenyltrichloroetane (DDT), dichlorodiphenyldichloroetene (DDE) are persistent in the environment. Both PCB and DDE are lipophilic compounds which bio-accumulate in adipose tissue and cross the placental barrier. The aim of this study was to examine the association between prenatal exposure to DDE and PCB and motor development and developmental milestones; crawling, standing-up and walking in 5 to 9 year old children.

Material and methods:

In 2002-2004, 1,441 mothers had a blood sample drawn and were interviewed concerning the pregnancy. At follow-up in 2010-2012, a total of 1,118 children were followed up. CB-153 and p,p'-DDE were measured in maternal blood as a bio-marker of the child's prenatal exposure to PCB and $\mathrm{DDE}$. Motor development was measured in terms of the screening tool Developmental Coordination Disorder Questionnaire (DCDQ), and developmental milestones were assessed via parental reports of child age at the first time of crawling, standing up and walking. The association between PCB/DDE and motor skills will be analyzed by means of logistic and multiple regression analyses and the associations between PCB/DDE and milestones will be analyzed by means of multiple regression analyses, using tertiles of exposure. Adjustment will be performed for the following covariates: Maternal age, maternal smoking during pregnancy, maternal alcohol before pregnancy, maternal education, parity, gestational age at blood sampling, preterm birth, breastfeeding, child sex and child age at interview. Analyses are currently being performed and results will be presented at the Ph.D.-day.

P36.01 Trine Allerslev HAEMATOLOGICAL CANCER AND RETURN TO WORK: A REGISTER-BASED Horsbøl COHORT STUDY 
T.A. Horsboel ${ }^{7,2}$, A. de Thurah ${ }^{3}$, B. Nielsen', C. Jensen ${ }^{2}$, C.V. Nielsen ${ }^{2}$

${ }^{1}$ Department of Haematology, Aarhus University Hospital, ${ }^{2}$ Department of Clinical Social Med., Public Health and Quality Improvement, Central Denmark Region and Department of Clinical Social Med. and Rehabilitation, School of Public Health, University of Aarhus, Denmark, ${ }^{3}$ Institute of Public Health, University of Aarhus, Denmark

Purpose: The aims of this study were to determine return to work (RTW) rates in a cohort of patients diagnosed with haematological cancer and to explore if socioeconomic, demographic and clinical factors were associated with RTW.

Materials and methods: The study population consisted of all individuals diagnosed with haematological cancer in Denmark between 2000 and 2007, who were aged 19-55 years at time of diagnosis, and who were on long-term sick leave after diagnosis $(n=1660)$.

Data were obtained from national registers, and all individuals were followed until 1 March 2012.

Cumulative incidence curves were computed to illustrate the course of RTW according to diagnosis, and Cox regression analyses were conducted to compare time to RTW between subgroups in the study population.

Results: The proportion of RTW for survivors was $49 \%$ one year after diagnosis and $80 \%$ four years after diagnosis.

According to our preliminary univariate analyses, use of antidepressants or anxiolytics after diagnosis was negatively associated with time to RTW (HR, 0.64; 95\% Cl 0.53-0.77). Patients with acute leukaemia and with myelomatosis had delayed time to RTW compared to patients with Hodgkin lymphoma ( $\mathrm{HR}_{\text {acute leukaemia }}, 0.46 ; 95 \% \mathrm{Cl}$ 0.38-0.57 and $\mathrm{HR}_{\text {myelomatosis, }}$ 0.33; $95 \% \mathrm{Cl}$ 0.25-0.44)

Female gender, lower education, lower income, being single, having no children and higher age were also negatively associated with RTW, whereas housing tenure and ethnicity were not related to time to RTW.

Conclusion: Univariate analyses suggest that most of the factors evaluated were associated with RTW, but multivariate analyses are ongoing and results of these are expected to be ready for presentation at the conference.

P36.02 Charlotte Handberg
MALE CANCER SURVIVORS PARTICIPATION IN MUNICIPAL CANCER REHABILITATION - A QUALITATIVE STUDY OF THE MALE AND THE HEALTH PROFESSIONAL PERSPECTIVE

\section{Handberg, ${ }^{1,2}$, C.V. Nielsen ${ }^{7,2}$, K. Lomborg ${ }^{3}$, J. Midtgaard ${ }^{4}$}

'Public Health and Quality Improvement - Centre for Research and Development in Social and Health Services, ${ }^{2}$ Department of Public Health, Section of Clinical Social Medicine and Rehabilitation, Aarhus University, ${ }^{3}$ Department of Public Health, Section of Nursing Science, Aarhus University, ${ }^{4}$ University Hospital Centre for Nursing and Care Research, Copenhagen

Aim: To establish a specific, research-based knowledge base for rehabilitation of male cancer survivors:

1) Describe and analyze the male cancer survivors lack of participation in municipal cancer rehabilitation and

2) Describe and analyze the health professional's perspective on men's participation in cancer rehabilitation

Method and materials: Qualitative method and the design to answer the research questions is Interpretive Description.

Data (interview, participant observation, documents) are generated by field studies at theAarhusUniversityHospital, oncology department and 3 
municipalities in Central Region of Denmark. The informants are male cancersurvivors and health professionels.

Data are conducted and analyzed over 1 year.

The project places itself within a sociological science tradition inspired by Herbert Blumer's theory of symbolic interactionism and builds on the assumption that rehabilitation is a collaboration between the professional, the patient and the relatives.

The target group are cancer survivors at risk of having substantial limitations in their functional ability.

Expected outcome: Acquired knowledge is disseminated in 4 scientific articles which hopefully will inform practice with important new knowledge.

Perspective: The perspective is on a research-based foundation to develop rehabilitation services that prevent complications and sequelae of cancer and enhances quality of life among male cancer survivors.

P36.03 Lotte Dahl Kristensen

LIFE AFTER CANCER: CHANGING THE PARADIGM OF FOLLOW-UP FOR LOW-STAGE GYNECOLOGICAL CANCER PATIENTS

\section{Dahl', I. Wittrup ${ }^{2}$, U. Vceggemose ${ }^{2}$, L.K.Petersen' , J. Blaakcer \\ 'Department of Gynecology and Obstetrics, Aarhus University Hospital, Denmark, ${ }^{2}$ CFK, Public Health and Quality Improvement}

Objectives: Each year about 1,800 new cases of gynaecological cancer arise in Denmark. After treatment, more than $90 \%$ of these patients complete a five-year follow-up programme. Evidence now reveals that this follow-up programme does not improve survival for the low-stage gynaecological cancer patients. We do not know how attending a followup programme affects the patients' quality of life (QoL) or if the existing follow-up programme meets patient needs. The aim of our study is to gain a deeper insight in QoL after cancer and the patients' needs regarding followup. In the light of this, we will suggest an alternative follow-up strategy.

Materials and methods: We include low-stage gynaecological cancer patients cured by surgery alone. Our data consist of an observational study of 18 follow-up visits, semi-structured individual interviews with seven patients, three focus-group interviews with health professionals and a large national survey including all women getting a diagnose of low stage gynaecological cancer during one year.

Preliminary results: QoL after cancer does not seem to be impaired. The patients use the follow-up as a kind of anchor that gives them comfort and security. The factor having the greatest influence on QoL after cancer is fear of recurrence and how they manage to cope with this fear.

Perspectives: We expect our new follow-up strategy to improve satisfaction for the patients as well as for the health professionals and to improve QoL for the patients. We believe that, with a few changes, this new model can also be applied to follow-up of other cancer forms. This means a more reasonable use of resources in the healthcare system.

P36.04 Louise Mahncke

EFFECT OF DIRECT REFERRAL FOR FAST CT SCAN IN EARLY LUNG CANCER DETECTION IN GENERAL PRACTICE. A CLINICAL CLUSTER-RANDOMISED TRIAL.

\section{L.M. Guldbrandt}

Department of Public Health

Background: Lung cancer (LC) is one of the most frequent cancers in Denmark. Its prognosis is heavily dependent on the stage at diagnosis. Chest $\mathrm{x}$-ray is a principal LC diagnostic tool in primary care. $15-25 \%$ of all LC patients have had a false negative $x$-ray before their diagnosis. On the other 
hand, it is shown that a CT scan has a high sensitivity, also for small tumours.

Objectives: To investigate the effect of a specific training programme in the diagnosis of lung cancer in general practice combined with direct access to fast, just-in-time low-dose CT scans to diagnose LC. Further, to evaluate the general practitioners' (GPs') satisfaction with CT as a diagnostic tool.

Design: We performed a cluster-randomised, two-armed clinical trial.

Methods: A total of 120 practices comprising 278 GPs in the catchment area of Aarhus University Hospital, Department of Pulmonary Medicine, were randomized into two groups. The intervention group was offered education about early LC diagnosis and direct access to CT scans, whereas the GPs in the control group referred their patients according to national guidelines.

Main outcomes: Length of diagnostic intervals and LC stage at diagnosis. Use of CT, fast-track and adverse events.

Perspectives: This project will provide a unique opportunity to gather the necessary knowledge about the effects of direct referral for fast CT scan when lung cancer is suspected. The programme may inform the decision to introduce direct referral for CT scans in general practice for a group of patients. The study will provide new knowledge about which diagnostic examination yields the shortest diagnostic interval.

Trial registration: clinicaltrials.gov: NCT01527214.

P36.05 Christina Maar DOES ATTACHMENT STYLE AFFECT PATIENT AND DOCTOR DELAY IN Andersen CANCER INVESTIGATION?

\section{C.M. Andersen, A.F. Pedersen, F. Olesen, P. Vedsted}

Research Centre for Cancer Diagnosis in Primary Care - CaP, Research Unit for General Practice, Department of Public Health, Aarhus University.

Research has shown that delay in cancer diagnosis can have serious consequences for the patients' prognosis and survival. The delay may partly be due to patients' delay of medical help-seeking, GP's lack of suspicion of serious disease and poor doctor-patient communication. This project focuses on the period from when the cancer patient experiences his/her first symptom of the disease until referral to diagnostic investigation. The time interval can be divided into patient delay and doctor delay.

Knowledge about psychological factors that may cause patient and doctor delay is limited, but will be essential in an intervention aimed at preventing delay. The attachment theory seems to be able to contribute as an explanatory model. This theory describes the evolutionary and developmental origin of patterns of close interpersonal relationships.

The aim of the present project is to examine whether attachment styles in GPs as well as in their patients influence length of patient delay and doctor delay in patients diagnosed with cancer. Interactions between patients' and GPs' attachment styles on patient and doctor delay will also be explored.

The project is a cross-sectional study based on registry data and questionnaires. The sample consists of newly diagnosed cancer patients ( $>18 \mathrm{yrs}$ ) from the Central Denmark Region and their GP. During one year of recruitment, a total of 3500 patients will be invited to participate.

If the results of the project show an association between delay in the diagnostic process and patients' and or GPs' attachment styles, this knowledge will be highly relevant in medical education and specialty training in general medicine. 


\section{M.L. Ingeman}

The Research Unit for General Practice, Aarhus University

Denmark has a high cancer morbidity and mortality compared to the rest of Western Europe. A longer diagnostic delay in Danish cancer patients probably plays an important role in these findings. As a result, fast tracks for patients with classic organ-specific alarm symptoms are currently in use, but only $50 \%$ of cancer patients had alarm symptoms at their first visit to their General Practitioner. In the light of these results, several new initiatives concerning the examination of patients with uncharacteristic or atypical symptoms are on their way. The Central Denmark Region has selected Silkeborg Regional Hospital to establish a fast track for patients with suspected occult cancer or other serious disease without organ-specific symptoms - a non-organ-specific fast track.

There is no scientific evidence of the effect of a non-organ-specific fast track. To our knowledge, no similar projects have been set up internationally. Furthermore, we do not know how the GPs will use this fast track in their diagnostic strategy nor which factors will influence this.

This project is a population-based, prospective questionnaire and registrybased study, and the aim is to examine GPs' need for and use of the nonorgan-specific fast track as well as to examine who is referred and why. Additionally, the results of the fast track will be examined.

P36.07 Peter Hjertholm VARIATION IN PROSTATE SPECIFIC ANTIGEN (PSA) TEST ORDERING AMONG DANISH GENERAL PRACTITIONERS AND THE INCIDENCE AND PROGNOSIS OF PROSTATE CANCER

P. Hjertholm, M. Fenger-Grøn, M.B. Christensen, M. Vestergaard, P. Vedsted

Research Unit for General Practice, Aarhus University

Background: Prostate cancer is the most common cancer among men and the incidence has increased dramatically in the last 15 years. Prostate specific antigen (PSA) testing is often used as a diagnostic tool, but screening is not recommended in Denmark. Thus, there are great variations in general practitioners' use of PSA testing. The aim of this study is to investigate whether this variation influences the incidence and prognosis of prostate cancer.

Methods: In a register-based historical cohort study using prospectively collected data, we investigate the use of PSA testing in the Central Denmark Region in 2004-2009. The cohort consists of all men in Health Insurance Group 1 aged 40 years or more $(n=348.476)$. In Denmark $99 \%$ of men are registered with a specific practice. The variation in PSA-testing rates among general practices $(n=509)$ is used as the exposure measure in an analysis of the incidence of prostate cancer and in a survival analysis of prostate cancer patients. The model will include relevant confounding variables.

Perspectives: The study will provide information about the consequences of the variations that exist among GPs' use of PSA as a diagnostic test. This will increase our understanding and form a basis for future recommendations regarding $P S A$ testing.

P36.08 Henry Jensen REDUCED DELAY IN DIAGNOSIS OF CANCER AFTER IMPLEMENTATION OF 'FAST TRACK'

H. Jensen ${ }^{\text {T, }}$, M.L. Tørring ${ }^{\text {T }}$, P. Vedsted ${ }^{7}$

'Research Centre for Cancer Diagnosis in Primary Care - CaP, The Research Unit for General Practice, Department of Public Health, Aarhus University, Denmark, ${ }^{2}$ Section for General Medical Practice, Department of Public Health, Aarhus University, Denmark

Background: In 2004, system delays, particularly in relation to diagnosing 
cancer, accounted for a substantial part of the total delay experienced by Danish cancers patients. In 2008, the Danish government introduced the National Integrated Cancer Pathways ('fast track') to reduce delays in diagnosis and treatment by re-organising the diagnostic cancer pathway.

Design: A national natural experiment with before and after analysis of time intervals. We sampled incident cancer patients in 2004/05, 2007/08 and in 2010 . The primary outcome was the total interval time, defined as the time from onset of cancer-related symptoms to start of treatment of cancer. Secondary outcomes were the patient, doctor and system intervals.

Results: From 2004 to 2010, total time interval decreased from 99 (58-168) days to 80 (43-152) days ( $p<0.001$ ), the patient interval decreased from 21 $(7-56)$ to $14(1-56)$ days $(\mathrm{p}<0.001)$, and system interval decreased from 55 (32-93) to 46 (27-83) days. The decrease in system interval occurred from $2004 / 05$ to $2007 / 08$ ( $p<0.001$ ) and sustained to 2010 ( $p=0.390)$. The doctor interval did not change over the period $(p=0.599)$, nor did the treatment interval $(p=0.266)$.

Lessons learnt and take-home message: In general, we saw a decrease in time intervals after the implementation of 'fast track' in Denmark, but the difference in treatment interval was not statistically significant.

The reduction in time intervals seemed to occur already from 2004/2005 to $2007 / 2008$, i.e. prior to the implementation of 'fast track' - indicating that other factors may also have influenced the length of the cancer diagnostic pathways. Further investigation of these factors and their impact is needed.

P37.01 Annesofie Lunde Jensen

\section{OSTEOPOROSIS GROUP EDUCATION: A WAY TO HEALTH MAINTENANCE}

\section{A.L. Jensen' ', G. Wing ${ }^{2}$, B. Langdahl ${ }^{3}$, K. Lomborg ${ }^{7}$}

${ }^{1}$ Department of Public Health, Section of nursing, ${ }^{2}$ Faculty of Arts, Department of Culture and Society, ${ }^{3}$ Department of Endocrinology and Internal Medicine, Aarhus University Hospital

Patient education has a number of potential advantages, and different criteria can be used to determine how patients with osteoporosis receive, employ and incorporate health care information. The existing knowledge of how patients with osteoporosis receive group education and integrate health care information into their daily lives is insufficient.

Our study describes how the osteoporosis group education progressed and focuses on the specific educational needs revealed by the patients' experiences.

The group education aimed to improve the patients' quality of life by providing information about the disease and counselling them about living with osteoporosis. Two classes were set up: one for patients with a vertebral fracture and one for patients without a vertebral fracture.

We used an interpretive description model with two groups of patients with osteoporosis. One group of informants included 20 patients starting group education. Our data consisted of semi-structured interviews before and 6 months after the group education and participant observation during the classes and the patients' everyday life. The other group comprised 331 programme attendees from 2006-2010 who answered a questionnaire, and 24 programme attendees from 2007 were interviewed.

We found that the participants needed clarification and simple guidelines on how to live with osteoporosis. Our findings support the fact that our disease-specific knowledge is incomplete and must be contextualised. Further, the composition of the class in general and the age and disease intensity of the informants in particular were important for how the patients experienced and benefitted from the group education. 


\section{Flarup, G. Moth, P. Vedsted, M.B. Christensen, M. Vestergaard, F. Olesen}

Research Unit for General Practice, Aarhus University

Background: In Denmark, general practice is the first line in a tax-financed healthcare system. Denmark has a high consumption of contacts to GPs outside daytime (Out-Of-Hours, $\mathrm{OOH}$ ). However, knowledge of the clinical and organisational aspects of $\mathrm{OOH}$ contacts is sparse. The aim was to describe the methods used for integrating a questionnaire unit into an existing electronic patient database and to present the registered reasons for encounter (RFE) at the $\mathrm{OOH}$.

Methods and materials: A prospective cross-sectional 1-year project, LVKOS2010, was conducted in the Central Denmark Region (1.25 million inhabitants) from May 2010 to May 2011 . Electronic pop-up questionnaires to the GPs were integrated into the $\mathrm{OOH}$ IT-system and popped up at varying intervals depending upon the type of contact. Data were automatically transferred to a database. RFEs stated in texts were coded using the ICPC-2 classification system.

Results: $98.4 \%$ of all $\mathrm{OOH}$ shifts were covered. In total, 387 representative GPs participated registering22,251 unique contacts. Approx. $60 \%$ of calls were terminated on the phone with advice or prescriptions. Children were highly represented in the telephone and consultation contacts. Home visits were primarily offered to older patients. Fever and other symptoms of infection were among the five most frequent RFEs.

Conclusion: The method of integrating electronic questionnaires into the existing $\mathrm{OOH}$ IT-system proved to be a highly feasible way to collect data on $\mathrm{OOH}$ contacts. We have generated significant data for scientific and clinical purposes.

P37.03 Kasper Grosen PREDICTION OF POSTOPERATIVE PAIN FOLLOWING CHEST WALL SURGERY

K. Grosen' , L. Vase ${ }^{2}$, M.P. Jensen ${ }^{3}$, H.K. Pilegaard' , A.M. Drewes ${ }^{4}$

'Department of Cardiothoracic and Vascular Surgery, Aarhus University Hospital, ${ }^{2}$ Department of Psychology, Aarhus University, ${ }^{3}$ Department of Rheumatology, Aarhus University Hospital, ${ }^{4}$ Mech-Sense, Department of Gastroenterology and Hepatology, Aarhus University Hospital

Aim of Investigation:

To predict the extent of clinical postoperative pain pain by preoperative experimental pain stimulation.

Methods: Patients $>15$ years of age scheduled for elective minimally invasive repair of pectus excavatum are enrolled in the study from May 2011 to May 2012. The difference in pressure pain thresholds (PPTs) before and after cold pressor test (CPT) indicates the effect of conditioned pain modulation. Hence, PPTs measured on the quadriceps muscle using a handheld pressure algometer serves as the 'test' stimulus and the cold pressor test ( $120 \mathrm{sec} . / 1$ degree Celsius) serves as the 'conditioning' stimulus. Patients recorded the daily intensity and discomfort associated with their postoperative pain and use of analgesics in a study-specific diary using 11 point numerical rating scales for up to six weeks postoperatively.

Results: Forty-one pain-free male patients undergoing surgical correction of funnel chest were available for follow-up of acute postoperative pain. Patients with efficient conditioned pain modulation consumed less morphine postoperatively than patients with inefficient conditioned pain modulation ( $F=6.0 ; P=0.015)$.

Conclusions: Preoperative assessment of conditioned pain modulation may 
be useful in predicting the time course of clinical postoperative pain and requirements for opioid analgesics. ENVIRONMENT - A QUALITATIVE INQUIRY \\ C. Timmermann' ${ }^{\text {, L. Uhrenfeldt }}{ }^{2}$, M. Terp Høybye ${ }^{3}$, R. Birkelund ${ }^{4}$ \\ ${ }^{1}$ Department of Public Health (Nursing Science), Health, Aarhus University, ${ }^{2}$ Department of Nursing Science, Health, Aarhus University, ${ }^{3} \mathrm{National}$ Institute of Health, University of Southern Denmark, ${ }^{4}$ Department of Nursing Science, Health, Aarhus University}

EXPERIENCING LIFE-THREATENING ILLNESS IN THE HOSPITAL

Aim: This study explores and describes how hospitalized patients with a lifethreatening illness experience the meaning of sensory impressions in the hospital environment such as the architectural space, the interior, decoration and natural daylight.

Background: Existing research is based mainly on quantitative methods and focused on how various sensory impressions in the hospital environment can reduce length of hospital stay, need of pain killers, anxiety and stress. However, healthcare research exploring the thoughts and experiences of hospitalized patients with a life-threatening illness are few.

Method: Data is obtained at a general hospital in Denmark through ethnographic fieldwork consisting of observations and qualitative interviews. Twelve patients participated in the study during their hospitalization and each patient is interviewed several times. The analysis process is guided by the hermeneutical-phenomenological theory of interpretation as presented by the French philosopher Paul Ricoeur.

Results: The participants experience that aesthetic sensory impressions in the hospital environment has a significant impact on their mood, generating positive thoughts and feelings and a sense of hope. Our findings also show that a more homelike hospital environment brings a sense of inner peace and offers the patients the ability to dwell.

Conclusion: Aesthetics and homely sensory impressions in the hospital environment influence patients' experience of existential phenomena's such as life-courage, hope and inner peace and can be conducive to general well-being and emotional empowerment.

P37.05 Ethel Mary Brinda Alexander
NATURE AND DETERMINANTS OF OUT-OF-POCKET HEALTH EXPENDITURE AMONG OLDER PEOPLE IN A RURAL INDIAN COMMUNITY

E.M. Brinda ${ }^{7}$, A.P. Rajkumar ${ }^{2,3}$, U. Enemark' ${ }^{7}$, M. Prince ${ }^{4}$, K.S. Jacob ${ }^{3}$

'Department of Public Health (Section for Health Services Research), Aarhus University, Aarhus-8000, Denmark, ${ }^{2}$ Department of Biomedicine, Aarhus University, Aarhus-8000, Denmark, ${ }^{3}$ Department of psychiatry, Christian Medical College, Vellore-632002, India, ${ }^{4}$ Department of health service and population research, Institute of Psychiatry, London, UK

Background: Increasing out-of-pocket health expenditure among older people worsens the inequitable access to essential health services in lowand middle-income countries (LMIC). We investigated various socioeconomic and health factors associated with out-of-pocket and catastrophic health expenditures among rural older people in India.

Methods: We recruited 1,000 participants aged above 65 years from Kaniyambadi block, Vellore, India. We assessed their out-of-pocket health expenditure, health service utilization, socioeconomic profiles, disability, cognition, and health status by standard instruments. We employed appropriate multivariate statistics evaluating these determinants.

Results: Male gender, poor sanitation, diabetes, tuberculosis, malaria, respiratory ailments, gastrointestinal diseases, dementia, depression and 
P37.06 Line Flytkjœr Jensen disability were associated with higher out-of-pocket expenditures. Illiteracy, tuberculosis, diabetes and dementia increased the risk for catastrophic health expenditures, while pension schemes protected against it. Income inequalities were associated with inequities on education, disease prevalence, and access to safe water, sanitation and nutrition.

Conclusions: Interactions between determinants of out-of-pocket health expenditure, economic inequality, and inequities on essential health care delivery to older people are complex. We highlight the need for equitable health services and policies, focusing on both medical and social determinants.

\section{THE ASSOCIATION BETWEEN DISTANCE TO SCREENING UNIT AND PARTICIPATION}

\section{L.F. Jensen, Anette Fischer Pedersen, Berit Andersen, Peter Vedsted}

Research Unit for General Practice, Aarhus University

When implementing a population-based screening programme, the geographical accessibility to screening units is an important issue to consider as this may influence a woman's ability to participate. Therefore, the aim of this study was to analyze the association between distance and participation in a breast cancer screening programme.

All women invited to the first round of breast cancer screening in the Central Denmark Region were eligible for inclusion ( $n=149,234)$. Participation in breast cancer screening was collected from a regional administrative database. The shortest road distance between each woman's residence and the screening unit was assessed using Network Analyst, ArcGIS. A cubic spline method was used to study the association between distance and participation.

In the unadjusted analyses, a U-shaped association was found between distance and participation indicating that both women living close to the screening unit (i.e. $<10 \mathrm{~km}$ ) and women living more than $15 \mathrm{~km}$ away were more likely not to participate compared with women living approximately $12 \mathrm{~km}$ from the screening unit. When adjusting for socio-demographic variables and assessing the impact of access to vehicle, the U-shaped association disappeared and now only women living far away from the screening unit were more likely not to participate.

When adjusting for socio-demography, women living more than $20 \mathrm{~km}$ from the screening unit were more likely not to participate in breast cancer screening. Women living less than $10 \mathrm{~km}$ away from the screening unit were also more likely not to participate; not because of distance, but because of their socio-demographic characteristics.

P37.07 Maria Theresa PHARMACO-EPIDEMIOLOGIC STUDY OF PREDICTORS FOR CLOZAPINE Wimberley TREATMENT IN PATIENTS WITH TREATMENT RESISTANT SCHIZOPHRENIA Böttger

\author{
T. Wimberley ${ }^{7}$, H. Støvring ${ }^{2}$, C. Gasse ${ }^{\text {l }}$ \\ ${ }^{1}$ National Centre of Register-based Research, Aarhus University, \\ ${ }^{2}$ Department of Public Health, Biostatistics, Aarhus University
}

Objective: Clozapine (clz) is recommended in treatment resistant schizophrenia (sz). Though approximately $30 \%$ of sz patients meet the criteria for initiating $\mathrm{clz}$, fewer actually start clz or the initiation is postponed probably due to the risk of severe side effects and mandatory regular blood monitoring. However, little is known about predictors which could identify patients eligible for $\mathrm{clz}$ and who would benefit from clz at an earlier stage, even before first-line treatment with other antipsychotics has failed. The first objective is to describe the current situation and determine time to and predictors of $\mathrm{clz}$ initiation.

Methods: Register-based linkage study using Danish data of all patients 
P37.08 Camilla Hoffmann Merrild
P38.01 Noora Ronkainen newly diagnosed with sz from 1995 to 2006 and their prescription (rx) information on antipsychotics over a 15-year period (1995-2010). Logistic regression analysis was performed to identify factors associated with $\mathrm{clz}$ initiation.

Results: Preliminary analyses show that $12.8 \%$ of sz patients $(N=12,566)$ filled their first rx for clz 2.3 years (median, IQR: 1.0-5.0) after their first diagnosis of sz. Female gender was associated with increased clz treatment, $O R=1.2$ (95\% Cl: 1.1-1.3), as well as $>50$ hospital days at first sz diagnosis, $O R=2.4$ (95\% Cl: 2.2-2.8), while older age at onset and later diagnosis were associated with up to $10 \%$ decreased odds per year.

Outlook: Future analyses will include somatic and psychiatric comorbidity, hospital admissions, other antipsychotic prescriptions and co-medications as well as other potential predictors to be identified from the existing literature with the aim of developing a prediction model for clozapine treatment response.

THE EMBODIMENT OF SOCIAL INEQUALITY: A COMPARATIVE ANTHROPOLOGICAL STUDY OF HEALTH SEEKING PRACTICES IN TWO DIFFERENT SOCIAL GROUPS

\section{Hoffmann Merrild ', R. Sand Andersen ', M. Bech Risør', P. Vedsted ${ }^{7}$}

'Danish Research Centre for Cancer Diagnosis in Primary Care (CAP), The Research Unit for General Practice, Department of Public Health, Aarhus University, ${ }^{2}$ Institutt for samfunnsmedisin Allmennmedisinsk forskningsenhet Det helsevitenskapelige fakultet Universitetet i Troms $\varnothing$

Background: Cancer is like most other health problems marked by social inequality, as people with a lower socioeconomic position (SEP) are more likely to die from their cancer disease than people with higher SEP. Research has suggested differences in stage of cancer at the time of diagnosis or of treatment as a major contributing factor to this disparity, but the processes leading to the differences in the timing of diagnosis are not well known. In fact we know very little about the timing of health seeking, what illness is taken to mean, how the body is interpreted and acted upon or how health seeking is practiced in the everyday life of different social groups.

Objective: To improve our understanding of the social differences in the timing of cancer diagnosis by prospectively seeking out an understanding of the way in which bodily changes and sensations are experienced and managed in different social groups in the healthy population.

Method: A longitudinal comparative anthropological fieldwork among two different social groups; the deprived and advantaged, respectively. Focus is on the practice of everyday life and the embodied experiences and processes which unfold when shifting from feeling 'fine' to feeling 'sick' prior to the care seeking. The methods used are participant observation, health diaries and repeated qualitative interviews.

Perspectives: The project will elucidate the ways in which illness is perceived, managed or prevented in different social groups. This will bring forth new knowledge on health seeking practices and how they are established, and provide a unique insight into the social processes surrounding social inequality in health.

RUNNING IN BEIJING - AN EXISTENTIAL INVESTIGATION OF CHALLENGED RUNNER IDENTITIES

N.J. Ronkainen ${ }^{\text {I M.E. Harrison }}{ }^{2}$, T.V. Ryba ${ }^{7}$

'Department of Public Health, Aarhus University, ${ }^{2}$ Department of English and Writing, University of Tampa 
This research explores expatriate runners' migration experiences to Beijing, China. The number of employees working internationally has increased rapidly, and several researchers have noted expatriates' difficulties in adaption (Chiu et al. 2009). While there is a body of research on the topic, there is a lack of studies on the role of athletic career in the process. However, athletic careers can be central identity projects in all levels, and threatened participation may raise similar psychological difficulties for both elite and recreational athletes (Lamont-Mills \& Christensen, 2006).

The data were collected during four months of ethnographic fieldwork in 2011 and 2012. The findings are interpreted within an existential psychology framework (Nesti 2004).

All runners experienced difficulties with the air quality, traffic and lack of running routes. The evaluation of the quality of the running experience in Beijing varied from 'adventure' to 'suffering'. For some, meaning in running shifted from performance to discovery and enjoyment of running and runner community. International companies could significantly support their employees' adaptation to foreign countries by providing information on sport facilities and training groups.

\section{References:}

Chiu, Y., Wu, M., Zhuang, W., \& Hsu, Y. (2009). Influences on expatriate social networks in China. The International Journal of Human Resource Management, 20, 790-809.

Nesti, M. (2004). Existential psychology and sport: Theory and application. London: Routledge.

Lamont-Mills, A., \& Christensen, S. (2006). Athletic identity and its relationship to sport participation level. Journal of Science and Medicine in Sport, 9, 472478.

\section{P. Corraini, V. Baelum, R. Lopez}

Department of Dentistry, Health, Aarhus University

Aims: To assess the intra-examiner reliability of clinical periodontal measurements, compare the reliability of direct versus indirect clinical attachment level (CAL) measurements, and investigate factors influencing intra-examiner reliability in adult subjects with a broad spectrum of periodontal conditions.

Materials and methods: Of 192 subjects volunteering in a prospective study on non-surgical periodontal therapy, 151 were eligible and 148 were clinically examined at baseline and approximately one week later. At both time points, a single trained examiner performed measurements of probing depth (PD), direct CAL (CALDIR) and gingival recession (GR) in 6 sites per tooth in all teeth, excluding third molars. The indirect CAL (CALIND) was calculated on the basis of PD and GR measurements.

Results: From a total of 22,740 duplicate measurements of CALDIR, PD, GR and $\mathrm{CAL}_{\text {IND }}$, exact agreement was observed in $64.5 \%, 69.1 \%, 84.2 \%$ and $61.6 \%$ of the recordings, whereas differences $\pm 1 \mathrm{~mm}$ were observed in $96.5 \%, 97.2 \%, 99.5 \%$ and $95.1 \%$ of the recordings, respectively. Multilevel logistic regression analyses showed that absolute measurement error $\geq 1$ $\mathrm{mm}$ was associated with type of site, teeth and subject characteristics ( $p \leq$ 0.01).

Conclusions: The reliability observed in this study was higher than those previously reported. CAL Reliability was associated with site, tooth location and subject characteristics. 


\author{
A.M.L. Würtz ${ }^{7}$, E.B. Schmidt ${ }^{2}$, K. Overvad ${ }^{7,2}$, M.U. Jakobsen ${ }^{7}$ \\ ${ }^{1}$ Section for Epidemiology, Department of Public Health, Aarhus University, \\ ${ }^{2}$ Department of Cardiology, Center for Cardiovascular Research, Aalborg \\ Hospital, Aarhus University Hospital \\ Background: Ischemic heart disease (IHD) remains a leading cause of \\ morbidity and mortality in most Western countries. Preventive strategies are \\ thus needed, and diet is an important modifiable risk factor. Most previous \\ studies on associations between diet and IHD have focussed on \\ macronutrients, and studies examining specific food groups have not \\ specified alternative food choices.
}

Objectives: The aims of this $\mathrm{PhD}$ project are to investigate substitutions for IHD prevention within and between the food groups of red meat, poultry and fish, and to investigate substitutions of red meat by vegetables and starchy foods.

Methods: The associations will be investigated in the prospective Danish Diet, Cancer and Health cohort of 57,053 men and women and replicated in the two larger American cohorts, Nurses' Health Study and Health Professionals Follow-up Study, including 173,229 participants altogether. Substitution models with an isocaloric approach will be used to calculate hazard ratios with $95 \%$ confidence intervals for replacement of red meat by poultry, fish, vegetables or starchy foods and among subtypes within these food groups.

Perspectives: Findings from the project, together with findings from other studies on food substitutions, will be translated into dietary recommendations for IHD prevention in the general population and tested in a randomised, controlled trial. This will provide important knowledge for improvement of existing dietary guidelines and for regulatory initiatives, such as food labelling and taxation.

P38.04 Gitte Susanne STRUCTURED PATIENT EDUCATION TO YOUNG PEOPLE WITH PSORIASIS: Rasmussen ANALYZING FOCUS GROUP DISCUSSIONS

\title{
G.S. Rasmussen ${ }^{7}$, H.T. Maindal', K. Kragballe' ${ }^{7}$ K. Lomborg ${ }^{2}$ \\ ${ }^{1}$ Department of Dermatology, Aarhus University Hospital, ${ }^{2}$ Department of Public Health, Aarhus University
}

Young people with psoriasis struggle to make the disease fit into their lives and minimize its influence on their appearance and social functioning. Among health scientists, there is a growing recognition of psoriasis as a serious chronic autoimmune skin disease with long-term impairment on the life course. The aim of this study is to interpret and describe the need for structured patient education to support self-management of psoriasis in everyday life in young people and their families, focusing on the first years of illness trajectory. In accordance with the interpretive description research strategy, we designed three different focus group discussions with young people at the age of 15-17 years, 18-20 years and 21-24 years to obtain a deeper and more nuanced understanding of the meaning of psoriasis in their everyday life. The content of this presentation is based on the preliminary analysis of the focus group discussions. The inductive analysis is currently ongoing, but salient first impressions appeared with "loneliness" as the most obvious. Furthermore, the themes "psoriasis as identity creator", "mothers working overtime in the health care system", "self limitation", "tripping oneself up" and "lack of disease-related linguistic tools" seem to be prevalent. In addition, it was evident that the participation in focus group discussions in itself had a therapeutic effect. The interpretive description will facilitate the development of components that should tailor an educational 
intervention and support the decision about the appropriate structure of the programme.

P38.05 Nanna Rolving DOES A PREOPERATIVE COGNITIVE INTERVENTION IMPROVE RETURN TO Rasmussen WORK AND DAILY LIFE IN PATIENTS UNDERGOING LUMBAR SPINAL FUSION SURGERY?
N.R. Rasmussen', L. Østergaard ', F.B. Christensen ${ }^{2}$, C. Bünger ${ }^{3}$, C.V. Nielsen ${ }^{4,5}$
'Department of Physiotherapy and Occupational Therapy, Aarhus University Hospital, ${ }^{2}$ Aarhus University, ${ }^{3}$ Department of Orthopedic Surgery, Aarhus University Hospital, ${ }^{4}$ Department of Public Health, Aarhus University, ${ }^{5}$ Public Health and Quality Improvement, Central Denmark Region

Background: Lumbar spinal fusion (LSF) surgery is a commonly offered treatment for chronic low back pain (CLBP) when conservative treatment has proven unsuccessful. Although high rates of radiographic fusion are achieved, many individuals continue to report pain and disability. Research has found certain psychological characteristics such as maladaptive coping strategies, fear-avoidance beliefs and pain catastrophizing to be predictive of worse outcomes on pain and disability after spine surgery. These determinants have proven susceptible to interventions using a cognitive behavioural (CB) approach, but this is not well investigated in LSF patients. Multidisciplinary rehabilitation has also shown positive effects, but more evidence is needed for LSF patients.

Aim: To examine the effect of a multidisciplinary CB intervention on disability, pain and return to work in LSF patients.

\section{Design: RCT}

Materials and methods: The study is powered to detect a difference of 13 points on the Oswestry Disability Index at a $5 \%$ significance level. Inclusion of patients was initiated in October 2011 and is ongoing. Patients are randomly allocated on a 2:1 ratio to either the intervention or treatment as usual. In the intervention group, patients are offered a well-defined 18-hour patient education in addition to usual treatment. The patient education brings into focus pain coping, training, and return to worklife and daily activities using a CB approach. Effect is measured on disability (primary outcome), pain, return to work, hospitalization, psychological parameters, quality of life and costs. Follow-up will be completed at 1 month, 3 months, 6 months and one year after surgery.

P38.06 Trine Nøhr Winding

\section{PERSONAL PREDICTORS OF EDUCATIONAL ATTAINMENT AFTER COMPULSORY SCHOOL: INFLUENCE OF MEASURES OF VULNERABILITY, HEALTH AND SCHOOL PERFORMANCE}

\author{
T.N. Winding' , E.A. Nøhr', M. Labriola ', K. Biering' , J.H. Andersen ${ }^{7}$ \\ 'Danish Ramazzini Centre, Department of Occupational Medicine, Regional \\ Hospital Herning,., 'Department of Public Health, Section for Epidemiology, \\ Aarhus University
}

Aims: Getting a secondary education is essential in preventing future inequalities in health and socioeconomic status. We investigated to what degree personal predictors like low school performance, high vulnerability and poor health status are associated with not completing a secondary education in a Danish youth cohort.

Methods: This prospective study used data from a questionnaire in 2004 and register data from 2003 to 2010 . The study population consisted of 3053 adolescents born in 1989. Information on educational attainment from Statistics Denmark was divided into 4 categories: completed, still studying, dropped out or never attained a secondary education. Data was analysed using multinomial logistic regression.

Results: Low grades when completing compulsory school predicted not 
P38.07 Mette Kjœrgaard Nielsen

P38.08 Else-Marie Dalsgaard having completed a secondary education by age 20/21 (odds ratios (OR) between 1.7 and 2.5). Low sense of coherence in childhood was associated with dropping out from a vocational education (OR 2.0 (95\% Cl 1.2-3.3)). Low general health status was associated with dropping out (OR $2.2(95 \% \mathrm{Cl}$ 1.1-4.2)) or never attaining a secondary education (OR 2.7 (95\% Cl 0.8-9.3)) and overweight was associated with never attaining a secondary education (OR 3.5 (95\% Cl 1.4-8.6)).

Conclusions: The study confirms the social gradient in educational attainment. Furthermore, the results indicate that factors related to the individual in terms of low school performance, low health status and high vulnerability predict future success in the educational system. It is recommended that these high-risk groups are recognized and targeted when designing guidance and supervision programmes for youth in secondary education.

DEPRESSION AND ANXIETY IN FAMILY CAREGIVERS OF TERMINALLY ILL PATIENTS. WHO IS AT RISK?

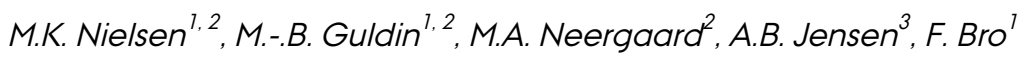

${ }^{1}$ Research Unit of General Practice, Aarhus University, ${ }^{2}$ The Palliative Team, Department of Oncology, Aarhus University Hospital, ${ }^{3}$ Department of Oncology, Aarhus University Hospital

Objective: Family caregivers of terminally ill patients are in a vulnerable position. Small-scale studies point to an increased risk of depression and anxiety in family caregivers. To our knowledge, no large-scale studies have been conducted so far. The aim of this study was to quantify the extent of depression and anxiety in a nationwide cohort of Danish family caregivers and to investigate the association with demographic factors in order to improve the identification of caregivers at risk.

Methods: During 2012, a list of all adult patients in Denmark having been granted drug reimbursement in connection with terminal illness was obtained on a weekly basis from The Danish Health and Medicines Authority. Every newly registered patient was mailed an information letter with a request to pass a questionnaire on to his/her spouse or closest relative. The assessment battery included Beck's Depression Inventory II (BDI-II), anxiety subscale of SCL-90 and a number of demographic questions.

Results: From 1 January until 31 August 2012, 6,600 patients have been approached and 2,491 caregivers have completed the questionnaire (response rate $37.7 \%$ ). The level of depression and anxiety among the respondents will be presented as well as the association between these levels and the respondents' demographic characteristics.

Perspectives: This study will provide valuable information on the level of depression and anxiety and related demographic risk factors in a nationwide population-based sample of Danish caregivers. The perspective is to optimize the support for family caregivers in an attempt to prevent depression and anxiety by establishing who are at risk.

SOCIOECONOMIC POSITION, CARDIOVASCULAR RISK FACTORS AND MEETING TREATMENT TARGETS AMONG PEOPLE WITH TYPE 2 DIABETES IDENTIFIED BY SCREENING

E.M. Dalsgaard', M. Vestergaard ', 2, M.V. Skriver', T. Lauritzen' , K. BorchJohnsen" ${ }^{3}$ A. Sandbcek'

'Department of Public Health, Section for General Practice, Aarhus University, ${ }^{2}$ Research Unit for General Practice, Aarhus University, ${ }^{3}$ Center for Health Economic Research, University of Southern Denmark

Background: Type 2 diabetes is a chronic metabolic disease associated 
with high morbidity and mortality and it is well known that there is socioeconomic inequality in prognosis of the disease.

Aim: To examine if socioeconomic position (SEP) was associated with cardiovascular risk factors or meeting treatment targets at five-year followup among people with screen-detected type 2 diabetes.

Methods: The study population consisted of 1,533 persons with type 2 diabetes identified from at stepwise diabetes screening programme in general practice, 2001-2006. Cardiovascular measures were assessed at baseline and at follow-up and data on SEP were obtained from Statistics Denmark. Associations were analyzed using logistic regression.

Results: HbA 1c, cholesterol and blood pressure were equally distributed among SEP groups. Persons with lower educational level (OR:1.7(1.2-2.4)), lower income level (OR:1.5(1.1-2.0)) or persons on social security (OR:1.7(1.2-2.4)) were more likely to be obese compared to persons with higher educational level, persons with high income level or persons in the labour force. Persons with lower education level (OR: 1.9(1.3-2.7)), lower income level (OR: 1.9(1.3-2.8)) or retired persons (OR: 1.6(1.0-2.5)) were more likely to meet the treatment target for anti-hypertensive medication than persons with higher educational level, persons with higher income level or persons in the labour force.

Conclusion: We found no consistent socioeconomic inequality in meeting treatment targets in this screen-detected type 2 diabetes population. However, low SEP was associated with obesity and meeting target for antihypertensive treatment.

P39.01 Marianne CONCURRENT PARTNERS - A PREDICTOR FOR CHLAMYDIA

Johansson

Jørgensen

M.J. Jørgensen ${ }^{1,2}$, F. Olesen ${ }^{2}$, H.T. Maindal ${ }^{3}$, K.S. Christensen ${ }^{2}$, B. Andersen ${ }^{1}$

${ }^{1}$ Department of Public Health Programs, Randers Regional Hospital, Department of Public Health Programs, Randers Regional Hospital, Central Region Denmark, ${ }^{2}$ The Research Unit for General Practice, Department of Public Health, Aarhus University, ${ }^{3}$ Section for General Medical Practice, Department of Public Health, Aarhus University

Background: Chlamydia trachomatis is the most common sexually transmitted bacterial infection among young Danes and the spread is highly dependent on the population's sexual behaviour. Previous studies have found concurrent partnerships to be a possible predictor for $\mathrm{C}$. trachomatis, but the significance of this compared with other well-known predictors has only been briefly described.

Aim: To examine if concurrent partners is an independent predictor for $\mathrm{C}$. trachomatis infection in young Danes aged 15-29 years.

Methods: Detailed sexual behaviour data were collected via a web-based questionnaire from 1000 randomly selected Danes (control group) and 1300 young Danes with a laboratory-verified C. trachomatis infection. All respondents were between 15 and 29 years. Using univariate analysis, we calculated the odds ratio (OR) for having had concurrent partners in the group of $\mathrm{C}$. trachomatis infected individuals as compared with the control group. Multivariate analysis taking multiple possible confounders into consideration will be performed.

Results: Young Danes diagnosed with a $C$. trachomatis infection are more likely to have concurrent partnerships than individuals in the control group.

- 1 overlap between sexual partners; $O R=3.1(95 \% \mathrm{Cl}: 1.7-5.8$ )

-2 overlaps between sexual partners; $\mathrm{OR}=4.3(95 \% \mathrm{Cl}: 1.6-13.3)$

-3 overlaps between sexual partners; $\mathrm{OR}=4.7(95 \% \mathrm{Cl}: 1.0-43.3$ )

Results are preliminary. Multivariate analyses will be performed and 
presented at the poster session.

Conclusion: These preliminary results suggest that concurrent sexual partners is an important predictor for C.trachomatis infection among young Danes aged 15-29. A more concise conclusion will be presented at the PhD day.

P39.02 Jette Pedersen DOES THE PRESENCE OF A CLINICAL DIETICIAN IMPROVE GERIATRIC PATIENTS' ENERGY INTAKE AND PREVENT WEIGHT LOSS?

\section{J. Lindegaard Pedersen}

Geriatric Department, Aarhus University Hospital

Background: Disease-related malnutrition in geriatric patients is a recurrent and well documented problem. Adequate energy intake is essential to prevent functional decline, dependency, morbidity and death. The Danish national quality standards require hospitals to identify patients at nutrition risk and to implement individual nutritional interventions for these patients.

Aim: To investigate if the presence of a clinical dietician may improve the patients' energy intake and prevent weight loss during hospital stays.

Material and methods: A clinical dietician was available for the health professionals on a daily basis to support, ensure and control that patients in nutritional risk were offered a diet corresponding to their individual energy needs. Dietary intake during the intervention period ( 1 May to 15 July 2011) was compared with a control period without intervention ( 1 January to 30 April 2011 ). Body weight was measured at admission and at discharge. Statistical analyses were performed by Student's t-test.

Results: Energy intake was measured in 345 patients at nutritional risk (intervention 148, control 197). The mean energy intake during intervention was $5993 \mathrm{KJ} /$ day $(95 \% \mathrm{Cl}$ : 5651 ; 6334), versus $5454 \mathrm{KJ} /$ day $(95 \% \mathrm{Cl}$ : 5190 ; $5718)(p=0.01)$. Body weight was measured in 529 patients (intervention 211 , control 318). The mean loss of body weight in the intervention group was $90 \mathrm{~g}(95 \% \mathrm{Cl}: 208$; -389$)$ during hospital stay $(\mathrm{p}=0.6)$. In the control group, the mean body loss was $308 \mathrm{~g}(95 \% \mathrm{Cl}: 25,590)(\mathrm{p}=0.05)$.

Conclusion: Including a clinical dietician in the interdisciplinary team at a geriatric ward seems to improve the patients' energy intake and to prevent weight loss.

P39.03 Allan Riis INTRODUCTION OF NEW LOW BACK PAIN GUIDELINES IN GENERAL PRACTICE

A. Riis ${ }^{1,2}$, F. Bro ${ }^{3}$, H.T. Maindal', C.E. Jensen ${ }^{4}$, K.D. Petersen ${ }^{4}$, L.H. Ehlers ${ }^{4}$, M.B. Jensen ${ }^{1,2}$

'Department of Public Health, Aarhus University, ${ }^{2}$ Research Unit for General Practice in the North Denmark Region, ${ }^{3}$ Research Unit for General Practice, Aarhus University, ${ }^{4}$ Danish Center for Health Care Improvements, Aalborg University

Introduction: Knowledge on how to introduce new guidelines effectively in general practice is sparse and earlier studies on guideline implementation have shown modest effect on health care provider behaviour. Implementation strategies that only include few elements could be the reason for unsatisfactory effects. New low back pain (LBP) guidelines are being implemented in the North Denmark Region in 2012/2013. The aim of this study is to evaluate whether an enhanced implementation strategy of the new guidelines will improve LBP treatment.

Methods: A cluster randomized trial will be carried out including one hundred general practices (clusters) randomly allocated to enhanced or usual implementation of the new guidelines. The practices are all situated in the North Denmark Region and count two hundred general practitioners 
P39.04 Charlotte Green

P39.05 Camilla Plambeck Hansen
(GPs). The study is designed to include 2,700 patients. Patients aged 18-65 consulting their GP for LBP will be included. Excluded are previously included patients, patients with serious pathology, pregnancy, or not able to fill in Danish questionnaires. General practices in the control group will receive normal guideline implementation and the intervention group will receive an enhanced implementation strategy. Primary outcome is referral rate to spine centres. Assessment of outcomes will be blinded.

Discussion: In this project, behavioural change in General Practice is studied. It will be evaluated whether an enhanced implementation strategy may improve guideline compliance, change treatment course and improve treatment results. Inclusion of patients will take place from the end of 2012 until the end of 2013.

RELIABLE AND VALID ASSESSMENT OF COMPETENCE IN OPEN INGUINAL HERNIA REPAIR

C.G. Carlsen' ', K. Lindorff-Larsen ${ }^{2}$, L. Lund ${ }^{3}$, P. Funch-Jensen ', P. Charles ${ }^{7}$

${ }^{1}$ Centre of Medical Education, Aarhus University, ${ }^{2}$ Kirurgisk

Gastroenterologisk afdeling, Aalborg Hospital, ${ }^{3}$ Kirurgisk afdeling, Viborg Hospital

Introduction: Open inguinal hernia repair (Lichtenstein) is a common general surgical procedure. It is one of the first procedures for trainees to meet, usually within 0-2 years of training. In spite of this fact, a formal assessment guide in this particular field has not been developed. The Objective Structured Assessment of Technical Skills (OSATS) described by Reznick and colleagues provides a relevant tool for assessment of open surgical procedures, but more complex procedures in the operating room (OR) require a new tool. We preferred a blinded assessment made possible with video recording. Research question: How do we develop a valid tool for assessment of open inguinal hernia repair (Lichtenstein) of 0-2 year surgical trainees?

Methods: We invited all surgical consultants responsible for education in each of the wards in Jutland and 12 trainees. Four consultants participated. None of the trainees responded to the invitation. The group of experienced surgeons met at one focus group meeting to define key events of the procedure, Lichtenstein hernia repair.

Results: Initially, the focus group debated key events. A draft was then made and sent out for comments by a member of the Danish Hernia Group, and comments were incorporated. The new tool covers eight issues assessed on a scale of 1-5. Finally, a smaller group of surgeons tested the tool in a pilot study discussing three different videos of hernia operations. There was good interrater agreement. It was accepted for further validation.

Conclusions: We developed a new tool for blinded assessment of Lichtenstein hernia repair for trainee surgeons. The assessment tool is now being further validated.

ADIPOSE TISSUE TRANS-FATTY ACIDS AND CHANGES IN BODY WEIGHT AND WAIST CIRCUMFERRENCE

C.P. Hansen 1, 2, 3 , T.L. Berentzen', J.N. Østergaard, 2, C.C. Dahm ", 2 , L.I. Hellgren $^{5}$, E.B. Schmidt ${ }^{2}$, A. Tjønneland ${ }^{4}$, T.I.A. Sørensen ${ }^{3}$, K. Overvad $^{\text {T, }}$, M.U. Jakobsen $^{7}$

'Section for Epidemiology, Department of Public Health, Aarhus University, ${ }^{2}$ Department of Cardiology, Center for Cardiovascular Research, Aalborg Hospital, ${ }^{3}$ Institute of Preventive Medicine, Copenhagen Capital Region, ${ }^{4}$ Danish Cancer Society Research Center, ${ }^{5}$ Department of Systems Biology, Technical University of Denmark

Background: Previous studies have suggested that trans-fatty acids (TFA) 
may play a role in the development of obesity. TFA are unsaturated fatty acids with at least one double bond in transconfiguration, and they are formed either by industrial hydrogenation or by biohydrogenation in ruminants. In fatty acids which are not synthesized endogenously in humans, such as TFA, the proportions in adipose tissue tend to correlate well with the habitual dietary intake. Biomarkers may provide a more accurate measure of habitual TFA intake than obtained with dietary questionnaires.

Objective: Our objective was to investigate the associations between specific TFA in adipose tissue and subsequent changes in body weight and waist circumference (WC). The association between adipose tissue TFA and changes in anthropometry may depend on the size of the fat mass at baseline. Therefore, potential effect modification by sex, age, body mass index (BMI) and WC at baseline was investigated.

Design: Adipose tissue biopsies from a random sample of 1869 men and women aged 50-64 y drawn from a large Danish cohort study were analyzed. Baseline data on weight, WC and potential confounders were available together with information on weight and WC five years after enrolment. The data were analyzed using multiple linear regression combined with cubic spline modelling.

Results and conclusion: Data analysis is currently in progress and results will be presented at the PhD Day 2013.

P39.06 Else Toft Würtz OCCUPATIONAL COPD. PREVALENCE AND GENETIC RISK FACTORS IN A POPULATION-BASED STUDY OF 45- TO 84-YEAR-OLD DANES

\section{E.T. Würtz ${ }^{1,2}$}

'Department of Occupational Medicine, Aalborg Hospital, Aarhus University Hospital, ${ }^{2}$ Danish Ramazzini Centre

Worldwide Chronic Obstructive Pulmonary Disease (COPD) was the fourth leading cause of death in 2004. Smoking is the major risk factor for COPD, but exposure to biomass smoke and occupational exposure to vapour, gases, dust and fumes (VGDF) are two other areas of concern. Growing evidence suggests that about $15 \%$ of COPD could be attributable to an occupational exposure.

Based on a population-based cohort of Danes aged $45-84$ years $(n=4757)$, the study aims to:

- Analyze the association between COPD (prevalence at baseline and incidence at follow-up) and occupational exposure to VGDF.

- Estimate the prevalence at baseline and the incidence at follow-up of occupational COPD (overall, among women and non-smokers), and furthermore estimate the population attributable fraction for the proportion of COPD due to work related exposures.

- Analyze for changes in lung function over time.

- Analyze genetic susceptibility to occupational COPD by single nucleotide polymorphisms (SNP's)/deletions in selected genes.

The study is based on data from the North Jutland COPD Prevention Study (NCPS) 2004 and subsequent data from follow-up in 2008-2009. The population was selected from two former Danish counties. Baseline data consisted of self-administrated questionnaire (about education, work, family lung disease, medical information, smoking and alcohol habits, asthma and allergy) spirometry tests (forced expiratory volume per second $\left(\mathrm{FEV}_{1}\right)$ and forced vital capacity (FVC)), blood samples, blood pressure, height, weight, waist and hip measurements. Follow-up data $(n=2,844)$ were almost identical, but without a new blood sample and a less comprehensive questionnaire. 
P39.07 Rasmus Østergaard Nielsen
P40.01 Pia Viuf Ørby
RUNNING-RELATED INJURIES AMONG NOVICE RUNNERS: A ONE-YEAR PROSPECTIVE FOLLOW-UP STUDY

R.O. Nielsen' ', I. Buist', H. Sørensen ', M. Lind ${ }^{3}$, S. Rasmussen ${ }^{4}$

'Section for Sport Science, Department of Public Health, Aarhus University, DK-8000 Aarhus, ${ }^{2}$ Center for Sports Medicine, University of Groningen, the Netherlands., ${ }^{3}$ Department of Orthopaedics Aarhus University Hospital, DK8000 Aarhus., ${ }^{4}$ Orthopaedic Research Unit. Science and Innovation Center, Aalborg Hospital, Aarhus University, DK-9000 Aalborg

Introduction:

The most frequent running-related injuries (RRISs) among recreational runners are patella femoral pain syndrome (PFPS), iliotibial band syndrome (ITBS), plantar fasciitis, meniscal injuries and medial tibial stress syndrome (MTSS).

Purpose:

The purpose of this study was to describe the most common incidents of musculoskeletal RRIs among inactive persons taking up a one-year running regime.

\section{Materials and methods:}

Healthy participants between 18 and 65 years of age, who had not been running on a regular basis in the previous twelve months, were eligible for inclusion. During the follow-up period, participants had to take up running with a minimum of 52 training sessions. GPS was used to quantify training patterns in each session. In case of RRIS, the participant attended a clinical examination and diagnose was registered.

\section{Results:}

A total of 933 inactive persons were included. Among women ( $n=465$ ) mean age and $\mathrm{BMI}$ were $36.8 \pm 10.0$ and $25.4 \pm 4.2$, while age and $\mathrm{BMI}$ for males were $37.6 \pm 10.6$ and $26.6 \pm 3.8$, respectively. Two-hundred and fortyone participants sustained at least one injury during follow-up. The cumulative risk of sustaining an injury after 500 kilometers of running was $27.2 \%$ [95\% Cl: $23.9 \% ; 30.9 \%$ ]. MTSS was the most common diagnosis ( $\mathrm{n}=$ $34,14.1 \%$ ), followed by PFPS ( $n=26,10.8 \%$ ), meniscal injuries ( $n=19,7.9 \%$ ), Achilles tendinopathy $(n=15,6.2 \%)$ and ITBS ( $n=10,4.1 \%$ ). Median duration per recovered injury was 54.5 days (interquartile range 45.5 ).

\section{Conclusion:}

The risk of injury after 500 kilometers of running among novice runners was $27.2 \%$. MTSS and PFPS were the two most frequently diagnosed injuries.

DIURNAL VARIATION IN POLLUTANTS AND POLLEN LEVELS BASED ON THREE URBAN POLLEN STATIONS IN AARHUS, DENMARK DURING THE TIME PERIOD 2009-2011.

P.V. Ørby ${ }^{7}$, R.G. Peel', C.A. Skjøth ${ }^{2}$, O. Hertel', J. Sommer', J. Bønløkke' , T. Ellerman $^{2}$, T. Sigsgaard ${ }^{7}$ V. Schlünssen ${ }^{7}$

'Department of Public Health, Section for environment, occupation and health, Aarhus University, ${ }^{2}$ Department of Environmental Science, Aarhus University, ${ }^{3}$ Asthma Allergy Association Denmark

Background: Air pollutants have the potential to affect atopic subjects directly by stressing the respiratory system but also indirectly by affecting the allergenicity of pollen. The purpose of the present study is to investigate how grass pollen and air pollution vary in the urban landscape.

Methods: Three pollen traps were placed at rooftops in Aarhus. Grass pollen was counted bi-hourly for the pollen seasons 2009-2011. Diurnal variation is estimated for rain-free peak pollen days ( $>50$ grains $\mathrm{m}^{-3}$ ). Levels of $\mathrm{NO}_{2}$ and 
$\mathrm{O}_{3}$ were obtained for $1 / 2$-hourly means from a road side and an urban background monitoring station.

Results: The mean diurnal pollen conc. on peak days varied between 23 pollen $\mathrm{m}^{-3}$ at 3 am rising to a maximum of 205 pollen $\mathrm{m}^{-3}$ at $7 \mathrm{pm}$. $\mathrm{NO}_{2}$ were lowest from midnight to $3.30 \mathrm{am}$, mean $13 \mathrm{ppb}$. It peaks at $6.30 \mathrm{am}$ ( $26 \mathrm{ppb}$ ), but decreases around $7 \mathrm{pm}$ ( $18 \mathrm{ppb}$ ) where the peak pollen levels occur. Average diurnal $\mathrm{O}_{3}$ levels in urban background were lowest from $3 \mathrm{am}$ $6 \mathrm{am}$, mean $20 \mathrm{ppb}$, hereafter rising to a maximum of $42 \mathrm{ppb}$ at $4 \mathrm{pm}$. Average $\mathrm{O}_{3}$ levels during the entire grass season only rises to a peak of 36 $\mathrm{ppb}$. The high ozone levels coincide with high pollen levels at $7 \mathrm{pm}$.

Discussion: Ozone levels as those measured can exacerbate asthma. The street level $\mathrm{O}_{3}$ concentrations can however be assumed to be low in areas with high traffic intensity due to the reaction between ozone and NO in traffic exhaust gasses leading to formation of $\mathrm{NO}_{2}$. Further studies will include analysis of variation between pollen counts from the three traps, variation in the diurnal pattern and analysis of $\mathrm{NO}_{2}, \mathrm{NO}_{x}$ and $\mathrm{O}_{3}$ at both rooftop and street level.

P40.02 Merete Møller SHOULDER INJURIES AND RISK FACTORS IN DANISH YOUTH HANDBALL - A 1-YEAR PROSPECTIVE COHORT STUDY

M. Møller', J. Attermann' ', N. Wedderkopp², G. Myklebust ${ }^{3}$, H. Sørensen ${ }^{7}$, M. Lind $^{4}$

'Department of Public Health, Aarhus University, Aarhus, Denmark, ${ }^{2}$ Institute of Regional Health Services Research and Center for Research in Childhood Health, IOB, University of Southern Denmark, ${ }^{3}$ Oslo Sports Trauma Research Center, Norwegian School of Sport Sciences, Oslo, Norway, ${ }^{4}$ Department of Orthopaedics, Aarhus University Hospital, Aarhus, Denmark

Introduction: Shoulder injuries (SI) among handball players may be an important cause of early development of osteoarthritis in the shoulder joint. In order to reduce the risk of SI, evidence based understanding of SI, and the mechanisms leading to $\mathrm{SI}$, is needed. The purpose of this study is to assess the weekly prevalence, incidence and risk factors for SI in youth handball.

Material and Method: A 12 months prospective cohort study of 200, 14-16 years old elite Danish handball players will be conducted. At baseline, prior to the season 2013-2014, scapula movement, shoulder joint movement and strength, will be measured. Subsequently, the players will be followed for 12 months where SI and handball exposure will be recorded weekly by a SMS messaging system. The injuries will be further classified by telephone interview and validated by health professionals. The primary outcome is any handball related SI, defined according to the 2006 injury consensus statement. This weekly binary outcome will be modelled by a logistic transitional model with dependence on the outcome in the previous week and the baseline movement patterns and stability, and with random components for teams and players. Based on normative values for movement patterns and stability, which will be estimated in a pilot study, players will be divided into different risk groups, and the risk of SI will be compared between these groups.

Perspectives: When risk factors for SI development have been identified, the effects of preventive interventions will be tested in a randomised controlled trial.

P40.03 Lotte Maxild POLYUNSATURATED FATTY ACIDS; INTERACTIONS, GENETIC PATHWAYS Mortensen AND RISK OF ATRIAL FIBRILLATION

L.M. Mortensen ${ }^{7,2}$, E.B. Schmidt ${ }^{7}$, M.H. Schierup ${ }^{3}$, P. Calder ${ }^{4}$, K. Overvad
'Department of Cardiology, Aalborg AF Study Group, Center for
Cardiovascular Research, Aalborg Hospital, Aarhus University Hospital
Aalborg, ${ }^{2}$ Department of Public Health, Section of Epidemiology, Aarhus 
University, ${ }^{3}$ Bioinformatics Research Centre, Aarhus University, ${ }^{4}$ Institute of Human Nutrition and Human Development and Health Academic Unit, Faculty of Medicine, University of Southampton, UK

Introduction: Atrial fibrillation (AF) is the most common cardiac arrhythmia and is associated with substantial morbidity and mortality. The main purpose of this study is to investigate the relation between intake of PUFAs, genotype of the PUFA pathway and the development of atrial fibrillation (AF)

Background: AF has been associated with inflammatory level in several studies. The PUFAs, consisting of two subgroups: the n-3 and the n-6 PUFAs, affect the inflammatory system in being precursors to the eicosanoids, a group of biologically active metabolites that affect physiologically processes, including the inflammatory system. The inflammatory effects of the two PUFA subgroups differ; the eicosanoids from the $n-3$ group being less inflammatory than those from $n-6$. The PUFAs are transformed in the PUFA pathway in which the two subgroups are metabolized by the same enzymes in a competitive way.

Hypothesis: The idea behind the project is that the tissue level of PUFAs greatly depends on diet, metabolic pathways and genetic variations. The hypothesis is that differences in the genes encoding the key enzymes of the PUFA pathway affect the risk of AF through differential processing of $n-3$ and n-6 PUFAs.

The project will use data from the Diet, Cancer and Health Cohort which contains information on diet, genetic material and adipose tissue biopsies from 57,000 Danish participants. The plan is to analyse the intake information of n-3 and n-6 fatty acids as well as SNP polymorphisms in the selected candidate genes measured as single SNP, haplotypes and whole gene level and correlate this with 1) levels of fatty acids in adipose tissue biopsies and 2) a diagnosis of AF.

P40.04 Therese Juul INTERNATIONAL VALIDATION OF THE LOW ANTERIOR RESECTION SYNDROME SCORE

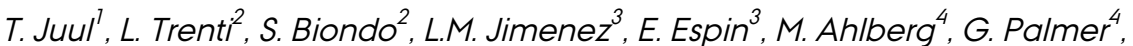

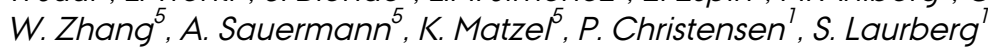

'Department of Surgery P, Aarhus University Hospital, Denmark, ${ }^{2}$ General and Digestive Surgery, Colorectal Unit, Bellvitge University, Barcelona, Spain, ${ }^{3}$ Hospital Valle de Hebron, Universitat Autonoma de Barcelona, Barcelona, Spain, ${ }^{4}$ Department of Molecular medicine and surgery, Karolinska Institute, Stockholm, Sweden, ${ }^{5}$ Department of Surgery, University Erlangen, Erlangen, Germany

Objective: The aims of this study were to translate and investigate the convergent and discriminative validity and reliability of the newly developed Low Anterior Resection Syndrome Score (LARS score) in an international setting.

Background: The LARS score was developed in order to provide a common international tool for measuring Low Anterior Resection Syndrome after rectal cancer surgery. The LARS score is a "quick and easy" selfadministered five-item-questionnaire, expected to be widely used in international research and clinical practice in the future. Therefore, a thorough validation in an international setting is of utmost importance.

Methods: The LARS score was translated into four languages according to current international recommendations. A total of 801 former rectal cancer patients in Sweden, Spain, Germany and Denmark participated in a postal survey. Participants completed the LARS score questionnaire including an anchor-question assessing the impact of bowel function on quality of life (QoL). In order to investigate the test-retest reliability of the score, a 
subgroup of 218 patients completed the LARS score twice.

Results: The various language versions of the LARS score demonstrated high convergent and discriminative validity. The score also demonstrated high reliability at test-retest in different European populations.

Conclusions: The Swedish, Spanish, German and Danish versions of the LARS score have proven to be valid and reliable tools for measuring LARS in European rectal cancer patients.

P40.05 Michael

Smcrup VESTIBULAR DYSFUNCTION IN 745 ELDERLY CITIZENS

Brandt

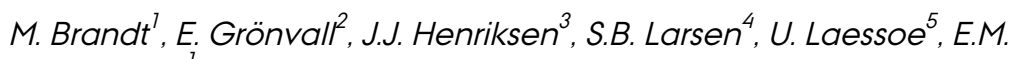

'Geriatric Department, Aarhus University Hospital, Denmark, ${ }^{2}$ Department of Computer Science, Aarhus University, Denmark, ${ }^{3}$ Department of Ear, Nose and Throat, Aarhus University Hospital, Denmark, ${ }^{4}$ The Alexandra Institute, Aarhus University, Denmark, ${ }^{5}$ Department of Health Science and Technology, Aalborg University, Denmark

Introduction: Elderly patients with vestibular dysfunction have an eight-fold higher risk of falling compared to other fall patients. A trend for the overall performance seems to be worse for central vestibular lesion or mixed central and peripheral lesion. The aim of this study was to identify and diagnose vestibular dysfunction in elderly citizens with complaints of dizziness.

Method: To recruit elderly persons with dizziness, we advertised in a local newspaper. Telephone interviews with the respondents were done by a physiotherapist (PT). Some patients were referred by their GP. The participants were tested by the PT in the Fall Clinic at the Department of Geriatrics, Aarhus University Hospital. The tests were videonystagmography and physiotherapeutic balance tests. If vestibular dysfunction was suspected, the patients were examined by a geriatrician and a specially trained otoneurologist at the ENT Department at Aarhus University Hospital.

Results: 745 elderly citizens responded to the advertisement. 174 patients were suspected of vestibular dysfunction and further tested in the Fall Clinic. 154 of these patients have been seen until now. In 55 patients (36\%), vestibular dysfunction was diagnosed. Thirteen patients had peripheral, 9 mixed and 33 central vestibular lesions.

Conclusions: Central vestibular dysfunction is common among elderly with complaints of dizziness. This prognosis are likely to be more limited vestibular rehabilitation than the patient with peripheral injury. The vestibular rehabilitation therapist should be aware of this when the rehabilitation programme is made.

P40.06 Mette Damborg SUBSTITUTIONS OF FOODS IN RELATION TO RISK OF ISCHEMIC HEART Hansen DISEASE

M.D. Hansen ', E.B. Schmidt ${ }^{2}$, K. Overvad $^{\text {, }}{ }^{2}$, M.U. Jakobsen ${ }^{7}$

${ }^{1}$ Department of Public Health, Section of Epidemiology, Aarhus University, ${ }^{2}$ Department of Cardiology, Center for Cardiovascular Research, Aalborg Hospital, Aarhus University Hospital

Background: Ischemic heart disease (IHD) including myocardial infarction (MI) is a leading cause of morbidity and mortality, and diet plays an important role in the development of IHD. Several studies have shown that vegetables may protect against development of IHD, probably due to the content of vitamins and minerals. Starchy foods, on the other hand, are energy rich and nutrient poor. The aim of this project is to investigate substitutions of vegetables for starchy foods.

Method: Data from the three large epidemiological studies will be used; the 
Danish Diet, Cancer and Health Follow-up Study $(n=57,053)$ and the two American trials Nurses' Health Study $(n=121,700)$ and the Health Professionals Follow-up Study $(n=51,529)$. All participants have completed food-frequency questionnaires at baseline and information on confounders is available. The outcome measures will be incident nonfatal and fatal Ml.

Individual studies: Study l: A follow-up study on energy intake from vegetables in place of energy intake from starchy foods and risk of IHD will be conducted in the Diet, Cancer and Health cohort.

Study II: Replication of study I in the Nurses' Health Study and the Health Professionals Follow-up Study. This will ensure replication and contribute to the evaluation of the external validity of the results.

Study III: A follow-up study on energy intake from vegetables and starchy foods in place of energy intake from meat will be conducted in the Diet, Cancer and Health cohort.

Perspective: The project will provide knowledge about substitutions of foods within and between major food groups and contribute to improvement of food-based dietary guidelines for prevention of IHD.

P40.07 Thomas

Winther Frederiksen
OCCUPATIONAL NOISE EXPOSURE AND INDIVIDUAL RISK FACTORS FOR HEARING LOSS AND TINNITUS

T.W. Frederiksen ${ }^{\text {1, }}$, H.A. Kolstad ${ }^{7}$, C.H. Ramlau-Hansen ${ }^{3}$, L. Tranebjcerg ${ }^{4}$

'Danish Ramazzini Centre, Department of Occupational Medicine, Aarhus University Hospital, ${ }^{2}$ Department of Otology, Head and Neck Surgery, Hospitalsenheden Vest, ${ }^{3}$ Department of Epidemiology, Aarhus University Hospital, ${ }^{4}$ Department of Audiology, Bispebjerg Hospital

Background: The WHO estimates that $10 \%$ of the world's inhabitants are exposed to injurious noise, and high noise levels are still reported in many Danish industries. The best documented hazardous effects of noise are noise-induced hearing loss ( $\mathrm{NIHL}$ ) and tinnitus. According to the ISO19991990 database, there is a tremendous individual susceptibility to noise, indicating that NIHL is a complex disease caused by an interaction of environmental and genetic factors.

Aim: The aim of this study is to clarify possible relations between noise exposure, NIHL and tinnitus in a multifactorial environment. Focusing on individual lifestyle factors and genetic variations, we hope to explain some of the individual variability in NIHL and tinnitus observed after identical levels of noise exposure.

Material and methods: The study is based on 665 workers selected as a random sample of 12 industrial trades in the former Aarhus County between 2009 and 2010. Ten of these trades had high notification levels of NIHL. The remaining two trades represented day care units for children and the financial sector. From the financial sector, 104 workers were chosen as controls.

The study database contains information on: smoking habits, leisure time noise, blood pressure, cholesterol levels, glycosylated haemoglobin, cortisol levels, psycho-social working conditions, individual noise dosimetries and hearing levels. Blood samples are ready for genetic analysis. Based on noise dosimetries from the same industries in 2001 , a noise exposure matrix is under construction to estimate retrospective noise levels. Data will be analyzed using multiple linear and logistic regression in a cross-sectional study design.

P40.08 Ditte Lammers A SYSTEMATIC REVIEW OF THE LONG-TERM OUTCOME OF EARLY ONSET Vernal SCHIZOPHRENIA

D.L. Vernal 
Research Unit for Child and Adolescent Psychiatry, Aalborg Psychiatric Hospital

Background: The current review analyzes the long-term outcome and prognosis of early onset schizophrenia based on previously published studies since 1980

Methods: A systematic search of articles published in the English-language literature after 1980 identified a total of 21 studies, which included 716 patients who were either suffering from early onset schizophrenia (EOS) or both EOS and other psychotic disorders (MIX). The authors of the current review scored the outcome as either "good," "moderate," or "poor."

Results: In general, the outcome in studies with EOS is worse than the outcome in MIX studies. Only $15.4 \%$ of the patients in EOS studies versus $19.6 \%$ of the patients in MIX studies experienced a "good" outcome. In contrast, $24.5 \%$ of the patients in EOS studies versus $33.6 \%$ in MIX studies experienced a "moderate" outcome, and $60.1 \%$ in EOS studies versus $46.8 \%$ in MIX studies experienced a "poor" outcome.

Conclusions: In contrast to the adult manifestation, the early manifestation of schizophrenia in childhood and adolescence still carries a particularly poor prognosis. According to these aggregated data analyses, longer follow-up periods, male sex, and patients having been diagnosed before 1970 contribute predominantly to the rather poor course of EOS.

A.01 Kristina VARIATION IN TREATMENT ACCESS TO PRIMARY ANGIOPLASTY IN Grønborg Laut SELECTED EUROPEAN COUNTRIES

K.G. Laut, ${ }^{1,2}$, C.P. Gale , $^{4,}$, T.L. Lash ${ }^{2,5}$, S.D. Kristensen ${ }^{7}$

'Department of Cardiology, Aarhus University Hospital, Skejby, DK, ${ }^{2}$ Department of Clinical Epidemiology, Aarhus University Hospital, DK, ${ }^{3}$ Centre for Epidemiology and Biostatistics, University of Leeds, UK, ${ }^{4}$ Department of Cardiology, York Teaching Hospital, NHS Foundation Trust, UK, ${ }^{5}$ department of Epidemiology \& Prevention, Wake Forest School of Medicine, Winston-Salem, NC, USA

Background: There are important differences between European countries in the degree of implementation of primary percutaneous coronary intervention (PPCI) for patients with ST-elevation myocardial infarction (STEMI). We studied: 1) the temporal implementation of PPCl and variation in access to PPCl and 2) whether characteristics of the country and the healthcare system may explain differences in the use of PPCl in 12 selected European countries.

Methods: An ecological study of aggregated data from national and international registries. Main outcome: number of PPCI per 1,000,000 population collected annually for the years 2003 to 2008 . Impact of year on PPCl implementation was modelled using linear regression, and random coefficient models were used to quantify associations between PPCl use and country-level parameters.

Results: The annual growth in utilization of PPCl was $1.11(1.03,1.20)$ per million. Country-level utilization rates varied from $0.82(95 \% \mathrm{Cl} 0.52,1.30)$ to $1.38(95 \% \mathrm{Cl} 1.15,1.64)$ per million per year. Numbers of physicians per 100,000 population, numbers of nurses and midwives per 100,000 population, numbers of acute care beds per 100,000 population, population density per $\mathrm{km}^{2}$ and proportion of population under 50 years old were associated with $\mathrm{PPCl}$ utilization.

Conclusions: All 12 EU countries demonstrated evidence of PPCI implementation from 2003 to 2008 . However, there was substantial variation in the use and rate of uptake of PPCl between countries. Differences in utilization rates of PPCl are associated with supply factors, such as numbers of beds and physicians, rather than patient-level factors, 
country-level finances or healthcare characteristics.

A.02 Charlotte

Hyldgaard

A.03
COMORBIDITY AND PROGNOSIS IN IDIOPATHIC PULMONARY FIBROSIS

\section{Hyldgaard, E. Bendstrup, O. Hilberg}

Department of Respiratory Diseases, Aarhus University Hospital

Introduction: Idiopathic pulmonary fibrosis (IPF) is the most common of the idiopathic interstitial pneumonias. It is a serious and progressive lung disease with a median survival of 3 years. In most cases, the disease is not diagnosed until pulmonary function is severely impaired. Specific treatment has only recently become available. Treatment does not stop disease progression, but may delay disease progression.

Objectives: The aim of this study is to characterize comorbidity and comedication in a cohort of Danish IPF patients, and to assess the impact of these factors on survival.

Methods: The study population consists of 121 patients diagnosed with IPF at Aarhus University Hospital between 2003 and 2009. Details on referral, diagnostic examinations, pulmonary function tests, concomitant diseases and medication have been recorded in the Western Danish ILD Registry.

Results: Preliminary data analyses have shown that ischemic heart disease, diabetes and depression are the most common comorbidities at the time of referral. $21 \%$ of patients received anticoagulant treatment during follow-up. We found a statistically significant difference in survival between patients receiving anticoagulant treatment and those who did not. The difference persists when adjusting for differences in the occurrence of heart disease, but further analyses are ongoing.

Perspectives:Recently, a randomized clinical trial investigating the effect of anticoagulant treatment in IPF was stopped early because of high mortality in the treatment arm. This study will provide new insight into the impact of anticoagulant treatment in a real-life cohort as well as other aspects of comorbid diseases in IPF.

Stine Elleberg EVALUATION OF FUNCTIONAL AND STRUCTURAL ANO-RECTAL CHANGES Petersen FOLLOWING RADIOTHERAPY FOR PROSTATE CANCER

S.E. Petersen', L. Bentzen', S. Bregendahl', M.F. Langschwager ${ }^{3}$, S. Laurberg ${ }^{2}$, K. Krogh ${ }^{4}$, L. Lundby ${ }^{2}$, M. Hoyer ${ }^{7}$

'Departmenf of Oncology D, Aarhus University Hospital, ${ }^{2}$ Department of Surgery P, Aarhus University Hospital, ${ }^{3}$ Department of Radiology, Aarhus University Hospital, ${ }^{4}$ Department of Hepatology and Gastroenterology V, Aarhus University Hospital

Purpose: To assess functional and structural long-term ano-rectal changes in patients with prostate cancer treated with external beam radiation therapy (EBRT).

Material and methods: 42 patients; 20 patients with ano-rectal symptoms and 22 without ano-rectal symptoms selected from a previous questionnaire-based cohort agreed to participate in the study. The anorectal dysfunction (ARD) score, originally constructed for use in patients with anterior resection for rectal cancer, was used to identify patients with and without symptoms. The patients underwent manometry, endoanal sonography and impedance planimetry to evaluate the anal pressures, rectal compliance and sensitivity. Structural changes of the rectal mucosa was assessed by flexible sigmoidoscopy and graded by the Vienna Rectoscopy Score (VRS).

Results: Endoscopic evaluation revealed statistically significant higher VRS scores in ARD patients compared to non-ARD patients $(p=0.028)$. Lower mean maximal resting pressure (MRP) and mean maximal squeeze pressure 
(MSP) were observed in patients reporting incontinence for liquid stool compared to those without this symptom $(p=0.002$ and $p=0.018)$. There was a non-significant trend for low MRP in patients reporting urge compared to those without urge $(p=0.068)$. No significant differences were found between rectal compliance and sensitivity among the two groups of patients.

Conclusions: Long-term ano-rectal symptoms, expressed by the ARD score, following EBRT for prostate cancer correlate significantly with structural changes of the rectal mucosa. The ano-rectal dysfunction reported by the patients may be caused by rectal mucosal injury and a weakened anal sphincter. ALTERNATIVE TREATMENT FOR LEG LENGTH DISCREPANCY

J.M. Shiguetomi Medina' , O. Rahbek' , H. Stødkilde-Jørgensen ${ }^{3}$, B. MøllerMadsen ${ }^{2}$

${ }^{7}$ Orthopaedics Research Laboratory, Aarhus University Hospital,

'Department of Children's Orthopaedic, Aarhus University Hospital, ${ }^{3}$ The MR Research Center, Aarhus University Hospital Skejby

Objective: Development of a new technique for epiphysiodesis using radiofrequency ablation in an experimental porcine model.

Methods: Six $35 \mathrm{~kg}$ pigs and two $25 \mathrm{~kg}$ non-mature pigs were used. A control leg was randomly selected and the contralateral treated at two ablation sites (lateral and medial) identified at the proximal tibia growth plate using $x$-ray. Under general anaesthesia, a probe was inserted and the ablation performed. $T_{1}, T_{2}$ and water content $M R$ images were performed right after the procedure, 12 weeks later for 6 animals, and 6 months later for the last 2 ones. The length of both tibiae was measured after the ablation and at the end of the study.

Results: Both legs were equal at the beginning of the study and, overall, there was a leg length difference $(P=0.006)$ in average of $4.8 \mathrm{~mm}(S D=2.25$, Median=3.88) at the end. For the 12-week follow-up we found an average leg length difference of $3.9 \mathrm{~mm}(S D=1.286$, Median=3.666, $P=0.014)$, and for the 6-month one we found a difference of $8.11 \mathrm{~mm}$ in average. No damage to the surrounding cartilage structures was found. The animals could walk normally after the anaesthesia without signs of pain or discomfort during the follow-up period.

Conclusion: Epiphysiodesis using radio frequency ablation is an innovative technique that may represent an alternative way of treatment that potentially involves less scarring, less exposure to $X$-rays, and reduces the risk of injuring the surrounding structures compared to current methods. These results show that this technique can arrest growth in a safe and effective way. However, longer studies must be performed to obtain more evidence of the safety and effectiveness of the procedure.

A.05 Pernille Endrup DEVELOPMENTAL ENAMEL DEFECTS IN CHILDREN PRENATALLY EXPOSED Jacobsen TO ANTI-EPILEPTIC DRUGS

\author{
P.E. Jacobsen', T.B. Henriksen ${ }^{2}$, D. Haubek', J.R. Østergaard ${ }^{3}$ \\ ${ }^{1}$ Section of Pediatric Dentistry, Department of Dentistry, Aarhus University, \\ ${ }^{2}$ Perinatal Epidemiology Research Unit, Department of Pediatrics, Aarhus \\ University Hospital, ${ }^{3}$ Center for Rare Diseases, Department of Pediatrics, \\ Aarhus University Hospital
}

Objective: Some anti-epileptic drugs (AED) have well-known teratogenic effects. The aim of the present study is to elucidate the effect of prenatal exposure to AED and the risk of enamel defects in the primary and permanent dentition. 
Methods: A total of 38 exposed and 129 non-exposed children, 6-10 years of age, were recruited from the Aarhus Birth Cohort and the Department of Neurology, Viborg Regional Hospital, Denmark. Medication during pregnancy was confirmed by the Danish Prescription Database. All children had their teeth examined, and outcomes in terms of enamel opacities and enamel hypoplasia were recorded.

Results: Children prenatally exposed to AED have an increased prevalence of enamel hypoplasia ( $11 \%$ vs. $4 \%$, odds ratio (OR) $=3.6[95 \%$ confidence interval (Cl): 0.9 to 15.4 ]), diffuse opacities ( $18 \%$ vs. 7\%, OR=3.0; [95\% Cl: 1.0 to $8.7, p<0.05]$ ) and numerous white opacities ( $18 \%$ vs. $10 \%, O R=2.2$; [95\%

Cl: 0.8 to 6.1$]$ ) in the primary dentition. In the permanent dentition, we found an increased risk of numerous white opacities (34\% vs. $12 \%, O R=3.3$; [95\% Cl: 1.3 to 8.4$]$ ).

Conclusions: The present study shows that children prenatally exposed to AED have an increased risk of developing numerous white opacities in their primary and permanent teeth. In addition, they also have an increased risk of developing diffuse opacities and enamel hypoplasia in their primary teeth. RISK FACTORS FOR PSYCHIATRIC DISORDERS

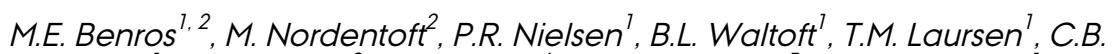
Pedersen', W.W. Eaton', S.O. Dalton ${ }^{4}$, N.H. Heegaard ${ }^{5}$, P.B. Mortensen ${ }^{7}$

${ }^{1}$ National Centre for Register-based Research, Aarhus University, ${ }^{2}$ Mental Health Centre Copenhagen, University of Copenhagen, Faculty of Health Sciences, ${ }^{3}$ Department of Mental Health, Johns Hopkins Bloomberg School of Public Health, Baltimore, ${ }^{4}$ Institute of Cancer Epidemiology, Danish Cancer Society, ${ }^{5}$ Department of Clinical Biochemistry and Immunology, Statens Serum Institut, Copenhagen

Immune responses have been shown to affect the brain and to experimentally induce psychiatric symptoms in vulnerable individuals. However, large-scale longitudinal studies of medical diseases involving inflammatory pathophysiological mechanisms and associations with psychiatric disorders have been lacking. We studied the associations in nationwide prospective cohort studies utilizing the extensive Danish registers. Data were analyzed using survival analysis techniques adjusted for calendar year, age and sex. Our results show that hospital contacts with autoimmune diseases increase the risk of subsequent mood disorders with $45 \%(95 \% \mathrm{Cl}=1.39-1.52)$ and the risk of schizophrenia with $29 \%(95 \% \mathrm{Cl}=1.18$ 1.41). Utilizing autoantibody test results from the national serum institute in Denmark (SSI), we confirmed associations and showed that persons with positive autoantibody tests had a $44 \%(95 \% \mathrm{Cl}=1.40-1.46)$ increased risk of subsequent psychiatric disorders. Hospital contacts with infections increase the risk of mood disorders with $62 \%(95 \% \mathrm{Cl}=1.60-1.64)$ and schizophrenia with $60 \%(95 \% \mathrm{Cl}=1.56-1.64)$. The number of infections requiring hospitalization increases the risk of developing both mood disorders and schizophrenia in a dose-response relationship, also in synergy with autoimmune diseases. Additionally, we showed that psychiatric symptoms might be some of the first symptoms of an undetected cancer with a 2.61 times $(95 \% \mathrm{Cl}=2.31-2.95)$ elevated risk of cancers during the first month after a first-time psychiatric contact. The associations found in our studies seem compatible with an immunological hypothesis for the development of severe mental disorders in subgroups of the patients.

A.07 Jan Danz PERIODONTAL EFFECTS OF ORTHODONTIC EXPANSION J.C. Danz ${ }^{1,2}$, A. Stavropoulos' , C. Katsaros ${ }^{2}$

'Sections of Orthodontics and Periodontology, Department of Dentistry, Aarhus University, ${ }^{2}$ Department of Orthodontics and Dentofacial 
Orthopedics, University of Bern

Expansion is an option in orthodontic treatment to resolve dental crowding or to compensate dento-skeletal discrepancies. However, expansive tooth movement beyond its alveolar bone housing may induce adverse periodontal effects such as bone dehiscences and gingival recession. On the other hand, mesio-distal tooth movement within the alveolar bone housing by low forces was shown to generate woven bone in front of the movement direction, possibly by similar mechanisms as found in stimulated bone remodelling after microdamage or in fracture healing.

The aim was to investigate the effect of orthodontic expansion on alveolar bone and gingiva under different force levels and different amounts of tooth movement.

Six groups were compared in a rat model at two time points (day 60 and day 90) and between three force levels (high force, low force and control). Tooth position, inclination, skeletal width, bone level and thickness, gingival level and thickness were measured at every facial root of each molar ( 6 sites).

Bone dehiscences, thinning of bone and decrease of the height and thickness of the free gingiva were moderately or strongly correlated with the tooth position of moved teeth. Severe gingival recession developed in two out of eight animals in the day 90 group. Tooth movement tended to be slower in the low-force group. Skeletal widening was higher in the highforce group. Soft and hard tissues were remodelled, but to a limited extent in both force groups.

Expansive tooth movement results in adverse effects on the facial periodontium. In relation to the amount of tooth movement and the interindividual variance, the force level was not a clinically relevant factor.

Finn Sørensen CARTILAGE ENGINEERING BY EQUINE MESENCHYMAL STROMAL CELLS HYALURONAN GEL CONSTRUCTS IN VITRO

F. Sørensen ${ }^{1,2}$, M. Ulrich-Vinther', K. Søballe ${ }^{7}$, T.G. Koch ${ }^{7,2}$

'Department of Clinical Medicine, Aarhus University, Denmark, ${ }^{2}$ Department of Biomedical Sciences, University of Guelph, Canada

Introduction: Synovial joint cartilage defects are the main reason for loss of training days and pre-mature retirement of sport horses. Tissue engineered (TE) cartilage often has good morphological appearance, but it lacks mechanical properties similar to normal cartilage. The hypothesis of this study is that maturation of TE cartilage by mechanical stimulation in vitro will improve the mechanical properties. The objectives are: 1) Optimize culture conditions for equine cord blood mesenchymal stromal cells (eCB-MSCs) in a hyaluronan (HA) gel, 2) Induce chondrogenesis of eCB-MSCs within a cell$\mathrm{HA}$-gel construct. 3) Assess the influence of sequential direct compressive forces on cell-HA-gel constructs.

Materials and methods: Cellular viability within the 3D construct is assessed by Calcein AM \& Propidium lodide stain after 1, 7, 14, 21 \& 28 days $(N=1$, $\mathrm{n}=3$ ). $\mathrm{pH}$, glucose, lactate and selected electrolytes are determined in conditioned medium sequentially. Chondrogenesis is induced by Transforming Growth Factor- $\beta 3$ with and without mechanical stimulation. Direct compression is applied by use of the Bose Orthopaedic BioDynamic 5110 Test Unit. Chondrogenesis is assessed by histology, biochemistry and gene expression.

Results: Viability declined from $96-99 \%$ post trypsinization to $70 \%$ within 24 hours of 3D encapsulation. 28-days post-encapsulation viability was $50 \%$ compared to pre-encapsulation, but $>80 \%$ of cells were viable compared to day 24 -hour post-encapsulation. Complete medium change daily the 1 st week followed by 3 times weekly maintains the assessed biochemical 
values most consistent. Objectives 2 and 3 are ongoing at the time of submission.

\section{EMPIRIC VERSUS IMAGING-GUIDED LEFT VENTRICULAR LEAD PLACEMENT IN CARDIAC RESYNCHRONIZATION THERAPY: DESIGN OF THE IMAGING CRT STUDY}

\section{A. Sommer, M.B. Kronborg, M. Bøttcher, S.H. Poulsen, J.C. Nielsen \\ Department of Cardiology, Aarhus University Hospital}

Background: Cardiac resynchronization therapy (CRT) is an established treatment in heart failure patients. However, only $60 \%$ of the patients respond to this pacing strategy. Retrospective studies have documented an improved response rate to CRT when the left ventricular (LV) lead is placed in the latest activated myocardial segment and in myocardial regions without scar tissue. This study aims to clarify whether multimodality imagingguided LV lead placement can improve clinical outcome after CRT. We hypothesize that this approach can increase the response rate to $80 \%$.

Methods and design: The ImagingCRT study is a prospective, randomized, double-blinded, two-armed trial. The study is designed to investigate the effect of imaging-guided left LV positioning on a clinical composite primary endpoint comprising all cause mortality, hospitalization for heart failure, or unchanged or worsened functional capacity (no improvement in New York Heart Association class and $<10 \%$ improvement in six-minute walk test). Imaging-guided transvenous LV lead positioning is targeted to the latest activated non-scarred myocardial segment by speckle tracking echocardiography, single-photon emission computed tomography and cardiac computed tomography. A total of 182 patients are included in the study and followed for six months.

Perspective: Imaging CRT is the first prospective, randomized, doubleblinded trial to assess the clinical effect of multimodality imaging-guided LV lead placement in CRT. The results are expected to make an important contribution to the pursuit of increasing response rate to CRT. PROGRAMME SUPPORTING ESTABLISHMENT OF BREASTFEEDING FOR PARENTS DURING SHORT-TIME HOSPITALIZATION POST PARTUM

\section{Nilsson}

\section{Section for Nursing, Department of Public Health. Aarhus University}

Background: Breastfeeding is a well documented health promoting and disease preventing action for mother and infant. While length of hospitalization post partum has decreased, the number of infants readmitted to the hospital has increased due to nutritional problems. No evidence exists of breastfeeding counselling during short-time hospitalization. Improving breastfeeding self-efficacy might be central in the counselling. The objective of this study is to develop and evaluate a programme for parents on establishing breastfeeding during short-time hospitalization.

Study part 1 Aim: to develop a programme for parents that enhance breastfeeding self-efficacy and support infant thriving.

Method: Intervention mapping

Study part 2 Aim: to evaluate the programme.

Design: Cluster randomized study

Method: The programme will be implemented at 5 hospitals. 5 other hospitals serve as control hospitals. 120 mothers will be included at each hospital. Primary outcome: parental breastfeeding self-efficacy. Secondary outcome: establishment and duration of breastfeeding, infant morbidity and 
use of the health care system. Data are collected via questionnaires.

Analysis: Intervention and control group will be compared, the principle of intention-to-treat used and the intra-class correlation will be taken into account

Study part 3 Aim: to evaluate the parents' experiences and the utility of the programme.

Design: Qualitative focus group interviews.

Method: Intervention-group parents express their experience with breastfeeding establishment and the programme. A semi-structured interview guide is used during facilitation.

Analysis: Interviews are analyzed using a hermeneutic/phenomenological approach.

CH.O1 Rikke Holm Jensen

MUTATIONAL STUDIES IDENTIFY A PUTATIVE TRANSPORT PATHWAY FOR THE $3^{\text {RD }} \mathrm{NA}^{+} I \mathrm{ON}$

\section{R. Holm, A.P. Einholm, B. Vilsen}

Institut of Biomedicine, Aarhus University

The crystal structure of the $\mathrm{Na}^{+}, \mathrm{K}^{+}$-ATPase has revealed a unique pocket or channel-like structure between transmembrane segment M5, M7, M8 and M10, capped by two C-terminal tyrosines, which we have shown regulate $\mathrm{Na}^{+}$affinity on both sides of the membrane. We have previously found a marked decrease in $\mathrm{Na}^{+}$affinity in the human a3 mutant D923N, which is associated with Rapid-onset Dystonia Parkinsonism. D923 is located in the cytoplasmic half of M8 in the channel-like structure. Here I present the results of replacing various residues of the channel in the rat al isoform to examine whether the channel functions as transport pathway. The mutational effects on $\mathrm{Na}^{+}$and $\mathrm{K}^{+}$affinities and the E1-E2 and E1P-E2P conformational transitions of the pump cycle were characterized. Replacement of D928 of rat a 1, equivalent to D923 of human a3, with aspargine, leucine, or glutamate resulted in significant reduction of apparent $\mathrm{Na}^{+}$affinity. External $\mathrm{K}^{+}$affinity is only affected in the D928L mutant. C932 is located close to the cytosolic mouth of the channel. Replacement with phenylalanine or leucine resulted in a conspicuous reduction in $\mathrm{Na}^{+}$affinity with little effect on $\mathrm{K}^{+}$ affinity, as would be expected if the bulky side chains of these residues specifically prevent the third $\mathrm{Na}^{+}$ion from entering the channel. The idea of a transport pathway involving the channel-like structure is further supported by the effects of mutations to Q856 placed deep in the channel. Hence, Q856A and Q856L also displayed a marked reduction of $\mathrm{Na}^{+}$affinity with little effect on $\mathrm{K}^{+}$affinity, suggesting that Q856 is associated with the $3^{\text {rd }} \mathrm{Na}^{+}$ ion.

CH.02 Sys Hasslund RAAV-GDF5 GENE DELIVERY IMPROVES JOINT FLEXION IN A MURINE Svensson MODEL OF FLEXOR TENDON REPAIR

\section{S. Hasslund Svensson}

Department of Orthopaedics E, Aarhus University Hospital

Repair of the flexor tendons of the hand is complicated by fibrotic adhesions that compromise the tendon gliding function and limit the joint flexion. To date, restoring the gliding function after primary repair of the flexor tendons, especially in Bunnell's "no man's land" or zone II, remains an unsolved problem. As an alternative, surgeons often use a tendon graft, passing it through the fibrous tunnel of zone II, and surgically attaching the proximal and distal graft ends outside of zone II.

Little is known about the factors involved in the formation of flexor tendon adhesions. To help elucidating the molecular mechanisms in the flexor tendon adhesion formation, we developed a mouse model of flexor 
digitorum longus (FDL) tendon reconstruction using a live autograft or a freeze-dried allograft. The model can aid in preliminary screening of molecular treatments of flexor tendon adhesions. We investigated the potential of rAAV-Gdf5-loaded freeze-dried tendon allografts as "therapeutically endowed" tissueengineering scaffolds to reduce adhesions. When the rAAV-Gdf5 loaded freeze-dried FDL tendon allograft is grafted into the FDL tendon, the metatarsophalangeal (MTP) joint flexion is improved significantly compared to the rAAV-lacZ control. Our data demonstrate the feasibility and efficacy of therapeutic tendon allograft processing as a novel paradigm in tissue engineering.

New studies are initiated using the mouse model to investigate other therapeutic targets to improve flexor tendon healing. Electroporation will be used as a new gene delivery method. This method is not only applicable in a tendon grafting model, but also in a primary tendon repair model.

CH.03 Efe Levent Aras COST-EFFECTIVENESS OF SURGICAL AND CONSERVATIVE TREATMENT OF SPINAL FRACTURES

E.L. Aras $^{3}$, R. Søgaard', E.S. Hansen ', C. Bunger ${ }^{7}$

'Orthopedic Surgery Department E, Aarhus University Hospital, ${ }^{2}$ CAST, University of Southern Denmark, ${ }^{3}$ Aarhus University Hospital, Orthopedic Surgery Spinal Research Lab.

Background:Management options of spinal fractures are widely evaluated in the literature. However the number of Level 1 studies are still limited. This scarcity probably is caused by the natural course of trauma which constitutes difficulties to conduct RCTs among these patient groups except some of thre very specific cases. For that reason, despite the evidence from RCTs, there might be a persisting rationale for observational studies with health economic perspectives that elucidate indications of treatments.

Materials and Methods:The $1^{\text {st }}$ phase was to define the relevant patient cohort and the $2^{\text {nd }}$ one was to recruit the needed data from the national registries. With this manner, the study was conducted to a prospectively registered spine fracture patients who were treated at the Dept. of Orthopedics and Neurosurgery, AUH from 01.01.1996 to 31.12.2011. Hospital registry system were used to retrieve admitted patients with relevant ICD-10 codes. 3049 patients were identified with abovementioned diagnostic codes. After identification of the cohort, we applied to Danmark Statistics in order to recruit the cost and health care utilization data. The Number and the type of the services from primary and secondary health care sector were calculated from the data which was provided by the Landspatientsregister and Sygesikringsregister. Costs of these services estimated by using the DRG and DAGS system. Changes in the dominant labor activity were defined as our major effect parameter, which was also provided from Danmarks Statistics.

Results:Full data recruitment were completed and analysis with the relevant health economical perspective is currently pending.

CH.04 Zhanna DISRUPTION OF RETINOID AND CYP SYSTEMS AND EMBRYO DEVELOPMENT Tairova IN MARINE ORGANISMS: A POTENTIAL MODEL FOR HUMANS

\section{Z. Tairoval, 2 , J. Strand ${ }^{2}$, E.C. Bonefeld-Jørgensen ${ }^{7}$}

${ }^{1}$ Center of Arctic Health \& Unit of Cellular \& Molecular Toxicology, Department of Public Health, Aarhus University, Aarhus., ${ }^{2}$ Department of Bioscience, Marine Ecology, Aarhus University, Roskilde.

Some environmental persistent organic pollutants (POPs) can be highly toxic and may pose a risk for both natural fauna populations and humans. POPs can disrupt an array of molecular and cellular mechanisms causing endocrine disruptions, cancer and teratogen effects. Potentially, POPs can 
interfere with embryo development and reproduction.

The PhD project was designed to investigate the link between exposure to POPs such as dioxin-like compounds and PAHs and effects in aquatic organisms by combining different in vivo and in vitro biomarkers in both laboratory and field studies to improve assessment of toxicological effects of these pollutants to aquatic organisms. The following hypothesis is tested in this PhD project: Exposure to xenobiotics such as dioxin-like compounds (DLCs) and polycyclic aromatic hydrocarbons (PAHs) leads to induction of CYP 450 enzymatic activities, which results in disruption of the CYPdependent retinoid metabolism and may potentially cause abnormal larvae and embryo development of organisms.

Eelpout (Zoarces viviparus) was exposed to different dioxin-like compounds in the laboratory throughout its whole gestation period. Different biomarkers, such as retinoid metabolism, CYP1A activity, reproductive success and embryo development, were measured on the adult female fish together with its brood. Additionally, the cell culture in vitro bioassay - the AhR transactivity assay - was applied on to the extracts of exposed fish tissue and blood serum. Results presented are used in order to test the hypothesis of the project and to explore the potential of such bioassay as an alternative and universal screening tool for environmental fish samples.

CH.05 Kresten Krarup BONE FORMATION AND RESORPTION ARE BOTH INCREASED IN Keller AUTOIMMUNE ARTHRITIS

K.K. Keller', J.S. Thomsen ${ }^{2}$, K. Stengaard-Pedersen ', F. Dagnces-Hansen ${ }^{3}$, J.R. Nyengaard', E.M. Hauge

'Department of Rheumatology, Aarhus University Hospital, ${ }^{2}$ Department of Biomedicine - Anatomy, Aarhus University, ${ }^{3}$ Department of Biomedicine, Aarhus University, ${ }^{4}$ Stereology and Electron Microscopy Laboratory, Centre for Stochastic Geometry and Advanced Bioimaging, Aarhus University Hospital

Introduction: Arthritic bone loss in the joints of patients with rheumatoid arthritis is the result of a combination of bone resorption and formation. This process is not completely understood, and especially the importance of local inflammation needs further investigation. We used 3D stereological estimators to evaluate how bone formation and bone resorption are altered in autoimmune arthritis.

Methods: Twenty-one SKG mice were randomized to either an arthritis group or a control group. After six weeks, the right hind paws were embedded in methylmethacrylate. Tissue sections were cut according to the principles of vertical sectioning and systematic sampling. Intercepts between a line grid and the tissue of interest were counted for surface estimation.

Results: We found that the mineralizing surfaces, eroded surfaces and osteoclast covered surfaces were elevated in arthritic paws compared to normal paws. Mineralizing surfaces were elevated adjacent to as well as not adjacent to inflammation in arthritic mice compared to normal mice. In arthritic mice eroded surfaces and osteoclast covered surfaces were larger on bone surfaces adjacent to inflammation than on bone surfaces without adjacent inflammation. However, we found no difference between mineralizing surfaces at bone surfaces with or without inflammation.

Conclusions: Arthritis caused bone formation to occur on more surfaces, despite the adjacent tissue being inflamed. Moreover, bone resorption was almost exclusively present at bone surfaces adjacent to inflammation. Therefore, arthritic bone loss is likely explained by an imbalance of bone resorption and bone formation. 

WITH POSTOPERATIVE IRRADIATION: FOCUS ON RADIATION DOSE AND TREATMENT TECHNIQUES

\section{T. Grantzau', M. Skovhus Thomsen' ${ }^{2}$ J. Overgaard}

'Department of Experimental Clinical Oncology, Aarhus University Hospital, ${ }^{2}$ Department of Medical Physics, Aarhus University Hospital

Objective: Several epidemiological studies have reported increased risks of second primary lung cancers among breast cancer patients treated with postoperative radiotherapy. In this study, we investigate the dose-response relationship of second primary lung cancers after breast cancer irradiation.

Methods: Within a national population-based cohort of 23,627 irradiated patients treated for histological confirmed first primary breast cancer, a nested case-case study of second lung cancer was conducted. All patients in the cohort had been treated according to the national guidelines of the Danish Breast Cancer Cooperative Group (DBCG) in the period from 1982 to 2007, and all patients had been treated on linear accelerators. For each case the medical records including smoking status, the full radiotherapy treatment technique and the radiographic image of the lung cancer were reviewed. Peripheral dose estimations according to the anatomical location of the lung cancer will be estimated on the basis of the dose-planningsystem Eclipse and phantom measurements.

Preliminary results: A total of 166 histologically confirmed second primary lung cancers were identified and available for analysis. Adenocarcinoma (35\%), small-cell carcinoma (30\%) and squamous-cell carcinoma (16\%) made up the majority of the lung cancers. $52 \%$ of the lung cancers developed in the ipsilateral lung (relative to the breast cancer) and $40 \%$ in the contralateral lung. In $80 \%$ of the cases, the women were current smokers.

Conclusion: This is an ongoing study and dose estimations are not completed.

CH.07 Michael René A HIGH ADIPOSE TISSUE ARACHIDONIC ACID CONTENT IS ASSOCIATED Skjelbo Nielsen WITH A HIGHER RISK OF MYOCARDIAL INFARCTION: A DANISH CASE COHORT STUDY

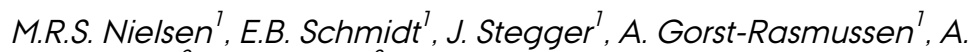
Tjonneland', K. Overvad ${ }^{3}$

'Department of Cardiology, Center for Cardiovascular Research, Aalborg Hospital, Aarhus University Hospital, Aalborg, ${ }^{2}$ Danish Cancer Society, Institute of Cancer Epidemiology, Copenhagen, ${ }^{3}$ Section for Epidemiology, Department of Public Health, Aarhus University

Objective: The primary aim of the study was to evaluate the association between adipose tissue arachidonic acid (AA) content and the risk of myocardial infarction (MI). The secondary aim was to assess the correlation between adipose tissue AA and dietary intake of AA and linoleic acid (LA).

Methods: We conducted a case-cohort study nested within the Danish prospective Diet, Cancer and Health (DCH) study. After appropriate exclusions, the study included 2,134 incident Ml cases. Gluteal adipose tissue biopsies were collected at recruitment, and the fatty acid composition was determined by gas chromatography. A weighted Cox proportional hazards model was used to evaluate the association between adipose tissue AA content and the risk of $\mathrm{MI}$.

Results: After adjusting for confounders, we found a positive association between adipose tissue AA content and the risk of Ml. Hazard ratios (HR) of $\mathrm{MI}$ relative to the lowest quintile of adipose tissue AA content increased across quintiles in a dose-dependent manner; second quintile (HR 1.19 
95\%Cl: 0.97-1.45), third (HR 1.24 95\%Cl: 1.02-1.52), fourth (HR $1.2895 \% \mathrm{Cl}$ : 1.03-1.60) and fifth quintile (HR $1.3995 \% \mathrm{Cl}: 1.10-1.77$ ). Adipose tissue AA levels were not correlated with dietary intake of $A A(r=0.03,95 \% \mathrm{Cl}:-0.01$, $0.06)$ and weakly negatively correlated with dietary intake of $L A(r=-0.12$, 95\% Cl: $-0.15,-0.08)$

Conclusions: The adipose tissue content of AA was positively associated with the risk of Ml, but did not correlate with dietary intake of neither AA nor LA.

CH.08 Ditte Olsen SORLA REGULATES GDNF ACTIVITY THROUGH SORTING OF GDNF AND ITS RECEPTORS GFRA 1 AND RET

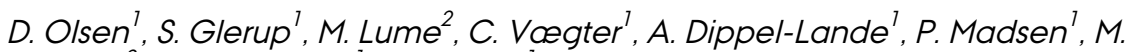
Saarma', C.M. Petersen', A. Nykjcer ${ }^{7}$

${ }^{1}$ MIND Centre, Department of Biomedicine, Aarhus University, ${ }^{2}$ Institute of Biotechnology, University of Helsinki

The glial cell line-derived neurotrophic factor (GDNF) is a potent neurotrophic factor that has reached clinical trials for Parkinsons's disease. GDNF binds to its co-receptor GFRal and signals through the transmembrane receptor tyrosine kinase RET, or RET-independently through NCAM or syndecan-3. Whereas the GDNF signalling cascades are well described, cellular turnover and trafficking of GDNF and its receptors remain poorly characterized. Here, we find that SorLA acts as sorting receptor for the GDNF/GFRal complex directing it from the cell surface to endosomes. Through this mechanism, GDNF is targeted to lysosomes and degraded while GFRa 1 recycles, creating an efficient GDNF clearance pathway. The SorLA/GFRal complex further targets RET for endocytosis, but not for degradation, affecting GDNF-induced neurotrophic activities. Hence, SorLAdeficient mice display elevated GDNF levels accompanied by altered dopaminergic function, marked hyperactivity and reduced anxiety; phenotypes previously related to abnormal GDNF activity. Taken together, these findings establish SorLA as a critical regulator of GDNF activity in the CNS.

CH.09 Jurgita Janukonyté

DIURNAL VARIATION IN THE PHARMACOKINETICS OF GROWTH HORMONE ADMINISTERED AS A CONTINUOUS SUBCUTANEOUS INFUSION IN GHDEFICIENT SUBJECTS

J. Janukonyté', T. Parkner ${ }^{2}$, J.S. Christiansen' ', T. Lauritzen ${ }^{3}$, T. Laursen ${ }^{4}$

'Department of Endocrinology and Internal Medicine, Aarhus University Hospital, ${ }^{2}$ Department of Clinical Biochemistry, Aarhus University Hospital, ${ }^{3}$ Department of Public Health, Section of General Practice, Aarhus University, ${ }^{4}$ Department of Biomedicine (Clinical Pharmacology), Aarhus University

Background: Previous studies in growth hormone (GH)-deficient (GHD) subjects have indicated a diurnal variation in the pharmacokinetics (PK) of $\mathrm{GH}$ dependent on the mode of $\mathrm{GH}$ administration. Thus, higher $\mathrm{GH}$ levels were observed during the night with constant subcutaneous (SC) infusion, and increased $\mathrm{GH}$ bioavailability was reported following daily SC injections in the evening versus morning.

Aim: To study whether diurnal variability in the PK of SC-administered exogenous $\mathrm{GH}$ can be reproduced.

Methods: Nine male GHD patients (59.8 18 years) received a continuous SC infusion of $\mathrm{GH}$ ( $3 \mathrm{mg} / 24$ hours (h)) for $60 \mathrm{~h}$ on two different occasions.

Diurnal variation in PK of GH was studied during steady state in the last $24 \mathrm{~h}$ of the infusion period.

Results: Mean integrated ( \pm SEM) GH levels were higher at night-time (23:00$07: 00 \mathrm{~h})$ than during the day $(10: 00-18: 00 \mathrm{~h})[6.3 \pm 2.1 \mathrm{ng} / \mathrm{mL}$ and $5.2 \pm 1.7$ $\mathrm{ng} / \mathrm{mL}$, respectively; $\mathrm{p}<0.05]$. Similar results were obtained comparing e.g. 
CH.10 Anne Skakkebcek Jensen

CH.1 1 Dirk Troitzsch PERIOPERATIVE MONITORING OF MYOCARDIAL TISSUE OXYGENATION AND POSTISCHEMIC CARDIAC PERFORMANCE IN PEDIATRIC CARDIAC SURGERY

D. Troitzsch ${ }^{1,2}$, S. Vogt ${ }^{2}$, R. Moosdorf ${ }^{2}$, J.M. Hasenkam ${ }^{7}$, H. Nygaard ${ }^{7}$

'Aarhus University, Faculty of Health Sciences, Department of Cardiothoracic and Vascular Surgery, T-Research, Department of Clinical Medicine, Aarhus, Denmark, ${ }^{2}$ Cardiovascular Research, Biomedical Research Center, Department of Cardiac and Thoracic Vascular Surgery, 
Philipps-University Marburg, Germany

Background: Imbalances in myocardial tissue oxygenation may be a mechanism of left ventricular (LV) dysfunction. We hypothesized that measurement of tissue oxygen tension may provide a marker for early detection of perioperative myocardial injury and identify patients at risk for decreased LV function.

Material/Methods: We examined myocardial tissue oxygen data in neonates ( $n=14$, age $5.5 \pm 4.8$ days) undergoing cardiac surgery for congenital heart disease. Flexible microcatheter oxygen probes (Licox®) were placed in the myocardial tissue (LV wall). Myocardial tissue oxygen tension $\left(\mathrm{ptiO}_{2}\right.$ ) was monitored continuously during surgery. Risk factors for critical myocardial oxygen levels were evaluated using multiple linear regressions to determine their impact on postoperative myocardial dysfunction.

Results: The myocardial oxygen level, which decreases to very low levels during ischemia, recovers during early reperfusion to levels higher than baseline. Three of the 14 patients demonstrated an abnormal elevation (overshoot) and low with even critical myocardial $\mathrm{ptiO}_{2}$ during reperfusion $(19.3 \pm 3.1 \mathrm{mmHg}$ vs. $38.9 \pm 5.7 \mathrm{mmHg}$ ). All 3 patients exhibited severe myocardial dysfunction, postoperatively. Prolonged cardiopulmonary bypass (CPB) and aortic cross-clamp time, age less than 5 days and weight less than $2.2 \mathrm{~kg}$ were associated with critically compromised myocardial tissue oxygenation and LV myocardial dysfunction in the early postoperative period.

Conclusion: Perioperative on-line tracking and continuous monitoring of myocardial tissue oxygen tension may indicate impaired postoperative myocardial performance in relation to myocardial tissue oxygenation in congenital heart surgery.

CH.12 Shallu Sharma LONG-TERM HEALTH CARE UTILIZATION AND OUTCOME AFTER ADULT SCOLIOSIS SURGERY

\section{S. Sharma, T. Andersen C. Bunger R. Soegaard}

Department of Orthopaedics, Aarhus University Hospital

The aim of scoliosis surgery in adults is to correct deformity and allow patients to lead a normal work-leisure life. Therefore. the question is: How are these patients? Do they report health states comparable to their controls, or do they subsequently become long-term patients? From this insight, it is relevant to investigate the socioeconomic impact of adult scoliosis surgery on patients' disability, work status and overall satisfaction.

A mail survey with EQ-5d, DPQ and LIVQS questionnaires was conducted. Data on health care usage was obtained from the National Health Insurance and the National Patient Registry. The cohort reports $30 \%$ disability in daily activities and $28 \%$ disability in work to pain, respectively. Disability due to anxiety and depression was $24 \%$. Patient's EQ-5d scores are significantly less compared to matched controls ( 0.68 vs 0.83 ). A significant shift from work force category to non-work force was seen; this may suggest deterioration of work status post surgery. The changes in the dosage and medication type suggested a reduction in pain medication use $(p=0.004)$. $10 \%$ patients reported worsening of the help requirements compared to prior operation. The activity levels improved in 38\% of the patients. $77 \%$ patients were completely satisfied with the outcomes of surgery. Surgery had the highest impact on health during the first 2 years after surgery. Services related to cardio-respiratory problems constituted the major chunk of resource utilization in the follow-up. Steady increase in musculoskeletal resources utilization was observed in the follow-up years. All the utilization figures plateau to preoperative levels only in the long term (>12 years). 
CH.13 Louise Tram Henriksen
CLINICAL ASPECTS OF ASPARAGINASE-ASSOCIATED ALLERGY IN THE TREATMENT OF CHILDHOOD ACUTE LYMPHOBLASTIC LEUKAEMIA IN THE NORDIC AND BALTIC COUNTRIES

L.T. Henriksen', A. Harila-Saari', J. Abrahamsson ${ }^{4}$, G. Vaitkeviciene ${ }^{5}$, O.G. Jónsson ${ }^{6}$, E. Ruud ${ }^{3}$, H. Schrøder ', B.K. Albertsen ${ }^{7}$

${ }^{1}$ Paediatric Research Department, Aarhus University Hospital, Skejby, ${ }^{2}$ Oulu University Hospital, Finland, ${ }^{3}$ Oslo Universitetssykehus, Rikshospitalet, Norway, ${ }^{4}$ Drottning Silvias Barn och Ungdomssjukhus Göteborg, Sweden, ${ }^{5}$ Vilnius University Children's Hospital, Lithuania;, ${ }^{6}$ Children's Hospital Reykjavik, Iceland

Background: Asparaginase is an important drug in the treatment of childhood acute lymphoblastic leukaemia. The use of asparaginase may be limited by serious adverse events of which allergy is the most frequent. The purpose of this study was to describe the clinical aspects of asparaginaseassociated-allergy in children and adolescents treated according to the NOPHO ALL-2008 protocol.

Procedure: In the NOPHO ALL-2008 protocol, low-dose intramuscular PEGasparaginase $1000 \mathrm{IU} / \mathrm{m}^{2}$ is given from day 29 over a period of approximately 30 weeks. In case of allergic reactions, PEG-asparaginase is substituted with Erwinase. Through an online toxicity registration, we identified patients registered with asparaginase allergy. Clinical data were collected using a questionnaire to the local clinicians.

Preliminary results: The frequency of clinical PEG-asparaginase associated allergy was $13 \%$ (74/580). The high-risk group had a higher frequency of allergy than the non-high risk. Forty-two patients (57\%) reacted with allergy after the second dose of PEG-asparaginase. Thirty patients (41\%) developed an allergic reaction more than two hours after the asparaginase injection. Nine patients (12\%) developed an anaphylactic reaction (grade 4). Sixty-three patients were switched to Erwinase. Four of $63(6 \%)$ experienced allergic reactions to Erwinase.

Conclusion: Allergic reactions to PEG-asparaginase occur after few doses. High-risk patients are more prone to develop allergic reactions than nonhigh risk. Nearly half of the allergic reactions presented more than two hours after PEG-asparaginase administration and were in general moderate in severity.

CH.14 Frank Holden Mose

\section{INCREASED NO ACTIVITY DURING STATIN TREATMENT IN PATIENTS WITH} NON-DIABETIC NEPHROPATHY

\section{F.H. Mose, J.M. Jensen, T. Larsen, J.N. Bech, E.B. Pedersen}

Department of Medical Research and Medicine, Holstebro Hospital

Purpose:We investigated the effects of short term atorvastatin treatment on blood pressure (DBP and SBP), GFR and fractional excretion of sodium (FE$\mathrm{Na}$ ) during inhibition of nitric oxide synthase (NOS) in patients with nondiabetic nephropathy.

Methods: Twenty-five patients with chronic kidney disease stage IV-Vwere examined in a randomised, placebo-controlled, double-blinded, cross-over study. All subjects attended 2 study days and were given either Atorvastatin $80 \mathrm{mg}$ per day or placebo 4 days prior to each examination day. During the treatment period subjects were on a standardized diet. On examination day L-NMMA was administered as bolus injection followed by infusion for one hour. Blood and urine samples were collected every 30 minutes during baseline period, during L-NMMA infusion and 60 minutes after cessation of L-NMMA infusion.

Results: Baseline levels of DBP, SBP, and HR were not different between groups. L-NMMA increased both DBP and SBP and decreased HR $(p<0.001)$. 
CH.15 Lau Brix

\section{$\mathrm{CH} .16$}

Steffen Bank
There were no differences in change in SBP, and HR between groups. GFR and $F E_{\mathrm{Na}}$ were similar at baseline. GFR decreased during L-NMMA infusion ($5.2 \pm 5.7 \mathrm{ml} / \mathrm{min} v \mathrm{~s}$. $-4.8 \pm 6.9 \mathrm{ml} / \mathrm{min}$, both $\mathrm{p}<0.05$ ), but there were no differences between groups $(p=0.818)$. L-NMMA infusion caused a significant reduction in $\mathrm{FE}_{\mathrm{Na}}$ in both groups $(-0.61 \pm 0.61 \% \mathrm{vs}$. $-0.80 \pm 0.82 \%$, $\mathrm{p}=0.001$ in both groups compared to baseline) and the reduction was similar $(p=0.224)$. In the post-LNMMA period $\mathrm{FE}_{\mathrm{Na}}$ the decrease was more pronounced in atorvastatin group compared to placebo $(-0.45 \pm 0.69 \%$ vs. $0.79 \pm 0.94 \%, p=0.024$ ).

Conclusions: Short term Atorvastatin treatment significantly increased the reduction in $\mathrm{FE}_{\mathrm{Na}}$ during NOS inhibition.

INTERACTIVE MR IMAGING AND RECONSTRUCTION OF MOVING ANATOMICAL STRUCTURES

\section{Brix ${ }^{1,2}$, T.S. Sørensen ${ }^{4,5}$, M. Ries ${ }^{3}$, B. Stausbøl-Grøn' ${ }^{2}$, S. Ringgaard ${ }^{2}$}

'Department of Procurement \& Clinical Engineering, Central Denmark Region, Denmark, ${ }^{2}$ MR Research Centre, Aarhus University Hospital, Skejby, Denmark, ${ }^{3}$ Image Sciences Institute, University Medical Center Utrecht, Utrecht, The Netherlands, ${ }^{4}$ Department of Computer Science, Aarhus University, Denmark,, ${ }^{5}$ Department of Clinical Medicine, Aarhus University, Denmark

Background: Real-time MRI imaging with real-time reconstruction has been around for some time. The technique acquires and presents MRI images to the operator at the instant they are acquired. However, besides catheter tracking and placement of electrodes during neurosurgery, the diagnostic value of the images are relatively unexplored.

Purpose: To test an interactive slice positioning system with corresponding real-time MRI reconstruction for imaging of moving anatomical structures on two different scanner brands by using inexpensive commodity computer hardware.

Materials and methods: The MRI data were sampled using two acquisition schemes: a Cartesian sampling scheme and a radial sampling scheme based on the Golden Ratio. Four anatomical targets, which exhibit nonperiodic movement, were identified and imaged: movement of the vocal chords during singing, movement of a fetus and movement of the peristaltic motions in the bowels as well as in the gastric ventricle.

Results: Informative anatomical images were obtained in different settings of moving targets. The implemented real-time system acquired, reconstructed and displayed MRI images in real-time with a high frame rate using inexpensive computer hardware on two standard clinical MRI scanners.

Conclusion: Our approach verified that when imaging selected moving anatomical targets, with no a priori knowledge of the movement, interactive slice positioning using real-time reconstruction may be a feasible approach for finding the optimal slice position in cases in which a standard 3D volumetric scan does not suffice. Future studies are needed to explore the full potential of the technique.

\section{CAN GENETIC MARKERS PREDICT THE RESPONSE OF TNF INHIBITOR} THERAPY?

\footnotetext{
S. Bank ${ }^{7}$, B.A. Nexø ${ }^{1,2}$, V. Andersen ${ }^{1,3,4}$, U. Vogel, 6 , P.S. Andersen ${ }^{7}$

${ }^{1}$ Medical Department, Viborg Regional Hospital, Viborg, Denmark, ${ }^{2}$ Department of Biomedicine, Aarhus University, Aarhus, Denmark, ${ }^{3}$ Medical Department, SHS Aabenraa, Aabenraa, Denmark, 'Institute of Regional Health Service Research, University of Southern Denmark, Odense, Denmark, ${ }^{5}$ National Research Centre for the Working Environment, Copenhagen,
} 
Denmark, ${ }^{6}$ Department of Micro- and Nanotechnology, Technical University of Denmark, Lyngby, Denmark, ${ }^{7}$ Department for Microbiological Surveillance and Research, Statens Serum Institut, Copenhagen, Denmark

Background: Inflammatory bowel diseases (IBD) including Crohn's disease (CD) and ulcerative colitis (UC) are chronic diseases with a complex aetiology comprising both genetic and environmental factors. Tumor necrosis factor-a (TNF-a) inhibitors are used for treatment of severe cases. However, approximately one-third of the patients do not respond adequately to the treatment. Genetic markers might predict which patients will have effect of the treatment.

Method: Blood samples sent to Statens Serum Institut (SSI) and other Danish laboratories for tuberculosis antigen test were collected from 9217 patients from 1 September 2009 to 30 March 2011. By using the National Patient Registry, 1378 patients with an ICD 10 code of K50-K63 were identified and their patient records were examined. DNA was purified by Maxwell 16 blood purification kit (Promega) and 40 single nucleotide polymorphisms (SNPs) were genotyped by KBioscience.

Results: Clinical data were available from 759 patients and response was achieved by 535 (70\%) patients. In consensus with other studies, CRP level, age and smoking was associated with response. Furthermore, patients with UC and gender were associated with response. Preliminary results indicate that functional polymorphisms in TNF-a, TNF-a receptor I (TNFR 1), toll like receptor 2 (TLR2), TLR4 and a few other genes involved in inflammation are associated with response.

Conclusion: We have not yet examined if response to TNF-a inhibitor treatment in patients with IBD can be predicted based on SNPs and/or biochemical tests. The study is retrospective and should be interpreted with care. A replica study in patients with IBD will be performed.

$\begin{array}{ll}\mathrm{CH} .17 & \text { Mariane } \\ & \text { Høgsbjerg } \\ & \text { Schleimann }\end{array}$

\section{THE HERPESVIRAL PROTEIN DR6 SUPPRESSES CELL PROLIFERATION M.H. Schleimann, P. Höllsberg \\ Department of Biomedicine, Aarhus University}

Human herpesvirus-6B ( $\mathrm{HHV}-6 \mathrm{~B})$ is a ubiquitous virus that infects more than $95 \%$ of children before the age of three. The virus gives rise to a latent infection that may reactivate later in life via poorly understood mechanisms. Although reactivation is most often asymptomatic, it may cause severe disease in the brain, including epilepsy and encephalitis.

To understand the HHV-6B host-cell interactions, we use a cellular model system. A HHV-6B protein DR6, has been reported to interfere with p53 and disturb normal cellular regulation. Our hypothesis is that DR6 by inhibiting p53 may inhibit apoptosis. To study this protein further, it was cloned to allow ectopic expression. Moreover, antibodies were generated to study the protein during $\mathrm{HHV}-6 \mathrm{~B}$ infections.

Characterization of the cellular localization of DR6 during HHV-6B infection demonstrated that it was recruited to compartments in the nucleus, known as viral replication compartments. Surprisingly, it did not co-localize with p53. Importantly, overexpression of DR6 suppressed cell proliferation. To examine this, a stable, inducible expression-cell line was generated by Flp recombinase-mediated integration to allow controlled induction of DR6 expression. This demonstrated a dose-dependent inhibition of cell proliferation by DR6.

Based on our data, we now speculate that DR6 serves as an anchor for one or more human proteins by recruiting them to the site of viral replication. When DR6 is overexpressed, the cell is depleted for these proteins; some of which are responsible for cell proliferation. This arrest in cell cycle may be critical for the replication of HHV-6B and may thus be a potential target for 
anti-viral drugs.

CH.18 Srikanth CYTOSOLIC DNA RECOGNITION IN KERATINOCYTES - A POTENTIAL Chiliveru IMPLICATION FOR EARLY PSORIASIS PLAQUE FORMATION

\section{S. Chiliveru, S.R. Paludan}

Department of Biomedicine, Aarhus University

Cytosolic localization of DNA has recently emerged as a critical activator of early innate defence, but the molecular mechanisms of recognition and immune activation remain largely unexplained. DNA detection in the cytoplasm leading to IFN- $\beta$ induction is thought to be one of the triggers for autoimmune and inflammatory conditions. Psoriasis is a chronic inflammatory skin disease and is characterized by infiltration of immune cells into the dermis leading to hyper-proliferation of epidermal keratinocytes.

Transfection of keratinocytes with a 60-base pair dsDNA oligo, derived from the HSV-1 genome (HSV 60mer), resulted in the induction of type I interferons. These results laid thrust on involvement of cytosolic DNA recognition in inflammation activation. The pre-treatment of keratinocytes with HSV6Omer followed by the administration of cytokine TNFa resulted in the high level induction of CCL20, a chemokine abundant in psoriatic plaques. A similar chemokine induction was observed when self DNA (sonicated) was replaced instead of the HSV6Omer. This revealed a possible synergistic effect of cytosolic DNA (HSV6Omer) and inflammatory cytokines, resulting in the induction of high level chemokine response in keratinocytes. The role of the endogenous human antimicrobial peptide LL-37 in relation to DNA transfection ability and immune-modulatory function in keratinocytes is also studied. Further studies aim at the identification of the probable DNA sensor recognizing the cytosolic DNA (synthetic \& self) and the various adaptors involved in the signalling pathway as a potential implication for early psoriatic plaque formation.

CH.19 René Østgård BOWEL INFLAMMATION IN SPONDYLOARTHRITIS IS DETECTABLE BY CALPROTECTIN AND AMELIORATED BY TREATMENT WITH ADALIMUMAB

R.D. Oestgaard ${ }^{1,2}$, H. Glerup', A.G. Jurik', B. Deleuran'

${ }^{1}$ Department of Medicine, Regional Hospital Sikeborg, ${ }^{2}$ Department of Biomedicine, Aarhus University, ${ }^{3}$ Radiological Department R, Aarhus University Hospital

The link between spondyloarthritis ( $\mathrm{SpA}$ ) and inflammatory bowel disease (IBD), especially Crohn's disease, has been known for over 20 years. In SpA guidelines, failure of at least two NSAIDs is required before anti-TNF treatment is recommended. NSAID is not recommended in IBD. Faecal calprotectin is a reliable marker of intestinal inflammation. In Sweden, elevated calprotectin was found in $68 \%$ of patients with ankylosing spondylitis, but no clinical studies were available to elucidate these findings.

The purpose of this study is to examine the prevalence of bowel lesions in SpA patients and the effect of adalimumab.

Using calprotectin as a screening marker, SpA patients with active axial disease are divided into two groups. As NSAIDs can affect the level of calprotectin, a 4-week washout period is required. Then endoscopy, MRI and clinical examinations are performed before anti-TNF treatment is initiated. Follow-up examination is performed after 20 weeks in the active group and in controls if intestinal lesions are found at baseline. Primary endpoint is Lewis score before and after treatment.

Though preliminary, the results are convincing. Eight patients in the active group underwent follow-up endoscopy and ten patients in the control group underwent capsule endoscopy. All patients with elevated calprotectin had 

CH.20 Louise Brøndt
Hartlev small bowel lesions; they all responded well to treatment with adalimumab resulting in a decrease in Lewis score. None of the patients with a normal calprotectin level had lesions.

Small bowel inflammation in SpA is detectable by calprotectin and ameliorated by treatment with adalimumab. The study continues to further elucidate the findings in $\mathrm{SpA}$.

DESIGN-BASED STEREOLOGY FOR ESTIMATION OF ABSOLUTE VOLUME AND SURFACE AREA OF THE HYALINE AND CALCIFIED CARTILAGE COMPARTMENTS OF HUMAN FEMORAL HEADS

\section{L.B. Hartlev', J.R. Nyengaard' ${ }^{2}$, J.S. Thomsen ${ }^{3}$, K. Stengaard-Pedersen ', E.M. Hauge}

'Department of Rheumatology, Aarhus University Hospital, ${ }^{2}$ Stereology and Electron Microscopy Laboratory, Center for Stochastic Geometry and Advanced Bioimaging, Aarhus University, ${ }^{3}$ Department of Biomedicine Anatomy, Aarhus University

Objective: We present an application of design-based stereological methods using the Cavalieri estimator and vertical sections to investigate entire undecalcified human femoral heads.

Methods: Ten entire human femoral heads were obtained from ten young normal individuals and 6-8 thin undecalcified vertical sections were obtained in each femoral head. The sections were analyzed in a light microscope with a new CAST software system. Absolute volumes and surface areas of the femoral head and the hyaline and calcified cartilage compartments were estimated. The average CE values of the stereological method were 0.03-0.06 (volume estimates) and 0.13-0.15 (surface area estimates)

Results: The femoral head volume was significantly $(p<0.05)$ smaller in the women $\left(24.8 \pm 0.9 \mathrm{~cm}^{3}\right)$ than in the men $\left(37.7 \pm 7.7 \mathrm{~cm}^{3}\right)$. The femoral head surface area was significantly $(p<0.05)$ smaller in the women $(32.2 \pm 2.9$ $\left.\mathrm{cm}^{2}\right)$ than in the men $\left(38.5 \pm 4.4 \mathrm{~cm}^{2}\right)$. The hyaline cartilage volume (women: $4.2 \pm 0.7 \mathrm{~cm}^{3}$, men: $5.2 \pm 0.7 \mathrm{~cm}^{3}$ ) and the hyaline cartilage surface area (women: $33.5 \pm 2.8 \mathrm{~cm}^{3}$, men: $40.7 \pm 6.4 \mathrm{~cm}^{3}$ ) did not differ significantly between the genders. The absolute volume (women: $0.27 \pm 0.1 \mathrm{~cm}^{3}$, men: $0.25 \pm 0.1 \mathrm{~cm}^{3}$ ), upper surface area (women: $29.3 \pm 4.3 \mathrm{~cm}^{2}$, men: $35.3 \pm 4.6$ $\mathrm{cm}^{2}$ ) and lower surface area (women: $45.7 \pm 10.1 \mathrm{~cm}^{2}$, men: $50.1 \pm 9.3 \mathrm{~cm}^{2}$ ) of the calcified cartilage compartment did also not differ significantly between the genders.

Conclusion: Design-based stereology including the Cavalieri estimator and vertical sections can successfully be applied to large undecalcified human tissue specimens in order to estimate the absolute volume and surface area of the tissue structures.

CH.21 Babak Jalilian GLATIRAMER ACETATE IN TREATMENT OF MULTIPLE SCLEROSIS: A TOOLBOX OF RANDOM CO-POLYMERS FOR TARGETING INFLAMMATORY MECHANISMS OF BOTH THE INNATE AND ADAPTIVE IMMUNE SYSTEM?

\section{B. Jalilian, H.B. Einarsson, T. Vorup-Jensen \\ Institute for Biomedicine, Aarhus University}

Multiple sclerosis is a disease of the central nervous system, resulting in the demyelination of neurons, causing mild to severe symptoms. Several antiinflammatory treatments now play a significant role in ameliorating the disease. Glatiramer acetate (GA) is a formulation of random polypeptide copolymers for the treatment of relapsing-remitting MS by limiting the frequency of attacks. While evidence suggests the influence of GA on inflammatory responses, the targeted molecular mechanisms remain poorly understood. Here, we review the multiple pharmacological modes-of- 
CH.22 Asger RIGHT VENTRICULAR HYPERTROPHY AND FAILURE ABOLISH

Andersen CARDIOPROTECTION BY ISCHEMIC PRECONDITIONING

actions of glatiramer acetate in treatment of multiple sclerosis. We discuss in particular a newly discovered interaction between the leukocyte-expressed integrin $a_{M} \beta_{2}$ (also called Mac-1, complement receptor 3, or CD 1 1b/CD18) and perspectives on the GA co-polymers as an influence on the function of the innate immune system.

\section{A. Andersen, J.A. Povlsen, H.E. Bøtker, J.E. Nielsen-Kudsk}

Department of Clinical Medicine, Department of Cardiology - Research

We investigated the response to ischemia and ischemic preconditioning in the hypertrophic and failing right heart.

Male Wistar rats $(n=74)$ were subjected to SHAM operation $(n=24)$, moderate pulmonary trunk banding (mPTB, $n=24$ ) or severe PTB (sPTB, $\mathrm{n}=26$ ). Four weeks after operation, right ventricle (RV) weight and function were evaluated. Hearts were quick-frozen $(n=28)$ or isolated and perfused with Krebs-Henseleit buffer a.m. Langendorff $(n=46)$. The perfused hearts were randomised to IPC ( $2 \times 5$ min of global ischemia) or no preceding ischemia (CON) followed by 40 min of global ischemia and $120 \mathrm{~min}$ of reperfusion. Measurement of the infarct size/area-at-risk (IS/AAR) ratio and post-ischemic RV function was used to evaluate the effect of IPC on the right ventricle. The quick frozen hearts were used to evaluate key components of the GPCR/NPR-AKT-eNOS-PKG and RISK pathways.

The MPTB procedure caused compensated RV hypertrophy and the sPTB procedure caused RV hypertrophy with failure. Hypertrophy of the RV caused an increase in infarct size in hearts from MPTB and SPTB animals compared to SHAM (IS/AAR: $66.5 \pm 3.4 ; 59.3 \pm 2.4$ vs. $35.6 \pm 2.9 \%$, respectively, $\mathrm{p}<0.0001)$. Cardioprotection by IPC was possible in SHAM and MPTB hearts measured by a decrease in IS/AAR and improved hemodynamic recovery of RV contractile function. In SPTB hearts with hypertrophy and failure, IPC did not improve IS/AAR or hemodynamic recovery and an increase in RV cGMP and PKG was observed.

Right ventricular hypertrophy increases infarct size and, when failure is present, increases CGMP and PKG and also abolishes cardioprotection by ischemic preconditioning in the right ventricular myocardium of the rat.

CH.23 Jonas Agerlund TEMPORAL CHARACTERIZATION OF CARDIAC ISCHEMIA-REPERFUSION Povisen INJURY

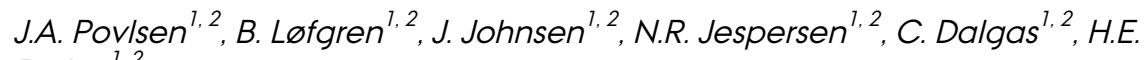
Bøtker ${ }^{1,2}$

${ }^{1}$ Department of Cardiology, Aarhus University Hospital, ${ }^{2}$ Department of Clinical Medicine, Aarhus University

Purpose: To do a temporal characterization of cardiac ischemia-reperfusion injury. Reperfusion is paramount to salvage ischemic myocardium, but in itself causes myocardial damage. As ischemic injury in the heart is often unpredictable, it is important to know when reperfusion injury occurs in order to optimize cardioprotective strategies.

Methods: In total, 79 male Wistar rats were allocated into 8 groups receiving 40 min of ischemia and either $60,90,120$ or 180 min of reperfusion combined with no ischemic preconditioning (Con) or ischemic preconditioning (IPC). Hearts were perfused retrogradely. IPC consisted of 2 cycles of 5 min ischemia +5 min reperfusion prior to index ischemia. Infarct size (IS) was determined by TTC staining in all groups, and lactate dehydrogenase release (LDH) was measured in coronary effluent in groups receiving 180 min reperfusion. An additional 20 rats were subjected to either prolonged ischemia (PI) or ischemic postconditioning (PCON), which 
attenuates reperfusion injury, to evaluate when cellular damage due to ischemic and reperfusion injury occur, respectively.

Results: IS increased progressively from 60 to 120 min reperfusion in Con hearts. IPC reduced IS by $\sim 42-44 \%$ at all reperfusion lengths, but with greatest significance in hearts receiving 120 min of reperfusion. $\mathrm{LDH}$ release was biphasic with peaks from 3-20 min (P1) and 45-120 min (P2) of reperfusion. IPC reduced both $L D H$ peaks. $P I$ increased $P 1$ without affecting $\mathrm{P} 2$. PCON decreased P2 without affecting P1.

Conclusions: Cardiac LDH release (cellular damage) due to ischemic injury occurs from 3-20 min of reperfusion while reperfusion injury occurs from 45120 min of reperfusion.

CH.24 Vibeke Secher FUNCTIONAL ROLE OF CA ${ }^{2+}$-ACTIVATED CL ${ }^{-}$CHANNEL CANDIDATES IN Nielsen VASCULAR SMOOTH MUSCLE CELLS

\section{Dam}

Department of Biomedicine, Aarhus University

The $\mathrm{Ca}^{2+}$-activated $\mathrm{Cl}^{-}$conductance in the vascular smooth muscle cells (VSMCs) is well characterized, but its molecular origin is under debate. TMEM1 6 and Bestrophin (Best) families are potent candidates for the $\mathrm{Ca}^{2+}$ activated $\mathrm{Cl}^{-}$channel-forming protein. We have previously characterized two $\mathrm{Ca}^{2+}$-activated $\mathrm{Cl}^{-}$currents $\left(\mathrm{I}_{\mathrm{Cl}(\mathrm{Ca})}\right)$ with distinct characteristics and suggested that at least one of these is important for synchronized rhythmic contraction of the arterial wall.

We tested here an association of TMEM16A and Bestrophins with $\mathrm{I}_{\mathrm{CI}(\mathrm{Ca})}$ and the importance of these proteins for VSMCs synchronization in the vascular wall.

We downregulated TMEM16A and Best-3 using in vivo siRNA transfection of rat MSA. Knockdown was confirmed at mRNA and protein levels. $I_{\mathrm{CI}}(\mathrm{Ca})$ was analyzed by patch clamp. Arteries were tested functionally in isometric myograph.

Downregulation of Best-3 induced secondary reduction in Best- 1 and -2 expressions. VSMCs downregulated for Best had significantly reduced the

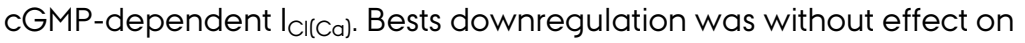
contractile responses. In contrast, TMEM16A downregulation abolished both

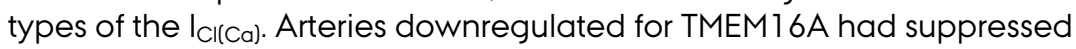
contractility to agonist (noradrenaline and vasopressin) stimulation and high extracellular $\mathrm{K}^{+}$solution. The amplitude of vasomotion was significantly reduced after both TMEM16A and Bests downregulation.

We conclude that both Bests and TMEM16A are associated with the CGMP-

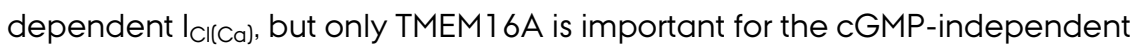

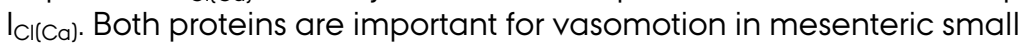
arteries, while only TMEM16A is involved in the contractile response.

CH.25 Carsten DIAGNOSTIC AND PROGNOSTIC POTENTIAL OF PREHOSPITAL HIGHLY Stengaard SENSITIVE TROPONIN T MEASUREMENT FOR TRIAGE OF PATIENTS WITH SUSPECTED ACUTE MYOCARDIAL INFARCTION

C. Stengaard', J.T. Sørensen ', E.F. Christensen' ${ }^{2}$, S.A. Ladefoged ${ }^{3}$, J.F. Lassen', H.E. Bøtker', C.J. Terkelsen ", K. Thygesen ${ }^{7}$

${ }^{1}$ Department of Cardiology, Aarhus University Hospital, ${ }^{2}$ Central Denmark Region's Prehospital emergency medical services, ${ }^{3}$ Department of Clinical Biochemistry, Aarhus University Hospital

Background: Prehospital triage of patients with heart attacks is essential to enhance the rapid management of patients with AMI. The aim of the study was to evaluate the capability of prehospital cardiac troponin $T$ measurement to identify patients with AMI already in the ambulance and 
determine the predictive significance for subsequent mortality.

Methods: In 1,099 cases with suspected AMI, the patient had a prehospital point of care cardiac Troponin T (POC-CTnT) analysis performed in addition to routine ECG. The prehospital blood samples were stored for later analysis with a high sensitive cardiac Troponin T (hs-cTnT) assay. Diagnostic and prognostic properties of the two assays were compared.

Results: POC-cTnT and hs-cTnT data were available for 905 cases of which 177 (19.6\%) had AMI. At the detection level of the POC-cTnT assay (50 $\mathrm{ng} / \mathrm{L}$ ) the sensitivity was $41 \%$ (95\% Cl: $33-48)$ and $40 \%$ (95\% Cl: $33-48)$ for hs-cTnT. At $14 \mathrm{ng} / \mathrm{L}$ the prehospital hs-cTnT analysis had a sensitivity of $71 \%$ (95\% Cl: 63-77). Prehospital hs-cTnT had significantly higher diagnostic accuracy than POC-cTnT (area under the curve (AUC)) 0.82 (95\% Cl: 0.79 $0.86)$ vs. 0.68 (95\% Cl: 0.64-0.72). Adjusted survival analysis showed that an elevated prehospital POC-cTnT or prehospital hs-cTnT was the strongest individual predictor of mortality ( $p<0.001$ for both assays), irrespective of presence of AMl or not

Conclusion: A decrease in the analytical cut-off level from $50 \mathrm{ng} / \mathrm{L}$ with a POC-cTnT assay to $14 \mathrm{ng} / \mathrm{mL}$ with a hs-cTnT assay increases the number of patients identified with AMI from $41 \%$ to $71 \%$. An elevated prehospital cardiac troponin $\mathrm{T}$ is a strong predictor of mortality in patients with heart attack symptoms.

CH.26 Christian Daugaard Peters

\section{A RANDOMIZED TRIAL OF THE ANGIOTENSIN II RECEPTOR BLOCKER IRBESARTAN IN CHRONIC RENAL FAILURE (SAFIR-STUDY): CARDIOVASCULAR EFFECTS IN NEWLY STARTED HAEMODIALYSIS PATIENTS

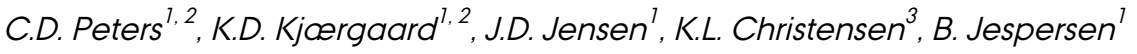 \\ 'Department of Renal Medicine, Aarhus University Hospital, Skejby, Denmark, ${ }^{2}$ Department of Clinical Medicine, Aarhus University, Denmark, ${ }^{3}$ Department of Cardiology, Aarhus University Hospital, Skejby, Denmark}

Background: Patients with chronic renal failure suffer from a high risk of cardiovascular disease (CVD), and CVD mortality is markedly above what is seen in the general population. Several studies suggest that angiotensin II receptor blocker (ARB) treatment has a favourable effect on CVD. Nevertheless, fear of elevated potassium and hypotension during dialysis often results in the abandoning of ARB treatment when patients begin haemodialysis (HD).

Hypotheses: Newly started HD-patients profit by ARB treatment due to:

- Stable or less cardiac hypertrophy

- Decreased arterial stiffness

- Improvement of intradialytic haemodynamics

Methods: The SAFIR-study began in 2009 and was primarily designed to investigate preservation of residual renal function. $82 \mathrm{HD}$-patients (HDvintage $300 \mathrm{~mL} /$ day) were randomized double-blind for treatment with irbesartan/placebo and followed for 1 year. Blood pressure (BP) was closely monitored and a systolic BP of $140 \mathrm{mmHg}$ predialysis was the target among all patients. Cardiac status was evaluated by echocardiography at entry and after 1 year. The degree of arterial stiffness was measured noninvasively by applanation tonometry using SphygmoCor. Intradialytic haemodynamic parameters (cardiac output, central blood volume and total peripheral resistance) were obtained with Transonic. Blood and urine samples were collected throughout the study period and biomarkers (IL-1 $\beta$, IL-6, IL-18, TGF- $\beta$, hsCRP and NT-proBNP) involved in inflammation, fibrosis and vascular calcification were also studied. End of study is December 2012. 
Perspectives: Reduction of CVD-burden in HD patients.

CH.27 Christoffer $300 \mathrm{~T}$ IN VIVO MRI $\mathrm{H}_{2} \mathrm{O}$ - THE NEW SUPER CONTRAST AGENT

Laustsen C. Laustsen ${ }^{1,2,3}$, S. Bowen ${ }^{3}$, J.H. Ardenkjaer-Larsen ${ }^{2,3}$

'MR Research Centre, Department of Clinical Medicine, Aarhus University,

${ }^{2}$ Danish Research Centre for Magnetic Resonance, Hvidovre Hospital,

${ }^{3}$ Technical University of Denmark, Department of Electrical Engineering

Introduction: Recent advances in MR methodology, hyperpolarized dissolution (DNP) MRI, have increased the polarization of the spins above 10,000-fold enhancement. This novel method utilized endogenous contrast agents, which are the source of signal, as in PET, but with the fundamental difference that molecules utilized in hyperpolarized MR are non-radioactive and biochemically equivalent to non-MR active molecules.

Aim: Implementation of a new superior coronary MRA methodology.

Methods: $200 \mathrm{uL}$ of $\mathrm{H}_{2} \mathrm{O}$ dissolved in $4 \mathrm{~mL}$ of degassed $\mathrm{D}_{2} \mathrm{O}$ was polarized for $30 \mathrm{~min}$ in a Hypersense polarizer. Male Sprague-Dawley rats (250-300 g) were anesthetized with $4 \%$ isoflurane and maintained with $1.8 \%$ isoflurane mixed with air and $5 \%$ oxygen. Tail vein catheters were inserted for injection of the hyperpolarized $\mathrm{H}_{2} \mathrm{O}$. Body temperature was maintained at 37.0-37.5 ${ }^{\circ} \mathrm{C}$, and respiration remained stable. $2.0 \mathrm{~mL}$ of the hyperpolarized solution was injected at a rate of $0.1 \mathrm{~mL} / \mathrm{s}$ (injection time of $20 \mathrm{~s}$ ). Images were acquired on a $4.7 \mathrm{~T} \mathrm{M}$ system, with a linearly polarized ${ }^{1} \mathrm{H} /{ }^{13} \mathrm{C}$ volume coil (Rapid Biomedical $\mathrm{GmbH}$ ) with an inner diameter of $80 \mathrm{~mm}$.

Results: The hyperpolarized water shows great contrast without requiring any other adjustments of the MRI system. Here we show for the first time DNP hyperpolarized water in vitro and in vivo, corresponding to a $300 \mathrm{TMRI}$ investigation. This new method shows prospects in angiography and imaging modality; speed and contrast are comparable to that of noninvasive $\mathrm{CT}$ in combination with the most natural contrast agent $\mathrm{H}_{2} \mathrm{O}$, but also has the high spatial and temporal resolution from ' ${ }^{\text {H }}$ MRI.

CH.28 Mark Reinhard POSTPRANDIAL MINERAL METABOLISM IN HEMODIALYSIS PATIENTS

\section{Reinhard', J. Frystyk', B. Jespersen', P. Ivarsen'}

'Department of Renal Medicine, Aarhus University Hospital, ${ }^{2}$ Department of Endocrinology and Internal Medicine \& Medical Research Laboratories, Department of Clinical Medicine, Aarhus University Hospital

Aim: The aim was to characterize postprandial mineral ion handling in hemodialysis (HD) patients compared with healthy volunteers.

Methods: On a non-HD day, 12 HD patients (M/F: 8/4; median age 61 years, range 39-74) and 12 healthy individually matched volunteers consumed a weight-adjusted standardized meal containing between $292-372 \mathrm{mg}$ of calcium and between 441-818 mg of phosphorus. Following an overnight fast, blood samples were collected at baseline and until $9 \mathrm{~h}$ after the meal.

Results: HD patients and healthy volunteers differed significantly in terms of changes in postprandial plasma phosphate $(p=0.001)$ and parathyroid hormone (PTH) $(p=0.02)$ levels, but not in ionized calcium levels. Whereas plasma phosphate levels did not significantly change over time in the healthy volunteers, the HD patients demonstrated an immediate reduction in plasma phosphate levels at 60 to 120 min (maximum of $9 \%, p<0.001$ ). The healthy volunteers demonstrated an immediate postprandial fall in PTH levels at 60 to 120 min (maximum of $15 \%, p<0.001$ ) followed by a transient rise, whereas plasma PTH levels rose above baseline at $240 \mathrm{~min}$ to the end of the study (maximum of $14 \%, p=0.004$ ) among the HD patients. The healthy volunteers demonstrated an immediate increase in fractional excretion of calcium (maximum of $154 \%$ at $120 \mathrm{~min}, \mathrm{p}<0.001$ ) and of 

CH.29 Karina Bech
Cullberg phosphate (maximum of $47 \%$ at $360 \mathrm{~min}, \mathrm{p}<0.001$ ). $<\mathrm{br} />$ Conclusion:

The postprandial response in plasma phosphate and PTH levels was significantly different between the HD patients and the healthy volunteers. The mechanisms governing the extrarenal phosphate clearance in HD patients are unclear, but may involve both skeletal and extraskeletal soft tissue deposition.

RESVERATROL INHIBITS THE HYPOXIC EFFECTS IN ADIPOSE TISSUE, ADIPOCYTES AND MACROPHAGES

\section{K. B. Cullberg, J. Ølholm, S. K. Paulsen, B. Richelsen, S. B. Pedersen}

Medical Department of Endocrinology and Internal Medicine, Aarhus University Hospital, Aarhus Sygehus THG

Introduction: In obesity, adipose tissue becomes hypoxic due to the inability of the vasculature to keep pace with the adipose tissue growth. Hypoxic conditions cause an increase in expression of genes involved in e.g. angiogenesis and inflammation. Resveratrol is a natural polyphenolic compound synthesized in a large number of plant species. It has been shown that resveratrol has powerful anti-inflammatory effects and may have beneficial effects on several metabolic factors.

Methods: The effect of hypoxia, induced by incubation at $1 \% \mathrm{O}_{2}$, was examined on the expression of angiogenic and inflammation-related adipokines in whole human adipose tissue cultures, 3T3-L 1 murine adipocytes and THP- 1 human macrophages - plus/minus resveratrol $(1,10$, 25 and $50 \mu \mathrm{M}$ ).

Results: Exposure of whole human adipose tissue cultures, adipocytes and macrophages to hypoxia for $24 \mathrm{~h}$ resulted in increases in mRNA levels compared to normoxia, of glucose transporter-1 (GLUT-1) (19-,12- and 5fold), vascular endothelial growth factor (VEGF) (10-, 3- and 9-fold) and interleukin-8 (IL-8) (8, 2 and 4-fold), respectively. Resveratrol (50 $\mu \mathrm{M})$ reduced the hypoxic response in mRNA expression of GLUT- 1 (3- and 2fold), VEGF ( 1 - and 6-fold), IL-8 ( 1 - and 2-fold) in both adipocytes and macrophages. Resveratrol $(50 \mu \mathrm{M})$ reduced the hypoxic response in whole adipose tissue by $100 \%$.

Conclusion: Resveratrol was able to partially counteract the effect of hypoxia in both adipocytes and macrophages on inflammation and angiogenesis. Thus, resveratrol may have implications in the treatment of some of the complications associated with an enhanced fat mass.

CH.30 Julie
Damgaard TRANSLOCATION T(6;9)(P22;Q34) IN PEDIATRIC AML: A RETROSPECTIVE INTERNATIONAL STUDY

Sandahl 
Institute for Cancer Research, Newcastle University, Newcastle upon Tyne, UK, ${ }^{11}$ Dutch Childhood Oncology Group, The Hague, NL, ${ }^{12}$ Department of Oncology and Pathology, St. Jude Children's Research Hospital, Memphis, TN, U.S.A. ${ }^{13}$ Pediatric Oncology/hematology, VU University Medical Center, Amsterdam, NL, ${ }^{14}$ Department of Pediatrics, Mackay Memorial Hospital, Taipei, Taiwan, ${ }^{15}$ Childhood Cancer Foundation, Taipei, Taiwan,

${ }^{16}$ Oncologia ed Ematologia Pediatrica, Ospedale Sant'Orsola Malpighi, Università di Bologna, Bologna, Italy, ${ }^{17}$ Unité de Cytogénétique oncohématologique, Hôpital Saint-Antoine, Paris, France, ${ }^{18}$ Italian Association of Pediatric Hematology Oncology, Clinica Pediatrica, Università Padova, Padova, Italy, ${ }^{19}$ Pediatric Hematology/ Oncology, AML-BFM Group, Germany, ${ }^{20}$ Department of Pediatrics, Tokyo Medical and Dental University, Tokyo, Japan, ${ }^{21}$ Institute of Cell and Molecular Pathology, Hannover Medical School, Hannover, Germany, ${ }^{22}$ Pediatric Hematology/Oncology, Fondazione IRCCS Policlinico "San Matteo", Pavia, Italy

The cytogenetic subgroup $\mathrm{t}(6 ; 9)(\mathrm{p} 22 ; \mathrm{q} 34)$ in AML has not been independently described in a pediatric cohort. In adults, t $(6 ; 9)$ is associated with young age and a very poor outcome. We aimed to characterize the clinical, genetic and morphological features of $t(6 ; 9)$ in childhood myeloid leukaemia.

Children aged $0-18$ years and diagnosed with de novo $t(6 ; 9)$ AML or MDS from 1993-2012 were included. All major pediatric AML study groups were invited to submit clinical data, smears were requested for central reviewing, and viable cells or RNA for gene expression profiling (GEP). GEP was performed on 297 pediatric AML patients including 6 with $t(6 ; 9) .4$ genes were selected for validation by RT-qPCR; EYA3, SESN1, RIZ1, and HIST2H4.

59 children from 24 study groups were included. Median age was 11 years (range $3-18)$, and male:female ratio was $39: 20$ ( $p<0.01$ ). The t(6;9) was further characterized by FAB-M2 and mild to moderate bilinear dysplasia. $17 \%$ had additional cytogentic aberrations. The 5 -year OS and EFS were $58 \%$ and $36 \%$. Patients treated with SCT had a 5 -year OS at $82 \%$ vs. $56 \%$ with chemotherapy, $(p=0.10)$. The GEP showed a unique signature with 180 significantly differentially expressed genes including EYA3, SESN1, RIZ1 and HIST2H4. Their expression was confirmed by RT q-PCR.

In conclusion, we present a large international series of 59 children with $t(6 ; 9)$ myeloid leukemia, representing $0.5 \%$ of all childhood AML. The cases were characterized by late onset, male predominance, myelodysplasia, and a unique gene expression signature. The 5-year OS was substantially better than reported in adults. SCT did non-significantly improve the OS compared with conventional chemotherapy alone.

CH.31 Lotte Sander MRI DELINEATION MAY REDUCE URINARY TOXICITY IN PROSTATE RADIOTHERAPY

\author{
L. Sander', J. Carl' \\ ${ }^{1}$ Dept. of Urology, Aalborg Hospital, ${ }^{2}$ Dept. of Medical Physics, Aalborg \\ Hospital
}

Objective: Late side-effects after radiotherapy (RT) of prostate cancer (PC) are dose-limiting and linked to the volume of normal tissue irradiated. On the other hand, dose escalation leads to better local tumor control. Accuracy is therefore important. Accuracy can be improved using MRI - not only CT, delineating the clinical target volume (CTV). The study evaluates late toxicity and Quality of Life (QoL) 3 years after high dose RT for prostate cancer using either MRI or CT for target delineation.

Methods: This non-randomized study includes 200 patients with locally or locally advanced PC (T1-T3NOMO) treated with RT between 2007 and 2009. 100 patients had target delineation on MRI (S-group), another 100 on CT (G-group). The groups received high dose (78Gy/39 fractions) RT. Three 
CH.32 Johanne Lade Keller

years after, RT toxicity and QoL were assessed using international validated questionnaires and scoring systems.

Results: 73 patients have been assessed in the S-group,72 in the G-group. There were 7 biochemical failures in the S-group and 3 failures in the Ggroup (NS Chi-sq test). No PC related deaths. In general, the long-term sideeffects were mild. The self-assessed symptoms and toxicity were comparable except for urinary symptoms being worse in the G-group (retention $\mathrm{p}<0.02$, pollakisuria $\mathrm{p}<0.03$ ). $<\mathrm{br} />$ Conclusion:

The study shows a tendency towards less long-term toxicity when outlining the prostate and CTV on MRI. These results support the hypothesis that target delineation on MRI may reduce the long-term side-effects after RT for PC.

Keller

THE IMMUNOHISTOCHEMICAL EXPRESSION OF TUMOR SUPPRESSOR P16 IS AN INDEPENDENT PROGNOSTIC MARKER IN CUTANEOUS MELANOMA
J. Lade-Keller', R. Riber-Hansen', P. Guldberg ${ }^{2}$, H. Schmidt ${ }^{3}$, S.J. Hamilton- Dutoit ${ }^{7}$, T. Steiniche ${ }^{\text {1 }}$

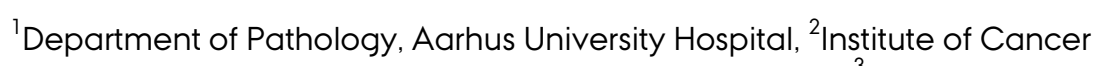 Biology, Danish Cancer Society, Copenhagen, Denmark, ${ }^{3}$ Department of Oncology, Aarhus University Hospital, Aarhus, Denmark

The tumor suppressor p16 induces cell cycle arrest and cellular senescence by retinoblastoma protein phosphorylation inhibition. Consequently, previous cell line studies, genetic analyses and relatively small immunohistochemical studies show melanoma progression and poor patient outcome with p16 loss.

We examined p16 immunohistochemical expression in tissue microarrays from 425 consecutively collected melanomas (median Breslow thickness: $1.10 \mathrm{~mm} ; 16 \%$ ulcerated tumors; $11 \%$ with tumor stage III) with a median follow-up of five years for relapse-free survival (overall-relapse-free and distant-metastasis-free) and eight years for melanoma-specific survival. The percentage of positive tumor cell nuclei was estimated semi-quantitatively and grouped as $0 \%, 1-9 \%, 10-99 \%$ and $100 \%$.

In multivariate analyses with Breslow thickness as a co-variate, the overallrelapse-free survival (HR: $0.63 ; 95 \% \mathrm{Cl}: 0.46-0.86 ; p=0.003$ ), the distantmetastasis-free survival (HR: $0.61 ; 95 \% \mathrm{Cl}: 0.42-0.87 ; p=0.007$ ) and the melanoma-specific survival (HR: 0.64; $95 \% \mathrm{Cl}$ : 0.43-0.94; $p=0.023$ ) were significantly decreased with decreasing $\mathrm{p} 16$ expression groups. Decreasing p 16 expression was also strongly associated with increasing primary tumor thickness $(p=0.0001)$, the presence of ulceration $(p=0.003)$ and tumor stage III $(\mathrm{p}=0.000)$.

In a large melanoma cohort, we have shown an increased risk of relapse, distant metastases and melanoma-specific death with reduced or absent p16 expression independent of primary tumor thickness. This suggests p16 as a potent new prognostic marker candidate in melanoma.

CH.33 Esben Schjødt 3D TIME-RESOLVED MOTION MONITORING DURING RADIOTHERAPY Worm

\section{E.S. Worm, M. Høyer, W. Fledelius, P.R. Poulsen}

Clinical Institute, Department of Oncology, Aarhus University Hospital

Background: Tumor motion during treatment challenges radiotherapy (RT) accuracy. This study demonstrates for the first time that the time-resolved 3D internal motion during RT can be determined using imaging equipment ( $M V+k V x$-ray) of a standard treatment machine (LINAC).

Methods: Ten patients with implanted gold markers received three-fraction RT for liver-tumors. Three cone-beam CTs (CBCT) were acquired for patient setup during each fraction. The raw CBCT projections were used to estimate $3 \mathrm{D}$ marker motion during $\mathrm{CBCT}$ acquisition ( $1 \mathrm{1Hz}$ resolution) by a 
monoscopic probability-based method. Throughout treatment field delivery, simultaneous $M V$ imaging $(8 \mathrm{~Hz})$ and orthogonal $\mathrm{kV}$ imaging $(5 \mathrm{~Hz})$ were used to determine $3 \mathrm{D}$ marker motion using either $\mathrm{MV} / \mathrm{kV}$ triangulation or the monoscopic method if marker segmentation was unachievable in either MV or $\mathrm{kV}$ images. Monoscopic motion estimation accuracy was investigated by also applying monoscopic estimation as a test for all fields where triangulation was possible.

Results: RMS deviations between monoscopic estimation and triangulation were $<1.0 \mathrm{~mm}$. The mean 3D liver motion range during RT was $11.3 \mathrm{~mm}$ (range, 2.1-35.5). Averaged over all fractions, the 3D mean marker position shifted $3.4 \mathrm{~mm}(0.7-14.5)$ during a RT fraction and the markers experienced $3 \mathrm{D}$ shifts $>8.4 \mathrm{~mm}$ in $10 \%$ of the treatment time.

Conclusions: Liver motion was determined with unprecedented detail throughout RT using standard equipment. Considerable motion was observed. The demonstrated methods provide a widely available approach for motion monitoring which, combined with motion-adaptive treatment techniques, has the potential to improve the accuracy of RT for moving targets.

CH.34 Eduardo NK-SUBTYPE CELL PROLIFERATION AND UPREGULATION OF CD56 Vazquez Garza SURFACE MARKER IN MONONUCLEAR CELLS FROM HEALTHY DONORS STIMULATED WITH HUMAN CYTOMEGALOVIRUS

E. Vazquez ${ }^{7}$, A. Møller-Larsen' ${ }^{7}$ B. Nielsen², M. Hokland ${ }^{7}$

${ }^{1}$ Department of Biomedicine, Aarhus University, ${ }^{2}$ Hematology Department R, Aarhus University Hospital

Background: Human cytomegalovirus (HCMV) infection/reactivation in immunocompromised patients shows increased morbidity/mortality. Natural killer cells are crucial in controlling these infections. NK cells consist of 2 subgroups: CD3-/CD56 ${ }^{\text {+dim }}$ and CD3-/CD56 $6^{\text {bright }}$, and the latter is increased in chronic inflammatory diseases. Short-term changes during cell culture of surface markers/proliferation when stimulated with HCMV are of key importance to understand the way HCMV and the immune system interact.

Hypothesis: HCMV induces a shift in the expression of CD56 in $\mathrm{HCMV}^{+}$, but not from $\mathrm{HCMV}^{-}$-donors.

Materials: In-vitro culture system, adding HCMV (AD 169) to human mononuclear cells from HCMV+ and HCMV- healthy donors. Flow cytometry assay using dye-dilution and multi-colour panels to characterize the effect of HCMV on NK cell subsets identified by the expression of NKG2A, -C, CD69 \& CD57.

Results and discussion: Mean values of NK cells from $\mathrm{HCMV}+$ donors were 1.3 times higher in the stimulated samples at day 3 and 2.4 times at day 6 . CD56 MFI values of NK cells were also higher in $\mathrm{HCMV}^{+}$donors stimulated with virus supernatant 5.3 at day 3 and 8.7 times higher at day 6 against $\mathrm{HCMV}$ - donors. $\mathrm{HCMV}^{+}$donors also exhibited specific upregulation of CD69 and NKG2C. The present work shows the upregulation of CD56 and changes regarding activation markers of $\mathrm{HCMV}^{+}$donors stimulated with HCMV supernatant.

A change in phenotype may be related to a different subtype of HCMVinduced memory NK cells, following a change from CD56 dim to CD56 bright This study points towards expansion of a NK ${ }^{\text {bright }}$ phenotype responding to an HCMV supernatant stimulation in a short-term in vitro culture setting.

CH.35 Jesper COMPARISON OF REGISTRATION TECHNIQUES TO IMPROVE DATA Kallehauge ANALYSIS OF DCE-CT

J.F. Kallehauge', F. Rasmussen', J.C. Lindegaard', E.M. Pedersen', S. Haack', K. Tanderup ${ }^{2}$ 
'Dept. Experimental Clinical Oncology, Aarhus University Hospital, ${ }^{2}$ Dept. Experimental Clinical Oncology, Aarhus University Hospital, ${ }^{3}$ Dept. Radiology, Aarhus University Hospital, ${ }^{4}$ Dept. Oncology, Aarhus University Hospital

One of the major issues with quantitative analysis of DCE-CT is the poor signal to noise ratio (SNR) giving poor fitting results. This can be improved by smoothing or binning the image data with the apparent drawback less spatial resolution. Part of the poor SNR in time stems from organ motion during scan acquisition. Two deformable registration approaches are here compared to determine which takes into account the anatomical changes.

A DCE-CT scan prior to radiotherapy fo a cervical cancer patient was used to compare the registration approaches. The first approach, Ridig Registration (RR), uses purely rotation and translation to maximize the mutual information between two different timepoints. This approach does not correct for any anatomical changes during image acquisition. The second approach, Reference Deformable Registration (RDR), propagates the image intensities from all timepoints back to a reference. The third approach, Consecutive Deformable Registration (CDR), applies one timepoint to its neighbouring timepoint and thus smoothly propagates the anatomical changes. Root mean square error was compared for the deconvolution of the three different registration techniques average and standard deviation are compared for the 3 techniques $p<0.05$ to determine if they are significantly different.

The RR approach showed residual of mean and standard deviation of $1.3 e+5 \pm 1.2 e+7$, the RDR had residual $55.4 \pm 43.6$ and the CDR had residual of $8.3 e+6 \pm 7.3 e+8$. T-tests showed no significant difference between the three techniques.

Further investigation needs to be pursued to improve the analysis of DCE$\mathrm{CT}$. The results show so far that no information is gained from performing registration in this limited dataset.

CH.36 Emilia Horjales INFLUENCE OF EMOTIONALLY-LOADED VISUAL STIMULI ON EXPERIMENTAL JAW-MUSCLE PAIN AND ITS RELATION WITH THE TRI-ALLELIC POLYMORPHISM ON THE SEROTONIN TRANSPORTER GENE

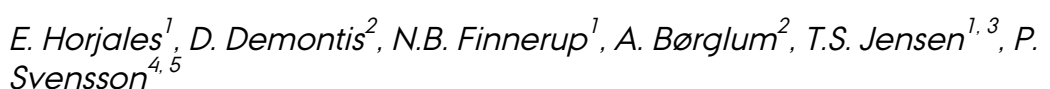

'Danish Pain Research Center, Aarhus University Hospital, ${ }^{2}$ Department of Biomedicine (Human Genetics), Aarhus University, ${ }^{3}$ Dept of Neurology, Aarhus University Hospital, ${ }^{4}$ MINDLab, Center of Functionally Integrative Neuroscience, Aarhus University Hospital, ${ }^{5}$ Department of Clinical Oral Physiology, School of Dentistry, Aarhus University

The perception of pain is determined by a combination of different factors. Recent studies have demonstrated an association between some genotypes and pain perception. In specific, great focus has been given to the triallelic polymorphism in the promoter region of the serotonin transporter gene. In this study, we aimed to investigate whether the modulatory effect of the visual stimuli on muscular pain perception observed in our previous study is genotype-dependent.

DNA was extracted from saliva obtained from 380 healthy Scandinavian volunteers (18-39 years old). To determine the triallelic 5-HTTLPR genotype, PCR-reactions were carried out using the GoTaq HotStart Polymerase and 80 ng genome template. Additionally, $10 \mu \mathrm{l}$ of the PCR product was digested for $2 \mathrm{~h}$ at $37^{\circ}$ with $1 \mu \mathrm{MSP} 1$. The genotypes were evaluated by running PCR products and digested PCR products on agarose gels.

A total of 150 healthy subjects ( 50 of each level of protein expression) proceeded to the next phase of our study. In this, experimental jaw muscle 
CH.37 Pauline de Bruijn

CH.38 Sascha Eichendorff pain was evoked by injecting $0.2 \mathrm{ml}$ hypertonic saline into the masseter muscle. With each injection, an emotion (positive, negative or neutral) was generated by visual stimuli (pictures taken from IAPS).The participants were asked to continuously rate pain intensity and un/pleasantness of the pictures.

In participants with a high expression of the protein serotonin transporter, conditioning with negative pictures increased VAS pain scores while positive pictures decreased it. However, there was no significant effect of the pictures on pain perception in participants with neither intermediate nor low expression of the protein.

BASOLATERAL P2X RECEPTORS TRIGGER A MARKED ALKALINIZATION OF MOUSE THICK ASCENDING LIMB

\section{P.I.A. de Bruijn}

Department of Biomedicine, Aarhus University

Extracellular ATP is an important regulator of renal tubular transport. Recently, we found that basolateral ATP markedly inhibits $\mathrm{NaCl}$ absorption in mouse medullary thick ascending limb (mTAL) via a P2X receptor. The underlying mechanism that mediates this ATP-dependent transport inhibition in mTAL is, however, unclear. To investigate this, we measured $\mathrm{pH}_{\mathrm{i}}$ in single perfused mouse mTALs using the fluorescent ratiometric dye BCECF. Interestingly, basolateral ATP ( $100 \mu \mathrm{M})$ caused a prominent and reversible alkalinization of $\mathrm{MTAL}$ with an average $\mathrm{pH}_{\mathrm{i}}$ increase of $0.14 \pm 0.01$ $(n=12)$. This effect was completely abolished in presence of the P2X receptor antagonist oxidized-ATP (50 $\mu \mathrm{M})$. Typically, G-protein coupled receptors that trigger an increase of $\left[\mathrm{Ca}^{2+}\right]_{i}$ cause a significant acidification of tubular epithelial cells. This was also observed in this study when $\mathrm{P}_{2} \mathrm{Y}_{2}$ receptors were stimulated with $100 \mu M$ UTP. The $\mathrm{pH}_{\mathrm{i}}$ decrease was $0.04 \pm$ $0.01(n=6)$. When the CaSR was stimulated with $5 \mathrm{mM} \mathrm{Ca}^{2+}$, a similar acidification was observed. This study therefore describes the surprising finding of a basolateral $\mathrm{P} 2 \mathrm{X}$ receptor triggered alkalinization in isolated mouse MTAL. These data may provide the basis to understand the signalling mechanism responsible for the pronounced ATP-induced transportinhibition in mouse MTAL.

CD 163-TARGETED LIPOSOMES WITH PH-SENSITIVE PEG-SHIELDING FOR ENHANCED INTRACELLULAR DELIVERY OF BIOACTIVE SUBSTANCES

\section{S. Eichendorff, M.D. Petersen, A. Etzerodt, S.K. Moestrup}

Department of Biomedicine, Aarhus University

CD163 is a scavenger receptor exclusively expressed in monocytes and a subset of macrophages (M2 type). Macrophages "scavenge" a broad range of cellular components and play a central role as effector cells and in the orchestrating of the immune defence in autoimmune diseases and infections. Maturation of monocytes into macrophages leads to a highly increased surface expression of CD163. During inflammation, cytokines induce an even further increase in CD163 expression, which makes the receptor an interesting target for intracellular drug delivery.

In the present study, we use liposomal formulations targeting CD 163 through surface modification with antibodies. Shielding liposomes with polyethylene glycol (PEG) attached to their surface increases the blood circulation time and thereby the specificity of the delivery. Nevertheless, the PEG layer decreases intracellular delivery of the cargo by inhibiting membrane fusion and endosomal escape after uptake. We have synthesized an acid-cleavable linker ( $\mathrm{N}$-ethoxybenzylimidazole-type) to attach PEG chains to a membrane anchor in a reversible manner. The linker hydrolyses with a half-life of $15 \mathrm{~min}$ at $\mathrm{pH} 5.0$ as opposed to $80 \mathrm{~min}$ at $\mathrm{pH}$ 7.4 , thus destabilizing the particles specifically in the endosomal milieu. 
Fluorescent microscopy techniques are used to evaluate the delivery efficiency of encapsulated fluorescent compounds to CD163 expressing cell lines.

CH.39 Jacob Mørup THE NUMBER OF FETAL CELLS IN MATERNAL BLOOD DOESN'T CHANGE Schlütter AFTER ULTRASOUND SCANNING

\author{
J.M. Schlütter ', I. Kirkegaard' , A.S. Ferreira' ${ }^{\prime}$, S. Kølvrad², N. Uldbjerg ${ }^{7}$ \\ 'Department of Gynecology and Obstetrics, Aarhus University Hospital, \\ ${ }^{2}$ Department of Clinical Genetics, Sygehus Lillebœlt
}

Introduction: We have established a robust method to identify and isolate a subgroup of placental-derived fetal cells in maternal blood ( $\mathrm{fmbs}$ ). These cells may be used as a source of genetic information to identify Down syndrome and other genetic disorders. A major challenge for the implementation is that we need at least six cells for effective prenatal screening, a number we haven't achieved for all pregnant women. We conducted a study to identify if ultrasound scanning affects the number of fcmbs.

Methods: Ten pregnant women at weeks 11-14 were included. Transvaginal and trans-abdominal ultrasound scans were performed in succession. Total scanning times varied from 17 to 30 minutes. The number of fcmbs was determined in $36 \mathrm{ml}$ maternal blood immediately before and after the scans. All Scans were performed by the same sonographer.

Results: A non-significant lower number of fcmbs were found in the after ultrasoundscannings (median: 3 vs. 2; $p=0.50$ ).

Conclusion: Ultrasound scanning doesn't change the number of fetal cells in maternal blood.

CH.40 Trine Dalsgaard DEVELOPMENT OF GENE THERAPY OF PKU

\title{
T.L. Dalsgaard, L. Aagaard, T.G. Jensen
}

Institute of Biomedicine, Aarhus University

Phenylketonuria (PKU) is an inherited disease resulting in elevated levels of phenylalanine. In most patients this is due to defects in the enzyme phenylalanine hydroxylase (PAH). PKU positive children are treated with a lifelong diet with low concentrations of phenylalanine preventing the development of neurological and psychological changes especially intellectual impairment. The main goal of the project is to improve the current techniques in gene therapy and to target the PKU-disease.

We have constructed lentiviral vectors containing the functional PAH gene. These viral particles were injected in PKU mice in hope of in vivo selection of PAH expressing cells. However the PAH expression could not be detected. The vector has been improved and we are now ready to repeat the experiment. I have made a control viral vector containing PAH fused with a tag, to detect in different tissues.

Currently we are testing 5 different promoters in cells and mice to determine the most efficient promoter in the lever. We are using plasmids and viral particles and different injection strategies to optimize the expression. The best promoter will be cloned in front of PAH.

We are testing site-specific zinc finger nucleases (ZFN) targeted against the $\mathrm{PAH}$ gene. The ZFN leads to specific double stranded breaks stimulating homologous recombination. The ZFN's are cotransfected with a donor plasmid containing the functional PAH gene to correct the mutation. Different cell lines has been tested and many ratios and different techniques, however we have not been able to show their activity, beside the toxic effect of high concentrations of both ZFN's. 
$\mathrm{CH} .41$ Nanna Cornelius
SECONDARY COQ10 DEFICIENCY IN RIBOFLAVIN RESPONSIVE MULTIPLE ACYL-COA DEHYDROGENATION DEFICIENCY (RR-MADD) PATIENTS; A RHODOBACTOR AND HUMAN CELL STUDY

\author{
N. Cornelius' , N. Gregersen', T.J. Corydon", C. Byron' ${ }^{4}$, I. Hargreaves ${ }^{3}$, R.K.J. \\ Olsen ${ }^{7}$
}

${ }^{1}$ Research Unit for Molecular Medicine (MMF), Aarhus University Hospital and Department of Clinical Medicine, Aarhus University, ${ }^{2}$ Department of Biomedicine, Aarhus University, ${ }^{3}$ Neurometabolic Unit, National Hospital, London, UK, ${ }^{4}$ Department of Chemistry, Ripon College, WI, USA

Coenzyme Q10 (CoQ10) functions as an electron transporter in the mitochondrial respiratory chain. It links the respiratory chain to fatty acid $\beta$ oxidation by accepting electrons from ETF-QO and passing them on to complex III. Recently, it has been shown that patients with variations in ETFQO also have secondary CoQ10 deficiency. In this study, we try to clarify if secondary CoQ10 deficiency is a general factor in RR-MADD patients with ETF-QO variations and if riboflavin and/or Q10 treatment can affect the CoQ10 level in patient fibroblasts. To further investigate the connection between ETF-QO variations and secondary COQ10 deficiency, we measured CoQ10 binding kinetics in an in vitro Rhodobactor model where the variations investigated in the patient fibroblasts have been introduced. In conclusion, we find that the CoQ10 level is decreased in all the RR-MADD patient fibroblasts analyzed and that riboflavin cannot compensate for the reduced CoQ10 level. Furthermore, we find that CoQ10 treatment of the patient cells can raise the level of CoQ10 to control level. In addition, we show that the patient cells have increased levels of ROS and that COQ10 treatment can decrease the level of ROS in the patient cells. Finally, analysis of COQ10 binding kinetics of overexpressed Rhodobactor ETF-QO variants shows that the variant ETF-QO proteins in general bind COQ10 less tightly than the wild-type ETF-QO. A hypothesis may be that variations in ETF-QO lead to increased oxidative stress in the cell and the positive effect of CoQ10 treatment might be the well-known antioxidant effect of CoQ10.

Martin Mørck MIRNA AND WHOLE GENOME PROFILING OF PROSTATE CANCER SAMPLES Mortensen

\begin{abstract}
M.M. Mortensen ${ }^{1,2}$, K.D. Sørensen ${ }^{2}$, S. Høyer ${ }^{3}$, T.F. Ørntoft ${ }^{2}$, M. Borre ${ }^{7}$, L. Dyrskjøtt ${ }^{2}$

${ }^{1}$ Dep. of Urology, Aarhus University Hospital, Skejby, ${ }^{2}$ Dep. of Molecular Medicine, Aarhus University Hospital, Skejby, ${ }^{3}$ Dep. of Pathology, Aarhus University Hospital
\end{abstract}

Introduction: A distinct feature of localized prostate cancer is the high prevalence of indolent, non-lethal cancer. The mechanism by which localized prostate cancer progresses to invasive lethal disease is still largely unknown. There is a great unmet need for tools capable of identifying patients with aggressive disease. In this study, we have profiled both miRNA and mRNA to identify novel biomarkers of aggressive prostate cancer.

Materials: We included 36 prostate cancer and 14 normal prostate samples. The tumor lesion was laser micro dissected, and the RNA and miRNA were extracted separately. The mRNA was profiled using Affymetrix U133+2 whole genome array and the miRNA fraction was profiled on Taq-man LDA cards covering 671 known miRNAs.

Results: Doing direct comparison, 33 miRNAs were differentially expressed between patients with recurrent disease compared with non-recurrent disease (ranksum test $p<0.05$ ). All of the 33 miRNAs were over-expressed in patients with recurrent disease. By using Gene set enrichment analysis (GSEA), we tested whether the mRNA targets of the 33 miRNAs were associated with disease outcome. Of the tested miRNAs, mir-149, mir-214, mir-182, mir-301b and mir30a-e were significantly enriched in the patients 
CH.43 Xue Lin

CH.44 Páll Karlsson with non-recurrent disease $(p<0.05, F D R<0.25)$, corresponding to a down regulation of their targets in the patients with recurrent disease.

Conclusion: miRNAs mir-149, mir-214, mir-182, mir-301b and mir30a-e are significantly over-expressed in recurrent prostate cancer and their direct mRNA targets are significantly down regulated, thus validating that the miRNAs have a functional role in the progression of localized prostate cancer.

INTEGRATIVE ANALYSES OF GENE EXPRESSION AND DNA METHYLATION PROFILES IN A BREAST CANCER CELL LINE MODEL OF TAMOXIFENRESISTANCE INDICATE A CRUCIAL ROLE OF CELLS WITH STEM-LIKE PROPERTIES

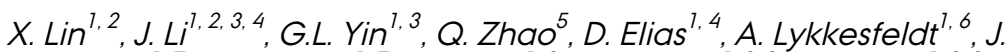

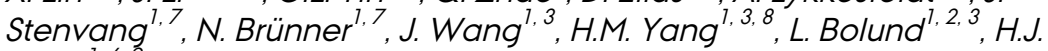
Ditzel ${ }^{7,4,9}$

'Sino-Danish Breast Cancer Research Centre, ${ }^{2}$ Department of Biomedicine, Aarhus University, The Bartholin Building, DK-8000, Aarhus C, Denmark, ${ }^{3}$ Beijing Genomics Institute, Shenzhen, 518083, China, ${ }^{4}$ Department of Cancer and Inflammation Research, Institute of Molecular Medicine, University of Southern Denmark, J. B. Winsloews Vej 25.3, DK-5000 Odense C, Denmark, ${ }^{5}$ School of Life Science and Technology, Tongji University, 1239 Siping Road, Shanghai 200092, China, 'Danish Cancer Society Research Center, Copenhagen, ${ }^{7}$ Department of Veterinary Pathobiology, Faculty of Life Sciences, University of Copenhagen, Dyrløegevej 88, 1870 Frederiksberg, Denmark, ${ }^{8}$ James D. Watson Institute of Genome Sciences, Hangzhou, China, 'Department of Oncology, Odense University Hospital, Søndre Boulevard 29, DK-5000 Odense C, Denmark

Resistance to tamoxifen is an important issue in the therapy of breast cancer patients. To investigate the mechanism of the resistance to tamoxifen, we applied modified DNA methylation-specific digital karyotyping (MMSDK) and digital gene expression (DGE) in combination with massively parallel sequencing to analyze a well-established tamoxifen resistant cell line model. Our present study demonstrates big differences in global gene expression and DNA methylation profiles between the parental tamoxifensensitive cell line and high-dosage tamoxifen treatment induced resistant sublines. Very high amounts of SOX2 transcripts and altered expression profiles of other SOX gene family, E2F gene family and RB-related pocket protein genes, as well as highlighted stem cell pathways, imply that cancer initiating cells/cancer stem-like cells may be responsible for the resistance to tamoxifen. Thus, better understanding of the expression and DNA methylation features of putative cancer initiating cells/cancer stem-like cells may suggest novel strategies to overcome tamoxifen resistance.

EPIDERMAL NERVE FIBER LENGTH IN HEALTHY SUBJECTS AND IN PATIENTS WITH NEUROPATHY

\section{P. Karlsson}

Danish Pain Research Center, Aarhus University

Taking $3 \mathrm{~mm}$ punch skin biopsies and determining intraepidermal nerve fiber density (IENFD) is often used when investigating patients with suspected painful neuropathy. Morphological changes such as axonal swellings may also predict degeneration of epidermal fibers, but their length has not been estimated before. Here we estimate the epidermal nerve fiber length in healthy subjects and in neuropathy patients using global spatial sampling, and compare the length with IENFD and axonal swellings. We analyzed 50- $\mu \mathrm{m}$ thick free-floating sections from 12 small-fiber neuropathy patients and 36 healthy subjects, immunoreacted to PGP 9.5. There was a statistically significant difference both for IENFD and length between the two groups. Mean IENFD in healthy subjects was $7.51 \mathrm{~mm}^{-1}\left(2.17 \mathrm{~mm}^{-1}\right)$, and 
CH.45 Line Granild Bie Mertz
CH.46 Zita Dósa mean length density was $565 \mathrm{~mm}^{-2}\left(240 \mathrm{~mm}^{-2}\right)$. Mean IENFD in patients was $2.22 \mathrm{~mm}^{-1}\left(1.63 \mathrm{~mm}^{-1}\right)$ and mean length density was $112 \mathrm{~mm}^{-2}\left(82.6 \mathrm{~mm}^{-2}\right)$. The correlation between the nerve fiber length and the IENFD was $r=0.16$ for healthy subjects and $r=0.39$ for patients, suggesting that the two variables provide different quantitative information. Furthermore, a statistically significant difference in swelling ratio was observed between healthy subjects and patients both per IENFD and nerve fiber length ( $p=$ 0.01 ). Although length estimation is more time consuming and requires additional equipment, this method may increase the mechanistic understanding of nerve fibers in the skin, and may also increase the efficiency in diagnosing SFN.

\section{ANGELMAN SYNDROME: GENOTYPE COMPARED WITH PHENOTYPE} L.G.B. Mertz

Department of Clinical Medicine, Aarhus University

Angelman syndrome (AS) is a neurogenetic disorder due to loss of expression of maternal, imprinted by genes on chromosome 15q11-13.

Clinical characteristic features of AS include severe intellectual disability and developmental delay, lack of speech, happy disposition, ataxia, craniofacial dysmorphology, autistic behaviour, and $90 \%$ are reported to have epileptic seizures. Furthermore, they present with a characteristic appearence including micro-brachycephaly, macrostomia, tongueprotrusion, prognathism, widely spaced teeth, puppet-like movements and wide-based gait.

AS is based on a deletion, a mutation, an imprinting defect or pUPD.

The aims of the present study were to investigate the birth incidence of AS in a homogenous and well-defined population sample, very thoroughly to characterize the size of the 15q11-13 deletions, and to analyze genotypephenotype differences between the different molecular mechanisms, including severity of autism, mental retardation, epilepsy, eating behaviour and anthropometric meassures.

We found a birth incidence of 1:25.000. Deletion patients were genetically analyzed using $1000 \mathrm{~K}$ array $\mathrm{CGH}$ and subdivided into class I deletion, class II deletion and three atypical deletions. A more severe phenotype was found in deletion patients compared to non-deletion patients regarding autism, mental development and epilepsy. Patients with pUPD presented with hyperfagia and weight gain similar to patients with prader willi syndrome. A tendency of a more severe phenotype in class I deletion as compared to class II deletion patients was evident throughout the study.

REDUCED HIPPOCAMPAL GABAERGIC ACTIVITY IN A LOW BIRTH WEIGHT RAT MODEL OF DEPRESSION

\footnotetext{
Z. Dosa', J.L. Nieto-Gonzalez', B. Elfving ${ }^{2}$, K.S. Hougaard ${ }^{3}$, M.M. Holm', G. Wegener $^{2,4}$, K. Jensen ${ }^{7,5}$

'Synaptic Physiology Laboratory, Department of Biomedicine, Aarhus University, Aarhus, Denmark, ${ }^{2}$ Center for Psychiatric Research, Aarhus University Hospital, Risskov, Denmark, ${ }^{3}$ National Research Centre for the Working Environment, Copenhagen, Denmark, ${ }^{4}$ Unit for Drug Research and Development, School of Pharmacy (Pharmacology), North-West University, Potchefstroom, South Africa, ${ }^{5}$ The Lundbeck Foundation Research Center MIND, Department of Biomedicine, Aarhus University, Aarhus, Denmark

Background: Epidemiological studies have shown that low birth weight (LBW) increases the risk of developing neuropsychiatric disorders, such as depression in later life. Adverse genetic and environmental impact during early development, such as glucocorticoid hyper-exposure, can lead to lower body size at birth. In a LBW rat model of depression, Sprague Dawley
} 
rats were exposed to dexamethasone, a synthetic glucocorticoid, during the last week of fetal life. These rats have a low body weight at birth and show depressive-like behaviour in adulthood.

Aim: As the GABAergic inhibitory system is proposed to be involved in the pathophysiology of depression, the aim of the study was to examine the electrophysiology of GABAergic inhibition in the hippocampus of LBW rats.

Methods: Whole-cell patch-clamp recordings were performed from dentate granule cells of brain slices to examine spontaneous and evoked GABA receptor mediated phasic inhibition.

Results: In 4-week-old LBW rats, a significant decrease in the frequency of spontaneous inhibitory postsynaptic currents (IPSCs) was observed, while action potential independent miniature IPSCs were unchanged. With respect to IPSCs evoked by extracellular paired-pulse stimulation in LBW rats, we observed a significantly higher paired-pulse ratio in 4-week-old rats compared to controls (LBW: $1.14 \pm 0.126, n=14$; control: $0.8 \pm 0.042, n=9 ; p$ $<0.05)$.

Conclusion: Our results demonstrate a dysfunction in the limbic GABAergic inhibitory system in LBW rats, which may contribute to the pathophysiology of depressive-like behaviour in adulthood.

$\begin{array}{ll}\mathrm{CH} .47 & \text { Nicolai } \\ & \text { Ladegaard }\end{array}$

$\mathrm{CH} .48 \quad$ Maria Tørring
SOCIAL COGNITION IN MAJOR DEPRESSIVE DISORDER

\section{N. Ladegaard}

Clinic for Affective Disorders, Aarhus University, Risskov

Social cognitive in major depressive disorder

Depressive disorders are frequently associated with significant and pervasive impairments in social functioning. Depressed patients have fewer social contacts and a less integrated social network than healthy people in general and frequently exhibit deficiencies in social problem solving. Consequently, examining the social cognitive grounds for social functioning has considerable potential to improve our understanding of depression. Social cognition refers to the capacities which allow us to make sense of oneself and others. We do so by a dialogical process of inferring and attributing mental states as well as reasoning about our own thoughts and feelings. While much work has focused on discrete social cognitive deficits, less is known about possible impairment in higher-order social cognition, e.g. theory of mind (ToM) and mentalization.

Primary measures: Metacognitive Assessment Scale (MAS), The Awareness of Social Inference Test (TASIT), Triangle Animation Task and Cambridge Neuropsychological Test Automated Battery (CANTAB).

NO EFFECT OF LACTATE ON THE DIAMETER OF PORCINE RETINAL ARTERIOLES WITH DIFFERENT DIAMETER IN VITRO

\section{M.S. Tørring ' , C. Aalkjcer', T. Bek ${ }^{7}$}

${ }^{1}$ Department of Ophthalmology, Aarhus University Hospital, ${ }^{2}$ Department of Biomedicine, Aarhus University

Background: Retinal ischaemia is involved in the pathogenesis of the major vision-threatening retinal diseases. The resulting hypoxia leads to anaerobic metabolism with the release of lactate, which is assumed to be one of the factors stimulating vasodilatation at the borders of the ischaemic areas. However, recent evidence suggests that the vasodilating effect of lactate may differ between the larger and the smaller retinal arterioles.

Methods: Porcine retinal segments were mounted in a newly developed tissue chamber for studying diameter changes of retinal arterioles with different calibers. The arterioles were preconstricted with endothelin- 1 $\left[3^{*} 10^{-8} \mathrm{M}\right]$, and the effect of sodium L-lactate [10 mM] at $1 \mathrm{st}, 2 \mathrm{nd}$, $3 \mathrm{rd}$ and 
4th order arterioles was studied.

Results: Lactate reduced the internal diameter in 1st order arterioles with 39 $\pm 23 \%(n=5)$, in 2 nd order arterioles with $23 \pm 17 \%(n=11)$, in 3rd order arterioles with $2 \pm 26 \%(n=11)$ and in 4th order arterioles with $-14 \pm 17 \%$ (n $=8$ ). The diameter changes in 1 st, 2 nd and 3 rd order arterioles did not differ significantly from the time controls, whereas the 4 th order was inconclusive.

Conclusion: Lactate did not change the diameter of porcine retinal arterioles with different branching level significantly. However, it cannot be excluded that a vasodilating effect of lactate may have been masked by a delayed effect of endothelin-1.

CH.49 Peter Niekerk ELUCIDATION OF STEM CELL BIOLOGY IN CHRONIC MYELOID LEUKAEMIA

P.B. van Kooten Niekerk' , A.S. Roug ', L. Nederby', C.G. Nyvold' ${ }^{7}$ E. Kjeldsen', L. Hokland', C.C. Petersen ${ }^{2}$, H.B. Ommen ${ }^{7}$, J. Stentoft ${ }^{7}$, P. Hokland

${ }^{1}$ Department of Hematology, Aarhus University Hospital, ${ }^{2}$ The FACS Core Facility, Aarhus University

Background: Despite achieving undetectable levels of minimal residual disease (MRD), at least $60 \%$ of patients with chronic myeloid leukemia (CML) relapse when taken off therapy due to persisting leukemic stem cells. We hypothesized that these rare cells could be identified through employing the recently discovered stem cell marker $\mathrm{hMICL}$ in enriching cell populations for stem cell specific MRD assessment.

Methods: Bone marrow aspirates or peripheral blood stem cells from CML patients at diagnosis $(n=8)$ and during treatment $(n=17)$ were FACS sorted into stem cells and $\mathrm{hMICL}+$ /- progenitors. Sorted fractions were analyzed for MRD by an optimized qPCR assay for BCR-ABL expression and subjected to growth in a 14-day colony-forming cell (CFC) assay.

Results: The progenitor compartment contained fewer hMICL+ cells at diagnosis of CML (23.1\%) compared to during treatment ( $37.9 \% ; p=0.05$ ). Sorted hMICL+ progenitors were significantly enriched for myeloid CFC's ( $92.6 \%$ vs. $7.8 \%$ in $\mathrm{hMICL}$ - progenitors; $\mathrm{p}<0.0001$ ) and significantly reduced in erythroid CFC's (7.1\% vs. 82.6\%; $p<0.0001$ ). Importantly, our improved qPCR assay revealed that out of 9 patients with undetectable MRD, 7 patients were still BCR-ABL positive. Six of the 7 patients were BCR-ABL positive only in the total MNC and/or the CD34- fraction and not in any of the sorted progenitor fractions.

Conclusions: Expression of hMICL is an early marker of myeloid differentiation and may identify granulocyte/macrophage progenitors. While detection of residual leukemic stem cells within the sorted fractions failed using mRNA-based methods, further studies are needed to determine whether this could be due to quiescence of these cells.

CH.50 Niklas Telinius CALCIUM DYNAMICS IMPORTANT FOR GENERATING CONTRACTIONS IN THE HUMAN THORACIC DUCT

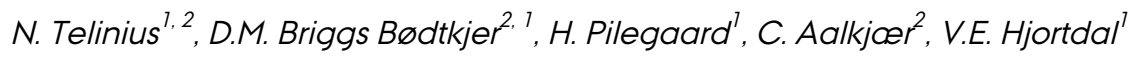
${ }^{1}$ Department of Cardiothoracic Surgery, ${ }^{2}$ Department of Biomedicine Introduction: The lymphatic vasculature regulates the tissue fluid balance. Excessive fluid is pumped away when the smooth muscle cells in the vessel wall generate phasic contractions.

Hypothesis: In this study, we aim to describe the calcium dynamics important for the human thoracic duct to generate contractions.

Material and methods: Thoracic ducts were harvested from 27 patients during esophageal cancer surgery. Ring segments were mounted in a wire myograph. Vessels generating phasic contractions were incubated with calcium channel blocker nifedipin (5,20 and 100nM), Rho kinase inhibitor 
CH.51 Julie Glavind TIMING OF ELECTIVE CAESAREAN SECTION AND NEONATAL MORBIDITY: A RANDOMISED CONTROLLED TRIAL

J. Glavind ${ }^{\text {', }}$, S.F. Kindberg ${ }^{\text {, N N. Uldbjerg }}{ }^{\text {', T.B. Henriksen }}{ }^{2,3}$

'Department of Obstetrics and Gynecology, Aarhus University Hospital,

${ }^{2}$ Perinatal Epidemiology Research Unit, Department of Clinical Medicine.

Aarhus University, ${ }^{3}$ Department of Pediatrics, Aarhus University Hospital

Objectives: To investigate whether elective caesarean section (ECS) before 39 completed gestational weeks increases the risk of adverse neonatal outcomes.

Design: Randomised controlled multicentre open-label trial.

Setting: Seven Danish tertiary hospitals from March 2009 to June 2011.

Population: Women with uncomplicated pregnancies, a single fetus and a date of delivery estimated by ultrasound were included when a decision to deliver by ECS was made.

Methods: ECS scheduled at a gestational age of either 38 weeks and 3 days or 39 weeks and 3 days (in both groups \pm two days).

Main Outcome Measures: The primary outcome was neonatal intensive care unit (NICU) admission within 48 hours of birth.

Results: 1274 women were included and available for follow-up. There was no significant difference in primary outcome between neonates randomised to ECS delivery at 38 weeks $(88 / 635 ; 13.9 \%)$ and 39 weeks (76/637; $11.9 \%$ ), risk difference (RD) $-1.9 \%$ ( $95 \% \mathrm{Cl}-5.6$ to 1.8 ). The risk of treatment with continuous oxygen for more than one day was significantly less frequent if randomised to 39 weeks, RD $-1.4(95 \% \mathrm{Cl}-2.7$ to -0.2$)$.

Conclusions: This study found no significant reduction in neonatal admission rate with ECS scheduled at 39 as compared to 38 gestational weeks. The results support routine scheduling of ECS after 39 weeks, but indicate that ECS scheduling three to five days prior to 39 weeks may be rather safe for the new-born.

Trial registration: www.clinicaltrials.gov, number NCT00835003

CH.52 Gry Kjœersdam CHILDREN AND ADOLESCENTS WITH ANOREXIA NERVOSA

Telleus

G. Kjcersdam Telléus

1. Aalborg Psychiatric Hospital, Unit for Child and Adolescent psychiatry, Aalborg, DK

Background: Cognitive deficits have previously been identified in adult 
women with anorexia nervosa. Currently, there is limited knowledge about the degree to which cognitive functions in children and adolescents with anorexia nervosa may be equally impaired.

Method: The aim of this study is to examine how cognitive functions in children and adolescents are impaired by anorexia nervosa, the type and degree of cognitive impairment and the correlation between intelligence, comorbidity and symptomatology. Another purpose of the study is to examine the role of gender, age and weight.

The study population consists of a cohort of patients with anorexia nervosa $(n=95)$. The data are gathered at the Eating Disorder Section and the Child and Adolescent Department at Aalborg Psychiatric Hospital, the Eating Disorder Section at the Mental Health Center for Child and Adolescents at Psychiatry Bispebjerg and the private practice of MD Eva Christiansen, Ny Vestergade 7, Copenhagen. A second cohort of control subjects is also established, consisting of 1:1 corresponding individuals matched for age, gender and comparable demographic background $(n=95)$.

Results: The cohort consists of 85 females and 10 males with a mean age of 14.3 years. The probands in the cohort have a BMI (age corrected) at 15.7. There is a history of eating disorders in $28.4 \%$ of the cohort subject families, while the history of other mental disorders is as high as $46.3 \%$.

Conclusions: Findings from the Danish Cohort of Children and Adolescents with anorexia nervosa $(n=95)$ shows that children and adolescents with anorexia nervosa have a normal IQ. At the same time, some impairment of the cognitive functions was found.

CH.53 Charlotte

GENERIC SUBSTITUTION APPEARS TO INCREASE ADHERENCE IN ELDERLY Olesen PATIENTS WITH POLYPHARMACY

C. Olesen' , P. Harbig' ', I. Barat', E.M. Damsgaard'

${ }^{1}$ Department of Geriatrics, Aarhus University Hospital, ${ }^{2}$ Medical Department, Horsens Hospital

Introduction: Generic substitution of prescription medications in Denmark means that the pharmacy must provide the cheapest medicine. Every time the patient buys a drug, the drug name or brand-name may have changed. Consequently the appearance of tablets or packagings may have changed. Substitutions therefore make many patients uneasy and can affect nonadherence to drugs.

Aim: Our aim was to study the impact of generic substitutions on nonadherence to drugs used by elderly patients with polypharmacy.

Methods: Nonadherence to drugs was measured in 509 patients aged 65+ years, using $>4$ drugs, and living inAarhus, Denmark. The drugs were consecutively sampled from a larger adherence study (MICMI).

Nonadherence was measured by pill count. A person was categorised as nonadherent if the mean nonadherence rate for all drugs consumed was $<80 \% .<$ br / > Information about substitutions for one year was collected from the National Health Insurance prescription database during the study period of 2008-2010. Only oral drugs for long term treatment were included.

Association between generic substitution and nonadherence was analysed with a $2 \times 2$ table.

Results: Nine percent of the elderly were categorised as nonadherent and $83 \%$ had one or more substitutions during one year.

The risk of being nonadherent (OR $0.43 ; 95 \% \mathrm{Cl} 0.22-0.85$ ) was significantly lower in elderly who had experienced substitutions of drug names etc. ( $8 \%$ ) compared to elderly who had not (17\%).

Conclusion: Generic substitution appears to increase adherence in elderly 
patients with polypharmacy.

CH.54 Palle Larsen EFFECTIVENESS OF FLUID RESTRICTION IN THE NON-PHARMACOLOGICAL REHABILITATION IN HEART FAILURE PATIENTS: A PROTOCOL FOR A REVIEW OF CURRENT LITERATURE

\section{P. Larsen, P.U. Pedersen}

University of Aarhus, Danish Centre of Systematic Reviews in Nursing: an affiliate centre of The Joanna Briggs Institute

Background: Heart failure is a major cause of morbidity and mortality. Rehabilitation, and especially the pharmacological part, has been seen to be effective in preventing further development of the disease.

In the nursing field focus is on the non-pharmacological rehabilitation. One of the points is the effect of restricted fluid intake heart failure patients

Aim: To identify the effectiveness of fluid restriction for patients with heart failure on readmission

Method: Meta-analysis or and Systematic Review

Inclusion criteria: Types of participants: Heart failure patients in hospital settings aged 18-80+ in NYHA I-IV.

Types of interventions: This review will consider studies that evaluate a more liberal administration of daily fluid intake for patients with heart failure compared with restricted fluid ( 1.5 and $2.0 \mathrm{l}$ /day) administration for heart failure patients

Types of outcomes: readmission

Types of studies:RCT, non-randomized controlled trials and quasiexperimental for inclusion.

Search strategy: The search strategy aims to find both published and unpublished studies. A three-step search strategy will be utilized in this review. An initial limited search of PubMed and CINAHL will be undertaken followed by analysis of the text words contained in the title and abstract, and of the index terms used to describe article.

The databases to be searched include: Cochrane, PubMed, Embase, Medline, Scopus and Cinahl

The search for unpublished studies will include: Mednar and EAGLE

Initial keywords to be used will be: Heart Failure, Heart Failure patients, fluid restriction, self-care behavior

Assessment of methodological quality: Validated checklists

CH.55 Malene

Krogsgaard Bording

\section{CLINICAL DECISION-MAKING IN OUTPATIENT MENTAL HEALTH CARE}

M. Krogsgaard Bording', B. Puschner', S.P. Olesen ${ }^{3}$, P. Munk-Jørgensen ${ }^{4}$

'Unit for Psychiatric Research, Aalborg Psychiatric Hospital, Aarhus University Hospital, ${ }^{2}$ Department of Psychiatry II, Ulm University, Germany, ${ }^{3}$ Department of Sociology, Social Work and Organisation, Aalborg University,

${ }^{4}$ Department M, Risskov, Aarhus University Hospital

Introduction: The major reason for lack of knowledge on clinical decisionmaking in outpatient mental health treatment is that research on clinical decision-making in health care has primarily focused on well-defined situations in physical conditions, while there has not been researched in this area in people with severe mental illness with its high demands on treatment adherence and therapeutic relationships.

Aims of the study: This study is about clinical decision-making for people with severe mental illness in outpatient routine mental health care. The study investigates the short- and long-term effects of decision-making on 
clinical outcome (symptom level, quality of life, needs) by taking into account significant variables moderating this relationship. Furthermore, we investigate the patients' understanding of the decision-making and identification of factors leading to this understanding.

Methods: This is a multi-national prospective observational study (bimonthly assessments during a one-year period; $n=588$, 6 European centres). Field observations and interviews with patients will also be applied.

Preliminary results: At follow-up, patients showed higher desire to be more involved in decision-making than at baseline. For staff, there was no change in desire to be more involved in decision-making from baseline to follow-up. On average, staff members in Denmark were more satisfied with decisions than staff across Europe, scoring an average satisfaction rate of 4.3 out of a total of 5. Danish patients in the study were also more satisfied with decisions than patients across Europe, scoring an average satisfaction rate of 4.5 out of 5 .

CH.56 Kirsten Hansen "WHEN A PARENT SUFFERS FROM DEPRESSION" - INTERVIEW INVESTIGATION AMONG DANISH FAMILIES

K. Hansen ', O.S. Kristensen ${ }^{2}$, K.S. Christensen ${ }^{3}$, H.J. Soegaard ${ }^{7}$

${ }^{1}$ Psychiatric Research Unit West, Central Denmark Region, ${ }^{2}$ Department of Psychology and Behavioural Sciences, Aarhus University, ${ }^{3}$ The Research Unit for General Practice, Aarhus University

Parental depression is a risk factor for a child. Parental depression may negatively affect the child's wellbeing and lead to psycho-social or cognitive impairment in childhood and psychiatric or somatic disease both during childhood and adult life. More than 300,000 citizens were suffering from depression in Denmark in 2010,

In Rebild, Hedensted and Viborg, job centres have established contact to 17 interviewees with 2-14-year old children.

More than half of the interviewees had experienced remission owing to treatment. However, 14 parents had suffered from severe and three from moderate depression.

Interviews focused on the impact of the depression on the child, its everyday life, and the parents' efforts to maintain the children's daily life as close to normal as possible.

The parents described three levels of wellbeing of their 36 children: a small group was unaffected, a small group was seriously affected and a large group of children was moderately affected due to the depression. A few children were described to be extrovert but most parents have reported on anxious and introvert children.

Three strategies were represented:

A number of parents inform their children of the depression carefully and within short time, the depression is open to conversation and the parents are active in easing the children's situation, i.e. by network support.

Other parents let time pass by without informing the children, depression is tabooed and the parents avoid facing the situation and take only little action.

In between, a group of parents feel in doubt about how to handle the situation. They are concerned for the children, seek information and would welcome professional advice.

CH.57 René Ernst INCREASING MORTALITY GAP FOR PATIENTS DIAGNOSED WITH Nielsen SCHIZOPHRENIA: A NATIONWIDE STUDY OVER THREE DECADES

R.E. Nielsen ", ${ }^{\text {, A.S. Uggerby', S.O.W. Jensen', J.J. McGrath }}{ }^{2,3}$ 
'Unit for Psychiatric Research, Aalborg Psychiatric Hospital, Aarhus University Hospital, Aalborg, Denmark, ${ }^{2}$ Queensland Centre for Mental Health Research, The Park Centre for Mental Health, Queensland, Australia, ${ }^{3}$ Queensland Brain Institute, The University of Queensland, Queensland, Australia, ${ }^{4}$ Team for young people with schizophrenia, Aalborg Psychiatric Hospital, Aarhus University Hospital, Aalborg, Denmark

Introduction: Increased mortality and decreased age at death are seen in patients with schizophrenia.

Methods: A nationwide register-based study of average age at death for patients diagnosed with schizophrenia and a representative sample of the Danish population not diagnosed with a psychiatric disorder covering the period from 1 January 1980 to 31 December 2010.

Results: Average age at death for males and females in the schizophrenia population was significantly lower compared to the general population, $\mathrm{p}<$ 0.001 . In the general population, we saw an average increase in age at death for males of $0.2895 \% \mathrm{Cl}(0.27-0.28), \mathrm{p}<0.01$, years per year, and an increase in age at death for females of $0.3195 \% \mathrm{Cl}(0.31-0.32), p<0.01$, per year. In the schizophrenia population, we saw an average negative increase in age at death for males of $-0.0495 \% \mathrm{Cl}(-0.09-0.00), \mathrm{p}<0.05$, and an average negative increase in age at death for females of $-0.0595 \% \mathrm{Cl}(-$ $0.09-(-0.01)), p<0.05$. Secondly, we did a reanalysis of our dataset, excluding all with intentional self-harm as a cause of death, showing an average negative increase in age at death for males of $-0.2495 \% \mathrm{Cl}(-0.28$ $(-0.20), p<0.001$, and an average negative increase in age at death for females of $-0.1995 \% \mathrm{Cl}(-0.23-(-0.19)), \mathrm{p}<0.001$, in the schizophrenia population.

Conclusion: We found a significant reduction in average age at death for patients diagnosed with schizophrenia over three decades, not explained by intentional self-harm. This finding in contrasted by the average increase of almost 0.3 years in age at death per year in the general population over the same three decades. 


\section{Index of authors}

A

Abhishek Kumar.......................................... 133

Aida Solhøj Hansen ....................................154

Akiko Shimada............................................. 131

Alice Østergaard........................................... 143

Allan Riis .................................................... 220

Anders Gade Kjœrgaard .............................. 49

Anders Jorsal ................................................... 96

Anders Raouf El-Galaly ................................. 176

Anders Riisager Sørensen .............................140

Anders Sommer Knudsen ............................ 233

Ane Birgitte Telén Andersen ............................. 66

Anette Liljensøe............................................. 133

Anette Tarp Hansen ..................................... 143

Anita Eskildsen ............................................ 167

Anja Pagh ................................................. 114

Ann Dyreborg Larsen ...................................200

Ann Marlene Gram Christensen ....................187

Ann Mosegaard Bak ....................................109

Anna Tietze ................................................164

Anne Birgitte Simonsen............................... 64

Anne Bodilsen .............................................. 118

Anne Dorte Blankholm.................................102

Anne Fia Grann...............................................73

Anne Grethe Schioldan .............................104

Anne Gulbech Ording .................................. 77

Anne Højland ............................................ 174

Anne Louise Askou....................................... 153

Anne Mette Lund Würtz ................................216

Anne Nakano Jensen ................................... 80

Anne Skakkebck Jensen ........................... 239

Anne Sophie Pinholt Kancir ........................ 100

Anne Sørensen .............................................. 58

Anne Vestergaard.........................................128

Anne Virring Sørensen ..................................166

Anne Yoon Krogh Grøndal Hansen .............. 179

Anne-Mette Haase.........................................70

Annesofie Lunde Jensen .............................210

Annette Søndergaard .................................. 82

Anto Praveen Rajkumar Rajamani ............... 151

Arnela Mehmedbasic .................................. 172

Asger Andersen ....................................... 246

B

Babak Jalilian ..............................................245

Bent Roni Ranghøj Nielsen ...........................53

Betina Hansen................................................72

Birgit Bjerre Høyer .................................... 205

Bjørn Bay .................................................... 203

Bjørn Borsøe Christensen .............................. 193

Bo Hønge ...................................................188

Bochra Zareini ...........................................192

Britt Borg................................................ 178

C

Camilla Hoffmann Merrild ............................214

Camilla Nyboe............................................ 94

Camilla Plambeck Hansen...........................221

Caroline Winther Tørring ................................ 49

Carsten Stengaard.....................................247

Casper Kornbech Larsen ............................140
Cathrine Bach ...............................................77

Cathrine Ladegaard Wildenschild Nielsen ....79

Charlotte Green ........................................221

Charlotte Handberg.................................... 206

Charlotte Hartig Andreasen........................... 44

Charlotte Hyldgaard .................................... 229

Charlotte K. Lautrup ........................................ 68

Charlotte Olesen........................................ 263

Christian Bo Poulsen .......................................81

Christian Daugaard Peters.......................... 248

Christian Lottrup .............................................67

Christina Daugaard Lyngholm.......................111

Christina Fischer ............................................168

Christina Gade Jespersen..............................51

Christina Kjcergaard Rasmussen ..................194

Christina Maar Andersen ...............................208

Christina Mørup Jørgensen ...........................61 61

Christina Sølvsten ..........................................165

Christoffer Laustsen ..................................... 249

Connie Timmermann...................................212

D

Daniel Belstrøm ............................................ 131

David Christoffer Hansen ................................124

Dea Jensen...................................................186

Dea Kejlberg Jensen....................................189

Dennis Kjølhede Jeppesen ..........................148

Dinah Sherzad Khatir ................................... 96

Dirk Troitzsch.............................................. 239

Ditte Lammers Vernal................................. 227

Ditte Olsen .................................................. 238

Dorthe Krogsgaard Bonnerup.........................74

E

Eduardo Vazquez Garza............................. 253

Efe Levent Aras ........................................ 235

Else Toft Würtz ............................................. 222

Else-Marie Dalsgaard ...................................218

Emil Hagen Ernst .........................................150

Emilia Horjales............................................ 254

Esben Schjødt Worm.................................. 252

Ethel Mary Brinda Alexander .......................212

Eva Amalie Nielsen .................................. 100

Eva Bjerre Ostenfeld ..................................... 70

Eva Futtrup Sørensen ...................................178

Eva Holm Greibe ..........................................4 41

Eva Scedder ..............................................75

F

Finn Sørensen ......................................... 232

Frank Holden Mose .....................................241

Freja Cecilia Brandt Bertelsen ..................... 171

G

Gitte Brinch Andersen ............................... 151

Gitte Bundgaard Christiansen ......................163

Gitte Julie Christensen ................................ 92

Gitte Susanne Rasmussen............................216

Gry Kjœersdam Telleus............................... 262

H

Halldór Bjarki Einarsson.................................148

Hanna Rahbek Mortensen .............................. 51

Hanne Rheder Ellegaard ............................190 
Heidi Cueto ..................................................200

Helen Nordahl Madsen..................................142

Helene Kirkegaard.........................................199

Helene Myrtue Nielsen................................. 115

Helga Haahr-Lillevang ................................. 197

Helle Kristensen......................................... 152

Henriette Bjerregaard ................................... 175

Henriette Lajgaard Christensen.....................138

Henrik Gammelager ..................................... 48

Henrik Lauridsen ......................................... 155

Henry Jensen ........................................... 209

I

Iben Bach Pedersen.......................................194

Ina Skyt Østergaard ....................................... 191

Inge Gram Carlsen ......................................154

Ingeborg Hedegaard Kristensen .................. 202

Ingrid Nilsson ............................................. 233

J

Jacob Gamst................................................60

Jacob Johnsen .............................................97

Jacob Mørup Schlütter ...............................256

Jan Danz ................................................ 231

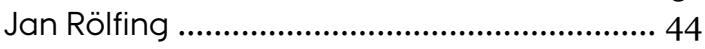

Janne Mortensen .........................................164

Janni Majgaard Jensen ................................ 94

Jannie Dahl Hald........................................ 137

Jannie Sørensen............................................. 181

Jannik Bertelsen ............................................102

Jenny-Ann Phan ....................................... 191

Jens Reumert Laurberg............................... 50

Jeppe Skov.....................................................107

Jesper Kallehauge ........................................253

Jesper Padkcr Petersen................................. 71

Jesper Sand Sørensen ....................................57

Jesper Thygesen .......................................... 127

Jette Pedersen ............................................. 220

Jill Rachel Mains.......................................... 125

Joan Fledelius ................................................ 127

Johan Frederik Berg Arendt........................... 145

Johan Heiberg ................................................93

Johanne Lade Keller....................................252

Johannes Martin Schmid .............................. 86

Jonas Agerlund Povlsen ............................... 246

Jonas Jensen.................................................150

Jonathan Montomoli...................................... 69

Juan Manuel Shiguetomi Medina................ 230

Julie Damgaard Sandahl........................... 250

Julie Glavind ............................................ 262

Julie Kristine Laustsen .................................183

Julie Prahl ............................................... 50

Julie Støy .................................................. 110

Jurgita Janukonyté...................................... 238

Justyna Zareba .......................................... 172

$\mathbf{K}$

Kang Ran ....................................................160

Kanja Krogh ................................................. 81

Karen Kjœr Larsen ........................................ 46

Karen Krogh Fjeldborg .................................105

Karen Lise Dahl Andersen.............................196

Karen Lund.............................................. 170
Karina Bech Cullberg...................................250

Karl Ole Köhler ...........................................190

Kasper Grosen............................................. 211

Kasper Hansen ............................................ 161

Katherina Farr...............................................111

Kathrine Hansen............................................. 87

Katja Glejsted Ingstrup..................................201

Katja Maretty Nielsen ................................... 117

Katrine Emmertsen........................................ 43

Kirsten Hansen ............................................. 265

Kirstine Kjœer Kirkegaard ...............................41

Kresten Krarup Keller .................................. 236

Kresten Rickers .......................................... 137

Kristian Andersen ......................................130

Kristian Krogh ................................................ 63

Kristian Stødkilde-Jørgensen ........................ 42

Kristina Grønborg Laut .................................. 228

Kristine Raaby Jakobsen...............................116

Kristoffer Koch .............................................. 71

L

Lars Markvardsen .......................................185

Lars Ølgaard Bloch ......................................195

Lau Brix ....................................................... 242

Lea Hougaard Pedersen ..............................153

Lea Johanne Brader ..................................... 56

Leif Rognås................................................... 65

Lena Hohwü ......................................................201

Lena Lindtoft Rosenbœk ................................ 45

Lene Duez.......................................................165

Lene Hee Christensen .................................. 78

Lene Hjelle Tauris ............................................ 161

Lene Rahr Wagner........................................135

Lene Sofie Granfeldt Østgård ....................... 115

Lene Søndergård Larsen.................................47

Line Flytkjœr Jensen...................................213

Line Gebauer Josefsen ................................ 53

Line Granild Bie Mertz ................................ 259

Line Nilsson............................................... 157

Line Raaby Olsen .......................................... 84

Lisbeth Lund Jensen ..................................... 171

Lise Lindahl.................................................. 155

Lise Thorsen .....................................................126

Lise Tornvig Erikstrup ...................................... 89

Lise Ventzel ................................................... 167

Lone Flarup .................................................. 211

Lone Ramer Nygaard Mikkelsen ..................134

Lotte Andreasen......................................... 119

Lotte Bonde Bertelsen ..................................123

Lotte Dahl Kristensen.................................. 207

Lotte Maxild Mortensen ............................... 224

Lotte Sander ..............................................251

Lotte Vinther Christensen ..............................185

Louise Brøndt Hartlev .................................. 245

Louise Mahncke .......................................... 207

Louise Rottbøll Poulsen ............................... 181

Louise Tram Henriksen ................................241

M

Mads Jensen.................................................. 54

Mads Lind Ingeman .................................. 208

Maj Høygaard Nicolaisen ............................129 
Maja Ludvigsen .............................................. 149

Malene Krogsgaard Bording ...................... 264

Malene Schou Nielsson..................................75

Malene Tanderup Kristensen ......................... 195

Manoj Ramachandran..................................136

Maria Charlotte Steffensen .............................59

Maria Rusan ................................................... 91

Maria Theresa Wimberley Böttger................213

Maria Tørring ............................................. 260

Mariane Høgsbjerg Schleimann .................. 243

Marianne Johansson Jørgensen ...................219

Marianne Kjcer Poulsen.................................108

Marie Beck Iversen .......................................... 85

Marie Juul Ørnstrup ....................................... 107

Marie Krarup Schrøder ....................................78

Marie Louise Bønnelykke-Behrndtz .............. 113

Marie Louise Schmitz ...................................169

Mark Reinhard ............................................. 249

Marlene Skovgaard Sørensen ....................... 192

Martin Bjerregård Pedersen .......................... 112

Martin Mørck Mortensen..............................257

Martin Skovmos Nielsen..............................120

Maryam Ardalan .......................................166

Merete Gregersen ...................................... 135

Merete Hartvigsen ........................................56

Merete Møller .............................................. 224

Mette Bohl Larsen ..........................................104

Mette Damborg Hansen ............................... 226

Mette Hansen Viuff.......................................184

Mette Holland-Fischer................................... 64

Mette Ji Riis-Vestergaard ..............................180

Mette Julsgaard Nielsen .................................47

Mette Kjœrgaard Nielsen .............................218

Mette Winther ............................................... 119

Mia Benedicte Lykke Roest Laursen ............. 157

Mia Møller..................................................158

Mia-Maiken Kallestrup Jørgensen ...............189

Michael Dalager-Pedersen...........................60

Michael Eriksen Benros ................................ 231

Michael René Skjelbo Nielsen ......................237

Michael Skovdal Rathleff ..............................134

Michael Smcrup Brandt.............................. 226

Michal Switnicki............................................. 156

Mie Rostved Rasmussen ...............................139

Mikkel Andreas Strømgaard Andersen ..........73

Mikkel Mylius Rasmussen ..............................170

Mikkel Tøttrup .................................................128

Mohamed Ahmed Hassan.............................117

Mohit Kothari .................................................. 42

Morten Christian Bay Grauballe .................... 132

Morten Leif Munding Stilund ......................... 89

Morten Schmidt ............................................. 62

Morten Torvund-Jensen ............................... 147

$\mathbf{N}$

Nanna Cornelius ........................................257

Nanna Rolving Rasmussen ......................... 217

Natalie Momen ........................................... 203

Navid Sahebekhtiari ......................................146

Nichlas Riise Jespersen................................. 177

Nicolai Ladegaard ................................... 260
Nicolaj Christopher Hansson......................... 101

Nicole Jeanette S. Springer...........................169

Nicoline Valentina Krogstrup ..........................6 61

Niels Bjerregård Matthiesen............................79

Niklas Telinius ...............................................261

Nikolaj Gehr ................................................182

Nilani Ramshanker.......................................106

Nina Jensen.................................................138

Ninna Aggerholm Pedersen ......................... 112

Nis Pedersen Jørgensen............................... 90

Noomi Gregersen........................................ 173

Noora Ronkainen ........................................214

$\mathbf{0}$

Omar Abuyaman .........................................142

$\mathbf{P}$

Páll Karlsson ................................................. 258

Palle Bager..................................................... 69

Palle Larsen ................................................. 264

Paula Fernandez Fernandez Guerra .............162

Pauline de Bruijn ....................................... 255

Per Qvist ......................................................55

Pernille Endrup Jacobsen ........................... 230

Peter Hjertholm ......................................... 209

Peter Niekerk ...................................................261

Philip Finn Rising Nielsen ............................ 204

Pia Løvschal-Nielsen .................................... 204

Pia Viuf Ørby ............................................. 223

Poul Vestergaard Nielsen ........................... 108

Priscila Corraini.............................................215

$\mathbf{R}$

Randi Heidemann Gottfredsen ..................... 83

Rasmus Østergaard Nielsen ........................ 223

Rasmus Otkjœr Bak ....................................... 58

René Ernst Nielsen ..................................... 265

René Østgård ........................................... 244

Rikke Esberg Kirkfeldt.................................. 52

Rikke Holm Jensen ...................................... 234

Rikke Kade ...................................................76

Rubens Spin-Neto .......................................126

$S$

Safa Talib Al Therwani .................................176

Sandy Mohamed Ismail Mohamed ...............122

Sanne Lemcke ............................................... 46

Sara Correia Marques .................................... 116

Sarah Holmboe ............................................. 98

Sascha Eichendorff ................................... 255

Sashia Pernille Bak-Nielsen ........................196

Sebastian Ranzi Kotze ...............................182

Sepp De Raedt ..........................................124

Shallu Sharma ............................................ 240

Sheyanth Mohanakumar ............................. 177

Shivani Joshi ................................................. 157

Simon Mølgaard Jensen ..............................174

Simon Winther................................................. 98

Simple Futarmal Kothari ............................. 175

Sine Kirstine Kratholm ................................187

Sine Knorr Sørensen ......................................103

Siri Hundtofte Strand .....................................159

Sisse Anette Thomassen ............................... 95

Solbritt Birla Grønbcek..................................184 
Søren Brandsborg ......................................... 82

Søren Brandt Poulsen................................. 141

Søren Dinesen Østergaard ...........................163

Søren Haack................................................... 123

Søren Hoberg .............................................186

Søren Møller Madsen ......................................105

Søren Ravn ................................................. 121

Srikanth Chiliveru ........................................ 244

Steen Fagerberg..........................................139

Steffen Bank.............................................. 242

Steffen Falgreen Larsen ............................... 113

Steffen Jensen.................................................5 57

Steven Brantlov ............................................ 99

Stina Lou.........................................................198

Stine Elleberg Petersen ................................ 229

Stinne Ravn Greisen...................................... 90

Susanne Bendesgaard Pedersen .................. 101

Susanne Haas ................................................... 68

Sys Hasslund Svensson .............................. 234

T

Therese Juul ...............................................225

Therese Koops Grønborg..............................198

Thøger Persson Krogh ..................................129

Thomas Aagaard Rasmussen........................ 84

Thomas Andersen Rix ...................................54

Thomas Deleuran...........................................63

Thomas Lyhne Ravkilde..................................122

Thomas Nordstrøm Kjœr ................................109

Thomas Winther Frederiksen ........................227

Tina Rask Elmholdt......................................144

Tine Jepsen Nielsen .......................................180

Tine Kjœrgaard .......................................... 141
Torben Hansen .............................................. 86

Torbjørn Halle Brøgger .................................... 93

Trine Allerslev Horsbøl................................. 205

Trine Dalsgaard ........................................... 256

Trine Eilenberg ............................................74

Trine Grantzau.............................................. 237

Trine Majken Gade Bonnesen .......................120

Trine Nielsen................................................... 43

Trine Nøhr Winding .....................................217

Trine Salomon Andreasen ..........................160

Troels Fogh Pedersen...................................97

Troels Johansen ............................................ 65

Troels Rønn Kjør ........................................ 87

Tue Kruse Rasmussen ................................... 92

Tue Wenzel Kragstrup....................................8 88

V

Veerle Paternoster...........................................146

Vibeke Secher Nielsen ............................... 247

W

Winnie Ridderberg....................................... 83

$\mathbf{X}$

Xiao Ma ......................................................147

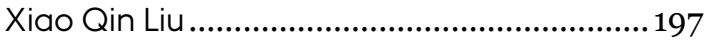

Xue Lin.................................................... 258

Y

Yujia Cai ...................................................159

$\mathbf{Z}$

Zahra Nochi ................................................. 145

Zara Ann Stokholm ....................................... 45

Zhanna Tairova.......................................... 235

Zhanyuan Kang ........................................... 66

Zita Dósa ................................................. 259 


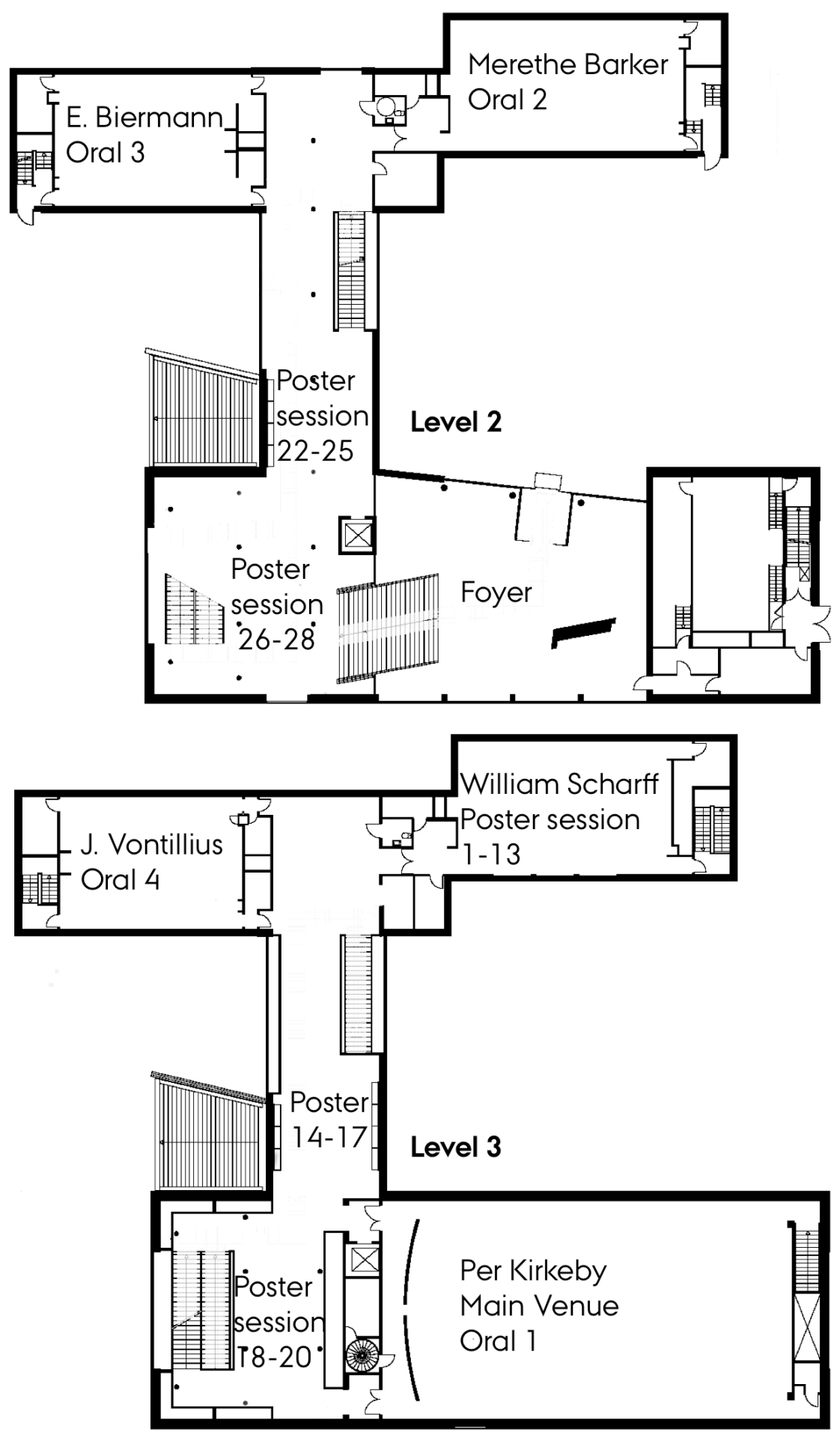

Level 4

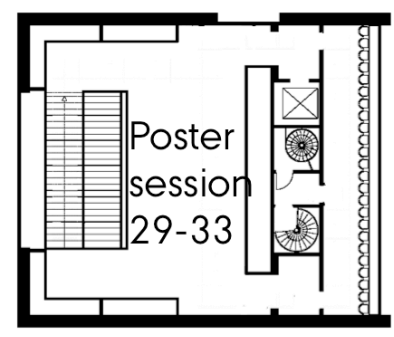

Bartholin Building

Oral 5

Poster session 34-40 
PHD DAY

11 JANUARY 2013

THE LAKESIDE LECTURE THEATRES AARHUS UNIVERSITY 